MARCELO GUERRA MARTINS

\title{
DEMOCRACIA FISCAL E SEUS FUNDAMENTOS À LUZ DO DIREITO \& ECONOMIA
}

\author{
Tese apresentada como requisito para \\ obtenção do Título de Doutor em Direito do \\ Estado pela Universidade de São Paulo - \\ Faculdade de Direito. \\ Professor Orientador: Enrique Ricardo \\ Lewandowski
}




\section{FOLHA DE APROVAÇÃO}

Marcelo Guerra Martins

Democracia Fiscal e seus Fundamentos à Luz do Direito \& Economia

Tese apresentada como requisito para obtenção do Título de Doutor em Direito do Estado pela Universidade de São Paulo - Faculdade de Direito.

Aprovado em:

Banca Examinadora

Prof. Dr.:

Instituição:

Assinatura:

Prof. Dr.:

Instituição: Assinatura:

Prof. Dr.:

Instituição: Assinatura:

Prof. Dr.:

Instituição: Assinatura:

Prof. Dr.:

Instituição: Assinatura: 
Dedico esta obra à memória de meu avô materno, Horácio José Guerra, advogado que me apresentou as Arcadas quando eu ainda muito jovem e, com isto, fez nascer o sonho de mergulhar num universo desafiador, fascinante e infinito.

Ao meu pai, Nelson Valente Martins, médico e professor da Escola Paulista de Medicina, por ter lançado em mim as primeiras sementes do amor à ciência e do desprezo à superstição.

Aos meus filhos, Guilherme e Henrique, quiçá um dia eu neles consiga lançar sementes tão férteis.

Em especial, aо meu orientador, Enrique Ricardo Lewandowski, professor titular do Departamento de Direito do Estado da Faculdade de Direito da Universidade de São Paulo e Ministro do Supremo Tribunal Federal, mestre dos mestres, pai acadêmico, por sua confiança e generosa liberdade concedida a este eterno aprendiz. 
Por mais que me esforce, não consigo reunir em palavras a minha profunda gratidão às forças que, de um modo que ainda não compreendi inteiramente, permitiram que uma concepção prefacial, sumária e difusa do assunto proposto se transformasse em convicção fundada.

À minha esposa Adriana, por seu decisivo e indispensável estímulo, apoio e compreensão, desde a ideia inicial até a conclusão da obra. Sua discreta presença ao tudo a minha volta cuidar foi, de fato, determinante para o finalizar do projeto.

À minha mãe Marilú, porque "mãe é mãe" e nada a substitui.

À todos aqueles que, de alguma forma, acreditaram e me auxiliaram nesse desafio gigante. 


\section{RESUMO}

Qualquer sociedade deve decidir como serão repartidas as despesas comuns e isso tem ocorrido há milhares de anos. A partir de elementos próprios do movimento da Law and Economics, esta tese elabora uma proposta científica sobre a questão. Trata-se da democracia fiscal.

Parte-se da constatação de que o direito e a economia se influenciam mutuamente numa dinâmica de constantes e infindáveis estímulos e feedbacks recíprocos, o que impede a observação da prevalência de um destes fenômenos sociais sobre o outro.

$\mathrm{Na}$ democracia fiscal, há três fundamentos que interagem como um sistema de pesos e contrapesos, de modo que um influencie e seja influenciado pelos demais em um desejável equilíbrio. São eles: a liberdade material, a igualdade de sacrifícios e a não inibição, pelo Estado, da atividade econômica.

A liberdade material se consubstancia no respeito aos direitos fundamentais da propriedade (em sentido amplo) e da livre iniciativa, cujo exercício permite ao indivíduo decidir como melhor satisfazer suas necessidades e desejos, não se submetendo, por conseguinte, aos desígnios estatais ou à caridade alheia.

A igualdade de sacrifícios se revela na necessidade de que a perda de bem-estar causada pelo pagamento dos tributos seja igualmente repartida entre todos os cidadãos, o que se obtém pela aplicação dos princípios da capacidade contributiva, progressividade e pessoalidade, de maneira que a arrecadação se origine, o máximo possível, dos tributos "diretos" pagos pelas pessoas físicas (sobre a renda, as propriedades e as transmissões de bens em geral). É que os tributos "indiretos", além daqueles pagos pelas empresas, de um modo geral, conferem caráter regressivo ao sistema de tributação.

A não inibição da atividade econômica permite $\mathrm{o}$ incremento da arrecadação, uma vez que as exações, em geral, incidem sobre fatos e atos de cunho econômico. Assim, com mais recursos, o Estado pode melhor se desincumbir de suas missões constitucionais. Logo, a tributação não pode ser desmedida a ponto de gerar distorções mercadologias ou, pior, estimular que os contribuintes abandonem o sistema legal e passem a operar, sempre que possível, na informalidade, sendo certo que em tais hipóteses o Tesouro Público é prejudicado.

Palavras-chave: conceito de ciência; direito, economia; relações entre o direito e a economia; Análise Econômica do Direito; democracia; democracia fiscal; liberdade econômica; respeito à propriedade; igualdade; igualdade formal e substancial; igualdade perante o fisco; impostos diretos; impostos indiretos; crescimento econômico. 


\begin{abstract}
Any society must decide how the common expenses will be shared and this has happened for thousands of years. From elements of the own movement of Law and Economics, this thesis formulates a scientific proposition about this theme. It's the fiscal democracy.

Starting from the basic assumption that the Law and the Economics influence each other in a dynamic of constant and no-ending stimulus and reciprocal feedbacks, this prevents the observation of the prevalence of one of these social phenomena over the other.

On the fiscal democracy, there are three substances that interact like a system of checks and balances so that one influence and be influenced by the others in a likewise balance. They are: material freedom, equality of sacrifices and the non-inhibition, by the State, of the economic activity.

The material freedom is about the respect to the basic rights of property (in ample sense) and free initiative, whose exercise allows to the individual decide how to better satisfy their needs and desires, not submitting themselves, wherefore, to the wills of the State and charity.
\end{abstract}

The equality of sacrifices reveals itself in the needing that the loss of welfare due to the tax payment to be equally shared amongst all citizens that's obtained by applying the principles of contributive capacity, progressivity and personality in order that the origin of tax, the maximum possible, is that from the direct taxes paid by the natural persons (over the income, property and goods trades in general). It's that the indirect taxes, besides those paid by companies, usually give an indirect regressive quality to the Tax System.

The non-inhibition of the economic activity allows the increase of the tax payment, once the taxes, in general, occur over economics facts and acts. This way, with more resources, State can better attain to the constitutional missions. Therefore, taxing cannot be in a way to create market distortions or, worse, stimulate that the contributors abandon the legal system and start working, always when possible, on the informality, because, in those cases, the Public Treasure is the one aggrieved.

Keywords: science comcept; economics; law; relations between law and economics; Law \& Economics; democracy; tax equality and democracy; economic freedom; respect to property; equality; direct taxes; indirect taxes; economic growth. 


\section{SINTESI}

Ogni società deve decidere come ripartire le spese comuni e tale fatto avviene da migliaia di anni. Partendo da elementi peculiari del movimento Law and Economics, la presente tesi elabora una proposta scientifica su tale questione. Si tratta della democrazia fiscale.

Si prende spunto dalla costatazione che Diritto ed Economia s'influenzano l'un l'altra attraverso una dinamica di costanti e interminabili stimoli e feedbacks reciproci, circostanza che impedisce l'osservazione della prevalenza di uno di questi due fenomeni sociali sull'altro.

Nella democrazia fiscale sono presenti tre elementi fondamentali che interagiscono come un sistema di pesi e contrappesi, in modo che ciascuno sia in grado di influenzare ed essere influenzato da parte degli altri in un auspicabile equilibrio. Tali elementi fondamentali sono: la libertà materiale, l'eguaglianza del sacrificio e la non inibizione dell'attività economica da parte dello Stato.

La libertà materiale consiste nel rispetto dei diritti fondamentali di proprietà (in senso ampio) e della libera iniziativa, l'esercizio dei quali permette all'individuo di soddisfare al meglio le proprie necessità e desideri, senza dover sottostare, in questo modo, alla volontà statale o alla carità altrui.

L'eguagliaznza del sacrificio si rivela nella necessità che la perdita di benessere causata dal pagamento dei tributi sia ripartita egualmente tra tutti i cittadini. Tale obiettivo si raggiunge grazie all'applicazione dei principi della capacità contributiva, della progressione e della personalità, in modo che il gettito fiscale provenga il più possibile da tributi "diretti" a carico delle persone fisiche (sul reddito, sulle proprietà e sulla trasmissione dei beni in generale). Il problema è che i tributi "indiretti", al di lá di quelli pagati da parte delle imprese, attribuiscono in modo generale al sistema tributario un carattere regressivo.

La non inibizione dell'attività economica permette l'incremento delle entrate tributarie, dal momento che da un punto di vista generale l'esazione incide su fatti e atti di carattere economico. In questo modo, avendo a disposizioni maggiori risorse, lo Stato può adempiere in modo migliore ai propri compiti costituzionali. La tributazione, dunque, non può essere smisurata a un punto tale da provocare distorsioni di mercato o, peggio ancora, spingere $i$ contribuenti ad abbandonare il sistema legale e a preferire operare, quando possibile, nell'informalità, essendo evidente che in tali ipotesi il Tesoro pubblico ne rimarrebbe pregiudicato.

Parole chiave: concetto di scienza; diritto, economia; relazione tra diritto e economia; Analisi Economica del Diritto; democrazia; democrazia fiscale; libertà economica; rispetto della proprietà; eguaglianza; eguaglianza formale e sostanziale; Eguaglianza dinnanzi al Fisco; imposte dirette; imposte indirette; crescita economica. 


\section{SUMÁRIO}

INTRODUÇÃO ........................................................................................................10

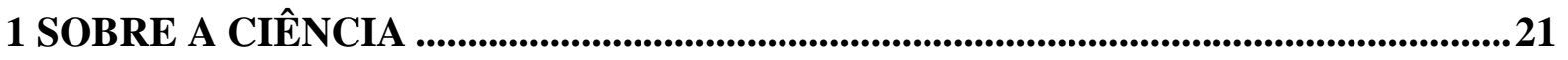

1.10 Tema ............................................................................................................................21

$1.2 \mathrm{O}$ princípio da verificabilidade ou empirismo …………..................................................25

1.30 princípio do falsificacionismo e a refutação...............................................................31

1.4 Os programas de pesquisa segundo Imre Lakatos ...........................................................37

1.5 Os paradigmas segundo Thomas Kuhn........................................................................40

1.6 Conclusão do capítulo .........................................................................................................46

2 RELAÇÕES ENTRE O DIREITO E A ECONOMIA ........................................................47

2.10 tema..............................................................................................................................47

$2.2 \mathrm{O}$ direito como um fenômeno social.................................................................................47

2.3 A ciência do direito ............................................................................................................67

2.4 A economia como um fenômeno social ...........................................................................75

2.5 A ciência da economia .........................................................................................97

2.6 Relações entre os fenômenos sociais direito e economia ............................................104

2.7 Relações entre as ciências do direito e da economia ...................................................164

2.8 Conclusão do capítulo ...................................................................................................174

3 O TRIBUTO COMO FONTE PRINCIPAL DE RECURSOS PARA O ESTADO...175

3.1 A Figura do tributo ...........................................................................................................175

3.2 Os tributos e sua concepção ao longo da história - breve esboço ............................179

3.3 As fontes de recursos financeiros do Estado ...................................................................194

3.4 Os tributos como as receitas públicas mais relevantes................................................203

3.5 Conclusão do capítulo .......................................................................................................204

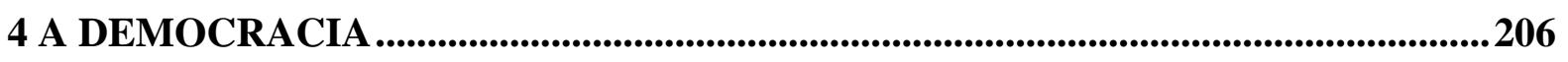

4.10 tema.............................................................................................................................206

4.2 Os tipos de democracia e sua prática.............................................................................209

4.3 Valores da democracia e suas implicações ...................................................................223

4.4 Conclusão do capítulo ..............................................................................................................238 
5 PRIMEIRO FUNDAMENTO DA DEMOCRACIA FISCAL: A LIBERDADE

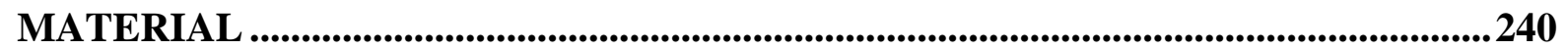

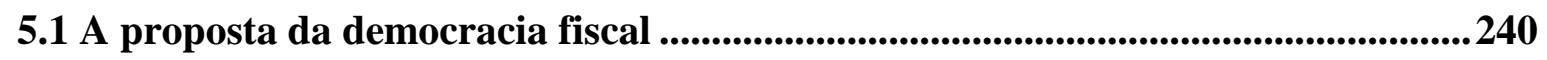

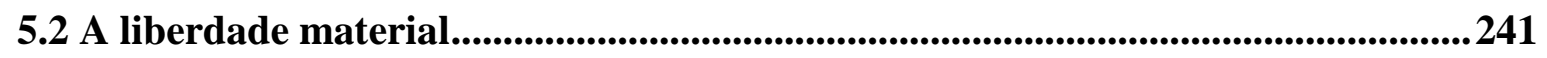

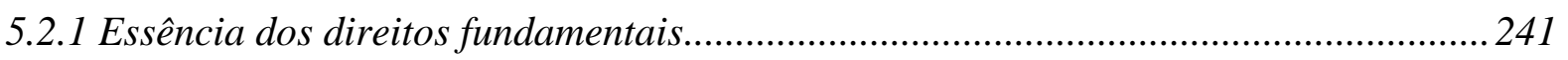

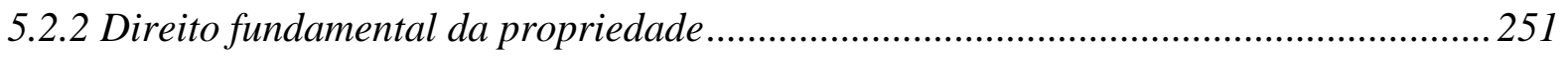

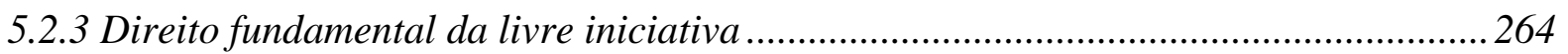

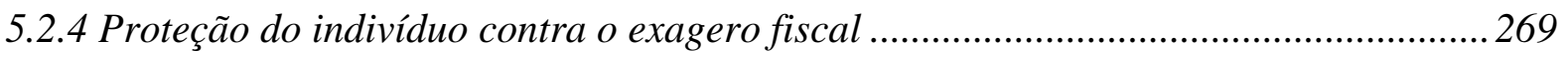

5.3 Conclusão do capítulo .............................................................................................................294

6 SEGUNDO FUNDAMENTO DA DEMOCRACIA FISCAL: IGUALDADE DE SACRIFÍCIOS PERANTE O FISCO ................................................................................295

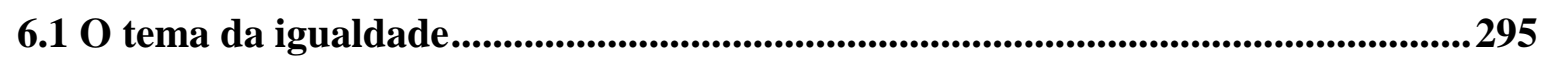

6.2 O princípio da capacidade contributiva, progressividade e solidariedade ..........297

6.3 A cláusula da pessoalidade e a questão dos tributos "diretos" e “indiretos".......303

6.4 A situação brasileira: maior detalhamento .....................................................317

6.5 Conclusão do capítulo .............................................................................................328

7 TERCEIRO FUNDAMENTO DA DEMOCRACIA FISCAL: MENOR INIBIÇÃO POSSÍVEL DA ATIVIDADE ECONÔMICA LEGAL ............................................330

7.1 Crescimento econômico e das receitas tributárias...............................................330

7.2 Inibição da atividade econômica por distorção no mercado ................................332

7.3 Inibição da atividade econômica legal e o exagero fiscal no âmbito coletivo........341

7.4 Conclusão do capítulo .....................................................................................361

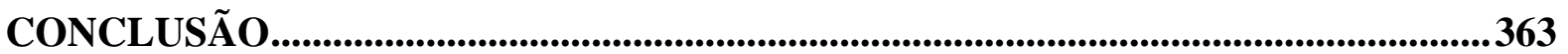

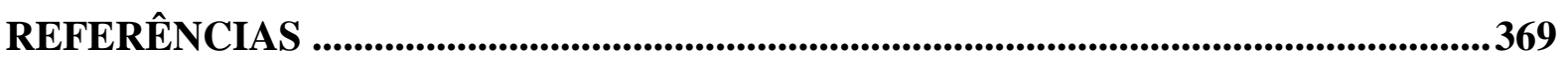




\section{INTRODUÇÃO}

Grupamentos humanos, dos mais efêmeros aos mais perenes, necessariamente, devem decidir acerca da divisão das despesas comuns, isso é, faz-se de rigor indicar quem e em que medida o patrimônio será onerado em prol do atendimento das necessidades não exclusivamente individuais.

Com efeito, tome-se como exemplo um prosaico passeio dominical de automóvel a ser realizado por três ou quatro pessoas. Obrigatoriamente, o grupo deverá acordar sobre questões como: quais critérios serão utilizados para saber quem arcará com as despesas de combustível e pedágio? A divisão será igual entre todos ou, de modo diverso, levará em conta a capacidade econômica de cada um? Deveria apenas o proprietário do veículo arcar com tudo?

E não apenas os gastos financeiros estarão em cena, mas também o "préstimo de serviços pessoais", donde podem emergir indagações como: quem será responsável pelo volante? Apenas um sujeito cuidará desta tarefa? Deveria haver um revezamento a cada cinquenta quilômetros?

Note-se que, nesses casos, por mais transitório que seja o conjunto - sua duração poderá se resumir a um par de horas -, não há como evitar a adoção de critérios delineadores do rateio das despesas comuns. Mesmo que o organizador do passeio, numa atitude de fidalguia e elegância, se proponha antecipadamente a arcar com todos os custos, inclusive se oferecendo para a direção do veículo, a aceitação desse generoso convite pelos demais se revelará, em última instância, numa decisão comum (do grupo) sobre o assunto.

O mesmo fenômeno ocorre em face de ajuntamentos mais estáveis, como, por exemplo, os condomínios de bens imóveis. A convivência estendida no tempo, aliada à relevância não apenas econômica, mas muitas vezes emocional do objeto comum ${ }^{1}$,

\footnotetext{
${ }^{1}$ É certo que exista aqui certa subjetividade, sendo bem provável que um mutuário que adquiriu sua "casa própria" após muitos anos de sacrifício considere sua unidade como de fulcral importância e de valor extremo, enquanto que outra pessoa que herdou sua unidade pense diversamente justamente por não ter dispensado tantos esforços nessa aquisição.
} 
presumivelmente, são potenciais geradoras de conflitos de interesses que podem se apresentar das mais variadas maneiras (v.g. valor do condomínio a ser pago por cada uma das unidades, rateio especial para reforma e manutenção das áreas comuns, contratação ou dispensa de empregados, instalação de antenas coletivas ou sistemas de televisão por assinatura ou, ainda, rede de internet, horários de uso das áreas de lazer, demarcação das vagas de garagem, etc.).

Muitos outros exemplos se mostram assemelhados, ou seja, decisões em torno de despesas comuns sempre se fazem presentes em: clubes sociais e desportivos, paróquias e templos religiosos, associações, sindicatos, sociedades profissionais, além, é claro, na própria sociedade civil que, jurídica e economicamente, se organiza sob o manto do Estado.

É intuitivo vislumbrar que, quanto maior o número de pessoas envolvidas num determinado grupamento, ainda mais se existirem diferenças relevantes entre elas sejam elas econômicas, sociais, culturais, etárias ou religiosas - se potencializa o surgimento de diferentes visões na escolha dos critérios a serem adotados para o suporte das despesas comuns. Inevitável, assim, o choque de interesses divergentes.

Dessa forma, enquanto numa associação alguns componentes menos aquinhoados financeiramente podem legitimamente preferir postergar a compra de uma nova sede sob o argumento de que a indigitada aquisição ocasionaria correspondente majoração nos valores das mensalidades, o que poderia obrigá-los a deixar a agremiação, outros membros, ao contrário, podem se alinhar com a proposta.

Noutro giro, a potente (e, por conseqüência, dispendiosa) iluminação das quadras de tênis de um clube, cujo benefício direto atinge no máximo quatro pessoas por partida, deve ser suportada por todos os sócios, de forma igualitária, por meio da mensalidade normal ou há de ser imposta uma contribuição especial aos tenistas? Prosseguindo, é bem plausível que condôminos de idades diversas tendam a eleger prioridades não coincidentes no edifício onde residem.

Em suma, a questão de saber quais patrimônios e sob qual grau serão onerados é recorrente e inevitável nos mais variados grupamentos humanos. O que se 
modifica é o grau de dificuldade para se atingir uma resolução razoavelmente aceita pelos envolvidos, percalço que se liga primordialmente às seguintes circunstâncias: a) relevância do objeto comum (v.g. passeio de automóvel, bem imóvel, clube ou associação, sociedade profissional, etc.); b) número de componentes do grupo; c) diferenças - econômicas, culturais, sociais e religiosas - entre os envolvidos.

Todavia, por mais espinhosas que se mostrem essas questões, decisões haverão de ser tomadas ainda que sob severo descontentamento e, possivelmente, protestos daqueles cujas propostas não se fizeram vingar.

Ora, se interesses conflitantes ou, ao menos, não coincidentes são verificáveis mesmo nos grupamentos socialmente menos expressivos e de perenidade relativa, o que dizer, então, quando esse tipo de decisão se trava do âmbito das despesas do Estado?

Além de milhões de pessoas cujos patrimônios são potencialmente atingidos, existem milhares de necessidades a serem sopesadas, desde o cuidar da segurança interna e da defesa das fronteiras, até o desenvolvimento das mais variadas políticas públicas (v.g. educação, saúde, preservação do meio ambiente e do patrimônio histórico, linhas de crédito para o financiamento agrícola e industrial, etc.).

Ora, não se pode negar que todas estas tarefas custam dinheiro, numerário que, via de regra, somente pode ser fornecido pela sociedade, principalmente por meio da arrecadação de tributos, uma vez que as outras formas de obtenção, principalmente a exploração do patrimônio dominical e a oferta de títulos da dívida pública, são insuficientes, pois a receita daquele é diminuta frente ao volume de necessidades públicas e a deste, por dever ser devolvida, em algum momento, ao prestamista, é claramente temporária.

Entretanto, a possibilidade de contribuição da sociedade em benefício do Estado é inegavelmente limitada, inclusive porque não se pode produzir riqueza infinita. É elementar, outrossim, perceber que existe, sob a dura realidade da escassez, um limite de suportabilidade à tributação, o que refletirá diretamente na capacidade do Estado de fazer 
retornar à sociedade na forma de comodidades e benefícios aquilo que previamente foi arrecado. Na incisiva colocação de CASTRO (2006, p. 51):

Do ponto de vista econômico, a implementação dos direitos sociais implica redistribuição de renda. Isto significa que o atendimento dos direitos sociais depende da despesa estatal, que, a seu turno, requer a existência de receita fiscal compatível. Portanto, o limite da capacidade dos governos de atender às reivindicações articuladas mediante a mobilização social equivale ao limite de possibilidade de despesa do Estado, dado por sua base fiscal (ou creditícia no caso da necessidade de algum endividamento estatal).

A importância do assunto se mostra verdadeira, sendo notório que, em muitos países, a carga tributária já está em aproximadamente ou, até, em alguns casos, supera os $40 \%$ do respectivo Produto Interno Bruto - $\mathrm{PIB}^{2}$, proporção semelhante às obrigações de trabalho do vassalo nas terras do senhor feudal que giravam em torno de dois ou três dias por semana, segundo informa HUBERMAN (s. d., p. 04).

Entra em cena, portanto, uma questão que não comporta resposta única, mas cujas soluções possíveis não são de simples engendramento: quais pessoas devem ter seus respectivos patrimônios atingidos pela tributação e sob qual intensidade isso deve ocorrer. Chegar a alguma conclusão é de suma importância, uma vez que, segundo prelecionam MURPHY e NAGEL (2005, p. 5):

Numa economia capitalista, os impostos não são um simples método de pagamento pelos serviços públicos e governamentais: são também o instrumento mais importante por meio do qual o sistema político põe em prática uma determinada concepção de justiça econômica ou distributiva.

A tributação se tornou, destarte, pedra angular na maioria das sociedades, notadamente pela concepção do tributo como "coisa pública", algo separado do patrimônio pessoal do rei, o que, na lição de TORRES (1991, p. 121 e ss.), somente ocorreu nos idos do século XVIII, como fruto da influência da doutrina liberal dos iluministas, cameralistas e fisiocratas.

O assunto ganha dimensão ampliada após a década de 1920 com o surgimento do welfare state, a partir de quando as funções e competências do Estado

\footnotetext{
${ }^{2}$ Conforme NUSDEO (2005, p. 299), o PIB corresponde a: "todos os bens e serviços produzidos por um sistema econômico ao longo de um dado período, normalmente um ano".
} 
passaram a se ampliar para bem além da garantia da ordem pública interna e da proteção das fronteiras contra invasões estrangeiras.

Fato é que, de um modo geral, o Estado sistematicamente passou a promover ações voltadas à universalização de serviços gratuitos como saúde, educação, previdência e assistência social. É fácil inferir que todas essas novas tarefas implicaram numa crescente necessidade de arrecadação de recursos financeiros de modo a fazer-lhes frente.

E, levando-se em conta que a quase totalidade dos serviços e atividades estatais dependem de remuneração em dinheiro, com raríssimas exceções (v.g. os mesários nos certames eleitorais e jurados no Tribunal do Júri), a tributação se mostra como fenômeno essencial e emerge como uma atividade de notório interesse público, posto que o Estado, atualmente, é o principal garantidor do ordenamento jurídico e da paz pública, além de financiador de diversas políticas públicas e sociais.

Nessa linha, segundo adverte CARVALHO (2005b, p. 103): "Sociedade sem Estado é uma impossibilidade, pois a entropia social fatalmente levaria à lei do mais forte ou a um Estado hobbesiano, anômico".

Dada a significativa diversidade de circunstâncias envolvidas nas sociedades ao redor do mundo, é que vários modelos de tributação podem se apresentar. De fato, nota-se que certos países tributam mais acentuadamente o patrimônio e a renda de seus cidadãos; outros optam por gravar mais intensamente o consumo de bens e serviços; alguns se apresentam como "paraísos fiscais" para incentivar a vinda de capitais externos, e assim por diante.

Evidentemente, é muito provável que todas essas escolhas não derivem simplesmente da vontade ou da ideologia do legislador local, mas sim da imposição das circunstâncias econômicas e sociais vigorantes em determinado instante.

Nessa toada, numa primeira hipótese, sociedades com elevado número de habitantes, mas cuja maioria dos respectivos membros apresente renda ou patrimônio pouco relevante, de modo a fazer com que a tributação de tais fatores redunde em baixa 
eficiência na arrecadação, usualmente, decidem por fortalecer a imposição sobre o consumo de bens e serviços, incluindo-se, se necessário for, alimentos e gêneros básicos de sobrevivência.

Mesmo que isso, em regra, signifique desigualdade de sacrifícios frente ao fisco ${ }^{3}$, uma vez que o ônus financeiro do gravame sobre o consumo atinge de forma idêntica pessoas em situações econômicas muito diversas, o baixo nível da riqueza per capita nessas sociedades obriga que o Estado retire os recursos para o seu sustento mínimo ignorando eventuais (ou mesmo até prováveis) iniquidades fiscais.

Diversamente, numa segunda suposição, sociedades estabelecidas em países com pequeno território (em certos casos se resumindo a poucos quilômetros quadrados), e que por isso não possuam muitas alternativas para gerar a riqueza necessária à garantia de um mínimo de bem-estar aos seus cidadãos (v.g. por meio da extração de recursos naturais do subsolo ou pela exploração agrícola ou industrial), comumente optam por criar um sistema imposicional amigável ao capital externo, por exemplo, instituindo impostos baixos sobre transações internacionais e poucas ou nenhuma exação face aos rendimentos de origem estrangeira.

Nessa última hipótese, mesmo que por força das alíquotas reduzidas em cada operação se arrecade bem pouco, o estímulo gerado por esse ambiente fiscal amistoso tende a implicar num volume suficiente de capital em movimento, com isso majorando o resultado final do Tesouro público.

Noutras realidades, numa terceira possibilidade, em locais desenvolvidos econômico e socialmente e que apresentem circulação de bens e riquezas sob proporção elevada em relação ao número de habitantes, é usual que o Estado opte por retirar a maior parte de seus recursos financeiros das incidências que atinjam a propriedade e a renda dos diversos sujeitos passivos, de modo a que o sacrifício fiscal de cada um ocorra em harmonia com a sua capacidade contributiva, instituindo-se, destarte, uma certa isonomia, ainda que mínima, no tocante ao esforço tributário de cada contribuinte em vista dos demais.

\footnotetext{
${ }^{3}$ Segundo OLIVEIRA (2005, p. 178): "A origem do nome fiscum é do cesto de junco ou de vime onde o coletor de impostos ia colocando o dinheiro que recolhia".
} 
Talvez, numa perspectiva mais realista, é provável que a maioria das sociedades ao redor do globo edifique seus sistemas de imposição fiscal sobre bases que resultem numa "mistura" das elucubrações acima, isso é, não seria estranha a constatação empírica de que muitos países adotam simultaneamente gravames tributários sobre o consumo de bens e serviços, patrimônio e a renda, bem como concedam certo alívio fiscal ao capital externo.

É quase certo não ser essa "mistura" homogênea, sendo perfeitamente esperado que cada sistema jurídico calibre diversamente dos demais a intensidade das exações sobre cada fator tributável e, ainda, ao longo do tempo insira modificações e ajustes para se adaptar a novas conjunturas que invariavelmente se sucedem, ainda mais num mundo em que a economia opera cada vez mais interligada com todos os continentes.

Diante de um cenário de possibilidades tão complexo, inegavelmente composto por uma enormidade de circunstâncias desprovidas de perenidade, é de se indagar sobre a viabilidade de cientificamente ser elaborada uma proposta apta a solucionar, de forma minimamente aceitável, a questão apresentada acima: quais pessoas numa sociedade devem ter seus respectivos patrimônios atingidos pela tributação e sob qual intensidade isso deve ocorrer.

Acredita-se que, pelo amalgamento dos valores primordiais da democracia (liberdade e igualdade) com medidas que promovam o crescimento e o desenvolvimento econômico, seja viável encaminhar uma resposta, culminando no objeto deste trabalho, denominado pelo autor de democracia fiscal.

Juntar conceitos próprios do Direito com outros afetos à Economia não deve causar grande aflição. Fato é que a doutrina mais atualizada vem aceitando cada vez mais a interdisciplinaridade desses campos do conhecimento. É que, na exposição de LEWANDOWSKI (2005b, p. 168):

O jurista, em verdade, transcende a esfera do mero ser, do Sein, para operar no campo do dever ser, ou seja, do Sollen. Ele, porém, não limita suas indagações ao plano do Sollen, pois não trabalha apenas com um conjunto de normas preceptivas, logicamente encadeadas, conforme queria Kelsen, mas opera com modelos jurídicos, que constituem, no dizer de Reale, uma síntese dialética resultante do embate entre certas 
exigências axiológicas a um dado complexo fático, travado no âmbito de determinada conjuntura histórica.

Numa apertadíssima síntese, democracia significa o governo do povo, no sentido de fazer coincidir o máximo possível governantes e governados. Assim, numa primeira ideia, a explicação da democracia considera o número de pessoas aptas a influírem nas decisões políticas de certa sociedade, que deve ser a maioria.

Segundo coloca BOBBIO (1995, p. 7), por democracia: "se entende umas das várias formas de governo, em particular aquelas em que o poder não está nas mãos de um só ou de poucos, mas de todos, ou melhor, da maior parte, como tal se contrapondo às formas autocráticas, como a oligarquia e a monarquia".

Com efeito, não se pode esquecer que o que se considera hoje por democracia, com a prática de direitos políticos universais, sem qualquer restrição quanto ao sexo, etnia, religião, escolaridade ou condição econômica, é notavelmente diferente do que se entendia por democracia no passado, recordando-se que na Atenas de Sócrates apenas uma pequena parcela da população estava autorizada a tomar as decisões políticas na Ágora.

Fato é que, finda a experiência grega, a ideia submerge por quase dois mil anos e somente ressurge ao final do século XVIII como fruto das ideias iluministas e liberais, mas não mais na forma direta, e sim mediante a representação num Parlamento eleito sob o voto censitário, segundo o patrimônio e a renda do eleitor, com as consequentes restrições quanto ao sufrágio. Os valores da liberdade e da igualdade, ainda que primordialmente sob o aspecto formal, naquele momento, são o cerne dos regimes liberais que se instalam nos Estados Unidos e na Europa após a queda do absolutismo monárquico.

A liberdade, nesse primeiro instante, teve uma conotação nitidamente econômica, ou seja, buscava-se proteger o indivíduo contra a ingerência do Estado em seus negócios particulares. Trata-se da conhecida doutrina do laissez faire, laissez passer, pois a famosa "mão invisível" do mercado se encarregaria de regular a economia, garantindo liberdade e prosperidade. Acreditava-se, outrossim, que, em face da liberdade 
mercadológica, com estímulo à concorrência e a ausência de exações de cunho extrafiscal, haveria a melhor alocação possível de recursos na sociedade.

A igualdade, de início, teve uma feição eminentemente formal, mas já representou enorme avanço na estrutura social então vigorante. Derrubados os privilégios da nobreza e do clero, muitos deles no campo fiscal, ao isentar aquelas classes das pesadas exações, proclamou-se a igualdade de todos perante a lei, sendo vedada, a partir daquele instante, qualquer distinção em vista de origem ou classe social.

Todavia, em vista de vários fatores que serão indicados no decorrer deste trabalho (v.g. ideias socialistas e marxistas, excessiva concentração de capitais, fortes crises econômicas e sociais), ocorreu uma mudança profunda na concepção desses valores. Em resumo, passou-se a aceitar certa restrição da liberdade em nome da existência de maior controle, pelo Estado, dos negócios particulares, de modo a imprimir uma direção econômica mínima e, com isso, caminhar na direção da igualdade material (não apenas perante a lei, mas na lei, ou seja, considerando as condições reais de vida da maioria dos cidadãos).

Logo, valores que anteriormente se completavam passaram potencialmente a se atritar, eis que, segundo certo entendimento da época, atingir a igualdade substancial dependeria necessariamente da profunda redução da liberdade econômica.

A proposta que buscou conciliar esse impasse deu ensejo ao welfare state e, mais tarde, à social democracia, que ainda hoje mostra sua força em países como Alemanha, França e Itália. A alternativa mais radical, que defendia a total transferência dos bens de produção para o Estado, resultou nos regimes comunistas e socialistas, dos quais restam somente dois exemplos moribundos: Cuba e Coréia do Norte.

Nessa linha de raciocínio, a democracia fiscal decorre da conjugação dos valores primordiais da democracia (liberdade e igualdade) na seara da tributação, tomando como pressuposto estar-se diante de uma democracia liberal ou, no máximo, de uma social democracia, regimes em que a maior parte dos bens de produção se pulveriza nas mãos dos indivíduos. 
Dessa feita, afirma-se que o conceito da democracia fiscal se alicerça em três fundamentos que devem operar de maneira harmônica, conjunta e interdependente, analogamente a um sistema de freios e contrapesos, em que um influencia e é influenciado pelos demais, apresentando-os a seguir, de forma inaugural. Este equilíbrio, aliás, é que indicará o grau de democracia fiscal vivenciado por determinado país.

1 ${ }^{\text {o }}$ fundamento: liberdade material. Trata-se da necessidade instransponível do Estado respeitar os direitos fundamentais da propriedade e da livre iniciativa, uma vez que é por meio do seu exercício regular que os indivíduos se tornam menos dependentes dos desígnios estatais ou da caridade alheia, ambas as situações que, se presentes, ostentam potencial para colocar sob risco a dignidade da pessoa humana. Logo, sendo a tributação um fenômeno que atua diretamente sobre estes direitos, não se pode praticá-la a tal ponto da liberdade material restar ameaçada.

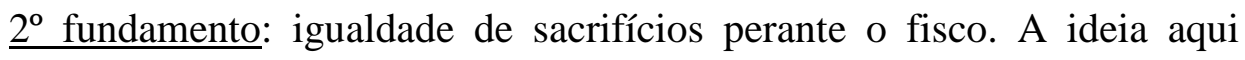
trazida preconiza que as exações devem incidir de modo que a perda do bem-estar pela obrigação de entregar parte dos recursos ao fisco seja proporcionalmente equivalente ao rico e ao pobre, que pode inclusive ser dispensado de qualquer contribuição fiscal se isso lhe ameaçar o mínimo vital. Em suma, o Estado deve buscar fazer com que o custo real, e não apenas o financeiro, seja o mais igual possível para todos.

Isso se consegue, principalmente, pela edificação de um sistema imposicional de tributação alicerçado primordialmente sobre tributos que respeitem a capacidade contributiva do obrigado e ostentem caráter pessoal, isso é, não permitam o repasse de seu ônus a terceiros. Trata-se, em síntese, de aplicar o valor da igualdade no campo da tributação.

30 fundamento: menor inibição possível da atividade econômica legal. A carga tributária imposta sobre uma coletividade qualquer não pode chegar a ponto de se tornar exagerada e passar a inibir a economia formal, na medida em que, se isso ocorrer, levando em conta que a maioria dos tributos incide sobre fatos econômicos ( $v . g$. aquisição de renda, transferência de bens e direitos, titularidade de propriedade, circulação de mercadorias, prestação de serviços, etc.), a arrecadação cairá na medida em que o fizer a própria economia. 
Consequentemente, com menos recursos em seu poder, o Estado diminuirá sua capacidade de exercer as diversas atribuições a competências constitucionalmente delineadas, ou seja, a própria sociedade civil, principalmente os mais pobres, sofrerão baixa no respectivo nível de bem-estar.

Quiçá seja ousadia desmedida pretender agregar mais um conceito de democracia ao par daqueles solidificados há tempos pelos mais doutos. Talvez o mais prudente fosse aposentar a pena num patamar mais modesto, contentando-se em chamar atenção à imperiosidade de se aprofundar as pesquisas na área da Law and Economics, evidenciando as inseparáveis interpenetrações diuturnamente travadas entre o direito e a economia, com seus estímulos e feedbacks recíprocos, numa dinâmica infindável verificada há tempos imemoriais.

Opta-se, contudo, pelo caminho que maior desafio encerra na esperança de que isso permita ao autor descortinar horizontes mais abertos e fecundos, que inclusive permitam melhor compreender a complexidade desse momento histórico particular, tanto no âmbito jurídico, como no econômico e, ainda, se não for desejar demais, que instigue a continuidade nessa trilha que provavelmente é sem fim. Com efeito, mesmo que diversos horizontes se sucedam diante dos olhos à medida que se caminha pela estrada, nunca se chega, de fato, a atingi-los algum dia.

Manifesta-se aqui o desejo sincero de contribuir, mesmo que sob o pálio de um pequeno passo, para a construção de uma proposta que consiga minimante ligar ditames e valores constitucionais de relevo, com destaque para a liberdade e a igualdade, já consagrados como componentes primordiais da democracia, com as inequívocas limitações materiais do cotidiano vivenciadas pela maioria das sociedades humanas. É o que se propõe. 


\section{SOBRE A CIÊNCIA}

\section{1 O Tema}

Antes de iniciar a caminhada propriamente dita, entende-se oportuno tecer algumas considerações a respeito da figura da ciência, no sentido de identificar melhor os objetivos e limites a serem procurados por esta tese, cujo escopo final é agregar conhecimento novo em torno do tema proposto. Este capítulo possui cunho epistemológico. Trata-se, destarte, de um breve - logo, não completo - discurso sobre o que pode ser entendido por ciência.

De início, é preciso frisar que há certo tempo a antes sólida, mas antiga, compreensão em torno das leis básicas de regência do universo, segundo as teorias precursoras de Copérnico, Galileu e Newton, foi superada por novas propostas, com destaque para a teoria da relatividade desenvolvida por Einstein, cuja base observa que o tempo se retarda na medida do aumento da velocidade, além da teoria quântica com seus princípios de incerteza na determinação simultânea do local e velocidade das partículas subatômicas em geral.

Ora, e porque seria razoável tratar desse tema? Não seria mais prático "fazer" ciência sem se preocupar com o que ela significa ou, ainda, de que maneira, procedimento, metodologia ou talvez passe de mágica ela emerge?

Bem, feliz ou infelizmente, não se pode esquecer que a aquisição de qualquer conhecimento a que se apregoe possuir cunho científico - evidentemente nem todos precisam conter tal avocação -, incluindo aqueles desenvolvidos na seara jurídica, deve necessariamente seguir certos parâmetros minimamente razoáveis e aceitáveis pela epistemologia, sob risco de meramente se auto-rotular "conhecimento científico", mas, de fato, não passar de mero palpite, sugestão ou conclamação, irremediavelmente anêmico que será quanto a um verdadeiro conteúdo persuasivo em termos de ciência.

Nessa esteira, não se pode negar - ao menos as regras de experiência assim apontam - que aquilo que for reconhecido como "cientificamente demonstrado", 
independentemente de corresponder à verdade, (v.g. um creme rejuvenescedor, uma vacina contra a gripe, a queda dos juros como meio de alavancar a economia, o recrudescimento das multas como medida profilática de controle de velocidade automotiva, etc.), adquire foros de autoridade quase incontestável.

Não cabe aqui perquirir os motivos, mas é fato que o "cientificamente testado" gera uma forte crença na veracidade da proposição, o que pode ser perigoso pelo engano potencial que encabeça no caso de o conhecimento em causa não tenha se submetido a um teste de qualidade mínima, somente realizável pela Academia.

Contudo, seria a ciência um elixir aplacador definitivo e eterno da dúvida? Seria ela anunciadora da verdade suprema? Haveria ressalvas? Qual a confiabilidade das comprovações científicas? É o que se abordará a seguir, com a tentativa de que se possa esclarecer o significado da figura da ciência e, ainda, como ela se manifesta em relação ao Direito e, por conseguinte, no âmbito deste trabalho.

Ciência é uma modalidade de conhecimento e, quanto a isso, não pairam dúvidas. Nessa linha, esse tipo peculiar de conhecimento, por preencher certos requisitos e métodos aceitos por uma comunidade de pesquisadores, se difere daquele tido por vulgar ou não-científico. Segundo FERRAZ JR. (1980, p. 10):

A ciência é constituída de um conjunto de enunciados que visa transmitir, de modo altamente adequado, informações verdadeiras sobre o que existe, existiu ou existirá. [...] O conhecimento científico, em conseqüência, constrói-se a partir de constatações certas, cuja evidência, em determinada época, nos indica, em alto grau, que elas são verdadeiras.

Entretanto, é intuitivo perceber que o conhecimento em geral pode ter outras origens. Nesse campo, dentre várias possibilidades, é possível afirmar que existe conhecimento: religioso, mítico, supersticioso, pessoal e o intuitivo que decorre das experiências pessoais de cada um. Certamente, apenas uma pequena parcela do conhecimento humano pode ser qualificada como científica.

Aliás, é bem razoável supor que uma pessoa, no desenvolvimento suas atividades diárias corriqueiras, pouco se interesse em qualificar a espécie de conhecimento - se científico ou não - que utiliza na solução de seus afazeres. Evidentemente, diante de 
algum problema, normalmente, o interessado verifica se o conhecimento disponível para resolvê-lo é útil ou não. Dessa feita, desde que possa solucionar o obstáculo encontrado, científico ou não, pouco importa a origem do conhecimento.

Por exemplo, não obstante ainda haver sérias dúvidas sobre a eficácia da vitamina $\mathrm{C}$ no combate à gripe, há uma crença geral de que essa substância funcione como meio eficaz para prevenir esta doença. Prosseguindo, muitas pessoas acreditam que o uso de medalhas, crucifixos, amuletos ou outros adereços junto ao corpo funcione como medida de proteção contra malefícios que sobre si poderiam se abater.

Noutros casos, a astrologia prega que a lua e os demais astros celestes exercem influências diversas sobre a personalidade e o destino das pessoas de acordo com o respectivo signo do Zodíaco. Ainda que as situações retratadas nos exemplos anteriores não pertençam ao âmbito da ciência, o conhecimento que transmitem, independentemente de sua complexidade, guia a vida de muitas pessoas.

Seria ingênuo supor que o conhecimento científico possui mais força persuasiva do que os demais. Isso só funciona para os que admitem o conhecimento científico como correspondente à verdade ou àquilo que mais dela se aproxima. Basta atentar ao fato de que milhares de pessoas refutam as teorias evolucionistas de Darwin, sob o argumento de que a Bíblia narra a criação da Terra de modo diverso. Para eles, com efeito, o conhecimento científico pouco ou nada vale, ainda que esteja amparado em fortes argumentos racionais e comprovações originadas da observação.

Destarte, pouco importa os métodos de datação radioativa e os registros fósseis de milhões de anos. Assim, por exemplo, para os adeptos do criacionismo, ninguém pode saber o que realmente aconteceu pela simples razão de que não havia gente para observar. Significa dizer que não há conhecimento dessas épocas e que a ciência só pode remontar ao início dos registros escritos. É interessante notar o teor de notícia publicada na internet em 26 de janeiro de $2006^{4}$ :

Londres - Mais da metade da população britânica não aceita a teoria da evolução, segundo uma pesquisa encomendada pelo programa Horizon,

\footnotetext{
${ }^{4}$ Disponível em: <http://www.estadao.com.br/arquivo/vidae/2006/not20060126p61444.htm〉. Acesso em: 15 set. 2008.
} 
da BBC. Além disso, mais de $40 \%$ dos entrevistados acreditam que o criacionismo, ou o chamado "projeto inteligente", deveria ser ensinado nas aulas de ciências das escolas. [...] Lorde Martin Rees, presidente da Royal Society, disse que "é surpreendente que muitos ainda sejam céticos em relação à teoria de Darwin. Darwin propôs sua teoria quase 150 anos atrás, e ela agora é embasada por grande quantidade de evidências. Nós somos, no entanto, sortudos em comparação com os Estados Unidos, já que nenhum grande segmento de grupos religiosos ou culturais britânicos se opõem a que a teoria da evolução seja incluída no currículo escolar".

Então, a diferença entre os vários modos de conhecimento reside no fato do conhecimento científico ser oriundo de determinada metodologia aceita por uma comunidade de pesquisadores numa certa época. Com efeito, verifica-se que o conhecimento científico é baseado em algum método que, conforme FERRAZ JR. (1980, p. 11), se constitui num "conjunto de princípios de avaliação da evidência, cânones para julgar a adequação das explicações propostas, critérios para solucionar hipóteses”. Com efeito, assevera GALVES (1967, p. 43) que:

Ciência é um conhecimento metódico e causal. Metódico porque é um modo de saber que se faz de conformidade com certas regras, e porque é um saber que expõe com ordem, e relacionando uns com outros, os resultados a que chega no estudo dos fatos e de suas causas. Causal, porque expõe a razão ou a causa, em virtude da qual os fatos são ou ocorrem desta ou daquela maneira.

Tais características afastam a ciência e o conhecimento que dela resulta, por exemplo, da ideologia, que, na colocação de GRAU (1998, p. 25):

não produz significados que valham por si mesmos, mas valores-verdades que se auto-referenciam, ou seja, valores referenciais que são verdadeiros ou falsos conforme suas relações com as pautas ideológicas que compõem sua instância de enunciação, seja como instância de conformidade, seja como contraste. $\mathrm{O}$ valor do verdadeiro ou falso, assim, no âmbito da ideologia, é arbitrário, formal - não ontológico, conteudístico. Por isso mesmo a ideologia é referencial ou monossignificativa, desconhecendo no real, por não reconhecer, tudo quanto seja com ela incompatível.

Mas, de fato, não se pode esperar que o conhecimento científico seja aceito e substitua outras crenças, sejam elas racionais, razoáveis, úteis ou não. Também não se pode afirmar que se trate de conhecimento superior, de melhor qualidade ou mesmo mais eficaz do que os demais, uma vez que isso dependerá primordialmente das finalidades do tipo de conhecimento observado em cada caso específico. 
Na lição de CHALMERS (2006, p. 212): “Cada área do conhecimento deve ser julgada pelos próprios méritos, e, em que extensão é capaz de alcançá-los. Mais ainda, os próprios julgamentos relativos aos objetivos serão relativos à situação social”.

Ademais, a concepção atual de ciência não nasceu pronta e nem possivelmente tenha se esgotado. Existe um processo histórico que permeia e influencia o respectivo significado deste modo de conhecimento e as formas de concebê-lo, conforme será a seguir esposado, ficando alertado, desde já, que o enfoque é genérico e resumido.

\subsection{O princípio da verificabilidade ou empirismo}

Prossegue-se enfocando o princípio da verificabilidade. Segundo essa corrente, cujo auge se manifestou nos séculos XVIII, XIX e início do XX, o conhecimento científico é dado pela indução a partir de uma base de dados segura fornecida pela observação. Nessa linha, quanto mais observações ocorrerem, mais confiável será a respectiva teoria.

Tal concepção foi encampada pelos componentes do chamado "Círculo de Viena", que, segundo VICENTE (2006, p. 108), se mostrou um movimento construído para tratar temas ligados à filosofia da ciência, cujo início data do começo do século passado e culmina em 1929 com um manifesto assinado por Hans Hahn, Rudolf Carnap e Otto Neurath e intitulado de $\mathbf{O}$ ponto de vista científico do Círculo de Viena. O referido autor enfatiza que (idem, p. 109):

O ideal de ciência era constituído, portanto, a partir de dois princípios básicos: o princípio do empirismo e o princípio do logicismo (daí porque esta corrente também era conhecida como empirismo lógico ${ }^{5}$ ). Daí resulta que os conceitos científicos devem ser reduzidos a conceitos observacionais.

Logo, segundo SOROS (2008, p. 57): "só as afirmações empíricas que pudessem ser confirmadas eram significativas", ou seja, apenas aquilo que é verificável por meio da observação pode ser tido como verdade científica. Todo o resto pertence à metafísica (religiões e crenças em geral). Assim, a ciência caminha para o alto e para frente, sendo que os conhecimentos novos sempre vão se somando aos adquiridos anteriormente.

\footnotetext{
${ }^{5}$ Outra denominação possível é positivismo lógico ou neopositivismo (VICENTE, 2006, p. 108).
} 
Expõe MAGEE (2003, p. 220) que: "O crescimento da ciência, acreditava-se, consistia na adição de certezas recém-descobertas a um corpo de certezas existentes em eterna expansão, como um baú de tesouros cujo conteúdo vai crescendo com o tempo".

Nesse diapasão, após ser constatado que vários tipos de metais, independentemente da temperatura ambiente inicial e da pressão atmosférica, se dilatam quando aquecidos, mesmo que não se faça a experiência com todo metal disponível do mundo, é viável aceitar cientificamente essa propriedade dos metais.

Verifica-se aqui que o raciocínio inicial é feito por indução, isso é, a partir de eventos relativamente restritos (a análise de um número $\mathrm{X}$ de metais aquecidos), chega-se, por dedução, a uma proposição geral e tida por verdadeira (todos os metais se dilatam frente ao calor). Do particular chega-se ao genérico.

Para tanto, nos dizeres de MILL (1974, p. 170), é preciso aceitar a proposição de "que o curso da natureza é uniforme" como um axioma geral, uma vez que, se os fenômenos físicos se relevarem desiguais ou não se desenvolverem de maneira idêntica em todos os locais, não será possível o estabelecimento de uma regra geral, salvo se sua aplicação se restringir a certa área ou circunstância particular, mas, então, perde-se a característica da uniformidade ou universalidade.

Noutro exemplo, suponha-se que alguém tenha lido vários textos sobre ciência e, como os achou enfadonhos, mesmo não tendo analisado - o que de fato seria impossível - todo o material disponível no mundo, por indução, formulou esta regra "todo texto que trata de ciência é cansativo". O presente texto trata de ciência, logo, por dedução, este texto é cansativo. É possível aqui observar:

$1^{a}$ premissa: todo texto que trata de ciência é cansativo.

$2^{a}$ premissa: este texto trata de ciência.

Conclusão: este tex to é cansativo. 
Constata-se que se as premissas forem tidas como verdadeiras, obrigatoriamente, a conclusão também será. Aqui não há como a conclusão ser falsa, sob pena de contradição, o que invalidaria a dedução por falta de lógica.

Entretanto, noutras hipóteses, ainda que as premissas sejam verdadeiras, a conclusão pode não ser. Tudo é uma questão de lógica. Atente-se a este outro exemplo:

$1^{a}$ premissa: a maioria dos textos que tratam de ciência são cansativos.

$2^{a}$ premissa: este texto trata de ciência.

Conclusão: este texto é cansativo.

Nesse caso, já um pouco diverso, mesmo que as premissas sejam aceitas como verdadeiras, a conclusão não é, uma vez que o texto pode pertencer à minoria não cansativa. Destarte, é inviável aceitar a conclusão como verdade.

Ainda:

$1^{\text {a }}$ premissa: todas as leis prescrevem condutas (permissivas ou proibitivas).

$2^{\mathrm{a}}$ premissa: a norma $\mathrm{X}$ é uma lei.

Conclusão: a norma $\mathrm{X}$ prescreve alguma conduta, seja permissiva ou proibitiva.

Será verdade que todas as leis prescrevem condutas (permissivas ou proibitivas)? A resposta é negativa, sendo notórios vários exemplos de leis que apenas nominam alguma rua ou avenida, bem como instituem autarquias, fundações e empresas públicas ou, ainda, tratam do orçamento anual. Nessas hipóteses, não há qualquer prescrição de conduta. Logo, se a $1^{\text {a }}$ premissa é falsa, por lógica, a conclusão segue o mesmo destino. 
Resta claro, pois, que um grande problema a ser superado no sistema indução-dedução reside em constatar a verdade das premissas. Quais métodos e sob que garantia é possível estabelecer que algo (um fato, circunstância ou suposição) é verdadeiro, ou seja, se identifica com a realidade?

Poder-se-ia responder afirmando que a indução válida é aquela baseada em observações (princípio da verificabilidade). Logo, em qualquer caso, bastaria atentar aos resultados fornecidos pelas observações para, com segurança, afirmar ser a premissa verdadeira. Porém, problemas de superação muitas vezes árdua podem surgir. Segundo CHALMERS (2006, p. 40):

O que deve ser considerado como uma variação significativa nas circunstâncias? Na investigação do ponto de fervura da água, por exemplo, é necessário variar a pressão, a pureza da água, o método de aquecimento e a hora do dia? A resposta às duas primeiras questões é "Sim" e às duas seguintes é "Não". Mas quais são as bases para essas respostas? Essa questão é importante porque a lista de variações pode ser entendida indefinidamente pelo acréscimo de uma quantidade de variações subsequentes tais como a cor do recipiente, a identidade do experimentador, a localização geográfica e assim por diante. A menos que tais variações "supérfluas" possam ser eliminadas, o número de observações necessárias para se chegar a uma inferência indutiva legítima será infinitamente grande.

Para melhor ilustrar, formulam-se estes exemplos simples: se os metais aquecidos se dilatam, conforme constatado desde tempos imemoriais, ao aquecer uma barra de aço, sendo o aço um metal, a barra se expandirá, certo? Em regra sim, pois as premissas aqui parecem ser verdadeiras. Outra situação: todos os dias alguém observa que o sol se põe, portanto a previsão de que ele irá se por hoje é verdadeira, certo? Errado, pois nas regiões polares, no verão, o sol não se põe.

Vê-se que mesmo a observação continuada e cuidadosa pode conduzir a premissas falsas, pois não é dado saber, com plena segurança, em que momento as verificações são suficientes para que se aceite alguma teoria como verdadeira.

Quantas observações são necessárias para se chegar a uma conclusão? Mesmo após milhares de procedimentos, é possível haver engano; veja-se o seguinte exemplo: alguém observa diariamente, durante vinte anos, que o ponteiro de sua bússola aponta para o norte magnético da Terra, concluindo, destarte, que esse evento sempre 
ocorrerá da mesma forma. Não é verdade, pois quando próximo do pólo (norte ou sul) esse instrumento fica pouco confiável, imprestável mesmo para fornecer orientação segura.

Ademais, como garantir que as observações foram corretas e que os resultados não são enganosos por problemas existentes em aparelhos de medições (termômetros, barômetros, cronômetros, estufas, etc.)? Portanto, a verdade como algo inatacável nunca será atingida, por mais observações que façamos. Mais uma vez, conforme CHALMERS (2006, p. 41): "Não podemos estar cem por cento seguros de que a próxima pedra atirada não 'cairá' para cima".

Isso invalida totalmente o raciocínio indutivo e a conclusão por dedução? Obviamente que não, sendo certo que a observação é, e provavelmente continuará sendo, de importância fulcral no desenvolvimento da ciência.

Todavia, é inegável a conclusão de que conhecimento científico não é conhecimento provado, mas representa conhecimento provavelmente verdadeiro, que pode se revelar inadequado com o passar do tempo pela continuidade das observações ou em vista do desenvolvimento de sistemas mais refinados de medição.

Indaga-se, nesse ponto, se o jurista poderia se utilizar desse método em suas asserções. A observação, de fato, compõe método passível de ser adotado nas pesquisas concernentes às ciências sociais, como é o caso do Direito, no que é complementada pela interpretação e pela comparação, segundo expõe LÉVY-BRUHL (1997, p. 99-100). E, como será abordado no capítulo seguinte, usualmente essa ciência procura descrever, explicar, circunstanciar, criticar e comparar as normas jurídicas em geral, podendo adotar uma inclinação dogmática ou zetética, dependendo dos objetivos ansiados pelo pesquisador.

Apoiando-se mais uma vez na lição de LÉVY-BRUHL (1997, p. 100), é certo que nas sociedades atuais as: "fontes de informação são, com efeito, abundantes e até, poderíamos dizer, superabundantes, o que por vezes impede dominá-las". Assim, num primeiro e simplificado exemplo, observando os dizeres do caput do art. $5^{\circ}$ da Constituição de 1988, conclui-se sem dificuldade que o ordenamento brasileiro acolhe, em patamar de direito fundamental, o direito à vida. 
Porém, é de se esperar que muitas propostas estarão mergulhadas em muito maior complexidade, pressupondo certamente a conjugação de várias normas além de outros elementos. De fato, antes de se propor que "o feto anencéfalo possui direito à vida, não sendo possível sua eliminação por meio de aborto", será de rigor verificar e analisar textos em vigor que tratem da matéria, passando pela Carta Magna e Códigos Penal e Civil.

E, mesmo que o assunto fosse inteiramente solucionado pelas normas positivadas (não o é!), haveria necessariamente de se considerar princípios acolhidos, expressa ou implicitamente, pela Constituição, possivelmente saindo do aspecto puramente jurídico para aportar em questões filosóficas, morais e éticas.

Vê-se que algumas constatações envolvem um raciocínio complexo, interdisciplinar e valorativo. Trata-se não apenas de uma mera observação, mas de uma compreensão. É que, na lição de FERRAZ JR. (1980, p. 15): “Ao expor diversas teorias referentes a um problema jurídico qualquer, o jurista não se limita a levantar possibilidades e, em certas circunstâncias, a suspender o juízo, mas é forçado a realizar, por vezes, uma verdadeira opção decisória”. De fato, na exposição de POSNER (2002, p. 107):

se apresentarmos um problema legal a dois pensadores do direito de igual distinção, escolhidos ao acaso, obteremos soluções completamente incompatíveis, pelo que, evidentemente, não podemos nos basear apenas no conhecimento legal para prover soluções definitivas aos problemas legais ${ }^{6}$.

Retornando ao exemplo do feto anencéfalo, não obstante serem analisados os mesmos elementos (Constituição, Códigos, princípios e questões filosóficas, etc.), dificilmente os juristas chegariam a um único resultado. Com efeito, alguns poderiam dar relevância maior a aspectos considerados secundários pelos outros.

Destarte, se o direito à vida for levado como absoluto e independente de outras circunstâncias, a tese que tenderá a prevalecer é a que nega o direito de abortar. Ao contrário, se a vida for enfocada como protegida apenas em face de viabilidade de seu

\footnotetext{
${ }^{6} \mathrm{O}$ texto original é o seguinte: "si presentarmos un problema legal a dos pensadores en derecho igualmente distinguidos, escogidos al azar, obtendremos soluciones completamente incompatibles, por lo que, evidentemente, no podemos basarnos sólo en el conocimiento legal para proveer soluciones definitivas a problemas legales".
} 
florescimento futuro, pressupondo-se que a ausência de cérebro inviabiliza que isso ocorra, a solução provavelmente se inclinará por aceitar a interrupção da gestação.

Resta claro, pois, comungando com o entendimento de SERRANO (2007, p. 66), que "para as proposições prescritivas se reservam critérios de avaliação diferentes dos de verdade e falsidade, embora também elas façam referência a uma realidade".

Então, face à constante possibilidade de, por métodos e argumentos razoáveis, juristas chegarem a resultados opostos ou, no mínimo, incompatíveis para um determinado tema, mesmo diante da análise de elementos idênticos, o método aqui tratado (observação pura e simples) é muito limitado para a ciência do direito.

Logo, é de pouca valia qualificar uma proposição jurídica de verdadeira ou falsa mesmo após a observação das normas que cuidam de determinado assunto.

\subsection{0 princípio do falsificacionismo e a refutação}

Começou-se a perceber que o conhecimento, mesmo que previamente qualificado de científico, poderia ser refutado, devendo, por conseguinte, ser retirado da "arca do tesouro" que o continha. Segundo MAGEE (2003, p. 220): "Os que tinham familiaridade com as idéias de Locke e Hume se apercebiam que as leis científicas não tinham sido provadas conclusivamente; mas em vista do sucesso aparentemente ininterrupto de sua aplicação por longos períodos de tempo".

Em verdade, é fato que as teorias, mesmo nas chamadas ciências naturais, sempre são produtos da mente humana, se materializando em construções linguísticas, e a realidade existe independentemente dessas teorizações. Assim, é imperioso concordar com CARVALHO (2005a, p. 106) quando diz que o cientista: "Está, em verdade, tentando produzir um modelo causal que busca reproduzir a realidade: tal empresa se aproxima mais de uma interpretação do que uma descrição do mundo".

Nessa toada, é o momento de se introduzir o falsificacionismo. Parte-se do princípio de que é impossível estabelecer uma regra científica irrefutável para sempre. 
Na melhor das hipóteses, uma teoria sobrevive bem por certo tempo até que, por vários motivos (novas técnicas e outras observações), reste clara sua não veracidade. O principal edificador e divulgador do princípio foi Karl Popper em meados da década de 1930 com a obra The logic of scientific discovery.

Nessa linha, conforme sua preciosa lição (POPPER, 1975, p. 41-42):

A meu ver não existe a chamada indução. Nestes termos, inferências que levam a teorias, partindo-se de enunciados singulares 'verificados por experiência' (não importa o que isto possa significar) são logicamente impossíveis. Conseqüentemente, as teorias nunca são empiricamente verificáveis. [...] Essas considerações sugerem que deve ser tomado como critério de demarcação, não a verificabilidade, mas a falseabilidade de um sistema.

Então, a base fundamental do falsificacionismo é a proposta de que a ciência, ao contrário de se ocupar primordialmente em estabelecer novos postulados, deve procurar sempre testar suas próprias teorias a partir de problemas intrínsecos que passam a ser observados no nascedouro ou com o passar do tempo.

Destarte, aquelas teorias que não resistirem aos testes e, por isso, forem refutadas, cedem lugar à subsequente, que será, então, a melhor teoria disponível para o momento, e assim por diante. Dessa feita, o papel do cientista é testar incansavelmente uma teoria até que eventualmente seja possível a refutação. Portanto, conclui-se que a crítica se torna um dos meios principais do progresso da ciência.

Atente-se que os falsificacionistas somente admitem como científicas afirmações que possam ser refutadas, ou seja, que façam juízos decisivos sobre seu objeto. É o próprio POPPER (1975, p. 42) quem diz: “[...] exigirei, porém, que sua forma lógica seja tal que se torne possível validá-lo através de recurso a provas empíricas, em sentido negativo: deve ser possível refutar, pela experiência, um sistema científico empírico".

Logo, a validação de uma teoria se faz por um critério negativo, isso é, as tentativas mal-sucedidas de invalidar uma teoria é que afirmam sua pertinência. Disso resulta concluir que afirmações como: "Deus existe", "o ser humano possui uma dimensão física, mental e outra espiritual", etc. estão definitivamente fora da ciência, pois se constituem em afirmações que não podem ser invalidadas por observações e, segundo 
MAGEE (2003, p. 223) "tudo o que poderia acontecer é compatível com sua verdade, então nada pode ser visto como prova para ela”.

Pode ser que Deus exista (o conhecimento religioso e a fé individual de cada um assim indicam), mas, como não se trata de algo refutável, não pertence à ciência, ao menos para esta corrente.

Conforme sintetiza SOROS (2008, p. 60), o método de POPPER é embasado em três elementos e três operações. Os elementos são: as condições iniciais; as condições finais e as generalizações de validade universal ou leis científicas. As operações são: a previsão (condições iniciais em consonância com a lei científica); a explicação (condições finais em harmonia com a lei científica) e o teste (somente admissível em sede de refutação e não de verificação).

Note-se que refutar uma teoria como "todos os cisnes são brancos" não implica dificuldade, pois a afirmação é categórica e única. Basta encontrar um único cisne não branco para que a refutação se materialize.

Contudo, a realidade normalmente se mostra muito mais complexa, podendo existir um labirinto de premissas a serem testadas conjuntamente. Em adição, nada garante que a refutação não esteja eivada de algum vício ou falha em suposições auxiliares ou parcela da descrição das condições iniciais.

Aqui, conforme CHALMERS (2006, p. 95): “Uma teoria não pode ser conclusivamente falsificada, porque a possibilidade de que alguma parte da complexa situação do teste, que não a teoria em teste, seja responsável por uma previsão errada não pode ser descartada".

Além disso, em certas circunstâncias, algo falsificado de início, posteriormente pode ser aceito, não apenas por uma questão de erro nos testes, mas pelo aprimoramento de outras técnicas "paralelas". Logo, nessas hipóteses, o que antes fora refutado, retorna vívido. CHALMERS (2006, p. 97 até 107) narra com detalhes quatro exemplos históricos: teoria gravitacional de Newton, teoria do átomo de Bohr, teoria cinética de Mexwell e a revolução copernicana. Portanto, em situações que tais, a 
falsificação não é capaz de garantir que uma teoria que chegue a refutar outra seja efetivamente mais precisa que a anterior "falsificada".

Trata-se, em resumo, de uma suposição, ou seja, via de regra, o que normalmente se observa é que a teoria apta de refutar outra é mais aproximada da verdade do que a antecessora, mas há exceções, com a "reabilitação" da teoria arquivada.

Diante de tal cenário é possível vivenciar algum desânimo. E, se nos dizeres de POPPER (1975, p. 305): “Nossa ciência não é conhecimento (episteme): ela jamais pode proclamar haver atingido a verdade ou um substituto da verdade, como a probabilidade", não seria inútil preocupar-se com ela? Em que pese essa conclusão algo decepcionante (para alguns), a resposta é dada, mais uma vez, pelo próprio POPPER, ao afirmar categoricamente que: "o esforço por conhecer e a busca da verdade continuam a ser as razões mais fortes da investigação científica” (idem).

Seria o falsificacionismo aplicado na ciência do direito? A resposta é afirmativa, mas de forma limitada, ou seja, somente é possível falsificar teorias jurídicas simples, como, por exemplo, a seguinte proposta: "a Constituição de 1988 não permite que o Estado brasileiro institua e aplique a pena de morte". Tendo em vista que o art. $5^{\circ}$, XLVII, "a" do Texto Maior admite a pena capital em caso de guerra declarada, a proposição é falsa, sendo certo que o Estado brasileiro poderá dela fazer uso nessa hipótese especial.

Prosseguindo, é de ser lembrado que, se as propostas mais complexas (exemplo do feto anencéfalo) não se coadunam com a insígnia de verdadeiro, também não lhes será apropriada taxá-las de falso, justamente porque entendimentos opostos são previsíveis e, desde que se façam por meio de argumentos racionais que contradigam as premissas da proposta, são plenamente viáveis em termos de ciência do direito. Aqui se têm divergências que se perduram no tempo, com debate doutrinário renovado e constante, sendo muito difícil, em muitas ocasiões, admitir a superação de uma delas.

Como é sabido, teorias rivais podem conviver durante anos sem que se possa afirmar ou prever um prazo para a suplantação de uma delas, v.g.: a natureza jurídica da posse como sendo um fato ou um direito, segundo a conhecida polêmica que se 
estabeleceu entre Savigny e Ihering e retratada por inúmeros civilistas, com destaque para GOMES (1993, p. 17 e ss.); a viabilidade de se utilizar preço ou tarifa pública como elemento de remuneração de serviços públicos (AMARO, 2007, p. 40 e ss.; CARRAZA, 2004, p. 491 e ss., COELHO, 1996, p. 52 e ss. e OLIVEIRA, 1997, p. 37 e ss.); o Município como entidade federada ou não (SILVA, 2008, p. 640 e ss.).

Evidentemente, é certo que muitas teses jurídicas sucumbiram em face de proposições posteriores, como, por exemplo, a propriedade vista como um direito absoluto e sua utilização sem correspondência ao seu fim social; o pacta sunt servanda a embasar a imutabilidade contratual mesmo diante de fatos imprevistos e excessivamente onerosos a uma das partes; a responsabilidade extracontratual do Estado com fulcro na teoria da culpa; o crédito público como um mero contrato de Direito Privado em que as partes se colocam em plena igualdade de direitos e obrigações.

Logo, em vista da impropriedade de se considerar falsificada uma tese jurídica, ao menos as complexas, propõe-se que a qualificação se restrinja a um juízo de aceitabilidade. Nessa ótica, enquanto acolhida pela maioria dos cientistas do direito, a tese resta "aceitável" e, entrando em cena o descrédito, passa a ser "não aceitável". O mesmo raciocínio pode ser aplicado em relação à ciência da economia, uma vez que, na explicação de POSNER (2007b, p. 488):

a teoria econômica se tornou tão rica e tão complexa que praticamente qualquer hipótese, mesmo a que parece negar uma implicação fundamental da teoria, como a lei da procura, poderia ser levada a ajustarse à teoria. Por exemplo, uma descoberta de que a procura de um produto aumentou em resposta a um aumento de seu preço poderia ser racionalizada ao se argumentar que o produto era uma mercadoria inferior (Giffen good), ou que os consumidores, enganados pelo aumento do preço, presumiriam que a qualidade do produto se tornara melhor; os consumidores, freqüentemente, estão certos ao fazê-lo. De fato, a lei da procura parece resistente; porém é desagradavelmente fácil invalidar as descobertas empíricas que parecem estar em conflito com as hipóteses e proposições teóricas básicas da economia.

Interessante notar que uma proposta pode nascer "não aceitável", talvez como fruto de um posicionamento isolado e, com o decorrer do tempo, passa a ser “aceitável”. Isso se deu no Brasil, por exemplo, com a doutrina atualmente dominante em torno da responsabilidade extracontratual do Estado, havendo sido percorrido um longo caminho para que se chegasse à responsabilidade objetiva (independentemente da culpa do 
agente público) positivada na Constituição de 1988 , no seu art. $37, \S 6^{\circ}$. Segundo noticia MEIRELLES (1996, p. 563):

Desde o império os nossos juristas mais avançados propugnavam pela adoção da responsabilidade sem culpa, fundada na teoria do risco que se iniciava na França, mas encontraram decidida oposição dos civilistas apegados à doutrina da culpa, dominante no Direito Privado, porém inadequada ao Direito Público, como o autorizam os nossos mais autorizados monografistas.

O direito positivo adotou uma posição algo ambígua em relação à doutrina então prevalecente, ressaltando-se que o previsto no art. 15 do Código Civil de 1916 permitiu interpretação em ambos os sentidos, ao preceituar o seguinte:

As pessoas jurídicas de direito público são civilmente responsáveis por atos de seus representantes que nessa qualidade causem danos a terceiros, procedendo de modo contrário ao direito ou faltando a dever prescrito por lei, salvo o direito regressivo contra os causadores do dano.

Todavia, a redação imprecisa do dispositivo permitiu a insurgência de autores que defendiam, mesmo sob a vigência do referido art. 15, que a responsabilidade seria objetiva, isso é, sem a imperiosidade de demonstração de culpa do agente público. Conforme a lição de DI PIETRO (2002, p. 529):

A expressão procedendo de modo contrário ao direito ou faltando a dever prescrito por lei conduzia à idéia de que deveria ser demonstrada a culpa do funcionário para que o Estado respondesse. No entanto, a redação imprecisa do dispositivo permitiu que alguns autores defendessem, na vigência desse dispositivo, a teoria da responsabilidade objetiva.

Vê-se, então, que paulatinamente a antes "não aceitável" tese da responsabilidade objetiva do Estado se fortalecia e ganhava novos adeptos, tornando-se posteriormente majoritária, a ponto do art. 194 da Constituição de 1946 a ter positivado ao determinar que: "As pessoas jurídicas de direito público interno são civilmente responsáveis pelos danos que os seus funcionários, nessa qualidade, causem a terceiros”. 


\subsection{Os programas de pesquisa segundo Imre Lakatos}

Conforme visto, o falsificacionismo puro não resolve todos os problemas, uma vez que, em várias hipóteses, uma teoria inicialmente considerada imprópria pode posteriormente ser reabilitada por outras observações ou reflexões mais acuradas.

Então, ciente dessa circunstância, Imre Lakatos apresenta a proposta de que a falsificação não deva ser instantânea ou mecânica, ao contrário, há de ser tratada sob a égide mais complexa e abrangente de um programa de pesquisa inicialmente proposto e colocado para se desenvolver.

Dessa feita, nesse programa de pesquisa haveria um núcleo irredutível a ser aceito pelos pesquisadores, surgindo daí teorias auxiliares e subjacentes, capazes de receberem refutações sem que reste comprometido o núcleo.

É o que CHALMERS (2006, p. 113) considera como um "cinturão protetivo" contra falsificações. A ideia é que, pelo "cinturão protetor", seja possível a determinado programa se desenvolver, atingindo seu ápice ou, ao contrário, entre em decadência por não mais conseguir explicar os fenômenos em coerência com o núcleo.

É a partir do núcleo, cuja base é alguma hipótese teórica geral, que os programas se realizam, sendo que apenas suposições adjacentes e acessórias podem ser refutadas, mas não o seu núcleo, pois esse deve ser aceito pelo pesquisador, ainda que provisoriamente. Assim, o núcleo deve ser tido por irrefutável, sob pena de se iniciar um novo programa.

Por exemplo, na exposição de SILVEIRA (1996, p. 02), o núcleo firme de Copérnico era a proposição de que as estrelas constituem o sistema de referência fundamental para a física; o de Newton era fundeado nas três leis básicas do movimento e na lei da gravitação universal; o de Piaget se fixava na hipótese de equilíbrio; o de Pasteur afirmava que a fermentação é um fenômeno correlacionado com a vida.

Nessa linha de raciocínio, mesmo diante de fatos e observações problemáticas (refutações ou anomalias), as premissas do núcleo não seriam descartadas de plano; tentar-se-ia, no primeiro momento, salvar o programa. 
Aqui, SILVEIRA (1996, p. 02) fornece um exemplo muito interessante e deveras esclarecedor: constatou-se que a órbita do planeta Urano não estava de acordo com a observação astronômica, salvo se a teoria de Newton (a mecânica) fosse refutada. Ao invés de considerar a teoria como "falsificada", em torno de 1845, Adams e Leverrier propuseram que a dita discordância deveria ser carreada à influência de algum outro planeta ainda não descoberto e, por isso, é que os cálculos restavam inexatos. A hipótese, ainda que meramente teórica, permitiu recalcular o trajeto desse sugerido "novo planeta", indicando locais mais precisos para novas observações que posteriormente confirmaram a existência de Netuno.

Entretanto, é certo que um programa pode entrar em decadência, chegando à exaustão e superação. E quando isso ocorreria? Conforme CHALMERS (2006, p. 117), o programa seria degenerescente frente a sua incapacidade de descobrir fenômenos novos, isso é, somente oferecer explicações a descobertas casuais ou a fatos antecipados e descobertos por um programa rival.

Portanto, segundo Lakatos (apud SILVEIRA, 1996, p. 04): "Se um programa de pesquisa explica de forma progressiva mais fatos que um programa rival, 'supera' a este último, que pode ser eliminado (ou se se prefere, arquivado)".

Evidentemente, o fenômeno não é instantâneo, mas decorre de um processo histórico, relembrando que o "cinturão protetor" deve ser capaz de absorver a pressão crítica de algumas refutações secundárias. Destarte, o pluralismo teórico com a coexistência de programas concorrentes é importante para o progresso da ciência. Contudo, nunca é dado saber o momento certo de se arquivar um programa, que pode se prolongar por décadas agonizando antes de perecer.

Seria admissível na área jurídica encontrar programas de pesquisas com um núcleo essencial e irredutível a serem desenvolvidos? Em princípio sim, desde que se tenha consciência de que a pesquisa numa ciência social como o Direito se serve de uma metodologia diversa daquela apropriada às ciências naturais.

De qualquer modo, à primeira vista, seria possível considerar a proposta da Law and Economics (ou Análise Econômica do Direito) como um programa de pesquisa 
latu sensu com origem nos Estados Unidos nos trabalhos de Ronald Coase: The problem of social cost, de 1960; Guido Calabresi: Some thougts on risk distribution and the law of torts, de 1961 e Richard Posner: Economic analisys of law, de 1973, segundo informa ALVAREZ (2006, p. 52).

Para essa escola, um ponto central que poderia ser identificado como um de seus programas de pesquisa merecedor de atenção do cientista é a proposta de que os indivíduos são agentes racionais que escolhem suas ações para maximizar suas utilidades individuais com base numa ordem coerente de preferências transitivas. Logo, as escolhas individuais seriam sempre guiadas por um raciocínio econômico do melhor proveito sob o menor custo possível, sendo que este raciocínio é que deve inspirar o legislador e o aplicador do direito.

Em rivalidade a esse programa, destaca-se a Critical Legal Studies (ou Escola Crítica do Direito), tendo como uma de suas propostas primordiais, segundo ALVAREZ (2006, p. 59), de que outros valores hão de ser considerados que não apenas a eficiência econômica das normas, de maneira a colocá-las a serviço de finalidades humanas e sociais. Aqui, então, questões éticas sobrepõem-se à eficiência do mercado.

Cada ramo de estudo do direito acaba por apresentar tais programas de forma mais ou menos explícita. Assim, por exemplo, programas quanto ao desenvolvimento do conceito e extensão de figuras como: dignidade da pessoa humana, interpretação das normas constitucionais, classificação dos tributos, interesses difusos e coletivos, competência regulamentar da Administração Pública, abuso do poder econômico, responsabilidade fiscal, negócio jurídico, e muitos outros.

Seria ingênuo esperar que a instalação de um programa seja precedida de alguma formalidade, com ata de sua constituição e registro em Cartório, algo semelhante a uma associação de pesquisadores. Óbvio que não se trata disso. Com efeito, o programa, jurídico, ou não, se constitui fundamentalmente numa tese ou proposição que gera frutos, isso é, que atrai atenção de outros pesquisadores que permanecem no estudo do tema aprofundando-o e levantando problemas e soluções viáveis até que um programa rival seja capaz de fazer o antigo decair e assim por diante. 


\subsection{Os paradigmas segundo Thomas Kuhn}

O paradigma pode ser equiparado a um modelo, um pressuposto ou um conjunto de premissas. Na lição de CHALMERS (2006, p. 124) "é composto de suposições teóricas gerais e de leis e técnicas para a sua aplicação adotadas por uma comunidade científica específica".

Em linha semelhante, segundo AMARAL JR. (1993, p. 17), o paradigma é "o conjunto de crenças, valores, conceitos, teorias e técnicas que são partilhados sem discussão por uma dada comunidade científica”.

Portanto, uma das suas principais características é, nos dizeres de FARIA (2004, p. 48), servir como "um princípio explicativo fundamental e algumas explicações exemplares, que são aceitas pelos cientistas a ponto de suspenderem o esforço crítico de discussão de seus pressupostos e de suas possíveis alternativas substitutivas”.

Evidentemente, um paradigma não surge pronto, tampouco decorre de um passe de mágica e muito menos pode ter sua aceitação pelos membros de uma comunidade imposta de modo coercitivo. Com efeito, trata-se do resultado de um consenso que se forma aos poucos, ao longo de certo interregno, perante determinado grupo de cientistas que lhe traça as bases paulatinamente.

Na colocação de KUHN (2003, p. 44): “Os paradigmas adquirem seu status porque são mais bem sucedidos que seus competidores na resolução de alguns problemas que o grupo de cientistas reconhece como graves".

Todavia, com o passar do tempo, as pesquisas realizadas sob o suporte de um paradigma tendem a se aprimorar culminando em novos obstáculos até que o modelo antes acolhido sem controvérsias já não responde satisfatoriamente às novas e inevitáveis arguições, empurrando a outrora e estável "ciência normal" para uma crise ou "revolução" até que ocorra a troca de paradigma que, segundo KUHN (2003, p. 116), representa "uma reconstrução da área de estudos a partir de novos princípios, reconstrução que altera algumas das generalizações teorias mais elementares do paradigma, bem como muitos dos seus métodos e aplicações". 
Vitorioso o novo paradigma, inicia-se, por conseguinte, a nova fase de "ciência normal" em que as pesquisas aprofundam e detalham as hipóteses inicialmente traçadas ao paradigma, até que, inevitavelmente, passado certo período, novamente aflore outra crise para abalar os seus pilares e assim se prossegue indefinidamente. Melhor explicando, segundo BORRADORI (2003, p. 210-211):

\begin{abstract}
A instauração da primeira, a fase normal, depende da imposição gradual de um sistema teórico mediante o consenso cada vez mais crescente da comunidade. De um período pré-paradigmático, conotado por uma acumulação caótica de fatos, a prática científica se normaliza em torno da instituição de um "paradigma", que representa uma mescla normativa de teoria e de método. [...] A certa altura, porém, a solidez do paradigma começa a rachar e a fase de ciência normal se transforma em fase de ruptura revolucionária. [...] A história é pontilhada destes exemplos: a transição do sistema aristotélico para o galileano e do ptolomaico para o copernicano, na astronomia, e a passagem da química do flogisto para a de Lavoisier são apenas os mais clássicos.
\end{abstract}

Na síntese proposta por FARIA (2004, p. 49): “da mesma maneira como um paradigma é uma crença partilhada pelos membros de uma comunidade científica, uma comunidade científica é um conjunto de cientistas reunidos em torno de um paradigma”.

Logo, qualquer raciocínio ou argumento é considerado "científico" por gozar de crédito junto aos pesquisadores membros e não porque efetivamente resulte da aplicação global de uma regra ou "verdade" universal ou provada.

Percebe-se disso que a tarefa primordial dos pesquisadores na fase de "ciência normal" não é tentar falsificar o paradigma, mas desenvolvê-lo ao máximo, eliminando discussões sobre seus fundamentos, fixando regras e padrões gerais aplicáveis na solução dos enigmas.

Com efeito, o paradigma e suas bases informadoras devem ser aceitos pelos cientistas da comunidade e, em princípio, eventuais falhas em solucionar problemas emergidos são encaradas, preliminarmente, como anomalias passíveis de superação no futuro, ainda mais porque, em termos práticos, conforme informa KUHN (2003, p. 45), os cientistas usualmente se mostram intolerantes com novas teorias, sendo que "a pesquisa científica normal está dirigida para a articulação daqueles fenômenos e teorias já fornecidos pelo paradigma". 
Evidentemente, a partir do instante em que os problemas se acumulam a ponto de desequilibrarem seriamente as bases do paradigma, é que se inicia a fase "revolução", isso é, ao mesmo tempo em que se passa a reconhecer expressamente o fracasso do paradigma até então vigente, trata-se de se iniciar a construção de outro, com adesão (cessando as críticas) aos novos parâmetros.

Nesse instante, é intuitivo antever que nem todos os componentes da comunidade em crise necessariamente darão o passo adiante, sendo plenamente possível que parte do grupo opte por permanecer insistindo em superar as incongruências já aceitas e incorporadas por outros, ocorrendo, destarte, uma ruptura entre os membros.

Não é possível prever com exatidão quanto tempo será necessário para a troca de paradigmas, sendo previsível inferir inclusive que a crise ou revolução possa perdurar por muito tempo. Conforme relata CHIBENI (s. d., p. 01):

\begin{abstract}
As investigações da ciência normal acabam levando, não intencionalmente, à acumulação de quebra-cabeças particularmente resistentes às tentativas de resolução. Essas dificuldades de ajuste do paradigma à Natureza não são vistas como falseadoras do paradigma, mas como meras anomalias (Seções 6 e 7). Quando incidem sobre partes vitais do paradigma, ou estão ligadas a algum fator externo premente, ou acumulam-se em grande número, ou resistem por muito tempo, essas anomalias levam a estados de crise (Seções 7 e 8). Somente então iniciase a busca deliberada de alternativas para o paradigma vigente. Fatores variados e não necessariamente racionais podem levar um indivíduo, ou um pequeno grupo de indivíduos, a se interessar por uma dessas alternativas, por embrionárias que sejam, e tomar para si a tarefa de desenvolvê-la, e, posteriormente, de convencer o restante da comunidade científica a que pertencem. Apenas nessas condições a comunidade científica pode se dispor a abandonar o seu paradigma; um paradigma nunca é rejeitado sem que concomitantemente um outro seja aceito. Esta é outra constatação importante de Kuhn (Seção 8).
\end{abstract}

Prosseguindo, não se nega, antes se admite, que diferenciar um paradigma de um programa de pesquisa nos moldes preconizados por Lakatos nem sempre é uma tarefa fácil.

É de ser lembrado, todavia, que o programa de pesquisa é algo relativamente abrangente, sendo dotado do mencionado "cinturão protetor", ou seja, se constitui no conjunto do trabalho de vários cientistas, enquanto o paradigma implica numa única ou poucas premissas essenciais que necessariamente precisam ser acatadas pelo 
pesquisador, cumprindo-se as fases de "pré-ciência", "ciência-normal" e "revolução". Portanto, as séries de pesquisas que resultam no "cinturão protetor" provavelmente adotarão por bases elementares alguns paradigmas.

Seria o fenômeno da sucessão dos paradigmas verificável no campo dos estudos jurídicos? Entende-se que sim, citando-se como exemplo as bases das escolas do jusnaturalismo, positivismo e pós-positivismo.

Conforme relata FRANÇA (1974, p. 37-38), para um jusnaturalista do século XVIII: “o Direito Natural seria um sistema completo, universalmente válido e imutável, deduzido de uma noção abstrata do homem e da sua natureza”. Na mesma linha, sobre as Declarações de Direitos que então surgiam (v.g. Declaração de Direitos de Virgínia, de 1776 e a Declaração dos Direitos do Homem e do Cidadão, de 1789), LEWANDOWSKI (1984, p. 11) assevera:

acreditava-se que os direitos individuais não constituíam uma ação do Estado, posto que existiam antes do advento deste, bastando, pois, para fazê-los respeitados, declarar expressamente a existência dos mesmos, depois de racionalmente deduzidos da natureza humana ${ }^{7}$.

Então, segundo tal concepção de direito, constata-se que o fundamento e a obrigatoriedade das normas jurídicas não residiam, como posteriormente passou a ser regra, no fato de terem sido legisladas segundo uma ordem pré-estabelecida, mas sim na circunstância de corresponder a um ideal de Justiça, cuja apreensão se faria pelo uso da razão humana.

Tratava-se, com efeito, de se "geometrificar" ou mesmo "matematificar" as normas jurídicas, afastando-as de uma concepção histórica, ou seja, como fruto da evolução e contínuo convívio entre os seres humanos.

Nesse sentido, conforme BOBBIO (1987, p. 21): "Se a interpretação foi o método tradicional da jurisprudência, o método da nova ciência do direito será - à imitação das ciências mais evoluídas - a demonstração".

\footnotetext{
7 Ainda acerca das Declarações, FERREIRA FILHO (2008, p. 16) indica que: "para os autores das Declarações, estas constituiriam o crivo pelo qual se aferiria a validade dos atos de governo. O poder estatal, portanto, havia de ficar dentro dos limites fixados pelas Declarações ao enunciar os direitos fundamentais. [...] Tais limites se impõem ao próprio poder constituinte".
} 
Logo, as regras jurídicas poderiam ser conhecidas com certeza, pois, segundo BOBBIO (1987, p. 23): "Em suma: o que os jusnaturalistas eliminam de seu horizonte é a interpretatio: mesmo que os juristas continuem a interpretar as leis, o jusnaturalista não é um intérprete, mas um descobridor".

No século XIX o jusnaturalismo decai por uma série de razões ${ }^{8}$ que não serão apresentadas neste tópico e, por meio de uma mudança de paradigma, em seu lugar inicia-se a escola positivista, cuja premissa, conforme delineado por ROSS (2003, p. 134), é que: "em toda comunidade existe uma vontade soberana, que é a fonte suprema de toda validade jurídica. A expressão desta vontade, o direito legislado, é, consequientemente, a fonte suprema do direito”. Em linha semelhante, para KELSEN (1987, p. 252):

Uma norma somente pertence a uma ordem jurídica porque é estabelecida de conformidade com outra norma desta ordem jurídica. Por esta via, somos reconduzidos à norma fundamental, que já não é estabelecida de conformidade com a determinação de uma outra norma e que, portanto, tem de ser pressuposta.

Então, por esse raciocínio, pouco interessa o fato da norma jurídica corresponder a um ideal de Justiça ou não, mas sim o respeito a um processo formal de edificação previamente estatuído.

Não obstante os paradigmas positivistas ainda estarem em voga no mundo ocidental, constata-se a presença de outras propostas denominadas de póspositivistas, que abandonam o paradigma do direito legislado como fonte basilar do direito para considerar também, segundo DANTAS (2005, p. 53): "os princípios e valores morais como fontes de Direito latu sensu quando eles aparecerem em um contexto jurídico, ou seja, quando são razões justificadoras no discurso jurídico". Em sentido análogo, enfatiza AMARAL JR. (1993, p. 91-92) que:

\footnotetext{
${ }^{8}$ Ressalta-se apenas o anseio geral dos agentes econômicos por segurança jurídica, o que teoricamente seria obtido pela concentração no Estado daquela que deveria ser a fonte primordial do Direito, no caso, a lei editada pelos Parlamentos. Segundo CORDEIRO (2007, p. 365-366): "A formação do Estado moderno foi o primeiro passo para a confirmação da hegemonia do positivismo jurídico. O seu advento é o pressuposto lógico da primeira característica do Direito positivo: o monopólio do Estado como fonte de Direito. [...] O Direito deveria ser proveniente de uma única fonte porque somente assim a ordem e a paz seriam asseguradas. E esta autoridade somente poderia ser o Estado. O Estado passa, então, a deter o monopólio da produção legislativa. Nessa idéia de necessidade de segurança jurídica (valor base do positivismo ético e sustentáculo ideológico da doutrina positivista) que surgiram as codificações oitocentistas, com a pretensão de universalidade e perpetuidade".
} 
O direito não é mais visto como a totalidade de regras postas, mas como conjunto de regras que se propõem continuamente. [...] Portanto, a questão decisiva para o novo saber jurídico passa a ser a construção de instrumentos teóricos que permitam compreender o processo de legitimação pelo qual normas, valores e princípios se tornam vinculantes em um sistema jurídico determinado.

Portanto, ao que tudo indica, na colocação de BARROSO (2007, p. 06): "O marco filosófico do novo direito constitucional é o pós-positivismo. Em certo sentido, apresenta-se ele como uma terceira via entre as concepções positivista e jusnaturalista". Logo à frente, o autor (idem, p. 09) noticia modificação de paradigma quanto ao modo de vivenciar as normas constitucionais. Em suas palavras:

Uma das grandes mudanças de paradigma ocorridas ao longo do século $\mathrm{XX}^{9}$ foi a atribuição à norma constitucional do status de norma jurídica. Superou-se, assim, o modelo que vigorou na Europa até metade do século passado, no qual a Constituição era vista como um documento essencialmente político, um convite à atuação dos Poderes Públicos. A concretização de suas propostas ficava invariavelmente condicionada à liberdade de conformação do legislador ou à discricionariedade do legislador. Ao Judiciário não se reconhecia qualquer papel relevante na realização do conteúdo da Constituição.

Vê-se, pois, que a sucessiva substituição de paradigmas também ocorre no campo jurídico. Portanto, é muito relevante para o desenvolvimento da ciência a diversidade de concepções. Em resumo, se alguma conclusão daqui se tira, fazendo-se coro a FRIEDE (1997, p. 04), é da de que:

a ciência não pode, sob pena de sublime subversão lógico-conceitual, ser encarada como algo que se traduz por uma verdade absoluta, mas, ao contrário, necessariamente deve ser entendida como algo que busca, de forma constante e permanente, a verdade (em sua acepção plena), aproximando-se cada vez mais da mesma, porém sem nunca poder atingila, ou tangenciá-la com plena segurança.

Na síntese precisa de NUSDEO (2005, p. 67): “A ciência pode ser vista como um jogo sem fim. E o parceiro que entenda deter uma proposição imune à

\footnotetext{
${ }^{9}$ Nos Estados Unidos este fenômeno teve início anteriormente. Segundo expõe CASALINI (2006, p. 264): "Nos Estados Unidos, entre 1764 e 1776, afirmou-se uma concepção de Constituição que representa um verdadeiro e próprio divisor de águas em relação ao pensamento constitucional pré-moderno. A Constituição não será mais entendida como um aglomerado de leis, costumes e tradições, mas será considerada um esquema fundamental de governo, reconduzível a um corpo sistemático e escrito de normas. A Constituição assume um caráter normativo e não mais simplesmente descritivo. A própria palavra Constitution é, pela primeira vez, utilizada naqueles anos no seu significado hodierno, e o poder da Constituição é posto claramente acima do poder do legislador ordinário".
} 
comprovação retirou-se desse jogo. Estará noutro campo: no da religião, no da ideologia ou da magia; não no da ciência".

\subsection{Conclusão do capítulo}

Por força do exposto nesse capítulo, resta claro que a ciência não corresponde ao acúmulo constante e crescente de conhecimento.

Logo, não pode ser equiparada a uma verdade demonstrada ou absoluta. Ao contrário, a vinda de novas e mais aprimoradas proposições acabam por resultar no abandono de concepções então vigentes, ainda que esse fenômeno ocorra de maneira gradual, em face da proteção conferida pelos "cinturões" dos programas de pesquisa ou, ainda, pela natural resistência das comunidades científicas substituírem um paradigma por outro.

Percebe-se que o passar do tempo atua como verdadeiro agente corrosivo sobre as bases das teorias e conclusões científicas. Então, afirmações tais como "verdadeiro" ou "falso" devem ser formuladas - e também aceitas - sob a máxima cautela, além de revestidas da cláusula "sob censura" ou "salvo melhor juízo", ainda mais quando estiver em foco uma ciência social, como é o caso do Direito. 


\section{RELAÇÕES ENTRE O DIREITO E A ECONOMIA}

\subsection{0 tema}

$\mathrm{Na}$ medida em que esta tese é embasada em conceitos jurídicos e econômicos, ainda que os primeiros prevaleçam no cômputo final do trabalho, este capítulo tem por intenção investigar algumas das relações que se travam entre o direito e a economia.

$\mathrm{Na}$ realidade, quando se aborda esse assunto, é possível inferir a existência de, no mínimo, dois níveis de convivência: o primeiro, estabelecido entre as normas jurídicas (o direito em si) e os fatos e ações de índole econômica (a economia), e o segundo, vigente entre as ciências que se debruçam sobre cada um destes fenômenos sociais, atentando-se que um fato ou conjunto de acontecimentos, seja de cunho natural ou social, não se confunde com a ciência que o vem a estudar ${ }^{10}$.

\section{$2.2 \mathrm{O}$ direito como um fenômeno social}

Se, na colocação de CARVALHO (2004, p. 02): “As regras do direito existem para organizar a conduta das pessoas, umas com relação às outras”, conclui-se que mesmo as primeiras sociedades humanas vivenciaram o fenômeno.

Noticia COULANGES (1954, v.1, p. 284-285) que: "Entre gregos e romanos, do mesmo modo que entre os hindus, desde princípio, espontaneamente, a lei surgiu como especialidade de sua religião". É oportuno relembrar nesse instante que um dos primeiros conjuntos de normas escritas de que se tem notícia data do décimo oitavo século antes de Cristo, sendo composto pelas duzentas e oitenta e duas regras inscritas no denominado Código de Hamurabi ${ }^{11}$.

${ }^{10}$ Assim, de modo a diferenciar o âmbito do fenômeno daquele da ciência que o analisa, nessa tese, a expressão direito, com a inicial minúscula, quer indicar o fenômeno. Contudo, se a inicial estiver em maiúscula, a referência é à respectiva ciência, o mesmo se aplicando aos vocábulos economia e Economia.

${ }^{11}$ Segundo VAZ (1993, p. 51): "HAMURABI é considerado o mais ilustre dos reis da Babilônia, tendo vivido entre 2003-1961 a.C. O Código foi elaborado em 1965 a.C., sobre 22 colunas horizontais em baixorelevo, encimadas pela figura de Hamurabi adorando o deus Shamash, que lhe teria ditado as leis". 
Nesse sentido, como bem preleciona RÁO (1991, p. 29): "encontra-se, pois, a origem do direito na própria natureza do homem, havido como ser social”, o que torna possível afirmar, portanto, que não há direito sem sociedade e vice-versa, conforme aponta REALE (1996, p. 703). E isso vem ocorrendo há milênios provavelmente porque, na colocação sucinta de PEREIRA (1980, p. 47): “o direito é feito para o foro, para a praça pública; sua experiência é uma experiência social ou, se se quiser, intersubjetiva (mais do que isso Heidegger dirá - 'ser é ser com os outros')".

Regular a conduta de seus membros predizendo a solução de potenciais divergências de interesses, além de impor efetivas sanções e penalidades aos faltosos, é essencial em qualquer sociedade que pretenda desfrutar de um ambiente não violento, visto que a convivência humana continuada é ordinariamente conflituosa.

Assim é que, de um modo geral, o conteúdo de uma norma jurídica reflete prescrições de proibição, permissão, estímulo ou desestímulo de condutas a serem praticadas pelos diversos agentes sociais, sendo que, pela lição de TELLES JR. (2001, p. 51): "Pelo simples fato de existir, a sociedade impõe essas interações. As finalidades da sociedade ou dos grupos sociais não seriam alcançadas se as mencionadas exigências não fossem permitidas".

Nessa linha de raciocínio, as normas jurídicas se revelam essencialmente como prescrições diretivas e têm como objetivo, de acordo com ROSS (2003, p. 31), não proclamar verdades teóricas, mas sim influenciar o comportamento dos membros que compõem certa comunidade. E assim ocorre provavelmente porque, conforme é ponderado por BETTI (1969, p. 368): “Qualquer norma, ou complexo de normas, corresponde à necessidade de pôr termo a conflitos de interesses socialmente relevantes ou de organizar funções socialmente úteis, ou a uma e a outra necessidade ao mesmo tempo".

Portanto, onde quer que exista ou tenha existido uma sociedade humana, é altamente presumível a sua regência por meio de normas, seja como fruto de antigos costumes ou de tradições imemoriais, ou, segundo hodiernamente é mais usual, como resultado da interação de várias forças políticas perante um Parlamento em obediência aos tramites formais de um processo legislativo. 
Nesse ponto, deixa-se claro que as normas jurídicas, apresentem-se sob a forma escrita ou não, advêm exclusivamente da vontade humana, ficando descartada qualquer visão que porventura encare o direito como um conjunto de regras presentes na natureza e demonstráveis pelo uso da razão, cuja validade inclusive se estenderia a todos os homens em qualquer época e local, conforme prediziam as teorias jusnaturalistas do século XVIII descritas por LEWANDOWSKI (1984, p. 11).

De fato, na abalizada lição de CARBONNIER (1979, p.177), todos os fenômenos jurídicos são sociais, isso é, oriundos da criação humana.

Então, sofrendo constantemente a intervenção humana e ao coadjuvarem a realidade fática e social, as normas jurídicas, segundo FRIEDE (1997, p. 78), usualmente ostentam características de manutenção de certa conjuntura ou do status quo, num sentido conservador ou, ao contrário, buscam a reestruturação ou transformação das relações sociais, numa perspectiva reformadora.

O que se observa, em realidade, é que, num mesmo ordenamento jurídico, convivem, simultaneamente, normas que ora representam modificações num ponto, ora noutro, depois implicam em retroação num terceiro item para, ao depois, refletirem nova mudança, num dinamismo constante.

Nos dizeres de LÉVY-BRUHL (1997, p. 29-30): "se o direito emana do grupo social, não poderia ter mais estabilidade que esse mesmo grupo". À evidência, não se pode negar que um mínimo de perenidade normativa e institucional é essencial, pois, conforme FRIEDMAN (1985, p. 152): "Nenhuma sociedade pode permanecer estável, a não ser que exista um núcleo básico de julgamentos de valor aceitos inconscientemente pela maioria dos seus membros".

Logo, ainda mais se considerado algum interregno temporal, é da essência do direito o caráter da mutabilidade, o que qualifica seus princípios, normas, regras, figuras e institutos como eminentemente transitórios e isso se intensifica notadamente após a entrada em cena da escola positivista no século XIX, conforme ressalta 
FERRAZ JR (1980, p. 43), a partir de quando o direito legislado - por isso positivado sobrepuja a aplicação dos costumes e tradições como parâmetro decisório ${ }^{12}$.

Com efeito, não se pode negar que a edição de uma lei pode alterar, de um dia para o outro, toda uma sistemática até então vigente, ainda que isso venha causar prejuízos a certas pessoas ou quebrar suas expectativas, como nas hipóteses em que a lei passa a exigir um número maior de anos de trabalho para o gozo da aposentadoria. Não se está aqui valorando esta plasticidade da norma positivada, apenas se registra uma característica cada vez mais incisiva na sociedade contemporânea.

Aliás, em adição a essa marca da não perenidade das normas jurídicas no tempo, de forma assemelhada, não se constata uma uniformidade nos ordenamentos dos diversos países, mesmo no que se refere a direitos elementares, o que significa, portanto, a impossibilidade de se admitir nessa seara o elemento da universalidade. Nessa linha, qualquer esperança quanto à possibilidade da prevalência de um ordenamento jurídico universal é qualificada por RÁO (1991, p. 74) como utópica.

Basta observar, por exemplo, as diferenças inconciliáveis entre os sistemas normativos nazi-fascistas e aqueles próprios dos Estados democráticos. Por isso, enfatiza LÉVY-BRUHL (1997, p. 30) que: “Uma confrontação com os sistemas jurídicos do passado ou dos países estrangeiros basta para se conceber a prodigiosa diversidade das normas jurídicas praticadas sobre a superfície do globo". Segundo expõe AZEVEDO (2008, p. 08-09):

\begin{abstract}
A idéia primitiva das cidades isoladas de que as leis eram imutáveis, promulgadas talvez por um legislador mítico (Licurgo) ou especial (Sólon), caiu por terra. O filósofo Protágoras (480-411 a.C.), fiel à sua concepção revolucionária de que "o homem é a medida de todas as coisas", sustentou, então, com clareza, e com algum escândalo, que as leis devem ser obedecidas, porque são fruto de decisão coletiva, mas que não têm nenhuma base natural ou divina.
\end{abstract}

Quiçá até se possa admitir certa uniformidade ou consenso em torno de alguns valores e princípios arraigados na consciência da maioria dos povos (v.g. respeito à

\footnotetext{
${ }^{12}$ Segundo BOBBIO (1988, p. 91-92): “Com o advento do positivismo jurídico, o problema da legitimidade foi completamente subvertido. Enquanto segundo todas as teorias precedentes o poder deve estar sustentado por uma justificação ética para poder durar, e portanto a legitimidade é necessária para a efetividade, com as teorias positivistas abre caminho a tese de que apenas o poder efetivo é legítimo".
} 
dignidade da pessoa humana, não discriminação quanto ao sexo ou condição social, liberdade religiosa, etc.), mas, mesmo assim, isso está muito longe de qualquer sentido de universalidade, sendo notório que a implantação de tais concepções não tem se mostrado equivalente nos diversos Estados dadas as controvérsias que ordinariamente se impõem sobre cada um desses temas. Confira-se, como mera ilustração, a seguinte notícia publicada na internet em 13 de setembro de $2008^{13}$ :

HANIE NEBEHAY - Países ocidentais manifestaram na quinta-feira preocupação com o número crescente de execuções no Irã, assim como com o "tratamento das mulheres como cidadãos de segunda categoria".

$[\ldots]$

A alta comissária da ONU para os Direitos Humanos, Louise Arbour, disse ter pressionado as autoridades iranianas na semana passada, em negociações em Teerã, a garantir o direito de manifestação, e levantado o assunto da execução de adolescentes.

O Irã, que não é membro pleno do conselho, costuma desqualificar as acusações de violar os direitos humanos, acusando o Ocidente de adotar dois pesos e duas medidas.

O número de execuções no país, muitas feitas em público, subiu desde julho, com uma operação repressiva contra o que o Irã chama de "comportamento imoral".

Pela sharia iraniana, homicídio, estupro, adultério, assalto a mão armada, apostasia e tráfico de drogas são passíveis de pena de morte.

[...]

A Anistia Internacional, segundo quem o Irã tem uma das mais altas taxas de execuções no mundo, afirmou na semana passada que tinha o registro de 210 execuções só este ano. No ano passado, tinham sido 177.

Em suma, descartada a visão de normas jurídicas de âmbito universal e atemporal, para fins desta tese, concebe-se o direito como um fenômeno de origem humana (e não natural) que sempre se mostra ativo em qualquer sociedade, expressando-se por um conjunto de normas não necessariamente escritas ou editadas segundo um processo legislativo qualquer, com a finalidade precípua de regular a convivência humana e solucionar possíveis conflitos, sempre sob as características marcantes da transitoriedade e da aplicação limitada no espaço.

Evidentemente, dado o nível de consciência humanitária apresentada pela maioria dos povos de hoje, ao menos no mundo ocidental, é sempre desejável que o conteúdo presente nas normas jurídicas respeite dignidade da pessoa humana, bem como

\footnotetext{
${ }^{13}$ Disponível em: <http://www.estadao.com.br/internacional/not_int51260,0.htm>. Acesso em: 10 dez. 2008.
} 
contemple, o máximo possível, os chamados direitos fundamentais de primeira, segunda e terceira geração ${ }^{14}$.

Todavia, resta inegável que a previsão e, sobretudo, a implantação de tal desiderato depende dos esforços e opções tomadas por cada uma das sociedades que habitam a Terra, uma vez que, segundo MAIA (2006, p. 183-184):

A função que o Direito exerce na sociedade é aquela de ser um sistema cognitivamente aberto para processar expectativas normativas passiveis de serem mantidas em situação de conflito. Diante dos conflitos sociais, o Direito deve mostrar-se apto a dar uma resposta, a tratar a decepção oriunda de uma expectativa desapontada.

Por fim, uma questão que daqui pode ser levantada é a pertinente aos critérios identificadores do status jurídico de uma norma, ou seja, mesmo que reste inegável a circunstância do direito se revelar por meio das normas, seria possível separá-las daquelas pertencentes à moral, à boa educação, à sociabilidade, à etiqueta e à religião?

Em resumo, trata-se de buscar um critério (ou mais) que consiga apontar uma ou mais características de uma norma capaz de incluí-la dentro do fenômeno social direito. O tema é de relevo, pois ao fracassar no encontro de uma resposta satisfatória, passaria ser de rigor reconhecer que o direito e quaisquer outras as normas, na verdade, se fundem.

A ciência do direito, cuja essência será abordada logo à frente, vem se debruçando há tempos em torno desta questão de solução não imediata. Segundo informa FERRAZ JR. (1988, p. 99): “É uma questão aberta, típica da filosofia jurídica, que nos levaria a indagações infinitas, sobre pressupostos e pressupostos dos pressupostos”.

Considerando não ser objeto desta tese investigar detalhadamente esse tema, nele se tangenciará de resvalo a seguir. Não obstante o assunto ser típico da ciência

\footnotetext{
${ }^{14}$ LEWANDOWSKI (2005b, p. 175) noticia que atualmente se cogita dos direitos de quarta geração, ou seja, para além dos direitos de terceira geração (v.g. autodeterminação dos povos, paz, desenvolvimento, meio ambiente protegido, etc.). Tais direitos decorrem: "de novas carências enfrentadas pelos seres humanos, especialmente em razão do avanço da tecnologia da informação e da bioengenharia". Trata-se da proteção contra a manipulação genética, a invasão desmedida da privacidade ou, ainda, a prevalência de uma burocracia autoritária e tentacular.
} 
jurídica, opta-se por incluí-lo neste tópico, uma vez que, salvo melhor juízo, se imbrica tenazmente com a compreensão do fenômeno social direito.

Destaca-se, em primeiro lugar, a exposição de BOBBIO (2005, p. 147176), que discorre e tece críticas ao redor de vários critérios que, segundo o autor, são os mais comumente encontrados na doutrina:

1) critério do conteúdo: por esse critério seria jurídica a norma cujo conteúdo regulasse uma relação intersubjetiva ou bilateral estabelecida entre duas pessoas, sendo que, de maneira interdependente, o direito de alguém corresponderia ao dever de outrem.

A norma moral, ao contrário, ostentaria um caráter unilateral ou de foro íntimo, posto que sua observância ficaria ao alvedrio do destinatário ou "obrigado". Essa constatação advém da impossibilidade de desconhecimento da dimensão empírica do direito como um regulamento das ações sociais dos homens.

Contudo, é de se concordar com BOBBIO (2005, p. 148) que este critério não obtém êxito em diferenciar as normas jurídicas das sociais ou de boa educação, uma vez que elas também abrangem relações intersubjetivas, o que implica na necessidade de adotar, ou ao menos conjugar, esse critério com outros elementos adicionais.

2) critério da finalidade: prega esse critério que o status jurídico de uma norma teria fundamento na circunstância de seu conteúdo regular relações intersubjetivas tidas como essenciais à preservação da sociedade, sendo essa, destarte, a finalidade primordial do direito, enquanto que as relações tratadas pelas normas meramente sociais não ostentariam esse quilate de essencialidade, ou seja, a sociedade não feneceria ante sua inexistência.

Logo, a juridicidade decorreria da alta relevância do assunto abrangido pela norma. Porém, conforme expõe REALE (1996, p. 702):

Sendo o Direito um bem cultural, nele há sempre uma exigência axiológica atualizando-se na condicionalidade histórica, de maneira que a objetividade do vínculo jurídico está sempre ligada às circunstâncias de cada sociedade, aos processos de opção ou de preferência entre os 
múltiplos caminhos que, como vimos, se entreabrem no momento de qualquer realização de valores.

Disso se revela a inequívoca fragilidade do critério da finalidade, ou seja, não se presta para reconhecer como jurídica uma norma no meio de outras, uma vez que, na exposição de BOBBIO (2005, p. 148): "regras consideradas essenciais numa sociedade podem ser diferentes das regras consideradas essenciais em outra sociedade. O que é norma social em uma sociedade pode se tornar norma jurídica em outra e vice-versa”.

3) critério do sujeito: conforme esse critério, a juridicidade se encontraria associada e decorreria do poder exercido por quem - pessoa ou órgão - editou a norma que, no caso, deve ser soberano, isso é, superior qualquer outra força social. Assim, toda vez que uma norma se fizer acompanhar de uma força coercitiva de tamanha magnitude, independentemente da forma assumida, conteúdo ou finalidade a que se proponha, entraria em cena o caráter jurídico.

Trata-se, segundo BOBBIO (2005, p. 149):

do mais autêntico positivismo jurídico, segundo o qual o soberano não apenas edita as normas essenciais para a conservação da sociedade, mas as normas estabelecidas pelo soberano tornam-se essenciais, só pelo fato de que se fazem valer também recorrendo à força.

Não se nega, antes se admite, que em grande medida o poder de coerção é ínsito ao direito. Todavia, seria viável considerar que a impressão do signo de juridicidade em certa norma resultaria apenas do poder exercido pelo respectivo editor?

É bem sabido que, mesmo sob a égide do Estado, detentor da soberania por excelência, bolsões de poder paralelo se estabelecem (sob variações de tempo e local), muitas vezes com intensidade suficiente para influir seriamente na vida de certas pessoas e comunidades, bastando recordar os códigos de honra da máfia italiana ou os "toques de recolher" que frequentemente são "decretados” por marginais em áreas com fraca presença estatal, mas muitas vezes nas proximidades ou até dentro de grandes centros urbanos.

Poderia, então, tal poder investir o quilate de jurídico às normas por si ditadas? Intuitivamente, a resposta inclina-se pela negativa, o que implica considerar a insuficiência desse critério para conferir juridicidade a qualquer norma. 
4) critério jusnaturalista ou de justiça: segundo esse critério, ainda que uma norma seja editada segundo certo procedimento e esteja acompanha da força coercitiva estatal, ela somente poderia ser entendida como jurídica se for inspirada em determinados valores tidos por essenciais, básicos e inalienáveis dos seres humanos, notadamente, a justiça.

Então, possivelmente seria considerada desprovida de juridicidade uma norma que determinasse fossem os doentes mentais de certo país tornados estéreis ou submetidos a injeções letais "não dolorosas".

Mesmo ao considerar-se a salutar preocupação com a criação de normas que reflitam os valores como a justiça, conforme assevera FERRAZ JR. (2003, p. 148), não se pode ignorar a circunstância de que: "O conceito de justiça, como todas as categorias fundamentais dentro da filosofia, é um dos mais disputados".

E isso se dá em grande medida porque, na colocação de MEFFETTONE e VECA (2005, p. XII): "questões de justiça são, na verdade, questões de justificação. A partir desse ponto de vista, encontramo-nos diante de uma variedade de modos de justificação ao longo do tempo".

Portanto, segundo preleciona RAWLS (2002, p. 03), mesmo que a justiça deva ser considerada como a primeira virtude das instituições sociais, assim como a verdade o é dos sistemas de pensamento, não se pode deixar de observar o fato de que as: "Sociedades concretas são, é óbvio, raramente bem-ordenadas nesse sentido, pois o que é justo e o que é injusto está geralmente sob disputa. Os homens discordam sobre quais princípios deveriam definir os termos básicos de sua associação” (idem, p. 05).

Portanto, sabendo-se que a solução dos conflitos sociais buscada pelo direito depende, em grande medida, de saber com a maior certeza possível quais normas efetivamente devem ser aplicadas a cada caso, a potencial insegurança que a adoção desse critério poderia gerar aponta para a sua pouca serventia prática.

5) critério da maneira como o destinatário recebe o comando: na exposição de BOBBIO (2005, p. 151), esse critério se subdivide em dois outros. 
De acordo com o primeiro, denominado de kantiano, o status jurídico da norma proviria das vantagens que sua obediência proporciona ao obrigado, independentemente, de sua concordância com o preceito (v.g. abster-se de furtar para evitar responder um processo penal com risco de perder a liberdade).

Trata-se, assim, de uma ação conforme ao dever que se difere da norma social ou moral porque o respeito a elas não revela vantagens do mesmo gênero, mas apenas o sentimento interno de dever cumprido. Trata-se, noutro giro, de uma ação pelo dever.

Em referência ao segundo critério ${ }^{15}$, BOBBIO (idem, p. 151) afirma que a qualidade de jurídica da norma emanaria: "somente quando aquele a quem ela se dirige está convencido de sua obrigatoriedade, e age como em estado de necessidade, enquanto normas não jurídicas, como as sociais, são caracterizadas por um menor senso de dependência do sujeito passivo frente a elas".

Aceitar sem reservas esse critério significaria entender que uma mesma norma poderia se mostrar jurídica para alguns (aqueles que, por exemplo, estão conscientes das vantagens de obedecer ao preceito) e não jurídica ou meramente social para outros (certas pessoas que, por exemplo, se disponham a furtar independentemente das consequências que o ato pode resultar). Ora, inegavelmente, na linha do esposado no item 4 acima, tal concepção resulta em insegurança ou falta de certeza em torno de quais normas devem ser aplicadas na solução de conflitos.

Após expor e criticar os critérios retro, BOBBIO (2005, p. 152 e ss.) oferta um critério supostamente mais apto a solucionar o assunto. Trata-se da qualidade da resposta à violação normativa, trazendo à baila a noção de sanção que, em resumo, significa a consequência negativa decorrente da não observância do estatuído por uma norma, seja por meio de uma conduta comissiva, seja omissiva. Nessa esteira, seria a partir das características relativas à sanção que se verificaria tratar-se de uma norma moral, social ou jurídica.

${ }^{15}$ BOBBIO noticia que este critério provém da teoria geral do Direito desenvolvida por Haesaert. 
Iniciando pelas normas de natureza moral, BOBBIO (2005, p. 155) argumenta que: “A única conseqüência desagradável da violação de uma norma moral seria o sentimento de culpa, um estado de incômodo, de perturbação, às vezes de angústia, que se diz, na linguagem ética, 'remorso' ou 'arrependimento"'.

Dessa feita, se a sanção que acompanha a norma moral é interior ou de consciência, sua ocorrência fica inteiramente ao alvedrio do sujeito, o que, em suma, não garante qualquer eficácia desta modalidade de norma para o fim de regular os conflitos sociais.

A sanção das normas sociais já revela uma natureza externa, isso é, há desaprovação de outras pessoas em face de determinado comportamento tido pela comunidade como inconveniente, grosseiro, exagerado, leniente, imprudente, escandaloso, etc.

É possível, no caso, que o ofensor se arrependa de seus atos e, por causa disso, arque com uma sanção moral imposta por sua consciência e, concomitantemente, seja hostilizado socialmente pelo grupo a que pertence que poderá, num sentido mais ameno, apenas impingir certa reprovação ou, de forma mais drástica, expulsar o sujeito de seu seio.

A sanção social mais grave é o linchamento que, na lição de BOBBIO (2005, p. 157): "é típica sanção de grupo, expressão daquela forma primitiva, espontânea e irrefletida de grupo social, que é a multidão".

Ao contrário do que se dá em face das normas morais, a sanção aqui é dotada de maior eficácia, principalmente, se o grupo for coeso e pouco numeroso. O receio de reprovação pelos demais, com o consequente descrédito social, de regra funciona como forte estímulo à não transgressão das normas comunitárias.

Todavia, constata-se que a sanção social é altamente instável e não igualitária, pois é possível que varie segundo os sujeitos que a aplicarão, ainda que se trate de transgressões idênticas praticadas num mesmo grupo. Além do mais, não é próprio da sanção social guardar proporcionalidade entre a violação e a resposta, notadamente porque 
muitas vezes a reprovação é embasada no resultado de um procedimento que garanta o exercício do direito de defesa.

Por fim, o status jurídico da norma afloraria toda vez que sua sanção possuir índole externa e institucionalizada, ou seja, nas hipóteses em que a reprovação se embasar em dispositivos que prevejam medidas punitivas fixas e precisas, além de aplicáveis na mesma medida para todos os casos assemelhados de transgressão, sempre sob os cuidados de pessoas expressamente designadas para o desempenho dessa tarefa, em regra, não envolvidas diretamente com os fatos.

Com isso, as normas jurídicas se destacam das morais e das sociais notadamente por possibilitarem maior:

a) previsibilidade e certeza, pois a sanção, sua intensidade e graduação devem estar descritas previamente ao respectivo descumprimento, o mesmo se aplicando às eventuais variações possíveis, tais como agravantes, atenuantes, extinção da punibilidade, perdão, prescrição, etc.;

b) igualdade ou isonomia, uma vez que em todas as hipóteses de descumprimento, desde que se trate de eventos da mesma natureza, a pena deve ser idêntica e impingida do mesmo modo e intensidade;

c) eficácia, tendo em vista que, salvo exceções indicadas no corpo da norma, a aplicação da sanção é obrigatória sempre que se constatar seu ferimento, não ficando sujeita, portanto, ao alvedrio de quem quer que seja ou mesmo a juízos de oportunidade e conveniência. Juntas, essas peculiaridades apontam para uma sanção de natureza externa e institucionalizada.

Entretanto, o critério da sanção externa e institucionalizada não é imune a sérios problemas que o enfraquecem se for tomado de forma exclusiva, pois é necessário reconhecer a existência de várias normas sem previsão de qualquer medida repressora para os casos de sua não observância, mas que deitam enorme influência no sistema jurídico, sendo muito dificultoso compreendê-lo como um complexo ordenado e racional sem o amparo dessas normas peculiares. 
Dentro desse grupo, não se pode deixar de reconhecer que inúmeras normas se limitam a definir algum instituto ou figura jurídica, como o faz, por exemplo, o art. 53 do Código Civil ao estatuir que: "Constituem-se as associações pela união de pessoas que se organizem para fins não econômicos".

Trata-se de um enunciado afirmativo, sem previsão expressa a qualquer modo de penalidade, ao contrário do que estabelece o dispositivo imediatamente posterior, o art. 54 do mesmo Codex, que inquina de nulidade (entrando em cena, pois, a sanção) o estatuto da associação que não contiver as indicações ali declinadas, tais como: a denominação, os fins e a sede da associação, os requisitos para a admissão, demissão e exclusão dos associados, etc.

Em complemento, várias normas trazem conteúdo interpretativo, isso é, buscam esclarecer ao intérprete o sentido de um mandamento anterior, a norma interpretada. Cita-se, como exemplo, o art. $3^{\circ}$ da Lei Complementar 118/2005 que estatui o seguinte:

Para efeito de interpretação do inciso I do art. 168 da Lei no 5.172, de 25 de outubro de 1966 - Código Tributário Nacional, a extinção do crédito tributário ocorre, no caso de tributo sujeito a lançamento por homologação, no momento do pagamento antecipado de que trata o §1o do art. 150 da referida Lei.

Merece destaque também normas que se limitam a conceder homenagens ou honrarias a personagens de relevo. Verifica-se, nesse caminho, o art. $1^{\circ}$ da Lei 10.796, de 05 de dezembro de 2003, cuja redação prevê que: "Será inscrito no 'Livro dos Heróis da Pátria', que se encontra no Panteão da Liberdade e da Democracia, o nome de Joaquim Marques Lisboa, o Marquês de Tamandaré".

Em sentido semelhante, há as leis que instituem datas comemorativas, assim como o fez a Lei 10.402, de 08 de janeiro de 2002, que, em seu art. $1^{\circ}$, criou o dia nacional do livro infantil a ser comemorado, anualmente, no dia 18 de abril, data natalícia do escritor Monteiro Lobato.

Prosseguindo, as leis de orçamento anuais (v.g. Lei 11.897, de 30 de dezembro de 2008), essenciais à ordenação das finanças públicas de qualquer país, naquilo 
em que realizam a previsão de receitas e autorizam o montante das despesas públicas durante certo período, também ordinariamente, em seu bojo, não declinam as sanções pelo seu descumprimento.

Aliás, consigne-se que quanto à parte referente à previsão das receitas, tratando-se da antecipação de um fenômeno que ocorrerá somente no próximo exercício financeiro, indiscutivelmente, sujeito a diversas variações da conjunta econômica não somente nacional, mas, em certa medida, mundial, é virtualmente impossível sequer pensar em edificar qualquer tipo de punição pelo erro de adivinhação do legislador.

Finalizando, é observável que as "normas de competência", ou seja, aquelas que estruturam, delimitam e regulamentam o exercício do poder coercitivo, delineando, inclusive, o aspecto institucional de seu exercício regular, raramente, se fazem acompanhar de sanções e isso se aplica, ainda, às normas constitucionais, bastando atentar, por exemplo, à redação do art. $1^{\circ}$ da Constituição de 1988:

Art. $1^{\circ}$ A República Federativa do Brasil, formada pela união indissolúvel dos Estados e Municípios e do Distrito Federal, constitui-se em Estado Democrático de Direito e tem como fundamentos:

I - a soberania;

II - a cidadania

III - a dignidade da pessoa humana;

IV - os valores sociais do trabalho e da livre iniciativa;

V - o pluralismo político.

Parágrafo único. Todo o poder emana do povo, que o exerce por meio de representantes eleitos ou diretamente, nos termos desta Constituição.

Ora, não seria tal aspecto um contra-senso? Como explicar que normas da mais elevada hierarquia do sistema poderiam ser desprovidas de sanção se a previsão de penalidade ou consequência pelo descumprimento seria justamente o indício primordial da marca jurídica da norma?

Poder-se-ia concluir, então, num primeiro passo, que normas assim não seriam efetivamente jurídicas. Contudo, isso implicaria em falta de coerência ou mesmo de lógica pela constatação de que os elementos mais elevados e inauguradores do sistema jurídico estariam fora dele. Então, se não pertencem ao sistema, como serviriam para dar embasamento a todas as demais normas? 
A essas observações, BOBBIO (2005, p. 167-170) pondera que a presença da sanção não se refere apenas à norma singularmente considerada, devendo existir um enfoque mais abrangente para encarar a sanção como um componente que pertence e permeia o sistema como um todo, onde todas as normas se inserem e interagem de modo que a falta da sanção específica, necessariamente, não decorre de um defeito ou ausência de juridicidade da norma, mas pode ser explicada por: "circunstâncias que tornam, naquele determinado caso, e só nele, ou inútil ou impossível a aplicação de uma sanção".

Quanto às "normas de competência", o autor agrega às considerações acima o argumento de que na observação de um ordenamento jurídico, passando-se dos planos mais baixos aos mais elevados, ocorre: "pouco a pouco, uma inversão das relações entre o direito e força, sem que seja possível precisar em que ponto essa inversão ocorre: nos planos mais baixos, a força está a serviço do direito; nos planos mais altos, o direito está a serviço da força”.

Portanto, seguindo este raciocínio, seria "natural" e esperado que as normas fundamentais do sistema jurídico não sejam acompanhadas por sanções, uma vez que tais normas, em última análise, representariam a própria força do ordenamento personificada sob o manto da juridicidade.

Seguindo adiante, pela proposta apresentada por FERRAZ JR. (1988, p. 104 e ss.), as normas, sejam jurídicas ou não, são estruturas que visam essencialmente à comunicação entre sujeitos, implicando na presença de um comunicador, um destinatário e um conteúdo que emana do primeiro em direção ao segundo.

A mensagem é passada sob dois níveis simultaneamente: o relato (a mensagem em si) e o cometimento (o modo em que é enviada). Assim, por exemplo, na expressão "sente-se", o relato indica uma orientação para alguém tomar assento, o que pode assumir, a título de cometimento, uma tonalidade de gentileza ou intenção de proporcionar ao destinatário um maior conforto em certo ambiente ou, em significância oposta, um tom de ordem imperativa, uma exigência do comunicador que espera ser obedecido. 
Segundo o autor, as normas em geral implicam numa relação de autoridade entre o comunicador e o destinatário, colocando o primeiro numa posição de superioridade em vista do segundo e esse fenômeno pode ter como causa vários fatores, tais como: força física (v.g. assaltante armado e a vítima), conhecimento técnico (v.g. médico e o paciente), força moral (v.g. sacerdote e o leigo), característica antropológica (v.g. pai e o filho), hierarquia (v.g. general e comandados), etc.

Em suas palavras (1988, p. 105-106), o que revelará o caráter jurídico da norma:

é a institucionalização desta relação de autoridade. O cometimento jurídico constrói-se por uma referência básica das relações entre as partes a um terceiro comunicador: por exemplo, o juiz, o consenso social, o legislador. É pela referência a este terceiro comunicador que se institucionaliza, na comunicação normativa, a relação complementar autoridade/sujeito. Assim, por exemplo, a norma firmada entre duas partes segundo a qual o não pagamento do aluguel até o dia aprazado implica uma multa de $10 \%$ sobre o valor da prestação requer, para ser jurídica, o consenso presumido da sociedade, de terceiros, o que é obtido por instituições como o contrato. O contrato é uma instituição no sentido de que as partes podem presumir que a expectativa global e anônima da sociedade é esperar o cumprimento do que foi pactuado livremente na forma contratual.

Entretanto, segundo alerta FERRAZ JR. (idem, p. 107), o critério em foco (grau de institucionalização) para a indicação do status da juridicidade: "pode parecer demasiadamente formal, no sentido de que parece ignorar o problema dos conteúdos, isso é, do relato normativo". Surge, destarte, a questão de saber se cometimentos, ainda que institucionalizados, comportariam quaisquer conteúdos, o que pode se tornar um problema dependendo da concepção que se aplique ao direito.

Essa questão atinente ao conteúdo não é considerada um problema por KELSEN (1987, p. 210), para quem, o caráter jurídico da norma, capaz de diferenciá-la das demais espécies, é simplesmente a circunstância de ter sido editada segundo um sistema ou procedimento previamente estipulado, cuja origem se constitui numa "norma fundamental" pressuposta. Não há qualquer relevo, em consequência, em atentar-se para o conteúdo ou a finalidade da norma. A observação do autor não deixa dúvidas: 
lógico do conteúdo de uma norma fundamental pressuposta, mas porque é criada de uma forma determinada - em última análise, por uma forma fixada por uma norma fundamental pressuposta. Por isso, e somente por isso, pertence ela à ordem jurídica cujas normas são criadas de conformidade com esta norma fundamental. Por isso, todo e qualquer conteúdo pode ser Direito.

Ainda que tal critério confira maior certeza na identificação do status jurídico de qualquer norma, clarificando aos obrigados as "regras do jogo" em torno de seus direitos e obrigações recíprocas, o problema reside inicialmente em fornecer uma explicação razoável do porquê de uma norma meramente pressuposta (ou seja, que sequer é materializada) ${ }^{16}$ é capaz de inaugurar e fundamentar toda uma ordem jurídica.

No caso, a não aceitação ou a contestação desse pressuposto hipotético faria ruir por completo o "edifício jurídico" na medida em que se a norma fundamental estivesse sujeita a qualquer tipo de embasamento superior, por uma questão de lógica, ela perderia a qualidade de vórtice inaugural do direito. O que se pode concluir, portanto, é que a norma fundamental se apresenta como um verdadeiro dogma: deve-se simplesmente vislumbrá-la como se existente fosse.

Em complemento, aceitar essa explicação implica em considerar jurídico (logo, válido e exequível coercitivamente) qualquer conteúdo imaginável, ainda que contrário a valores tradicionais assentados e pacificamente aceitos pela maioria das sociedades ao redor do mundo, como, por exemplo, o direito à vida, a impossibilidade de reduzir o ser humano à condição de escravo, devido processo legal e ampla defesa, vedação de discriminação com fulcro em sexo, raça ou condição social, etc.

Apenas para reforçar, LEWIS (2005, p. 238-239) recorda que:

Em análise mecanicista da solução final nazista, verificou-se que o processo de extermínio dos judeus, homossexuais, ciganos, deficientes mentais e qualquer outro indivíduo que pudesse tornar-se uma ameaça ao ideal estatal ocorreu não pura e simplesmente pelo arbítrio, mas por uma estratégia jurídica sofisticada, que buscou em primeiro lugar excluir o indivíduo alvo da abrangência de determinadas prerrogativas legais, reconhecidas até então a todos, para que simplesmente deixasse de ser sujeito de direitos e passasse a ser objeto de uma política de profilaxia

\footnotetext{
${ }^{16}$ Segundo OLIVEIRA JR. (1999, p. 100), a norma fundamental: "não existe empírica ou positivamente, mas sem ela não poderia se construir uma fenomenologia jurídica, uma ontologia do direito, enquanto um ser distinto de outro ser, como da moral e dos costumes, por exemplo, que também se exprimem por normas".
} 
social. Com efeito, verificou-se que todos os que foram exterminados nos campos da morte, foram privados de seus direitos de forma juridicamente legítima, sob manto protetor da famosa Constituição de Weimar.

De fato, segundo GOMES (2004, p. 234): “A norma fundamental não afirma qualquer valor”. Na explicação de CHAMON JR. (2007, p. 20), esse inegável alheamento ao conteúdo da norma ocorre pelo fato: "de sua teoria ter uma preocupação meramente genética, no sentido de verificar se aquilo produzido segue uma ordem silogística que, para tanto, toma em consideração uma estrutura hierarquizada e escalonada de normas".

Semelhante em alguns pontos, mas com marcas próprias que a afastam da proposta kelseniana, é a "regra de reconhecimento" idealizada por HART (1986, p. 104 e ss.). Trata-se, em linhas breves e gerais, não da necessidade de se pressupor a existência de uma norma fundamental da qual verteriam todas as normas que compõem o sistema jurídico, mas da identificação - comumente realizada pelos juristas e operadores do direito - de critérios dotados de autoridade capazes de identificar as normas consideradas jurídicas dentro do sistema em referência.

Não há uma forma especial para que a regra de reconhecimento se apresente. Assim, para uma sociedade primitiva, ela pode se constituir em simples inscrições dentro de um pergaminho, enquanto que, para um sistema jurídico desenvolvido e de muito maior complexidade, sua origem pode estar ligada ao fato de possuir consonância com valores tidos como socialmente relevantes e ordinariamente aceitos pela comunidade ou de ter sido expressamente criada por certo órgão (v.g. uma Constituição escrita) ou, ainda, decorrer de longa e perceptível prática consuetudinária.

Nas palavras do autor (1986, p. 133):

Na maior parte dos casos a regra de reconhecimento não é enunciada, mas a sua existência manifesta-se no modo como as regras concretas são identificadas, tanto pelos tribunais, ou outros funcionários, como pelos particulares ou seus consultores. [...] $\mathrm{O}$ uso pelos tribunais e outras entidades de regras de reconhecimento não afirmadas, para identificar as regras concretas do sistema, é característico do ponto de vista interno. Aqueles que as usam deste modo manifestam através desse uso a sua própria aceitação das regras como regras de orientação e, relativamente a esta atitude, está associado um vocabulário característico diferente das expressões naturais do ponto de vista externo. 
Nessa linha, constata-se que o caráter jurídico de alguma norma se revelaria, em essência, quando ela se inserir dentro de um contexto regido pela mencionada "regra de reconhecimento", sendo que o fenômeno se deflagra, ainda que implicitamente, a partir do labor dos mais variados operadores jurídicos em determinada sociedade (constituintes, legisladores, tribunais, autoridades, funcionários, etc.) ao reconhecerem, em consonância com a "regra de reconhecimento", aquelas normas que trazem à baila aplicam no desenrolar de suas atividades.

Disso resulta concluir, segundo HUPFFER (2006, p. 83), que a existência de uma regra com tal peculiaridade funcional:

é uma questão de fato, pois é necessária face à complexidade em identificar o Direito, tendo como referência determinados critérios. $\mathrm{O}$ critério último de validez jurídica advém da prática dos tribunais em aceitar uma Regra de Reconhecimento. Como exemplo, Hart coloca que, no sistema jurídico inglês, a regra de reconhecimento último estabelece como critério último a produção normativa do Parlamento.

Por fim, seguindo por uma linha inegavelmente pragmática, caminha o entendimento de ROSS (2005, p. 54-55), para quem, esse tipo de discussão não possui sentido aceitável, uma vez que, em sua explicação: “O vocábulo 'direito' não é comum a uma classe de regras de direito, mas sim a uma classe de ordenamentos jurídicos individuais".

Portanto, o que existiria e poderia ser pinçado pelo observador seria o direito dinamarquês, o direito norueguês, o direito sueco e assim por diante, não havendo qualquer utilidade em se identificar o que essas normas possuem em comum que possa conferir-lhes o status de jurídicas.

Significa dizer que, independentemente do conteúdo, objetivo ou finalidade, as normas são aplicadas na prática sem que o fato de se descobrir o que eventualmente possuam em comum possua qualquer influência nesse fenômeno. Em suas palavras (idem, p. 55):

As intermináveis discussões filosóficas tocantes à "natureza" do direito se fundam na suposição de que o direito extrai sua "validade" específica de uma idéia a priori, e que a definição do direito é, portanto, decisiva para 
determinar se uma dada ordem normativa pode apresentar a reivindicação ao "título honorífico" do direito.

Numa analogia proposta pelo autor em referência, para se praticar futebol, tênis, xadrez ou mesmo bridge, basta conhecer as regras específicas de cada um desses jogos, sendo irrelevante averiguar o que há de comum entre elas que as elevariam à qualidade de "regras de jogos".

Portanto, deixando de lado a questão nominativa, toda manifestação normativa se revela como um fato, seja um sistema jurídico nacional, o direito internacional, a ordem de um bando de criminosos ou a ordem mantida pelo poder ocupante de um país. De maneira incisiva ROSS (idem, p. 56) afirma que:

a ordem que prevalece numa quadrilha, por exemplo, seja denominada "ordenamento jurídico" (direito da quadrilha) é um problema que, considerado cientificamente (quer dizer, a palavra "direito" sendo liberada de sua carga emotivo-moral) não passa de uma questão arbitrária de definição.

Constata-se, então, que por esse enfoque o destaque repousa sobre o fenômeno normativo manifestado de forma fática, nas suas mais variadas realidades possíveis, sem maior preocupação de identificar se existe algum elemento dentro de certas normas capaz de as tornar jurídicas, o que possibilitaria separá-las conceitualmente das normas morais e sociais.

Em vista da exposição desses vários pontos de vista, se alguma conclusão daqui se pode extrair é a viabilidade de se considerar, ao menos como plausível, a existência de certos elementos cuja presença em determinada norma é capaz de conferirlhe o status jurídico, separando-a, destarte, dos mandamentos morais ou sociais.

Contudo, se outra conclusão resta autorizada, é a insuficiência para tal desiderato da utilização isolada de apenas um dos vários critérios acima ventilados. A conjugação, senão entre todos, ao menos de um punhado deles, não se excluindo, inclusive, outras possibilidades que sequer aqui foram consideradas, parece ser inevitável.

É certo que muito mais poderia ser aqui falado. Todavia, considerando que este tópico objetiva estampar uma visão extremamente simplificada acerca do 
fenômeno social direito, entende-se que esse objetivo já foi alcançado. Opta-se, então, por encerrar o assunto e prosseguir na exposição.

\subsection{A ciência do direito}

Nota-se que, enquanto nos eventos naturais vige o princípio da universalidade, pelo qual um fenômeno qualquer ocorre da mesma maneira em todo e qualquer local do universo ${ }^{17}$, quanto às normas jurídicas, essa característica é totalmente ausente, pois é inegável que variam, constantemente, no tempo e no espaço numa verdadeira plasticidade, conforme visto acima.

Nesse sentido, seria possível aplicar ao direito métodos científicos de busca de conhecimento? A constante alteração das normas e a impossibilidade de se estatuí-las sob o cunho da universalidade não tornaria estéril um empreendimento como esse? Resumindo, o fenômeno direito seria viável de ser investigado dentro de métodos pré-ordenados?

Em complemento, se, conforme visto acima, a doutrina ainda não chegou à conclusão definitiva acerca dos critérios que permitem separar a norma jurídica das demais existentes na sociedade, a questão se torna ainda mais complexa, ou seja, seria factível construir uma ciência cujo objeto primordial de estudo (as normas jurídicas) não se possa identificar com certeza em todos os casos?

A resposta a ambas as questões comporta juízo positivo, mas desde que se leve em conta que, segundo propõe AGUILLAR (1996, p. 62), o status de ciência implica no prévio caráter convencional, ou seja, do consenso conferido essencialmente por uma comunidade de pesquisadores cientistas que se ligam ao redor de um paradigma ou programa de pesquisa.

\footnotetext{
${ }^{17}$ Acerca do assunto, segundo ZEILINGER (2005, p. 22): "Hoje sabemos que a constante de Planck h é uma constante universal da natureza. Isso significa que ela possui um valor fixo que independe de circunstâncias externas. E que tem a mesma grandeza tanto entre nós como em galáxias distantes e tampouco se altera com o tempo. Ou seja, a quatro bilhões de anos atrás a constante de Planck h era exatamente tão grande quanto hoje. Essas constantes universais da natureza são de grande importância para a descrição física do mundo. Uma outra constante da natureza semelhante é a velocidade da luz c. Sabemos que as constantes da natureza não se alteram com o tempo e que matem sua dimensão tanto muito longe de nós quanto aqui na Terra por observações experimentais meticulosas, sobretudo pelas medições exatas do espectro da luz que chega até nós oriunda de estrelas e galáxias distantes".
} 
Destarte, a par da dificuldade de identificar em todas as hipóteses o objeto observado, o Direito deve conviver com a possibilidade da constante mudança do conteúdo do seu objeto.

Na síntese de PEREIRA (1980, p. 50): "a definição de ciência do direito, como realidade ou possibilidade, como fato a descrever ou processo em vias de atualização, depende de nossos juízos ontológicos e da eficácia dos métodos que empregamos para o desvelamento do objeto direito".

É de se atentar que o direito em si não é ciência. Ele pode ser objeto de ciência, isso é, suas prescrições podem ser investigadas de maneiras variadas e para diversas finalidades. Certamente, não há que se confundir o fenômeno com a sua análise.

Assim, a maçã que cai da árvore poderá ser objeto de observação pela ciência da mecânica desenvolvida por Newton, mas a fruta e as forças que sobre ela atuam em si não são ciência, ao contrário, são objetos dela. Nesse ponto, segundo bem enfatiza LUHMANN (1990, p. 41): "Naturalmente, não se deve confundir as proposições com seus respectivos objetos" ${ }^{\prime 18}$.

Com o fenômeno direito, o mecanismo se assemelha, sendo assim amplamente reconhecido. De fato, segundo KELSEN (1987, p. 89/90): “O jurista científico que descreve o Direito não se identifica com a autoridade que põe a norma jurídica”.

Portanto, será ciência um texto elaborado por um eminente Professor a respeito do homicídio. Não será ciência, mas se constituirá no próprio direito, a norma insculpida no art. 121 do Código Penal.

Enfatizando, na lição de ROSS (2003, p. 32):

Na medida em que a literatura jurídica pretende ser conhecimento do que é efetivamente o direito vigente, tem que se constituir em asserções, não em diretivas. Toda proposição de um livro precisa ser entendida sob a condição geral de que o autor está expondo o direito vigente dentro de um sistema legal específico, o direito de Ilinois, o direito da Califórnia, a common Law, etc.

${ }^{18} \mathrm{O}$ texto original é o seguinte: "Naturalmente, no se deben confundir lãs proposiciones com sus proprios objetos". 
Dessa forma, a ciência jurídica trabalha com ilações sobre o direito, mas com ele não se confunde. Conforme FRIEDE (1997, p. 71), a distinção se revela precisamente na circunstância das proposições doutrinárias não atribuírem, in concreto, deveres ou direitos a quem quer que seja, sujeitando-se a qualificações de aceitabilidade ou não, enquanto que as normas jurídicas não se mostram verdadeiras ou falsas, mas sim válidas ou não, concorde-se ou não com seu conteúdo.

Essa separação entre o direito e a ciência que o investiga é uma visão relativamente nova. No ensinamento de FERRAZ JR. (1988, p. 55):

O conhecimento do direito, como algo diferenciado dele, é, pois, uma conquista tardia da cultura humana. A distinção, pois, entre direitoobjeto e direito-ciência exige que o fenômeno jurídico alcance uma abstração maior, desligando-se das relações concretas (como as de parentesco: o pai tem direito de vida e morte sobre o filho, porque é pai, sem que se questione por que a relação pai/filho se identifica com uma relação jurídica de poder de vida e morte), tornando-se um regulativo social capaz de acolher indagações a respeito de divergentes pretensões.

Aliás, segundo GRAU (2005, p. 37), não haveria uma, mas várias ciências do direito, v.g., Filosofia do Direito, Teoria Geral do Direito, História do Direito, Sociologia do Direito, Dogmática Jurídica, etc.

Segundo o autor: "Todas as ciências do direito são ciências sobre o direito. Assim, as linguagens das ciências do direito são metalinguagens". O direito, destarte, é uma manifestação denominada por GRAU (idem, p. 42) de prudência que não se confunde com os estudos que o abordam.

E, conforme FRIEDE (1997, p. 04), dentro da classificação binária das ciências que as divide entre as naturais e as sociais, a ciência do direito se encaixa nesse último grupo na medida em que seu objeto não é desvendar ou explicar as ocorrências dos inúmeros fenômenos naturais, mas sim se debruçar em torno do evento da ordenação social por meio de normas jurídicas criadas e moldadas pelo homem ao longo dos tempos.

Prosseguindo, pela exposição de FERRAZ JR. (1988, p. 44 e ss.), o resultado da pesquisa científica jurídica pode se alinhar a duas perspectivas. A primeira, denominada pelo autor de zetética, tem como característica primordial a constante abertura ao questionamento em torno das bases e pressupostos do objeto analisado, sendo que aqui 
o jurista ordinariamente se socorre de disciplinas auxiliares na construção de suas proposições, por exemplo, sociologia, filosofia, economia, biologia, política.

A segunda, chamada de dogmática, não permite tal abertura e obriga o cientista a aceitar certos enunciados, sendo-lhe vedado questionar sua validade ou legitimidade, sob pena de assim o fazendo adentrar no campo da zetética. Melhor explicando, segundo o autor citado (idem, p. 44):

O importante aqui é a idéia de que uma investigação zetética tem como ponto de partida uma evidência, que pode ser frágil ou plena. E nisto ela se distingue de uma investigação dogmática. Em ambas, alguma coisa tem de ser subtraída à dúvida, para que a investigação se proceda. Enquanto, porém, a zetética deixa de questionar certos enunciados porque os admite como verificáveis e comprováveis, a dogmática não questiona suas premissas porque elas foram estabelecidas (por um arbítrio, por um ato de vontade ou de poder) como inquestionáveis. Neste sentido, a zetética parte de evidências, a dogmática parte de dogmas. Propomos, pois, que uma premissa é evidente quanto está relacionada a uma verdade; é dogmática, quando relacionada a uma dúvida que, não podendo ser substituída por uma evidência, exige uma decisão. A primeira não se questiona porque admitimos sua verdade, ainda que precariamente, embora sempre sujeita a verificações. A segunda, porque diante de uma dúvida, seríamos levados à paralisia da ação: de um dogma não se questiona não porque ele veicula uma verdade, mas porque ele impõe uma certeza sobre algo que continua duvidoso.

Em conclusão, é possível afirmar que o fruto da pesquisa realizada sob a ótica da dogmática será, em suma, a descrição das normas e figuras jurídicas como um todo e sob abstenção axiológica, por isso que dogmática se revela. O enfoque, então, se centra na norma em si e não adentra em possíveis relações ou implicações decorrentes de sua aplicação.

Nessa linha, conforme colocado por FARIA (2004, p. 45):

No limite, portanto, a dogmática almeja tornar possível a redução da experiência jurídica à dimensão estrita da norma. Para tanto, configura o jurídico como uma realidade que basta a si mesma, ou seja, que é capaz de se autofundar e de não ser condicionada nem por poderes absolutos nem por ideologias [...] Deste modo, o pensamento jurídico não está autorizado a promover julgamentos morais ou avaliações políticas sobre a experiência jurídica, devendo encarar as relações sociais concretas exclusivamente pela ótica das prescrições normativas, ou seja, pela relação de imputação entre sanções e atos considerados ilícitos. 
Portanto, verifica-se que a dogmática, segundo AMARAL JR. (1993, p.88), "não procura explicar a existência das normas jurídicas segundo o princípio da causalidade ou analisar a eficácia do direito sobre a vida social. A sua função é simplesmente a de explicitar critérios para a aplicação e funcionamento do direito positivo".

É dizer, conforme esclarece LUHMANN (1983, p. 27), que: “A característica mais importante no conceito da dogmática para sua compreensão habitual é a proibição de negação: a impossibilidade de negar os pontos de partida e as correntes de argumentação. Estão subtraídos da crítica"19.

Percebe-se, dessa forma, que a pesquisa realizada sob a ótica da dogmática se apresenta primordialmente como um problema ontológico, isso é, não leva em conta questões como a "justiça da norma" ou mesmo valores sociais capazes de fundamentar sua existência, de modo que o resultado seja simplesmente identificar o direito como ele se apresenta no mundo real e não como ele deveria ser idealmente estruturado.

Aduz KELSEN (1987, p. 01) que é essa a linha que deve ser seguida pelo cientista, sob pena de desbordar da proposta de limitar a investigação ao âmbito de uma "teoria pura", cujo objeto primordial é: "responder esta questão: o que é e como é o Direito? Mas já não lhe importa a questão de como deve ser o Direito, ou como deve ele ser feito. É ciência jurídica e não política do direito". A proposta se resume em "libertar a ciência jurídica de todos os elementos que lhe são estranhos. Esse é o seu princípio metodológico fundamental" (idem, p. 01).

Segundo coloca ROSS (2003, p. 25), a ciência, nesses termos, visa a um desiderato duplo: "por um lado livrar a ciência do direito de qualquer ideologia moral ou política, de outro livrá-la de todo vestígio de sociologia, isto é, considerações referentes ao curso efetivo dos eventos".

${ }^{19}$ O texto original é o seguinte: "La característica más importante em el concepto de la dogmática para la comprensión habitual es la prohibición de la negación: la no-negabilidad de los puntos de partida de lãs cadenas de argumentación. Están sustraidos a la crítica". 
Por outro lado, se o enfoque for zetético, o resultado do trabalho não se limitará na descrição do sistema e respectivas normas, mas adentrará na consideração e introdução de elementos próprios de outros ramos do conhecimento, galgando o campo da análise explicativa, da comparação, da fundamentação, da valoração, da interpretação, da indicação de origens e bases históricas, além da formulação de juízos críticos e propostas de lege ferenda.

Nesse diapasão, tomando como exemplo a isenção concedida pelo Decreto-lei 2.324, de 30 de março de 1987, e revogada pelo art. $7^{\circ}$ da Lei 7.988 , de 28 de dezembro de 1989, um enfoque dogmático do ocorrido estaria limitado a descrever a referida isenção, as hipóteses de cabimento e, ainda, que ela se aplicou a partir do exercício de 1987 (com base no incremento das exportações dos produtos manufaturados dos exercícios de 1986 e de 1985), bem como que deveria ter vigorado até 31 de dezembro de 1991, mas que foi revogada antes da previsão inicial por força do art. $7^{\circ}$ da Lei 7.988/89.

O mesmo caso, sob a perspectiva zetética, teria início com a descrição acima, mas acrescentaria considerações complementares, nessa linha: a impossibilidade de se revogar a isenção concedida prazo por certo e sob condições é importante para assegurar segurança jurídica em determinadas circunstâncias.

Ora, muitas vezes o exercício de alguma atividade econômica, por implicar em investimentos vultosos, bem como em vista de peculiaridades mercadológicas, somente é viável se acompanhada da desoneração tributária, ainda que por certo período.

O incentivo fiscal tem por função justamente isso, ou seja, estimular atividades que possam gerar riqueza em determinadas situações e regiões que não se implementariam sob o jugo da tributação plena. Nessas hipóteses, a retirada da isenção (ou sua diminuição) representaria um ludíbrio e efetivo sinal para que o agente econômico deixe de acreditar em futuros acenos semelhantes do Estado.

Ao contrário da pesquisa dogmática que enfrenta o direito de maneira essencialmente ontológica, pois apenas intenta descrever uma realidade como efetivamente se apresenta e não como deveria ser construída, o enfoque zetético aborda o direito de 
modo predominantemente deontológico, uma vez que, dentre outros objetivos, aceita sejam perquiridas questões ligadas à “justiça da norma” e, nos dizeres de $\operatorname{BOBBIO}(2005$, p. 46):

O problema se uma norma é justa ou não é um aspecto do contraste entre o mundo ideal e mundo real, entre o que deve ser e o que é: norma justa é aquela que deve ser; norma injusta é aquela que não deveria ser. Pensar sobre o problema da justiça ou não de uma norma equivale a pensar sobre o problema da correspondência entre o que é real e o que é ideal. Por isso, o problema da justiça se denomina comumente de problema deontológico do direito.

Nota-se que, tanto a zetética, quanto a dogmática, atualmente, convivem na ciência jurídica, não sendo oportuno nesse ponto tecer considerações valorativas sobre cada uma delas, mesmo porque, em princípio, possuem objetivos e espaços de ação diferentes.

O que se colocou, e em linhas gerais, são apenas as características principais que os resultados da pesquisa jurídica podem ostentar, sendo que não existe uma linha fronteiriça clara entre tais enfoques, podendo uma mesma tese tratar de certos assuntos sob inspiração zetética e outros amparada por critérios mais ligados à dogmática.

Não seria razoável esperar que uma ciência social, como é o caso do Direito, consiga formular proposições com o mesmo nível de exatidão, pureza e isenção valorativa próprio das ciências naturais que se socorrem dos resultados fornecidos por aparelhos refinados.

As ciências sociais não se debruçam sobre a realidade pouco mutável da natureza; ao contrário, concentram seus estudos num universo cujos princípios e características não são estáveis e ostentam compreensão muitas vezes subjetiva, haja vista, por exemplo, as controvérsias inconciliáveis a respeito da pena de morte ou do aborto assistido pelo Estado.

Com efeito, segundo AGUILLAR (1996, p. 22): “o estudo do direito não tem conduzido a respostas de validez universal. Ao contrário, convivemos com muitas correntes, que resistem ao tempo e às críticas permanentemente formuladas por seus adversários". 
E, conforme sintetizado por ROSS (2003, p. 370-371), mesmo que sob grande esforço se procure tratar o objeto escolhido (v.g. uma lei, um princípio geral de direito) com objetividade, constata-se que dificilmente: "o cientista social deixará de ser, em algum grau, também um reformador social”. E isso ocorre, segundo o autor citado, em vista de que:

Mesmo após haver feito a mais exaustiva coleta de todos os fatos e suas correlações, sempre haverá um salto a ser dado, o que significa que todas as considerações serão levadas em conta e pesadas numa resolução, isto é, num ato irracional. A ciência social jamais pode pretender uma solução, quer dizer, uma diretiva que brote inequivocamente do objetivo dado em conexão com o conhecimento técnico.

Trazendo em socorro mais uma vez o comento de AGUILLAR (1996, p. 64): "uma ciência social é somente possível se se admite um certo traço de relativismo, vale dizer, se se tolera uma convivência de ideologias que se afrontam na base da produção teórica", sendo importante, para que não se diga fulcral, que tais alertas sempre acompanhem, mesmo que implicitamente, a pena do cientista do direito.

Aliás, segundo SOROS (2008, p. 101): “Conceder à ciência social o prestígio da ciência natural possibilita que teorias científicas sejam utilizadas para propósitos manipulativos em vez de cognitivos".

Essa característica peculiar das ciências sociais, notadamente da ciência do direito, faz com que surja a possibilidade das pesquisas realizadas sob sua órbita influenciarem de algum modo o próprio objeto de análise de estudo, algo impensável de se manifestar perante as ciências naturais.

De fato, não seria absurdo considerar que as manifestações da doutrina jurídica (v.g. com formulações e propostas de lege ferenda) possam servir de embasamento ao trabalho futuro dos legisladores e operadores do Direito, sendo a recíproca verdadeira, ou seja, nos casos em que o cientista empreender laboro descrevendo modificações ocorridas em determinada norma ou comentando os termos de alguma decisão judicial.

Conforme assevera CARVALHO (2005, p. 175-176): 
O feedback, que o direito positivo processa a partir das mensagens enviadas pela Ciência do Direito, influencia o próprio caminho a ser escolhido pelo sistema normativo. Isso é plenamente verificável quando percebemos que diversas decisões jurisdicionais importantes, ou mesmo leis fundamentais de nosso ordenamento, jamais teriam existido se não fosse pelo advento de teorias marcantes no curso de nossa história jurídica.

Esse fenômeno relativamente comum das ciências sociais é denominado por SOROS (2008, p. 34) de reflexividade.

Em conclusão, mesmo que a ciência do direito não se confunda com seu objeto primordial de pesquisa, no caso os princípios de normas jurídicas em geral, tratando-se de eventos separáveis criados pelo labor humano, não se pode ignorar a existência de uma íntima relação, para que não se diga interpenetração entre ambos, sendo concebível um certo nível de mútua influência ou reflexividade, o que acaba ocorrendo também em relação às demais ciências sociais, como a ciência da economia.

\subsection{A economia como um fenômeno social}

Nesse ponto, inicia-se a digressão a respeito do que se constitui a economia, expressão cuja origem etimológica é grega, qual seja, do termo oikonomia, extrai-se a ideia da constituição de normas dirigidas à administração, organização e provisão da casa: oikos (casa) + nomos (lei ou regra), segundo colaciona ROSSETTI (1987, p. 47) e NUSDEO (2005, p. 31).

Destaca-se, aqui, segundo RISTER (2007, p. 40), que a ideia de casa: "possuía na Antigüidade um sentido mais abrangente que o atual, constituindo uma unidade não limitada ao consumo, mas igualmente à produção, dentro do regime de autoconsumo".

Entender como funciona a dinâmica da economia, aqui também vista como fenômeno social, implica considerar que os recursos materiais de alguém nunca são suficientes para atender a todos os seus desejos sem qualquer tipo de restrição, visto que, sob essa ótica, os anseios podem tender ao infinito. 
Nessa linha, mesmo os milionários encontram limites para realizar suas pretensões, devendo, necessariamente, moldá-las, de alguma forma, à sua capacidade financeira de aquisição e manutenção dos mais variados bens.

O mesmo raciocínio é válido para a própria sociedade, ou seja, não é viável atender à plenitude a todos os anseios de uma comunidade, ainda que em sua maioria sejam perfeitamente legítimos. Essa constatação, denominada de "escassez", foi encampada como um dos pressupostos da ciência da economia, que merecerá considerações adiante.

Nessa toada, reconhece-se que sempre existirá algum nível de escassez, seja em termos individuais, seja sociais, isso é, não surpreende a insuficiência de meios para satisfazer tudo o que se necessita ou se deseja. Ainda que sob severas variações em face de circunstâncias de local (v.g. comparando o nível médio de bem-estar vivido atualmente na Europa com o da África) e de tempo, a insuficiência de recursos - ora mais, ora menos severa - sempre ocorreu na humanidade e isso não é novidade, ao contrário, segundo noticia NUSDEO (2005, p. 27):

\footnotetext{
A lei da escassez é uma lei férrea e incontornável, tendo submetido os homens a seu jugo desde sempre, levando-os a se organizarem e a estabelecerem entre si relações específicas a fim de enfrentá-la ou, melhor falando, conviver com ela, atenuando-lhe o quanto possível a severidade.
}

De fato, o desenvolvimento econômico, com significativa melhoria na qualidade de vida de milhões de pessoas, é algo que remonta há, quiçá, meros 200 anos e tal interregno é certamente diminuto se comparado àquele que o separa do surgimento do homo sapiens. Nessa esteira, em realidade, até recentemente, o que prevalecia era a pobreza generalizada, com exceção, segundo SACHS (2005, p. 53):

de uma minoria muito pequena de governantes e grandes proprietários de terras. A vida era tão difícil em boa parte da Europa quanto na Índia ou na China. Com muito poucas exceções, nossos trisavôs eram provavelmente pobres e viviam no campo. O historiador de economia Angus Maddison estima a renda média por pessoa na Europa Ocidental de 1820 em torno de $90 \%$ da renda média da África de hoje. Em 1800, a expectativa de vida na Europa Ocidental e no Japão estava ao redor de quarenta anos. 
De maneira a ilustrar o desenvolvimento da renda per capita no mundo nos últimos 2000 anos, o gráfico abaixo ${ }^{20}$ mostra um notável - quiçá explosivo - aumento experimentado nos últimos 100 anos:

FIGURA 2 - RENDA PER CAPTA MÉDIA DO MUNDO

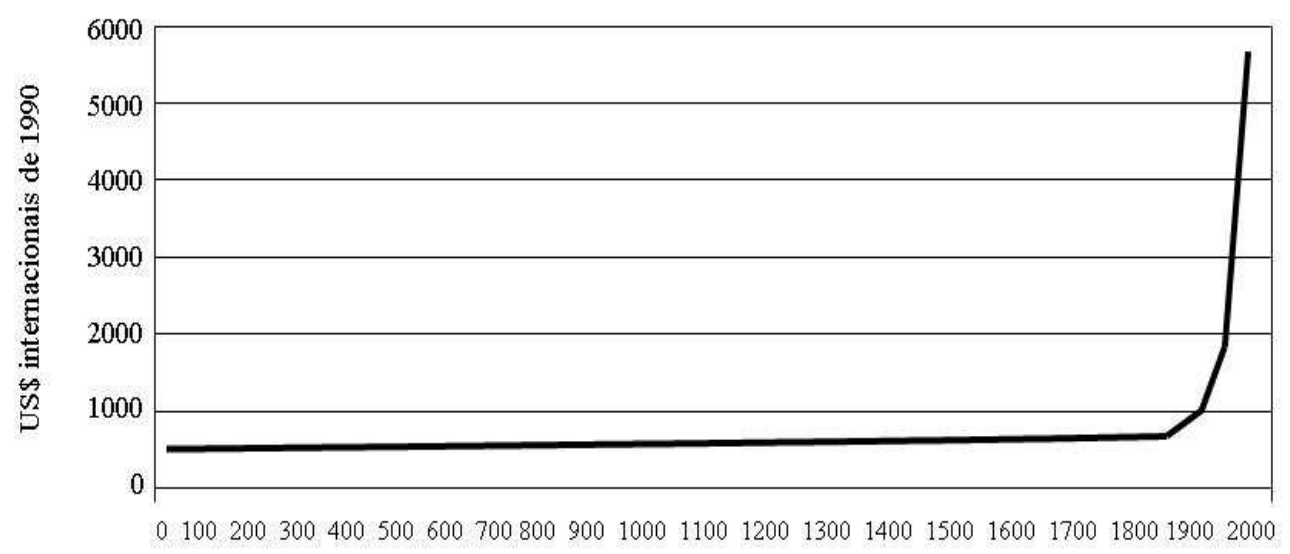

Em linha semelhante, NÓBREGA (2005, p. 58) aponta que a economia mundial: "dobrou de tamanho nos primeiros quinhentos anos do segundo milênio. Hoje, bastam oito anos para a china obter o mesmo resultado. [...] Em menos de dois séculos, de 1820 a 1998, o crescimento explodiu: 1800\%!".

Sem sombra de dúvida, não obstante o mundo atual ainda ostentar contrastes acentuados entre as várias regiões, nota-se que o desenvolvimento se operou não apenas em termos econômicos, mas atingiu as searas sociais e políticas. Pela exposição de SEN (2008, p. 09):

$\mathrm{O}$ século $\mathrm{XX}$ estabeleceu o regime democrático e participativo como modelo preeminente da organização política. Os conceitos de direitos humanos e liberdade política hoje são parte da retórica prevalecente. As pessoas vivem em média muito mais tempo do que no passado. Além disso, as diferentes regiões do globo estão agora mais estritamente ligadas do que jamais estiveram, não só nos campos da troca, do comércio e das comunicações, mas também das idéias e ideais interativos.

Não se pode negar a gigantesca evolução experimentada pela população européia, ainda mais se forem recordadas as precárias condições de vida dos servos nos feudos medievais onde, segundo HUBERMAN (s. d., p. 04 e ss.):

\footnotetext{
${ }^{20}$ Fonte: SACHS (2005, p. 55).
} 
O camponês vivia numa choça do tipo mais miserável. Trabalhando longa e arduamente em suas faixas de terras espalhadas (todas juntas tinham, em média, a extensão de 6 a 12 hectares, na Inglaterra, e 15 a 20, na França), conseguia arrancar do solo apenas o suficiente para uma vida miserável [...] A propriedade do senhor tinha que ser arada primeiro, semeada primeiro e ceifada primeiro.

Mesmo que profundas melhorias tenham se verificado no nível de bemestar dos seres humanos, notadamente, a partir do século passado, os recursos materiais continuam e permanecerão finitos frente ao gigantesco volume de necessidades ou desejos (individuais ou coletivos).

Em último grau, aliás, esses limites acabam sendo impostos implacavelmente pelo próprio meio ambiente, que, inclusive, há certo tempo já vem acenando certa exaustão, bastando atentar às notórias e inegáveis alterações do clima nos últimos anos, bem como reconhecer que uma das principais fontes de energia e matéria prima de uma enormidade de bens - o petróleo - pode se esgotar nas próximas décadas ou século.

Nesse sentido, inserido numa ambiência muito poucas vezes amigável em termos de detenção de recursos, qualquer pessoa que desejar obter certa comodidade (v.g. uma refeição, um remédio, um automóvel, uma máquina fotográfica, uma viagem, um lote de ações de uma companhia aberta, etc.), usualmente, age racionalmente e compara as possibilidades de aquisição que despontam diante de si, de maneira a escolher a que, em seu juízo, mais lhe agregar benefícios e utilidades, isso é, corresponder ao melhor custobenefício. Aliás, o "agir racionalmente" também é outro elemento de relevo na ciência da economia.

Vale ressaltar a intuição de BENTHAN (1974, p. 09), que, no final do século XVIII, ao edificar as bases do utilitarismo, afirmou que o ser humano sempre está às voltas e sob o domínio da dor e do prazer, elementos estes que "nos governam em tudo o que fazemos, em tudo o que dizemos, em tudo o que pensamos, sendo que qualquer tentativa que façamos para sacudir este senhorio outra coisa não faz senão demonstrá-lo e confirmá-lo".

Nada há para espantar, ao contrário, no dia a dia é muito usual esse tipo de atitude, desde as mais comezinhas situações, até as decisões que implicam em prévia 
reflexão qualificada, como, por exemplo, a compra de um bem de raiz. Nesse caso, aliás, é certo que com a mesma quantia de dinheiro é possível adquirir um imóvel de proporções diminutas num bairro nobre e silencioso ou outro de metragem maior em localidade mais popular e não tão tranquila. A decisão dependerá de quais necessidades e satisfações o futuro proprietário anseie.

Independentemente do grau de reflexão engendrado pelo agente em cada caso concreto, é certo que alguém pode vir a comprar um imóvel de maneira leviana, sem avaliar-lhe corretamente o preço pedido ou a sua futura utilidade, fato é que, nos dizeres de RODRIGUES (2007, p. 14):

Todas as nossas escolhas, dando ou não lugar a um desembolso monetário, têm custos: se de verdadeiras escolhas se trata, quando optamos por uma alternativa abdicamos de outras. [...] A necessidade de escolher decorre do confronto de desejos, potencialmente ilimitados, do agente econômico e as restrições que enfrenta.

Ressalte-se que, em regra, não se trata de esperar que o agente sempre possua uma tendência em escolher a opção mais barata disponível. Outros critérios ordinariamente são levados em conta.

Assim, o tempo que será despendido na pesquisa de mercado pode se mostrar importante caso exista urgência na aquisição ou, ainda, na hipótese de o agente, por ter que empregar parte de seu tempo na procura do item desejado, deixar de exercer alguma outra atividade que lhe daria mais prazer do que o eventual benefício advindo da busca mais acurada.

Isso não implica abandono do "agir racionalmente", ao contrário, o confirma. É que, segundo POSNER (2007a, p. 48): “as decisões tomadas com base em informação incompleta são racionais quando os custos de adquirir mais informação superam os benefícios prováveis da capacidade de tomar uma decisão melhor"21.

Outras circunstâncias também se destacam como fatores de relevo para a escolha de modo que acabam conjugadas com o preço dentro desse usual juízo do custo-

${ }^{21} \mathrm{O}$ texto original é o seguinte: "las decisiones tomadas con base en información imcompleta son racionales cuando los costos de adquirir más información superan los beneficios probables de la capacidad de tomar una decisión mejor". 
benefício, tais como: a qualidade e durabilidade do produto, o prazo de entrega e os limites da garantia oferecida, eventual tributação adicional caso o bem venha do exterior, o status social que o bem possa conferir ao seu titular, o simples prazer de possuí-lo e tudo o mais que a mente humana, individualmente, for capaz de fantasiar.

À evidência, tais reflexões serão variáveis de pessoa para pessoa. Não existe um padrão que se poderia chamar de correto ou mais acertado. Há opções individuais que agridem flagrantemente a razão comum, como, por exemplo, utilizar drogas ou conduzir veículos sob efeito do álcool e colocar em risco a própria vida e a de terceiros.

No entanto, é sabido que tais escolhas são recorrentes para muitos indivíduos. Coloca, nesse sentido, GALVES (1967, p. 58) que: "a necessidade econômica faz abstração do juízo moral ou jurídico sôbre a natureza ou o objeto da necessidade: o desejo de coisas inúteis ou mesmo nocivas pode determinar atividades econômicas de produção, mercado, preços, consumo".

Em conclusão, o pré-falado "agir racionalmente" significa muito mais o engendramento de uma estratégia qualquer para obter um prazer, a procura pela autosatisfação, um sentimento hedonista, do que uma ação precedida de minuciosa reflexão em torno da melhor opção objetivamente considerada. Na lição de POSNER (2007b, p. 474):

\footnotetext{
Deve ficar subentendido que tanto as satisfações não-monetárias quanto as monetárias entram no cálculo individual de maximização (de fato, para a maioria das pessoas o dinheiro é um meio, e não um fim), e que as decisões, para serem racionais, não precisam ser bem pensadas no nível consciente - na verdade, não precisam ser de modo algum conscientes. Não nos esqueçamos de que "racional" denota adequação de meios a fins, e não meditação sobre as coisas, e que boa parte de nosso conhecimento é tácita.
}

Em resumo, essa maneira de agir, normalmente encontrada na maioria das pessoas, se mostra como uma "atividade econômica", independentemente, do nome a si atribuído pela ciência ( $v \cdot g$ ação-racional, hedonista, egoística, auto-satisfatória, etc.).

Expõe WEBER (2006, p. 09-10) que: "uma atividade é econômica quando está orientada a procurar "utilidades" (bens e serviços) desejáveis ou as probabilidades de disposição sobre as mesmas", ou seja, ainda segundo o autor, a ação 
econômica está: "condicionada e orientada pela escassez de meios: para satisfazer o desejo de certas utilidades, cujos meios, quando somente se dispõe deles com limitação, devem submeter-se à gestão econômica".

Destaque-se que a "ação econômica" não envolve necessariamente a presença ou a circulação de dinheiro, posto que as diversas operações possam ocorrer na forma de trocas de bens em espécie, como ocorria no início da Idade Média, época em que o feudo produzia quase tudo que seria consumido pelas famílias, havendo poucas e esporádicas trocas em mercados semanais mantidos junto a mosteiros ou castelos controlados pelo bispo ou o senhor local, conforme HUBERMAN (s. d., p. 15-16).

Disso se fazem cabíveis os termos "economia natural" (desconhece o dinheiro) e "economia monetária" (utiliza o dinheiro de forma preponderante) por sugeridos WEBBER (2006, p. 13).

Certamente que o emprego da moeda, meio de troca por excelência ${ }^{22}$, eis que em regra aceita por todos agentes econômicos, facilita em muito a materialização das transações entre as pessoas que desejam satisfazer suas mais diversas necessidades, justamente porque, ao dispor de um bem, é possível guardar o numerário entregue em contra partida para, depois, utilizá-lo na aquisição de alguma outra necessidade ${ }^{23}$.

Todavia, a ação econômica não se resume, nem sequer pressupõe, seja indispensável a presença de dinheiro, ainda mais porque, sob certas circunstâncias (v.g. episódios de hiperinflação, como ocorreu na Alemanha na década de 1930), o regime de trocas diretas entre as partes interessadas ganha revelo especial. Com efeito, frente a episódios de hiperinflação, aponta BELLUZZO (2009, p. 204) que as: "finanças públicas e a intermediação financeira entram em colapso. A economia regride para o escambo".

\footnotetext{
${ }^{22}$ Na lição de GALVES (1967, p. 210-211): “O dinheiro ou moeda é, pois, um meio geral de trocas, aceito por todos, dentro de uma comunidade social, ou comunidade de pagamentos. [...] Que tipo de bem econômico é o dinheiro? Não é um bem de consumo, porque, salvo o caso do usuário que se deleita com sua contemplação, não satisfaz de modo direto nenhuma necessidade humana. Não é, também um bem de produção, porque diretamente não dá nascimento a outros bens. Entra numa categoria à parte: é um bem de troca.

23 Assim ordinariamente ocorre porque, na exposição de BELLUZZO (2009, 212): "Nas economias contemporâneas, a moeda está fundada na confiança. A confiança é um fenômeno coletivo, social. Tenho confiança na moeda porque sei que o outro está disposto a aceitá-la como forma geral de existência do valor das mercadorias particulares, dos contratos de riqueza".
} 
Prosseguindo, não apenas os seres humanos individualmente considerados se deparam com dilemas a serem superados diuturnamente, mas a própria sociedade também deve realizar opções em torno de uma série de necessidades coletivas (v.g. segurança pública, proteção ao meio ambiente, políticas públicas de educação e saúde, etc.), relembrando-se que, inevitavelmente, não haverá recursos suficientes para o atendimento integral e simultâneo de todas elas, pois a possibilidade de contribuição compulsória dos indivíduos em benefício de um "caixa comum” é inegavelmente limitada, inclusive, porque não se pode produzir riqueza infinita.

Logo, à medida que uma pessoa (ou a própria sociedade) escolhe certa necessidade para contemplar, independentemente de sua relevância ou urgência, é intuitivo, para que não se diga obrigatório, concluir que outra provavelmente remanescerá pendente, isso é, toda e qualquer opção implica numa simultânea renúncia ao exercício de outra possibilidade e nisso se revela a dinâmica econômica.

Tome-se, como ilustração, uma comunidade hipotética constituída por 100 pessoas que diariamente produzem o alimento estritamente necessário à sobrevivência de seus membros. Dessa forma, a cada manhã todos saem aos campos e, ao anoitecer, retornam com uma quantidade de gêneros que será dividida igualmente entre todos, supondo-se que não há sobra (ou poupança), ou seja, o total produzido é inteiramente consumido durante a noite, repetindo-se essa rotina indefinidamente.

Obviamente, trata-se de uma situação ideal que dificilmente se consumaria na prática, mas que serve de modelo elucidativo elementar da dinâmica econômica.

Suponha-se, ainda dentro dessa proposta, que, como moeda (meio de troca), essa comunidade se sirva de pedras verdes redondas ${ }^{24}$, do seguinte modo: ao final

\footnotetext{
${ }^{24}$ Com efeito, a moeda, como meio de troca, não é necessariamente o dinheiro impresso oficialmente por um país. Assim, por exemplo, é notório que nas cadeias os cigarros têm tal serventia. Uma hipótese absolutamente curiosa é narrada por MANKIW (2007, p. 631). Cuida-se da moeda utilizada em Yap, uma minúscula ilha localizada no Pacífico Sul. Em que pese ser um território norte-americano, há mais de dois mil anos os yapenses utilizam discos de pedras calcárias como moeda de pagamento para grandes aquisições (v.g. terras, canoas, licenças de casamento). O dólar somente entra em cena nas transações de pequena monta, como aquelas do supermercado e do posto de gasolina, que também podem ser quitadas com cerveja. Os discos de pedra chegam a ostentar 90 centímetros de diâmetro ou mais, o que requer a força de vários homens para carregá-los quando necessário. O autor informa, ainda, que na ilha
} 
do dia, quando um indivíduo entrega o que produziu no lado direito do armazém geral e recebe da autoridade A cinco pedras.

De posse delas, pode se dirigir ao lado esquerdo do armazém e, mediante controle feito pela autoridade B, é possível trocar as pedras pelos gêneros alimentícios que ali se encontram e que foram produzidos pelos demais indivíduos até que tudo o que foi entregue no lado direito tenha sido retirado no lado esquerdo e todos se recolham em descanso.

Suponha-se, mais uma vez e em continuação desse exemplo, que, numa certa ocasião, tenha se percebido que, na eventualidade de se majorar os resultados, haveria melhora na qualidade de vida e saúde de todos, uma vez que a quota diária de calorias de cada um poderia ser ampliada.

Todavia, não se sabe exatamente qual a melhor maneira de se implantar tal desígnio. Então, na manhã seguinte, são designadas 10 pessoas para pesquisar possíveis técnicas de aumento da produtividade, recebendo elas ao final do dia a mesma quantidade de pedras verdes que os 90 que seguiram aos campos.

O que ocorrerá de início? Se o resultado do trabalho de 100 era inteiramente consumido, não havendo qualquer sobra, presume-se que, pelo labor de apenas 90, não haverá a mesma quantidade disponível de alimentos do dia anterior. Não se pode esquecer que 10 pessoas, por estarem desenvolvendo tecnologia por meio de pesquisa, deixaram de produzir alimentos em espécie.

Cria-se, imediatamente, a necessidade de se rediscutir a divisão do produto social e isso se dará, por exemplo, com um sacrifício geral e uma redução no consumo diário individual, na esperança de que no futuro, pelos resultados da nova tecnologia que se desenvolve, se consiga não apenas retornar ao patamar anterior, mas se dê um passo adiante no nível de bem-estar.

Caso não se concorde com isso, ou seja, em se querendo a mantença do mesmo nível de consumo e bem-estar, a insuficiência de alimento gerará inflação em seu 
preço $^{25}$ de maneira a que aqueles que realmente desejarem consumir a mesma quantidade do dia anterior ofereçam em troca algo mais do que as cinco pedras verdes redondas recebidas (v.g. tomando com a autoridade A um empréstimo de mais duas pedras a ser pago em uma semana - o tempo suficiente para o mutuário encontrar novas pedras da mesma espécie na natureza).

Note-se, contudo, que, se ocorrer aumento expressivo do número de pedras em circulação, seu valor intrínseco diminuirá dado o excesso de moeda em curso, havendo risco da autoridade B passar a exigir a entrega de seis ou sete pedras para entregar os alimentos diários em vista da predominância do volume monetário sobre o econômico.

Trata-se, em suma, da aplicação da vetusta regra oferta-demanda como indicadora do preço. Na explicação de MANKIW (2007, p. 647): “O que determina o valor da moeda? A resposta a essa questão, como muitas questões em economia, está na oferta e na demanda. Assim como a oferta e a demanda de bananas determinam o preço das bananas, a oferta e a demanda determinam o valor da moeda".

Em conclusão, ao considerar o exemplo em tela, quanto mais pedras verdes redondas (a moeda) circularem, menos bens e comodidades cada uma poderá comprar com uma mesma quantidade de pedras.

Outra solução seria simplesmente colocar em vigor a lei do mais forte, sendo que a divisão se realizaria pela força bruta, isso é, quem conseguisse se apossar de maior quantidade dos gêneros, melhor aquinhoado estaria.

Contudo, esse caminho dificilmente seria o mais eficiente em termos econômicos, uma vez que a violência gerada certamente causaria prejuízo à força de trabalho da comunidade, pois os feridos (e quiçá mortos) estariam impossibilitados de produzir no dia seguinte, diminuindo ainda mais a quantidade final produzida.

\footnotetext{
${ }^{25} \mathrm{Na}$ lição de GASTALDI (1970, p. 264): “De fato, o mais correntio conceito de inflação é o que a considera como a resultante de um excesso de procura de bens e serviços sôbre a oferta dos mesmos, aos preços correntes".
} 
A realidade demonstra que as sociedades em geral sempre se defrontam com esse tipo de dilema: deve-se preparar o futuro e, com isso, passar alguma privação no presente ou, ao contrário, o melhor é consumir imediatamente todo o produto social? ${ }^{26}$

Consta-se, destarte, que as diversas opções que se descortinam frente às variadas circunstâncias da vida diária, sob pálio da já referida escassez presente, geram implicações (ainda que em potencial) diversificadas e impedem que se desfrute dos eventuais benefícios de uma opção não escolhida, entrando em cena, pois, os custos de oportunidade ou tradeoffs. Melhor explicando, segundo MANKIW (2007, p. 05):

Quando as pessoas estão agrupadas em sociedade, deparam-se com tipos
diferentes de tradeoff. O tradeoff clássico se dá entre "armas e manteiga".
Quanto mais gastamos em defesa nacional (armas) para proteger nossas
fronteiras de agressores estrangeiros, menos podemos gastar com bens de
consumo (manteiga) para elevar nosso padrão de vida interno. Igualmente
importante na sociedade moderna é o tradeoff entre um meio ambiente
sem poluição e um alto nível de renda. As leis que exigem que as
empresas reduzam a poluição elevam o custo de produção de bens e
serviços. Devido aos custos mais elevados, essas empresas acabam
obtendo lucros menores, pagando salários menores, cobrando preços mais
elevados ou fazendo alguma combinação dessas três coisas. Assim,
embora os regulamentos antipoluição nos proporcionem o benefício de
um meio ambiente com menos poluição e a melhor saúde que dele
decorre, eles trazem consigo o custo da redução da renda dos
proprietários das empresas, trabalhadores e clientes.

Por conseguinte, a organização da economia em qualquer sociedade implica na resolução de algumas questões elementares, mas de fulcral importância no desenho social que se pretende imprimir. Conforme sugerido por BOARATI (2006, p. 1516), é preciso que se tomem decisões acerca dos seguintes tópicos:

1) O que será produzido? Dada a insuficiência (escassez) de recursos materiais, não sendo possível atender a todas as necessidades (e ou desejos) simultaneamente, é preciso fazer opções e escolhas sobre a quantidade e qualidade de bens e serviços que serão confeccionados num dado momento histórico.

\footnotetext{
${ }^{26}$ A esse respeito ROSSETTI (1987, p. 149) indica que: "Não há exemplos históricos de economias de rápido desenvolvimento que não tenham reduzido suas taxas de consumo. As que sucumbiram à sedução do consumo enfraqueceram seus potenciais de acumulação - trocaram pelo ilusório consumo do presente as possibilidades de um bem-estar mais sólido no futuro".
} 
2) Como será produzido? Frente a diversos processos produtivos possíveis em que cada um apresenta custo e resultado diferente, de modo a evitar o desperdício e se atingir um patamar de maior eficiência, é de rigor decidir quais meios de produção devem ser aplicados para cada finalidade desejada.

3) Quem serão os destinatários do que foi produzido? Significa resolver como será a distribuição de renda na sociedade, de forma a determinar como o produto resultante da ação econômica dos indivíduos deve ser dividido.

Aqui entra em cena uma série enorme de questões, incluindo, por exemplo: o mercado será predominantemente livre ou existirá algum nível de controle sobre a fixação dos preços praticados pelos agentes econômicos? Se a opção for pela existência do controle, em quais setores isso se operará e sob qual intensidade? Qual a extensão dos direitos de propriedade? Uma vez que pela tributação é possível redistribuir parte da riqueza produzida, como se edificará o sistema tributário? O maior enfoque será dado às exações que gravam a propriedade e a renda ou, noutro sentido, será o consumo de bens e serviços objeto de maior rigor fiscal? Em adição, quais serviços e benefícios serão fornecidos gratuitamente pelo Estado à população? Quanto dos impostos arrecadados será empregado na segurança pública ou na proteção do meio ambiente? E assim por diante.

Das respostas a tais questões, segundo detalhadamente coloca NUSEO (2005, p. 100-125), podem resultar, em síntese, três sistemas básicos de organização econômica, denominados pelo autor de: tradicional, autoridade e autonomia, sendo que, obviamente, cada um deles comporta sub-sistemas com suas matizes e características peculiares segundo condições de tempo e local, nos seguintes termos.

1) sistema da tradição: é marcado por quatro características básicas, quais sejam:

a) estabilidade nas formas de agir e nos usos e costumes, cujas alterações se ultimam de modo realmente lento ou quase imperceptível, sendo necessário um intervalo de duas ou mais gerações para que seja possível notar qualquer mudança de relevo; 
b) ausência de um marco temporal definido como identificador da adoção de certo costume ou cabedal cultural da comunidade, o que confere àquele modus operandi econômico um âmbito "definitivo";

c) papel secundário da economia no conjunto da vida social, sendo ele ordinariamente mera atividade-meio para o desenvolvimento de atividades-fins, tais como: religião, danças, guerra, esporte ou saber;

d) não unidade de regimes, isso é, sensíveis variações no conteúdo das diversas tradições de cada comunidade inserida no regime tradicional, o que não impede, contudo, que a mecânica operacional de todos seja, em essência, a mesma e se resuma à obediência a padrões comportamentais imemorialmente estabelecidos.

Nesse tipo de sociedade, em regra, se produzem os bens necessários e suficientes à reprodução e manutenção do status quo, ou seja, dos padrões anteriormente já consagrados e isso ocorre "de forma natural" (v.g. alimentos, vestuário, objetos de culto, armas), sendo que as técnicas empregadas na produção tendem a se reiterar, o mesmo se aplicando quanto à posterior distribuição dos bens. O que se dá basicamente porque em tais sociedades não existe mobilidade social, apresentando-se em estamentos.

Assim, com o nascimento, já se define a posição do indivíduo na hierarquia comunitária, fixando-se suas funções, deveres e direitos na repartição do produto social. Interessante notar, segundo expõe NUSDEO (2005, p. 05) que, "nas sociedades tradicionais ou orgânicas, como regra, a riqueza segue o poder, enquanto que nas sociedades não-tradicionais dá-se o contrário, isto é, o poder segue a riqueza”.

A um sacerdote, então, pode ser direcionada significativa parcela dos bens produzidos, notadamente alimentos e vestuário, não como retribuição da riqueza material que ele consegue produzir, mas em face da posição ou status que detém no grupo.

Historicamente, esse tipo de sistema preponderou na humanidade até o final da Idade Média e início da Era Moderna, quando, pelo crescente contato entre as várias civilizações, o comércio se desenvolve e tem início o mercantilismo. Atualmente, apenas comunidades isoladas têm a vida econômica marcada pelo sistema tradicional (v.g. 
indígenas, esquimós, aldeões no Oriente Médio, ordens religiosas que vivem em confinamento).

2) sistema da autoridade: aqui as decisões econômicas, ao menos as principais, são centralizadas pelo poder político, sendo que, como regra, a titularidade dos bens de produção não é privada, mas "coletiva". Independente do nome que se dê ao órgão central controlador ( $v . g$. comitê, conselho, departamento, ministério, secretaria), fato é que cabe à autoridade política responder às três questões acima elencadas (o que, como e para quem produzir?), além de tomar as providências cabíveis à implementação das políticas pré-estabelecidas.

Em face dessa característica, o sistema usualmente se operacionaliza por meio de planos econômicos, por isso também são denominados de sistemas de planejamento ou planificados.

Dependendo do nível de organização e complexidade social em cada caso observado, o processo poderá se desenrolar sob a forma piramidal, com vários níveis hierárquicos e de competências de atuação.

Dessa forma, por hipótese, num primeiro estágio, um órgão máximo e central estabeleceria as diretrizes e as metas a serem alcançadas ao final de certo tempo, inclusive adentrando na pré-fixação de preços e salários de praticamente todas as categorias profissionais, também fixando aos indivíduos, segundo a posição em que se encaixam no sistema, quotas periódicas de consumo máximo, inclusive por racionamento de bens se necessário.

Na sequência, centros regionais espalhados pelas diversas províncias do país se encarregariam de regulamentar tais decisões, passando instruções mais detalhadas às gerências locais que, por sua vez, as transmitiriam às variadas unidades de produção, desde o setor agropecuário, passando pela indústria de base (v.g. mineradoras, siderúrgicas, refinarias, montadoras de máquinas e veículos), fábricas de produtos diversificados (v.g. higiene, alimentos, vestuário, eletrodomésticos) e todo o variado setor de serviços. 
Ao depois, dados estatísticos seriam periodicamente remetidos aos centros decisórios para análise e eventuais adaptações nas metas inicialmente fixadas. Em complemento, às unidades de produção caberia identificar, pormenorizadamente, suas respectivas necessidades de operação (v.g. majoração no envio semanal de aço para que se consiga confeccionar tantas toneladas de trilhos ferroviários). $\mathrm{O}$ atendimento às essas demandas ficaria a cargo da autoridade (regional ou central, dependendo do caso), mas a recusa poderia implicar na necessidade de revisão das metas inicialmente traçadas.

Em suma, procurar-se-ia congregar da maneira mais harmônica possível, levando em conta a natural escassez dos bens materiais, as decisões relativas a toda produção e todo consumo em certo interregno, de modo a que se atinja um equilíbrio social segundo as premissas adotadas previamente pela autoridade central.

Em realidade, não há notícia de que algum sistema até hoje tenha conseguido tamanho grau de centralização e controle econômico. O que se expõe aqui é, por conseguinte, um modelo basilar, cujas características primordiais se refletem na realidade fática atual e pretérita das sociedades, ora de forma mais incisiva em certos pontos, ora mais presente noutros aspectos.

Como exemplos históricos, NUSDEO (2005, p. 114-116) cita os seguintes:

a) os jesuítas das Missões (Brasil meridional, Argentina centetrional e Paraguai) que procuraram subtrair os indígenas do sistema escravagista então vigente e, com isso, criar "uma quase autarquia com um regime de produção conduzido centralizadamente pelos religiosos, dentro de rígidos padrões de produção e distribuição";

b) o sistema mercantilista, no que toca às concessões reais para os empreendimentos marítimos;

c) a Rússia pós-revolução de 1917 e os países sob sua influência na Europa oriental, com destaque para a Albânia entre 1947 e 1990, bem como a China e Cuba; 
d) a Alemanha sob o regime nazista onde a propriedade e o contrato teriam sido mantidos apenas formalmente, pois o Estado é quem, em última análise, ditava as direções a serem adotadas pelos empresários;

e) regimes militares da América Latina, eis que "acentuaram pronunciadamente, o grau de centralização das decisões econômicas”.

3) sistema da autonomia: é um modo de organização onde cabe primordialmente aos agentes privados, por meio de sua inter-relação no mercado, implantar respostas às três questões fundamentais acima postas. Nessa linha, pela conjugação dos vetores da oferta e da demanda em torno dos inúmeros bens e serviços possíveis de serem produzidos, é que se decidirá o que, como e para quem a produção se destinará, num processo dinâmico e variável.

Então, se a procura por certo bem aumenta, não importando aqui os motivos, os respectivos fabricantes se interessarão em confeccioná-lo em maior quantidade e, possivelmente, cobrarão um preço maior, uma vez que o incremento na demanda pelo bem gera expectativa de majoração nas vendas e, consequentemente, no lucro do agente produtor.

Todavia, na medida em que mais bens são ofertados no mercado e os interessados em possuí-lo têm o anseio atendido (desde que paguem por ele, obviamente), o preço deve se estabilizar num patamar a partir do qual não mais existam pessoas dispostas a adquiri-1o ${ }^{27}$.

Cria-se, então, um equilíbrio entre a oferta e a demanda que serve de sinal para que os fabricantes mantenham o nível de produção. Caso a demanda aumente outra vez, o processo tende a se repetir e, caso diminua, o inverso provavelmente ocorrerá, isso é, diminuição na produção até que um novo equilíbrio se estabeleça.

\footnotetext{
${ }^{27} \mathrm{Na}$ explicação de ARAÚJO (2008, p. 101): "numa compra e venda o comprador tem que evidenciar uma disposição de pagar que permita formar um preço superior à disposição mínima de vender; e o vendedor tem que evidenciar que esta disposição mínima permite a formação de um preço inferior à disposição máxima de pagar pelo comprador (ambos têm que evidenciar reciprocamente uma certa disposição de acordarem num preço aceitável).
} 
Verifica-se, pois, conforme assevera BOWLES (1985, p. 64) que: "as mudanças nos preços não se originam em qualquer coisa de autônomo ou mesmo fruto do acaso: são, de fato, determinadas pelo comportamento dos compradores e dos vendedores" 28 .

O resultado desse comportamento que tende ao equilíbrio, ainda que evidentemente nem sempre estável, é expresso teoricamente com base na denominada lei da demanda e oferta ${ }^{29}$, que, segundo BOARATI (2006, p. 63): “consiste na conclusão de que o preço de qualquer mercadoria sempre se ajusta de forma a equilibrar a oferta e a demanda desse bem. Esse preço evidentemente pode variar ao longo do tempo quando as forças de demanda ou oferta se modificam”. Os gráficos a seguir ilustram a exposição ${ }^{30}$ :

\section{O Equilibrio de Oferta e Demanda \\ 0 equilibrio é encontrado no ponto em que ocorre intersecção da curva de oferta e da curva de demanda. Ao preço de equilibrio, a quantidade ofertada é igual à quantidade demandada. Aquil, o preço de equilibrio é \$2: a esse preç, sõo ofertados 7 sorvetes de casquinha e são demandados 7.}

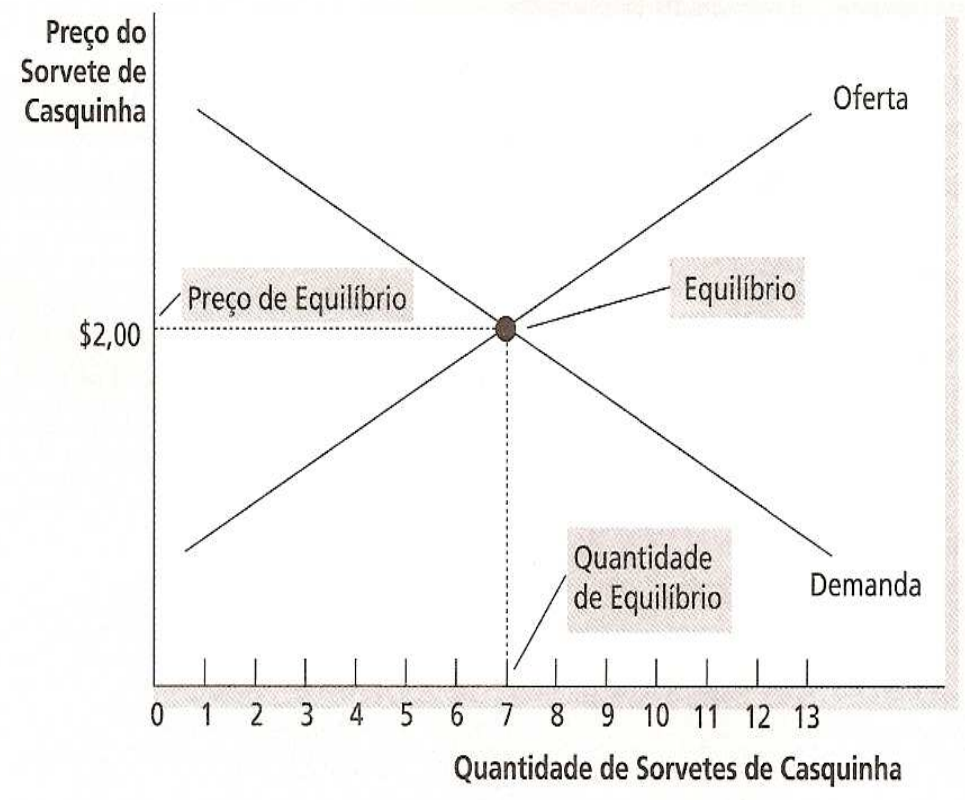

${ }^{28}$ O texto original é o seguinte: "I mutamenti dei prezzi non constituiscono tuttavia qualche cosa di autonomo o attribuibile al caso: sono direttamente determinati, infatti, dal comportamento dei compratori e dei venditori".

${ }^{29}$ Dependendo do bem ou serviço envolvido haverá diferença no deslocamento do ponto de equilíbrio. O fenômeno é denominado de elasticidade. Conforme MANKIW (2007, p. 90): “A demanda por um bem é chamada elástica se a quantidade demandada responde substancialmente a mudanças no preço. Diz-se que a demanda por um bem é inelástica se a quantidade demandada responde pouco a mudanças no preço". Usualmente, os bens de luxo ou supérfluos (v.g. relógios suíços, roupas de grife, automóveis exclusivos etc.) costumam ser mais elásticos dos que os básicos (v.g. açúcar, cereais, etc.). Assim, a majoração no preço dos primeiros normalmente é seguida por forte queda em sua demanda, o que já não ocorre com os outros, ao menos não na mesma intensidade. Influirá também na elasticidade a existência de bens que podem se substituir mutuamente com certa facilidade (v.g. manteiga e margarina, óleo de soja e óleo de milho, carne bovina e de aves, etc.).

${ }^{30}$ Fonte: MANKIW (2007, p. 76 e 82). 
Deslocamento Tanto da Oferta Quanto da Demanda

Observamos aqui, simultaneamente, um aumento da demanda e uma redução da oferta. Há dois resultados possíveis. No painel (a), o preço de equilibrio aumenta de $P_{7}$ para $P_{2}$ e a quantidade de equilibrio aumenta de $Q_{1}$ para $Q_{2}$. No painel $(b)$, o preço de equilibrio novamente aumenta de $P_{7}$ para $P_{2}$, mas a quantidade de equilibrio cai de $Q_{1}$ para $Q_{2}$.

(a) O Preço Aumenta, a Quantidade Aumenta

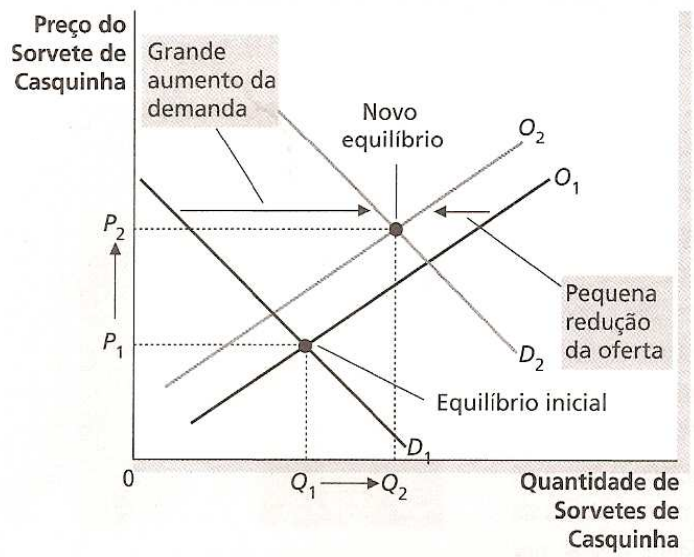

(b) O Preço Aumenta, A Quantidade Diminui

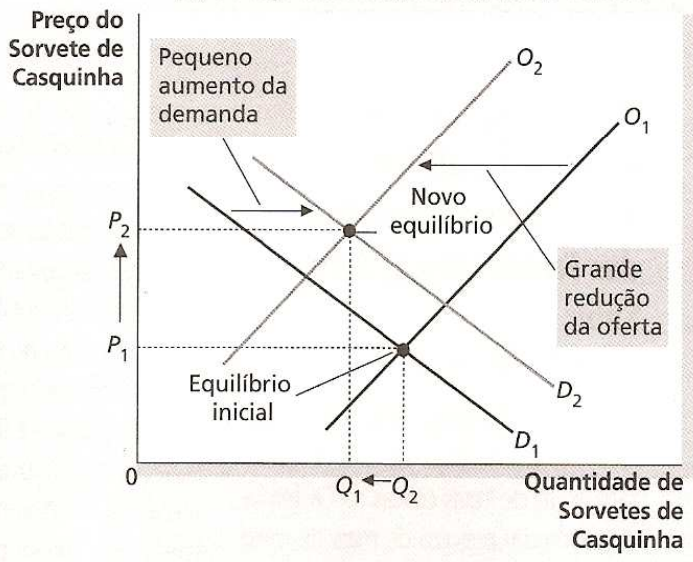

Tratando-se o mercado de um sistema social eminentemente dinâmico, o equilíbrio perfeito entre os vetores da demanda e da oferta nunca será atingido, eis que tal fenômeno é ínsito apenas aos sistemas estáticos.

Nesse posto, CARVALHO (2005, p. 255) esclarece que: "Uma ordem dinâmica complexa requer um quantum de instabilidade para sua auto-reprodução. Por isso é que há sempre tendência ao equilíbrio, mas nunca o equilíbrio total, o que equivale à estagnação sistêmica".

Dessa circunstância, costuma-se afirmar que o mercado livre promove a melhor alocação possível dos bens produzidos, pois, conforme explica MANKIW (2007, p. 77): "Uma vez que o mercado atinja seu equilíbrio, todos os compradores e vendedores ficam satisfeitos e não há pressão nem para cima nem para baixo sobre o preço". 
Recorde-se aqui com RODRIGUES (2007, p. 56) que, numa economia de mercado, os bens tendem a acabar nas mãos de quem mais os valorize, pois caso contrário a avença não ocorreria por falta de interesse de uma das partes (v.g. caso o comprador discorde do preço pedido e o vendedor se recuse a baixá-lo). Numa pergunta exemplificativa formulada por POSNER (2007a, p. 34-35):

Por que o agricultor A oferece para comprar a granja de B o preço maior que mínimo esperado por B pela propriedade? Porque a propriedade vale mais para $\mathrm{A}$ do que para $\mathrm{B}$, o que significa que A pode usá-la para produzir um bem mais valioso medido por aquele que os consumidores estão dispostos a pagar ${ }^{31}$.

Sob esse prisma, conclui-se que, findo o negócio, as partes se encontram em situação melhor do que no instante anterior, desde que, obviamente, não exista quaisquer hipóteses de nulidade ou anulabilidade legalmente estabelecidas. Evidentemente, não se pode conceber que alguém melhore sua posição após certa avença se há mácula por erro, dolo, coação ou mesmo lesão contratual.

Tanto assim é que a ocorrência de quaisquer desses vícios cria ao prejudicado a possibilidade de invocar remédios jurídicos (v.g. ações anulatórias ou com objetivo de reequilibrar o pacto), o que, em última análise, se revela como uma forma de intervenção do direito na economia.

Não obstante, mesmo nas hipóteses de intervenção judicial (que devem acontecer apenas em casos muito excepcionais), em regra, o negócio jurídico é preservado após o reequilíbrio das prestações, salvo se a mácula se revelar uma nulidade insanável (v.g. compra e venda firmada por pessoa legalmente interditada). Trata-se do que os juristas denominam de "princípio da preservação do negócio jurídico" e essa doutrina foi construída sob a percepção, ainda que indireta, do desejo das partes num contrato majorarem seu bem-estar com sua realização.

Como exemplo, ao discorrer sobre as consequências da ocorrência do vício da lesão num contrato, anteriormente à sua previsão no art. 157 do atual Código

\footnotetext{
${ }^{31} \mathrm{O}$ texto original é o seguinte: "?Por qué el agricultor A oferece comprar la granja de B a un precio mayor que el precio mínimo de B por la propriedad? Porque la propriedad vale más para A que para B, lo que significa que A puede usarla para producir un bien más valioso medido por los precios que los consumidores están dispuetos a pagar".
} 
Civil, ao comentar a previsão do art. $4^{\circ}$, "b", da Lei 1.521/51, conhecida como Lei de Economia Popular, BRANDÃO (1991, p. 167-168 ) deixa claro que:

a estipulação é absolutamente nula. Negando-se-lhe validade, como conseqüência necessária de sua natureza, os contraentes estarão restituídos à situação anterior, sem que do ato que praticaram haja decorrido qualquer efeito jurídico. Mas, por força do que se dispõe em seguida, compelindo-se o magistrado ao dever de equilibrar as prestações, já a solução é diversa. Ali, pelo fato da nulidade, nada se aproveita. $\mathrm{O}$ ato, uma vez desfeito, tem apagadas, totalmente apagadas, as suas conseqüências. Agora, porém, adota-se o princípio da conservação do negotio juris. A estipulação é mantida, apenas ajustada. E, assim, também o contrato, que em virtude da intervenção judicial, se tornou razoável.

Aliás, a conservação do negotio juris após o reequilíbrio das prestações já era prevista há milênios pelos Romanos com as figuras da laesio enormis ou laesio ultra dimidiam, segundo a narração de MARTINS (2001, p. 31):

Nesse sentido, toda vez que tal fenômeno ocorria, mediante a intervenção da autoridade competente, ao vendedor, que havia sido prejudicado em mais da metade do justo preço, era facultado rescindir o contrato, restabelecendo-se a situação anterior. Para tanto, era de rigor que este devolvesse ao comprador aquilo que tinha sido recebido como preço. $\mathrm{O}$ comprador, por sua vez, deveria devolver a coisa. Também era possível a preservação do contrato, desde que o comprador complementasse a parcela restante para a obtenção do justo preço.

Nessa esteira, em princípio, e como regra geral, é possível afirmar, na esteira da lição de RODRIGUES (2007, p. 33) que: “o primeiro teorema da Economia do bem-estar, afirma precisamente que, respeitadas determinadas condições, o resultado do funcionamento do mercado é eficiente", o que indica deva a intervenção judicial ser ultimada sob a máxima cautela.

Na hipótese, a eficiência se mostra como um efeito advindo da escolha de uma opção (dentre todas as possíveis em certo momento) capaz de maximizar o proveito e minimizar os custos em relação a certo objetivo perseguido por alguém ou mesmo por uma sociedade. Em outras palavras, segundo FORGIONI (2006, p. 39): "Uma escolha eficiente é aquela tomada quando não há outra alternativa que seria preterida por todos os envolvidos, levando em conta os seus objetivos e as preferências individuais". 
Além do mais, é de se atentar que a natureza dos fins ansiados - nobres, justos ou mesmo indignos - não modificam a essência do conceito. Explica ZANCHIM (2006, p. 61) que: "A eficiência, do modo como exposta, aparece como um critério de julgamento de opções, ou seja, como referência para um juízo de valor sobre as condutas. Ela não se confunde com os fins, que podem se de toda ordem".

Portanto, a eficiência não se revela como um valor em si, mas pode, na exposição de TOMAZETTE (2007, p. 195) ser: "um componente de valor que somada a outros valores pode servir para se alcançar objetivos maiores".

Então, caso um bonus pater familias pretenda um gasto eficiente de combustível, a velocidade que melhor equaciona o dispêndio de tempo com os litros consumidos gira em torno dos $100 \mathrm{~km} / \mathrm{h}$. Contudo, se a preocupação for exclusivamente gastar o mínimo possível, deixando de lado o fator tempo (v.g. um indivíduo que se esqueceu de abastecer e trafega numa estrada isolada), o mais indicado é trafegar a velocidades mais baixas e, noutro giro, caso exista urgência na situação (v.g. um bandido que foge da polícia ou alguém que transporta um ferido ao hospital), deve-se acelerar acima dos $100 \mathrm{~km} / \mathrm{h}$, ainda que isso reflita um aumento no consumo.

Logo, se a eficiência resulta de medidas (ou opções) tomadas pelos interessados, ela se fará presente, nos dizeres de SALAMA (2008, p. 22), quando: "não for possível aumentar os benefícios sem também aumentar os custos".

O mesmo raciocínio pode ser aplicado ao mercado livre, isso é, se for tomado como verdadeiro o efeito de que, a partir de seu funcionamento normal, os diversos bens e serviços tendam a se alocar nas mãos de quem mais os valorize, qualquer medida que se tome a título de regulação ou interferência termina por atrapalhar este fluxo, gerando, em consequência, ineficiência.

Logo, a prática do mercado livre seria a opção mais eficiente para a distribuição dos bens e comodidades numa sociedade ${ }^{32}$, bem como seria o melhor caminho

32 Os cientistas da economia trabalham o conceito de eficiência em suas pesquisas, com destaque, em primeiro lugar, aos tradicionais "critérios de Pareto" edificados pelo economista, sociólogo e engenheiro italiano Vilfredo Pareto que viveu entre 1848 e 1923, conforme informa RODRIGUES (2007, p. 26). Trata-se da "melhoria de Pareto" e do "ótimo de Pareto". Na primeira, também chamada de "Pareto superior", uma alteração qualquer (v.g. numa lei ou outra norma jurídica) beneficia ao menos uma pessoa 
para maximizar a riqueza ${ }^{33}$. Nesse ponto, indica FRIEDMAN (1985, p. 151) que: “o princípio central de uma economia de mercado é a cooperação através de troca voluntária. Os indivíduos cooperam entre si porque podem, desta forma, satisfazer suas necessidades de modo mais efetivo".

Todavia, conforme será visto adiante, essa presunção é válida apenas para mercados constituídos ao mesmo tempo por um grande número de agentes ofertantes e demandantes em torno de bens ou serviços não exclusivos ou facilmente substituíveis. Aqui, na advertência de FRIEDMAN (1985, p. 33): “A troca só é verdadeiramente voluntária quanto existem alternativas praticamente equivalentes".

Verifica-se, então, que, no sistema da autonomia, há uma separação entre os planos decisórios políticos (cabentes ao Estado) e econômicos (indivíduos, famílias, associações, sociedades, cooperativas, sindicatos e outros entes coletivos).

e não prejudica quaisquer outras. O segundo, também indicado como "Pareto eficiente", implica no alcance de uma situação tal na alocação de bens que não seja mais possível aumentar as utilidades de alguém sem causar prejuízo a outrem. Assim, segundo COELHO (2007a, p. 192): "quando a condição é satisfeita, é impossível que um indivíduo ganhe sem que outro tenha perda”. A principal crítica a tais critérios é que nada diz respeito à eqüidade ou justiça na distribuição dos bens. De fato, segundo SALAMA (2008, p. 23-24): "em tese a concentração de todos os recursos da sociedade em um único agente seria ótima no sentido de Pareto, porque qualquer realocação deixaria este único detentor de bens em uma situação pior. Note que, pelo critério Paretiano, praticamente nenhuma mudança (por exemplo, uma mudança legislativa) será possível na ausência de unanimidade, e isso é uma limitação muito séria à utilização da eficiência Paretiana como guia de políticas públicas". Por tais motivos, costuma-se prestar maior reverência ao critério de Kaldor-Hicks que permite a realização de mudanças mesmo que existam perdedores. A única condição é que os ganhadores possam e estejam dispostos a compensar estas perdas, mesmo que não venham a fazer na prática. Conforme RODRIGUES (2007, p. 28): "não se exige que os beneficiários compensem efetivamente os prejudicados; apenas que estivessem dispostos a fazê-lo, se tal fosse necessário para garantir a concretização da alteração".

33 Adverte POSNER (2007a, p. 45) que riqueza, em termos econômicos, não se mostra como um conceito contábil, mas mede-se pelo que as pessoas estariam dispostas a pagar ou receber em certa avença e não por aquilo que efetivamente pagam ou recebem. Esclarece SALAMA (2008, p. 28) que ela: "diz respeito à soma de todos os bens e serviços, tangíveis e intangíveis, ponderados por dois tipos de preços: os preços de procura (quanto o indivíduo estaria disposto a pagar por bens que ainda não possui) e os preços de oferta (quanto o indivíduo precisaria receber para vender bens que já possui)". Então, por exemplo, numa negociação de um quadro, suponha-se que A (o comprador) entenda que seu valor é de R\$1000 e este é o limite que se dispõe a pagar, enquanto que B (o vendedor) não se desfaria do bem por menos de $\mathrm{R} \$ 800$ (obviamente, ele não revela isto para A). Suponha-se, ainda, que fechem o negócio por R\$1000. No caso, ainda que A não tenha obtido vantagem econômica no ato, pois antes do negócio possuía os R\$ 1000 que correspondiam exatamente ao valor que atribuía ao quadro que adquiriu, se o valor do quadro para B era de $\mathrm{R} \$ 800$ e, se após a negociação, ele recebeu R\$1000, conclui-se que houve um aumento de riqueza na sociedade na ordem de $\mathrm{R} \$ 200$. De fato, constata-se que antes da negociação o valor total envolvido era de R\$ 1.800 (a soma dos valores atribuídos por A e B ao indigitado quadro), sendo que finalizado o pacto o valor final atingiu a cifra $\mathrm{R} \$ 2000$ (a soma do valor atribuído por A com o montante efetivamente recebido por B). Em conclusão, SALAMA (2008, p. 29) esclarece que: "a noção de maximização de riqueza é diferente da noção de maximização do PIB". 
Nota-se, ainda, que essa separação indica haver uma relação entre liberdade econômica e política, isso é, uma influencia e se deixa moldar pela outra. De fato, o que se constata é que, em países onde a liberdade econômica seja amesquinhada, há uma tendência do mesmo ocorrer com a política. Aqui, conforme SEN (2008, p. 23): “A privação da liberdade econômica pode gerar privação de liberdade social, a privação de liberdade social ou política pode, da mesma forma, gerar privação de liberdade econômica".

Fica advertido, para finalizar, não existir na realidade um sistema que seja regido totalmente pela autonomia, ainda mais após a década de 1920, com o início da concepção do welfare state e a subsequente edição de inúmeras normas jurídicas que procuraram - e ainda tentam -, não apenas neutralizar as circunstâncias que afetam o equilíbrio ideal do mercado, mas também fomentar o crescimento econômico.

Na precisa constatação de ROSSETTI (1987, p. 318): “O mundo real compõe-se, assim, de misturas de planejamento e sistemas de mercado. As proporções da mistura variam conforme os regimes econômicos, mas os sistemas nunca chegam a se substituir por completo".

\subsection{A ciência da economia}

Segundo expõe BOARATI (2006, p. 03): “A economia é uma ciência social que estuda o processo de tomada de decisão pelos indivíduos na produção e no consumo de bens capazes de atender a alguma necessidade humana e que são limitados na natureza".

Em linha semelhante, POSNER (2007a, p. 25) coloca que:

a economia é a ciência da escolha racional num mundo - nosso mundo onde os recursos são limitados em relação às necessidades humanas. A tarefa da economia, assim definida, consiste em explorar as implicações de supor que o homem procura de forma racional aumentar ao máximo seus fins na vida, suas satisfações: o que chamamos de 'interesse próprio' $^{34}$.

\footnotetext{
${ }^{34} \mathrm{O}$ texto original é o seguinte: "la economía es la ciencia de la elección racional em um mundo - nuestro mundo - donde los recursos son limitados en relación com las necesidades humanas. La tarea de la economía, así definida, consiste en la exploración de las implicaciones de suponer que el hombre procura
} 
Conforme pondera SCHUMPETER (1961, p. 137), trata-se de uma ciência baseada na observação e na interpretação, significando que oportunidades para o surgimento de divergências de opinião podem ser reduzidas, mas não eliminadas por completo. Isso certamente se acentua pela circunstância de se estar diante de uma ciência social e não natural.

Em verdade, a ciência da economia não se resume à observância de fenômenos isolados, mas, na proposição de ROSSETTI (1987, p. 38), requer uma análise de cunho fortemente interdisciplinar, qual seja: "a interpretação de toda uma série de ocorrências históricas, políticas, geográficas, antropológicas, sociais, jurídicas e até mesmo religiosas, no sentido de que o economista possa contar com um diversificado instrumental de trabalho".

Aliás, tratando-se de ciência social, as mesmas advertências feitas acima - quando se abordou a ciência do direito - aqui se aplicam, isso é, não é razoável pretender que seja apta a formular proposições com o idêntico patamar de exatidão e isenção valorativa próprio das ciências naturais dada a marcante diversidade das características dos objetos de estudo de cada modalidade.

De fato, ROSSETTI (1987, p. 58) claramente indica que: "As leis econômicas, talvez em sua maior parte, são mutáveis no tempo e no espaço e não atingem um rigoroso grau de precisão [...] O laboratório da Economia é a própria sociedade humana". Tomado tal pressuposto como guia, é viável a concepção de uma ciência da economia inserida como uma modalidade de ciência social.

O fenômeno das ações de viés econômico é efetivamente milenar, sendo notado nas mais diversas sociedades desde tempos imemoriais. Todavia, o estudo científico e sistematizado destas ações é muito mais recente, sendo que ROSSETTI (1987, p. 31 e 48) aponta o seu despertar para os idos do século XVIII, com a vinda de duas importantes obras: por primeiro, em 1758, da autoria de François Quesnay, foi publicada Tableau économique; em seguida, em 1776, escrita por Adam Smith, editou-se An 
inquiry into the nature and causes of the wealth of nations. Então, seria uma ciência que atualmente conta com pouco mais de 200 anos, reconhece BOWLES (1985, p. 48).

É certo que, anteriormente, alguns pensadores já haviam abordado o tema, mas com uma preocupação voltada mais para a pragmática do que propriamente a edificação de modelos ou mesmo teorias científicas, isso é, conforme GASTALDI (1970, p. 30), antes o que havia eram: "estudos esparsos sobre assuntos ou temas isolados; tais análises, fragmentárias, sôbre questões de natureza econômica, eram realizadas sem a preocupação de conjunto ou de sistematização".

Complementando, noticia ROSSETTI (1987, p. 83) que:

Durante e após a constituição desses três tipos de organização surgiram os primeiros filósofos-políticos universais: PLATÃO, ARISTÓTELES e XENOFONTE, na Grécia; CATÃO, VARRÃO, COLUMELA e PALÁDIO, no Império Romano. PLATÃO dedicou-se à planificação de um Estado ideal, no qual seriam evitadas as instituições decadentes e as injustiças sociais então existentes. ARISTÓTELES desenvolveu diversas idéias sobre o Estado e discutiu a usura e os salários, o intercâmbio e a aquisição, o valor e a formação da riqueza. XENOFONTE escreveu diversos ensaios sobre a agricultura e o sistema tributário, reunindo em As Formas de Aumentar as Recitas de Atenas (355 a.C.) suas principais idéias econômicas".

A depender do enfoque e dos objetivos ansiados pelo pesquisador, de um modo geral, os economistas costumam dividir sua ciência em dois ramos básicos, denominados de "Economia positiva" e "Economia normativa".

O primeiro - a "Economia positiva" - procura essencialmente descrever os variados fenômenos econômicos, identificando suas causas e consequências. Informa ROSSETTI (1987, p. 67) que: "através dela que a realidade começará a ser submetida a um criterioso tratamento científico, no sentido de que possam ser analisadas as relações básicas que se estabelecem entre os diversos agentes que compõem o quadro da atividade econômica".

O segundo - a "Economia normativa" - se liga mais a um tipo de "dever ser", pois nela se incluem propostas que o cientista acredita devam ser tomadas para que sejam atingidos tais e quais resultados. É mais uma proposição ou diretriz a ser tomada do 
que apenas constatação de uma realidade. A diferença entre ambos é marcante, explica ROSSETTI (1987, p. 70) que:

enquanto, no âmbito da Economia Positiva, o observador não se preocupa em julgar os fatos nem avaliar cada uma de suas consequiências sociais, políticas ou econômicas, no âmbito da Economia Normativa serão fixadas normas de conduta, procedendo-se aos julgamentos correspondentes aos procedimentos práticos que venham a ser recomendados ou desencadeados. Este segundo domínio pode, pois, dar margem a controvérsias, bem como a posições não raro diametralmente opostas.

Segundo mostra NUSDEO (2005, p. 87), os ramos acima referenciados ainda comportam subdivisão, nos seguintes termos:

\begin{tabular}{|l|l|}
\hline a) ECONOMIA POSITIVA & a.1) teoria ou análise econômica \\
& a.2) economia aplicada \\
\hline b) ECONOMIA POLÍTICA & b.1) doutrina econômica \\
& b.2) política econômica \\
\hline
\end{tabular}

A "teoria ou análise econômica" corresponde à tentativa da criação de modelos acerca do comportamento econômico de modo a explicar a realidade, mas simplificando-a ao máximo, estabelecendo possíveis relações de causa e efeito entre as diversas ocorrências passíveis de se materializar, sem identificar, contudo, situações concretas.

Assim, por exemplo, a já mencionada regra da oferta-demanda é um modelo ideal que prediz o comportamento dos preços conforme variar o interesse por determinados bens. Vários outros modelos podem ser lembrados, sendo que alguns deles já foram mencionados no texto, destacando-se: o pressuposto da escassez material em todas sociedades, as escolhas racionais dos agentes econômicos, os critérios de eficiência na alocação dos diversos bens e serviços, o equilíbrio do mercado como sinal de eficiência, os excedentes (do produtor, do consumidor e social), elasticidades, etc. 
Em suma, a maioria dos modelos consagrados é citada logo de início na maioria dos manuais de Economia.

Como se disse, tratando-se de modelos teóricos e simplificadores da realidade, é esperado que sua aplicação não se encaixe perfeitamente em todas as hipóteses que podem ocorrer na complexa vida econômica atual. E isso se dá provavelmente porque, nos dizeres de POSNER (2007a, p. 48): “A economia se ocupa de explicar e prognosticar tendências e conjuntos, antes que o comportamento individual de cada pessoa, e numa amostra razoavelmente grande os desvios aleatórios do comportamento racional normal se cancelam reciprocamente" ${ }^{, 35}$.

Nesse sentido, considerando que os modelos criados pela teoria econômica conseguem explicar uma enormidade de fenômenos - talvez a maioria dos casos - sua utilização é mais que oportuna. É, de fato, elementar, pois uma teoria que abarque toda a complexidade de um fenômeno provavelmente deixará de ser uma explicação para tornar-se, antes de tudo, uma descrição pormenorizada.

A "economia aplicada", como a própria denominação sugere, procura inserir um modelo criado pela teoria ou análise econômica em situações reais, formulando explicações para tanto, o que, de certa maneira, significa um teste para o modelo teórico.

Utilizando-se, por suposição, o modelo da regra oferta-demanda, é possível compreender que o aumento no preço dos sorvetes em certa cidade deu-se em vista da chegada do verão e o forte calor fez com que muitas pessoas buscassem no sorvete uma opção para se refrescarem. Nota-se que o modelo anteriormente concebido foi aplicado a uma situação específica ocorrida.

Todavia, conforme lembra ROSSETTI (1987, p. 67): “A maior parte dos fatos encontra-se inter-relacionada através de um encadeamento de reações, de motivações e de influências recíprocas", o que pode resultar na aplicação imprecisa de determinado modelo, requerendo, em tais eventos, seu aperfeiçoamento ou mesmo substituição.

${ }^{35}$ O texto original é o seguinte: "La economía se ocupa de explicar y pronosticar tendencias y agregados, antes que el comportamiento de cada persona individual, y en una muestra razonablemente grande las desviaciones aleatorias del comportamiento racional normal se cancelarán recíprocamente”. 
A "doutrina econômica" se mostra como uma linha de pensamento que supostamente deveria ser adotada na organização das ações econômicas presentes na sociedade. Não se cuida de prever ou aplicar modelos, nem apenas descrever certa realidade, mas da prescrição de caminhos ou escolhas, tais como aqueles citados por MELLO (1968, p. 181-203): capitalismo, socialismo, socialismo-democrático, comunismo, cooperativismo, corporativismo, democracia-cristã, neoliberalismo, keynesianismo e societarismo.

Melhor esclarecendo, segundo NUSDEO (2005, p. 89-90):

As doutrinas discutem os fundamentos dos sistemas econômicos e podem ser assimiladas à ideologia. Elas situam-se na zona lindeira entre a Economia e a Filosofia, pois seu substrato é formado pelos valores de caráter ético-filosófico. É no campo da doutrina que se forjam os sistemas econômicos, os quais, uma vez definidos, darão origem às possíveis manifestações do fenômeno valor econômico.

Mesmo que, na antiguidade, tenham ocorrido manifestações esporádicas acerca de como as ações de cunho econômico deveriam se encaminhar, somente é possível falar em doutrina econômica após o aparecimento da ciência da economia nos idos do século XVIII. Na colocação de MELLO (1968, p. 180):

Até então tudo era confuso e nebuloso no mundo complexo dos fenômenos econômicos. Com a formulação das leis que regem a formação das riquezas, sua circulação e sua repartição - forjou-se, em verdade, o instrumento para se deduzir ou induzir-se sistemas doutrinários de ordenamento de economia.

Por fim, "a política econômica" também ostenta caráter prescritivo. Contudo, por tomar como ponto de partida um sistema econômico já instalado (e aceito), impinge forte conteúdo pragmático em suas asserções. As medidas de política econômica são inúmeras e as mais variadas possíveis, dada a forte influência que ordinariamente o Estado assume na Economia de muitos países.

Logo, assentam-se dentro da política econômica, tanto sugestões de pequenas modificações nas alíquotas dos impostos, como propostas para reformas abrangentes de sistemas inteiros - v.g. tributário, previdenciário, setores da Administração Pública, política das agências financeiras oficiais de fomento, etc. Nos dizeres de 
ROSSETTI (1987, p. 68), cuida-se de: “um ramo voltado para o condicionamento da atividade econômica".

Informa PEREIRA (1997, p. 147) que a política econômica: "numa economia capitalista é o processo por meio do qual do Estado intervém no mercado, corrigindo-o, orientando-o para determinados objetivos".

Segundo o autor, há dois tipos de política econômica. A primeira, estrutural e de longo prazo, que se divide em planejamento econômico e política de rendas. A preocupação se centra no desenvolvimento econômico, na taxa de acumulação, nos desequilíbrios regionais e na distribuição de renda. A segunda serve para lidar com fenômenos mais imediatos do equilíbrio macroeconômico e financeiro, tais como: inflação, taxa de juros, equilíbrio externo, etc.

Quanto ao âmbito da pesquisa, na lição de NUSDEO (2005, p. 92 e ss.), a ciência da economia é dividida em microeconomia e macroeconomia. Aquela estuda o comportamento das "unidades econômicas", tais como: o produtor, o consumidor, a empresa e a maneira como interagem nos mercados de produtos identificados.

Não se cuida, todavia, de uma análise individualizada e dirigida para cada caso concreto ( $v$.g. o consumidor $\mathrm{X}$ ou a empresa $\mathrm{Y}$ ), mas foca em centros decisórios não identificados. Com efeito, aduz ROSSETTI (1987, p. 73) que:

A Análise Microeconômica pode, portanto, ser considerada como um processo teórico elaborado com vistas a determinar as condições gerais de equilíbrio da economia a partir do comportamento dos agentes econômicos individuais - produtores e consumidores. Em tal sentido, pode também ser considerada como um ramo tradicionalmente ligado à ideologia do individualismo e do liberalismo.

Noutro sentido, os estudos macroeconômicos surgiram principalmente a partir da constatação de que o mercado requer intervenção em certas hipóteses de modo a neutralizar suas falhas, ou seja, percebeu-se que a liberdade plena dos agentes econômicos nem sempre faria os ajustes necessários à manutenção do equilíbrio entre a oferta e demanda, sendo de rigor estudar os motivos. 
Entende ROSSETTI (1987, p. 73) que a macroeconomia foi particularmente desenvolvida a partir da publicação, em 1936, da The general theory of employment, interest and money, de autoria do inglês John Maynard Keynes.

Nessa esteira, a macroeconomia cuida dos "grandes agregados": macroeconomia do consumo, renda, emprego, poupança, do saldo da balança comercial e inflação. Não há identificação de produtos ou mercados específicos, ao contrário, a pesquisa procura um foco global.

Ainda que a microeconomia e a macroeconomia se constituam em ramos de investigação distintos, compondo ambas a mesma ciência, é esclarecido por MANKIW (2007, p. 27) que: "estão intimamente ligadas. Como as mudanças na economia resultam das decisões de milhões de pessoas, é impossível entender os desdobramentos macroeconômicos sem considerar as decisões microeconômicas a elas associadas".

Segundo o autor, por exemplo, os efeitos macroeconômicos gerados na produção geral decorrente de um corte nos impostos devem considerar as decisões de consumo das famílias em face da submissão a uma menor carga fiscal.

\subsection{Relações entre os fenômenos sociais direito e economia}

Expostas as características essenciais do direito (visto como um conjunto de normas criadas pelo homem com o escopo elementar de regular a mútua convivência em sociedade) e da economia (focalizada como a inescapável necessidade do ser humano constantemente "agir de forma econômica" com o objetivo de melhor sobreviver num ambiente de escassez), bem como as noções elementares de como as ciências que se debruçam sobre tais fenômenos operam, passa-se a verificar como o direito e a economia interagem na vida real.

Sem embargo de dúvida, inicia-se afirmando que existe íntima relação entre o direito e a economia na medida em que aquele tenta ordenar, de modo coercitivo e sob o poder do Estado, como os bens escassos devem ser repartidos entre os indivíduos e, com isso, minimizar a hipótese da apropriação ocorrer sob o pálio da violência pura e simples, com a provável perda de vidas que, no mínimo, representaria diminuição na capacidade da sociedade produzir riqueza nova. 
Com efeito, sem a proteção geral conferida aos bens pelo direito, seria muito mais oneroso a qualquer pessoa, por exemplo, deixar a propriedade em que reside para ir trabalhar, uma vez que no retorno poderia encontrar o local ocupado por outro sujeito, obrigando o desapossado a recorrer às vias de fato com óbvios gastos de energia vital, de resultado incerto, mas com alta possibilidade de se sair da refrega ferido ou até morto.

Outra opção seria arcar com os custos para que outra pessoa (presumivelmente de sua confiança) vigiasse ininterruptamente o local durante a sua ausência de maneira a espantar eventuais invasores.

Num sistema tal, o custo gerado pela proteção à residência seria tão elevado que as pessoas provavelmente iriam preferir nunca se ausentar do local, produzindo o necessário apenas à sobrevivência da família em um modelo de subsistência que nada ou pouco se interligaria com o meio externo, ou seja, sem estímulo à produção de excedentes, haveria baixa circulação de bens e riquezas.

Por outro lado, em existindo a citada proteção jurídica, mesmo que alguém encontre sua propriedade indevidamente ocupada por outrem, pode providenciar a retomada, ainda que necessite ajuizar demanda com requerimento de força policial para tanto, ferramenta que, por um lado, desestimula as invasões e, por outro, minora os custos de proteção.

O mesmo raciocínio pode ser estendido a formas mais sofisticadas da propriedade, notadamente a imaterial, como as marcas e patentes e se aplica, em grande medida, aos contratos na medida em que dificilmente alguém firmaria compromissos se o direito não garantisse a obrigatoriedade dos pactos, não oferecendo mecanismos efetivos e ágeis de execução forçada em caso de descumprimento.

É de se convir que, na impossibilidade de utilizar meios adequados de coerção, não havendo garantias de fazer valer o que foi previamente pactuado, o contrato seria uma ferramenta muito pouco utilizada, pois o risco de uma parte entregar sua prestação e nada receber da outra seria por demais elevado. 
Não se pode negar que a simples existência dos remédios e ferramentas jurídicas garantidoras não apenas da observância pactual, mas também de sua execução forçada com acréscimo de penalidade, funciona como elemento dissuasivo de eventuais comportamentos oportunistas. Em exemplo formulado por POSNER (2007a, p. 68):

Imaginemos uma sociedade em que hajam sido abolidos os direitos de propriedade. Um agricultor semeia trigo, o fertiliza e instala espantalhos; porém quando o trigo amadurece, seu vizinho o colhe e carrega consigo. $\mathrm{O}$ agricultor não dispõe de qualquer remédio legal contra a conduta do vizinho porque não é proprietário da terra que semeou nem do cultivo. A menos que sejam viáveis algumas medidas defensivas (e suponha-se que não momento não existam), após alguns incidentes como este o cultivo será abandonado destas terras e a sociedade empreenderá métodos de subsistência (como a caça) que implicam menos intervenção preparatória. Como sugere este exemplo, a proteção legal dos direitos de propriedade cria incentivos para explorar os recursos eficazmente ${ }^{36}$.

Em seguida, sob linha assemelhada, o autor (idem, p. 69-70) enfatiza e clarifica o tema por meio da seguinte hipótese:

Imaginemos que vários agricultores sejam proprietários de uma pastagem; significa dizer, nenhum tem o direito de excluir os demais e, ainda mais, nenhum pode cobrar dos demais pelo uso dos pastos. Pode-se afastar os aspectos dinâmicos do problema supondo-se que o pasto é natural (não cultivado), de modo que não há modo de melhorá-lo por meio da inversão. Ainda assim, o pastoreio das vacas adicionais impingirá um custo a todos agricultores. As vacas terão que caminhar mais de modo a ingerir a mesma quantidade de capim, e isto reduzirá seu peso. Porém em face de que nenhum dos agricultores paga por usar o pasto, não se levará em conta este custo ao se decidir quantas vacas adicionais podem pastar, de modo que pastarão mais vacas do que seria eficiente (Poderia haver alguma analogia com o tráfego congestionado?). O problema desapareceria se uma pessoa fosse proprietária do pasto e cobrasse de cada agricultor pelo respectivo uso (para as finalidades desta análise é devemos esquecer os custos de cobrança). A cobrança de cada agricultor faria por incluir o custo que ele impõe aos demais ao colocar vacas adicionais para pastar, porque tal custo reduz o valor do pasto para

${ }^{36} \mathrm{O}$ texto original é o seguinte: "Imaginemos una sociedad en la que han sido abolidos los derechos de propiedad. Un agricultor siembra trigo, lo fertiliza e instala espantapájaros; pero cuando el trigo está maduro, su vecino lo cosecha y se lo lleva para su propio uso. El agricultor no tiene ningún remedio legal contra la conducta de su vecino porque no es propietario de la tierra que sembró ni del cultivo. A menos que sean viables algunas medidas defensivas (y supongamos por el momento que no las hay), después de unos cuantos incidentes como éste se abandonará el cultivo de las tierras y la sociedad empleará métodos de subsistencia (como la caza) que implican menos inversión preparatoria. Como lo sugiere este ejemplo, la protección legal de los derechos de propiedad crea incentivos para explotar los recursos eficientemente. 
os demais agricultores e, portanto, o preço que estão dispostos a pagar ao proprietário pelo direito de pastar ${ }^{37}$.

E, se conforme assevera VIDIGAL (1977, p. 88): “O regime jurídico da propriedade e do contrato constitui o núcleo das condições para a atividade econômica", a primeira conclusão possível é a de que a mais basilar e imediata relação travada entre o direito e a economia se resume na construção e na garantia daquele de um ambiente institucional normativo que confira segurança, previsibilidade e certa perenidade em torno dos institutos e figuras jurídicas.

O resultado dessa congruência de fatores contribui para minorar os riscos que uma atuação sob regramento fluído e pouco estável naturalmente implicam e, ainda, permite que as ações econômicas se intensifiquem na comunidade.

Conforme expõe ROSSETTI (1987, p. 43): "Reconhecidamente, nenhuma ordem econômica é possível sem que o Direito limite as liberdades em função das responsabilidades recíprocas, solucionando claramente os conflitos potenciais observados", ou seja, na realidade exposta por CASTRO (2006, p. 42): "Os mercados, em que atuam as empresas comerciais e outros agentes econômicos, não existem no vazio institucional". Constata-se, assim, de acordo com a formulação de IRTI (2008, p. 96), que o mercado é um locus artificialis cuja arquitetura é esboçada pelo direito.

Com isso não se quer afirmar que o direito é que condiciona a economia ou que esteja numa categoria de fenômeno social de hierarquia superior. Em realidade, mesmo ao considerarem-se as significativas variações sócio-econômicas vigorantes ao redor do Globo, ao que tudo indica, o Direito e a Economia se influenciam mutuamente, sendo difícil reconhecer a sobrepujança de um sobre o outro, ou seja, existem vários

${ }^{37} \mathrm{O}$ texto original é o seguinte: "Imaginemos que varios agricultores son propietarios de un pastizal en común; es decir, ninguno tiene el derecho de excluir a los otros y, por ende, ninguno puede cobrar a los demás por el uso de los pastos. Podemos olvidarnos de los aspectos dinámicos del problema suponiendo que el pasto es natural (no cultivado), de modo que no hay manera de mejorarlo mediante la inversión. Aun así, el pastoreo de vacas adicionales impondrá un costo a todos los agricultores. Las vacas tendrán que caminar más a fin de comer la misma cantidad de zacate, y esto reducirá su peso. Pero en virtud de que ninguno de los agricultores paga por usar el pasto, ninguno tomará en cuenta este costo al decidir cuántas vacas adicionales pastarán, de modo que pastarán más vacas de lo que sería eficiente (Puede ver alguna analogía con el congestionamiento carretero?). El problema desaparecería si una persona fuera propietaria del pasto y cobrara a cada agricultor por su uso (para los fines de este análisis olvidemos el costo de la recaudación de tal cobro). El cobro a cada agricultor incluiría el costo que este impone a los otros agricultores al pastar vacas adicionales, porque ese costo reduce el valor del pasto para los demás agricultores y, por lo tanto, el precio que están dispuestos a pagar al propietario por el derecho de pastar". 
estímulos reciprocamente considerados entre cada um destes sistemas que geram feedbacks, em um processo contínuo de inter-relacionamento ou acoplamento estrutural, de modo que, na explicação de VILLAS BÔAS FILHO (2006, p. 250) "não ocorre a determinação do sistema pelo entorno, mas simples irritação ou perturbação de um pelo outro".

De fato, segundo GRAU (2005, p. 59): “O direito é produzido pela estrutura econômica mas, também, interagindo em relação a ela, nela produz alterações. A economia condiciona o direito, mas o direito condiciona a economia".

Verifica-se, então, pela exposição de SZTAJN (2005, p. 82) que: “A relação entre Direito e Economia perpassa todo o espectro de Direitos patrimoniais, notadamente propriedade, contratos e responsabilidade civil, havendo quem a projete até mesmo para o campo delitual penal e relações de família e sucessões", podendo chegar ao ponto de, na visão de NUSDEO (2005, p.32), em certos casos ser: "difícil dizer-se até que ponto o Direito determina a Economia, ou, pelo contrário, esta influi sobre aquele".

O fenômeno não é novo, ou seja, há séculos existem normas que procuram regular a distribuição de bens e riquezas por pactos firmados a partir das necessidades sociais. Confira-se, como exemplo, a narração de LÉVY-BRUHL (1997, p. 80 e 81) que remonta ao século III antes de Cristo. Segundo o autor:

$\mathrm{O}$ direito arcaico de Roma era, pois, ao que parece, perfeitamente adaptado a essa sociedade de pequenos agricultores. No século III a. C., os romanos, de agricultores, tornam-se comerciantes. Essa modificação em sua estrutura econômica vai repercutir em seu direito. A organização familiar, que doravante se encontra submetida ao controle da sociedade global, torna-se menos rígida: procura-se multiplicar o número dos súditos de direito em virtude da intensificação das relações sociais. Assim, encontra-se um meio indireto, a emancipação, para fazer o filho escapar à autoridade tirânica do pai, outro para libertar a mulher casada da de seu marido e multiplicam-se os modos de alforria dos escravos. $\mathrm{O}$ formalismo atenua-se, notadamente pela introdução no direito da noção de boa fé. Inventam-se operações pelas quais o simples consentimento será capaz de criar obrigações entre as partes contratantes. Os estrangeiros deixam de ser tratados como inimigos.

No mesmo caminho, basta atentar que o desenvolvimento do Direito Comercial se deve, em síntese, às necessidades da sociedade mercantilista nascente que 
carecia de instrumentos mais completos e ao mesmo tempo elásticos capazes de garantir a eficácia das transações pela maior liberdade dispositiva das partes.

Daí que, conforme ASCARELLI (1947, p. 30), novas regras de cunho jurídico:

foram-se elaborando para atender às exigências de uma economia que ia se renovando e que, com a chamada revolução industrial, procurou encontrar instrumentos jurídicos adequados para a realização dos inventos técnicos e para a transformação econômica deles decorrente.

Logo adiante, o renomado professor enfatiza que:

As exigências econômicas a que se prendiam os institutos do direito comercial fizeram-se sentir, de início, em um âmbito limitado; sucessivamente, se foram estendendo a tôda a economia.

[...]

Coaduna-se, destarte, o direito comercial no terreno da economia, não com determinada atividade econômica, mas com determinado sistema de economia, encontrando no aparecimento e desenvolvimento dêste sistema a explicação de sua constituição como direito especial e do seu desenvolvimento. Apresenta-se, por isso, o direito comercial, historicamente ligado nas suas origens, com a economia capitalística que, por seu turno, històricamente se liga à constituição da economia de massa; apresentam hoje, muitos institutos do direito comercial uma correlação geral com a economia de massa constituindo o instrumento jurídico desta" (idem, p. 45-46) ${ }^{38}$.

Aprofundando o tema, o surgimento do Estado ${ }^{39}$, por volta dos idos dos séculos XV e XVI, segundo expõe DALLARI (1989, p. 43-101), é severamente marcado por controvérsias de fundo econômico, religioso e político que instauraram expressiva insegurança no meio social medieval, principalmente pela migração de milhares de camponeses paras as cidades "livres", em vista de epidemias e revoltas ocorridas ao final da Idade Média.

${ }^{38}$ A crescente complexidade econômica implica na constante atualização das regras jurídicas, bem como requer a criação de novas disciplinas, como, por exemplo, os Bancos Centrais dos diversos países, órgãos reguladores da moeda e do crédito, essenciais ao bom desempenho econômico. No Brasil essa figura apareceu apenas na década de 1960, conforme narra DE LUCCA (2007, p. 194-206).

${ }^{39}$ A expressão "Estado" surgiu pioneiramente em 1513 na obra O príncipe, cuja autoria pertence a Nicolau Maquiavel, conforme noticiam BARROS (2007, p. 41) e MIRANDA (2003, p. 34). Aliás, segundo BOBBIO (1988, p. 68): "Maquiavel não começa apenas a fortuna de uma palavra mas a reflexão sobre uma realidade desconhecida dos escritores antigos, da qual a palavra nova é um indicador, tanto que seria oportuno falar de 'Estado' unicamente para as formações políticas nascidas da crise da sociedade medieval, e não para os ordenamentos precedentes". 
$\mathrm{O}$ crescimento urbano possibilitou que pessoas desprovidas de terras ou de qualquer título nobiliário (posteriormente chamadas de burgueses), pela constante e reiterada prática do comércio, conquistassem um ascendente poder econômico e isso se dá porque, na explicação de LEWANDOWSKI (1984, p. 14):

os feudos, anteriormente auto-suficientes com relação aos produtos de uso cotidiano, começaram a depender também, de forma crescente, dos bens produzidos e comerciados nos burgos, isto é, dentro dos limites da zona urbana fortificada. Esta circulação forçada de dinheiro e de mercadorias engendrou uma incipiente economia monetária que, ao desenvolver-se, foi deslocando, pouco a pouco, a influência política dos senhores feudais para os detentores de numerário.

Então, uma vez atingido certo patamar de riqueza e influência negocial, a burguesia passou a defender e mesmo exigir modificações nas instituições normativas de então, basicamente, com o fulcro de derrubar ou neutralizar ao máximo as restrições ordinariamente impostas pelos diversos éditos feudais que atrelavam o direito de comerciar ao beneplácito do respectivo senhor ou, ainda, às regras que restringiam severamente a estipulação de juros nos empréstimos a dinheiro ou mesmo a obtenção de lucro nas diversas transações mercantis, conforme narra HUBERMAN (s. d., p. 34 e ss.).

Além disso, segundo aponta CAMARGOS (2003, p. 88), vivia-se numa insegurança generalizada, sendo que a: "arbitrariedade e a violência dos senhores feudais se estendiam aos habitantes das cidades, que eram por eles constantemente saqueadas. E tal fato tornou as cidades aliadas naturais do soberano contra a aristocracia”.

O inegável choque de valores cria uma ambiência cada vez mais conflitante, culminando com o surgimento de um poder superior a toda e qualquer facção ou grupo organizado.

Foi então que o rei deixou de ser um mero aliado de grupos rivais para tornar-se um soberano acima das próprias leis. Segundo HUBERMAN (s. d., p. 69), assim fixou-se porque as vantagens oferecidas por um governo central forte eram do interesse da burguesia que sustentava economicamente a realeza em troca de privilégios econômicos. De fato, naquele instante histórico, pela narração de LEWANDOWSKI (1984, p. 18), constata-se que: 
A burguesia, pois, interessada na paz interna e numa ordem jurídica uniforme, começou a apoiar política e financeiramente os reis e determinados príncipes, com objetivo de unificação do poder. Um dos primeiros e quiçá mais importantes passos encetados para a obtenção da superioridade política dos reis foi justamente a aquisição do monopólio da força militar.

Com efeito, o canhão acabou por fazer a diferença em favor do rei, dando-lhe, em franca e efetiva realidade, o monopólio da força capaz de impor seu poderio militar poder sobre os outros senhores leigos e clericais. A concentração do poder, destarte, resultou no Estado nacional unificado, dando ensejo, então, ao absolutismo monárquico ${ }^{40}$. Na lição de BARROS (2007, p. 40):

Foi a dinâmica econômico-social e, portanto, a lógica político-jurídica do capitalismo que implicaram uma necessária, embora relativa, autonomia dos agentes políticos em face dos agentes econômicos. A fixação dessa distinção pelo modo de produção capitalista é tão marcante, que autoriza concluir que o início do capitalismo - no mercantilismo - está o início do próprio Estado.

Portanto, em princípio, o Estado surge no instante em que se separam os aparatos político e econômico, recordando-se que, nas palavras de BOBBIO (1988, p. 123): "Na sociedade feudal, o poder econômico e o poder político são indissociáveis um do outro", o que foi oportunamente percebido pela doutrina econômica clássica do final do século XVIII.

A sequência da história confirma a constante, mas nem sempre serena relação entre o direito e a economia, num infindável processo de estímulos recíprocos. Com efeito, a normatização jurídica construída sob a égide do Estado absolutista europeu, com seus controles, restrições e concessões de monopólios de exploração, além de elevadas taxações sobre o comércio em geral, estava muito longe de refletir a liberdade ansiada pela maioria da classe burguesa que almejava mercadejar sob o prisma da maior liberdade possível.

${ }^{40}$ Segundo noticia BOBBIO (1988, p. 115): "Como forma intermediária entre o Estado feudal e o Estado absoluto, o Estado estamental distingue-se do primeiro por uma gradual institucionalização dos contrapoderes e também pela transformação das relações pessoa a pessoa, próprias do sistema feudal, em relações entre instituições: de um lado as assembléias de estamento, de outro o rei com seu aparato de funcionários que, onde conseguem se afirmar, dão origem ao Estado burocrático característico da monarquia absoluta. Distingue-se do segundo pela presença de uma contraposição de poderes em contínuo conflito entre si, que o advento da monarquia absoluta tende a suprimir". 
Reflexos na doutrina da época são notáveis, com destaque inicial para HUME (1973, p. 257), que, nos idos de 1741-42, aventou que o comércio floresce primordialmente nas cidades livres, mas concentrou o ataque não em suposta ausência de segurança e previsibilidade gerada pelo Estado absoluto, mas no detalhe da classe política dominante (nobreza e clero) considerar a mercancia como atividade não honrosa. Em suas palavras:

em minha opinião, o comércio poderá decair sob os governos absolutos, mas não devido a ser menos seguro, e sim devido a ser menos honroso. A monarquia não pode subsistir sem uma subordinação de classes. $\mathrm{O}$ nascimento, os títulos e a posição devem ser honrados acima da indústria e da riqueza. E, enquanto for esta a opinião dominante, todos os mercadores importantes estarão sujeitos à tentação de abandonar seu comércio, a fim de adquirir qualquer um desses empregos que trazem privilégios e honrarias.

Deixando fora de dúvida seu reclamo contra a invasão normativa na economia caminha SMITH (1974, p. 104) quando, em 1776, propugnou que: "a política européia não deixa as coisas evoluírem em plena liberdade, dá origem a desigualdades muito mais importantes”. Logo adiante, complementa o raciocínio (idem, p. 109):

A pretensão de que as corporações são necessárias para um melhor governo dos negócios não tem qualquer fundamento. A disciplina real e efetiva que é exercida sobre um trabalhador não é da corporação mas a dos seus clientes. É o medo de perder o emprego que restringe suas fraudes e corrige suas negligências. Uma corporação exclusiva necessariamente enfraquece a força desta disciplina.

Outro grande defensor da liberdade econômica de então foi RICARDO (1974, p. 335), destacando-se o seguinte trecho (publicado originalmente em 1817), que bem reflete a aversão do autor à intromissão normativa do Estado na economia:

Mas em todos os países, por erradas noções de política, o Estado tem interferido para impedir uma taxa de juros de mercado justa e livre, impondo pesadas e ruinosas penalidades a todos aqueles que recebam mais do que a taxa fixada por lei. Essa lei é provavelmente violada em todos os países, mas os registros nos dão pouca informação sobre este tópico, apontando mais a taxa legal e fixada que a de mercado.

Pretendia-se, em verdade, a implantação da doutrina do laissez faire, laissez passer, isso é, o direito não deveria intervir ou regular a economia de modo a obstaculizar o comércio e os ganhos que cada um conseguisse por seus próprios esforços, 
ainda mais porque, conforme BARROS (2007, p. 08) “A sociedade não mais suportava os desmandos", principalmente a manutenção cada vez mais dispendiosa dos privilégios em prol da nobreza ${ }^{41}$ e do clero que, além de não produzirem riqueza nova, se encontravam ordinariamente isentos aos tributos ${ }^{42}$, o que, em contra-partida, implicava num achaque tributário não apenas aos comerciantes, mas também em face dos habitantes mais pobres e sem capacidade contributiva.

Logo, além da questão ligada à liberdade, havia os entraves fiscais, cujas normas inegavelmente repercutem severamente sobre a economia. Na visão de HUME (1973, p. 258):

Os maiores abusos ocorrem na França, país que é o mais perfeito modelo de monarquia pura, não derivam de lá haver impostos em número e em importância superior aos que se encontram nos países livres, mas sim do método dispendioso, desigual, arbitrário e complicado de cobrá-los que em grande medida desencoraja a indústria dos pobres, sobretudo a dos camponeses e lavradores, e torna a agricultura um trabalho miserável e escravizante.

Com efeito, segundo HUBERMAN (s. d., p. 135), na França "pré revolução", nada menos do que $80 \%$ da renda dos camponeses se destinava a pagar pelos impostos. Em suas palavras, o autor conclui que: "Não é de se espantar que uma má colheita o deixasse à beira da fome. Nem que muitos dos seus vizinhos vagassem pelas estradas como mendigos famintos".

Então, após a vitória das chamadas revoluções "liberais"43 (com destaque para a Americana de 1776 e a Francesa de 1789), instaura-se "definitivamente" o regime capitalista de produção, segundo expõe LEWANDOWSKI (1984, p. 29), marcando-se, no campo jurídico, a constitucionalização dos principais anseios burgueses, notadamente a liberdade econômica e a igualdade jurídica entre todos os cidadãos.

${ }^{41}$ Aqui cabe indicar um exemplo notável colacionado por HUBERMAN (s. d., p. 133-134): trata-se de um barbeiro francês do século XVIII, de nome Ducrest, que recebera o direito a uma pensão anual de 1.700 libras, por ter sido o cabeleireiro da filha do conde d'Artois, mesmo ante o fato de a menina ter falecido muito jovem, antes mesmo de possuir cabelos penteáveis.

42 NOGUEIRA (1997, p. 72) explica que: "A nobreza não estava sujeita a impostos porque - tal a fundamentação política e filosófica então imperante - já contribuíam com o derramamento do seu sangue na defesa do Reino".

${ }^{43}$ Segundo FERREIRA FILHO (2008, p. 01) "A idéia de direito que então se generaliza, e que inspira as revoluções americana e francesa, é tão marcada pela preocupação com a liberdade, que se tornou conhecida como 'liberal'”. 
Procura-se, então, proteger os indivíduos contra o Estado que passa a ser considerado um mal, embora necessário (FERREIRA FILHO, 1995, p. 249 e BOBBIO, 1995, p. 21). Aliás, esse é um ponto elementar na separação entre o liberalismo e o anarquismo. Nesse diapasão, pontua BOBBIO (1988, p. 117) que:

O reconhecimento dos direitos do homem e do cidadão, primeiro apenas doutrinário através dos jusnaturalistas, depois também prático e político através das primeiras Declarações de direitos, representa a verdadeira revolução copernicana na história da evolução das relações entre governantes e governados: o Estado considerado não mais ex parte principis mas ex parte populi. $\mathrm{O}$ indivíduo vem antes do Estado. $\mathrm{O}$ indivíduo não é pelo Estado mas o Estado pelo indivíduo. As partes são anteriores ao todo e não o todo anterior às partes (como em Aristóteles e Hegel).

Tanto é assim que as Constituições editadas entre o último quarto do século XVIII e o término da Primeira Guerra Mundial outorgam ao Estado a competência restrita de garante mor da segurança, seja pela defesa das fronteiras contra alguma invasão estrangeira, seja pelo dever de resguardo da ordem pública interna. Então, socorrendo-se mais uma vez do magistério de BOBBIO (1988, p. 124):

O estado liberal, que se contrapõe polemicamente ao Estado eudemonológico ${ }^{44}$, é ao mesmo tempo laico com respeito à esfera religiosa e abstencionista com respeito à esfera econômica (e não por acaso é freqüentemente designado por um termo da linguagem religiosa: "agnóstico"). Também é definido como Estado de direito (num dos vários significados desta expressão), não tendo fins externos que lhe provenham do não-Estado, não tendo outrossim senão o de garantir juridicamente o desenvolvimento o mais autônomo possível das duas esferas fronteiriças, ou seja, a mais larga expressão da liberdade religiosa e a mais larga expansão da liberdade econômica.

A economia, destarte, deveria ser naturalmente regulada pela mão invisível $^{45}$ do mercado com o mínimo de normas jurídicas interferindo em seu funcionamento, que deveriam, em suma, se limitar à disciplina da propriedade e da

${ }^{44}$ Conforme esclarece o autor, seria o Estado que: “se propõe como fim a felicidade de seus próprios súditos, entendida a felicidade no sentido mais amplo, como possibilidade de perseguir, mais do que o maior bem terreno, o bem ultraterreno que apenas a verdadeira religião pode assegurar".

${ }^{45}$ Trata-se de uma figura hipotética idealizada por Adam Smith no final do século XVIII e se constituiria no resultado do conjunto de ações econômicas existentes na sociedade com cada agente buscando em primeiro lugar seu próprio interesse. Segundo tal concepção, explica NUSDEO (2005, p. 122) que no mercado seria a mão invisível que "guiaria os seus operadores para as aplicações mais corretas de recursos, correção essa que eles, movidos apenas pelo espírito hedonista, não conseguiam discernir ou não procurariam conscientemente alcançar, mas para cujo resultado favorável contribuíam à sua própria revelia". 
obrigatoriedade do cumprimento dos contratos livremente pactuados sob pena de execução forçada. Em complemento, quase nada a respeito de políticas públicas ou sociais deveria ser levado a efeito com o Estado à frente. Segundo mostra TORRES (1991, p. 136):

Mas, nesta fase inicial de capitalismo e do liberalismo era muito rígido o tratamento dado à pobreza, especialmente aos trabalhadores assalariados, cujos problemas deveriam obter solução de mercado e que não mais mereciam os elogios dos filósofos, agora deslocados para a classe rica ${ }^{46}$.

Todavia, é bem sabido que as "imperfeições do liberalismo, associadas à incapacidade de auto-regulação dos mercados, conduziram à atribuição de nova função do Estado" (GRAU, 1998, p. 15). Segundo narra LEWANDOWSKI (2005b, p. 174):

\begin{abstract}
A crescente pressão das massas forçou o Estado a abandonar a posição de mero expectador passivo dos conflitos sociais, na qual havia se colocado pelos ideólogos liberais, obrigando-o a atuar na busca de soluções para os problemas da comunidade. Renunciando à sua postura abstencionista, o Estado passou a adotar uma atitude positiva, conferindo ao indivíduo, enquanto membro da coletividade, os denominados direitos econômicos, sociais e culturais, de segunda geração.
\end{abstract}

Nesse contexto, é que, nas primeiras décadas do século XX, se inicia a edificação do welfare state ou Estado Social, intervencionista e regulador da economia por meio da confecção de normas jurídicas.

Tenha-se em mente, contudo, que mesmo o Estado liberal não era absolutamente impenetrável às intervenções econômicas pontuais. Aduz GABARDO (2003, p. 119) que: “A intervenção do estado fez-se presente mesmo no regime liberal do século XIX. Todavia, foi no século XX que o intervencionismo cresceu de forma radical, tendo em vista a necessidade de correção das imperfeições do liberalismo".

Não é uma transição ou ruptura imediata com o modelo liberal até então vigente. De fato, conforme BERCOVICI (2002, p. 119) ela: "se dá aos poucos, com o Estado liberal, ao longo do tempo, emendando-se, contradizendo-se, mudando seus parâmetros". Destarte, começa-se a conceber não apenas a possibilidade, mas a

\footnotetext{
${ }^{46}$ Havia, não se pode negar, uma preocupação social mínima. Nessa linha, a Constituição brasileira de 1824 previa a garantia dos "socorros públicos" (art. 179, XXXI), bem como a instrução primária gratuita a todos os cidadãos (art. 179, XXXII).
} 
necessidade do Estado interferir no processo econômico por meio de normas jurídicas especialmente editadas para tal desiderato.

Dentre as conhecidas causas que concorreram para tal fenômeno, destacam-se a eclosão de movimentos sociais na segunda metade do século XIX e as graves crises econômicas geradas pela Primeira Guerra Mundial. Com efeito, esse grave conflito, segundo expõe GABARDO (2003, p. 121): “quebra com os resquícios do modelo liberal, em decorrência da falta de capital, da precariedade dos mercados, da exacerbação do nacionalismo e da política protecionista adotada pelos Estados Unidos”.

Então, Constituições como a do México de 1917, a da Alemanha de 1919, a da Espanha de 1931, seguidas por várias outras, inclusive as brasileiras de 1934, 1937, 1946, 1967 e 1988, passaram a incluir em seus textos mandamentos sobre a condução econômica, com participação crescente do Estado nesse setor como um regulador e fomentador do mercado, além de garantidor de direitos muito mais amplos que outrora, tais como saúde, moradia, transporte, educação, etc.

Mesmo os Estados Unidos da América, de formação eminentemente liberal, após o crash da bolsa de valores de Nova Iorque em 24 de outubro de 1929, marco inicial da retração econômica mais grave do século passado em vários países, iniciaram uma fase de participação relevante do Estado na economia (o chamado new deal) ${ }^{47}$, colocando em prática as ideias defendidas por Keynes, cuja proposta, segundo BOARATI (2006, p. 32):

foi que o governo interferisse nesse ciclo descendente por meio da realização de gastos acima de sua arrecadação total (déficits sistemáticos). Esses gastos deveriam ser realizados preponderantemente em obras públicas. Com isso, o governo conseguiria aumentar o nível de emprego na economia, e os trabalhadores novamente passariam a adquirir bens e serviços. Esse aumento da demanda efetiva resultaria em queda dos estoques empresariais, significando um incentivo ao aumento da produção e conseqüente aumento da contratação de mão-de-obra até o ponto em que a economia chegasse ao nível de pleno emprego. E

${ }^{47}$ Esclarece FERREIRA FILHO (2008, p. 149-150) que: "O New Deal de Roosevelt foi, sem dúvida, a mais ousada tentativa de debelar pela intervenção do Estado a depressão econômica dos anos 30. Logo após sua posse em 4 de março de 1933, tomou Roosevelt medidas de impacto. Proclamou, em 6 de março, uma 'emergência nacional', e, invocando como base norma do Trading with the Enemy Act, de 6 de outubro de 1917, decretou um feriado bancário, proibiu a exportação de ouro e prata, bem como transações com moeda estrangeira. Depois, obteve do Congresso a aprovação de numerosa legislação de intervenção na economia". 
finalmente no aumento do pagamento de impostos. Esse fenômeno é conhecido como efeito multiplicador dos gastos públicos, o chamado multiplicador keynesiano ${ }^{48}$.

Nesse ponto, RODRIGUEZ (1999, p. 83) assevera que: “A doutrina keinesiana permitiu ao capitalismo superar o problema das crises cíclicas, tendo dado ensejo ao surgimento do Welfare State, no período compreendido entre o final da Segunda Guerra Mundial e o início dos anos 70".

Com efeito, essa nova postura tomada pelo Estado ${ }^{49}$ pressupôs uma forte mudança no conteúdo da legislação até então usualmente editada, seja no sentido de conferir certo dirigismo aos vários agentes econômicos do mercado, seja para limitar o poder de livre disposição das partes nos contratos, segundo constatação de SAN TIAGO DANTAS (1952, p. 05 e ss.):

comparando a legislação civil e comercial do início do século XIX com a que se veio editar no fim do século e, sobretudo, no início do seguinte, é fácil observar-se o aumento quantitativo e qualitativo das normas imperativas, principalmente através do direito especial. Quer isso dizer que sob condições sociais diferentes das que cercam o primeiro surto do capitalismo industrial no ocidente, o princípio da autonomia da vontade entrou a perder terreno para o da supremacia da ordem pública.

Com efeito, apenas como exemplo, é de se recordar que os arts. 115 e 138 da Constituição Federal de 1934 deixaram fora de dúvidas a então nascente preocupação do constituinte em conferir ao Estado tarefas de intervenção e fomento na seara econômica.

Nessa linha, o art. 115 previa que a ordem econômica deveria ser organizada conforme os princípios da justiça e das necessidades da vida nacional de modo que possibilitasse a todos uma existência digna, sendo garantida a liberdade de ação econômica dentro desses limites. Por sua vez, o art. 116 autorizava a União, por motivo de

${ }^{48}$ Conforme indica BOBBIO (2006, p. 139): "Já se disse muitas vezes que a política keynesiana foi uma tentativa de salvar o capitalismo sem sair da democracia, contra as duas opostas soluções de abater o capitalismo sacrificando a democracia (a prática leninista) e de abater a democracia para salvar o capitalismo (o fascismo). Agora se diria que para os liberais da nova geração, o problema é, ao contrário, o de salvar - se ainda for possível e em nome daquele tanto que ainda pode ser salvo - a democracia sem sair do capitalismo".

${ }^{49}$ Por tais circunstâncias, NOGUEIRA (1997, p. 195) qualifica o Estado como uma "entidade mutante" e segundo DALLARI (1989, p. 118) é preciso: "conciliar a idéia de ordem, no sentido de situação estabelecida, com o intenso dinamismo social, que ele deve assegurar e promover e que implica a ocorrência de constante mutação". 
interesse público e mediante lei especial, a monopolizar indústria ou atividade econômica, asseguradas indenizações conforme o caso.

$\mathrm{Na}$ sequência, o art. 117 incumbia a lei de promover o fomento da economia popular, o desenvolvimento do crédito e a nacionalização progressiva dos bancos de depósito, bem como a nacionalização das empresas de seguros em todas as suas modalidades. O parágrafo único desse dispositivo, ao proibir a usura e determinar sua punição segundo a lei, interferiu diretamente no percentual de juros cobrados nos empréstimos.

Interessante notar que a Constituição anterior de 1891 não trazia normas com tais propósitos, eis que editada numa época em que, conforme já afirmado, não se via como um bem a intervenção do Estado na economia, ou seja, se interferência houvesse, deveria ser mínima.

Em termos atuais, a situação permanece. Analisando a Constituição de 1988, verifica-se que o $\$ 4^{\circ}$ do art. 173 da Constituição de 1988 assenta que: "A lei reprimirá o abuso do poder econômico que vise à dominação dos mercados, à eliminação da concorrência e ao aumento arbitrário dos lucros".

Em seguida, o $\S^{\circ}$ do mesmo dispositivo estatui que:

A lei, sem prejuízo da responsabilidade individual dos dirigentes da pessoa jurídica, estabelecerá a responsabilidade desta, sujeitando-a às punições compatíveis com sua natureza, nos atos praticados contra a ordem econômica e financeira e contra a economia popular.

Imediatamente a seguir, no mesmo sentido, o art. 174 prevê um Estado como agente normativo e regulador da atividade econômica, sendo sua competência exercer, na forma da lei, as funções de fiscalização, incentivo e planejamento, atuação essa impositiva para o setor público e indicativa para o setor privado. $\mathrm{E}, \mathrm{o} \S 1^{\circ}$ desse artigo delega à lei estabelecer as diretrizes e bases do planejamento do desenvolvimento nacional equilibrado, o qual incorporará e compatibilizará os planos nacionais e regionais de desenvolvimento. 
Certeza há, portanto, de que essa intervenção é precedida e amparada em normas jurídicas, notadamente a lei. Se assim é, evidenciado está que direito e economia se interagem e mutuamente refletem a dinâmica social, sendo que esse relacionamento se intensificou a partir do final do século XIX e início do XX e assim tem ocorrido até a atualidade.

Tomando como base o preceituado no art. 170, parágrafo único, da Constituição de 1988, conclui-se que no Brasil o exercício da atividade econômica somente pode ser limitado ou disciplinado por regramento jurídico expresso.

Portanto, as normas que tratam do assunto, além da mencionada garantia dos direitos de propriedade e da regra geral que estatui a obrigatoriedade dos pactos, podem apresentar, em síntese, estes conteúdos: 1) proibição; 2) proteção ou direção contratual; 3) regulação de determinado setor ou atividade econômica; 4) incentivo ou inibição de comportamentos.

Ressalte-se não se tratar de um rol exaustivo e, ainda, constata-se a presença de uma inter-relação entre todos, conforme analisado a seguir:

1) conteúdo de proibição: há várias atividades de cunho econômico que, por representarem risco à saúde ou algum tipo de conflito com o interesse público, ou mesmo por razões políticas, têm sua prática completamente vetada pelo Direito.

Cita-se, por exemplo, as ações voltadas à produção e ao comércio de substâncias entorpecentes, que, além de legalmente vedadas na maioria dos países, ordinariamente, são qualificadas como conduta criminosa, o que também se aplica a diversas outras hipóteses tidas por socialmente nocivas, v.g. o furto, a apropriação indébita, o estelionato, os crimes contra o patrimônio em geral, a exploração de jogos de azar (atividade proibida no Brasil por força do Decreto-lei 9.215, de 30 de abril de 1946).

Vale aqui recordar também a $18^{\mathrm{a}}$ Emenda à Constituição norteamericana, de 16 de janeiro de 1919, que implantou a famosa "lei seca", ou seja, tornou ilícito o fabrico, varejo, transporte, importação ou exportação de bebidas alcoólicas nos Estados Unidos. 
É certo que muitos outros exemplos poderiam ser trazidos à baila, sendo que a todos eles uma circunstância peculiar pode ser aferida, qual seja: a interdição total e irrestrita de qualquer atividade econômica representa um conflito aberto entre as forças de mercado (os vetores sociais da oferta e da demanda por determinado bem ou serviço) e as respectivas normas proibitivas.

Logo, o simples fato de certa proibição ter sido normativamente posta não representa ou garante sua observância automática, seja por produtores, fornecedores ou mesmo pelos consumidores. Nessa linha, segundo coloca CARVALHO (2005, p. 265):

Como o sistema normativo não interfere diretamente nas condutas, apenas as estimula, sempre há possibilidade de escolha por parte do receptor da mensagem prescritiva. Sendo assim, o sistema econômico pode reagir tanto no sentido de acolher as ordens jurídicas, como no sentido de desobedecer-lhes ou burlá-las.

Aliás, é inferível que a resistência ao seu cumprimento se faça na mesma proporção da espectativa de ganhos do agente econômico. Assim, quanto maior for o potencial de ganho, mais dificultosa se mostrará a adesão dos agentes à norma.

Evidentemente, alguma eficácia é se esperar da norma proibitiva, eis que, ante ao simples fato de se decretar certa atividade como ilícita, normalmente há uma imediata retração na oferta. Usando como exemplo os entorpecentes, é razoável supor que, logo em seguida à proibição, muitos fabricantes e comerciantes encerrem esse tipo de atividade, pois não querem se sujeitar ao risco da correspondente punição, resultando, como consequência, numa produção em níveis notavelmente inferiores àqueles esperados caso a vedação não existisse.

A primeira e mais marcante consequência, nesse caso, é o aumento do preço das substâncias, uma vez que a produção, além de dimunuída pela saída de cena vários agentes, o que reforça a escassez do produto, é mais dispendiosa do que no instante anterior à proibição, eis que a produção necessariamente deve passar a ser ultimada em segredo, às escondidas das autoridades, sob disfarces e artimanhas, longe dos centros urbandos, implicando em complexas e sigilosas operações de transporte do material aos locais de venda. 
Em adição, os agentes que permaneceram no ramo (e aqueles que se iniciarem), obviamente, fazem incluir no valor cobrado do usuário uma compensação proporcional ao perigo corrido pelo desempenho da atividade ilegal, mais um fator que, aliado à escassez e ao elevado custo de produção, torna o preço final extremamente alto, somente podendo ser pago por pessoas de certo poder aquisitivo ou que realmente desejem o produto proibido, muita vezes não medindo esforços para obtê-lo.

Logo, não se pode negar que a proibição de certa atividade acaba por diminuir o seu mercado em termos de oferta e demanda, mas é pouco provável que consiga pleno êxito em extingui-la.

Assim, em que pese os reconhecidos esforços mundiais no combate à produção e comércio de drogas ilícitas, essa atividade permanece vívida e é de conhecimento geral que ela movimenta quantias astronômicas ao redor do mundo.

O gráfico abaixo, elaborado por MANKIW (2007, p. 109), ilustra o que aqui é tratado:

Políticas para Reduzir o Uso de Drogas llegais

A politica de proibição das drogas reduz a oferta de $\mathrm{O}_{1}$ para $\mathrm{O}_{2}$, como no painel (a). Se a demanda por drogas é inelástica, então a quantia total paga pelos usuários de drogas aumenta, muito embora a quantidade utilizada de drogas caia. Em comparação, a política educacional contra as drogas reduz a demanda por drogas de $D_{1}$ para $D_{2}$, como no painel (b). Como tanto o preço quanto a quantidade diminuem, a quantia paga pelos usuários de drogas é menor.

(a) Política de Proibição das Drogas

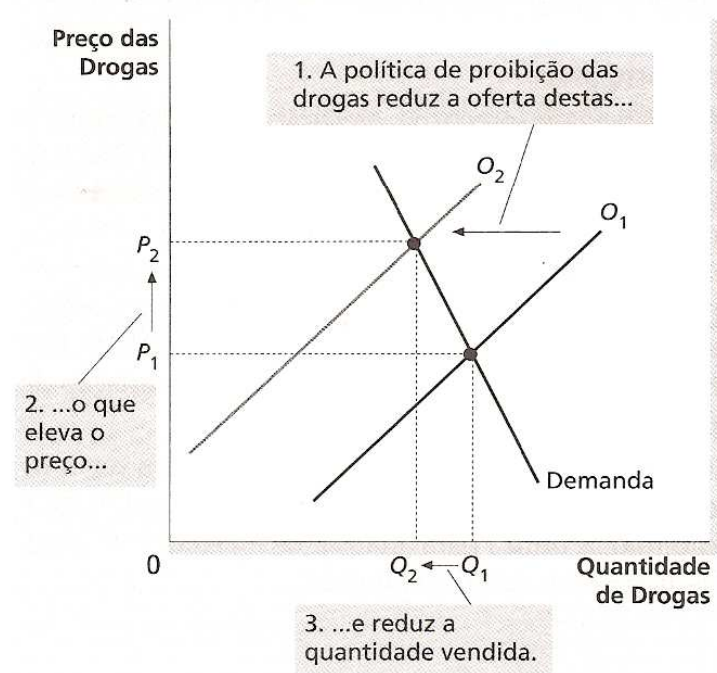

(b) Política Educacional contra as Drogas

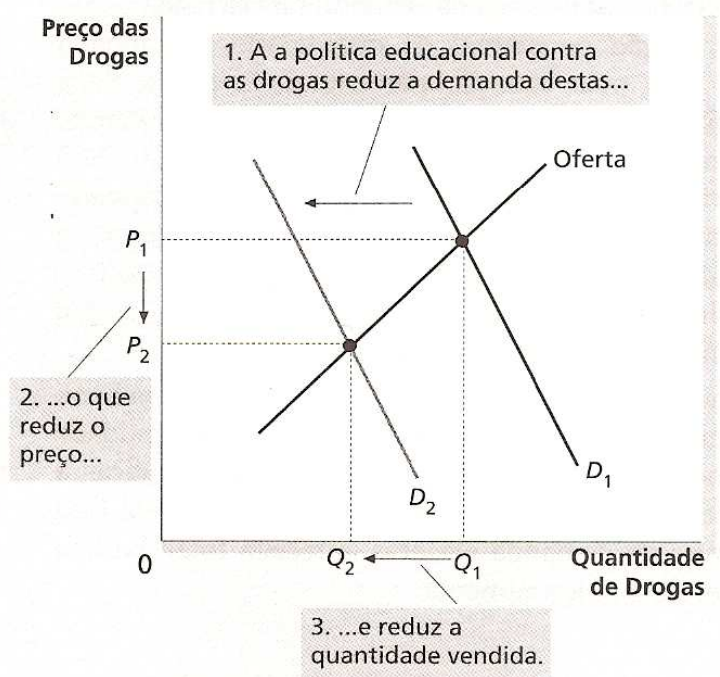


Outros exemplos dessa situação são notórios, a começar pelo retumbante fracasso da citada "lei seca" americana, que culminou em sua revogação, em 05 de dezembro de 1933 pela 21 a Emenda. Quanto à exploração dos dos jogos de azar, é de se admitir não ser incomum a publicação de notícias relatando o fechamento por autoridades policiais de cassinos ou bingos clandestinos, o que comprova a persistência subterrânea dessa atividade.

Ainda dentro da seara criminal, o aumento expressivo do cobre no mercado internacional refletiu em proporção semelhante nos furtos de cabos de iluminação pública na cidade de São Paulo, deixando vários espaços no escuro, conforme trancrição de notícia publicada na internet em 05 de dezembro de $2007^{50}$ :

[...] Em agosto, a roubalheira bateu recorde histórico: 215 quilômetros, contra 142 em julho e 128 no início de 2007. "Os números são alarmantes e a situação já preocupa", afirma Walter Bellato, diretor do Ilume, departamento responsável por administrar os 17000 quilômetros de cabeamentos de São Paulo. O crime se intensificou nos últimos quatro anos, período em que a média mensal de fios furtados mais que triplicou (veja o gráfico). Um dos principais motivos para esse aumento é a valorização do cobre. Em 2005, ano em que a cotação do metal teve a maior alta dos últimos dezesseis anos no mercado internacional, os furtos cresceram $71 \%$. Naquela época, os ferros-velhos da capital pagavam 6 reais pelo quilo do metal. Hoje, segundo a polícia, esse valor pode atingir 14 reais.

É muito raro que uma norma jurídica consiga banir completamente alguma atividade da economia, ainda que o Estado inquine a conduta de criminosa e faça implementar mecanismos de fiscalização e repreensão. Usualmente, o que se observa é a recalcitrância de um certo mercado "paralelo", ou seja, mesmo que, a partir da edição de certa norma, se consiga inibir uma atividade econômica qualquer, é praticamente impossível expurgá-la totalmente ${ }^{51}$.

Em resumo, isso revela um diálogo ou relação um tanto conflituosa entre o direito e a economia quando o primeiro pretende extirpar certa atividade econômica do

${ }^{50}$ Disponível em: <http://vejasaopaulo.abril.com.br/revista/vejasp/edicoes/2037/m0144814.html〉. Acesso em: 22.11.2008.

${ }^{51}$ Mesmo sob tal perspectiva, não se defende aqui a legalização da produção e do comércio de entorpecentes ou da prática dos jogos de azar, visto que tais assuntos não se resumem ao aspecto econômico que os envolvem, mas tangem políticas de saúde pública e questões afetas aos costumes sociais. Vê-se, portanto, que o raciocínio econômico nem sempre se identifica com o jurídico, pois, segundo explicado por LOPES (2004, p. 142): "as regras de direito funcionam realmente como limites e obstáculos à extensão universal da racionalidade de meios e fins a todos os objetos de interesse na vida". 
seio social. Pode-se dizer que cada um dos sistemas emite ao outro mensagens ou estímulos, mas com feedbacks precários, incertos e inconstantes;

2) conteúdo de proteção ou direção contratual: conforme visto acima, o agir de modo econômico implica e corresponde a uma série de atos praticados sob o pálio da escassez material, obrigando a que cada pessoa, na busca de satisfazer seus desejos e necessidades, escolha desfrutar das comodidades que, em sua racionalidade, correspondam ao melhor custo-benefício possível.

Assim, por exemplo, se alguém pretende comprar um veículo é de rigor que entregue o preço ao vendedor, abrindo mão, então, da possibilidade de adquirir outros bens com aquele valor que deixará seu patrimônio para se inserir no do vendedor, independentemente do pagamento ocorrer na base da troca (v.g. o comprador transfere ao vendedor certo número de cabeças de gado) ou da entrega de dinheiro.

E, na medida em que os indivíduos atuam negociando entre si, o resultado é a circulação de inúmeros bens e riquezas na sociedade. Todo esse fenômeno econômico, salvo exceções pontuais, se desenrola sob o manto da figura jurídica do contrato nas suas diversas formas acolhidas e disciplinadas pelo direito.

O contrato, na simples e precisa exposição de BEVILACQUA (1955b, p. 194), é "o acôrdo de vontades para o fim de adquirir, resguardar, modificar ou extinguir direitos". No mesmo sentido é a lição de FRANÇA (1994, p. 713), que acrescenta possuir essa convenção uma natureza patrimonial.

De fato, é uma figura que tem por objeto, segundo SZTAJN e VERSOÇA (2003, p. 09), "assegurar e regular a pacífica circulação de riqueza; evitar a violência na alocação eficiente dos bens na economia; e a promover sua transferência entre as pessoas de forma lícita, uma vez que obriga as pessoas por suas declarações e promessas".

Dessa feita, o contrato se assume como uma promessa capaz de gerar legítimas expectativas de comportamento entre as partes envolvidas, cuja eficiência estará relacionada à previsões de incentivos e/ou sanções para as hipóteses de observância e 
descumprimento do pacto, respectivamente, com influência também trazida pelo ambiente institucional, leia-se as normas jurídicas e a maneira como são aplicadas.

Todavia, ainda que o contrato funcione como verdadeiro catalisador da economia, os ordenamentos jurídicos em geral trazem preceitos acerca de vários aspectos da manifestação de vontade inerente a tais instrumentos, seja para limitá-la em certos casos, seja para estipular condições mínimas a serem respeitadas pelas partes de modo que o direito acolha o pacto sob sua proteção. Conforme explica BRUTAU (1988, p. 07):

Por suposto que os particulares não podem alterar os preceitos relativos à capacidade de contratar, nem as normas que determinam quais objetos são lícitos ou de possível contratação, nem cabe perseguir um fim ilícito, imoral ou proibido, nem é possível deformar a estrutura peculiar de cada contrato, como pretender que um comodato seja remunerado, etc. A distinção entre Direito cogente (ius cogens) e Direito cujos efeitos podem ser afastados por convenção privada (ius dispositivum), assinalam limites indubitáveis à liberdade contratual ${ }^{52}$.

Portanto, ao menos no direito brasileiro, qualquer contrato não pode estar maculado por quaisquer das causas de nulidade previstas nos arts. 166 e 167 do Código Civil, tais como, incapacidade absoluta de uma das partes; objeto ilícito, impossível ou indeterminável; desrespeito à forma legal quando for exigida; simulação.

No mesmo sentido, é de rigor a não presença de um dos defeitos geradores da anulabilidade, nos termos previstos no art. 171 do mesmo Codex, ou seja: incapacidade relativa de um dos contratantes, erro, dolo, coação, estado de perigo, lesão ou fraude contra credores.

Além disso, a proteção jurídica ao pacto somente se manifestará se entre as declarações de vontades manifestadas por cada uma das partes existir uma coincidência de fundo que, conforme GOMES (1995, p. 10) "é necessária nos pontos essenciais e decisivos para a formação do contrato, segundo a vontade de uma ou das duas partes. Sempre que faltar, o contrato não nasce, ou será ineficaz".

${ }^{52} \mathrm{O}$ texto original é o seguinte: "Por supuesto que los particulares no pueden alterar los preceptos relativos a la capacidad para contratar, ni las normas que determinan que objetos son de licita o posible contratación, ni cabe perseguir un fin ilícito, inmoral o prohibido, ni es posible deformar la estructura peculiar de cada contrato, como pretender que un comodato sea retribuido, etc. La distinción entre Derecho necessario (ius cogens) y Derecho que puede dejarse sin efecto por lo convenido privadamente (ius dispositivum), señala limites indudables a la libertad contractual”. 
Prosseguindo, o conteúdo do contrato, isso é, as promessas e obrigações assumidas pelas partes, não podem ferir mandamentos de "ordem pública" ou "leis imperativas" que se constituem em normas jurídicas (em regra a lei) que, restringindo a liberdade de disposição livre de cláusulas, dirigem de algum modo a formação do contrato, inserindo ou vedando a inclusão de preceitos que o legislador entenda prejudicial a uma das partes, presumidamente mais fraca em termos econômicos. Segundo GOMES (1995, p. 33):

O processo de conversão de leis supletivas em imperativas ensejou a elaboração de novo princípio do Direito Contratual, o da regulamentação legal do conteúdo dos contratos, hoje admitido, sem maior relutância, em relação a certas espécies contratuais. Consiste em regular o conteúdo do contrato por disposições legais imperativas, de modo que as partes, obrigadas a aceitar o que está predisposto na lei, não possam suscitar efeitos jurídicos diversos. Em conseqüência, a vontade deixa de ser autônoma e a liberdade de contratar retrai-se. Não mais regras supletivas, que as partes observam se coincidem com seus interesses, mas normas imperativas, a cuja observância não podem furtar-se. Contratos padronizados. Fala-se, então, em dirigismo contratual.

Nota-se que a interferência normativa para limitar o conteúdo dos contratos é um fenômeno que se acentua no decorrer século XX e certamente se liga à préfalada crescente intervenção do Estado na ordem econômica no mesmo período. E, se o direito estipula sobre os limites e a extensão da possibilidade das pessoas agirem de forma econômica (aliás, a primeira intervenção aqui é a própria previsão normativa da figura do contrato e da sua obrigatoriedade), é porque são sistemas que trabalham sob objetivos nem sempre coincidentes.

Enquanto, em essência, a ação econômica busca maximizar os benefícios do agente pela atuação mais eficiente e menos custosa possível, o direito busca harmonizar esse desejo, inegavelmente um tanto quanto egoísta, com o bem comum ou interesse social, de maneira a criar uma convivência harmônica entre os seres humanos.

Conforme aduz LOPES (2004, p. 139-140), “o direito e a economia dão conta das ações humanas de modo diferente. São duas disciplinas que se referem a dois sentidos diferentes da ação. Tomam os indivíduos como tipo, mas como tipos ideais". A seguir, o autor vislumbra o constante diálogo entre as matérias: 
o raciocínio jurídico e a boa dogmática jurídica não são surdos aos saberes alheiros e se dão conta de que vários objetos constituídos por outras disciplinas são matéria prima sobre a qual decidem. Embora decidindo segundo regras, o jurista sabe que o objeto de sua decisão, o caso sobre o qual ele quer aplicar as regras, não são as regras mesmas, mas as relações entre pessoas e estas são explicitadas e constituídas por muitos saberes que não apenas o direito.

No direito brasileiro, há vários exemplos de normas cujo teor autoriza a interferência externa (via de regra por meio da atuação judicial) no conteúdo das promessas contratuais, merecendo especial destaque o Código de Defesa do Consumidor (Lei 8.078, de 11/09/1990), que, dentre várias previsões, traz dispositivos sobre a previsão do direito do consumidor de revisão de cláusulas contratuais nos casos em que sua prestação for desproporcional àquela da outra parte, a resultar numa vantagem excessiva ou lucro exagerado (arts. $6^{\circ}, 39, \mathrm{~V}$, e 51 , IV), assunto inclusive desenvolvido pelo autor deste texto em dissertação de mestrado apresentada à Faculdade de Direito da Universidade de São Paulo (MARTINS, 2001, p. 211 e ss.), bem como há previsão da responsabilidade objetiva (independentemente da aferição de culpa) e solidária entre o fabricante, vendedor ou fornecedor de bens ou serviços ao consumidor (arts. 12 e 18).

Há ocasiões, possivelmente reveladoras de excesso de zelo legislativo, em que se chega a delinear o tamanho dos caracteres gráficos nos contratos de adesão, como fez a Lei 11.785 , de 22 de setembro de 2008, que modificou a redação do $\S 3^{\circ}$ do art. 54 do Código de Defesa do Consumidor e previu que: "Os contratos de adesão escritos serão redigidos em termos claros e com caracteres ostensivos e legíveis, cujo tamanho da fonte não será inferior ao corpo doze, de modo a facilitar sua compreensão pelo consumidor".

Ao contrário do que ocorre em relação às normas cujo conteúdo seja proibitivo, existe diálogo mais cordial e harmônico entre direito e economia quando se estiver diante do elemento limitação ou proteção contratual. Infelizmente, esse diálogo não é fluído ou de fácil desenlace, significando dizer que o direito nem sempre acolhe os estímulos econômicos com a rapidez que os agentes esperam e vice-versa. Nesse sentido, segundo ZOLO (2006, p. 72-73):

Mas o direito é um instrumento muito mais rígido e lento com respeito à flexibilidade e rapidez evolutiva de subsistemas como, em particular, o científico-tecnológico e o econômico, que são dotados de alta capacidade 
de autoprogramação e de autocorreção. Deste fato, deriva a crise inflacionária do direito, que traz consigo desvalorização, redundância e instabilidade normativa e, enfim, impotência reguladora.

Se esse descompasso temporal entre o direito e a economia é uma realidade perceptível, senão mesmo inegável, infere-se que alguma consequência daí advirá, eis que, conforme indicado por PINHEIRO (2008, p. 43):

os agentes econômicos não assistem impassíveis aos problemas colocados para a economia pelos ditames do direito. Para a economia, o tempo do direito, se mais lento do que o seu, torna-se um custo e um risco adicional, que vai ser embutido nos preços e nas decisões empresariais e de consumo. Neste sentido, a morosidade tem um custo para a economia, custo que é pago por alguém.

Certamente, alguns assuntos são mais nevrálgicos que outros, dada a relevância social que possuem, o que pode implicar em algumas dificuldades no diálogo entre o direito e a economia. Nessa linha, por exemplo, tem-se os serviços de saúde organizados pela iniciativa privada.

Aqui, não obstante o art. 196 da Constituição de 1988 estabelecer a saúde como um direito de todos e dever do Estado, o art. 197 permite que os serviços a ela relacionados sejam realizados por terceiros, cabendo ao Poder Público dispor, nos termos da lei, sobre sua regulamentação, fiscalização e controle.

Dadas as notórias deficiências dos serviços públicos de saúde no Brasil em todas as esferas federativas, parcela significativa da população arca com os custos dos serviços privados, o que confere grande relevância ao assunto, uma vez que indiscutivelmente a saúde se liga diretamente ao nível de bem-estar dos indivíduos.

Como em qualquer atividade econômica, há potencial conflito entre os interesses dos contratantes e eventuais beneficiários dos serviços - que legitimamente pretendem pagar o mínimo possível pela proteção - e os das empresas que administram os serviços - que, sob a mesma legitimidade, procuram obter o maior lucro possível no negócio.

Todavia, tratando-se de um sistema que depende do equilíbrio atuarial, aliás, se, conforme ZANITELLI (2008, p. 209), contratos de planos de saúde são uma 
forma de seguro, é possível que surja também um conflito entre os próprios beneficiários dependendo do grau de risco que ostentem e, consequentemente, a maior ou menor probabilidade de utilização dos serviços disponíveis.

Explica-se: um idoso, presumivelmente, socorre-se muito mais vezes dos serviços - em quantidade e complexidade de procedimentos - do que um jovem em plena saúde. Na mesma esteira, pessoas cujo comportamento sexual seja preponderantemente descuidado, por se colocarem num grau probabilístico superior às demais em termos de aquisição de doenças sexualmente transmissíveis, potencialmente, utilizam com mais frequência os serviços de médicos e hospitais, o que se aplica também para usuários contumazes de entorpecentes e álcool.

Em conclusão, tomando como premissa a necessidade de se respeitar o equilíbrio atuarial (sob pena de desmantelamento do sistema), para que não se institua indiretamente um "auxílio" ou "subsídio" involuntário das pessoas que portam os menores riscos em benefício daquelas sujeitas aos maiores, é de rigor existir uma variação do prêmio pago pelos segurados segundo o risco apresentado em cada caso.

Atende-se, com isso, o que ZANITELLI (2008, p. 204 e ss.) denomina de “princípio da justiça atuarial”. Do contrário, sem sombra de dúvida, caso o valor do prêmio pago fosse rigorosamente idêntico e independesse do risco individual, aqueles que pouco utilizarem o sistema - ainda que em termos de probabilidade -, estariam custeando as despesas daqueles cuja saúde fosse mais frágil. Tanto é assim que ordinariamente a contribuição mensal varia segundo a faixa etária e o histórico de doenças individuais e familiares.

Constata-se, entretanto, que a liberdade das partes no que tange à inclusão ou exclusão de futuros eventos a serem atendidos é efetivamente minúscula, se é que existe em algum grau. Em todos os sentidos, para esse aspecto, impera o dirigismo contratual.

Veja-se, por exemplo, que no Brasil o segurado, com intenção de baratear sua prestação, não pode por contrato dispensar a cobertura referente ao tratamento de eventos como a AIDS. Em conclusão, se essa cobertura é sempre obrigatória, sendo 
obviamente os respectivos custos diluídos pelas empresas-administradoras em todos os pactos celebrados, as pessoas que apresentem um risco menor ao infortúnio (em vista do comportamento sexual mais comedido, etc.) acabam concorrendo, mesmo que com isso não concordem, para cobrir as despesas com o tratamento dos portadores doentes e isso fere o "princípio da justiça atuarial”.

Contudo, não se pode negar que permitir seja o mercado o único vetor a regular o assunto, sem qualquer espécie de intervenção legal nesse tópico, pode resultar em situações que desrespeitem valores sedimentados e sentimentos sociais de justiça, como, por exemplo, na hipótese de alguém que tenha rigorosamente pago durante vários anos suas obrigações para com a empresa administradora, mas que, por ter chegado a certa idade, não tenha mais condições econômicas de manter o contrato, visto que os valores sobem segundo os riscos e presumivelmente os idosos estão mais propensos a demandar atendimento.

Na mesma linha e pelos mesmos motivos, a viger a plena liberdade contratual, é possível aventar que as empresas rescindam os contratos a partir do momento em que os segurados atinjam de uma determinada idade, nunca mantendo pactos com idosos, mesmo que muitos deles tenham sido seus clientes de longa data.

Portanto, na área em foco, vislumbra-se que o já mencionado "princípio da justiça atuarial" usualmente é temperado e conjugado com o "princípio da solidariedade" de modo a socializar os custos. Nesse instante, entra em cena o Direito com o objetivo de moldar a "racionalidade econômica" dos agentes de mercado ao determinar, por exemplo, no art. 14 da Lei 9.656/98 que: "Em razão da idade do consumidor, ou da condição de pessoa portadora de deficiência, ninguém pode ser impedido de participar de planos privados de assistência à saúde".

Evidentemente, o equilíbrio entre o "princípio da justiça atuarial" com o "princípio da solidariedade" é tarefa das mais complexas e que cabe em primeiro lugar ao legislador. De fato, um excesso de "justiça atuarial” pode afastar várias pessoas do sistema, principalmente na medida em que a idade avança, o que pode contrariar visões de justiça ou equidade. Por outro lado, um excesso de "solidariedade" é capaz de gerar um "auxílio" ou "subsídio" indireto exacerbado pago por aqueles cujos riscos sejam menores. 
Outros dispositivos também ostentam nítido caráter protetivo, com destaque para o art. 11 da citada lei, que veda a exclusão de cobertura às doenças e lesões preexistentes após 24 meses de vigência do instrumento contratual, bem como para o art. 13, II, que permite a suspensão ou rescisão contratual por inadimplência do segurado apenas no caso de não-pagamento da mensalidade por período superior a 60 dias (consecutivos ou não, nos últimos 12 meses de vigência do contrato), desde que o consumidor seja comprovadamente notificado até o quinquagésimo dia de inadimplência ${ }^{53}$.

Porém, não se pode esquecer, e este é um fenômeno econômico gerado pela proteção legal, que o montante das garantias a serem cobertas pelo sistema é forte componente dos custos impingidos aos consumidores, mesmo que órgãos governamentais - v.g. Agência Nacional de Saúde - tentem disciplinar e impor limites aos valores das parcelas.

Logo, como não seria viável pretender que as empresas-administradoras operem gratuitamente ou mesmo sob prejuízo, pois isso as colocaria em risco de extinção, quanto mais obrigações estiverem incluídas nos contratos, maior será o preço cobrado do segurado. E, no caso de excesso, a elevação será tamanha que impedirá o acesso ao sistema de possíveis interessados. Segundo narra ZANITELLI (2008, p. 207):

Um efeito perverso da intervenção estatal é, não obstante, o de negar acesso ao seguro para os que não queiram ou não possam suportar a alta de preços resultante das vantagens legalmente asseguradas. Entre os consumidores mencionados estão possivelmente os menos sujeitos ao risco (para os quais os benefícios legais talvez tenham menor valor e não compensem a elevação de prêmios) e os de baixa renda.

Prosseguindo, a área de locação imobiliária para residências também é potencialmente conflituosa. Sobre o tema, hipótese dessa interdependência entre o direito e a economia é formulada por POSNER (2007b, p. 483):

\footnotetext{
${ }^{53} \mathrm{Na}$ área de serviços privados de educação, indiscutivelmente de elevada relevância social, o art. $6^{\circ}$ caput e seu $\S^{\circ}$ da Lei 9.870/99 estipula que: "Art. $6^{\circ}$ - São proibidas a suspensão de provas escolares, a retenção de documentos escolares ou a aplicação de quaisquer outras penalidades pedagógicas por motivo de inadimplemento, sujeitando-se o contratante, no que couber, às sanções legais e administrativas, compatíveis com o Código de Defesa do Consumidor, e com os arts. 177 e 1.092 do Código Civil Brasileiro, caso a inadimplência perdure por mais de noventa dias. $\S^{\circ}-\mathrm{O}$ desligamento do aluno por inadimplência somente poderá ocorrer ao final do ano letivo ou, no ensino superior, ao final do semestre letivo quando a instituição adotar o regime didático semestral".
} 
uma regra que facilite aos inquilinos pobres o rompimento dos contratos de locação com senhorios ricos irá induzir estes últimos a aumentar os aluguéis a fim de suportar o impacto dos custos mais altos impostos pela regra, e os inquilinos vão suportar o preço dos custos elevados. Na verdade, a principal redistribuição realizada por tal regra pode abranger desde o inquilino prudente e responsável, que pode obter pouca ou nenhuma vantagem dos direitos jurídicos adicionais a serem usados contra os senhorios - direitos que podem permitir que um inquilino evite ou adie o despejo pelo não-pagamento do aluguel -, até o inquilino inconseqüiente. Trata-se de uma redistribuição extravagante.

À conclusão semelhante chega ARIDA (2005, p. 63-64) ao afirmar que "Se o legislador, no entanto, optar por proteger os inquilinos congelando o valor das locações, terminará por criar inúmeras distorções que afastam a economia do ótimo de Pareto" $" 54$.

Exemplo notável (para que não se diga trágico) envolvendo o tema, inclusive com graves repercussões sociais, foram as denominadas "guerras urbanas" travadas na Holanda no final da década de 1970, ocasião em que aproximadamente 3000 pessoas invadiram diversos imóveis desocupados, implicando em severos choques com as forças policiais quando da retomada dos bens pelos respectivos proprietários, conforme retrata SALAMA (2008, p. 21).

Segundo indicado pelo autor, uma das principais causas que levaram ao episódio reside na circunstância de que:

a legislação congelara os preços dos aluguéis e tornara os despejos de locatários inadimplentes extremamente lentos e complicados. Assim, aqueles locadores que finalmente retomavam seus imóveis tinham incentivos para deixá-los desocupados (além é claro de reduzirem novos investimentos na manutenção dos imóveis já existentes e na construção de novos imóveis para locação). Por conseguinte, naquela ocasião havia diversos imóveis desocupados na cidade de Amsterdã. Isso levou diversas pessoas a invadirem tais imóveis, uma prática que as cortes e tribunais holandeses estavam relutantes em impedir. Força policial foi finalmente usada após algumas vitórias dos locadores nos tribunais, e no momento da desocupação pela polícia surgiram os choques.

Do acima narrado, dentro dos infindáveis estímulos e feedbacks recíprocos entre o direito e a economia, fica claro que não são apenas as normas jurídicas e as leis de cunho geral e abstrato que compõem essa verdadeira relação de simbiose, uma

\footnotetext{
${ }^{54}$ O conceito de "ótimo de Pareto" será abordado ainda neste capítulo.
} 
vez que nela também interagem fortemente as decisões oriundas das diversas Cortes de Justiça na solução dos casos concretos que a si são trazidos.

Aliás, isso se aplica não apenas no assunto da proteção contratual, mas efetivamente se manifesta nas demais relações jurídicas de cunho patrimonial, cujos limites tenham sido remodelados por meio da intervenção judicial.

Nessa linha, ainda que ordinariamente uma decisão judicial deite seus efeitos jurídicos apenas sobre as partes que compuseram uma determinada relação processual $^{55}$, conforme inclusive preceituam os arts. 467 a 474 do Código de Processo Civil brasileiro, os efeitos econômicos quase sempre extrapolam as bordas dos autos e acabam por influenciar, em algum grau, as estratégias negociais de agentes econômicos que se enquadram em circunstâncias análogas a certo decisum, desde simples agricultores, até grandes companhias abertas.

Ao menos em sistemas normativos em que o Judiciário é constitucionalmente competente para aplacar em última instância qualquer controvérsia, como é o caso brasileiro, os precedentes jurisprudenciais atuam como verdadeiros sinais indicativos a embasar uma atuação futura dos atores de mercado.

Dispensar atenção ao tópico é de suma importância, eis que, segundo expõe PINHEIRO (2008, p. 22): “variações na qualidade dos sistemas legais e judiciais são importantes determinantes do ritmo de crescimento e desenvolvimento dos países”.

De fato, o melhor ou pior desempenho judicial de qualquer país, incluindo variáveis como a garantia de acesso ao sistema, previsibilidade do resultado segundo a jurisprudência dominante e a presteza na finalização do processo, impacta o desempenho econômico, notadamente, para estimular ou inibir novos investimentos. Nessa altura, é de se concordar com PINHEIRO (idem, p. 29) que:

um sistema legal e judicial de má qualidade distorce os preços da economia, na medida em que introduz um risco jurídico nos preços, que,

\footnotetext{
55 Evidentemente, há exceções a essa regra geral, como é o caso das demandas cujas decisões ostentam amplitude erga omnes, tais como a "ação civil pública" (art. 16 da Lei 7.347/85) e as "ações diretas" de competência do Supremo Tribunal Federal (art. 102, §2 da Constituição de 1988).
} 
ao incidir de forma não-uniforme nos vários mercados de bens e serviços, distorce os preços relativos e diminui a eficácia alocativa da economia.

Passa-se a analisar alguns exemplos em torno da atuação do Poder Judiciário brasileiro, especificamente dentro do tópico aqui tratado: a proteção ou direção contratual. Antes, de modo a explicitar o raciocínio ora proposto, de início, toma-se como um primeiro parâmetro o alerta formulado por TIMM (2008, p., 66):

a excessiva intervenção judicial nos contratos pode trazer instabilidade jurídica e insegurança ao ambiente econômico, acarretando mais custos de transação às partes, para que negociem e façam cumprir os pactos. Além disso, a excessiva intervenção judicial pode originar externalidades negativas (i.e., efeitos a serem suportados por terceiros), porquanto o risco da perda ou a perda efetiva do litígio pela parte "mais forte" tende a "respingar" ou ser repassado à coletividade, que acaba pagando pelo mais fraco judicialmente protegido (como ocorre paradigmaticamente coma as taxas de juros bancários, com os contratos de seguro e como aconteceu em casos de contratos de financiamento de soja no Estado de Goiás), sem, entretanto, receber o benefício compensatório de maior bem-estar.

Não se está aqui propondo aos juízes que deixem de intervir nas relações contratuais discutidas sob sua pena, mesmo porque o sistema jurídico nacional assim permite, notadamente frente às causas legais de nulidade e anulabilidade. Portanto, apenas se constata o risco da intervenção judicial resultar em alguma distorção econômica num determinado mercado, bem como na possibilidade de terceiros alheios à lide sofrerem algum tipo de consequência nociva independentemente de sua vontade ou da prática de qualquer ato que pudesse justificar o prejuízo.

Há, pelo menos, dois episódios retratados por TIMM (2008, p. 89 e ss.) capazes de ilustrarem o tema e demonstrarem o acima indicado, isso é, que a intervenção judicial nos contratos é capaz de gerar efeitos econômicos nocivos em certa coletividade.

Inicia-se analisando os casos do financiamento do plantio e cultivo da soja no Estado de Goiás, que se resume no seguinte: vários produtores daquele Estado firmaram contratos de venda antecipada de $\operatorname{soja}^{56}$ com indústrias processadoras do grão, fixando o preço a ser pago por estas quando da entrega do produto.

${ }^{56} \mathrm{O}$ site do jornal Valor Econômico informa que estes contratos são conhecidos como "CPRs de gaveta" ou "contratos de soja verde" e noticia que em passado recente chegaram a financiar $80 \%$ da safra de soja do 
Todavia, em abril de 2004, após o expressivo aumento das cotações internacionais da commodity, muitos agricultores demandaram judicialmente em busca de revisões dos valores contratuais firmados anteriormente sob a alegação de onerosidade excessiva ou mesmo de lesão enorme no contrato, na medida em que a majoração $a$ posteriori do valor da soja permitiria às indústrias um lucro muito maior do que o esperado inicialmente sem que o produtor pudesse participar de parte desse sobre-valor.

No âmbito estadual, alguns produtores obtiveram vitórias conferidas pelo Tribunal de Justiça do Estado de Goiás (com destaque para casos submetidos à Primeira Câmara Cível), com a revisão de suas avenças com fulcro na função social do contrato e boa-fé objetiva, nos termos das seguintes ementas:

\begin{abstract}
APELAÇÃO CÍVEL. AÇÃO DE RESCISÃO CONTRATUAL. COMPRA E VENDA DE SOJA. FUNÇÃO SOCIAL DO CONTRATO. LESÃO ENORME. ONEROSIDADE EXCESSIVA. OFENSA AO PRINCÍPIO DA BOA-FÉ OBJETIVA E DA EQUIVALÊNCIA CONTRATUAL. RESCISÃO. POSSIBILIDADE. NOS CONTRATOS DE EXECUÇÃO CONTINUADA OU DIFERIDA. O DESATENDIMENTO DA FUNÇÃO SOCIAL DO CONTRATO E A OFENSA AOS PRINCÍPIOS DA BOA-FÉ OBJETIVA E DA EQUIVALÊNCIA CONTRATUAL FAZ EXSURGIR PARA A PARTE LESIONADA O DIREITO DE RESCINDIR O CONTRATO, MORMENTE SE OCORREREM ACONTECIMENTOS EXTRAORDINARIOS E IMPREVISÍVEIS QUE TORNEM EXCESSIVAMENTE ONEROSO O CUMPRIMENTO DA PRESTAÇÃO A QUE SE OBRIGARA. EXEGESE DOS ARTS. 421, 422 E 478, TODOS DA LEI 10.406/02, NOVO CÓDIGO CIVIL BRASILEIRO. APELAÇÃO CONHECIDA E IMPROVIDA.

(1 $1^{\text {a }}$ Câmara Cível, apelação cível $n^{\circ}$ 79.859-2/188, j. 24.09.2004, DJ 26.11.2004, Rel. Des. Jeová Sardinha de Moraes).
\end{abstract}

VENDA A FUTURO. SOJA. PRECO PRÉ-FIXADO. DESPROPORÇÃO DAS OBRIGAÇÕES. DISSOLUÇÃO DO CONTRATO DE COMPRA E VENDA. NO ATUAL ESTÁGIO DO DIREITO OBRIGACIONAL, HÁ QUE SE TER EM DESTAQUE AXIAL OS PRINCÍPIOS DA BOA-FÉ OBJETIVA, DA PROBIDADE, DO EQUILÍBRIO ECONÔMICO E DA REPULSA À ONEROSIDADE EXCESSIVA, DE MODO QUE, VERIFICADA A QUEBRA DESTE MICRO SISTEMA, MORMENTE EM RAZÃO DA MANIFESTA DESPROPORÇÃO DAS OBRIGAÇÕES, TAL CIRCUNSTÂNCIA IMPORTA RESOLUÇÃO DO PACTO, AO TEOR DOS ARTS. 187, 421, 422, 478 E 2035, PARÁGRAFO ÚNICO, TODOS DO CÓDIGO CIVIL BRASILEIRO. APELAÇÃO CÍVEL CONHECIDA E IMPROVIDA. 
( $1^{\text {a }}$ Câmara Cível, apelação cível $\mathrm{n}^{\text {o }}$ 82.254-6/188, j. 22.02.2005, DJ 17.03.2005, Rel. Des. Leobino Valente Chaves).

A partir de decisões como essas, o instrumento praticamente desapareceu do mercado, sendo certo que, nos anos seguintes, os produtores em geral passaram a sujeitarem-se à venda já durante a safra e isso pode ter contribuído, por exemplo, para manter os preços mais baixos do produto internamente. Ainda que haja tendência do Superior Tribunal de Justiça em reverter o resultado dessas demandas (v.g. recursos especiais $\mathrm{n}^{\circ} 803.481-\mathrm{GO}^{57}$ e $\mathrm{n}^{\mathrm{o}} 783.404-\mathrm{GO}$, ambos da $3^{\mathrm{a}}$ Turma e da relatoria da Ministra Nancy Andrighi), a dificuldade em se obter essa modalidade especial de financiamento perdura ainda hoje.

Em estudo realizado especificamente sobre os contratos "da soja verde", REZENDE e ZYLBERSZTAJN (2007, p. 28-29) constataram o seguinte:

Em entrevistas com os agentes foi constatado que durante os quinze últimos anos estes agentes negociaram sem que houvesse problemas relevantes. Porém, no momento da colheita das safras 2002/2003 e 2003/2004 o preço praticado no mercado spot estava muito mais alto do que o contratado, ao contrário do que aconteceu nos anos anteriores. Um choque externo, qual seja a grande demanda pela China e a quebra da safra de soja norte-americana, afetou a relação contratual, tornando vantajoso, sob a percepção de alguns produtores, o rompimento do contrato.

[...]

Entretanto, muitos produtores se sentem prejudicados em relação à reação das empresas que, segundo eles, foi indiscriminada, atingindo todos os produtores, mesmo aqueles que sempre cumpriram seus contratos.

[...]

Mais relevante que o número de contratos quebrados foi a repercussão gerada a partir deste fato. A maior parte dos produtores entrevistados declarou que sentiu efeito das quebras contratuais dos outros produtores. As consequiências mais citadas foram a maior exigência de garantias para crédito e custeio, maior dificuldade para negociar com a empresa e a redução do volume de contratos de venda antecipada efetuados. De acordo com produtores e indústrias a redução no volume de contratos a termo se deve às seguintes razões: a) preço baixo da saca de soja, devido ao excesso de oferta; b) expectativa do produtor de elevação de preços durante a safra, como aconteceu em 2003 e 2004; b) ocorrência de quebra ou descumprimento de contrato nas duas últimas safras. Ainda não há

${ }^{57}$ Conforme trecho da respectiva ementa: "O fato do comprador obter maior margem de lucro na revenda, decorrente da majoração do preço do produto no mercado após a celebração do negócio, não indica a existência de má-fé, improbidade ou tentativa de desvio da função social do contrato. A função social infligida ao contrato não pode desconsiderar seu papel primário e natural, que é o econômico. Ao assegurar a venda de sua colheita futura, é de se esperar que o produtor inclua nos seus cálculos todos os custos em que poderá incorrer, tanto os decorrentes dos próprios termos do contrato, como aqueles derivados das condições da lavoura". 
consenso na jurisprudência acerca da rescisão dos contratos de compra e venda. Foi observado que as indústrias/tradings efetuaram no ano que seguiu, menos contratos de compra antecipada de soja verde, quando comparado ao mesmo período do ano anterior. Não está claro se existe causalidade entre a insegurança jurídica devido às diferentes decisões dos tribunais, no entanto, em uma oficina de trabalho realizada com os agentes foi citado que caso as decisões continuem a favor das rescisões contratuais, as empresas poderão transferir suas atividades para outro Estado que lhes confira maior segurança jurídica.

Em conclusão, em termos sociais ou coletivos, os produtores do Estado de Goiás (inclusive aqueles que judicialmente num primeiro passo se saíram exitosos) perderam em relação aos anos seguintes uma opção ${ }^{58}$ até então usual para o financiamento de sua safra futura de soja, confirmando-se, destarte, a existência dos efeitos econômicos e “extra-autos" emanados das decisões da Corte local.

Em continuação, aborda-se os casos da limitação dos juros em contratos de mútuo decididos pelo Tribunal de Justiça do Rio Grande do Sul.

Inicia-se relembrando que, anteriormente à Emenda Constitucional 40/2003, o $\$ 3^{\circ}$ do art. 192 da Constituição de 1988 previa que as taxas de juros reais, nelas incluídas comissões e quaisquer outras remunerações direta ou indiretamente referidas à concessão de crédito, não poderiam ser superiores a $12 \%$.

Em que pese o Supremo Tribunal Federal, ao decidir a ação direta de inconstitucionalidade $\mathrm{n}^{\circ}$ 4, em 07.03.1991, ter considerado que a aplicação desse índice dependia de regulamentação via edição de lei complementar, inaugurando inclusive uma série de precedentes no mesmo sentido ( $v . g$. recurso extraordinário $\mathrm{n}^{\mathrm{o}}$ 168.501-RS, DJ 03.12.1993, p. 26.355, Rel. Min. Celso de Mello e no 156.399-RS, DJ 02.06.1995, p. 16.239, Rel. Min. Sydney Sanches), parcela das instâncias judiciais a quo, notadamente o Tribunal de Justiça do Rio Grande do Sul, discordaram do entendimento excelso e permaneceram modificando vários contratos de mútuo de modo a enquadrar os juros pactuados ao valor indicado pelo referido $\S 3^{\circ}$. Apenas como exemplo:

\footnotetext{
${ }^{58}$ Ao que tudo indica, essa opção era de fato importante, uma vez que o financiamento governamental seria insuficiente. Ao menos é o que foi ventilado na Oficina de Trabalho citada por REZENDE e ZYLBERSZTAJN (2007, p. 21).
} 
APELAÇÃO CÍVEL. CONTRATO DE ABERTURA DE CRÉDITO COM ALIENAÇÃO FIDUCIÁRIA. AÇÃO REVISIONAL. DOS JUROS - LIMITAÇÃO.

A orientação desta Câmara, a qual me filio, acolheu o entendimento que a taxa de juros encontra limitação, fundada na auto-aplicabilidade da norma do art. $192, \S^{\circ}$ da $\mathrm{CF} / 88$, como pela incidência da legislação infraconstitucional -"Por mais respeito que deva ter ao acórdão proferido na ADIn 4-7/600, a ele não posso prestar homenagem. Entre ele e o Brasil, fico com este, enquanto a usura, condenada pela Constituição no mais explícito e terminante de seus preceitos, e contudo, pimpante, gordacha, próspera e luzidia, não destruí-lo. Em outros tempos se dizia que ou o Brasil destruía a saúva ou a saúva destruiria o Brasil. O mesmo se pode dizer da usura, ou o Brasil a destrói ou por ela será destruído. Penso que não tardará o momento em que o Supremo Tribunal Federal terá de reenfrentar a questão, que é de viva atualidade e crescente importância" (JSTF vol. 209, pág. 212)." (trecho do voto do ilustrado Ministro jubilado Paulo Brossard, retirado de passagem da declaração de voto do eminente Des. Carlos Prudêncio, na Apelação Cível $\mathrm{n}^{\circ}$ 96.003308-4, da $1^{\text {a }}$ Câmara Civil do TJSC). - "Quando a Corte apreciou a questão alusiva à auto-aplicabilidade do $\$ 3^{\circ}$ do artigo 192 da Carta da República, no que impõe o respeito ao limite máximo de doze por cento para os juros reais - Ação Direta de Inconstitucionalidade $n^{\circ} 4$, relatada pelo Ministro Sydney Sanches -, fiquei vencido, na companhia honrosa dos Ministros Carlos Velloso, Paulo Brossard e Néri da Silveira, no tocante à conclusão sufragada pela Corte de origem, ou seja, da eficácia imediata do preceito. Passei a ressalvar, no campo monocrático e na Turma, a convicção pessoal. Todavia, os ditames da consciência levaramme a assumir, ultimamente, posição diversa, voltando a sustentar a tese que desde o início defendi. É que a usura vem vencendo o Brasil, com nefastos efeitos no campo social. Grassa o desemprego, fato que contribui para o aumento da criminalidade. As contas públicas estão seriamente comprometidas com os acessórios da dívida interna. Por isso, voltei a expressar o convencimento externado nos idos de 1991, e que, com a passagem do tempo, somente restou robustecido. Tenho como autoaplicável, tal como vem proclamando o Poder Judiciário do Estado do Rio Grande do Sul, a regra do $\$ 3^{\circ}$ do artigo 192 da Carta, que, a rigor, deveria estar em dispositivo autônomo. A única justificativa para o lançamento da norma em parágrafo é a notória fuga do legislador constituinte de 1988 à elaboração de um diploma constitucional com número excessivo de artigos." (destaquei - trecho da decisão monocrática proferida pelo eminente Ministro Marco Aurélio no AGRAVO DE INSTRUMENTO N. 234.873-1 - RS) - Se assim não pudesse ser entendido - isto é, afastando-se a incidência da norma constitucional, do Decreto 22.626/33 e do Código de Defesa do Consumidor, por depender a primeira de regulamentação e os dois últimos por não se aplicarem as instituições financeiras - , assim mesmo o apelado não poderia exigir taxa de juros superiores a $12 \%$ a. a., pois não comprovou nos autos tenha autorização do CMN para praticar taxas superiores. - Precedente do Superior Tribunal de Justiça. DA CAPITALIZAÇÃO -Vedada é a possibilidade da prática do anatocismo (capitalização de juros de uma soma de dinheiro, vencendo novos juros), vedação que persiste mesmo quando convencionada, conforme encontra-se assentado na Súmula $\mathrm{n}^{\circ}$ 121 do Supremo Tribunal Federal. APELO PARCIALMENTE CONHECIDO E, NESTA PARTE, PROVIDO. 
(TJRS, 13a Câmara Cível, apelação cível no 70001436633, j. 21.03.2002, Rel. Des. Marco Aurélio de Oliveira Canosa).

Os efeitos que decisões nesse sentido ordinariamente geram são, em suma, de duas ordens distintas.

Primeiramente, para os todos os demais tomadores de empréstimos não beneficiados judicialmente é possível antever aumento nos juros exigidos pelos financiadores para os próximos contratos, aliás, em caminho diametralmente contrário ao desiderato que emana do julgado retro transcrito, ou seja, ainda que alguns, ou a "parte mais fraca", tenham conseguido certo alívio em suas dívidas, a sociedade como um todo, ao menos os indivíduos e empresas que demandaram novos financiamentos, muito provavelmente arcaram com algum custo adicional (não se sabendo aqui precisar o quanto) pelo risco majorado pelo Poder Judiciário ao afastar o princípio do pacta sunt servanda.

Na colocação de PINHEIRO (2008, p. 29) aplicada à hipótese sob comento, não se pode perder de vista a realidade de que: "o risco jurídico é um componente importante dos juros", pois, segundo explica RODRIGUES (2007, p. 128129):

\footnotetext{
A protecção legal conferida aos contratos desempenha um papel fundamental numa economia de mercado ao assegurar a credibilidade dos compromissos assumidos. Esta credibilidade permite, em particular, que as partes façam investimentos cuja rentabilidade depende do cumprimento do contrato. [...]

A confiança que as partes depositam no cumprimento do contrato altera os riscos em que cada uma incorre.
}

Em suma, os juros equivalem ao preço cobrado pelo empréstimo de dinheiro, significando o montante que o prestamista deve pagar para usufruir certo numerário a si entregue. Ora, a tendência natural do preço de qualquer mercadoria ou bem é subir se o risco do negócio aumentar.

Nessa linha, os juros tendem a ser mais elevados em ambientes jurídicos instáveis e pouco previsíveis, ressaltando-se que sua fixação a partir de certo patamar, segundo expõe PINHEIRO (2008, p. 29): “contribui para reduzir a oferta de crédito e levar 
a métodos de produção mais ineficientes do que os encontrados em economias com juros mais baixos"

Por segundo, é razoável antever um aumento no número de ações interpostas nos pretórios gaúchos na medida em que o sucesso da revisão judicial dos juros para alguns, obviamente, estimulou outros devedores em situação idêntica, no anseio de aliviar suas prestações a adotarem o mesmo remédio.

Estudo desenvolvido pelo Conselho Nacional de Justiça para o ano de 2005 (p. 349 e ss.) constata que o Rio Grande do Sul é o Estado brasileiro que apresenta a maior taxa de feitos novos por 100.000 habitantes $^{59}$. Mesmo que não se possa afirmar com certeza ser o evento exclusivamente originário da uma postura jurisprudencial "prórevisão" dos juros, é muito provável que esses julgamentos contribuam de alguma forma para o incremento dos números.

E, se isso for aceito, ainda que no campo da mera plausibilidade, a conclusão inarredável é que a intervenção judicial, in casu, colaborou para criar um círculo vicioso, isso é, quanto mais contratos foram coercitivamente revistos, maior foi o risco assumido pelos credores nos novos negócios e, por conseguinte, conforme já aventado, houve tendência de se elevar cada vez mais os juros em prejuízo dos possíveis novos prestamistas que tiveram de se submeter a condições mais adversas na obtenção do crédito ou deixarem de tomar financiamentos.

Certamente, efeitos econômicos e "extra-autos" emergidos de decisões judiciais que revisam contratos podem nascer de muitas outras hipóteses além das acima dissecadas, tais como, as seguintes decisões do Superior Tribunal de Justiça que mostram alguns das tendências fixadas naquela Corte:

a) avenças relativas aos financiamentos celebrados sob a égide do Sistema Financeiro da Habitação:

AGRAVO REGIMENTAL. SISTEMA FINANCEIRO DA HABITAÇÃO. CAPITALIZAÇÃO DE JUROS NA APLICAÇÃO DA TABELA PRICE. REVISÃO DOS VALORES DO SEGURO SUSEP.

\footnotetext{
${ }^{59}$ Consideraram-se apenas os processos entrados em Primeira Instância e nos Juizados Especiais.
} 
OPORTUNIDADE PARA PRODUÇÃO DE PROVA ORAL. INCIDÊNCIA DA TR NA ATUALIZAÇÃO DO SALDO DEVEDOR. CRITÉRIO DE AMORTIZAÇÃO DO SALDO DEVEDOR. REPETIÇÃO EM DOBRO DO INDÉBITO.

I - "A existência, ou não, de capitalização de juros no sistema de amortização conhecido como Tabela Price, constitui questão de fato, a ser solucionada a partir da interpretação das cláusulas contratuais e/ou provas documentais e periciais, quando pertinentes ao caso. Recurso especial não conhecido" (REsp 410775/PR, Rel. Ministro CARLOS ALBERTO MENEZES DIREITO, Rel. p/ Acórdão Ministra NANCY ANDRIGHI, TERCEIRA TURMA, DJ 10.5.04).

II - O acórdão recorrido afirmou não existirem provas de cobrança excessiva do seguro habitacional devido nos termos da Tabela da SUSEP, de modo que a pretensão revisional formulada no recurso especial encontra obstáculo nas Súmulas 5 e 7 desta Corte. Precedentes.

III - Não configura cerceamento de defesa o julgamento da causa, sem a produção de prova pericial, quando o Tribunal de origem entender substancialmente instruído o feito, declarando a existência de provas suficientes para seu convencimento. Incidência da Súmula 7 deste Superior Tribunal de Justiça.

IV - Esta Corte Superior firmou entendimento de que a TR pode ser utilizada na atualização do saldo devedor de contrato vinculado ao Sistema Financeiro da Habitação, ainda que firmado anteriormente ao advento da Lei 8.177/91, desde que pactuado o mesmo índice aplicável à caderneta de poupança. Precedentes.

V - Não é ilegal o critério de amortização do saldo devedor mediante a aplicação de correção monetária e de juros, procedendo, em seguida, ao abatimento da prestação mensal do contrato de mútuo para aquisição de imóvel pelo Sistema Financeira da Habitação. Precedentes.

VI - A devolução em dobro dos valores pagos a maior pelo mutuário é cabível apenas quando demonstrada má-fé, o que não foi comprovado na hipótese dos autos.

Agravo regimental improvido.

(STJ, $3^{\text {a }}$ Turma, autos $n^{\circ}$ 913.093, j. 26.06.2008, DJ 22.08.2008, Rel. Min. Sidnei Beneti).

b) possibilidade ou não de interrupção dos serviços de água e energia elétrica quando o usuário se torna inadimplente:

ADMINISTRATIVO. SERVIÇO PÚBLICO CONCEDIDO. ENERGIA ELÉTRICA. SUSPENSÃO DO SERVIÇO. INADIMPLÊNCIA. IMPRESTABILIDADE DE MEDIDOR. EXAME DE PROVA. SÚMULA 7/STJ.

1. Este Tribunal Superior, encampando entendimento sedimentado no Pretório Excelso, firmou posição no sentido de que a contraprestação cobrada por concessionárias de serviço público de água e esgoto tem natureza jurídica de tarifa ou preço público, seja o serviço prestado diretamente pelo Estado ou por empresa privada, concessionária do serviço.

2. Os serviços públicos essenciais, remunerados por tarifa, podem sofrer interrupção quando há inadimplência, como previsto no art. $6^{\circ}, \S^{\circ}$, II, da Lei 8.987/95. Exige-se, entretanto, que a interrupção seja antecedida de aviso, existindo na Lei 9.427/97, que criou a ANEEL, idêntica previsão. 
3. A continuidade do serviço, sem o efetivo pagamento, quebra o princípio da igualdade das partes e ocasiona o enriquecimento sem causa, repudiado pelo Direito (arts. 42 e 71 do CDC, em interpretação conjunta). 4. Quando no recurso especial a tese jurídica abstraída fica na dependência do exame de provas para verificar-se a existência ou não de culpa do consumidor, esbarra o conhecimento no óbice da Súmula 7/STJ 7.

7. Recurso especial improvido.

(STJ, 2 ${ }^{\mathrm{a}}$ Turma, autos $\mathrm{n}^{\mathrm{o}}$ 887.389, j. 22.04.2008, DJ 12.08.2008, Rel. Min. Eliana Calmon).

c) ajuste nos contratos de leasing de veículos face ao aumento expressivo do dólar frente ao real em janeiro de 1999:

AGRAVO REGIMENTAL. EMBARGOS DE DECLARAÇÃO. AGRAVO DE INSTRUMENTO. ARRENDAMENTO MERCANTIL. VARIAÇÃO CAMBIAL. DÓLAR NORTE-AMERICANO. DESVALORIZAÇÃO DA MOEDA NACIONAL. JANEIRO DE 1999.

1. Na linha da jurisprudência firmada na Segunda Seção do STJ, o art. $6^{\circ}$, inciso V, do Código de Defesa do Consumidor incide apenas para retirar a onerosidade decorrente de fato superveniente que afeta a capacidade do consumidor adimplir o contrato. Assim, no caso presente, a partir de janeiro de 1999, as prestações do contrato de

leasing devem ser reajustadas pela metade da variação cambial verificada.

2. Agravo regimental improvido.

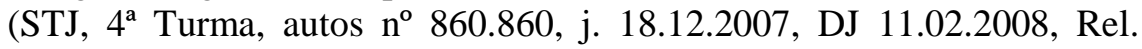
Min. João Otávio de Noronha).

d) possibilidade ou não de inscrição do nome do devedor nos cadastros

públicos de proteção ao crédito:

AGRAVO REGIMENTAL. ARRENDAMENTO MERCANTIL. INOVAÇÃO DA LIDE EM SEDE RECURSAL. IMPOSSIBILIDADE. NULIDẢDE DE CLÁUSULAS ABUSIVAS. DECLARAÇÃO DE OFÍCIO. INADMISSIBILIDADE. MORA. CARACTERIZAÇÃO. INCLUSÃO DO NOME EM CADASTRO DE INADIMPLENTES. INVIABILIDADE. JUROS REMUNERATÓRIOS. LIMITAÇÃO AO PERCENTUAL DE $12 \%$ AO ANO. IMPOSSIBILIDADE. CONTRATO DE ARRENDAMENTO MERCANTIL. ANTECIPAÇÃO DO VALOR RESIDUAL GARANTIDO. NÃO DESCARACTERIZAÇÃO DO CONTRATO. INCIDÊNCIA DO ENUNCIADO N. 293 DA SÚMULA DESTA CORTE. AGRAVO IMPROVIDO.

1. É inviável inovar a lide em sede de agravo regimental.

2. Descabe o reconhecimento, ex officio, de nulidade de cláusulas contratuais consideradas abusivas, exigido, para tanto, o pedido expresso da parte interessada.

3. "O pedido em procedimento judicial que busca o cancelamento ou a abstenção da inscrição do nome do devedor em cadastro de proteção ao crédito (SPC, CADIN, SERASA e outros) deve ser deferido com cautela, ao prudente arbítrio do juiz, sendo indispensável a existência de prova 
inequívoca ou da verossimilhança do direito alegado, ou ainda, da fumaça do bom direito, consubstanciados na presença concomitante de três elementos: a) a existência de ação proposta pelo devedor, contestando a existência integral ou parcial do débito; b) a efetiva demonstração de que a cobrança indevida se funda em jurisprudência consolidada do Supremo Tribunal Federal ou do Superior Tribunal de Justiça; c) o depósito do valor referente à parte incontroversa do débito ou que seja prestada caução idônea" (REsp 527618/RS, 2a Seção, Rel. Min. César Asfor Rocha, DJ 24.11.2003).

4. Em se tratando de juros remuneratórios, não incide a limitação a $12 \%$ ao ano, prevista no Decreto $\mathrm{n}^{\circ} 22.626 / 33$, salvo hipóteses legais específicas, visto que as instituições financeiras, integrantes do Sistema Financeiro Nacional, são regidas pela Lei ${ }^{\circ}$ 4.595/64.

5. "A cobrança antecipada do valor residual garantido (VRG) não descaracteriza o contrato de arrendamento mercantil" (Súmula $\mathrm{n}^{\circ}$ 293/STJ).

6. Agravo regimental improvido.

(STJ, $4^{\text {a }}$ Turma, autos $n^{\circ}$ 759.965, j. 27.11.2007, DJ 17.12.2007, Rel. Min. Massami Uyeda).

e) limite do montante das multas condominiais estipuladas em convenções ou atos de natureza privada:

PROCESSUAL CIVIL E CIVIL. CONDOMÍNIO. TAXAS CONDOMINIAIS. MULTA CONDOMINIAL DE 20\% PREVISTA NA CONVENÇÃO, COM BASE NO ARTIGO 12, §3º, DA LEI 4.591/64. REDUÇÃO PARA 2\% QUANTO À DÍVIDA VENCIDA NA VIGÊNCIA DO NOVO CÓDIGO CIVIL. NECESSIDADE REVOGAÇÃO PELO ESTATUTO MATERIAL DE 2002 DO TETO ANTERIORMENTE PREVISTO POR INCOMPATIBILIDADE. RECURSO PROVIDO.

1 - In casu, a Convenção Condominial fixou a multa, por atraso no pagamento das cotas, no patamar máximo de $20 \%$, o que, à evidência, vale para os atrasos ocorridos antes do advento do novo Código Civil. Isto porque, o novo Código trata, em capítulo específico, de novas regras para os condomínios.

2 - Assim, por tratar-se de obrigação periódica, renovando-se todo mês, a multa deve ser aplicada em observância à nova situação jurídica constituída sob a égide da lei substantiva atual, prevista em seu art. 1336, $\S 1^{\circ}$, em observância ao art. $2^{\circ}, \S 1^{\circ}$, da LICC, porquanto há revogação, nesse particular, por incompatibilidade, do art. $12, \S 3^{\circ}$, da Lei 4.591/64. Destarte, a regra convencional, perdendo o respaldo da legislação antiga, sofre, automaticamente, os efeitos da nova, à qual não se pode sobrepor.

3 - Recurso conhecido e provido para restabelecer a sentença de primeiro grau.

(STJ, 4 ${ }^{\text {a }}$ Turma, autos $n^{\circ}$ 762.297, j. 11.10.2005, DJ 07.11.2005, Rel. Min. Jorge Scartezzini).

Em todos esses casos - e nos muitos outros que poderiam ser colacionados, dependendo do caminho escolhido pela jurisprudência na solução dos diversos casos concretos, os agentes econômicos envolvidos, incluindo nesse rol os 
consumidores, passam a comportar-se em determinados sentidos, expandindo ou retraindo suas diversas ações, tendo como fator de alto relevo para isso o grau de previsibilidade e a estabilidade do ambiente institucional que se encontram inseridos.

Conforme expõe AMARAL (2001, p. 39), a atuação judicial em tais hipóteses, em verdade, enfrenta um conflito entre a micro (o caso sub judice) e a macrojustiça (os casos que em potencial se encontram na mesma circunstância). O autor aqui defende que: "A justiça do caso concreto deve ser sempre aquela que possa ser assegurada a todos que estão ou possam vir a estar em situação similar, sob pena de quebrar-se a isonomia".

Seja qual for a opção engendrada, entende-se de rigor que os juízes compreendam e bem tenham fixado em seus veredictos, na ênfase de MICHELS (2005, p. 226), que: "Não há desenvolvimento da sociedade que não esteja ancorado num quadro institucional baseado em regras estáveis e legítimas, que propiciem segurança jurídica e recebam aceitabilidade social" ${ }^{\prime 60}$;

3) conteúdo de regulação de determinado setor ou atividade econômica: acima se acenou com a presunção de que, num mercado constituído ao mesmo tempo por um grande número de ofertantes e demandantes em torno de bens ou serviços não exclusivos ou facilmente substituíveis, o preço representa o ponto de equilíbrio entre os interesses dos respectivos pólos em determinado instante, sendo essa a opção mais eficiente de se alocar os bens na sociedade.

Porém, há tempos, é sabido que o mercado em funcionamento apresenta algumas falhas, ou seja, a suposta mão invisível ${ }^{61}$, que cuidaria do equilíbrio perfeito retro,

60 Ainda dentro do tema, segundo VIEIRA (2008, p. 57): "Para alguns analistas o fortalecimento da autoridade dos tribunais tem sido uma conseqüência imediata da expansão do sistema de mercado, em plano global. Aos olhos dos investidores, os tribunais constituíram um meio mais confiável para garantir a segurança jurídica, estabilidade e previsibilidade, do que legisladores democráticos, premidos por demandas 'populistas' e necessariamente pouco eficientes, de uma perspectiva econômica”.

${ }^{61}$ O próprio sistema de tributação latu sensu é, em última instância, uma maneira de intervenção do Estado na economia na medida em que pode redistribuir parte da riqueza produzida entre os indivíduos, minorando desigualdades exacerbadas. Segundo MANKIW (2007, p. 12): "A mão invisível não garante que todos tenham comida suficiente, roupas descentes e atendimento médico adequado. Muitas políticas públicas, por exemplo, o imposto de renda e o sistema de seguridade social, têm por objetivo atingir uma distribuição mais eqüitativa do bem-estar econômico". 
acenado não tem pulso suficiente para neutralizar o surgimento de circunstâncias prejudiciais capazes de interferir na suposta melhor alocação possível dos bens circuláveis.

Logo, nota-se que o Estado, essencialmente por meio da edição de normas jurídicas variadas, tenta minimizar essas discrepâncias ${ }^{62}$ com o objetivo de garantir que os agentes econômicos operem numa ambiência que procure acompanhar os princípios e diretrizes traçadas pelo art. 170 da Constituição de 1998.

Trata-se da denominada atuação ou intervenção estatal ${ }^{63}$ na economia. Na lição de FERRAZ JR. (1995, p. 24):

Mesmo no exercício de prerrogativas legítimas, conferidas por lei ou não proibidas pela legislação, a ação econômica pode ferir interesses, lesar terceiros, produzir desequilíbrios no mercado. Trata-se então de uma lesão de direito que, inobstante a legitimidade da prática, pode gerar responsabilidade. Ou seja, o ato que obedece os limites da lei mas que, no exercício do direito, viola princípios de finalidade econômica da instituição social do mercado, produzindo um desequilíbrio entre o interesse individual e o da coletividade, constitui um abuso do poder econômico enquanto poder juridicamente garantido pela Constituição.

Nos termos expostos por NUSDEO (2005, p. 142 e ss.), as principais falhas capazes de afetar o equilíbrio mercadológico dizem respeito a estas ocorrências: a) rigidez de fatores; b) falta de acesso às informações relevantes; c) concentração econômica; d) externalidades; e, e) utilização de bens coletivos; conforme a seguir delineado de maneira resumida:

a) rigidez de fatores: constitui-se na circunstância dos agentes do mercado, por motivos de ordem física, operacional, institucional e até psicológica, usualmente levarem certo tempo para reagirem aos sinais concernentes à oferta e demanda.

${ }^{62}$ Evidentemente, as ações neutralizadoras perpetradas pelo Estado não estão isentas de falhas. Contudo, assevera FARINA (1997, p. 128) que: "embora a regulamentação das atividades econômicas esteja sujeita a falhas, não se pode concluir que deva ser rejeitada como forma de organização econômica".

63 A doutrina distingue as expressões atuação estatal e intervenção. Nessa linha, segundo GRAU (1998, p. 122-123), intervenção significa interferência do Estado em área típica da iniciativa privada ( $v . g$. atividade bancária), enquanto que atuação estatal tanto pode indicar a mesma coisa, mas em sentido amplo, isso é, atuação em face da Economia como um todo sem distinguir as áreas típicas do Estado daquelas próprias dos particulares, ou, em sentido estrito, intervenção do Estado em área cuja titularidade lhe cabe (v.g. serviços públicos). 
Nessa linha de raciocínio, mesmo que ocorra aumento na demanda por determinado produto, a reação dos fabricantes para majorar a oferta raramente é imediata, sendo indispensável compreender, na afirmação de ARIDA (2005, p. 63), que: “O mecanismo endógeno de equilibração dos mercados exige tempo". Num esclarecedor exemplo indicado por NUSDEO (2005, p. 143):

\begin{abstract}
Altos preços do café podem levar - e normalmente levam - à plantação de extensos cafezais em terras favoráveis ao seu cultivo. No entanto, cada cafezal, para entrar em fase de produção comercial, leva cerca de quatro ou cinco anos e, quando isto acontece, é muito possível verificar-se uma pletora do produto, ou seja, uma superprodução a abarrotar os mercados provocando baixa nos preços.
\end{abstract}

No exemplo acima, a produção excessiva - acima do que o mercado poderia absorver razoavelmente - e a subsequente queda nos preços desestimulará fortemente a continuidade da cafeicultura e, com isso, gerará malefícios sociais.

Em primeiro lugar, é muito provável, nesse sentido, que os agricultores comprem menos tratores e outras máquinas agrícolas, prejudicando as vendas dos fabricantes desses bens.

Em adição, aliás, inclusive como consequência imediata, é quase certo que dispensem vários empregados das lavouras, diminuindo a renda de suas famílias, quiçá empurrando-as ao seguro social.

Também não pode ser descartada a possibilidade de muitos inadimplirem os financiamentos de plantio, contribuindo para aumentar os juros nesses contratos face à exasperação do risco que passam a ostentar e assim por diante.

É intuitivo considerar que a notável complexidade dos processos produtivos da atualidade, ainda mais quando estiver envolvida alta tecnologia e investimentos de relevo (v.g. telecomunicações, extração de petróleo, indústria automobilística e aeronáutica, etc.), pode majorar seriamente essa ausência de automatismo reacional dos respectivos agentes, redundando na acentuação dos riscos do negócio (e sociais também) caso ocorra um descompasso verdadeiro entre o estímulo e o tempo em que se implementa a correspondente reação. 
Exemplo de demora prolongada no equilíbrio entre oferta e demanda é o caso da implantação da telefonia celular no Brasil, conforme narra SIQUEIRA (2008, p. 62):

Quando foi lançado o telefone celular no Rio de Janeiro, em fins de 1990, a procura foi tão elevada que a operadora local, a Telerj, resolveu exigir um depósito-caução no valor de US\$ 22 mil dólares dos novos assinantes do telefone móvel. O dinheiro só era devolvido depois de dois anos, apenas com correção monetária, sem qualquer rendimento. $\mathrm{O}$ desequilíbrio entre a oferta e demanda se tornou tão elevado que mais de 2 mil cidadãos e empresas aceitaram essas condições e adquiriram uma assinatura de telefone celular analógico, sem incluir nesse preço o aparelho.

No caso, a oferta de linhas de telefonia móvel somente aumentou significativamente após 1995 com a abertura da exploração do mercado à iniciativa privada, sendo que a estabilização dos vetores oferta-demanda, como é bem sabido, somente veio acontecer vários anos depois.

Portanto, mercados que negociem bens cuja confecção encontre acentuada dificuldade para reagir aos estímulos, tanto para majoração, quanto para refreamento da produção, carecem da inserção de mecanismos capazes de minimizarem essa letargia, tais como, por exemplo, uma contribuição de intervenção no domínio econômico, nos moldes autorizados pelo art. 149 da Constituição de 1988, a ser exigida periodicamente dos agentes envolvidos, com o intuito de, posteriormente, em casos de necessidade, financiar ações que visem neutralizar os desequilíbrios que naturalmente surgem ao longo do tempo (v.g. empréstimos a juros reduzidos cujos recursos devam ser destinados a modernizar as técnicas produtivas, subsídios para que consumidores adquiram produtos a preços mais baixos, instituição e sustento de um órgão governamental - agência regulatória - específica para cuidar de determinado setor, etc.).

b) falta de acesso às informações relevantes: constata-se que, num sistema de mercado descentralizado, muitas vezes existe assimetria de informações entre as partes em torno do objeto transacionado, o que pode implicar em cálculos e previsões equivocadas quanto ao risco do negócio pela falta de transparência.

É esperado, nessa esteira, que, na maioria dos produtos vendidos aos consumidores em geral (v.g. remédios, alimentos, roupas, cigarros, eletrodomésticos, 
produtos para faxina), o fabricante conheça com elevada precisão as efetivas propriedades daquilo que oferta ao público, bem como eventual potencial danoso. Na assertiva de FARINA (1997, p. 117):

Se compradores e vendedores não dispuserem de informações necessárias para tomar suas decisões corretamente, o modelo de concorrência perfeita não funciona como previsto. Entretanto, a maioria dos consumidores não têm consciência dos efeitos associados ao consumo de certos produtos.

Face à notória desigualdade de informações nesses casos, é que normas como o Código de Defesa do Consumidor (Lei 8.078/90) trazem preceitos destinados a coibir - ou ao menos minimizar - a propaganda enganosa, bem como para obrigar o fabricante a indicar, nas embalagens, extensos dados acerca do produto posto à venda, tais como: prazo de validade, perigos potenciais, número de calorias, ingredientes, composição, maneiras de conservar, instruções de operação, etc.

Em verdade, os exemplos são os mais variados possíveis, partindo da compra de um automóvel usado ${ }^{64}$, hipótese em que o vendedor possuirá muito mais informações relevantes sobre o veículo do que o comprador que toma contato com o bem pela primeira vez, até a aquisição de ações de determinada companhia, cujos conselheiros e diretores, por acompanharem diuturnamente o negócio e sua situação financeira, são capazes de prognosticar mais corretamente as tendências de ganhos ou prejuízos ao final do exercício.

Sob esse pensamento, caso não existissem restrições legais que impedissem tais pessoas - conhecidas como inseder trading - de utilizarem informações privilegiadas para comprar ou vender as ações, cujas tendências de alta ou baixa conhecessem previamente, além da possibilidade de obterem lucros exorbitantes em cada negócio, a demanda e a oferta pelas respectivas ações restaria distorcida, deixando de refletir os reais anseios do mercado em torno destes títulos.

\footnotetext{
${ }^{64}$ Sobre o tema, segundo MANKIW (2007, p. 481): "Os vendedores de carros usados conhecem os defeitos dos veículos, ao passo que os compradores freqüentemente os desconhecem. Como os proprietários dos piores carros têm maior probabilidade de vendê-los do que os proprietários dos melhores carros, os compradores muitas vezes têm medo de adquirir um 'abacaxi'. Com isso, muitas pessoas evitam comprar veículos no mercado de carros usados. O problema dos "abacaxis" pode explicar por que um carro com apenas algumas semanas de uso pode ser milhares de dólares mais barato do que um carro novo do mesmo tipo". Outro exemplo citado pelo autor é o mercado de seguros de saúde, uma vez que os potenciais usuários sabem muito mais sobre si do que a empresa seguradora e podem tentar esconder informações negativas que tornariam o prêmio mais elevado.
} 
Nota-se que, mesmo sob a crescente facilidade de acesso à informação, notadamente por meio da utilização da informática pelas redes como a internet, COELHO (2007a, p. 200) adverte que:

os fabricantes detêm muito mais informações que os consumidores sobre a qualidade e o funcionamento de seus produtos, e os diretores e administradores de uma empresa conhecem muito melhor a saúde financeira e as perspectivas de futuros negócios que seus acionistas.

c) concentração econômica: é um evento que pode influir no equilíbrio do mercado, recordando-se com NUSDEO (2005, p. 149) de que o seu bom funcionamento requer: "um número razoavelmente elevado de compradores e vendedores em interação recíproca, e nenhum deles excessivamente grande ou importante".

Com efeito, numa feira livre, a eventual ausência de um comerciante de tomates em nada - ou muito pouco - influirá nos preços do vegetal, sendo certo que os artigos não vendidos pelo ausente serão facilmente supridos pelos concorrentes. Aqui, se a concorrência não for perfeita, é suficiente para impedir que a decisão individual de um agente isolado, tanto no sentido de aumentar, quanto de frear a oferta de seus produtos, possa afetar o preço como resultado esperado da conjugação dos interesses de inúmeros vendedores e adquirentes.

Todavia, a evolução do sistema capitalista, com a crescente complexidade dos processos produtivos, fez com que muitos setores da economia somente pudessem operar mediante mobilização de elevadíssimas somas de capital a título de investimento, o que não pode ser conseguido pelas pequenas e isoladas unidades fabris, cujo funcionamento não carece de tanta tecnicidade nem do desenvolvimento de alta tecnologia. Conforme bem coloca NUSDEO (2005, p. 150):

no dealbar da revolução industrial, as unidades produtoras eram de dimensões reduzidas pelo fato de a maquinaria por elas exigida ser de pequeno porte e de grande simplicidade mecânica. Isso implicava uma necessidade reduzida do chamado capital fixo máquinas, equipamentos e utensílios, o que, na prática, tornava muito mais fácil a entrada de novos produtores em um dado mercado, quando este se revelasse promissor, e a saída em caso contrário, pois aquele capital fixo, representado por equipamento não muito sofisticado, poderia, com algumas adaptações, ser aproveitado em outros ramos da indústria. A grande especificidade e o aumento do volume das máquinas - e conseqüentemente de seu valor -, 
nos dias de hoje, foi algo gradualmente trazido pela revolução industrial durante os últimos 200 anos.

A concentração econômica de maior densidade possível é denominada de monopólio, que ocorre nos casos de, num mercado qualquer, existir apenas um único fabricante ou fornecedor para certo bem ou serviço que não possua substituto próximo. A realidade fornece exemplos muito variados, sendo possível pinçar desde um único posto de combustível localizado num Município, até uma grande empresa multinacional que confeccione um específico e sofisticado programa para computadores utilizado em todo mundo.

Em hipóteses tais, não há concorrência no que diz respeito à oferta. Noutra ponta, é possível, ainda, que a falta de concorrência diga respeito ao pólo da demanda, circunstância denominada de monopsônio (v.g. uma montadora de veículos que compre de vários fornecedores peças exclusivamente fabricadas para si). Tanto o monopólio, quanto o monopsônio apresentam: "características opostas ao mercado de concorrência perfeita. Aqui, a empresa influencia seu mercado" (BOARATI, p. 69). Fato é que, segundo coloca FRIEDMAN (1985, p. 33): “O monopólio implica ausência de alternativas e inibe, portanto, a liberdade efetiva da troca"

Nota-se, ainda, a figura do monopólio natural, que se manifesta, segundo MANKIW (2007, p. 316): "quando só uma consegue ofertar um bem ou serviço a um mercado inteiro a um custo menor do que duas ou mais empresas [...] Neste caso, uma só empresa pode produzir qualquer quantidade de produto a um custo menor". Exemplos clássicos são o fornecimento de água potável, gás encanado e energia elétrica.

Um grau menor de concentração corresponde ao oligopólio. Cuida-se de mercados onde a oferta dos bens ou serviços é ultimada por intermédio de poucos agentes (v.g. empresas aéreas, provedores de internet e de televisão por cabo, empresas de telefonia, etc.), operando num regime de concorrência restrita, isso é, suas decisões são capazes de influenciar o mercado.

A hipótese inversa é o oligopsônio: casos em haja poucos compradores para bens ou serviços apresentados por muitos ofertantes (v.g. indústrias lácteas que adquirem o leite - sua matéria prima elementar - de milhares de pecuaristas). 
O fenômeno da concentração não é necessariamente negativo, mas fato é que pela racionalidade econômica usual, existindo possibilidade, haverá tendência dos preços serem fixados em patamar mais elevado daquele que possivelmente ocorreria caso houvesse maior concorrência. De fato, pela colocação de FARINA (1997, p. 120-121):

não há qualquer conseqüência nefasta para a economia se uma empresa, ou grupo de empresas, detém posição dominante em um mercado. $\mathrm{O}$ problema está no exercício do arbítrio que essa posição lhes confere. Do ponto de vista do agente privado, tal prática é perfeitamente racional, já que lhe permite o máximo rendimento. Entretanto, causa perdas para o sistema econômico geral à medida que provoca uma oferta menor de produto e, conseqüentemente, um preço mais elevado. Há uma redistribuição da renda em favor desses setores e impactos em todos os mercados a ele relacionados.

Com efeito, a concorrência incipiente pode inibir que os preços dos bens e serviços envolvidos em certo mercado sejam indicados primordialmente pelo sistema da auto-regulação, sendo que, na advertência explicativa de $\operatorname{NUSDEO~(2005,~p.~153):~"a~alta~}$ de preços proveniente de um aumento da procura não necessariamente levará a um aumento da oferta, pelo simples fato de ser mais fácil para as poucas unidades nele atuantes conluiarem-se e elevarem mais os preços".

Em realidade, segundo RODRIGUES (2007, p. 162): “em concorrência perfeita as empresas conseguem apenas um lucro normal. Esta não é, portanto, uma alternativa interessante para o monopolista. É preferível vender uma quantidade menor por um preço mais elevado".

Portanto, na lição de POSNER (2007a, p. 435), um efeito decorrente da concentração é: "fazer com que alguns consumidores satisfaçam suas demandas por substituição a bens cuja produção seja mais custosa para a sociedade [...] O custo adicional é um desperdício para a sociedade" ${ }^{65}$.

Ademais, para além da questão do preço propriamente dita, não se pode deixar de considerar que a competição promovida pela concorrência é capaz de resultar na criação de produtos mais modernos e de melhor qualidade, visto ser esperado que as

${ }^{65} \mathrm{O}$ texto original é o seguinte: "hacer que algunos consumidores satisfagan sus demandas cambiándose a bienes cuya produción es más costosa para la sociedad [...] El costo adicional es um desperdicio para la sociedad". 
empresas estejam constantemente preocupadas não apenas em manter sua fatia do mercado - seu market share - como também em conquistar, a cada momento, mais consumidores, situação essa que a elevada concentração certamente pode prejudicar.

Em vista dessas circunstâncias BOARATI (2006, p. 70), RODRIGUES (2007, p. 163-165) e MANKIW (2007, p. 325-329) indicam que uma densa concentração econômica, notadamente aquela presente nos monopólios, via de regra, é ineficiente em termos de alocação dos bens na sociedade. A esse respeito ROSSETTI (1987, p. 303) assevera que:

Do ponto de vista social, a estrutura de mercado que melhor parece compatibilizar os interesses privados com os da sociedade como um todo é a da concorrência perfeita. Os economistas admitem que uma economia em que todos os setores de produção estejam operando com base em estruturas perfeitamente competitivas é a que pode alcançar o emprego mais eficiente dos escassos recursos disponíveis.

De modo a prevenir ou mesmo reparar os problemas trazidos pela concentração econômica excessiva é que o direito, por meio da política antitruste ${ }^{66}$, procura interferir nas ações dos diversos agentes envolvidos regulamentando os mercados.

Com isso, verifica-se, nos termos do proposto por MIRAGEM (2005, p. 144), que: "os interesses protegidos pela defesa da concorrência identificam-se basicamente com dois elementos essenciais: a preservação do mercado e a promoção de sua eficiência econômica, assim como a satisfação dos consumidores".

Aponta NUSDEO (2005, p. 153) que: "todos os países do Ocidente contam com leis destinadas a combater ou atenuar o poder de controle dos oligopólios, monopólios ou formas diversas de concentração econômica sobre os mercados”.

No Brasil, em termos legislativos, inicialmente, regularam a matéria os Decretos-lei 7.666/42 e 8.162/45, seguidos pelas Leis 4.137/62 e 8.158/91. Atualmente, o tema é disciplinado pela Lei 8.884/94, destacando-se o Conselho Administrativo de Defesa

${ }^{66}$ Conforme FARINA (1997, p. 120): "Política Antitruste, Política de Defesa da Concorrência, Política de Controle do Abuso do Poder Econômico constituem três nomes diferentes utilizados para designar o mesmo processo: a intervenção governamental sobre os negócios privados, visando harmonizar os interesses públicos, com a busca, legítima, de maximização de resultados das empresas, na presença de poder de monopólio". 
Econômica - CADE, autarquia federal competente para tomar as decisões no âmbito administrativo concernentes às possíveis infrações à ordem econômica.

d) externalidades: refere-se à parcela de custos ou benefícios decorrentes de determinada atividade que são atribuídos a terceiros estranhos à unidade responsável pela sua condução.

Ainda que haja modificação sobre o bem-estar de outrem, o mercado não consegue atribuir um preço a tais efeitos. Portanto, segundo aduz COELHO (2007a, p. 196), as externalidades indicam: "a tendência dos agentes econômicos de excluir a própria responsabilidade por todos os custos necessários à sua produção e de, por outro lado, procurar apropriar-se das vantagens, por circunstâncias provocadas por terceiros".

Se o impacto sobre o terceiro é adverso, tem-se a externalidade negativa. Ao contrário, ocorrendo um resultado benéfico, entra em cena a externalidade positiva. Explica MANKIW que, "Como os compradores e vendedores desconsideram os efeitos externos de suas ações quando decidem quando demandar ou ofertar, o equilíbrio de mercado não é eficiente quando há externalidades".

Como exemplo de externalidade negativa, cita-se a poluição gerada por uma indústria química com o consequente aumento da incidência de doenças respiratórias, o que inclusive pode resultar num maior dispêndio estatal com a saúde pública.

Na mesma linha, a queimada da cana de açúcar antes do corte, pela fuligem grossa que libera, usualmente gera os mesmos males, além contribuir sobremaneira para o aumento da sujeira nas regiões urbanas circunvizinhas. A construção de um grande edifício provavelmente majora o trânsito local. Uma festa de arromba que termine apenas no dia seguinte certamente incomoda os vizinhos, o mesmo valendo para um bar que toque músicas em alto volume até tarde da noite.

Fato é que esses prejuízos podem ser mais eficazmente minimizados através da intervenção do direito, seja impondo a instalação de filtros específicos nas indústrias, limitando os períodos de queima da cana, não permitindo a edificação acima de 
certo patamar, considerando passível de imposição de multa a perturbação da paz pública, etc.

Ressalte-se que, para NUSDEO (2005, p. 156):"não se trata, em nenhum dos casos até aqui citados, de uma ação delituosa ou ilegal por parte dos causadores dos custos". Porém, a não intervenção do Estado nesses casos estimula a permanência das externalidades com os prejuízos sociais daí advindos.

Como dito, na externalidade positiva, alguém gera um benefício a outrem sem correspondente remuneração. Exemplo marcante ocorrido no Brasil são as diversas estações de rádio-comunicação instaladas pela empresa de aviação Panair do Brasil nas décadas de 30 e 40 do século passado, equipamentos que foram utilizados não apenas em auxílio à navegação de suas aeronaves, mas a qualquer uma que cruzasse os céus brasileiros em vôos internacionais. Pela narração de SASAKI (2005, p. 74):

A eficiência desse serviço ficou comprovada pela Organização de Aviação Civil Internacional (OACI/ICAO), que, ao implementar a sua Rede de Telecomunicações Fixas Aeronáuticas (Aeronautics Fixed Communications Network - AFTN), nela incluiu dez circuitos da Rede Panair, passando a Panair do Brasil S.A., por delegação do governo brasileiro, a dar cobertura de comunicações a todas as aeronaves, de qualquer empresa aérea, de qualquer nacionalidade, em viagens internacionais. Em decorrência disso, a companhia passou a funcionar como agência operativa da União Federal. Ela - e somente ela - fazia a cobertura de proteção ao vôo internacional no Atlântico Sul, serviço que, tendo sido atribuído ao governo brasileiro pela Convenção de Chicago (1944), era executado pela Panair, desde 1948, sem qualquer remuneração.

Da mesma forma, a pesquisa de novas tecnologias resulta numa externalidade positiva, eis que cria conhecimento que pode ser utilizado por terceiros. Logo, é esperado que, se o direito não instituir um sistema que permita ao inventor receber algum benefício de seu labor, mesmo que por tempo determinado ( $v . g$. as patentes de medicamentos e afins), não haverá estímulo ao desenvolvimento desse tipo de atividade, estando a sociedade condenada à estagnação científica. 
e) utilização de bens coletivos: também chamados pelos economistas de bens públicos ${ }^{67}$, a amplitude de seu uso também pode se mostrar como uma falha de mercado a receber atenção do direito. Explica FARINA (1997, p. 117) que:

Uma vez produzidos, o número de consumidores não altera o custo de sua provisão, ao mesmo tempo que não é possível excluir consumidores. Nessas circunstâncias, a provisão de bens públicos pelo mercado será subótima, além de estimular o comportamento "carona" (free-ride) dos agentes econômicos que, sabendo que não poderão ser excluídos do consumo, não querem arcar com o custo de sua provisão.

Nessa esteira, o bem coletivo (ou público para os economistas) possui duas características marcantes, conforme BOARATI (2006, p. 73-74). São "não excludentes", isso é, não é possível afastar alguém de desfrutá-lo, e também são "não rivais", pois o seu consumo pode ocorrer simultaneamente por mais de uma pessoa. Exemplo clássico é a defesa nacional, comodidade promovida pelo Estado que beneficia a todos residentes ao mesmo tempo.

Noutro giro, a extinção de uma praga que afete determinada lavoura se caracteriza da mesma maneira, uma vez que os benefícios dessa empreitada se estendem a todos os agricultores, não sendo possível excluir quem quer que seja.

Logo, ante a possibilidade desse comportamento carona, é normal não haver grande incentivo aos particulares investirem preciosos recursos em pesquisas e outras tarefas afins com esse tipo de desiderato. Fato é que, segundo NUSDEO (2005, p. 164), "Uma economia fundada apenas no mercado tenderá a discriminar fortemente os bens coletivos e a exagerar a produção de bens exclusivos".

Assim, é oportuna a intervenção do Estado nesses casos, por exemplo, criando e financiando com recursos tributários um programa para tais fins, quiçá pela instituição de uma exação especial sobre os agricultores atingidos pela praga, utilizando os recursos arrecadados para desenvolver tecnologias que visem à respectiva extinção. Muitas

${ }^{67}$ Enquanto que, para os juristas, o bem público é aquele que pertence a uma pessoa jurídica de direito público, segundo o art. 98 e ss. do Código Civil, os economistas designam como público qualquer bem que seja não-rival e não-exclusivo independentemente de sua titularidade. Narra COELHO (2007a, p. 197) que: "Para a Ciência Econômica, bem público ou coletivo é o bem para o qual o princípio da exclusividade não se aplica, ou seja, ele poderia ser simultaneamente consumido por mais de um indivíduo sem diminuir o seu consumo por qualquer pessoa". 
outras hipóteses poderiam ser aventadas, pois, em verdade, na afirmação de COELHO (2007a, p. 198-199):

Muito dificilmente, deixando-se as forças de mercado agirem sem interferência, o sistema de saúde será implementado, uma campanha de alfabetização iniciada, ou os transportes públicos melhorados. O mercado apresenta aqui uma falha, uma vez que não pode perceber os sinais manifestados pela população que se beneficiaria diretamente com tais bens. Ademais, mesmo que os percebesse, submeter o acesso a tais bens aos mecanismos de oferta e demanda implicaria uma grande exclusão social.

Outro campo que merece destaque nesse tópico é o sistema de proteção às descobertas por meio das patentes, inegável fruto do sistema jurídico. Assim, por exemplo, é intuitivo perceber que, se a fórmula de um novo medicamento não receber a garantia de uma patente, não haverá estímulo a que novos investimentos destinados a descobertas subsequentes sejam ultimados, o que poderá colocar em risco a saúde pública no futuro ${ }^{68}$.

É importante consignar que todo esse amplo conjunto de medidas decorrentes da atuação estatal definitivamente não procura amesquinhar o sistema econômico baseado fundamentalmente na livre-iniciativa, uma vez que, conforme indica SCHOUERI (2005, p. 73): “o modelo de Estado intervencionista, antes de ser uma rejeição da concepção liberal, revela-se como evolução deste, já que um e outro adotam a mesma crença no mecanismo de mercado", ou, nas palavras de GRAU (1998, p. 28): "Essa sua atuação, contudo, não conduz à substituição do sistema capitalista por outro. [...] O sistema capitalista é assim preservado, renovado sob diverso regime".

Observa-se que usualmente a atuação estatal se intensifica sobre áreas da economia que englobam milhares ou até milhões de consumidores simultaneamente, implicando, em consequência, numa parcela considerável da criação de riqueza e circulação de bens em determinada sociedade ou país, em relação direta com o bem-estar que os indivíduos podem desfrutar no presente e no futuro.

Dentre outros, merecem destaque a exploração, pela iniciativa privada, dos principais serviços públicos, tais como: saúde, educação, energia elétrica, telefonia, gás

\footnotetext{
${ }^{68}$ Também trata-se de uma hipótese de externalidade, segundo visto acima.
} 
e transportes. Idêntica relevância deve ser carreada a áreas estratégicas e indispensáveis ao normal funcionamento de qualquer país (v.g. petróleo e seus derivados, atividade bancária e de seguradoras).

4) conteúdo de incentivo ou inibição de certos comportamentos do agente econômico: é possível, ainda, que normas jurídicas objetivem incentivar ou inibir certos comportamentos econômicos que o legislador entende como desejáveis ou não. Logo, não há uma determinação ou mesmo uma proibição expressa para que certas atividades ocorram ou cessem. Em certa medida, os instrumentos aqui utilizados se assemelham àqueles empregados na domação de animais, quais sejam: prêmios e punições a depender do ato praticado.

Segundo expõe SCHOUERI (2005, p. 43-44), esse tipo de norma se caracteriza como dispositiva na medida em que: "O agente econômico não se vê sem alternativas; ao contrário, recebe ele estímulos e desestímulos que, atuando no campo de sua formação de vontade, levam-no a se decidir pelo caminho proposto pelo legislador".

Desde a concepção do welfare state, isso é, a partir do final da década de 1920, normas com tais características passaram a ser muito comuns principalmente em áreas como a tributação ${ }^{69}$, sendo certo que, por meio do sistema imposicional, o Estado atua efetivamente sobre a ordem econômica e social, tentando moldá-la segundo os desígnios constitucionais.

Com isso, a antes tradicional finalidade fiscal dos tributos, até então vistos essencialmente como ferramentas para o sustento exclusivo das despesas estatais típicas $^{70}$, passa a repartir cada vez mais espaço com a extrafiscalidade, aceitando-se a

${ }^{69}$ Destaque-se o art. 146-A da Constituição de 1988, incluído pela Emenda 42/2003, cuja redação estatui: "Lei complementar poderá estabelecer critérios especiais de tributação, com o objetivo de prevenir desequilíbrios da concorrência, sem prejuízo da competência de a União, por lei, estabelecer normas de igual objetivo".

${ }^{70} \mathrm{Na}$ explicação de SCHOUERI (2005, P. 112), a doutrina da época justificava esta neutralidade do sistema exacional com base no pressuposto de que: "sendo o Estado improdutivo, também a tributação seria mínima, visando a deixar a maior quantidade de recursos nas mãos do setor produtivo da economia. [...] Neste sentido, o Estado deveria, seja em seus gastos, seja em sua arrecadação, evitar qualquer medida que tivesse a finalidade ou a provável conseqüência de desviar o mecanismo de distribuição do mercado da sua trilha 'natural', o que implica afastarem-se tributos aduaneiros protecionistas, subvenções, auxílios sociais etc.". 
instituição de exações muito mais vocacionadas a induzir comportamentos do que representar fonte substancial de receita. Conforme indica FALCÃO (1981, p. 47-48):

a tributação extrafiscal é fenômeno que caminha de mãos dadas com o intervencionismo do Estado, na medida em que é ação estatal sobre o mercado e a, antes sagrada, livre iniciativa. Contribui, além disso, para modificar o conceito de justiça fiscal, que não mais persiste somente em referência à capacidade contributiva. Pressupõe uma estrutura adequada da fazenda pública, o conhecimento das possibilidades de intervenção de que se pode cogitar e o desejo de fazer uso dessas possibilidades, inclusive forçando seu alargamento, pois imobilismo e extrafiscalidade são coisas que se excluem.

De fato, em realidade, mesmo no século XIX e início do XX, é possível constatar-se a função extrafiscal impositiva, mas essa não era o objeto ou característica angular da tributação. Com efeito, segundo NABAIS (2005a, p. 420): “toda fiscalidade tem inerente uma certa dose de extrafiscalidade. isso mesmo quando a extrafiscalidade esteve de todo ausente dos propósitos do legislador fiscal ao moldar a disciplina dos impostos".

Nesse tópico, desde logo, merecem destaque os vetustos tributos aduaneiros, que, aliás, já eram praticados há mais de 2000 anos pelos Romanos por meio da imposição da portorium sobre produtos diversos que transitassem nos vários pontos aduaneiros das fronteiras e dentro do próprio Império, conforme narra SIDOU (1978, p. 24).

No Brasil, esse tributo encontra-se previsto no art. 153, I, da Constituição de 1988. Segundo a explicação de BALEEIRO (1998, p. 190-191):

Uma das mais antigas aplicações do imposto para desempenho de funções extrafiscais é a existência de direitos alfandegários altamente onerosos para proteção da produção nacional, já que essa política provoca o encarecimento das mercadorias estrangeiras, afugentando-as da concorrência ou permitindo que as nacionais se possam vender por preços mais remuneradores. Outras vezes, o mesmo resultado é obtido pela isenção a certos ramos da atividade nacional, de sorte que o custo da produção desta fique na paridade da mercadoria importada. Geralmente, as duas formas se combinam para o mesmo fim.

Há episódios relativamente recentes em que a modificação das alíquotas desse imposto gerou forte impacto econômico e, por via reflexa, social. Assim é que, segundo noticia FARINA (1997, p. 123): 
Tradicionalmente, as políticas industriais estiveram associadas à eliminação da concorrência internacional, em mercados previamente selecionados, com o intuito de permitir e estimular o desenvolvimento da produção doméstica. $\mathrm{O}$ argumento da indústria infante compunha a base normativa das políticas industriais que se desenvolveram no bojo das teorias de desenvolvimento econômico.

A política desenvolvida pelo Governo Collor procurou modificar as barreiras que conferiam certa proteção em prol da indústria brasileira. Dentre outras providências, menciona-se a abertura das importações dos tecidos sintéticos no início da década de 1990, ocasião em que as empresas que se dedicavam à confecção de tais produtos sofreram grandes prejuízos, visto que esses materiais começaram a chegar do exterior - originários principalmente da China - a preços muito menores do que os empresários brasileiros poderiam praticar.

Uma das regiões mais afetadas do país foi a do pólo industrial de Americana no Estado de São Paulo, sendo certo que nessa época muitas tecelagens fecharam suas portas, gerando inclusive elevado desemprego na região.

Sem dúvida, esse foi um efeito econômico inicialmente deletério diretamente causado por normas jurídicas que reduziram as barreiras de importação dos tecidos, conforme narra KELLER (s. d., p. 16):

A região de Americana foi duramente atingida pelas importações dos tecidos asiáticos, com destaque para os tecidos artificiais e sintéticos, que são exatamente a especialidade do pólo têxtil. No ano de 1991, a quantidade de tecidos artificiais e sintéticos importados ainda era pequena, com o total de 3.201 toneladas. O montante evoluiu até atingir o pico de 45.583 toneladas de tecidos no ano de 1995 (BNDES, 2001). O segmento de tecelagem, o principal em Americana, foi o primeiro a ser atingido. Reduzindo-se a demanda, com a avalanche de tecidos importados, os pequenos produtores foram os primeiros afetados, já que viviam em uma situação de instabilidade baseada nas relações de subcontratação de capacidade. Logo, outros segmentos também sofreram, como tinturarias, estamparias e fiações - enfim, todos os elos da cadeia produtiva. Em seguida, instalou-se o caos na cidade, com grande número de desempregados, unidades produtivas fechadas, queda do comércio e perda de arrecadação do município. Dados do Sindicato das Indústrias de Tecelagem de Americana, Nova Odessa, Santa Bárbara e Sumaré (SINDITEC) demonstram que, das 1.486 tecelagens planas que operavam na região em 1990, apenas 665 permaneceram em atividade até 1998, representando uma redução de $45 \%$. Dos 31.057 empregos formais existentes na região têxtil, em 1990, restaram apenas 15.300 em 1998, representando uma redução de $49 \%$. 
Contudo, é interessante notar que, após certo tempo, esse primeiro e imediato efeito negativo acabou por servir de estímulo para que as empresas que sobreviveram à intempérie tomassem medidas para aumentar sua produtividade com a modernização de seus parques e melhora no gerenciamento de recursos humanos e financeiros para fazer frente à concorrência estrangeira, fato que também é narrado por KELLER (s. d., p. 18 e ss.):

Em 1998, já era possível perceber sinais da virada na produtividade das empresas têxteis locais que conseguiram empreender seus processos de modernização. A produção no ano de 1990 era de 100 milhões de metros lineares/mês. No período mais sério da crise, chegou a 45 milhões e em 1998 já dava sinais claros de recuperação com 130 milhões de metros lineares/mês.

[...] O atraso tecnológico das empresas remanescentes foi revertido e a produtividade retomada, com a indústria têxtil reorganizada e ainda sendo a atividade industrial mais importante na região e a principal empregadora. Baseados em dados do Rais, Souza et al. (2001) afirmam que as atividades têxteis (têxtil-confecção) representavam, em 2001, 60\% das unidades produtivas de todos os setores industriais de Americana, com predomínio da pequena empresa.

Ora, se recuperação vem ocorrendo, é porque a indústria local obteve êxito em praticar preços que consigam competir com os materiais importados, donde se pode considerar consolidada a criação de melhores condições de compra para as confecções e demais agentes da cadeia produtiva e, em última instância, ao consumidor final.

Ocorrências tais não são propriamente raras na maioria dos sistemas econômicos, principalmente naqueles inspirados pelos princípios da livre iniciativa e liberdade concorrencial, como é o caso do brasileiro. Em termos coletivos, percebe-se que cada ameaça ou obstáculo é capaz de resultar no desaparecimento de alguns agentes do mercado com consequências sociais nocivas (v.g. desemprego, queda na arrecadação fiscal).

Todavia, em contrapartida, decorrido certo interregno, segue-se uma adaptação dos que lograram permanecer ativos, restabelecendo ou mesmo superando o patamar anterior. É o que SCHUMPETER (1961, p. 108) denomina de destruição criadora. Em suas palavras: 
O capitalismo é, por natureza, uma forma ou método de transformação econômica e não, apenas, reveste caráter estacionário, pois jamais poderia tê-lo. Não se deve esse caráter evolutivo do processo capitalista apenas ao fato de que a vida econômica transcorre em um meio natural e social que se modifica e que, em virtude dessa mesma transformação, altera a situação econômica. Esse fato é importante e essas transformações (guerras, revoluções e assim por diante) produzem freqüentemente transformações industriais, embora não constituam seu móvel principal. Tampouco esse caráter evolutivo se deve a um aumento quase automático da população e do capital, nem às variações do sistema monetário, do qual se pode dizer exatamente o mesmo que se aplica ao processo capitalista. $\mathrm{O}$ impulso fundamental que põe e mantém em funcionamento a máquina capitalista procede dos novos bens de consumo, dos novos métodos de produção ou transporte, dos novos mercados e das novas formas de organização industrial criadas pela empresa capitalista.

[...]

Este processo de destruição criadora é básico para se entender o capitalismo. É dele que se constitui o capitalismo e a ele deve se adaptar toda a empresa capitalista para sobreviver.

Outro tributo de função predominantemente extrafiscal é o Imposto Territorial Rural, devendo servir muito mais como instrumento inibidor da permanência no cenário rural de grandes extensões improdutivas do que fonte de receitas, à luz da dicção do art. $153, \S 4^{\circ}$, da Carta de 1988 , a seguir transcrito:

O imposto previsto no inciso VI terá suas alíquotas fixadas de forma a desestimular a manutenção de propriedades improdutivas e não incidirá sobre pequenas glebas rurais, definidas em lei, quando as explore, só ou com sua família, o proprietário que não possua outro imóvel.

De fato, dentro do mencionado sistema de prêmios e punições, a Lei 9.393, de 19 de dezembro de 1996, estabeleceu alíquotas progressivas em função da área do imóvel e, simultaneamente, do grau de sua efetiva utilização.

Com efeito, o quantum devido pelo sujeito passivo não se extrai simplesmente da aplicação da alíquota sobre a base de cálculo legalmente indicada, como ocorre com a maioria dos demais impostos, mas dá-se a partir da aplicação da tabela trazida pelo art. 11 da citada lei, transcrita abaixo:

\begin{tabular}{|l|l|l|l|l|l|}
\hline \multicolumn{1}{|c|}{$\begin{array}{c}\text { Área total do imóvel } \\
\text { (em hectares) }\end{array}$} & \multicolumn{4}{c|}{ GRAU DE UTILIZAÇÃO EM PORCENTAGEM } \\
\hline & $\begin{array}{l}\text { Maior que } \\
80\end{array}$ & $\begin{array}{l}\text { Maior que } \\
65 \text { até } 80\end{array}$ & $\begin{array}{l}\text { Maior que } \\
50 \text { até 65 }\end{array}$ & $\begin{array}{l}\text { Maior que } \\
30 \text { até 50 }\end{array}$ & Até 30 \\
\hline Até 50 & 0,03 & 0,20 & 0,40 & 0,70 & 1,00 \\
\hline Maior que 50 até 200 & 0,07 & 0,40 & 0,80 & 1,40 & 2,00 \\
\hline
\end{tabular}




\begin{tabular}{|l|l|l|l|l|l|}
\hline Maior que 200 até 500 & 0,10 & 0,60 & 1,30 & 2,30 & 3,30 \\
\hline Maior que 500 até 1.000 & 0,15 & 0,85 & 1,90 & 3,30 & 4,70 \\
\hline Maior que 1.000 até 5.000 & 0,30 & 1,60 & 3,40 & 6,00 & 8,60 \\
\hline Acima de 5.000 & 0,45 & 3,00 & 6,40 & 12,00 & 20,00 \\
\hline
\end{tabular}

A partir da análise da tabela de alíquotas, verifica-se, por exemplo, que um imóvel com área total de até 50 hectares, cujo grau de utilização seja maior do que $80 \%$, estará sujeito à alíquota de $0,03 \%$. O mesmo imóvel, caso tenha grau de utilização de até $30 \%$, ficará sujeito à alíquota de $1 \%$. Já o imóvel cuja área seja maior que 5.000 hectares, desde que tenha grau de utilização superior a 80\%, se sujeitará à alíquota de 0,45\%. E, o mesmo imóvel, caso tenha utilização inferior a 30\%, ficará gravado por uma alíquota de $20 \%$.

Aqui, aceitando-se como pressuposto a existência de um desejo generalizado de se gastar o mínimo possível com o pagamento dos tributos, percebe-se que o legislador confere um prêmio ao contribuinte na forma de uma imposição que diminui conforme se alarga o grau de utilização do imóvel rural, sendo o contrário também viável, isso é, o prêmio deixa de existir e aos poucos se transmuda em penalidade sob o pálio da tributação progressiva na medida em que a produção diminui em face da área do bem.

Nesse horizonte, conforme inclusive assinala SCHOUERI (2005, p. 205), é possível afirmar que o sucesso desse tipo de norma fiscal reside justamente na ausência de arrecadação relevante, pois, quanto maior for o número de contribuintes não sujeitos ao fato gerador agravado, mais intensamente foram praticadas as ações intentadas pelo legislador (v.g. no caso do Imposto Territorial Rural, evitando-se a improdutividade das terras).

Mesmo em face de exações cuja finalidade seja precipuamente de arrecadação, como é o caso do Imposto sobre a Propriedade Territorial Urbana - IPTU, no Brasil de competência dos Municípios, a indução econômica por meio de seu regramento, inclusive constitucional, se mostra relevante. Em verdade, segundo CARVALHO JR. (2006, p. 15):

Muito embora a arrecadação do IPTU seja uma fonte de receita importante para as grandes cidades brasileiras e para as jurisdições locais do mundo inteiro, a importância do impacto extra-fiscal do imposto é 
bastante relevante, senão superior à importância da arrecadação municipal.

Nota-se aqui que o Texto de 1988 se encarregou de compartilhar a matiz fiscal com a extrafiscal no IPTU, principalmente após o advento da Emenda 29, de 13 de setembro de 2000 , que inseriu o $\S 1^{\circ}$ ao art. 156 , determinando que: "O imposto previsto no inciso I poderá ser progressivo, nos termos de lei municipal, de forma a assegurar o cumprimento da função social da propriedade ${ }^{71}$, , o que também é tratado no art. $182, \S 4^{\circ}$, II, da Carta, cuja redação prevê:

$\S 4^{\circ}$ - É facultado ao Poder Público municipal mediante lei específica para área incluída no plano diretor, exigir, nos termos da lei federal, do proprietário do solo urbano não edificado, sub-utilizado ou não utilizado, que promova seu adequado aproveitamento, sob pena, sucessivamente de: [...]

II - imposto sobre a propriedade predial e territorial urbana progressivo no tempo.

Deixando o campo dos impostos, não se pode esquecer da existência de exações especiais cujo objeto é, por sua natureza intrínseca e imutável, exclusivamente extrafiscal. São as denominadas contribuições de intervenção no domínio econômico, previstas nos arts. 149 e 177, ambos da Constituição de 1988, citando-se como exemplo a Lei 10.168/2000 (contribuição sobre os royalties pagos por pessoas jurídicas) e a Lei 10.633/2001 (contribuição sobre os combustíveis).

Outra estratégia de indução frequentemente utilizada é a adoção de mecanismos que resultem no alívio tributário do agente econômico. Tratam-se dos genericamente chamados incentivos fiscais ou, como o faz o art. 14 da Lei Complementar $101 / 2000^{72}$, renúncia fiscal, com as figuras da anistia, remissão, subsídio, crédito presumido e isenção, sendo que SCHOUERI (2005, p. 208-209) ainda refere expressamente às técnicas da depreciação acelerada e especial.

Em síntese, o resultado ansiado é o mesmo, isso é, estimular certas condutas supostamente capazes de gerar mais benefícios sociais do que as receitas que deixaram de compor o Tesouro naquele instante.

\footnotetext{
${ }^{71}$ Segundo estabelece o $\S 2^{\circ}$ do art. 182 da Constituição de 1988: “A propriedade urbana cumpre sua função social quando atende às exigências fundamentais de ordenação da cidade expressas no plano diretor".

${ }^{72}$ Conhecida como Lei de Responsabilidade Fiscal.
} 
Em regra, o benefício é condicionando ao preenchimento de certas condições legalmente impostas, como, por exemplo, a implantação de um parque industrial em uma determinada localidade com a meta de empregar posteriormente certo número mínimo de pessoas e, com isso, aumentar do nível de renda da população.

Do acima exposto, percebe-se, na lição de SCHOUERI (2005, p. 88), que: “o uso do instrumento tributário em sentido extrafiscal não só é legítimo constitucionalmente, mas tornou-se um dever constitucional do Estado".

Encerrando a exposição realizada nos subitens 1 a 5, entende-se como afastadas quaisquer dúvidas em torno do real e inafastável acoplamento estrutural entre os sistemas sociais direito e economia, ambos se operacionalizando de maneira continua e recíproca sob inúmeros e diuturnos estímulos e respostas.

Em breve resumo, na feliz síntese de RADBRUCH (1999, p. 32): “O direito não é uma forma, dentro da qual a matéria das relações sociais se deixa moldar docilmente, mas a forma que essa matéria assume irresistivelmente", ou seja, conforme assevera MOCELLIN (1998, p. 1.032), se:

de um lado a legislação condiciona as decisões e o comportamento da unidade econômica, seja no nível desagregado (microeconomia), seja no nível agregado (macroeconomia); de outro, o legislador e o intérprete não podem ignorar as proposições econômicas ${ }^{73}$.

Portanto, em vista e por causa destas inegáveis relações mantidas entre esses sistemas sociais, FARIA (2004, p. 127/128) conclui que:

a tradicional concepção do direito como um sistema basicamente fechado, unitário, hierarquizado, axiomatizado, completo, sem lacunas ou antinomias foi sendo progressivamente substituída por um direito organizado sob a forma de "rede", dado o número crescente desses microsistemas e dessas cadeias normativas, com suas inter-relações basilares procurando capturar toda a complexidade da realidade sócioeconômica.

E assim ocorre, na explicação de $\operatorname{SIDOU}(1978$, p. 07), porque: “Sem economia a ideia de Estado seria um vazio despido de objetivismo, do mesmo modo como

${ }^{73} \mathrm{O}$ texto original é o seguinte: "da un lato la legislazione condiziona le decisioni e i comportamenti delle unità economiche sia a livello disaggregato (microeconomia) sia a livello aggregato (macroeconomia); dall'altro, il legislatore e l'interprete non possono ignorare le proposizioni economiche". 
seria teratológica toda concepção de um Estado sem direito ou sem política, isso é, sem corpo de administração".

Verificadas as principais relações que unem o fenômeno social direito e o fenômeno social economia, passa-se à análise das ciências que os tem por objeto.

\subsection{Relações entre as ciências do direito e da economia}

Se, conforme visto acima, há forte interpenetração entre os fenômenos sociais do direito e da economia, é mais do que esperado que as ciências cujo objeto seja o estudo de tais eventos passassem, aos poucos, a se relacionar de forma crescente, originando novas perspectivas em termos de pesquisa interdisciplinar.

Com efeito, conforme MIRAGEM (2005, p. 143): "O enorme desenvolvimento econômico e tecnológico do último século reclamou de ambas as ciências, direito e economia, uma célere e contínua aproximação".

Dessa feita, um dos resultados dessa aproximação entre os cientistas do direito e da economia foi a construção da disciplina Law and Economics (Análise Econômica do Direito ou, ainda, Direito e Economia) que, originalmente, surgiu nos Estados Unidos.

Assim, um elemento primordial apontado pelos pesquisadores, segundo indica TOMAZETTE (2007, p. 179), foi, desde o início, a noção de que: “o diálogo entre a ciência econômica e a ciência jurídica é fundamental para a solução de uma série de problemas que se apresentam hoje em dia, tanto para o direito quanto para a economia".

A esse respeito, segundo POSNER (2007a, p. 55), até 1960, o movimento era quase sinônimo de Direito da concorrência ou antimonopólio. Em suas palavras: "o novo direito e economia teve início com o primeiro artigo de Guido Calabresi acerca da responsabilidade civil por atos ilícitos e com o trabalho de Ronad Coase ${ }^{74}$ sobre os custo social",75.

74 Trata-se do The problem of social cost, de 1960. Segundo FARACO e SANTOS (2005, p. 30): “As conclusões de Coase no referido texto passaram a ser chamadas em sede doutrinária e jurisprudência como Teorema de Coase, o qual pode ser definido da seguinte maneira: em não havendo custos de transação 
Teriam sido esses, então, os primeiros esforços para aplicar sistematicamente a análise de cunho econômico a áreas do Direito que não cuidavam explicitamente de relações econômicas, o que é confirmado por SZTAJN (2005, p. 74), que coloca o próprio Richard Posner - aliás, com muito mérito - como um dos cofundadores da moderna Law and Economics.

Essa divisão entre a "velha" e a "nova" Análise Econômica do Direito, a partir de 1960, é expressamente admitida por CALABRESI (1990, p. 47): "ante o fato de se aplicar os instrumentos próprios da análise da ciência econômica a normas que, ao menos declaradamente, o escopo econômico seja estranho"

De fato, conforme narra COELHO (2007b, p. 04), nos idos das décadas de 40 e 50 do século XX, a "velha escola" do Direito e Economia centrava seus estudos em temas jurídicos com viés eminentemente econômico, tais como: antitruste, comercial, regulação e tributário. Irradiação dessa novel visão houve, destarte, para as áreas como: responsabilidade civil e infortunística, penal, processual, família e sucessões, ambiental, criança e adolescente, administrativo, trabalho, etc.

Quanto à metodologia elementar de trabalho, SZTAJN (2005, p. 75) conclui que: "Comum aos estudos de Law and Economics é a percepção da importância de recorrer a alguma espécie de avaliação ou análise econômica na formulação de normas jurídicas visando a torná-las cada vez mais eficientes".

Nesse diapasão, em linhas gerais, as pesquisas tomam como premissa a circunstância de o ser humano agir racionalmente dentro do pré-mencionado usual juízo

(aqueles envolvidos na ordenação da atividade econômica, através de trocas voluntárias, como custos em se obter informação, por exemplo), a alocação inicial de um direito não afetará ulteriores usos desse direito". Logo, a posição inicial dos direitos de propriedade não importaria. Complementando com TOMAZETTE (2007, p. 185): “A partir destas conclusões formou-se o teorema de Coase, pelo qual se os custos de transação forem nulos ou irrisórios, a atribuição de direitos efetuada pelo ordenamento jurídico não influirá sobre o resultado da controvérsia, pois os envolvidos acabarão por resolvê-la, através de um processo de negociação, no sentido da distribuição mais eficiente dos recursos [...] Todavia, o próprio Coase reconhece que a situação sem levar em conta os custos de transação é irreal, pois sempre há custos de negociação, de formulação e supervisão de contratos, entre outros". A partir disto, resta evidenciado o papel essencial do direito (e das instituições que nele se embasam) como componente da equação cujo resultado é a alocação dos bens na sociedade, isso é, dependendo do papel assumido, as normas jurídicas influem diretamente na produção e circulação de bens e riquezas.

${ }^{75} \mathrm{O}$ texto original é o seguinte: "El nuevo derecho y economía se inició con el primer artículo de Guido Calabresi sobre los cuasidelitos y con el artículo de Ronald Coase sobre el costo social".

76 O texto original é o seguinte: "per il fato di applicare gli strumenti di analisi propi delle scienze economiche anche a norme cui, almeno dichiaratamente, scopi di tipo economico sono estranei”. 
acerca dos custos e benefícios em todas suas ações, e que, ainda, reage aos incentivos promovidos pelas normas jurídicas.

Por tais razões, afirma COÊHO (2007b, p. 10) que: "no contexto da Análise Econômica do Direito, faz-se um paralelo entre preços e normas jurídicas no sentido de que essas, assim como aqueles, atuam como estímulos à atividade dos indivíduos". Aqui, explicam FARACO e SANTOS (2007, P. 31) que:

Trata-se de um apoditismo, ou seja, uma premissa básica, a qual, evidentemente, pode ser contestada em termos concretos. Todavia, essa premissa é necessária pois permite investigar padrões comportamentais, e, assim, avaliar a previsibilidade das condutas, o que torna possível a teorização a respeito dos comportamentos humanos, em face da escassez.

Então, considerando como premissa básica ser esperado que os seres humanos reajam a incentivos em geral, seja para agirem, ou se absterem de qualquer ato, é possível explicar, mesmo que de maneira não absoluta ou definitiva, por exemplo, a diferença nas taxas médias de homicídios entre países diversos. Então, um pressuposto da ciência da economia - a reação humana a estímulos do ambiente -, contribui para elucidar assuntos ligados à criminologia.

Nesse ponto, segundo ROTH (2006, p. 43), o Brasil possui 322 policiais por grupo de 100.000 habitantes, média superior à dos Estados Unidos, cujo patamar gira em torno de 283. Contudo, como explicar que o número médio de homicídios é maior no Brasil? A resposta possivelmente se relaciona com o fato de, mais uma vez conforme ROTH (idem, p. 43), os Estados Unidos solucionarem aproximadamente $70 \%$ dos homicídios contra apenas 3\% do Brasil.

Ainda que fatores outros possam contribuir para o número médio dos homicídios em determinada região (v.g. policiamento preventivo eficiente, fechamento de bares e casas noturnas após certo horário, conscientização social acerca do respeito pela vida humana, etc.), é intuitivo considerar que a quantidade de casos esclarecidos, nos quais se identifique o autor e seja aplicada a respectiva pena, influi de alguma maneira na taxa média, sendo difícil negar que a expectativa da impunidade pode contribuir para sua majoração. 
Dando prosseguimento, em linha assemelhada à epistemologia própria da ciência da economia, a Law and Economics admite um espectro positivo e outro normativo (ou prescritivo). Segundo SALAMA (2008, p. 09):

O Direito e Economia Positivo se ocupa das repercussões do Direito sobre o mundo real dos fatos; o Direito e Economia Normativo se ocupa de estudar se, e como, noções de justiça se comunicam com os conceitos de eficiência econômica, maximização da riqueza e maximização de bem-estar.

Partindo dessas considerações, FARACO e SANTOS (2005, p. 27-28) afirmam que as pesquisas desenvolvidas na área possuem os seguintes objetivos e ou finalidades essenciais:

a) explicar fatos econômicos que constem de previsões legais, como, por exemplo, o conceito de "mercado relevante de bens ou serviços" utilizado pelo art. 20, II da Lei 8.884/94. Nesse caso, a partir de uma construção oriunda da ciência da economia, o jurista consegue melhor compreender a dicção legal.

In casu, a não utilização desse arsenal científico econômico poderia gerar uma aplicação equivocada do dispositivo pelas autoridades competentes, seja no âmbito administrativo, seja judicial, sem falar que essa ignorância majora a possibilidade da construção de dispositivos legais inoperantes;

b) antever certos efeitos econômicos que uma determinada norma jurídica ou mesmo decisão são aptos a gerar. Num esclarecedor exemplo citado por FORGIONI (2006, p. 54):

quando da formulação de texto normativo que fixe em patamar demasiadamente baixo a multa incidente sobre atrasos no pagamento das condominiais, entende a $\mathrm{AED}^{77}$ ser obrigatório ponderar que o estímulo à inadimplência será a consequiência econômica esperada e que, portanto, faltarão os recursos necessários à manutenção dos serviços comuns.

Até aqui, operou preponderantemente a Law and Economics em sua dimensão positiva, isso é, o conhecimento econômico foi utilizado apenas para constatar

\footnotetext{
${ }^{77}$ AED corresponde à abreviação de Análise Econômica do Direito.
} 
certas realidades encontráveis no mundo, sem, contudo, colocar-se em cena a preocupação de modificá-las num sentido ou noutro;

c) propor o conteúdo de normas jurídicas ou decisões com vistas a alcançar certos resultados, ou seja, com fulcro nas previsões dos efeitos econômicos decorrentes de certas opções, conforme indicado no item "b" acima, é possível aos estudiosos sugerirem quais os supostamente melhores caminhos a serem seguidos, conforme a concepção de eficiência, equidade e justiça de cada um.

Logo, a dimensão normativa (ou prescritiva) da Law and Economics aqui se sobressai, sendo certo que os resultados dessas pesquisas podem servir de valioso apoio aos legisladores e aplicadores do direito em suas atividades basilares, uma vez que poderão com maior acuidade identificar a probabilidade dos objetivos que anseiam serem ou não conseguidos a partir da norma (ou decisão) que se pretende edificar.

Assim, tomando-se de volta o exemplo da obrigação condominial acima transcrito, a consciência de que a intensidade da multa pelo atraso no respectivo pagamento pode influir na taxa de inadimplência, melhor capacita o legislador na fixação dos limites dessa penalidade, bem como auxilia o juiz em eventual decisão acerca de sua excessividade ou não.

Não que tais constatações sempre obriguem a fixação das multas em patamares sempre elevados, pois podem existir razões - sobretudo políticas - para que assim não ocorra, mas, indiscutivelmente, mesmo que sob motivos que desbordam da eficiência econômica, a tomada de uma opção é feita com maior segurança quanto aos resultados que advirão. Frente a tais considerações, FARACO e SANTOS (2005, p. 48) enfatizam que:

o instrumental teórico da economia permite ao operador jurídico avaliar se, no caso, os meios previstos normativamente para alcançar o compartilhamento servem ao fomento desse propósito ou não. Caso o operador jurídico restrinja sua análise à conformidade estrutural entre as normas em questão, nada terá a dizer a respeito do cumprimento, por essas normas, das finalidades perseguidas pelo legislador ou pelo administrador ao editá-las. 
O movimento da Law and Economics não está isento de matizes epistêmicas, o que permite identificar em seu seio escolas que operam sob paradigmas relativamente diferentes, notadamente, quando em cena a versão normativa (ou prescritiva). Nesse ponto, SALAMA (2008, p. 28 e ss.) identifica três versões possíveis: a) fundacional; b) pragmática e c) regulatória.

Conforme as linhas mestras da versão fundacional, o objetivo primordial do direito, no qual inclusive repousaria seu fundamento (daí a expressão "fundacional"), é contribuir para a maximização da riqueza ${ }^{78}$, notadamente pela garantia da propriedade e da obrigatoriedade dos contratos, uma vez que, ausentes tais figuras, minguam os intercâmbios econômicos de mercado. Segundo prega essa versão, FORGIONI (2006, p. 37) enfatiza que:

os mercados funcionam de forma mais eficiente se ligados a um ambiente institucional estável, no qual os agentes econômicos podem calcular, i. e., razoavelmente prever o resultado de seu comportamento e o daqueles com quem se relacionam.

Em suma, conforme a versão fundacional, a maneira mais eficiente do direito maximizar a riqueza é simplesmente não intervir nas relações do mercado, pressupondo-se que qualquer regulação nessa seara é ineficaz, mesmo que sob o mote de neutralizar as falhas já citadas. Nesse ponto, expõe YAZBEK (2007, p. 39) que:

Assim, entre fins da década de 1950 e o início da década de 1960, começam a surgir análises, em especial provenientes da chamada Escola de Chicago, de acordo com as quais a regulação estatal tendia a trazer custos ainda maiores do que os males que se pretendia evitar, contrapondo-se, então, market failures a government failures. Presumivelmente, ante essas novas falhas caia por terra o argumento típico da regulação, passando-se a vê-la, muito mais, como fruto das pressões de grupos de interesse ou como decorrente da necessidade de autopreservação dos políticos e de burocratas.

Nesse raciocínio, não deveria ser vetado por lei, por exemplo, a compra e venda de órgãos humanos para transplante, crianças para adoção, entorpecentes e outras substâncias nocivas à saúde, etc. A explicação para tamanha liberalidade é mencionada por FORGIONI (2006, p. 47), isso é, para os fundacionistas:

\footnotetext{
${ }^{78}$ Este conceito e também o de "eficiência" foram ventilados em notas de rodapé ao final do item 1.4 acima.
} 
As decisões individuais dos agentes econômicos são marcadas pelo desejo egoístico de satisfação de suas necessidades; a solução "geral e natural" encontrada pelo mercado corresponde à consideração global dessas preferências. Em vez da hercúlea e impossível tarefa de buscar o "justo" ou o "adequado", o normal funcionamento do mercado trará a resposta a ser adotada em cada situação. É admitida mais de uma solução [=decisão] correta desde que todas [e cada uma delas] levem ao mesmo resultado.

O mais relevante defensor da versão fundacional foi Richard Posner, precursor da chamada "Escola de Chicago" da Law and Economics, segundo apontam FARACO e SANTOS (2005, p. 37). Em verdade, segundo é consignado por FERES (2001, p. 34):

Richard Posner elegeu o critério da eficiência econômica como único a ser levado em conta no momento da decisão judicial. Esta deve ter por fim a maximização da riqueza, despojando-se de quaisquer outros valores e princípios que não se coadunam com a certeza e objetividade fundamentais a um mais preciso processo judicial. É, pois, relevante ter em mente que o liberalismo norte-americano acentuado acaba por influir na escolha desse único valor a garantir, grosso modo, ao mais eficiente ganho de causa.

As principais críticas à versão fundacional são condensadas por FORGIONI (2006, p. 59) ao asseverar que: "A sociedade civil não se resume ao mercado, há princípios [jurídicos] que não atendem à lógica econômica e que também compõem a chamada "ordem jurídica do mercado"”.

No mesmo caminho, FERES (2001, p. 37): "É evidente que a social wealth, enquanto fim em si, não atende aos reclamos da justiça, enquanto valor, que leva em consideração as diferenças entre as pessoas e a distribuição".

Disso resulta que o próprio Richard Posner, nos idos de 1990, reviu a proposta da maximização de riqueza como fundamento prioritário do direito, instituindo, por conseguinte, a versão pragmática da Law and Economics. Conforme noticia SALAMA (2008, p. 33):

O Posner pragmático, portanto, reconheceu que, por mais que se tente justificar a defesa das liberdades individuais com base em critérios de eficiência (por exemplo, sustentando que no longo prazo o Estado Democrático de Direito promove o desenvolvimento econômico e as liberdades individuais), haverá casos em que a repulsa ao trabalho escravo, à exploração de menores, à tortura, às discriminações raciais, 
religiosas ou sexuais, etc. terá que ser feitas em bases outras que não a eficiência.

A versão pragmática revela uma compreensão do direito como instrumento voltado à consecução de certos fins sociais, ainda com especial destaque à maximização da riqueza por meio da liberdade econômica, mas com temperamentos frente a valores sociais assentados e tipos por intransponíveis, que podem variar segundo as circunstâncias de tempo e local.

Por fim, a versão regulatória considera o Direito como uma ferramenta de amparo na concretização de políticas públicas, isso é, a eficiência econômica não serve como embasamento angular ou exclusivo para a aferição do "justo jurídico", sendo certo que questões de distribuição e equidade influem no resultado obtido.

Logo, por exemplo, na discussão sobre a legalização da prostituição não são levados em conta exclusivamente os custos e benefícios econômicos que poderiam surgir desse labor (ora, no mínimo, poder-se-ia esperar um aumento na arrecadação do Imposto Sobre Serviços e quiçá do Imposto de Renda), mas entram em jogo dilemas eminentemente éticos e morais. Essa linha é defendida pela "Escola de New Haven" ou "de Yale" e tem Guido Calabresi como um dos principais expoentes. Na constatação de FERES (2001, p. 34-35):

é interessante, ainda, apontar que, enquanto a escola posneriana defende a abordagem positiva da análise econômica do Direito, Calabresi constrói o prédio de sua teoria sob o ponto de vista normativo. Ao invés de explicar o mundo tal como é, intenta-se melhorá-lo, operar mudanças a fim de atingir-se a almejada justiça, com eficiência econômica e distribution. Assim, a preocupação, para tal autor, é o comportamento regulado que desempenha importante função na formulação de políticas e contribui para a análise econômica normativa do Direito.

Enquanto a "Escola de Chicago" é considerada positivista, a "Escola de Yale" adentra fortemente no terreno prescritivo ou normativo, ou seja, a partir do pressuposto de o ser humano usualmente reagir a incentivos, procura indicar qual conteúdo normativo seria o mais adequado à consecução de certos objetivos, temperando a inspiração da eficiência econômica com valores sociais de relevo assentados, mesmo que eles possam variar no tempo e no espaço. 
Entretanto, ainda que a versão fundacional (de Chicago) e regulatória (de Yale) possam apresentar soluções distintas para os problemas que lhes são postos, FERES (2001, p. 35) indica que ambas buscam, em última instância, dar ao sistema jurídico um fundamento marcadamente econômico. Complementando essa assertiva com SALAMA (2008, p. 36), tem-se que:

A questão, portanto, não é tanto se eficiência pode ser igualada à justiça, mas sim como a construção da justiça pode se beneficiar da discussão de prós e contras, custos e benefícios. Noções de justiça que não levem em conta as prováveis consequiências das suas articulações práticas são, em termos práticos, incompletas. Num certo sentido, o que a Escola de Direito e Economia de New Haven buscou é consagrar a ética conseqüencialista da Economia com a deontologia da discussão do justo.

Nota-se inclusive que a variação epistemológica encontrada no movimento da Law and Economics não se esgota nas visões retro. Assim é que, conforme noticia SZTAJN (2005, p. 77):

às duas correntes incorpora-se a Escola da Public Choice (ou da Escolha Pública, cujo foco está voltado para a Ciência Política), a que se segue a Escola denominada Economia Institucional e, mais recentemente, a da Nova Economia Institucional, na qual se destacam Douglass North e Steven Medema.

Em linhas gerais, os pesquisadores ligados a essa linha consideram que as instituições de uma sociedade, isso é, as "regras do jogo", não são apenas as normas, mas, sobretudo, o modo como elas são usualmente aplicadas.

É que, por influírem nos custos de troca e produção, deixam suas marcas na dinâmica econômica, implicando, destarte, na necessidade de se levar em conta essa interação nos respectivos estudos e análises. Nessa toada, conforme apontam ZYLBERSZTAJN e SZTAJN (2005, p. 03):

Em contraste com a lógica do paradigma neoclássico, mecanismos de coordenação econômica, dados por instituições políticas e legais, restringem as necessidades, as preferências e as escolhas dos atores econômicos: a ação individual não é soberana tal como querem os neoclássicos, mas é influenciada pelas instituições formais e informais.

Portanto, o desenvolvimento econômico e social de uma sociedade não é fruto de causa única. Conforme relata NÓBREGA (2005, p. 68): 
A educação, o investimento, a acumulação de capital e mão-de-obra e a tecnologia são os fatores mais comumente associados ao crescimento, mas reuní-los numa combinação propícia à geração de riqueza depende do ambiente criado pelas instituições.

Com efeito, na contundente adução de SOUZA (2008, p. 299):

um ambiente sócio-econômico desfavorável constitui um entrave ao desenvolvimento econômico. Instituições precárias e contrárias ao espírito capitalista dos negócios inibem os investimentos e incentivam a fuga de capitais para outros países. Aumentando os riscos dos negócios, reduz-se o diferencial entre a taxa de retorno dos investimentos e a taxa de retorno considerada mínima, inviabilizando a acumulação de capital. Ao contrário, instituições favoráveis estimulam o crescimento econômico.

Uma constatação empírica do que se está a tratar é demonstrada por NORTH (1991, p. 26-27) ao discorrer sobre o resultado do centralismo estatal, em termos econômicos, em países como Inglaterra, Holanda, França, Espanha e Portugal nos idos dos séculos XVI a XVIII. Em suas palavras:

Nos casos da Holanda e da Inglaterra, o controle descentralizado [do mercado] produziu um conjunto de adaptações eficientes nas instituições que se ajustaram à necessidade das mudanças; deste modo, a competição gradualmente forçou o desenvolvimento de instituições mais eficazes e de instrumentos que incrementaram o comércio, e, em conseqüência, reduziram os custos de transação nestas economias. As burocracias da Espanha, Portugal e França, por outro lado, ficaram para trás, sufocando iniciativas que poderiam ter induzido o aumento de produtividade, e Espanha e Portugal permaneceram decaindo por este caminho que perduraria por séculos ${ }^{79}$.

Do acima exposto, é possível verificar que o movimento da Law and Economics resulta do amalgamento entre as ciências da economia, nas suas versões positiva e normativa, e do direito, nos enfoques zetético e dogmático, e vem encontrando crescente acolhimento nos meios acadêmicos, ainda que sob a roupagem dada por cada uma das suas Escolas, isso é, na ênfase de WILLIAMSON (2005, p. 16): “Ainda que não seja unanimidade, a Análise Econômica do Direito é largamente reconhecida como um caso de sucesso".

${ }^{79} \mathrm{O}$ texto original é o seguinte: "In the case of Netherlands and England, decentralized control produced an adaptively efficient set of institutions that adjusted to changing nedds; thus, copmpetition gradually forced the development of more efficient institutions and instruments the promoted commerce and trade, and, in consequence, lowered transaction costs in these economies. The bureaucracies of Spain, Portugal, and France, on the other hand, lagged behind, stifling initiatives that would have induced increased productivity, and Spain and Portugal pursued a downward path that would continue for centuries". 


\subsection{Conclusão do capítulo}

Em conclusão deste capítulo, afirma-se que a incessante interação entre os fenômenos sociais do direito e da economia, promovendo infindáveis estímulos e feedbacks recíprocos, justificou que as ciências que estudam estas ocorrências sofressem um certo amalgamento de modo a permitir uma compreensão mais acurada da realidade.

Ainda que alguns juristas apresentem certa resistência em incluir em seu campo de investigação os conceitos elaborados pela ciência da economia, entende-se que esse caminho é amplamente transitável, ressaltando-se que parcela significativa da comunidade científica jurídica entende oportuna - quiçá indispensável - essa interdisciplinaridade.

Entende-se que nada impede - aliás, muito ao contrário, tudo indica - que o preconizado amalgamento científico também se desenvolva em matérias tipicamente ligadas ao Direito Público, como é o caso do presente trabalho que propõe criar um novo enfoque para a figura da democracia.

Na precisa síntese de SZTAJN (2005, p. 82): "Reagir contra o diálogo entre Direito e Economia, para condená-lo, é posição de que carece de racionalidade". A comprovar está, por exemplo, o cada vez mais consolidado movimento da Law and Economics. 


\section{O TRIBUTO COMO FONTE PRINCIPAL DE RECURSOS PARA O ESTADO}

\subsection{A Figura do tributo}

No direito positivo pátrio, conforme definido pelo art. $3^{\circ}$ do Código Tributário Nacional (Lei 5.172/65), tributo é considerado toda e qualquer prestação pecuniária compulsória em moeda ou cujo valor nela se possa exprimir, que não constitua sanção de ato ilícito, instituída em lei e cobrada mediante atividade administrativa plenamente vinculada.

Como sabido, a imposição desta prestação especial (o tributo) é oriunda do poder de tributar, cuja definição, segundo TORRES (2003, p. 74-75) é:

O poder de tributar, enquanto manifestação funcional da soberania na ordem interna, é poder constituído, estabelecido constitucionalmente para gestão do respectivo sistema tributário, apto, por via de seus princípios e normas, a possibilitar a entrada de receitas suficientes para o financiamento das atividades inerentes ao Estado, com a aplicação dos tributos existentes, conforme os limites demarcados constitucionalmente para tanto.

Assim, para ostentar a natureza jurídica de tributo, é de rigor que uma prestação $^{80}$, de maneira concomitante, seja:

a) compulsória: toda prestação que resulte de uma relação jurídica tributária é de natureza compulsória, isso é, sua formação independe da vontade de quem está obrigado a pagar (o sujeito passivo), ao contrário, por exemplo, de uma prestação cuja origem seja contratual, onde um dos principais pressupostos de validade - e consequente obrigatoriedade - é justamente a manifestação da vontade das partes envolvidas.

\footnotetext{
${ }^{80}$ A prestação é o objeto principal da obrigação, que se consubstancia num vínculo jurídico ou relação jurídica que une credor (o Fisco que tem o direito de exigir) e devedor (o contribuinte que está obrigado a pagar o tributo). Conforme GOMES (1992, p. 20): "Enquanto os direitos reais têm como objeto uma coisa, os direitos obrigacionais visam à prática de determinada ação ou omissão do sujeito passivo. A ação, ou omissão, do devedor chama-se prestação, que é, com efeito, o objeto da obrigação".
} 
b) satisfeita em moeda ou em algo que possa exprimir valor econômico: há certo tempo, notadamente após o surgimento do Estado moderno, o tributo é quase sempre pago em dinheiro, sendo as exceções verdadeiramente pontuais. Entretanto, em casos especiais, é viável que a satisfação da obrigação ocorra com base em algo que represente valor econômico, mas não se constitua dinheiro propriamente dito. Como exemplo ilustrativo, pela narrativa de PAULSEN (1998, p. 183), é possível recordar que:

A Medida Provisória $n^{\circ}$ 1586/97 dispôs sobre a utilização de Títulos da
Dívida Pública, de responsabilidade do Tesouro Nacional, na quitação
de débitos com o INSS. Essa Medida Provisória permitiu a quitação de
dívidas mediante pagamento em TDAs, mas com um desconto sobre o
valor de face.

Noticia BALEEIRO (1998, p. 269) que: “ainda há, em poucos países, prestações em natureza ou em trabalho, mas em casos tão reduzidos e em quantidade tão ínfima, que podem ser desprezados". A regra geral, portanto, afasta a prática dos tributos in natura e in labore ${ }^{81}$, carecendo as exceções de previsão legislativa.

c) instituída por lei: trata-se do vetusto princípio da legalidade tributária, cuja origem remota repousa na Magna Carta assinada pelo Rei João-Sem-Terra em 1215, ocasião em que o monarca inglês, após uma revolta dos barões de então, se comprometeu a instituir ou aumentar tributos apenas sob a prévia concordância dos obrigados.

Logo, ao menos naquelas plagas de além-mar, já no século XI da era cristã, lançou-se uma das primeiras centelhas do tributo como uma obrigação autoconsentida, mesmo que autorizada por meio de representantes, dando ensejo ao conhecido brocardo: no taxitation without representation.

A legalidade tributária deixa de se revelar como uma prática de exceção de países isolados para se transmudar em regra apenas no final do século XVIII, fincando alicerces na maioria das sociedades. Na assertiva de TORRES (1991, p. 113):

\footnotetext{
${ }^{81}$ Segundo MACHADO (2002, p. 58): "Tributo in natura seria aquele estabelecido sem qualquer referência a moeda. Por exemplo, imposto sobre a importação de trigo cuja lei instituidora determinasse que por cada tonelada de trigo importado o importador entregaria cem quilos de trigo à União. [...] Tributo in labore seria aquele instituído também sem qualquer referência a moeda. Por exemplo, um imposto sobre a atividade profissional, cuja lei instituidora determinasse que todo profissional liberal seria obrigado a dar um dia de serviço por mês à entidade tributante".
} 
O princípio da legalidade tributária foi incorporado por todos os grandes textos constitucionais do Estado de Direito. A Declaração de Direitos (Bill of rigths) inglesa dizia ser ilegal "levantar dinheiro para uso da coroa, sob pretexto de prerrogativa, sem permissão do parlamento". Na Constituição dos Estados Unidos reservou-se ao Congresso o poder de criar tributos. Na França, a Declaração de Direitos e a Carta de 1814 proclamaram o princípio da legalidade. Na Espanha, traduziu-se no princípio da anualidade.

Então, prevista no art. 150, I, da Constituição de 1988, mas com fundamento remoto também no art. 5, II, conforme aduz CARRAZZA (2004, p. 229), a legalidade tributária: "garante a segurança das pessoas diante da tributação. De fato, de pouco valeria a Constituição ter garantido a propriedade (arts. $5^{\circ}$, XXII e 170, II) se inexistisse a garantia cabal e solene de que os tributos não seriam fixados pelo Poder Executivo, mas só por lei” ${ }^{\prime 2}$.

d) cobrada mediante atividade administrativa plenamente vinculada: a dívida tributária apenas pode ser exigida pelo fisco se forem estritamente seguidas as regras estabelecidas pela legislação para tanto. E, no alerta de MARTINS e MARONE (1997, p. 34):

Seguir as regras da lei significa que o Poder Público, ao cobrar o tributo, só poderá tomar procedimentos previstos normativamente. Exigir determinado tributo por meio diverso do expresso em lei (lançamento de ofício quando a lei prevê lançamento por declaração, por exemplo) é procedimento eivado por ilegalidade, o qual acarreta na exigibilidade da prestação.

Nessa linha de raciocínio, é de ser ressaltado que a cobrança de qualquer tributo não está sujeita a um critério de discricionariedade da autoridade fiscal. Então, não podem prevalecer critérios de oportunidade ou conveniência, sendo certo que, uma vez ocorrido o fato gerador descrito em lei, a autoridade administrativa está obrigada a constituir o crédito tributário e a efetuar sua cobrança caso o sujeito passivo não o faça voluntariamente.

\footnotetext{
${ }^{82}$ Atualmente, a imposição desta prestação especial - o tributo - provém do usualmente denominado poder de tributar, cuja definição, segundo TORRES (2003, p. 74-75) é: “O poder de tributar, enquanto manifestação funcional da soberania na ordem interna, é poder constituído, estabelecido constitucionalmente para gestão do respectivo sistema tributário, apto, por via de seus princípios e normas, a possibilitar a entrada de receitas suficientes para o financiamento das atividades inerentes ao Estado, com a aplicação dos tributos existentes, conforme os limites demarcados constitucionalmente para tanto".
} 
e) não oriunda de uma sanção por ato ilícito: o tributo sempre decorre de ato lícito. Nesse ponto, ele se distingue da penalidade, ou imposição de multa, uma vez que esta é imposta em face da ocorrência de um ato ilícito por parte do contribuinte.

O que importa ressaltar é que o fato que dá origem à obrigação tributária é em si lícito, isso é, não contrário ao Direito. Com efeito, ressalta PAULSEN (1998, p. 184) que: "Não há que se confundir o tributo em si com a receita, também derivada e compulsória, que são as multas administrativas por prática de ato ilícito, fundadas no poder de punir, e não no poder fiscal".

Em verdade, a multa aplicada pelo não recolhimento de algum tributo é compulsória, podendo ser exigida coercitivamente através do competente procedimento relativo às execuções fiscais, o que também ocorre para os tributos. Entretanto, isso não implica que a multa possua caráter tributário na medida em que sua origem sempre será um ato ilícito.

Segundo adverte ATALIBA (1997, p. 31): "Evidentemente, não é função de lei nenhuma formular conceitos jurídicos". Contudo, o caso do art. $3^{\circ}$ do Código Tributário Nacional se revela numa exceção bem sucedida, notando-se que a comunidade científica, de forma preponderante e relativamente homogênea, consente nessa definição legislativa, ressaltando-se as lições de: $\operatorname{AMARO}$ (2007, p. 18 e ss.); COSTA (2004, p. 21); DENARI (2000, p. 48); CARVALHO (2004, p. 19); COELHO (2000, p. 229); MACHADO (2002, p. 57); NOGUEIRA (1993, p. 156) e TORRES (2001, p. 333). Aliás, o próprio ATALIBA (idem, p. 31) reconhece que: "O conceito legal, in casu, coincide com o doutrinário".

Verifica-se que a definição do art. $3^{\circ}$ do CTN possui cunho nitidamente formal, nada afirmando quanto ao aspecto material, ou melhor, os fundamentos, funções e objetivos essenciais dos tributos. É claro que eles existem, sendo possível notar uma variação nesse entendimento ao longo da história. Aliás, a ideia de pagamento de tributo em dinheiro, bem como do seu emprego em benefício do bem comum ou da coletividade dos contribuintes é relativamente recente. É o que será resumidamente observado a seguir. 


\subsection{Os tributos e sua concepção ao longo da história - breve esboço}

De início, percebe-se que a figura do tributo, mesmo que sob inspiração diversa do conceito doutrinário atual ${ }^{83}$, mostra-se presente entre os homens há milênios. Nota-se que toda comunidade humana minimamente organizada sempre procurou formas de satisfazer as necessidades coletivas por meio de contribuições de seus integrantes. Com efeito, noticia QUEIROZ (2005, p. 241) que:

As primeiras referências de tributos remontam mais ou menos há seis mil anos, no território de Sumer (ilha situada entre os rios Tigre e Eufrates, onde hoje se situa o Iraque). No início os impostos gravavam qualquer coisa. Na Grécia, os tributos já eram pagos de forma consentida.

No Velho Testamento, são encontradas referências ao "dízimo", que, segundo GOUVEIA (1999, p. 08), seria um imposto de renda primitivo e "uma das fontes de renda mais significativas e estáveis, e vultosas, para o sustento do estado-igreja hebraico, especialmente do reformulado e organizado governo sacerdotal instalado, após Salomão, no Templo de Jerusalém" 84 .

Merece destaque o aprofundado estudo realizado por SIDOU (1978, p. 15-35) que chega a apontar disposições de cunho impositorial no Código de Manu - 13 séculos antes de Cristo -, passando pela China, Pérsia, Egito, Cartago e Grécia, indicando que, em Atenas, havia um verdadeiro "ministério das finanças" que controlava as despesas ordinárias da Cidade, o pagamento de funcionários, a abertura de estradas, a assistência a órfãos, enfermos e feridos de guerra. Em Atenas, segundo GODOY (1999, p. 06):

O poder público subvencionava os necessitados, distribuindo entradas para as peças teatrais, o chamado ingresso teórico. Gastava-se com caridade, os órfãos viviam do Estado. Gastava-se com obras portentosas, a exemplo do Partenon, símbolo mais acabado da superioridade Ática.

\footnotetext{
${ }^{83}$ Neste sentido, segundo GODOY (1999, p. 05-07): “Os gregos desconheciam categorias contemporâneas de Direito Tributário, não alcançavam a idéia de tributo, de obrigação tributária, de crédito tributário, de lançamento, de compensação [...] Aparentemente não há racionalidade no modelo tributário helênico, que não alcançou objetivamente patrimônio, renda, serviços. Verifica-se uma prática intuitiva".

${ }^{84} \mathrm{O}$ autor indica as seguintes passagens: a) Gênesis, cap. 14, onde se narra uma guerra entre diversos reis, com a intervenção de Abraão para libertar seu sobrinho Ló, "retornando vitorioso, com Ló, liberto, recuperados seus haveres com acréscimos, entregou Abraão a Melquisedeque, rei de Salém, o dízimo de tudo que trouxera na campanha"; b) Levíticos, cap. 27, vs. 30 e ss.; c) Números, cap. 18, vs. 21 e seg; Deuteronômio, Cap. 14, vs. 22 "uma verdadeira e primeira regulamentação, um conjunto de regras especificas de cobrança do dízimo".
} 
Pela opinião de FRANCISCO NETO (2008, p. 27): “Na Grécia Antiga, na Cidade-Estado de Atenas, encontram-se os fundamentos de uma Fazenda Pública organizada, senão totalmente submetida, ao menos inspirada pelo princípio do interesse público".

Curioso notar, nos moldes indicados por GODOY (1999, p. 06), que os cidadãos propriamente ditos usualmente contribuíam voluntariamente para muitas das despesas comuns, isso é, uma série de prestações que não revelavam cunho obrigatório: eram as epidóseis. E, por meio das liturgias (leitourgíai), transferia-se aos particulares o ônus da manutenção de diversas cerimônias cívicas e religiosas, com destaque para: corégia (chorégia) no custeio dos festivais dramáticos; ginasiarquia (gymnasiarchía) para o financiamento das despesas com as corridas com tochas dos jogos panatenéois; hestíase (hestíasis) no suporte dos banquetes religiosos; trierarquia (trierarchía) no suporte das despesas de equipagem das tirremes.

Durante a guerra, havia uma contribuição especial, a eisphorá. Fato é que o sistema das liturgias acabou por tornar menos necessária a imposição de contribuições coercitivas (FRANCISCO NETO, 2008, p. 28).

A ausência de coercibilidade tributária aos cidadãos, ao menos no que tange aos tributos pessoais - sobre o patrimônio e a renda -, é explicada por OLIVEIRA (2005, p. 177):

O cidadão, dada sua elevada concepção de deveres para com o Estadocidade, rejeita qualquer ingerência sobre seu patrimônio ou bens, uma vez que instauraria uma relação de servidor, o que era inaceitável. Em verdade, a relação que nasce é de auxílio ao Estado, na perseguição do bem público que era a defesa.

Como exceção, indica FRANCISCO NETO (2008, p. 30-31) que, nos períodos de guerra, lançava-se mão de tributos extraordinários, sendo essa a única situação em que o cidadão grego tolerava a intromissão fiscal sobre seus bens e haveres.

Considerando-se, todavia, que tais turbulências eram frequentes, a exceção, em muitas ocasiões, terminou por se travestir em regra, passando tais imposições de caráter extraordinário para um quase que permanente. 
Em adição, o autor em tela constata que: "Os tributos extraordinários, lançados a princípio, para se preparar para a guerra, e depois, para sustentá-la, servirão, mais tarde, para tornar possível o trânsito para a economia dos tempos de paz, até que outro trágico evento possa reiniciar o mesmo ciclo".

Assim, é possível afirmar que, em tempos de paz, fora as contribuições voluntárias acima mencionadas (epidóseis e leitourgíai), a principal fonte de recursos fiscais de Atenas provinha dos tributos ditos indiretos ${ }^{85}$, conforme apresentado por FRANCISCO NETO (2008, p. 29), quais sejam:

1) direitos aduaneiros, sob uma alíquota ad valorem de $2 \%$ sobre o montante da mercadoria que entrasse ou deixasse o território;

2) direitos portuários, com alíquota de $1 \%$ sobre a carga, não se sabendo ao certo os critérios de sua avaliação;

3) direitos sobre consumos, pela tributação de todos os bens que cruzassem os portões da Cidade;

4) direitos de praça, pagamento obrigatório a todo aquele que se instalasse em pontos estratégicos com fulcro de expor ou vender mercadorias.

Essa aversão aos tributos diretos ou de caráter pessoal também se manifestava em relação aos romanos pelos mesmos motivos observados na sociedade grega. Na explicação adicional de SIDOU (1978, p. 38), perfeitamente válida para os dias de hoje, nos impostos diretos o sujeito:

paga premido por um ato impositivo, sem qualquer satisfação imediatista, enquanto que os tributos indiretos (os de circulação, por exemplo) são exigidos quando o contribuinte vai satisfazer um desejo espontâneo: a aquisição de um bem cujo tributo figura no preço sem que ele disto se aperceba.

\footnotetext{
${ }^{85}$ Entenda-se por indiretos, neste contexto, as imposições que recaiam sobre a circulação de riqueza em geral (v.g. importação e exportação, compra, venda, doações, etc.), cuja base de cálculo levava em conta o valor da operação e não a capacidade econômica do sujeito que pratica o ato.
} 
Fato é que, em regra, Roma evitou tributar pesadamente seus cidadãos pela forma direta. Contudo, na advertência de OLIVEIRA (2005, p. 178): "Isto ocorre, evidentemente, no meio dos cidadãos. Não é o que ocorria, por exemplo, sobre as terras conquistadas. Estas eram obrigadas ao pagamento de determinadas quantias, para o sustento de Roma”. Nesse ponto, segundo CUNHA (2002, p. 03-04):

Em outra indicação de resistência dos judeus ao pagamento de impostos, vimos que, no tempo de Cristo, os cobradores de impostos - os publicanos $^{86}$ - eram equiparados, socialmente, aos pecadores e às mulheres de má-fama (Marcos 2: 13-16; Mateus 9: 9-12; Lucas 5:27-30). Se bem que nesse caso, a maior resistência pode ser explicada pelo fato de os dominadores romanos serem os destinatários da arrecadação.

Informa FURLAN (2007, p. 63) que: "no que tange à Roma antiga, sua política financeira era essencialmente parasitária, baseando-se não apenas nas pilhagens e extorsões, mas principalmente na exploração fiscal dos povos vencidos e territórios conquistados". Não obstante tais circunstâncias, segundo assevera GODOY (1999, p. 05), tão somente aos romanos pode-se imputar um ensaio de técnica de tributação.

Nesse tema, SIDOU (1978, p. 23-28) descreve a complexidade da tributação na época de Augusto (Caio Júlio César Otaviano Augusto, o primeiro imperador de Roma, que governou entre 27 a.C. e 14 d.C.). Em linhas gerais, nesse período, as fontes do Tesouro romano se dividiam em tributos diretos e indiretos. Em brevíssimo resumo, o sistema assim estava edificado:

1) tributos diretos:

1.1) vectigal e ager publicus: na península itálica, onde a propriedade da terra era privada; incidiam em razão da ocupação e da possibilidade de desfrute do bem.

1.2) stipendium: nos demais territórios conquistados, onde a terra não era particular, mas pertencia integralmente ao Império. Logo, a obrigação não decorria do desfrute do bem, mas sim do poder de domínio romano. Devido, ora em dinheiro, ora em

\footnotetext{
${ }^{86}$ Noticia FURLAN (2007, p. 64) que: "No auge de sua expansão, a cobrança dos tributos nas províncias passou a ser terceirizada. Os publicanii adiantavam o dinheiro ao governo e depois recuperavam o investimento cobrando impostos. A riqueza das províncias e o crescente aporte de recursos possibilitaram uma das primeiras formas de desoneração tributária em massa, com a suspensão da cobrança dos tributos devidos pelos cidadãos romanos em 167 d. C.”.
} 
espécie, o stipendium poderia assumir, alternativamente, duas sistemáticas: a) tributum soli (dízimo proporcional); ou, b) tributum capitis (imposto territorial fixo).

Na realidade, grande parte das rendas do Império Romano de então era proveniente dessas exações fixadas sobre a terra que, de uma maneira geral, se assemelhavam ao que hoje se denomina de arrendamento, principalmente no que concerne às terras públicas dos territórios conquistados, conforme enfatiza COUTO E SILVA (1997, p. 83-84).

Também nessa categoria de tributos diretos, incluem-se outras exações que não possuíam relação com a posse ou ocupação da terra, a saber:

1.3) tributum ex censu, de caráter extraordinário, surgiu no período da realeza e, em regra, era cobrado a cada cinco anos, por isso também denominado de lustralis collatio. $\mathrm{O}$ valor restava baseado nos haveres do obrigado, conforme registrado em censos anteriores. $\mathrm{Na}$ verdade, mais se assemelhava ao empréstimo compulsório da atualidade, permitindo a restituição tão logo o erário permitisse. Essa exação surgiu no período da realeza por volta de 435 ou 427 a.C. (FURLAN, 2007, p. 71);

1.4) sacramenta ou aposta judiciária ${ }^{87}$;

1.5) vicessima hereditária, cobrada dos herdeiros legítimos e testamentários a partir do ano 6 d.C., correspondia à vigésima parte dos bens transferidos Noticia FRANCISCO NETO (2008, p. 37) que: "Esse imposto não atingia as sucessões de baixos valores, e nem também as heranças deixadas aos menores de idade". [...] Mais tarde, Nero isentou o imposto das mães, e, depois, Trajano eximiu os pais pela herança a seus filhos" ${ }^{\prime 88}$.

2) Tributos indiretos 89 :

${ }^{87} \mathrm{O}$ autor não fornece qualquer explicação do que se constituiria este tributo. Não há remissões a seu respeito nos demais textos consultados.

${ }^{88}$ Entretanto, o autor informa que Caracála majorou a alíquota ao patamar de $10 \%$, passando em seguida para $20 \%$, bem como suprimiu todas as isenções anteriores.

${ }^{89}$ Conforme aponta SIDOU (1978, p. 26), os cidadãos romanos viam nos impostos indiretos a única prática fiscal compatível com a liberdade civil. Segundo o autor (p. 27-28), ao contrário da regra basilar vislumbrada na modernidade, nalgumas províncias os gravames eram exigidos em dinheiro, noutras in 
2.1) portorium $^{90}$ ou aduaneiros, sobre produtos que transitassem nos vários pontos aduaneiros das fronteiras e dentro do próprio Império;

2.2) centesima rerum venalium, em vista das vendas ou arrematações em geral, equivalente a $1 \%$ do valor da operação, foi criada em 6 d.C.;

2.3) quinta et vicesima manciporum, sobre a compra e venda de escravos, também instituída em 6 d.C. sob a alíquota de 4\%;

2.4) vicessima libertatis, pela libertação ou alforria de escravos (exação bem antiga existente deste 375 a.C.).

Mais adiante, sob o governo de Diocleciano (entre 284 e 305 d.C.), frente a graves dificuldades econômicas, principalmente pelo advento de latifúndios e a ida da população às cidades, com o abandono do campo aos escravos, operou-se uma reforma fiscal de larga envergadura, utilizando-se a captatio ou jugatio, ${ }^{91}$ imposto de caráter pessoal (homem-terra) incidente sobre toda população agrária, cuja complexidade burocrática para o cálculo redundou em sua ineficácia. Narra SIDOU (1978, p. 28) que:

a unidade era o caput, a pessoa, multiplicada pela dimensão da área ocupada, a qual variava em razão da qualidade da terra. Para efeito desse complexo cálculo, ao homem adulto correspondia uma unidade e à mulher meia unidade, ou meio caput. E a qualidade da terra obedecia uma escala via da qual um jugo de terra própria a viticultura valia mais que a mesma extensão própria ao pastoreio.

Ainda conforme o autor acima, o insucesso dessa sistemática contribuiu para o surgimento dos futuros senhores feudais - os barões -, os únicos que conseguiam pagar o tributo e, por isso, fixaram-se cada vez mais às respectivas terras, o que marcou o

natura (v.g. no Egito a regra era a entrega de cereais) ou, ainda, ora em dinheiro, ora in natura, o que também é mencionado por FURLAN (2007, p. 73) e FRANCISCO NETO (2008, p. 36).

${ }^{90}$ Esclarece FRANCISCO NETO (2008, p. 38) que: "A rigor, o portorium correspondia a três classes de tributos: a aduana, ou seja, aquele percebido na fronteira de uma província, por conta dessa província; o arbítrio, cobrado por ocasião da entrada ou saída de uma cidade, por conta e favor dessa cidade; e o pedágio, cobrado pela passagem em certos lugares, como, uma ponte".

${ }^{91}$ Esta exação não foi instituída neste instante, eis que muito mais antiga. O que parece ter ocorrido é uma modificação em sua sistemática. Conforme explica FURLAN (2007, p. 69): "No século V a.C., a capitatio era um imposto de valor igual para todos. Posteriormente, passou-se a cobrar o tributo consoante as classes sociais. Os decuriões formavam a classe divisora. Acima deles estavam as classes isentas. Abaixo, os plebeus, alvos principais da incidência tributária, motivo pelo qual o imposto era conhecido como capitatio plebeia. As mulheres pagavam metade do valor devido pelos homens". Na mesma linha, segundo MEIRA (1995, p. 18): “Abaixo dos decuriões se estendia a grande massa sujeita ao tributo: a plebe”. 
aparecimento, ao passar das décadas, do processo de formação dos feudos e início da prática de uma economia predominantemente natural que foi a tônica da Idade Média.

Interessante notar que o sistema romano contou com a presença de tributos que atualmente seriam, no mínimo, estranhos, para que não se afirme um tanto exóticos. A respeito, segundo FURLAN (2007, p. 62), havia imposições sobre o uso do ar e janelas (vectigal aerum) ${ }^{92}$; colunas (ostiarium e colunarium); chaminés e expedição de fumaça; em favor do Imperador a cada ano novo (strenae); em benefício dos generais vitoriosos (Aurum coronarium).

Prosseguindo, com a desintegração do Império Romano do Ocidente, a Europa entra na Idade Média, período que, convencionalmente, se inaugura em 476 para se encerrar em 1453 com a queda de Constantinopla, cuja principal marca política foi a descentralização do poder. Como ensina DALLARI (1989, p. 58): “a ordem era bastante precária, pela improvisação de chefias, pelo abandono ou pela transformação de padrões tradicionais, pela presença de uma burocracia voraz e quase sempre todo-poderosa, pela constante situação de guerra".

É sabido que, à exceção de algumas Cidades livres, os camponeses e pequenos proprietários, incapazes de cuidar da própria defesa, aos poucos, agruparam-se ao redor de fortalezas e castelos e rogavam por proteção ao senhor local, o que era concedido mediante a entrega de suas terras e do préstimo da vassalagem. O resultado foi uma profunda pulverização do poder.

Então, aquele indivíduo reconhecido como rei, em realidade fática, encontrava-se em condições materiais e políticas muito assemelhadas a de outros vizinhos, também "chefes de castelos", todos com forte autonomia para prover a lei, a ordem e a justiça em seus domínios.

Logo a tributação passou a ser caracterizada como uma atividade primordialmente privada decorrente da relação senhor-servo e dissociada de um poder superior organizado - ius imperium, como existiu no período romano. De fato, segundo

\footnotetext{
${ }^{92}$ Não apenas os romanos tiveram esta idéia. FRANCISCO NETO (2008, p. 59) noticia que em 1.696 foi criado um imposto inglês sobre o número de janelas das casas.
} 
FRANCISCO NETO (2008, p. 49): “o tributo deixava de ser uma instituição de direito público para converter-se em símbolo de servidão".

Ademais, com a pouquíssima circulação de bens e riquezas entre os feudos, tendo a economia adotado um viés fortemente natural, os tributos eram quase todos devidos in natura ou in labore, por exemplo, por meio da corvéia que implicava no trabalho servil nas terras próprias do senhor durante dois ou três dias por semana (HUBERMAN, s. d., p. 04 e ss.).

Não havendo regras claras ou limites razoáveis à capacidade de contribuição, SIDOU (1978, p. 29) assevera que a tributação restou: "extremamente onerosa, arbitrária e exigida dos vassalos no exclusivo interesse do suserano".

Além do mais, a enormidade de tributos praticados ao longo daqueles séculos, aliada à notável diversidade sócio-econômica que vigia nas várias regiões européias, criou enorme dificuldade em sistematizar ou mesmo encontrar semelhanças nos diversos modelos imposicionais de então.

Ainda que assim seja, enumera-se a seguir a extensa lista proposta por FRANCISCO NETO (2008, p. 50-52), composta de exações que muito variaram em termos de tempo e local:

1) laudêmio: sem prejuízo do regular pagamento ao senhor de quantias referentes ao direito de ocupar e explorar certa parcela de terra, os colonos deveriam pagar o laudêmio por ocasião da transmissão na posse da terra por si ocupada ${ }^{93}$.

2) fonsadeira: tributo devido ao monarca por aqueles que manifestavam o desejo de não ir à guerra. Surgiu por volta do século $X$, tendo sua arrecadação empregada nos gastos bélicos em geral e, ainda, nos reparos de fossos e castelos;

\footnotetext{
${ }^{93}$ Sob a mesma inspiração - transferência da posse - ainda hoje no Brasil o laudêmio é cobrado pela União Federal, segundo o art. $3^{\circ}$ do Decreto-lei 2.398/87 cuja redação prevê: “Art.3º Dependerá do prévio recolhimento do laudêmio, em quantia correspondente a $5 \%$ (cinco por cento) do valor atualizado do domínio pleno e das benfeitorias, a transferência onerosa, entre vivos, do domínio útil de terreno da União ou de direitos sobre benfeitorias neles construídas, bem assim a cessão de direito a eles relativos".
} 
3) moedas: presente na Espanha, denominado "moeda foreira", tinha como fato gerador o início de cada reinado, sendo a cobrança renovada a cada sete anos algumas vezes cinco. Sua extinção ocorreu em 1537 pela Corte de Valladolid;

4) martinega: exação cobrada dos colonos ou servos que exploravam terras pertencentes à Coroa e se constituía numa quantia determinada a ser entregue no Dia de São Martin;

5) albana ou albanágio: direito em benefício dos monarcas medievais sobre bens dos estrangeiros que faleciam sobre sua jurisdição;

6) mouraria: tributo feudal exigido dos mouros, cuja presença era tolerada entre os cristãos;

7) alfama: exação devida pelos judeus que permaneceram na Espanha até sua expulsão definitiva determinada pelos reis Fernando e Isabel em março de 1492;

8) pedágios em geral: imposições oriundas do trânsito sobre certos locais, tais como estradas e pontes;

9) cena de ausência e de presença: a primeira era exigida dos mouros ante ao fato de o rei não transitar pelos povoados onde se concentrava essa população. Noutro giro, a cena presença era cobrada em face da passagem do rei pelos demais locais;

10) contribuição decimal: exigida em espécie e se constituía na décima parte sobre os frutos da agricultura;

11) alcavala: tributo exigido mediante aplicação de uma porcentagem sobre os valores das operações de compra e venda e permutas sobre bens móveis, imóveis e semoventes;

12) subsídios eclesiásticos: diversas exações devidas em benefício do clero; 
13) direitos de chancelaria e notariado: o primeiro era pago ao chanceler em razão da autorização com o "selo real" dos privilégios, graças e mercês em proveito de um indivíduo ou de uma cidade. O segundo era devido ao notário quando da lavratura de escrituras em geral;

14) direito de peso: presente em Aragão, na Espanha, se revelava como uma obrigação imposta em face de pesos e medidas de vários bens;

15) dote da rainha e das infantas: exação recebida por ocasião das bodas da rainha ou das princesas.

Derrocado o feudalismo em face do crescimento do poder político nas mãos do rei, conforme inclusive já mencionado antes, foi com surgimento do Estado nacional que se pode admitir o nascimento da figura do tributo em moldes semelhantes aos atuais, isso é, como uma prestação criada por lei - ideia de auto-consentimento -, obrigatória e devida essencialmente em dinheiro, que vai se apresentar como principal fonte de recursos para o pagamento das despesas estatais.

Logo, aos poucos, o Estado patrimonial, cujas necessidades eram atendidas em sua maioria pelas rendas dos bens dominicais, além dos serviços pessoais não remunerados prestados pelos súditos, cedeu lugar ao Estado financeiro. Assevera TORRES (1991, p. 02) que:

É inútil procurar o tributo antes do Estado Moderno, eis que surge ele com a paulatina substituição da relação de vassalagem do feudalismo pelos vínculos do Estado Patrimonial, com as suas incipientes formas de receita fiscal protegidas pelas primeiras declarações de direito.

É, com efeito, durante a Idade Moderna, principalmente sob o denominado "absolutismo esclarecido", que se aperfeiçoa a administração financeira, bem como se fixa a concepção da receita fiscal como um patrimônio diverso daquele pessoal do rei, ainda que em sua pessoa tenha se concentrado o poder imposicional tributário ${ }^{94}$.

\footnotetext{
${ }^{94}$ Este fenômeno, por óbvio, não ocorreu de maneira repentina nem uniforme na Europa. Segundo TORRES (1991, p. 23): “Com a formação do Estado Moderno, transfere-se para o rei ou para o príncipe territorial o poder de exigir impostos. Mas, nos países que aderiram ao patrimonialismo, o senhorio e a Igreja conservaram, perifericamente, o direito a algumas rendas fiscais e patrimoniais. É o resquício do
} 
Aponta SIDOU (1978, p. 32) que por essa novel proposta: “os ingressos para a caixa pública não são mais que exigências do poder público, e que se estabeleceram os orçamentos, feitos mais no sentido de dar satisfação ao povo, por intermédio de seus representantes nos parlamentos, do que 'fazer crescerem as riquezas do rei' ".

Não significa dizer, contudo, que a tributação do período tenha sido praticada sob nível de razoável equidade ou justiça tributária ${ }^{95}$, como, por exemplo, pela cobrança de acordo com a capacidade contributiva do obrigado.

Em verdade, a quase totalidade dos sistemas impositivos era nitidamente regressiva, encontrando-se os pobres e desvalidos ordinariamente sujeitos a uma carga fiscal proporcionalmente muito mais elevada do que as classes compostas por pessoas socialmente bem situadas. Aqui, narra TORRES (1991, p. 45) que:

Os pobres não eram imunes aos tributos. Daí resultava uma estrutura impositiva essencialmente injusta, prejudicial à liberdade e à dignidade do homem e permanentemente deficitária, pelo pequeno aporte de recursos dos impostos indiretos pagos pela população carente.

Ora, tal estado de coisas nada mais representou além daquilo que a humanidade, salvo raríssimas exceções, até então fizera em termos de tributação, seja pela extorsão pura e simples de povos conquistados, seja em vista da primazia dos tributos indiretos sobre os diretos, ou, ainda, por causa da imunidade tributária das castas sociais mais relevantes ${ }^{96}$.

Foi apenas no último quarto do século XVIII, notadamente como fruto das ideias iluministas, que questões como a justiça fiscal entraram na pauta de debates, destacando-se, em primeiro plano, o art. 13 da Declaração dos Direitos do Homem e do

feudalismo, que vai declinar no Estado de Polícia e que só desaparecerá com o advento do capitalismo e do liberalismo. A fiscalidade tripartida entre a realeza, o senhorio e a Igreja aparece com diferentes intensidades na Alemanha, na Itália, na Espanha e em Portugal, sendo que neste último o fenômeno surge independentemente do fato de lá não ter-se instalado jamais um vero regime feudal. Nos países em que a estrutura patrimonialista era frágil, como na Inglaterra e Holanda, ou em que desde cedo se manifestou o absolutismo, como na França, o senhorio não manteve o poder fiscal".

${ }^{95}$ Já foi afirmado anteriormente que a noção de justiça não é unívoca, ao contrário, é controvertida (item 1.2, alínea "d"). Logo, a expressão deve ser aqui considerada como um parâmetro para a atualidade, isto é, provavelmente a tributação regressiva e segundo a posição social do obrigado deveria ser considerada justa e correta na Idade Média, ao menos por grande parte daqueles que se beneficiavam das imunidades e isenções.

${ }^{96}$ Nesse tema, noticia FRANCISCO NETO (2008, p. 49) que: "o visigodo pagava igual ao romano; o nobre, menos que o plebeu; o homem livre, menos que o servo; e, o clero, menos ainda que as outras classes". 
Cidadão, obra da Assembleia Nacional francesa, de 26 de agosto de 1789, cuja redação transcreve-se: "Para a manutenção da força pública e para as despesas de administração é indispensável uma contribuição comum que deve ser dividida entre os cidadãos de acordo com suas possibilidades".

No Brasil, a Constituição de 1824, em seu art. 179, §15, estabelecia que ninguém estava isento de contribuir para as despesas do Estado segundo a proporção de seus haveres.

Aqui resta fora de dúvida que a tributação deveria atingir a todos, não mais se excetuando os componentes da nobreza ou do clero e, ainda, a oneração deveria seguir o critério da capacidade contributiva, no sentido de identificar a possibilidade ou "potência" para contribuir de cada um.

Nota-se, de fato, segundo TORRES (1991, p. 137-138) que: “a doutrina liberal começa a se preocupar com o assunto, para legitimar a incidência fiscal sobre a propriedade privada, desde que observados certos limites quantitativos".

Com efeito, isso não é pouco, representando séria mudança na concepção de como a sociedade deveria financiar as despesas comuns, tudo aliado à necessidade das exações serem precedidas de auto-consentimento dos obrigados, ainda que por intermédio de representantes eleitos nos moldes do art. 14 da referida Declaração. Não se trata de um fenômeno adstrito às fronteiras francesas. Pela narração de COSTA (1996, p. 16):

\footnotetext{
Neste momento histórico, tão arraigada já se encontrava a idéia de capacidade contributiva na consciência dos povos civilizados, que vários episódios políticos de relevo podem ser atribuídos, direta ou indiretamente, a sua inobservância. Assim, a "Boston Tea Party", evento no qual os norte-americanos rebelaram-se contra a tributação inglesa das importações efetuadas pelos colonos, entre elas a de chá, e que se constituiu em importante precedente da independência (1773); a Revolução Francesa, que teve como causa, dentre outras, a precária situação do governo de Luis XVI, que o obrigava a sangrar o povo com impostos (1789); e a Inconfidência Mineira, provocada pela opressiva política fiscal da Coroa Portuguesa, por ocasião da "derrama" (1789).
}

Nessa linha raciocínio, percebe-se, desde então, uma crescente preocupação das sociedades em torno da adoção da capacidade contributiva. Dessa forma, de acordo com a lição de TIPKE e YAMASHITA (2002, p. 30): “A realização do princípio 
da capacidade contributiva é um progresso perante uma tributação arbitrária, sem princípios, perante uma tributação segundo o oportunismo político, perante um pragmatismo ou fiscalismo ilimitado".

Em adição, percebe-se que esse instante de passagem do século XVIII para o XIX marca, no que tange às finanças públicas, a transição do Estado Patrimonial para o Estado Fiscal de Direito, ocasião em que, segundo assevera TORRES (1991, p. 121): "A fiscalidade privada desaparece, e o tributo cobrado pelo Estado deixa de emanar de relações de privacidade e ingressa na esfera da publicidade".

Ainda segundo o autor, é no Estado Fiscal que se reforça a ideia imunizar os pobres da tributação, garantido-lhes, assim, o mínimo existencial. Em suas palavras:

\begin{abstract}
A questão da pobreza sofre também modificação radical. No Estado Patrimonial é possível cobrar tributo dos pobres, em nome da justiça comutativa, e a assistência social se faz por meio da Igreja, com a arrecadação dos dízimos. No Estado Fiscal imuniza-se o mínimo necessário à existência humana digna contra a incidência dos impostos, e a assistência social se transfere para o poder público (idem, p. 150).
\end{abstract}

Interessante notar que justamente é nessa época que surge o imposto que mais se identifica com o respeito à capacidade contributiva do contribuinte: trata-se do Imposto sobre a Renda que, na opinião de SIDOU (1978, p. 38) representa "o ponto mais avançado da história administrativa dos povos". Adiante, o autor assevera que:

Embora a tarifação da renda possa vir com suas raízes de tempos imemoriais (Metzger pretende situá-la na prática fiscal do Egito de 580 antes de Cristo), o tributo com seu caráter moderno é decorrência da evolução da economia capitalista e representa, na história tributária, o limiar da concepção segundo a qual a capacidade econômica do contribuinte passou a ser elemento impartível na exigibilidade do imposto. E assim porque amplia consideravelmente esse princípio da justiça distributiva ao buscar a lógica da desigualdade (idem, p. 45).

A instituição do Imposto de Renda nos moldes semelhantes aos que atualmente se entende desta exação, isso é, como uma imposição que incide precipuamente sobre o acréscimo patrimonial líquido, remonta à Inglaterra.

Com efeito, informa SIDOU (1978, p. 46) que, por obra do Primeiro Ministro Pitt, a sua cobrança teve início em 1799, mesmo que sob fortes protestos 
liderados, essencialmente, por James Fox. Ainda no século XIX, conheceram o Imposto de Renda a Áustria (1848), a Itália (1864) e a Holanda (1893). Entre 1874 e 1891 as regiões alemãs de Saxe, Baden e Prússia implantaram o imposto em tela, sendo que, em 1920, já sob o regime da Constituição de Weimar, o Einkommensteuer passou à competência legislativa da União que o devolvia, na proporção de 2/3 (dois terços), aos Estadosmembros.

No século XX, sua adoção na França e na Hungria data de 1909. Nos Estados Unidos, seu advento ocorreu em 1913, após a Emenda XVI que possibilitou ao Congresso "impor e arrecadar contribuições fiscais, seja qual for sua origem, sem necessidade de distribuição proporcional entre os vários Estados, e sem reger-se por censo ou enumeração alguma". A Suíça incorporou essa exação em 1915. Logo adiante, nos anos 1920, o Imposto de Renda é adotado em vários países latino-americanos, tais como Brasil, Bolívia, Colômbia, El Salvador e México.

Entretanto, o limitado papel desenvolvido pelo Estado liberal, segundo já mencionado antes, contribuiu para a eclosão das graves crises sociais do final do século XIX e início do XX, desaguando, destarte, na concepção do welfare state, o que também é acompanhado por uma alteração da concepção do papel da tributação na sociedade.

De simples forma de divisão das despesas comuns, passa-se a compreender o sistema exacional como uma ferramenta de intervenção econômica e de financiamento de políticas públicas com inúmeros desideratos. À regra da capacidade contributiva acrescentaram-se os princípios da progressividade e da solidariedade na tributação. Na síntese de TAVARES (2008, p. 65-66):

o indivíduo, pelo dever de solidariedade, é levado a sacrificar uma parcela de seu patrimônio, sem necessariamente obter uma contraprestação específica, com vistas ao fim do interesse coletivo consubstanciado no custeio do Estado em cuja sociedade ele está incluído. Nesse sentido os tributos devem ser divididos, sim, de forma que os mais ricos paguem mais que os mais pobres. Mas isso nada tem a ver com a questão do igual sacrifício ou da mensuração dos respectivos benefícios, mas sim com o fato de que, tendo em vista o dever de solidariedade, inerente aos seres humanos e elevado constitucionalmente ao status de objetivo fundamental do Estado, é imprescindível para a humanidade (e não meramente para o sustento do Estado) que a repartição tributária seja feita dessa maneira. 
Portanto, informa MICHELS (2005, p. 229) que: "na visão socialdemocrata, desenvolvida a partir das crises do liberalismo, o tributo aparece como um dever social necessário ao estabelecimento de um laço social fundado no ideal de solidariedade”. Em complemento, na lição de SACCHETTO (2005, p. 26):

Foi a mudança de perspectiva - no fim do século XIX - da concepção de tributo como preço dos serviços prestados pelo Estado para o da solidariedade que justificou a passagem do tributo proporcional ao progressivo. A mera proporcionalidade do imposto não parecia mais satisfatória para manter a equidade fiscal, porque ela não conseguia manter a igualdade de sacrifícios entre os cidadãos. $\mathrm{O}$ tributo, na forma do imposto, torna-se o instrumento para realizar a justiça que opera por meio de uma redistribuição de rendimentos.

Tanto é assim que, atualmente, conforme noticia GODOI (2005, p. 152): "a doutrina européia radica exatamente na solidariedade social o fundamento do dever constitucional de pagar impostos". Trata-se, outrossim, do que os norte americanos, na lição de LIVINGSTON (2005, p. 195), denominam de "balanço entre equity e efficiency", ou seja, da tentativa de conciliar a necessidade de manter um mínimo de justiça social com a não menos importante necessidade de manutenção dos incentivos particulares no conjunto da economia.

No Brasil, em termos constitucionais, essa nova percepção pode ser aferida já na primeira metade do século XX. Assim, o art. 128 da Constituição de 1934 estatuía que ficavam sujeitas ao imposto progressivo as transmissões de bens por herança ou legado. O art. 202 da Constituição de 1946 exprimia que os tributos deveriam possuir caráter pessoal além de, sempre que possível, serem graduados conforme a capacidade econômica do contribuinte. A Constituição de 1988 certamente foi a que mais avançou nesse tópico.

Assim, por exemplo, o princípio genérico da solidariedade se insculpe no art. $3^{\circ}, \mathrm{I}$, preceito que fixa como um dos objetivos fundamentais da República Federativa do Brasil a construção de uma sociedade livre, justa e solidária.

Prosseguindo, já dentro do campo tributário especificamente, o $\S 1^{\circ}$ do art. 145 determina que, sempre que possível, os impostos terão caráter pessoal e serão graduados segundo a capacidade econômica do contribuinte. 
$\mathrm{O} \S 2^{\circ}$ do art. 153 estipula que o Imposto sobre a Renda será informado pelos critérios da generalidade, da universalidade e da progressividade. Em linha assemelhada, o $\S 4^{\circ}$ do mencionado art. 153 prevê que o Imposto sobre a Propriedade Territorial Rural terá suas alíquotas fixadas de forma a desestimular a manutenção de propriedades improdutivas e não incidirá sobre pequenas glebas rurais, definidas em lei, quando as explore, só ou com sua família, o proprietário que não possua outro imóvel.

Por fim, o art. $156, \S 1^{\circ}$, incisos I e II, possibilita que o Imposto sobre a Propriedade Territorial Urbana seja progressivo e, ainda, tenha alíquotas fixadas em função da utilização do bem e da sua localização.

As questões da capacidade contributiva, progressividade e solidariedade tributária serão novamente estudadas em momento posterior ao analisar-se o segundo elemento da democracia fiscal.

\subsection{As fontes de recursos financeiros do Estado}

É sabido que o Estado desenvolve suas inúmeras competências quase que exclusivamente por meio do emprego de dinheiro. As hipóteses de préstimos de serviços obrigatórios não remunerados são verdadeiramente raras, quiçá se resumindo aos mesários nas eleições e aos jurados no Tribunal do Júri ${ }^{97}$. Logo, é absolutamente essencial ao Estado arrecadar numerário, sob pena de comprometer a realização das tarefas mais comezinhas.

Em resumo, na atualidade, constata-se que existem cinco maneiras para o Estado auferir os recursos financeiros, existindo diferenças fulcrais entre todas, tanto em tanto em termos quantitativos, quanto qualitativos, conforme a seguir esposado:

1) exploração do patrimônio dominical: o Estado, como pessoa jurídica de direito público, ordinariamente, é titular de vasto patrimônio, o que é reconhecido e definido por normas jurídicas, como, por exemplo, no caso da União Federal, o art. 20 da Constituição de 1988.

\footnotetext{
${ }^{97}$ Aliás, por tal circunstância, o tributo chega a ser qualificado como o preço da liberdade, pois, segundo TORRES (1991, p. 03): "é o instrumento que distancia do homem do Estado", que paga esta prestação e, com isto, se liberta de prestar pessoalmente serviços em prol da comunidade, como ocorrida na era medieval em que os próprios servos realizavam tais tarefas (v.g. abrir estradas, construir pontes, muralhas, fossos, etc.).
} 
Trata-se, na lição de DI PIETRO (2002, p. 544-548): dos bens de uso comum do povo (v.g. praias, praças, jardins, ruas e logradouros, etc.); dos bens de uso especial ou do patrimônio indisponível, assim chamados porque afetados a uma finalidade pública específica ( $v . g$. edifícios que abrigam as diversas repartições e órgãos públicos, hospitais, universidades, escolas, museus, viaturas, ambulâncias, bens móveis em geral, máquinas e equipamentos, obras de arte, etc.); e dos bens do domínio privado ou dominicais, isso é, aqueles não destinados à finalidades públicas determinadas ${ }^{98}$.

Quanto aos últimos, DI PIETRO (idem, p. 548) revela que:

1. comportam uma função patrimonial ou financeira, porque se destinam a assegurar rendas ao Estado, em oposição aos demais bens públicos, que são afetados a uma destinação de interesse geral; a consequiência disto é que a gestão dos bens dominicais, não era considerada serviço público, mas uma atividade privada da Administração; 2. submetem-se a um regime jurídico de direito privado, pois a Administração Pública age, em relação a eles como um proprietário privado. (grifos do original).

Nota-se, outrossim, que a exploração do patrimônio dominical se mostra como fonte capaz de gerar receitas financeiras que, por serem provenientes do seio do próprio Estado, recebem a nominação de "originárias" (ALVES e GOMES, 2001, p. 60; JARDIM, 2008, p. 70; OLIVEIRA e HORVATH, 1997, p. 35). Conforme expõe HARADA (2008, p. 33-35), tais receitas se subdividem, conforme a fonte geradora, em: imobiliárias, mobiliárias, industriais, comerciais e de serviços. Assim:

a) o patrimônio imobiliário já mencionado corresponde justamente aos bens imóveis não afetados a uma finalidade pública;

b) o patrimônio mobiliário corresponde à propriedade de títulos e valores mobiliários (conforme definidos pelo Direito Comercial), bem como de títulos representativos de crédito. Esses valores mobiliários, principalmente as ações, acabam por render frutos que podem assumir a forma de juros ou de dividendos, sendo o Estado o seu destinatário, eis que o titular desses direitos;

${ }^{98}$ Conforme dispõe o art. 64 do Decreto-lei 9.760/46: "Os bens imóveis da União não utilizados em serviço público poderão, qualquer que seja a sua natureza, ser alugados, aforados ou cedidos”. 
c) pelo patrimônio empresarial, o Estado desenvolve atividades econômico-empresariais. No Brasil, a possibilidade de atuação do Estado nessa área somente é possível em razão do art. 173 da Constituição. Atualmente, o Estado é proprietário de diversas empresas: industriais (mineração, siderurgia, indústria bélica etc.), comerciais-serviços (telefonia, energia elétrica, correios, água e esgoto, infra-estrutura etc.) e financeiras (bancos e caixas econômicas e outras instituições financeiras e seguradoras).

O patrimônio empresarial também pode ser denominado de patrimônio industrial (quando se referir apenas à exploração de indústrias) e de patrimônio agropecuário (ao tratar exclusivamente da exploração de atividade agrícola e pecuária, cuja raridade deve ser ressaltada).

É notório, contudo, que o volume das receitas geradas a partir da exploração dos bens dominicais é muito aquém do montante necessário à mínima satisfação das necessidades públicas. Portanto, ainda que revelem boa qualidade, dado que se incorporam ao patrimônio público de maneira perene, a quantidade dessas receitas é, sob todos os aspectos, incipiente.

2) imposição de tributos em geral: o conceito e as características essenciais dos tributos foram vistas logo acima. A Constituição de 1988 menciona expressamente cinco espécies de tributos. São elas: a) os impostos (art. 145, I); b) as taxas (art. 145, II); c) as contribuições de melhoria (art. 145, III); d) os empréstimos compulsórios (art. 148, I e II); e, e) as contribuições gerais (art. 149; art. 195; art. $7^{\text {o }}$, III; art. 212, §5 ; art. 239; art. 240 e art. 62 do ADCT).

Em termos doutrinários, essa classificação é sugerida por MARQUES (2000, p. 247-248). Ressalte-se, porém, conforme retratado por MARTINS (2004, p. 2379), que existe profunda controvérsia na doutrina acerca da existência autônoma de todas as cinco espécies. Contudo, considerando que essa discussão aqui não cabe, eis que em nada acrescentaria à elucidação da proposta inicial, o problema fica apenas mencionado.

O imposto, segundo usualmente compreendido, é um tributo cuja obrigação tem por fato gerador uma situação independente de qualquer atividade estatal específica, relativa ao contribuinte. 
Assim, o imposto é devido em razão da ocorrência de um fato descrito na lei (por exemplo: importar mercadoria, auferir renda, realizar doação, prestar serviço tal, etc.), sendo que esse fato não implica em qualquer ação do Estado em face do sujeito passivo. A obrigação surge apenas e tão somente porque a situação prevista na norma se concretizou.

Então, considerando-se que não há vinculação entre o contribuinte e qualquer atividade estatal, os impostos são denominados de tributos não vinculados (MACHADO, 2002, p. 67). Nessa esteira, na síntese de MARQUES (2000, p. 248):

\begin{abstract}
Impostos: tributos em relação aos quais (a.1) não há exigência constitucional de vinculação da materialidade do antecedente normativo ao exercício de uma atividade por parte do Estado, referida ao contribuinte; (a.2) não há exigência constitucional de previsão legal de destinação específica para o produto de sua arrecadação; e (a.3) não há exigência constitucional de previsão legal de restituição do montante arrecadado ao contribuinte; ao cabo de determinado período.
\end{abstract}

A taxa, em linha diversa, é tributo cobrado com base numa atividade realizada pelo Estado em relação à pessoa do contribuinte. Essa atividade poderá ser o exercício do poder de polícia (v.g. emissão de alvarás e autorizações para o exercício de atividade econômica em geral) ou, ainda, a prestação de serviços públicos específicos e divisíveis, ou seja, que beneficiem sujeito passivo determinado ( $v . g$. fornecimento de água potável, energia elétrica, gás, telefonia, etc.).

Assim, a taxa é chamada de tributo vinculado (MACHADO, 2002, p. 67). Na colocação de MARQUES (2000, p. 248):

Taxas: tributos em relação aos quais (b.1) há exigência constitucional de vinculação da materialidade do antecedente normativo ao exercício de uma atividade por parte do Estado, referida ao contribuinte; (b.2) há exigência constitucional de previsão legal de destinação específica para o produto de sua arrecadação; e (b.3) não há exigência constitucional de previsão legal de restituição do montante arrecadado ao contribuinte; ao cabo de determinado período.

Ademais, tem-se que, em regra, a taxa apenas retribui ao Poder Público, por uma atuação especial e individualizada em proveito de contribuinte determinado, os valores despendidos, não promovendo, por isso, relevante distribuição de renda na sociedade, portanto, sua importância para os fins deste trabalho possui menor relevo. 
Com efeito, a taxa visa precipuamente impedir que alguém obtenha enriquecimento sem causa à custa do Estado, notadamente quando se constituir na contraprestação por serviços públicos.

Essa característica peculiar, inclusive, justifica a não aplicação do princípio da capacidade contributiva em face da taxa, diversamente ao regime dos impostos e contribuições em geral (COSTA, 1996, p. 102).

A contribuição de melhoria se mostra como um tributo devido em razão de obras públicas. Procura-se com sua cobrança retornar ao Estado uma parcela do patrimônio valorizado em decorrência, exclusiva e sem qualquer participação do contribuinte, da implementação de determinada obra pública.

De certa forma, trata-se de aplicar o princípio geral que proíbe o enriquecimento sem causa em linha análoga ao já falado quanto à taxa. Assim, por exemplo, se de uma melhoria urbana qualquer promovida pelo Poder Público (v.g. asfaltamento ruas e avenidas, arborização ou recuperação de parques, construção de linhas de metrô, etc.), os imóveis situados nas vizinhanças se valorizarem, o ente público que realizou o empreendimento poderá tributar a mais valia imobiliária a titulo de contribuição de melhoria.

Em termos gerais, os limites da contribuição de melhoria são: para a Administração, o custo total da obra e, para o contribuinte, a valorização do seu imóvel.

As contribuições de melhoria, na mesma linha das taxas, são tributos vinculados, ou seja, necessariamente, implicam numa ação estatal específica relativa ao contribuinte, no caso, a obra pública. A aplicação dos recursos, da mesma maneira que se dá relativamente aos impostos - e ao contrário das taxas -, é geral e não específica. Segundo condensa MARQUES (2000, p. 248):

Contribuições de melhoria: tributos em relação aos quais (c.1) há exigência constitucional de vinculação da materialidade do antecedente normativo ao exercício de uma atividade por parte do Estado, referida ao contribuinte; (c.2) não há exigência constitucional de previsão legal de destinação específica para o produto de sua arrecadação; e (a.3) não há exigência constitucional de previsão legal de restituição do montante arrecadado ao contribuinte; ao cabo de determinado período. 
Contudo, a contribuição de melhoria apresenta-se como um tributo de pouquíssima utilização, eis que saber a exata valorização do imóvel nos casos concretos, bem como fixar um raio razoável de abrangência do gravame é tarefa verdadeiramente árdua, tantas as nuances a serem vergadas.

Assim, na prática, nota-se, nas últimas décadas, uma quase absoluta ausência desse tributo no direito pátrio. Em consequência, não é absurdo suspeitar da existência de benefícios econômicos decorrentes de inúmeras obras públicas não ressarcidos, o que, em última análise, implica na transferência indireta de renda do Estado para particulares sem que exista motivo relevante para tal resultado.

O empréstimo compulsório mostra marca única e inconfundível dentre as demais espécies de tributos, pois deve ser restituído ao sujeito passivo no prazo e na forma determinada pela lei que o instituir.

Em adição, é necessário que o produto de sua arrecadação tenha aplicação direcionada a neutralizar as causas de sua criação (v.g. calamidade pública, guerra, investimento público de caráter urgente e de relevante interesse nacional). No enfoque de MARQUES (2000, p. 248-249):

Empréstimos compulsórios: tributos em relação aos quais (e.1) não há exigência constitucional de vinculação da materialidade do antecedente normativo ao exercício de uma atividade por parte do Estado, referida ao contribuinte; (e.2) há exigência constitucional de previsão legal de destinação específica para o produto de sua arrecadação; e (e.3) há exigência constitucional de previsão legal de restituição do montante arrecadado ao contribuinte; ao cabo de determinado período.

À semelhança do que se constata em relação às contribuições de melhoria, o empréstimo compulsório é elemento raro em termos tributários, não se tendo notícia de sua implantação há mais de duas décadas.

Por fim, a contribuição geral se notabiliza por ter a arrecadação dirigida ao financiando de determinadas atividades estatais, conforme constitucionalmente definido, tais como: seguridade social, seguro desemprego, desenvolvimento da educação, serviços de aprendizagem e aperfeiçoamento de mão de obra comercial, industrial e rural, fundo de garantia por tempo de serviço, etc. 
Em que pese custear ações específicas que podem beneficiar certas pessoas, as contribuições, em semelhança aos impostos, são tributos não vinculados, isso é, não implicam na necessidade de um benefício concreto sempre ocorrer.

Trata-se de algo em potencial, ou seja, a "vantagem" ocorrerá dependendo de uma série de circunstâncias legalmente designadas (v.g. não obstante o empregado recolher mensalmente um percentual de seu salário à Seguridade, apenas poderá receber o benefício do auxílio doença se contrair enfermidade que o incapacite temporariamente para o labor).

Com isso, vê-se que a contribuição não pode ser exigida de qualquer contribuinte independentemente de sua situação específica. Com efeito, é de rigor a existência de um liame lógico-jurídico que evidencie a relação do sujeito passivo, ainda que indireta e longínqua, com a finalidade definida para a contribuição. Conforme esclarece ATALIBA (1997, p. 170-171):

O arquétipo básico da contribuição deve ser respeitado: a base deve repousar no elemento intermediário (pois, contribuição não é imposto e não é taxa); é imprescindível circunscrever-se, na lei, explicita ou implicitamente um círculo especial de contribuintes e reconhecer-se uma atividade estatal a eles referida indiretamente. Assim, ter-se-á um mínimo de elemento para configuração da contribuição. (...) Em outras palavras, se o imposto é informado pelo princípio da capacidade contributiva e a taxa informada pelo princípio da remuneração, as contribuições serão informadas por princípio diverso. Melhor se compreende isto, quando se considera que é da própria noção de contribuição - tal como universalmente entendida - que os sujeitos passivos serão pessoas cuja situação jurídica tenha relação direta, ou indireta, com uma despesa especial, a elas respeitantes, ou alguém que receba da ação estatal um reflexo que possa ser qualificado como "especial".

Vistas a vôo de pássaro as características mais elementares das espécies de tributos, o que importa consignar é que as receitas oriundas de tais gravames, principalmente as referentes aos impostos e às contribuições gerais, tomadas em seu conjunto, são as mais relevantes para o Estado Fiscal, e isso se manifesta em termos quantitativos e qualitativos. Significa dizer que tais recursos, em regra, superam em volume todos os demais e, ainda, apresentam o melhor resultado em termos de custobenefício em sua aquisição, conforme será mais explicitado adiante. 
3) empréstimo público: são receitas que resultam da participação do Estado no mercado financeiro por meio da oferta de títulos públicos para serem adquiridos pelos particulares em geral. Trata-se, sem embargo de dúvida, de uma ferramenta capaz de gerar elevadas somas de recursos para o Estado, mas, por outro lado, se utilizada de maneira indiscriminada ou irresponsável, pode representar riscos à estabilidade das finanças públicas.

O empréstimo público difere dos tributos na medida em que representa uma relação contratual bilateral, eis que não há qualquer obrigatoriedade na aquisição destes títulos.

No tributo, como já assinalado, a voluntariedade não existe. Outra grande diferença com relação aos tributos é que eles não necessitam serem restituídos (salvo os empréstimos compulsórios), enquanto que, no empréstimo público, o Estado é obrigado a restituir o que recebeu mais os juros contratualmente acordados. É justamente a expectativa de recebimento acrescido no futuro que gera o interesse do mercado em celebrar este tipo de negócio com o Estado.

Portanto, na verdade, as receitas adquiridas através do empréstimo público majoram o patrimônio estatal apenas temporariamente, uma vez que deverá ocorrer a devolução no futuro. Apenas para ilustrar, conforme aponta ROTH (2006, p. 72), em 2004 o Brasil pagou, apenas como juros de sua dívida pública, o montante aproximado de $\mathrm{R} \$$ 125.000.000.000,00 (cento e vinte e cinco bilhões de reais) e, em 2005, as despesas com juros chegaram a $\mathrm{R} \$ 157.000 .000 .000,00$ (cento e cinquenta e sete bilhões de reais).

É natural perceber que, quanto mais elevado for o risco de inadimplência ao termo contratual, maior juro será exigido pelo mercado para adquirir os títulos, o que pode descambar num círculo vicioso, isso é, o mercado percebe que o Governo está passando por dificuldades financeiras e, então, somente mostra interesse em adquirir novos títulos caso os juros equivalham ou superem determinado patamar. Noutra ponta, o Governo, ciente de que necessita urgentemente de numerário para cumprir suas obrigações, oferece juro maior, o que contribuirá para piorar ainda mais suas finanças. 
O montante dos juros, de um modo geral, não é fruto exclusivo de uma opção de política governamental. Nesse ponto, estudos mencionados por DELFIM NETO e GIAMBIAGI (2005, p. 323) indicam que: "quando a relação Dívida/PIB se aproxima de $55 \% / 56 \%$, o mercado sofre uma situação de stress e exige juros maiores para continuar a financiar a dívida". Aliás, nesse tópico o Brasil usualmente percorre uma "corda bamba", pois, segundo indica GIAMBIAGI (2006, p. 02), a relação entre dívida líquida do setor público e o PIB nacional nos últimos anos apresentou a seguinte porcentagem:

\begin{tabular}{|c|c|}
\hline Exercício & Relação dívida pública/PIB \\
\hline 2002 & $55,5 \%$ \\
\hline 2003 & $57,2 \%$ \\
\hline 2004 & $51,7 \%$ \\
\hline 2005 & $53,5 \%$ \\
\hline
\end{tabular}

Logo, o patamar dos juros oferecidos ao mercado não resulta exclusivamente da vontade das autoridades monetárias, sendo certo que existe uma influência relevante nesse ponto advinda da relação dívida pública e o montante do Produto Interno Bruto, que, como é bem sabido, pode variar significativamente segundo conjunturas externas, bastando apontar a crise econômica que eclodiu em 2008 nos Estados Unidos, mas que rapidamente se espalhou por diversos países e criou gigantesca perda de riquezas face à forte recessão ocasionada, talvez a mais grave desde o crash da Bolsa de Nova York em 1929.

Essas circunstâncias prescrevem cautela no manejo do crédito público por qualquer Estado, o que redunda no fato dessas receitas, mesmo que quantitativamente relevantes quando adentram e passam a compor o Tesouro, serem qualitativamente inferiores às tributárias pelo acréscimo meramente temporário que geram no patrimônio público $^{99}$.

Em suma, dependendo do caso, as gerações futuras é que serão oneradas com a obrigação de saldar as dívidas assumidas anteriormente. Aliás, conforme assevera BALEEIRO (1998, p. 475):

99 Por tal motivo, OLIVEIRA (1997, p. 35) denomina estes recursos de "movimento de caixa" e não os considera como verdadeiras receitas públicas. Na mesma linha BALLEIRO (1998, p. 459). 
Uma velha concepção, geralmente aceita, a ponto de tornar-se popular, quer que os empréstimos públicos sejam a técnica pela qual as gerações futuras partilham as despesas da atualidade. Os financistas, que comungam dessa opinião, classificam, então, o crédito público como processo de repartição de encargos governamentais no tempo, em contraste com a tributação, que divide os mesmos gravames apenas entre indivíduos e classes do presente.

4) receitas diversas: como o próprio nome aponta, tratam-se de recursos cuja origem não se encaixa em quaisquer das demais hipóteses. Nesse sentido, podem aqui ser enquadradas, por exemplo, o produto do recolhimento das multas e outras penalidades pecuniárias em geral e das eventuais doações em dinheiro aos cofres públicos (v.g. em prol do programa "Fome Zero" ou para auxílio de flagelados por fenômenos climáticos). É comezinho reconhecer que o montante dessas receitas é ínfimo em vista das competências a serem ordinariamente ultimadas.

5) impressão de moeda: é possível, ainda, que o Estado simplesmente decida por emitir moeda destinada a saldar seus compromissos. Notoriamente, o aumento no meio circulante, segundo já ventilado no item 2.4 retro, gerará inflação dos preços em geral, podendo resultar em instabilidade acentuada nos vetores que comandam a demanda e a oferta por bens e serviços. Em última instância, a emissão indiscriminada de moeda causa instabilidade social, o que torna esses recursos indiscutivelmente de péssima qualidade. Com efeito, não se pode perder de vista que a moeda por si só não é riqueza, apenas representa-a como meio de troca por excelência que é. Logo, a sua impressão em nada modifica o nível de bem-estar social.

\subsection{Os tributos como as receitas públicas mais relevantes}

Embora existam outras fontes capazes de fornecer dinheiro ao Estado, se for levado em conta as variáveis "quantidade relevante" e "perenidade", conclui-se que os tributos ostentam maior qualidade em vista das demais espécies, o que os torna os itens principais de receita pública na atualidade (NABAIS, 2005b, p. 24), pois:

a) as receitas provindas da exploração do patrimônio dominical, não obstante acrescerem o patrimônio com viés definitivo, são notoriamente incipientes frente ao tamanho das necessidades a serem cobertas. O mesmo ocorre em face das receitas originadas por multas e doações em dinheiro; 
b) os recursos oriundos do crédito público, ainda que possam aflorar em quantidade elevada, não representam aumento perene no patrimônio, pois, ao final de certo tempo, devem ser devolvidos ao prestamista com acréscimo de juros. Logo, acrescem o Tesouro apenas temporariamente;

c) a receita criada pela emissão indiscriminada de moeda, conforme visto, não revela qualquer vantagem digna de nota, ao contrário, os custos sociais de tal política costumam em muito superar os eventuais benefícios.

$\mathrm{Na}$ linha do que se afirma, basta atentar, por exemplo, para o Anexo I da Lei 11.897/2008 - do orçamento da União para o exercício de 2009 - naquilo em que cuida da previsão de receitas, conforme a tabela abaixo:

\begin{tabular}{|c|c|}
\hline RECEITAS & MONTANTE EM REAIS \\
\hline Patrimoniais em geral & 8.023 .997 .490 \\
\hline Tributárias & 733.995 .606 .453 \\
\hline Empréstimos públicos & 525.546 .563 .343 \\
\hline
\end{tabular}

Nota-se claramente que as receitas patrimoniais representam parcela diminuta do total esperado. Apesar de as receitas decorrentes do empréstimo público serem consideráveis, sabe-se que no futuro deverão ser restituídas, levando consigo, ainda, a parcela referente aos juros. Assim, não resta alternativa senão concluir que as receitas provenientes dos tributos são, de fato, de melhor qualidade para o Estado, o que torna estratégica as questões ligadas à política tributária de um país.

\subsection{Conclusão do capítulo}

Nesse capítulo verificou-se que contribuições obrigatórias em prol da satisfação das necessidades coletivas se manifestam há milhares de anos nas diversas sociedades que se sucederam ao longo da história, com significativas variações quanto à forma de imposição e sistemática praticada em geral.

Todavia, a figura do tributo, concebida como uma prestação compulsória e ordinariamente devida em dinheiro, instituída mediante lei ou norma equivalente, guiada 
pelo princípio da capacidade contributiva, nasce somente a partir do último quarto do século XVIII, sendo complementada, mais adiante, pelas noções de progressividade e solidariedade tributária.

No Estado Fiscal de Direito, as receitas tributárias são as mais relevantes, seja porque sobrepujam em quantidade todas as demais, seja porque se revelam perenes em termos de acréscimo ao patrimônio público. 


\section{A DEMOCRACIA}

\subsection{O tema}

Na medida em que este estudo se propõe a criar um novo enfoque para a democracia, ou seja, a democracia vista pela ótica fiscal, que deve operar dentro do Estado de Direito e sob a égide de uma Constituição, é de rigor analisar alguns aspectos dessa figura, principalmente, sua evolução histórica, seus enfoques mais comuns e principais valores.

A democracia, em realidade, é uma das formas ${ }^{100}$ de governo que um povo pode adotar. Expõe DALLARI $(1989$, p. 189) que a classificação mais antiga de tais formas foi edificada na Grécia por Aristóteles e tem como base o número de governantes.

Assim, tem-se a tradicional tripartição: realeza, no caso do governo caber a um só indivíduo; aristocracia, quando uns poucos governam e democracia - ou república segundo alguns tradutores -, em face da multidão poder governar. A cada uma destas formas correspondente uma degenerescência, quando quem governa deixa de se inspirar no interesse geral e passa a atentar mais às conveniências particulares. Então, a realeza se degenera em tirania; a aristocracia em oligarquia e a democracia em demagogia, dando origem às formas impuras de governo.

Ainda seguindo a lição de DALLARI (idem, p. 189-192), Maquiavel aprofundou a questão, tecendo considerações sobre o "governo em ciclos".

Do estágio inicial anárquico, "o mais robusto e valoroso" seria escolhido como o chefe que todos os indivíduos obedeceriam, iniciando-se, assim, a monarquia. Entretanto, após certo interregno, seria inevitável a sua transformação em tirania. No passo

${ }^{100}$ Conforme FERREIRA FILHO (1995, p. 65-66), é de se distinguir a forma, o sistema e o regime de governo. Assim, por forma de governo se entende uma definição abstrata ou "pura" de um modo de atribuição do poder, como, por exemplo, a democracia, a aristocracia e a realeza. O sistema de governo corresponde à institucionalização por meio de normas jurídicas (v.g. Constituição, leis, decretos, etc.) de uma das formas possíveis. O regime de governo, por fim, é a maneira efetiva de como se estabelece o poder numa sociedade, visto que nem sempre a prática se identifica com as formas abstratas ou com os preceitos normativos editados pelo Estado. 
seguinte, os indivíduos mais influentes da sociedade, cansados dos abusos do tirano, instituiriam uma aristocracia.

Contudo, novamente com o passar do tempo, em vista do natural desgaste provocado pelas vicissitudes da realidade diária, o regime acabaria se corrompendo numa oligarquia, com abandono da procura inicial de se governar em prol do bem comum, ou seja, os interesses particulares dos poucos governantes é que, em realidade, seriam atendidos.

Por fim, o povo como um todo se revoltaria e, lembrando dos males da tirania e, na intenção de criar um governo que se preocupe antes de tudo com o bem comum, inauguraria a democracia. Porém, mais uma vez, o sistema se degeneraria pela incapacidade do povo para se autogovernar, implicando no retorno à anarquia. Novo ciclo, então, teria início.

Observando-se a realidade atual da maioria dos países, percebe-se sem dificuldade que a democracia pode ser considerada como um valor de alto relevo, isso é, quase todos os povos a colocam como uma de suas bases de organização. Mesmo os governos que pouco toleram a diversidade de opiniões, quiçá por isso totalitários ${ }^{101}$, raramente assim se assumem. Ao contrário, é usual que se proclamem como servos da democracia, independentemente do que sua prática política seja capaz de mostrar.

Ocorre que, segundo alerta COMPARATO (2006, p. 190): "Essa unanimidade atual, constituída em torno da democracia, é evidentemente suspeita". Significa dizer, por conseguinte, que essa onda democrática atualmente vivenciada pela humanidade somente pode ser avaliada analisando os casos concretos dos diversos povos, pois tomar o fenômeno como uma tendência universal é arriscado.

Feita essa primeira advertência, é necessário reconhecer, nos dizeres de AIETA (2006, p. 101), que a democracia se mostra: "como o sonho acalentado pela Humanidade através dos tempos, cujo alicerce principal reside no sentimento de fraternidade humana".

${ }^{101}$ Segundo BOBBIO (1988, p. 37): "o Estado totalitário, que é o Estado no qual a sociedade civil é inteiramente absorvida pelo Estado, é um Estado sem opinião pública (isto é, com uma opinião pública apenas oficial)". 
Portanto, a figura da democracia é dotada de uma força intrínseca, como a pedra angular de um grande templo, algo que serve de sustento para todo um sistema social de valores que constantemente irradia as diversas normas que regulam a convivência humana, cujo perecimento é capaz de fazer ruir toda construção anteriormente feita em seu nome.

A primeira e mais basilar noção de democracia, conforme tradição inaugurada na Grécia antiga, notadamente em Atenas, é em sentido político, de modo que sua prática implique na maior coincidência possível entre governantes e governados, presumindo-se que, se as decisões são tomadas pela maioria, há maior probabilidade de se atender aos interesses coletivos, ao bem comum de determinada sociedade. Nessa linha, não restam dúvidas, pela exposição de BOBBIO (1995, p. 31), que:

O pensamento político grego nos transmitiu uma célebre tipologia das formas de governo das quais uma é a democracia, definida como o governo dos muitos, dos mais, da maioria, ou dos pobres (mas onde os pobres tomam a dianteira é sinal de que o poder pertence ao pléthos, à massa), em suma, segundo a própria composição da palavra, como o governo do povo, em contraposição ao governo de uns poucos.

Em suma, conforme sintetiza STARR (2005, p. 55): "A democracia, afinal, é um sistema de governo em que aqueles que em geral são considerados capazes de avaliar por si mesmos a situação política têm a última palavra". O ideal limite, mais uma vez segundo BOBBIO (2006, p. 31), é a oniocracia, isso é, o governo de todos.

Todavia, é certo que existem diversas nuances em torno dessas ideias aqui inicialmente postas, a começar pelo sentido que se dá à democracia, que certamente varia muito ao redor da Terra, dependendo inclusive de questões ideológicas, circunstâncias de tempo e de local enfocado, sendo muito claro reconhecer que o que se entende hoje por democracia é bem diverso do que já se concebeu no passado.

Em adição, ainda mais se for levado em conta os valores primordiais que permeiam a democracia - sufrágio, liberdade e igualdade -, hodiernamente, a análise do tema não comporta apenas a dimensão estritamente política, mas permite, e até impõe, seu estudo sob enfoques variados e mais complexos, tais como, por exemplo, a democracia substancial, que coloca em relevo de destaque a igualdade material - e não apenas formal entre os cidadãos. 


\subsection{Os tipos de democracia e sua prática}

Inaugura-se esta exposição pela denominada democracia direta, cuja primeira prática na humanidade tem início em 509 a.C. quando Clístenes reformou as leis antes postas por Sólon e tem seu fim em 322 a.C., conforme expõe AIETA (2006, p. 145).

É considerada direta porque as decisões eram tomadas em assembleia pelo voto direto proferido pelos presentes que gozavam de isonomia (igualdade entre todos os votantes - o voto de cada um contava com o mesmo peso dos demais), isotomia (qualquer cidadão poderia ascender aos cargos públicos) e isagoria (garantia de amplo direito de manifestação àqueles aptos a votar nas assembleias) ${ }^{102}$.

Ressalte-se, porém, que apenas uma minoria de habitantes - os cidadãos $^{103}$ - gozavam de tal direito. Na estimativa de STARR (2005, p. 54), antes da Guerra do Peloponeso (entre 431 a 404 a.C.), aproximadamente 18\% da população estava apta a votar, ou seja, algo em torno de 43.000 eleitores para um total de 172.000 residentes $^{104}$.

Ainda segundo o autor em foco (idem, p. 55 e ss.), como a maioria dessas pessoas estava fixada nas regiões rurais, distantes até 45 quilômetros da Ágora, dada as sérias dificuldades locomotivas de então, bem como a imperiosidade do cuido diuturno da terra, apenas uma minoria dos cidadãos - os mais bem situados economicamente realmente compareciam às cerca de 40 sessões anuais da Assembleia, o que, na prática, reduzia bastante o número de votantes.

Com efeito, entre a população rural, aqueles que dispunham de um burro para o deslocamento já seriam considerados ricos e, na área urbana, a maior parte dos cidadãos laborava de maneira estafante na cidade ou nas docas. Destarte, somente questões

\footnotetext{
${ }^{102}$ Na Roma antiga, pela lição de LEWANDOWSKI (2005a, p. 195), apenas os cidadãos de pleno direito (optimo jure), ao contrário dos estrangeiros (peregrini), detinham direitos políticos (jura politica), correspondentes ao voto nos comícios, elegibilidade para as magistraturas, acesso ao sacerdócio e a faculdade de apelar quando processados.

${ }^{103}$ Conforme STARR (2005, 53): "Chegando à idade adequada, os filhos eram apresentados pelos pais a seus pares e dêmos: deviam prestar dois juramentos - de que o filho tinha 18 anos e de que era realmente um cidadão, ou seja, o fruto de um casamento legal ou que tivesse sido adotado oficialmente para portar o nome da família".

${ }^{104}$ Interessante notar, na constatação do autor (idem p. 56), que passados mais de 20 séculos, no máximo $20 \%$ da população norte-americana de 1860 detinha o direito de voto, proporção quase idêntica à de Atenas do século V a.C.
} 
de muita relevância tinham a força necessária para reunir grande número de interessados em votar. Não significa dizer, entretanto, que os atenienses não valorizavam a participação política dos cidadãos. Noticia COMPARATO (2006, p. 197) que:

De um modo geral, sempre foram vistos com maus olhos os que se abstinham sistematicamente de comparecer e votar nas reuniões da Ekklesia, sendo por isso qualificados como idiotai, ou seja, indivíduos unicamente preocupados com os assunto de seu interesse particular. A neutralidade política, de resto, era considerada em Atenas como uma atitude contrária ao bem comum.

A questão do trato com as finanças públicas e a respectiva fiscalização daqueles que com elas lidavam já se fazia presente então. Conforme narra STARR (idem, p. 68-69):

Os atenienses estavam longe de confiar uns nos outros no que se refere ao dinheiro público; no fim do seu mandato, os auditores investigavam todos os magistrados que houvessem lidado com os fundos do Estado, e a cada pritania um comitê do conselho também examinava as contas públicas. Mesmo assim, Aristóteles observava com pesar que os seus contemporâneos queriam sempre obter cargos públicos, "movidos pelos lucros a serem obtidos dos cargos e do trato da propriedade pública". No século IV, os generais e oradores também podiam obter vantagens consideráveis de seus cargos, provavelmente de subornos vindos do estrangeiro, como se havia anteriormente alegado com relação a Temístocles.

Infelizmente, nota-se que, mesmo passados mais de 2.500 anos de convivência humana, a sanha por se apoderar da "coisa pública", em franco prejuízo do bem comum, ainda persiste, em que pesem os cuidados legais e judiciais para sua erradicação, tais como: a atuação dos Tribunais de Contas em auxílio ao Poder Legislativo no desempenho do controle externo dos órgãos públicos, os remédios judiciais da ação popular e da condenação por improbidade administrativa, bem como, em último grau, as sanções penais.

É intuitiva a extrema dificuldade, para que não se diga impossibilidade, de se efetivar a democracia direta na atualidade, na qual todos os cidadãos possam ter voz ativa nas mais diversas questões de governo. Por primeiro, haveria o problema do espaço físico, ou seja, deveria ser superada a questão de como alojar milhares - ou até milhões de pessoas em assembleia com todas as implicações daí inerentes (v.g. segurança, fornecimento de água e alimentos, sanitários, etc.). 
Não seria absurdo aqui conceber um sistema de participação à distância, por meio eletrônico através da internet, verdadeira revolução nas comunicações de massa. Logo, esse impasse, desde que os votantes tenham acesso aos competentes terminais e saibam operá-los, é, em tese, superável.

Contudo, o obstáculo mais árduo não parece ser a garantia do acesso ao voto, mas a capacitação do eleitor para opinar de forma direta e decisiva acerca de questões que muitas vezes se encontram bastante além de compreensão usual da maioria dos seres humanos, e cuja interação demandaria esforços de monta, seja em termos de tempo, ou mesmo de dinheiro. Aliás, é notório que muitas das decisões a serem tomadas dentro de qualquer Estado comportam elevadíssima complexidade e sofisticação.

Imagine-se, por exemplo, a perplexidade de um médico, ou de um engenheiro, e por que não de um jurista, frente a um assunto que envolva política financeira, cambial ou creditícia. A árida tecnicidade destes temas, por uma questão de prudência e bom senso, recomenda que seu exame fique a cargo do corpo técnico e especializado de funcionários que compõem os quadros das instituições burocráticas especialmente concebidas para decidir a respeito (v.g. Banco Central, Ministério da Fazenda, etc.).

Nesse ponto, não se pode descartar que possivelmente a maioria dos cidadãos preferiria praticar a chamada "ignorância racional", isso é, uma opção deliberada por não se aprofundar em certos temas, toda vez que o ganho daí advindo não compensar os recursos empregados no respectivo esclarecimento.

Então, em muitas ocasiões, ou o indivíduo não compareceria para votar, ou, se o fizesse, a probabilidade de proferir uma opinião inconsequente, impensada ou imprestável seria muito grande, ainda que firme estivesse na intenção de escolher a melhor saída. Frise-se que opções mal sucedidas geralmente geram graves custos sociais e retardam o aumento do padrão de vida dos mais pobres.

Também não se pode deixar de considerar que um número considerável de votantes optaria pela pura mesquinharia, não comparecendo à Assembleia para não deixar de receber algum recurso em face do exercício de profissão ou atividade econômica, 
revelando essa atitude um verdadeiro comportamento free ride (carona livre), uma vez que estariam transferindo a terceiros - os votantes - os ônus das escolhas feitas e não teriam "perdido o dia".

O tema da aptidão do povo para governar não é novo e chegou a ser tratado pelos gregos. Noticia COMPARATO (2006, p. 206) que: "muito se falou naquela época da amathia popular, substantivo que na língua grega continha a dupla significação de ignorância e tolice". Aqui, chamam-se à baila as seguintes palavras de BOBBIO (2006, p. 69):

O efeito do excesso de politização pode ser a revanche do privado. A participação multidirecional tem seu reverso da medalha, que é a apatia política. O custo que se deve pagar pelo empenho de alguns é com frequiência a indiferença de muitos. Ao ativismo dos líderes históricos ou não-históricos pode corresponder o conformismo das massas.

Essa realidade, contudo, não significa a inexistência de mecanismos capazes de engendrar um governo que procure atender minimamente ao bem comum. Reconhece e aduz COMPARATO (2006, p. 205) sobre esse tema que:

O povo soberano não pode e não deve governar. O governo, sobretudo nas sociedades altamente complexas do mundo moderno, é uma tarefa especializada, que deve ser deixada a cargo de agentes executivos. Mas compete, antes de tudo, ao povo o poder-dever de controlar a ação dos governantes ${ }^{105}$.

A verdade é que democracia exercida na forma direta se mostrou um fenômeno político de extrema raridade, ao menos da maneira como ultimada na Atenas do século IV a VI a.C., destacando-se que, uma vez suplantado aquele sistema, a ideia somente ressurge muitos séculos depois no ultimo quarto do século XVIII com o pensamento iluminista e liberal.

Todavia, não se pretendia instituir um sistema assemelhado aos antigos gregos, mas, ao contrário, a partir do pressuposto da impossibilidade de se governar com a participação direta dos cidadãos, salvo em Estados muito reduzidos em termos de território

\footnotetext{
${ }^{105}$ Segundo o autor, esses mecanismos são: a) aprovação de uma Constituição; b) fixação de diretrizes de governo; c) eleições periódicas para o Legislativo e Executivo; d) poder de fiscalização direta sobre os titulares dos cargos públicos, com a respectiva punição dos faltosos (idem, p. 205-206).
} 
e de população, ou seja, absolutas exceções à regra geral, intentava-se implantar a democracia indireta ou por representação.

Nessa esteira, as críticas de $\operatorname{ROSSEAU~(1973,~p.~} 90$ e ss.) contra a democracia direta são contundentes, acusando-a de ser carente de estabilidade, com as seguintes palavras:

não há forma de governo tão sujeita às guerras civis e às agitações intestinas quanto a forma democrática ou popular, porque não há outra que tenda tão forte e continuamente a mudar de forma, nem que exija mais vigilância e coragem para ser mantida na forma original. É sobretudo nessa constituição que o cidadão deve armar-se de força e constância, e ter presente no coração, todos os dias da vida, o que dizia um palatino virtuoso na dieta da Polônia: Malo periculosam libertatem quam quietum servitium. Se existisse um povo de deuses, governar-se-ia democraticamente.

Assim, a ideia central da democracia indireta prega que as decisões políticas e de governo sejam tomadas por representantes eleitos pelo povo para tal finalidade, teoricamente, os mais aptos a desenvolverem a tarefa, sendo que, dentro dessa proposta, se encaixam as seguintes variações: sistema puro ou tradicional, democracia pelos partidos e democracia cesarista ou plebiscitária.

Foi o sistema puro ou tradicional que primeiramente restou implantado pelas revoluções liberais do final do século XVIII. Na lição de DALLARI (1989, p. 124125), o Estado democrático nasceu das lutas contra o absolutismo, sendo através de três grandes eventos políticos que se transpõe do plano teórico ao prático os seus princípios basilares, a saber: a Revolução Inglesa, com o Bill of Rigths de 1689; a Revolução Americana, com a Declaração de Independência das 13 colônias de 1776; e, a Revolução Francesa, com a Declaração dos Direitos do Homem e do Cidadão de 1789.

A esse respeito, segundo explica AIETA (2006, p. 185): "Nesse tipo de democracia, existe a perfeita distinção entre governantes e governados, sendo que estes escolhem os primeiros mediante processo seletivo. Após isso, passam a representá-los, sobretudo na votação das mudanças no Ordenamento Jurídico do Estado". Na prática, contudo, conforme explana FERREIRA FILHO (1995, p. 71-72): 
Esse governo representativo era um sistema imaginado para institucionalizar a forma aristocrática de governo. Visava-se a dar o efetivo exercício do poder à minoria dos mais capazes, eleitos pelo povo em geral. Esta era a intenção de Montesquieu ao lançar n' $O$ espírito das leis, as bases da representação e, mais tarde, de Siéyès, ao fixar definitivamente os seus traços, em plena Revolução Francesa. Esta, aliás, claramente opunha o governo representativo, que propugnava, ao governo democrático, que lhe repugnava.

Segundo DALLARI (1989, p. 156): “quando se buscou, na França do século XVIII, a afirmação do sufrágio universal, o que se pretendia era abrir caminho para a participação política dos que, não sendo nobres, não tinham qualquer posição assegurada por direito de nascimento".

Constata-se, portanto, que os governos surgidos nessa época possuíam nítido caráter aristocrático, notadamente porque em muitos locais o exercício dos direitos políticos basilares de votar e ser votado foi vinculado à posse de certa renda e ou patrimônio, o que se deu inclusive no Brasil com a Constituição de 1824, que não permitia dúvidas acerca dessa inclinação, conforme se demonstra pela transcrição de alguns preceitos que bem ilustram o tema:

Art. 45. Para ser Senador requer-se:

(...)

IV. Que tenha de rendimento annual por bens, industria, commercio, ou Empregos, a somma de oitocentos mil réis.

Art. 92. São excluidos de votar nas Assembléas Parochiaes.

(...)

V. Os que não tiverem de renda liquida annual cem mil réis por bens de raiz, industria, commercio, ou Empregos.

Art. 93. Os que não podem votar nas Assembléas Primarias de Parochia, não podem ser Membros, nem votar na nomeação de alguma Autoridade electiva Nacional, ou local.

Art. 94. Podem ser Eleitores, e votar na eleição dos Deputados, Senadores, e Membros dos Conselhos de Provincia todos, os que podem votar na Assembléa Parochial. Exceptuam-se

I. Os que não tiverem de renda liquida annual duzentos mil réis por bens de raiz, industria, commercio, ou emprego.

Art. 95. Todos os que podem ser Eleitores, abeis para serem nomeados Deputados. Exceptuam-se

I. Os que não tiverem quatrocentos mil réis de renda liquida, na fórma dos Arts. 92 e 94. 
Tais características levam COMPARATO (2006, p. 193) a afirmar que: "a grande falsidade da democracia moderna é a atribuição ao povo de uma soberania puramente retórica ou ornamental". Mais adiante, o autor enfatiza sua ideia ao consignar que:

Comparada com a matriz grega, ela representou, pelo menos no início, uma completa inversão funcional. O mecanismo de representação popular, que deu origem à democracia formal, constituiu, na realidade, um claro impedimento à soberania do povo. Ele serviu para encobrir, sob uma aparência democrática, a consolidação do sistema oligárquico, ou seja, o regime da soberania dos ricos (idem, p. 197).

Mesmo sob a égide do sufrágio restrito, logo se percebeu a incompletude do sistema representativo puro na medida em que o eleito, uma vez investido no cargo, não obstante exercer um mandato, não possuía qualquer vínculo jurídico com os votantes que o obrigasse a seguir certas orientações ou mesmo a prestar contas de suas ações (FERREIRA FILHO, 1995, p. 78).

O alívio desse inconveniente, mesmo que não tenha representado uma solução final, passou pela democracia dos partidos, entidades que, inicialmente, desempenharam papel semelhante ao de uma associação de direito privado com objetivo primordial de defender o interesse de seus membros e não propriamente promover o aperfeiçoamento da consciência política do povo ou mesmo de cuidar do planejamento de governo em caso de vitória nas eleições.

Entretanto, superado o viés privatístico inaugural, o partido político passou a ter papel muito mais relevante, pois, ao menos em teoria, foi pensado de modo a desempenhar duas tarefas importantes.

A primeira, com a elaboração de programas governamentais suficientemente precisos e exequíveis. Portanto, o eleitor estaria votando com base no programa apresentado ao invés de votar no candidato, ou seja, não escolheria um mero representante totalmente desvinculado de qualquer tipo de compromisso assumido na campanha, mas optando por um programa previamente traçado.

A segunda, na seleção prévia de possíveis candidatos, dentre os cidadãos mais qualificados e dispostos a trabalharem pelo bem comum. Sob essa suposição, que 
sabidamente na prática não se mostrou verdadeira, ao menos de forma plena, expõe FERREIRA FILHO (1995, p. 79) que: "o povo se governaria, ainda indiretamente, por fixar também a orientação do governo e não apenas designar os representantes que, livres de qualquer predeterminação, tomariam, em seu nome e em seu lugar, as decisões políticas".

Pressuposto dessa ideia é a fidelidade ao partido, pois se livre fosse a mudança de agremiação, sem qualquer tipo de sanção ao eleito, o sistema ruiria por completo, uma vez que não seria possível assegurar que as decisões tomadas no cumprimento do mandato seriam conforme a orientação partidária. Não haveria qualquer segurança.

Disso decorre que o mandato pertenceria ao partido e não ao eleito, sendo possível, nessa linha, destituir o parlamentar que desbordasse das instruções do partido, substituindo-o por outro.

Entretanto, esse modelo também não se mostrou suficientemente adequado para garantir uma representação menos oligárquica, sendo certo que os programas apresentados raramente foram precisos, ao contrário, sempre enveredaram por preleções excessivamente genéricas com a finalidade de acomodar interesses variados que poderiam se conflitar em caso de maior precisão do programa inicial (v.g. promover e garantir a democracia, o desenvolvimento nacional em prol do bem comum).

Em suma, o máximo que os programas partidários ainda hoje conseguem fazer é apontar para uma tendência de governo e modelo de Estado, mas sem que exista, de fato, compromisso nessa implantação. Os exemplos são tão conhecidos que dispensam maiores comentários.

Além disso, sobre os partidos políticos, assevera AIETA (2006, p. 122)

que:

Malgrado sua importância, têm sido objeto de profundas lesões, tais como: o abuso do poder econômico pelas elites, a dificuldade da vinculação do deputado para com o seu eleitor e com o próprio partido, sendo vítimas, por fim, de um sistema que os enfraquece, já que a disputa 
eleitoral transforma-se, muitas vezes, numa luta implacável entre candidatos de uma mesma legenda.

Contudo, não obstante os problemas inerentes à dinâmica dos partidos políticos em ação numa democracia, a autora (idem, p. 198) reconhece que:

o partido político torna-se um canal vital para a difusão e o ajuste das parcelas mais próximas da opinião pública, sendo também veículo garantidor da ação política organizada, entre eleitores e eleitos, com a finalidade de transformar as linhas mestras da opinião pública em decisão política (grifos do original).

Nessa esteira, os partidos políticos seriam uma consequência inevitável da democracia eleitoral de massa, organizando a opinião pública a ponto de tornar as eleições, ao menos em teoria, uma escolha entre um rol de alternativas.

A democracia cesarista ou plebiscitária consiste em conferir o poder a um dirigente único, havendo consulta diretamente ao povo acerca de medidas importantes. Na realidade, esse sistema sempre procurou disfarçar ditaduras, sendo aplicado por Napoleão, Napoleão III e Hitler, segundo noticia FERREIRA FILHO (1995, p. 81).

Aliás, na informação de COMPARATO (2006, p. 214): “É preciso não esquecer que a junção dos cargos de presidente do Reich e chanceler em 1934, que instituiu a ditadura, bem como as nefandas leis anti-semitas de 1935, foram aprovadas em plebiscitos por $90 \%$ do povo alemão".

Com efeito, a experiência demonstrou que, por diversos fatores (v.g. propaganda oficial, horror ao vazio, medo da incerteza, etc.), o povo acaba sempre dizendo sim ao "César", o que culmina no desenfreio do poder. Em adição, pelo alerta de AIETA (2006, p. 186-187):

submeter uma decisão política à multidão reduz necessariamente o resultado desta empreitada na simples escolha entre a manifestação da aprovação ou da rejeição de cada indivíduo, ou seja, o indivíduo não teria uma participação efetiva no processo de feitura da lei, não sendo possível examiná-la nas minúcias nem tampouco lhe propor as devidas alterações.

Recentemente, a América Latina parece querer repetir a experiência com Presidentes da República que intencionam permanecer no cargo indefinidamente e, para 
tanto, se utilizam da consulta direta com o mote de obter autorização popular para concorrerem quantas vezes desejarem nas eleições.

O exemplo mais conhecido é Hugo Chaves na Venezuela, que iniciou o primeiro mandato em 1998 e, durante esse período, promoveu vários plebiscitos, sendo que no início de 2009, por meio desse expediente, a maioria da população permitiu fosse eterno candidato, ressaltando-se que, no final de 2007, também por meio de plebiscito, havia sido derrotado nesse intento.

Em continuação, a terceira espécie de democracia é a semidireta. Aqui, existe a representação tradicional, geralmente um parlamento composto por meio de eleições periódicas, que convive com a possibilidade de participação dos cidadãos de forma direta, por exemplo, nos referendos, plebiscitos, projetos de lei de iniciativa popular e o chamado recall. Desse modo, a hegemonia parlamentar resta contra-balançada pela participação direta dos cidadãos em certas ocasiões excepcionais.

O referendo normalmente é uma consulta à opinião pública acerca de uma Emenda Constitucional ou uma lei em face de interesse público relevante, e pode ser ante legem ou post legem. Esclarece DALLARI (1989, p. 130) que: “A origem do referendum se encontra nas antigas Dietas das Confederações Germânicas e Helvéticas, quando todas as leis eram aprovadas ad referendum do povo".

Nesse tópico, COMPARATO (2006, p. 213) situa sua origem no século XIII e afirma, ainda, que: "O principal órgão do governo cantonal era a Landsgemeinde, assembleia de todos os homens livres, que deliberava soberanamente sobre as questões de maior importância na comunidade e votava as normas gerais do cantão".

Quanto ao plebiscito, outra maneira de participação popular nas decisões políticas, segundo expõe COMPARATO (idem, p. 214):

Originalmente, eram denominadas as decisões (scita) votadas pelo concílio da plebe e autorizadas pelo senado, em Roma. Sua obrigatoriedade, por isso mesmo, só existia, de início, para a própria plebe e não para o patriciado. Em 287-286 a.C., no apogeu da república, a lex Hortensia suprimiu a autorização do senado e tornou tais decisões da plebe obrigatórias para todo o populus Romanus. 
Atualmente, essa figura mostra-se como uma consulta prévia ao povo de caráter excepcional, uma vez que diz respeito à questão de alto relevo, ligado a princípio constitucional, forma de Estado ou de governo. Trata-se, conforme DANTAS (2009, p. 133), da denominada forma ampla.

Assim, por exemplo, conforme determinado pelo art. $2^{\circ}$ do Ato das Disposições Constitucionais Transitórias da Constituição de 1988: "No dia 7 de setembro de 1993 o eleitorado definirá, através de plebiscito, a forma (república ou monarquia constitucional) e o sistema de governo (parlamentarismo ou presidencialismo) que devem vigorar no País", tendo sido escolhido a república e o presidencialismo.

Noutro giro, o plebiscito deve ser utilizado também nas hipóteses de incorporação, subdivisão e desmembramento de Estados e Municípios (art. 20, $\S \S 3^{\circ}$ e $4^{\circ}$ da Constituição de 1988). É a chamada forma orgânica (DANTAS, idem, p. 133).

Outro instrumento de participação direta do povo nas decisões políticas é facultar a certo número mínimo de eleitores, ou mesmo a associações representativas de certas categorias econômicas ou profissionais, o poder de apresentar projetos de lei junto ao Poder Legislativo, deflagrando, destarte, o processo legislativo. Trata-se da chamada iniciativa popular.

O Texto Magno de 1988 prevê legisladores eleitos periodicamente no âmbito de todos os entes federativos e também a realização de referendos, plebiscitos e a figura da iniciativa popular legislativa, nos termos do seu art. 14.

Entretanto, as exigências postas para que um processo legislativo seja deflagrado por meio da iniciativa popular são de monta, segundo se depreende do disposto no $\S 2^{\circ}$ do art. 62 , ou seja:

$\S 2^{\circ}$ - A iniciativa popular pode ser exercida pela apresentação à Câmara dos Deputados de projeto de lei subscrito por, no mínimo, um por cento do eleitorado nacional, distribuído pelo menos por cinco Estados, com não menos de três décimos por cento dos eleitores de cada um deles.

Certamente, o rigorismo engendrado pelo dispositivo acima funciona como barreira quase instransponível à inauguração de projetos legislativos que tenham os 
cidadãos como seus autores diretos. Então, quiçá para minimizar essa circunstância, a Câmara Federal criou, no ano de 2001, a Comissão de Legislação Participativa. Segundo esclarece o site da entidade ${ }^{106}$ :

A Comissão de Legislação Participativa (CLP) da Câmara dos Deputados foi criada em 2001 com o objetivo de facilitar a participação da sociedade no processo de elaboração legislativa. Através da CLP, a sociedade, por meio de qualquer entidade civil organizada, ONGs, sindicatos, associações, órgãos de classe, apresenta à Câmara dos Deputados suas sugestões legislativas. Essas sugestões vão desde propostas de leis complementares e ordinárias, até sugestões de emendas ao Plano Plurianual (PPA) e à Lei de Diretrizes Orçamentárias (LDO).

Para ampliar o acesso da população ao Poder Legislativo, a CLP também disponibiliza um Banco de Idéias, formado por sugestões apresentadas ao Parlamento pelos cidadãos e cidadãs brasileiros individualmente.

Por meio desta Comissão, a Câmara dos Deputados abre à sociedade civil um portal de acesso ao sistema de produção das normas que integram o ordenamento jurídico do País, chamando o cidadão comum, os homens e mulheres representados pelos Deputados Federais, a levar diretamente ao Parlamento sua percepção dos problemas, demandas e necessidades da vida real e cotidiana.

Na lição de DALLARI (1989, p. 131), nos Estados Unidos, é possível encontrar uma diferenciação entre a iniciativa popular direta e indireta. Na primeira, um projeto legislativo contendo assinatura de número mínimo de cidadãos deve ser submetido à aprovação popular nas próximas eleições.

Na segunda, o Poder Legislativo Estadual tem a faculdade de discutir e votar projeto legislativo dos eleitores antes de sua submissão à aceitação popular nas eleições. Apenas no caso de sua rejeição é que se tomará a opinião dos eleitores, havendo Estados que, nesses casos, exigem número adicional de assinaturas apoiando o projeto de modo a submetê-lo à decisão popular em seguida.

Oriundo do sistema norte americano, tem-se o recall, figura que, tanto pode operar no sentido de anular a eleição de um legislador ou funcionário eletivo, quanto para reformar uma decisão judicial. No primeiro caso, pela lição de DALLARI (1989, p. 131):

106 Disponível em <http://www2.camara.gov.br/comissoes/clp/comissao.html>. Acesso em: 26.03.2009. Anota-se que a Associação dos Juízes Federais do Brasil - AJUFE apresentou o primeiro projeto de lei no âmbito desta Comissão, que tomou o $\mathrm{n}^{\circ}$ 5828/2001, convertido posteriormente na Lei 11.419/2006, e trata da informatização do processo judicial. Infelizmente, ao menos até a presente data, não se tem notícia de outro projeto ofertado perante a Comissão que tenha se transformado em lei. 
exige-se que um certo número de eleitores requeira uma consulta à opinião do eleitorado, sobre a manutenção ou revogação do mandato conferido a alguém, exigindo-se dos requerentes um depósito em dinheiro. Em muitos casos, dá-se àquele cujo mandato está em jogo a possibilidade de imprimir sua defesa na própria cédula que será usada pelos eleitores. Se a maioria decidir pela revogação esta se efetiva. Caso contrário, o mandato não se revoga e os requerentes perdem para o Estado o dinheiro depositado.

O recall judicial, ainda segundo DALLARI (idem, p. 131), foi preconizado por Theodore Roosevelt em 1912 numa de suas campanhas eleitorais. Trata-se de uma figura altamente controvertida, eis que, por decisão de certo número de eleitores, veredictos de juízes ou de Tribunais, com exceção daqueles proferidos pela Suprema Corte, que considerassem uma lei inconstitucional, poderiam ser revistos.

Vários Estados norte americanos chegaram a adotar o recall judicial em suas Constituições, sendo que a figura foi levada a efeito principalmente com objetivo de superar a obstaculização judicial à aplicação de certas leis sociais. Em verdade, o recall judicial pode significar quebra na segurança jurídica que alicerça a estabilidade institucional de qualquer sociedade que pretenda viver em paz, frisando-se que as decisões judiciais ordinariamente são muito mais inspiradas pela técnica jurídica do que por sopesamentos políticos.

Não obstante sua restrita utilização, é razoável reconhecer, conforme expressa AIETA (2006, p. 181), que o recall - excepcionando-se o judicial pelos motivos retro alinhados - se mostra como: "uma arma democrática para o povo, permitindo aos eleitores controlarem politicamente os funcionários públicos e os parlamentares, com maiores possibilidades de concretizar, em nível prático, o princípio constitucional democrático".

Nesse sentido, é possível inferir que, sob a ameaça constante de um recall, no mínimo, haveria maior cuidado dos parlamentares em seguirem uma linha ideológica que revele coerência básica com suas propostas de campanha, restringindo, por exemplo as trocas de partido motivadas por vantagens pessoais.

Então, quiçá para não se sujeitarem aos respectivos efeitos, nunca se percebeu tenham os legisladores efetivamente se preocupado em desenvolver a aplicação 
do recall em quaisquer de suas modalidades. Aliás, no direito brasileiro atual trata-se de uma figura ausente.

Contudo, a questão das vantagens do recall para o aperfeiçoamento da democracia é de alta complexidade, merecendo, destarte, grande e aprofundada reflexão, na medida em que, por detrás de uma proposta dessa magnitude, perfeitamente, podem estar escondidos interesses inconfessáveis de grupos favoráveis à destituição de certo indivíduo, que atuarão de modo ostensivo junto à população na tentativa de induzi-la a escolher certo caminho que nem sempre coincidirá com o interesse público.

Diante de todas essas ferramentas de participação popular nas decisões políticas de um país, é que AIETA (2006, p. 116) denomina a democracia semidireta de sistema democrático participativo, considerando que

não obstante ser um sistema cuja base decisória do poder se dá por via oblíqua (indireta), isto não significa que os cidadãos não possam também exercer diretamente, em certas circunstâncias, e, através de instrumentos decisórios conjugados ou diretos, os poderes governamentais.

Constata-se, ademais, que, nesse modelo de democracia, existe um elo de interseção que aproxima a utopia da democracia direta à tendência oligárquica da indireta. Nessa dinâmica, reforçando essa ligação, há a participação dos partidos políticos como os verdadeiros titulares dos mandatos eletivos. Trata-se, na lição de LEWANDOWSKI (2005b, p. 178), da "transmudação da democracia representativa para uma democracia participativa".

Todavia, é de se considerar que muito mais relevante do que a previsão textual de tais ferramentas, é identificar como elas operam na prática, o que também se aplica à figura da representação pelo mandato parlamentar. Nesse exato ponto, BOBBIO (2006, p. 56) adverte ser um: “dever da crítica descobrir e denunciar as soluções meramente verbais, transformar uma fórmula de efeito numa proposta operativa, distinguir a moção dos sentimentos de conteúdo real”.

Portanto, é a partir dessa asserção que se passa a analisar os valores elementares da democracia, conforme vêm sendo entendidos ao longo do tempo, bem como os reflexos trazidos em face das suas aplicações. 


\subsection{Valores da democracia e suas implicações}

A opção de um povo pela democracia e suas diversas vertentes é eminentemente política. Ora, se de opção política se trata, entra em cena determinadas escolhas que, por sua vez, são adotadas com fundamento em certos valores e objetivos a serem alcançados. Nessa linha, a partir de agora, serão expostos os valores primordiais da democracia, bem como as implicações daí advindas. São eles: o sufrágio, a igualdade e a liberdade.

O sufrágio é o primeiro grande valor da democracia, uma vez que confere ao cidadão o direito de participar da vida política de uma sociedade de maneira pacífica, o que se revela muito importante, ainda mais se for considerado que as rebeliões e as guerras civis como um todo, em regra deflagradas com intenção de modificar os rumos políticos anteriormente traçados, sempre geram enorme perda de vidas e bens materiais, resultando numa sociedade mais pobre economicamente, ou seja, menos capaz de satisfazer as necessidades de seus componentes, sendo os exemplos mais significativos oriundos de países da África, tais como Guiné-Bissau, Sudão, Angola e Moçambique.

Nessa linha de raciocínio, segundo coloca AIETA (2006, p. 114), é possível constatar que: "O regime democrático se caracteriza por permitir a livre formulação das preferências políticas, de forma a assegurar a disputa eleitoral, em intervalos regulares, entre líderes e partidos, com a finalidade de alcançar o poder através de meios não violentos”. Portanto, consigna BOBBIO (1995, p. 43) que:

O único modo de tornar possível o exercício da soberania popular é a atribuição ao maior número de cidadãos do direito de participar direta e indiretamente na tomada das decisões coletivas; em outras palavras, é a maior extensão dos direitos políticos até o limite último do sufrágio universal masculino e feminino, salvo o limite da idade (que em geral coincide com a maioridade).

A conquista do sufrágio universal é recente na história da humanidade.

Foi somente no século XX que muitos países, incluindo o Brasil, ampliaram os direitos políticos a todos os cidadãos, salvo limites quando à idade mínima, perfazendo-se, nos dizeres de AIETA (2006, p. 120): "a fórmula inglesa: a cada homem um voto". 
Ao lado do sufrágio, também devem ser destacadas as maneiras de participação direta do povo na vida política, por intermédio dos referendos, plebiscitos, iniciativa popular e o recall, pois, a quem pertence a soberania, afinal? Se ao povo, segundo usualmente se concebe (v.g. parágrafo único do art. $1^{\text {o }}$ da Constituição de 1988), esses instrumentos merecem constante aperfeiçoamento e aplicação. Fato é que, na acepção proposta por DALLARI (1989, p. 256-257):

\begin{abstract}
Quando um governo, ainda que bem intencionado e eficiente, faz com que sua vontade se coloque acima de qualquer outra, não existe democracia. Democracia implica autogoverno, e exige que os próprios governados decidam sobre as diretrizes políticas fundamentais do Estado. $\mathrm{O}$ argumento de que o povo é incapaz de uma decisão inteligente não pode ser aceito, porque contém o pressuposto de que alguém está decidindo se a orientação preferida pelo povo é boa ou não.
\end{abstract}

Porém, é de se convir que garantir o direito de votar apenas, ou seja, permitir que alguém escolha entre algumas opções aqueles que tomarão as principais decisões políticas da sociedade, por si só, não é mais suficiente para considerar a democracia plenamente em vigor.

Em verdade, aceitar que um povo ignorante, com baixa instrução, manipulável e com poucas expectativas quanto ao futuro eleja seus representantes talvez não resulte em diferença marcante se comparado aos resultados de um governo déspota. $\mathrm{O}$ mesmo raciocínio é válido quando se permite o voto, mas há único partido e controle oficial sobre as instituições formadoras da opinião pública, tais como: imprensa, universidades, associações, sindicatos, etc.

Portanto, dada a natural heterogeneidade do povo, hão de existir requisitos mínimos para que se possa qualificar sua vontade manifestada como autêntica, indicando DALLARI (idem, p. 257) os seguintes: a) vontade livremente formada, assegurando-se o amplo debate de ideias, sem restrições, criando-se, com isso, múltiplas opções de escolha; b) vontade livremente externada, colocando-a a salvo de qualquer coação ou vício, com mecanismos de aferição imunes a influências externas; c) direito de divergir, que deve ser amplamente assegurado, sendo esse inclusive "o fundamento do predomínio da vontade da maioria, que tem por pressuposto que a vontade de todos indivíduos é substancialmente igual em valor”. 
Assim, segundo BARROSO (2007, p. 03): "Na configuração contemporânea do Estado e da sociedade, a idéia de democracia já não se reduz à prerrogativa popular de eleger representantes, nem tampouco às manifestações das instâncias formais do processo majoritário".

O que se verifica aqui é a necessidade do sufrágio se inserir num processo mais amplificado que permeie toda a sociedade, não se resumindo, portanto, na instituição dos parlamentos e na garantia do voto puro e simples em certas datas. Nesse tópico, coloca BOBBIO (1988, p. 157) que:

Hoje, quem deseja um indicador do desempenho democrático de um país deve considerar não mais o número de pessoas que têm direito de votar, mas o número de instâncias diversas daquelas tradicionalmente políticas nas quais se exerce o direito de voto. Em outros termos, quem deseja dar um juízo sobre o desenvolvimento da democracia num dado país deve pôr-se não mais a pergunta "Quem vota?", mas "Onde se vota?"

Em resumo, pondera AIETA (2006, p. 198) que o grau de democracia das sociedades ocidentais não depende apenas das eleições livres, como também da possibilidade de debate político real. Em suas palavras: “o desejo de uma sociedade mais democrática implica, obrigatoriamente, o necessário afastamento das práticas políticas do despotismo eletivo que pretende, muitas vezes, se justificar pelo voto popular".

Avançando, os valores da igualdade e liberdade também são vistos como ínsitos ao regime democrático. Porém, o significado axiológico de cada um deles é variável segundo se considere a democracia sob uma perspectiva mais afeta aos valores liberais ou, noutra banda, mais reverente às propostas socialistas com todas as matizes encontráveis entre essas visões extremas. Daí é também possível conceber a democracia em sentido formal e substancial (BOBBIO, 1995, p. 38).

Iniciando-se pela igualdade, é de se notar que o tema chegou a ser tratado pelos estóicos que, na lição de LEWANDOWSI (2005b, p. 170), tinham:

a concepção de que todas as pessoas eram iguais $a b$ origine. Epiceto, escravo liberto e um dos mais notáveis pensadores do estoicismo, assinalava com relação ao tema que todos os homens provinham de um mesmo pai, Zeus, sendo, pois, frutos de uma semente comum. 
Contudo, foi com o pensamento liberal do século XVIII que a questão da igualdade agregou inúmeros defensores, notadamente em decorrência das lutas contra o absolutismo quando ela se materializa com a ausência de quaisquer privilégios de indivíduos em relação a outros.

Logo, inicialmente nas Declarações ${ }^{107}$, todos são proclamados iguais perante a lei, não havendo posição social que possa alterar essa situação. Portanto, nenhuma criação artificial - instituída pelo próprio homem -, com destaque para os títulos nobiliários e clericais, poderia ensejar que o Estado conferisse a alguns de seus cidadãos mais benefícios do que a outros.

Recorde-se, com FERREIRA FILHO (2008, p. 28), que: "a certos homens, os integrantes da nobreza e do clero, não se aplicava o direito comum. Gozavam eles de um estatuto jurídico especial, que excepcionava esse direito comum e que, portanto, os privilegiava".

Com efeito, essa visão igualitária, ainda que resumida ao campo formal, sem dúvida é decorrência das "revoluções liberais" do final do século XVIII já mencionadas anteriormente (item 2.6), que influenciaram também na concepção da liberdade, outro valor angular da democracia.

Para o liberal, a liberdade econômica ocupa uma posição destacada. É verdadeira viga de sustentação pensada pelos arquitetos da democracia moderna, essencialmente representativa. As características desse pensamento, cujo auge se identifica no final do século XVIII, e cujo declínio inicia-se a partir da metade do século seguinte, já foram indicadas neste trabalho (item 2.6), isso é, em suma, a partir do reconhecimento de direitos ínsitos e inalienáveis do homem, pregava-se a maior liberdade econômica possível, com mínima intervenção do Estado, sendo o mercado a melhor e mais eficiente maneira de alocação dos diversos bens na sociedade.

${ }^{107}$ Com destaque, segundo LEWANDOWSKI (2005, p. 173), para a Declaração de Direitos do Bom Povo de Virgínia, de 1776; Declaração de Independência dos Estados Unidos da América, também de 1776; Declaração dos Direitos do Homem e do Cidadão, de 1789, na França; nas 10 primeiras emendas à Constituição americana de 1787, promulgadas em 1789. 
Trata-se do famoso laissez faire, laissez passer. Recorda AIETA (2006, p. 119) que: "o Estado passa ter a finalidade de assegurar as condições de competição, pois garantindo a ordem, por via oblíqua, pode-se garantir, também, a liberdade”. Foi esse, então, segundo BOBBIO (1988, p. 129), um denominador comum do pensamento liberal.

Quanto à liberdade sob a ótica política, o liberalismo clássico se contentou com o direito de escolher os governantes por meio da opinião da maioria, posto que a unanimidade não era factível (AIETA, idem, p. 102), anotando-se que a maioria aqui referida, em realidade, era a minoria da população em termos absolutos face às já mencionadas restrições de sufrágio.

É bem sabido que esse sistema não conseguiu implantar uma igualdade efetiva ou real em termos de capacidade de satisfação das necessidades dos indivíduos de maneira a proporcionar o desenrolar da vida das pessoas sob razoável dignidade.

Em resumo, em termos sociais, o que ocorria sob o jugo do feudalismo e do absolutismo, com a maioria do povo enfrentando condições muito duras de sobrevivência, perdurou no liberalismo, modificando-se apenas o endereço da minoria que detinha o poder econômico e político. Nesse ponto, LEWANDOWSKI (2005b, p. 174) pontua que as péssimas condições de vida dos trabalhadores do século XIX:

Desencadearam um surto de greves, agitações e rebeliões por toda a Europa. Dentre as sublevações populares, decorrentes das lutas operárias, destacam-se as revoluções na França e na Alemanha de 1848, a Comuna de Paris, de 1871 e, em especial, por seus desdobramentos, a Revolução Russa de 1917.

Essas rebeliões constituíram o caldo de cultura em que se desenvolveu o sindicalismo de Sorel, Pouget, Labriola e Panunzio, de cunho revolucionário, o trade-unionismo de Owen, de natureza reformista, o anarquismo de Proudhon, Bakunin e Kropotkin, o socialismo utópico de Saint-Simon, Fourier e Blanki, o socialismo científico de Marx e Engels, cujo Manifesto Comunista (1848) findava com a famosa conclamação: "Proletários de todo o mundo, uni-vos". Até mesmo a Igreja, que até então se mantivera eqüidistante das questões sociais, engajou-se na disputa, editando a Encíclica Rerum Novarum (1891), subscrita pelo Papa Leão XIII.

Nessa linha, não há dúvida de que a igualdade formal não foi capaz de tirar plenamente do papel a liberdade para que qualquer pessoa pudesse praticar atividade econômica segundo suas conveniências e convicções, o que fazia da liberdade, ao menos 
para um grande segmento dos indivíduos, mera ficção. Diante disso, narra AIETA (2006, p. 105):

a partir da Revolução Industrial, o Poder Público foi obrigado a participar das questões sociais e econômicas, deixando de ser meramente expectador passivo, pois o povo já não se contentava com a liberdade exclusivamente no plano formal, ambicionando uma liberdade e igualdade de fato, no âmbito material.

Percebe-se, por outro lado, que as propostas socialistas ${ }^{108}$, surgidas a partir da metade do século XIX, pregaram a restrição da liberdade, principalmente em termos econômicos e da propriedade dos bens de produção, em benefício da construção da igualdade, mas não apenas igualdade formal perante a lei, mas sim uma igualdade material, onde a maioria pudesse satisfazer às suas necessidades, ao menos as mais elementares.

Fala-se, então, em democracia socialista ou, nos dizeres de AIETA (2006, p. 129), democracia marxista. Na concisa explicação de BOBBIO (1995, p. 84):

No binômio liberalismo mais democracia, democracia significa principalmente sufrágio universal e, portanto, um meio de expressão da livre vontade dos indivíduos singulares; no binômio democracia mais socialismo, democracia significa ideal igualitário que apenas a reforma da propriedade proposta pelo socialismo poderá realizar. No primeiro binômio é conseqüência, no segundo um pressuposto. Como conseqüência, no primeiro completa a série das liberdades particulares com a liberdade política; como pressuposto, no segundo, será completada tão-somente pela futura e esperada transformação socialista da sociedade capitalista.

Disso é possível distinguir as propostas de democracia sob as óticas formal e substancial, sendo que um regime somente poderia ser qualificado de democrático quando se encaixar no caráter substancial. Esclarece BOBBIO (1988, p. 157) nesse tópico que:

O princípio destes fins ou valores, adotado para distinguir não mais apenas formalmente mas também conteudisticamente um regime democrático de um regime não democrático, é a igualdade, não a

${ }^{108}$ Segundo KUNTZ (1997, p. 01): "De certo modo, Marx matou a charada mostrando a correspondência entre liberdade formal e desigualdade material. Sua conclusão podia ser muito engenhosa, teoricamente, mas envolvia um considerável problema prático: a reconciliação entre liberdade e igualdade, em termos materiais e formais, só seria possível noutro sistema. Nem todos estavam preparados para aceitar essa implicação, tanto no seu tempo quanto nos cem anos seguintes. Rejeitada a proposta, o problema permaneceu: em que sentido, e até que ponto, os homens poderiam, se é que poderiam, ser livres e iguais no mundo capitalista e com base nos valores liberais?" 
igualdade jurídica introduzida nas Constituições liberais mesmo quando estas eram formalmente democráticas, mas a igualdade social e econômica (ao menos em parte). Assim foi introduzida a distinção entre democracia formal, que diz respeito precisamente à forma de governo, e democracia substancial, que diz respeito ao conteúdo desta forma.

A expressão "democracia econômica", no sentido que a atribui VAZ (1993, p. 47), pode ser considerada como sinônimo da democracia substancial, uma vez que ela procura: "traduzir a possibilidade de participação efetiva de todas as camadas sociais, não apenas enquanto destinatárias de direitos políticos, mas como titulares do direito a uma existência digna".

Caminhando, a experiência histórica demonstrou que, se o liberalismo puro apenas manteve uma desigualdade política e econômica já presente há milênios, o socialismo também não representou avanço significativo, pois, sob o pretexto de criar uma igualdade verdadeira, ao censurar, em regra, a liberdade de expressão e instituir partido único, fez minguar a iniciativa individual em inúmeros aspectos, não apenas econômicos, mas também políticos e culturais.

É de se concordar com FRIEDMAN (1985, p. 17) quando afirma que: "uma sociedade socialista não pode ser também democrática, no sentido de garantir a liberdade individual". Assim foi que, na lição de VAZ (idem, p. 41):

O próprio tempo se encarregaria de revelar que nem mesmo um dos mais fiéis adeptos do marxismo, Lenine, fora capaz de aplicar integralmente, na Rússia, após a Revolução de 1917, as concepções doutrinárias originais de Marx e Engels. O Estado que deveria prevalecer apenas como instrumento de transição para o comunismo, após a assunção do poder pela ditadura do proletariado, acabou assumindo papel preponderante. Sustentado pelo Partido Comunista da União Soviética, PCUS, que desenvolvia a teoria do centralismo democrático, o Estado, na Rússia, acabou sendo dirigido por uma minoria.

Outros exemplos marcantes são: China após 1949, Cuba após 1959 e Coréia do Norte. Apenas para enfatizar, é de se recordar que quando ruiu o Muro de Berlim em 1989, ficaram muito claras as sensíveis diferenças entre as duas Alemanhas em termos de condições gerais da população.

Enquanto os habitantes do lado ocidental - a República Federal da Alemanha - francamente capitalista, desfrutavam de uma série de confortos da vida 
moderna, talvez o maior nível de bem-estar da Europa de então, os orientais - a República Democrática da Alemanha, de influência planificada e soviética, viviam sob a égide de uma notável escassez material, ao menos paras os padrões europeus.

Conforme informa VAZ (1993, p. 167-168), em 1988, a distância no nível médio da renda per capita também era notável: US\$ 18.000,00 (dezoito mil dólares norte americanos) para os ocidentais e US\$ 9.000,00 (nove mil) para os orientais.

Em todas as hipóteses, o que se infere do socialismo posto em prática é que, se distribuição de riqueza inicialmente ocorreu, se prejudicou sobremaneira a continuidade de sua criação, precipuamente pela retirada de cena do agente econômico do mercado que, ainda que movido pelo anseio do lucro, justamente por causa desse desejo, produz bens e serviços destinados a atender necessidades de outros seres humanos. Isso sem falar na eliminação de quaisquer divergências que pudessem contrariar as linhas indicadas pelo regime oficial.

Na verdade, se bem refletido for, é de se concluir que a igualdade formal não se antagoniza com a material, eis que se constitui como um pressuposto desta última, ou seja, não apresentam noções opostas. Somente a partir da garantia da igualdade perante a lei - ou formal - é que se pode antever a possibilidade de se construir uma igualdade substancial, pois, no enfoque de ROMITA (2005, p. 392): "mesmo que a igualdade real preexistisse, ela não subsistiria sem a garantia do direito".

Nessa linha de raciocínio, percebe-se uma evolução no conceito da igualdade como um valor democrático, e não uma ruptura como pode parecer à primeira visão.

Então, um possível ponto de equilíbrio que reflete esse avanço, eventual junção de ambos os enfoques, surge com a chamada social democracia (e não socialista), onde predomina o valor da liberdade, mas não se relega a igualdade a um patamar meramente formal, havendo, por exemplo, intervenção econômica, fomento e programas estatais de assistência social (FERREIRA FILHO, 1995, p. 86-87). 
Nesse norte, o Estado-social, nos dizeres de BONAVIDES (2007, p. 184): “conserva sua adesão à ordem capitalista, princípio cardeal a que não renuncia".

O Brasil pode se enquadrar aqui, segundo se depreende da leitura de vários dispositivos da Constituição de 1988, que, de um lado, garantem a livre iniciativa, mas, de outro, impõem que a atividade econômica tenha por fim assegurar a todos existência digna, conforme os ditames da justiça social, com a diminuição das desigualdades sociais e regionais (art. 170).

Ressalte-se, ainda, que, nos moldes do $\S 1^{\circ}$ do art. 174 , a lei deve estabelecer as diretrizes e bases do planejamento do desenvolvimento nacional equilibrado, incorporando e compatibilizando os planos nacionais e regionais de desenvolvimento.

Aliás, esses caracteres são claramente anunciados logo no início do Texto Maior nos seus arts. $1^{\circ}$ e $3^{\circ}$, que assim determinam:

Art. $1^{\circ}$. A República Federativa do Brasil, formada pela união indissolúvel dos Estados e Municípios e do Distrito Federal, constitui-se em Estado Democrático de Direito e tem como fundamentos:

(...)

III - a dignidade da pessoa humana;

IV - os valores sociais do trabalho e da livre iniciativa;

Art. $3^{\circ}$ Constituem objetivos fundamentais da República Federativa do Brasil:

I - construir uma sociedade livre, justa e solidária;

II - garantir o desenvolvimento nacional;

III - erradicar a pobreza e a marginalização e reduzir as desigualdades sociais e regionais;

IV - promover o bem de todos, sem preconceitos de origem, raça, sexo, cor, idade e quaisquer outras formas de discriminação.

Nesse ponto, entra em cena, segundo indicado no caput do art. $1^{\circ}$, a figura do Estado Democrático de Direito. É colocado por SILVA (2008, p. 119-120) que:

A configuração do Estado Democrático de Direito não significa apenas unir formalmente os conceitos de Estado Democrático e Estado de Direito. Consiste, na verdade, na criação de um conceito novo, que leva em conta os conceitos dos elementos componentes, mas os supera na medida em que incorpora um componente revolucionário de transformação do status quo. E aí se entremostra a extrema importância do art. $1^{\circ}$ da Constituição de 1988 , quando afirma que a República Federativa do Brasil se constitui em Estado Democrático de Direito, não 
comemora promessa de organizar tal Estado, pois a Constituição aí já o está proclamando e fundando. [...] A democracia que o Estado Democrático de Direito realiza há de ser um processo de convivência social numa sociedade livre, justa e solidária $\left(\operatorname{art.~} 3^{\circ}\right.$, I), em que o poder emana do povo, e deve ser exercido em proveito do povo, diretamente ou por representantes eleitos (art. $1^{\circ}$, §único); participativa, porque envolve a participação crescente do povo no processo decisório e na formação dos atos de governo; pluralista, porque respeita a pluralidade de idéias, culturas e etnias, e pressupõe assim o diálogo entre opiniões e pensamentos divergentes e a possibilidade de convivência de formas de organização e interesses diferentes da sociedade; há de ser um processo de liberação da pessoa humana das formas de opressão que não depende apenas do reconhecimento formal de certos direitos individuais, políticos e sociais, mas especialmente da vigência de condições econômicas suscetíveis de favorecer o seu pleno exercício.

Tais anseios decorrem, ainda, da interpretação que se dá ao princípio republicano, nos termos da explicação formulada por LEWANDOWSKI (2005a, p. 198):

o princípio republicano, na sistemática constitucional vigente, não se resume apenas à eleição dos representantes do povo, por uma mandato renovável periodicamente (arts. $27, \S 1^{\circ} ; 28 ; 29$, I e II; e 82 ), mas implica também a igualdade de acesso aos cargos públicos, eletivos ou-não, preenchidos os requisitos legais (art. $14, \S 3^{\circ}$ e 37 , I), além de contemplar a progressiva superação das causas da pobreza e dos fatores de marginalização, simultaneamente à supressão dos privilégios de todo gênero (arts. $1^{\circ}$, I e II; $3^{\circ}$, I, III e IV; $5^{\circ} ; 6^{\circ} ; 7^{\circ} ; 23$, X; e 170, VII).

Nesse entendimento, COMPARATO (2006, p. 191) esclarece que: “A democracia constitui, pois, o complemento necessário da república”.

A figura dos tributos na social democracia é de reconhecida importância como instrumento não apenas apto a rechear os cofres públicos, mas também como ferramenta capaz de financiar políticas públicas e promover ou induzir a atividade econômica.

Enfatiza AIETA (2006, p. 123) sobre o tema que: “A idéia de sacrifício parcial da liberdade com o fito de assegurar a todos o bem-estar e condições mínimas de vida, encontrou no instrumento do imposto seu maior aliado, pois através dele poder-se-ia distribuir melhor a renda atenuando as desigualdades". 
Aliás, esse novo papel dos tributos já foi, por mais de uma vez, mencionado neste trabalho, principalmente no item 2.6, quando se transcrevram as lições de FALCÃO (1981, p. 47-48) e NABAIS (2005a, p. 420).

Então, é cada vez mais aceito que tenham os tributos funções tipicamente extrafiscais, o que não era admitido, ao menos de modo seguro, há um século. Em verdade, na feliz expressão criada por SIDOU (1978, p. 44), o tributo é: "chamado a representar saliente papel na revolução pelo consentimento", ou, ainda, conforme aduz ROMITA (2005, p. 394): "Daí a função social do tributo, que tem por objetivo a implementação das políticas sociais desenvolvidas pelo Estado intervencionista, com base nas finanças públicas".

Atente-se, todavia, que jamais se deve confundir social democracia com Estado social. Nesse sentido, é de se reconhecer que a Alemanha nazista, a Itália fascista, a Espanha franquista, o Portugal salazarista, a Inglaterra de Churchill e Atle, a França com a Quarta República e o Brasil após a Revolução de 1930 foram Estados sociais, eis que objetivavam não apenas garantir a ordem interna e a proteção das fronteiras, mas intervieram em questões econômicas e sociais. Porém, não obstante essas atuações, não se revelaram verdadeiras democracias (BONAVIDES, 2007, p. 184).

Conclui-se, destarte, que um Estado pode se intitular como social e não ser democrático formal e substancialmente. Percebe-se, então, que regimes de inclinação liberal - no espectro político e econômico - são capazes de conviver com a democracia, tanto é que deram origem à democracia social acima mencionada. Todavia, regimes autocráticos não revelam a mesma adaptabilidade, conforme reconhece BOBBIO (1995, p. 44):

Hoje, apenas os Estados nascidos das revoluções liberais são democráticos e apenas os Estados democráticos protegem os diretos do homem: todos os Estados autoritários do mundo são ao mesmo tempo antiliberais e antidemocráticos.

É de se convir que a democracia é uma figura em constante evolução, não sendo possível afirmar tenha atingido seu ápice ou mesmo já esteja em decadência. Avanços e retrocessos, naturais na complexa dinâmica da convivência humana, são esperados e, de fato, vêm emergindo ao longo dos anos. Cada época engendra uma série de 
desafios, cuja capacidade de adaptação às novas adversidades se impõe. É de se enfatizar, segundo BONAVIDES (2007, p. 139-140), que:

A sobrevivência da democracia liga-se ao êxito que eventualmente possa alcançar uma teoria política que afirme e reconcilie a idéia dos direitos sociais, que faz lícita uma maior intervenção do poder estatal na esfera econômica e cultural, com a idéia não menos justa do individualismo, que pede a segurança e o reconhecimento de certos direitos fundamentais da personalidade, sem os quais esta se deformaria, como fonte que deve sempre conservar de iniciativas úteis, livres e fecundas.

Em realidade, várias questões ainda estão por se resolver. Chama-se ao foco, por exemplo, o problema da cada vez maior importância dos diversos grupos de interesses (v.g. associações, federações, sindicatos, grandes conglomerados empresariais e financeiros, etc.) nas democracias atuais em detrimento da relevância política do indivíduo isolado.

Sob tal prisma, as opções tomadas por uma sociedade, seja em que área for, passam a ser fruto não mais da soma das decisões individuais de cada eleitor, mas do resultado do confronto entre as vontades manifestadas por entidades de cunho coletivo, muito mais capazes de influenciarem os legisladores e demais autoridades responsáveis pela implementação das políticas públicas. Conforme salienta BOBBIO (2006, p. 35) a esse respeito:

Os grupos e não os indivíduos são os protagonistas da vida política numa sociedade democrática, na qual não existe mais um soberano, o povo ou a nação, composto por indivíduos que adquiriram o direito de participar direta ou indiretamente do governo, na qual não existe mais o povo como unidade ideal (ou mística), mas apenas o povo dividido de fato em grupos contrapostos e concorrentes, com sua relativa autonomia diante do governo central (autonomia que os indivíduos perderam ou só tiveram num modelo ideal de governo democrático sempre desmentido pelos fatos).

Esse fenômeno também é sentido por LEWANDOWSKI (2005b, p. 178) ao considerar que:

O final do século XX e o século XXI, certamente, entrarão para a História como épocas em que o indivíduo se eclipsa, surgindo em seu lugar as associações, protegidas constitucionalmente, multiplicando-se as chamadas organizações não-governamentais, no plano interno e internacional, para a defesa dos direitos humanos. 
Nota-se, nesse sentido, que o sistema normativo brasileiro confere a partidos políticos, associações e sindicados vários instrumentos que possibilitam sua interferência no desenrolar da vida social, com nítidos reflexos para aqueles que compõem as mencionadas entidades. Assim, como exemplos, citam-se:

a) a legitimidade que as entidades associativas, quando expressamente autorizadas, têm para representar seus filiados judicial ou extrajudicialmente (art. $5^{\circ}, \mathrm{XXI}$, da Constituição de 1988);

b) o mandado de segurança coletivo, que pode ser impetrado por partido político com representação no Congresso Nacional ou organização sindical, entidade de classe ou associação legalmente constituída e em funcionamento há pelo menos um ano em defesa dos interesses de seus membros ou associados (art. 5, LXX, da Constituição de 1988);

c) a denúncia de irregularidades ou ilegalidades perante o Tribunal de Contas, que pode ser manejada por qualquer cidadão, partido político, associação ou sindicato (art. 74, §2º da Constituição de 1988);

d) os instrumentos de controle abstrato da constitucionalidade operados no Supremo Tribunal Federal, que podem ser aforados, dentre outros, por partido político com representação no Congresso Nacional e confederação sindical ou entidade de classe de âmbito nacional (arts. 102 e ss. da Constituição de 1988);

e) a ação civil pública, cuja legitimidade ativa também pertence às associações constituídas há mais de um ano e que incluam entre suas finalidades institucionais a proteção ao meio ambiente, ao consumidor, à ordem econômica, à livre concorrência ou ao patrimônio artístico, estético, histórico, turístico e paisagístico (art. $5^{\circ}$, V, “a” e "b", da Lei 7347/85);

f) a faculdade de tais coletividades proporem projetos de lei de sua autoria junto à já citada Comissão de Legislação Participativa da Câmara dos Deputados.

Em adição, não se deve desconsiderar a capacidade que tais entidades possuem de influenciar diretamente os parlamentares na defesa de seus interesses - o 
famoso lobby, mesmo que seja difícil, na maioria das hipóteses, averiguar o efetivo grau de sua interferência no desenrolar do processo legislativo.

Outro assunto de alto relevo que inegavelmente passa pelo tópico da criação de uma democracia substancial em termos de igualdade é o sistema de quotas ou “ações afirmativas”. Aqui, segundo FERREIRA FILHO (2008, p. 31):

Essas ações afirmativas tiveram origem nos Estados Unidos da América em meados do século XX e hoje se difundiram pelo mundo, estando presentes no Brasil atual. São elas distinções no sistema normativo, em benefícios de grupos determinados - negros, mulheres, minorias etc. que visam equipará-los (igualá-los) a grupos outros que servem de padrão de referência.

A dificuldade se origina na complexidade de, na vida cotidiana de uma sociedade, identificar, até que ponto, o Estado pode ou mesmo deve interferir nessa equação. O autor acima (idem, p. 31-32) propõe a adoção de seis regras elementares supostamente aptas a impedir que a intenção de igualar grupos se transmude em privilégio, devendo ser observado o seguinte:

1) identificação do grupo desfavorecido e seu âmbito de forma objetiva (regra da objetividade);

2) a discriminação ou avantajamento deve corresponder à desigualdade a ser corrigida (regra da medida ou proporcionalidade);

3) as normas de avantajamento necessitam ser adequadas ao objetivo que perseguem (regra da adequação ou razoabilidade);

4) a finalidade dessas normas deve se dirigir à neutralização das desigualdades verificadas (regra da finalidade);

5) as medidas devem ser temporárias, ou seja, devem cessar à medida que desaparece a desigualdade (regra da temporariedade);

6) não pode ocorrer uma onerosidade excessiva aos demais grupos sob pena de se inverter a desigualdade que se busca corrigir (regra da prudência). 
No campo do valor liberdade, também se sucedem inúmeras dúvidas ainda não devidamente equacionadas pela doutrina ou pelo próprio direito. Isso se manifesta principalmente no que se refere aos limites da intervenção do Estado na atividade econômica, seja atuando na forma direta, como agente econômico propriamente dito, seja de maneira indireta, como regulador, fomentador e, em certas hipóteses, fiscal da economia.

Aliás, esse tema será tratado no capítulo seguinte com maior profundidade, bastando atentar que, por exemplo, por meio da tributação, é possível constranger ou estimular os atores mercadológicos, o que gera reflexos na produção e distribuição de riqueza por toda a sociedade. Aqui, na exposição de BONAVIDES (2007, p. 198): "Com a reconciliação entre o capital e o trabalho, por via democrática, todos lucram".

Por fim, a democracia se justifica por uma razão extremamente prática e, sobretudo, empírica. É que vem se percebendo que os países democráticos, mesmo com todas as nuances desse regime que possam existir na realidade, tendem a alcançar um nível de estabilidade e desenvolvimento mais elevado do que os autocráticos. A franqueza com que FUKUYAMA (2008, p. 47) coloca o tema merece a transcrição de suas palavras:

Os países autoritários poderiam ter bons resultados se pudessem todos ser governados por Lee Ywan Yew; mas como quase sempre eles são governados por um Mobutu ou um Marcos, não é de surpreender que os regimes autoritários apresentem variações muito maiores que os democráticos em termos de desenvolvimento. Os regimes democráticos ao menos contam com controles institucionais contra as piores formas de incompetência ou rapacidade: eles podem votar pela saída dos maus líderes.

Não é raro ouvir algum "especialista" afirmar que o regime autoritário seria capaz de gerar crescimento econômico rápido. Todavia, é de se atentar que a denominada "tese Lee" não é unânime. Conforme expõe SEN (2008, p. 30): "comparações mais abrangentes entre países não forneceram nenhuma confirmação dessa tese e há poucos indícios de que a política autoritária realmente auxilie o crescimento econômico". 
Aliás, ao que tudo indica, a tendência é justamente o contrário, ou seja, quanto mais democrático for um país, em termos políticos e da liberdade de crítica em geral, maior será sua propensão ao crescimento, pois, na explicação de SEN (idem, p. 30):

O funcionamento da democracia e dos direitos políticos pode até mesmo ajudar a impedir a ocorrência de fomes coletivas e outros desastres econômicos. Os governos autoritários, que raramente sofrem os efeitos de fomes coletivas (ou de outras calamidades econômicas como essa), tendem a não ter estímulos para tomar providências preventivas oportunas. Os governos democráticos, em contraste, precisam vencer eleições e enfrentar a crítica pública, dois fortes incentivos para que tomem medidas preventivas contra aqueles males.

Nesse diapasão, entende-se que a proposta de democracia fiscal objeto deste trabalho é apenas uma das possibilidades que, agregada a outras propostas, acreditase possa auxiliar a sedimentação da democracia ideal, notadamente quanto à convivência o mais harmônica possível entre os valores da igualdade e da liberdade.

\subsection{Conclusão do capítulo}

Em conclusão, é certo que a ideia de democracia remonta à Grécia antiga nos séculos VI e IV antes de Cristo, principalmente em Atenas, quando era exercida pela forma direta, não obstante apenas uma parcela diminuta da população ser detentora do direito de voto em assembleia. Tratou-se de uma experiência pioneira e relativamente isolada na história da humanidade.

A ideia foi retomada a partir do final do século XVIII, com a vitória das "revoluções liberais", mas sob a sistemática da representação com sufrágio altamente restrito e, ainda, considerando os valores da igualdade e da liberdade vistos sob a ótica eminentemente formal.

Em contraposição, a democracia socialista ou marxista, cujas ideias elementares na busca pela igualdade material nasceram a partir da metade do século XIX, sufocou a liberdade econômica e política, não tendo conseguido alcançar resultados significativos, vistos os exemplos históricos disponíveis.

A síntese dessas experiências, ao que tudo indica, é a social democracia, figura ainda em evolução, que, sob a égide e o respeito ao sufrágio universal, tenta 
conjugar os valores da igualdade e da liberdade num ponto intermediário entre a visão exclusivamente formal e aquela absolutamente substancial.

Contudo, muitas questões ainda se põem perante a democracia atualmente praticada no mundo, com destaque para o amesquinhamento da importância política do indivíduo isoladamente considerado em contraposição ao crescimento da participação dos grupos e entidades coletivas, bem como, no que se refere ao valor da igualdade, aos limites de atuação do Estado na minoração das desigualdades sociais com fulcro de instituir a democracia substancial e, quanto à liberdade, às possibilidades do Estado interferir na atuação da vida econômica. 


\section{PRIMEIRO FUNDAMENTO DA DEMOCRACIA FISCAL: A LIBERDADE MATERIAL}

\subsection{A proposta da democracia fiscal}

Antes de adentrar no primeiro fundamento propriamente dito, é de rigor construir uma breve introdução acerca da democracia fiscal e a integração de seus fundamentos de modo a melhor compreender os passos que se seguirão.

Se, conforme dito imediatamente acima, a proposta de democracia fiscal visa auxiliar a sedimentação da democracia, tem-se como pressuposto um regime que vise estatuir um equilíbrio entre os valores básicos da igualdade e da liberdade, isso é, não considerados meramente sob o enfoque formal, como num sistema liberal purista, mas também não ansiados de maneira absolutamente substancial, segundo ambicionaram as doutrinas socialistas.

Em resumo, a democracia fiscal, sob o manto aqui sugerido, somente será possível em regimes que garantam a propriedade e a livre iniciativa, bem como, notadamente por meio de uma tributação perpetrada sob a cláusula da razoabilidade, tendam a promover a igualdade material por intermédio de políticas públicas, cujos custos sejam financiados por exações diretas e inspiradas na capacidade contributiva do sujeito passivo.

É certo que esses fundamentos devem operar de maneira harmônica, conjunta e interdependente, analogamente a um sistema de freios e contrapesos, onde determinado vetor influencia e é influenciado pelos demais, onde estímulos e feedbacks se alternem na busca de um equilíbrio.

Acredita-se que o modelo proposto se vergue simultaneamente aos preceitos da equidade e da eficiência, sendo, portanto, dentre as demais proposições possíveis, quiçá uma dos mais capazes de promover as condições que permitam satisfazer o maior número possível de necessidades humanas, proporcionando, em conclusão, um desenvolvimento social mais justo, abrangente e perene. 
A importância do tema é inegavelmente manifesta, pois, segundo ponderam MURPHY e NAGEL (2005, p. 08): "Numa economia não socialista, em que os meios de produção não estão nas mãos da administração pública, os impostos e os gastos do governo são os focos principais de todas as discussões sobre a justiça econômica". E, como complementam adiante: "a tarefa daquele que formula o sistema é a de inventar um esquema que seja ao mesmo tempo justo e eficiente" (idem, p. 16).

Evidentemente, o pressuposto inicial e inalterável é a garantia do sufrágio universal por meio de eleições livres e periódicas, admitindo-se limitações naturais da idade e do gozo da sanidade mental, bem como a existência de um ambiente social e institucional sadio, que privilegie a livre manifestação do pensamento e circulação das ideias. É o que será aprofundado neste capítulo, sem dúvida o mais importante de todo o trabalho.

\subsection{A liberdade material}

O primeiro fundamento da democracia fiscal - a liberdade material liga-se ao tema dos direitos fundamentais e se identifica com a imperiosa e inafastável necessidade de o Estado respeitar os direitos fundamentais da propriedade e da livre iniciativa, conforme será discorrido a seguir.

\subsubsection{Essência dos direitos fundamentais}

De início, afirma-se que o objetivo primordial dos direitos fundamentais, segundo BONAVIDES (2008, p. 560), é: "Criar e manter os pressupostos elementares de uma vida na liberdade e na dignidade humana". Em complemento, nos termos do exposto por PEZZI (2008, p. 29): “A fundamentalidade material decorre da circunstância de serem esses direitos elementos da Constituição material, que contém decisões fundamentais sobre a estrutura básica do Estado e da sociedade".

Qualificar um direito como fundamental, de acordo com sucessivas Constituições, significa reconhecer que sua ausência pode redundar numa agressão à dignidade da pessoa humana. Conforme aponta SARLET (2001, p. 63-64):

Os direitos fundamentais, como resultado da personalização e positivação constitucional de determinados valores básicos (daí seu conteúdo axiológico), integram, ao lado dos princípios estruturais e organizacionais 
(a assim parte orgânica ou organizatória da Constituição), a substância propriamente dita, o núcleo substancial, formado pelas decisões fundamentais, da ordem normativa, revelando que mesmo num Estado constitucional democrático se tornam necessárias (necessidade que se faz sentir da forma mais contundente no período que sucedeu à Segunda Grande Guerra) certas vinculações de cunho material para fazer frente aos espectros da ditadura e do totalitarismo.

Antes de prosseguir, é preciso ter em mente que o tema dos direitos fundamentais é ínsito à cultura ocidental, cuja nota distintiva é o humanismo que tem no homem seu "valor-fonte". Na lição de LEWANDOWSKI (2005b, p. 169): "funda-se basicamente na idéia da sacralidade essencial das pessoas e na crença de que existem determinadas regras transcendentais às quais súditos e governantes estariam indistintamente submetidos".

Noticia o autor em foco, que esses valores, mesmo que de forma não sistematizada, provêm de longo tempo como herança da cultura judaico-cristã, bem como dos clássicos gregos e latinos, da jurisprudência latina e da teologia medieval. Logo, tais ideias são estranhas, ainda que apenas num primeiro instante, às culturas não-ocidentais ${ }^{109}$.

Contudo, foi somente a partir das lutas contra o absolutismo nos séculos XVII e XVIII, notadamente, com as ideias iluministas, que se generalizou, no pensamento ocidental, a noção de que os indivíduos seriam titulares de direitos "naturais", inalienáveis e imprescritíveis, além decorrentes da própria natureza humana. De fato, a lição de ROSSEAU (1973, p. 55) é no sentido de que:

Todos os serviços que um cidadão pode prestar ao Estado, ele os deve desde que o soberano os peça; este, porém, de sua parte, não pode onerar os súditos com qualquer pena inútil à comunidade, nem sequer pode desejá-lo, pois, sob a lei da razão, não menos do que sob a da natureza, nada se faz sem causa.

Naquele instante, mais uma vez pelo ensinamento de LEWANDOWSKI (idem, p. 173): “se acreditava que os direitos dos indivíduos não constituíam uma criação

${ }^{109}$ Na explicação de LEWANDOWSKI (idem, p. 169): “No Oriente, como se sabe, a ênfase da cultura dá-se no universal, no coletivo, no social, seja na religião, seja na política. Basta pensar-se, por exemplo, no nirvana budista, que corresponde, em suma, a um estado espiritual alcançado por meio da supressão do desejo e da consciência individual, isto é, à completa integração da pessoa na natureza circundante. Também no confucionismo, que dominou por mais de dois mil anos o sistema filosófico da China, a partir do século V a.C., e influencia até hoje o modo de pensar chinês e de boa parte do mundo oriental, baseia as relações pessoais no interesse mais amplo da comunidade". 
do Estado, existindo antes do advento deste. Bastava, assim, para que fossem respeitados, arrolá-los solenemente num documento formal", como se deu, por exemplo, com a Declaração da Virgínia, em 12 de janeiro de 1776, na América do Norte, e da Declaração dos Direitos do Homem e do Cidadão, em 26 de agosto de 1789, na França. A cláusula primeira da Declaração da Virgínia, conforme DALLARI (1989, p. 176), estatuía que:

todos os homens são por natureza igualmente livres e independentes, e têm certos direitos inerentes, dos quais, quando entram em qualquer estado de sociedade, não podem por qualquer acordo, privar ou despojar os pósteros; quer dizer, o gozo da vida e da liberdade, com os meios de adquirir e possuir propriedade, e perseguir e obter felicidade e segurança.

É sabido, e assim já foi aqui consignado (item 2.5), que o paradigma que alicerçou o "jusnaturalismo" está superado, mas não se pode negar que, à época, se tratava de uma proposta revolucionária capaz de abalar os valores sociais então vigorantes.

A questão terminológica deve, nesse ponto, ser analisada, uma vez que diversos termos procuram designar os direitos fundamentais. $\mathrm{Na}$ colocação de BONAVIDES (2008, p. 560), autores anglo-americanos e latinos costumeiramente utilizam mais "direitos humanos" e "direitos do homem", enquanto que a expressão “direitos fundamentais” é mais usual dos publicistas alemães.

Segundo constata de SILVA (2008, p. 175 e ss.), as principais expressões utilizadas são: direitos naturais, direitos humanos, direitos do homem, direitos individuais, direitos públicos subjetivos, liberdades fundamentais, liberdades públicas e direitos fundamentais, sendo que a última seria, em seu pensamento, a designação que se mostra mais adequada em vista do seguinte:

A expressão "direitos naturais" pode ensejar confusão com a doutrina jusnaturalista, que concebia sua existência como algo ínsito à natureza humana, isso é, independentemente de qualquer positivação ou previsão constitucional. Com efeito: "não se aceita mais com tanta facilidade a tese de que tais direitos sejam naturais, provenientes da razão humana ou da natureza das coisas" (idem, p. 176). 
O termo "direitos humanos" é mais específico para documentos internacionais e, além disso: "não há direito que não seja humano ou do homem, afirmando-se que só o ser humano pode ser titular de direitos" (idem, p. 176).

A designação "direitos individuais" remete a atenção ao indivíduo isoladamente considerado, o que implica numa associação com os direitos fundamentais de primeira geração. Logo, não abrange a evolução que o tema experimentou. Tanto é assim que: "é usada na Constituição para exprimir o conjunto de direitos fundamentais concernentes à vida, à igualdade, à liberdade, à segurança e à propriedade" (idem, p. 176).

A nomenclatura "direitos públicos subjetivos", por sua vez, também implica conferir uma noção de individualismo ao tema, notadamente porque parece ressaltar os limites do Estado quanto à possibilidade de interferência na vida pessoal de cada um. Em suma, não englobaria toda a dimensão que o assunto compreende, deixando de fora, por exemplo, os direitos difusos e coletivos, próprios da terceira geração. Pela mesma trilha, seguem as expressões "liberdades fundamentais" e "liberdades públicas" (idem, p. 177-178).

Por fim, o termo "direitos fundamentais do homem" é o mais adequada para este estudo, porque aqui: "acha-se a indicação de que se trata de situações jurídicas sem as quais a pessoa humana não se realiza, não convive e, às vezes, nem mesmo sobrevive [...]. Direitos fundamentais do homem significa direitos fundamentais da pessoa humana" (idem, p. 178). No mesmo sentido, SARLET (2001, p. 31 e ss.) e PEZZI (2008, p. 27) informam ser essa designação a preferida pela moderna doutrina constitucional.

Identificam-se, nos direitos fundamentais, algumas características especiais, segundo ordinariamente se revela nas diversas Constituições que os reconhecem, isso é, são traços encontrados de maneira constante independentemente da geração a que pertençam, a saber: historicidade, inalienabilidade, imprescritibilidade, irrenunciabilidade, universalidade, limitabilidade e concorrência (SILVA, 2008, p. 181 e ss.).

A historicidade decorre da constatação dos direitos fundamentais apresentarem uma linha evolutiva ao longo do tempo, iniciando sua concepção 
sistematizada nos séculos XVII e XVIII, com sua inserção nas Declarações para desaguar na atualidade em várias Constituições no nível de terceira e quarta geração.

Pela inalienabilidade, entende-se que os direitos fundamentais são inegociáveis, eis que não dotados de conteúdo econômico-patrimonial, principalmente porque as ordens jurídicas como um todo os outorgam a cada ser humano. Logo, são direitos indisponíveis, definitivamente res extra comercium.

A notória essencialidade desses direitos para a garantia da dignidade da pessoa humana os torna imprescritíveis. Então, o eventual não exercício por parte do seu titular não importa em perecimento.

Os direitos fundamentais também são irrenunciáveis. É possível aceitar o seu não exercício (v.g. alguém que deixa transcorrer in albis o prazo para contestar uma demanda e, com isso, é condenado judicialmente), mas não é válida a renúncia ao direito "de fundo" (v.g. uma hipótese - um tanto bizarra - de se lavrar um documento em que o declarante eternamente abra mão de exercitar o direito de defesa em qualquer tipo de demanda).

A universalidade se manifesta pela vocação dos direitos fundamentais de se destinarem ao ser humano enquanto gênero, abrangendo a todos, e não apenas uma classe ou determinada categoria de pessoas.

Não há direito fundamental absoluto, daí ser a limitação uma de suas características. Portanto, eles devem conviver entre si da forma mais harmônica possível, sendo certo que o exercício de um desses direitos não pode anular ou macular outro e os casos concretos são solucionados principalmente com fulcro nos princípios da razoabilidade e da proporcionalidade $^{110}$ (SCHÄFER, 2001, p. 132-133). Assim, por

110 Dentro do universo das normas jurídicas, a doutrina identifica diferenças entre princípios e regras. Segundo BARROSO (2007, p. 14-15): "Princípios não são, como as regras, comandos imediatamente descritivos de condutas específicas, mas sim normas que consagram determinados valores por diferentes meios [...] Como se percebe claramente, a menor densidade jurídica de tais normas impede que delas se extraia, no seu relato abstrato, a solução completa das questões sobre as quais incidem. Também aqui, portanto, impõe-se a atuação do intérprete da definição concreta de seu conteúdo e alcance". Na mesma linha, SILVA (2002, p. 25) esclarece que: "Regras expressam deveres definitivos e são aplicadas por meio de subsunção. Princípios expressam deveres prima facie, cujo conteúdo definitivo somente é fixado após sopesamento com princípios colidentes [...] são, por conseguinte, mandamentos de otimização". 
exemplo, o exercício do direito de informação está condicionado ao respeito ao direito à intimidade, ambos direitos fundamentais.

Ainda que não pairem dúvidas acerca da possibilidade de restrição dos direitos fundamentais, coloca PEZZI (2008, p. 38) que, no atual sistema constitucional brasileiro: “qualquer limitação ou restrição a direitos fundamentais somente é possível mediante lei, em sentido formal ou material, ou ainda por outro meio, desde que por ela autorizado".

Pela cumulatividade, conforme SARLET (2001, p. 49), percebe-se a possibilidade de se desfrutar de mais de um direito fundamental simultaneamente (v.g. o caso de um âncora de um telejornal que informa acerca de uma notícia qualquer e, logo em seguida, faz uma crítica, um juízo de valor a respeito, ao mesmo tempo, ele exerceu os direitos de informação, comunicação e opinião).

Avançando, é bem sedimentada a classificação doutrinária que divide os direitos fundamentais em gerações de acordo com o momento de aparecimento no curso da história.

Nessa esteira, os direitos fundamentais de primeira geração são justamente aqueles que resultam das já mencionadas lutas liberais contra o absolutismo e que figuraram inicialmente no rol das Declarações da Virgínia e dos Direitos do Homem e do Cidadão. Entram em cena, outrossim, a enunciação do direito à vida, à igualdade, à segurança, à liberdade, à propriedade, etc. Constata-se que todos, em síntese, têm como objeto primordial o indivíduo isoladamente considerado e são oponíveis ao Estado.

Aduz BONAVIDES (2008, p. 563) que: "já se consolidaram em sua projeção de universalidade formal, não havendo Constituição digna desse nome que não os reconheça em toda a extensão". Em complemento, na percepção de FELDENS (2008, p. 57):

Em razão do locus constitucional que ocupam, os direitos fundamentais se notabilizam pela resistência que oferecem ao legislador, o que garante a seus titulares, notadamente naquilo que constitua seu conteúdo essencial, uma zona de atuação imune a intervenções dos poderes públicos. Nesse âmbito, os direitos de liberdade formam parte de um 
núcleo indisponível à decisão majoritária, razão pela qual são identificados como direitos contramajoritários, no sentido de que sua configuração não está à livre disposição das maiorias parlamentares.

É possível, ainda, identificar essa primeira geração de direitos fundamentais como "direitos a ações negativas”. Segundo SCHÄFER (2005, p. 46), esses "direitos de defesa" podem ser divididos em três grupos:

a) direitos ao não impedimento de ações, tais como a possibilidade de ir, vir e permanecer;

b) direitos à não-afetação de propriedades e situações, com destaque para a salvaguarda das esferas privadas (v.g. inviolabilidade do domicílio), bem como o respeito ao direito à vida;

c) direitos à não-eliminação de posições jurídicas, notadamente o instituto da propriedade.

Ainda que o autor não se refira expressamente, entende-se que nesse item poderia constar, também, a proteção ao direito adquirido, ao ato jurídico perfeito e à coisa julgada.

Em seguida, principalmente nas primeiras décadas do século $\mathrm{XX}$, em vista da antes citada insuficiência do sistema liberal purista e das ideias que pregavam a necessidade da igualdade não se manifestar apenas perante a lei, mas, com efeito, em termos materiais, surgem os direitos fundamentais de segunda geração, cuja conotação é positiva. Trata-se de uma imposição ao Estado para que atue em áreas sociais (v.g. saúde, educação, moradia popular, serviços de assistência e previdência social, salário mínimo, seguro desemprego, limite para a jornada de trabalho, etc.).

Apenas para recordar, isso positivou-se em várias Constituições então editadas, com destaque para a mexicana de 1917, a alemã de 1919, a espanhola de 1931 e a brasileira de 1934. Segundo BONAVIDES (2008, p. 564):

Da mesma maneira que os da primeira geração, esses direitos foram inicialmente objeto de uma formulação especulativa em esferas filosóficas e políticas de acentuado cunho ideológico; uma vez 
proclamados nas Declarações solenes das Constituições marxistas e também de maneira clássica no constitucionalismo da social-democracia (a de Weimar, sobretudo), dominaram por inteiro as Constituições do segundo pós-guerra.

A ideia central inspiradora desses direitos é que, tão importante quanto proteger o indivíduo contra o arbítrio do Estado, é cuidar de sua sobrevivência, ao menos garantindo condições elementares de dignidade.

Destarte, a consequência seria o provável fortalecimento das instituições sociais, com a abertura de um espaço maior para que a pessoa realize plenamente seu desenvolvimento e liberdade nos mais diversos sentidos possíveis. Aqui, enfatiza LEWANDOWSKI (2005b, p. 174) que: "O homem abstrato do passado, assim, cedeu lugar ao trabalhador do presente, que passou a ser o novo sujeito de direitos".

Na segunda metade do século $\mathrm{XX}$, vem a somar-se às preocupações de cunho material o interesse e a necessidade da preservação do ser humano como gênero. Vislumbra-se, portanto, direitos que pertencem não apenas a um ser humano, mas a toda a sociedade e, em certos casos, à própria humanidade. Trata-se dos denominados interesses difusos e coletivos. São os direitos de solidariedade ou fraternidade (LEWANDOWSKI, 2005b, p. 175).

Nessa linha, as Constituições passam a enunciar caber ao Estado proteger a infância e a juventude, o consumidor hipossuficiente, o mercado concorrencial, a família, o meio ambiente, o patrimônio histórico, artístico e cultural, etc., sendo de amplo conhecimento que no Brasil a Constituição de 1988 traz vários mandamentos nesse sentido.

Independente da geração à qual possam ser incluídos, o art. $60, \S^{\circ}$, protege os direitos fundamentais contra eventual avanço do constituinte derivado, inserindo-os dentro do rol das cláusulas pétreas. Dentro desse grupo, segundo NOGUEIRA (1997, p. 174), estaria a denominada "ecologia tributária", ou seja:

O direito a um ambiente tributário limpo e respirável insere, segundo pensamos, a impossibilidade no campo da "ecologia tributária", expressão aqui utilizada em sentido próprio (insuportável nível de imposição tributária), e não no de função extrafiscal, ou seja, de sujeitar o "agente poluidor do ambiente" a uma tributação mais forte. 
Atualmente, começa-se a identificar a quarta ou, até mesmo, a quinta geração dos direitos fundamentais que decorrem: "de novas carências enfrentadas pelos seres humanos, especialmente em razão do avanço da tecnologia da informação e da bioengenharia" (LEWANDOWSKI, 2005b, p. 175).

Incluem-se nessa categoria a proteção contra a manipulação genética e outros direitos de cunho nitidamente difuso ou coletivo, como aqueles que se relacionam com a autodeterminação dos povos, à paz, ao desenvolvimento, à não prevalência de uma burocracia estatal tentacular e outros afins.

Fato é que, embora a previsão das sucessivas gerações de direitos fundamentais consolide-se cada vez mais nos vários textos constitucionais ao redor do Globo, a sua implementação ainda mostra-se instável. Com efeito, salvo aqueles de primeira geração, cujo investimento financeiro resume-se praticamente à manutenção das instituições legais e da ordem pública, os demais direitos fundamentais requerem gastos de muito maior monta.

Nesse ponto, nota-se uma conexão diretamente proporcional entre a capacidade do Estado de fazer cumprir a Constituição (notadamente naquilo em que lhe são incumbidas competências de agir) e o volume de riqueza gerado por uma sociedade, com a correspondente capacidade social de contribuir em prol do bem comum.

Dada a impossibilidade de produzir-se ad infinitum, necessariamente, as escolhas de conteúdo eminentemente político estarão em primeiro plano. Então, em períodos de recessão ou crise econômica, é maior a probabilidade de emergir um estresse de efetividade dos direitos fundamentais, principalmente os de segunda e demais gerações.

A complexidade de circunstâncias aptas a modificarem o resultado dessa equação faz com que, nos dizeres de SARLET (2005, p. 112-113): "a problemática do assim denominado Estado social e democrático de Direito - e, conseqüentemente, da efetiva implementação de padrões mínimos de justiça social - constitui um dos temas centrais da nossa época". 
Não se trata de um desafio atual. Nessa linha, ZOLO (2006, p. 78) noticia que a pioneira Constituição de Weimar teve efetividade incerta, posto que:

são necessários serviços públicos - previdência, transferências monetárias, garantias de níveis mínimos de instrução, saúde e bem-estar etc. - que consomem uma quantidade muito alta de recursos. É, portanto, natural, que pela sua relevante incidência sobre os mecanismos de riqueza e do imposto de renda, os "direitos sociais" apresentem, no contexto de uma economia de mercado, caráter aleatório.

Nesse cenário, a figura dos tributos exerce uma influência de relevo, chegando a ser estratégica, não se podendo esquecer que, via de regra, conforme aduz ROMITA (2005, p. 393), os titulares dos direitos fundamentais de cunho positivo - aqueles de segunda e demais gerações - são simultaneamente devedores, já que contribuintes para o fisco, sabendo-se que as receitas tributárias é que financiam grande parte das políticas públicas. Logo, segundo pondera o autor em foco (idem, p. 393), esses direitos: "Sujeitamse à existência de recursos no orçamento e, em conseqüência, dependem da arrecadação de tributos".

Dada a notória situação social do Brasil, não é preciso muita tinta para concordar que a concretização dos direitos fundamentais de segunda e demais gerações aqui ainda está distante, mesmo que melhoras pontuais e tímidas sejam aferíveis nas últimas décadas. E isso ocorre numa situação fiscal em que a sociedade entrega atualmente ao Estado quase a metade daquilo que produziu, visto ser de conhecimento geral que a carga tributária beira os $40 \%$ do $\mathrm{PIB}^{111}$. É no mínimo curioso, para que não se diga trágico.

Logo, ou o montante de dinheiro não é suficiente dado o número de habitantes, sendo, então, um problema do tamanho da economia, ou, ainda, o retorno à sociedade do que é arrecadado é feito de maneira ineficiente, com desperdício e outras circunstâncias que travam o avanço social. O mais provável é que os dois fenômenos interajam.

${ }^{111}$ Nessa linha, a carga tributária, quando comparada ao PIB, nos últimos anos foi a seguinte: $1986=$ $22,39 \% ; 1987=20,28 \% ; 1988=20,01 \% ; 1989=22,16 \% ; 1990=29,91 \% ; 1991=24,61 \% ; 1992=$ $25,38 \% ; 1993=25,09 \% ; 1994=28,61 \% ; 1995=28,92 \% ; 1996=25,19 \% ; 1997=25,47 \% ; 1998=$ $27,38 \% ; 1999=28,33 \% ; 2000=30,67 \% ; 2001=31,01 \% ; 2002=32,65 \% ; 2003=32,54 \% ; 2004=$ $33,49 \% ; 2005=34,13 \% ; 2006=34,52 \% ; 2007=35,54 \%$ e $2008=36,56$. Fonte: Instituto Brasileiro de Planejamento Tributário. Disponível em: 〈http://www.ibpt.com.br/img/_publicacao/13651/176.pdf〉. Acesso em: 30/7/2009. 


\subsubsection{Direito fundamental da propriedade}

A regulação da propriedade por meio de normas revela-se uma decorrência da percepção humana - quiçá ligada ao próprio instinto de sobrevivência - de que a apropriação de elementos que representem, mesmo que em potencial, utilidades ao seu detentor podem propiciar no futuro uma vida sob menores percalços, como fazem, aparentemente por puro comando genético, as abelhas e as formigas ao usualmente abrigarem em seus habitats certos gêneros. Relembrando com GASTALDI (1970, p. 04):

Quando o ser humano passou a possuir a preocupação da provisão, como elementar cautela para satisfazer necessidades mais mediatas, nesse preciso instante ultrapassou o denominado estado selvagem, constituindo em animal não apenas sociável, mas também em animal econômico.

Infere-se, portanto, a antiguidade do fenômeno, pois é provável que esse sentimento tenha se instalado no intelecto dos seres viventes antes mesmo do primeiro homo sapiens. Assim, num primeiro instante, a propriedade resumiu-se em apoderações "de fato", provavelmente, levadas a efeito segundo "a lei do mais forte".

Por uma série de razões, possivelmente como causa mais importante o anseio de poupar energia e até mesmo vidas em torno das disputas pelas diversas comodidades, a figura da apropriação ganhou tratamento jurídico há muitos séculos, conforme, por exemplo, já estava previsto no Direito Romano pela cláusula: dominum est jus utendi, fruendi et abutendi re sua, quatenus juris ratio patitur, citada por BEVILAQUA (1955a, p. 44).

Em verdade, segundo aponta VAZ (1993, p. 25-26), o Velho Testamento faz remições à propriedade. Nessa linha, em Gênesis, XIII, 15: "Crescei e multiplicai-vos e enchei a terra e sujeitai-a”, havendo indicações, ainda, em Levítico XXV, 11, 13, 23 e 24, e Números XXXIII, 51-54.

O vetusto Código de Hamurabi, cuja elaboração data de 18 séculos antes de Cristo, traz vários dispositivos que permitem perceber o valor que a propriedade então ostentava, dada a gravidade das penas colimadas aos transgressores. Confira-se, por exemplo, a previsão da cláusula 6a: "Se alguém furta bens do deus ou da Corte deverá ser morto; e mais quem recebeu dele a coisa furtada também deverá ser morto". Na mesma linha, a cláusula 22: "Se alguém comete roubo e é preso, ele é morto". Pala cláusula 226: 
"Se um tosquiador, sem ciência do senhor de um escravo, lhe imprime a marca de escravo indelével, dever-se-á cortar as mãos desse tosquiador".

A figura da locação também já era conhecida, pois, conforme a cláusula 244 "Se alguém aluga um boi e um burro e no campo um leão os mata, isto prejudica o seu proprietário”. Dentre as 282 cláusulas desse Código pioneiro, é possível encontrar outros preceitos relacionados com a proteção da propriedade, como as regras que ditam a indenização em caso de danos.

Assim, é inegável que a propriedade vem sendo regulada há muito tempo pela quase totalidade das sociedades humanas, com exceção, talvez, de comunidades isoladas, como os povos indígenas, mas mesmo nesses casos é intuitivo considerar a existência de formas coletivas de propriedade, seja quanto aos utensílios, armas, vestimentas e habitações.

Com efeito, é preciso ficar claro que o desejo de apoderar-se de utilidades em geral pode ser natural, ou mesmo ínsito ao instinto de proteção de cada ser humano, mas a regulação normativa desse anseio geral e esperado - denominada de propriedade - é de natureza convencional.

Todavia, segundo MURPHY e NAGEL (2005, p. 11): “A natureza convencional da propriedade é ao mesmo tempo óbvia e facílima de ser esquecida", talvez porque as pessoas nasçam e vivam em sociedades nas quais a figura já tenha sido estabelecida e regulada há tempos, o que pode gerar a sensação de sua origem provir "da natureza das coisas".

No Brasil, a propriedade foi incluída em todas as Constituições: 1824 (art. 179, XXII), 1891 (art. 72, §17), 1934 (art. 113, alínea 17), 1937 (art. 122, alínea 14), 1946 (art. 141, §16), 1967 (art. 150, §22), 1967, após a Emenda 01, (art. 153, §22) e 1988 (art. $5^{\circ}$, XXII), o que evidencia a sua relevância na estruturação e funcionamento da dinâmica social desde o nascimento do país no início do século XIX. É bem verdade que a propriedade já era prevista anteriormente nas Ordenações. Todavia, segundo alerta VAZ (1993, p. 137): 
A Constituição outorgada por Dom Pedro I marca uma ruptura com a legislação absolutista das ordenações portuguesas e confere outro sentido àqueles "direitos reais", que deixam de ser atribuídos à pessoa do Rei, com o qual se confundia a noção de Estado, tal como ocorria na França no antigo regime.

Evidentemente, segundo as circunstâncias de tempo e local - o que, aliás, demonstra a origem convencional e não natural da propriedade -, serão encontradas sensíveis variações no tratamento normativo dessa figura (v.g. até 1889 era possível no Brasil ser proprietário de seres humanos - os escravos, algo absurdo para atualidade).

Noutro giro, mesmo os países que adotaram um regime comunista ou socialista, com o objetivo principal de que, com a distribuição da riqueza, diminuíssem as disparidades sociais, a propriedade não chegou a ser integralmente abolida, uma vez que passou à titularidade do Estado primordialmente os bens de produção, mas não os relativos ao uso pessoal e indispensável à sobrevivência dos indivíduos.

É bem possível que tal fenômeno tenha por base a imperiosa e inafastável necessidade de as pessoas titularizarem um mínimo de bens e comodidades para conseguirem planejar, mesmo que modestamente, seu cotidiano e ações futuras. Quanto a isso, segundo informa VAZ (1993, p. 61-62):

o Código Civil da U.R.S.S. garante proteção judicial à propriedade privada de certos bens, conforme dispõe o artigo 58: "Nos limites estabelecidos pela lei, o proprietário tem direito de possuir os bens sobre os quais incide sua propriedade, de usá-los e deles dispor" [...] A Lei Fundamental Russa, de 5 de dezembro de 1936, em seu artigo 10, dispunha que o direito do cidadão à propriedade pessoal das rendas e poupanças provenientes de seu trabalho, à propriedade de sua casa de habitação e da economia doméstica auxiliar, dos utensílios domésticos e de uso quotidiano, dos objetos de consumo e de comodidades pessoais e o direito de herdar a propriedade pessoal eram protegidos pela lei.

Mesmo diante da diversidade de detalhes na maioria das regras que cuidam da propriedade, o seu âmago permanece íntegro, isso é, cuida-se da possibilidade de alguém assenhorar-se, com exclusividade, de algo geralmente escasso, por isso com aptidão para mostrar-se como uma comodidade ou utilidade para o seu titular, que poderá desfrutar-lhe dos benefícios quando melhor lhe aprouver, bem como passá-lo adiante mediante ato oneroso ou não. 
Tradicionalmente, a doutrina civilista classifica a propriedade dentro dos Direitos Reais ou das Coisas, por significar o poder dos homens sobre os bens em geral - o domínio, sendo assim classificada pelo Código Civil de 2002 (art. 1228 e ss.). Nesse sentido, as lições de BEVILAQUA (1955a, p. 07), GOMES (1993, p. 01) e NADER (2009, p. 86). Aliás, em termos da ciência jurídica, anota RODRIGUES (1989, p. 75) que:

dentro do sistema de apropriação de riqueza em que vivemos, a propriedade representa a espinha dorsal do direito privado, pois o conflito de interesses entre os homens, que o ordenamento jurídico procura disciplinar, se manifesta, na quase generalidade dos casos, na disputa sobre bens. Trata-se, como é óbvio, de um direito real, ou seja, de um direito que recai diretamente sobre a coisa e independe, para o seu exercício, de prestação de quem quer que seja.

No entanto, esclarece-se que, para fins deste trabalho, a figura da propriedade significa algo mais amplo, de modo a identificá-la com a titularidade de quaisquer bens ou direitos de alguém, englobando, por conseguinte, todo o seu patrimônio, ou seja, bens móveis ou imóveis, fungíveis ou infungíveis, materiais ou imateriais, objeto de direito real ou mesmo pessoal.

Em suma, qualquer coisa, situação de fato ou de direito que possa ser aferida em termos econômicos (v.g. prédios e casas, terras, automóveis, aeronaves, barcos, semoventes, pedras e metais preciosos, obras de arte, dinheiro, ações e debêntures, quotas sociais, quadros, direitos de uso e fruto sobre algo, direitos autorais e sobre marcas e patentes, títulos da dívida pública, créditos em geral, obrigações contratuais, etc.) e que sirva, caso assim deseje seu titular, como meio para a satisfação de suas necessidades e ou desejos.

Destarte, segundo decorre da elevada complexidade do sistema normativo, a figura singular da propriedade pode ser enfoca em termos plurais, segundo expõe SILVA (2008, p. 274) ao explicitar que:

Em verdade, uma coisa é a propriedade pública, outra a propriedade social e outra a privada; uma coisa é a propriedade agrícola, outra a industrial; uma, a propriedade rural, outra a urbana; uma, a propriedade de bens de consumo, outra a de bens de produção; uma, a propriedade de uso pessoal, outra a propriedade/capital [...] Tudo isso, aliás, não é difícil de entender, desde que tenhamos em mente que o regime jurídico da propriedade não é uma função do Direito Civil, mas um complexo de 
normas administrativas, urbanísticas, empresariais (comerciais) e civis (certamente), sob fundamentos das normas constitucionais.

A existência de várias disciplinas da propriedade, de modo a permitir vislumbrá-la inclusive como figuras diferentes, ainda que ligadas por um âmago mínimo comum, não é nova. Segundo NADER (2009, p. 84): “Houve, em Roma, diversas espécies de propriedade sendo a quiritária a principal delas. Nesta modalidade, apenas os cidadãos romanos podiam assumir a titularidade, enquanto aos não-romanos acessível era apenas a posse do ius commercci”. O autor apresenta, ainda, as propriedades: pretoria ou bonitária, res publicae e res religiosae.

Em verdade, o termo "propriedade" comporta acepções diversas para além dos direitos reais. Esclarece PONTES DE MIRANDA (1955, 09) que existe um sentido constitucional e outro afeto às leis civis. Em sua lição:

Em sentido amplíssimo, propriedade é o domínio ou qualquer direito patrimonial. Tal conceito desborda do direito das coisas. O crédito é propriedade. Em sentido amplo, propriedade é todo direito irradiado em virtude de ter incidido regra de direito das coisas (cc. arts. 485, 524 e 862). Em sentido quase coincidente, é todo direito sôbre as coisas corpóreas e a propriedade literária, científica, artística e industrial. Em sentido estritíssimo, é só o domínio. O primeiro sentido é o de propriedade, no art. 141, §16, da Constituição de 1946.

Outra maneira de enfocar o assunto é dividir a propriedade numa dimensão estática e noutra dinâmica. A primeira caracteriza-se pela possibilidade do titular fruir dos benefícios inerentes à natureza do bem independentemente de qualquer ação positiva de sua parte.

Na explicação de VAZ (1993, p. 319): "uma propriedade rural, um terreno urbano, uma casa de residência, uma poupança ou um lote de ações de uma sociedade, não requer, usualmente, nenhuma atividade do proprietário para produzir frutos, gerar rendimentos, proporcionar benefícios ou utilidades ao titular".

No segundo caso - propriedade dinâmica - aparece a ideia de ação, de empreendedorismo, de intervenção do titular para que os frutos apareçam. Segundo a autora citada: "O núcleo, por excelência, das propriedades dinâmicas é a empresa" (idem, p. 323). 
De fato, constata-se que na empresa, em regra, se conjugam os vários fatores de produção que implicam na titularidade simultânea sobre de vários tipos de propriedades (v.g. bens móveis e imóveis, materiais e imateriais, direitos de créditos, marcas e patentes, etc.).

Em conclusão, neste estudo, a figura da propriedade não se resume ao domínio sobre algo que englobe fundamentalmente as faculdades de usar, gozar, e dispor segundo a vontade do titular, respeitadas as disposições de ordem pública. Propriedade aqui é utilizada no seu sentido amplíssimo, sendo, pois, qualificada como qualquer utilidade econômica (de cunho material ou não) cuja fruição seja não-rival, isso é, apenas o seu titular - que eventualmente pode se manifestar como uma coletividade (v.g. condomínios, associações, clubes, pessoas jurídicas, etc.) - é que pode diretamente retirar os benefícios dessa situação, o que cria uma circunstância de exclusividade com efeitos erga omnes.

Em termos funcionais, uma primeira e elementar característica da propriedade, embora não muito alardeada na doutrina, é a sua forte relação com a figura da dignidade da pessoa humana, tema esse que, segundo PEZZI (2008, p. 33), somente começa a aparecer nas Constituições após a Segunda Guerra Mundial: "como marco evolutivo no sentido de que o ser humano constitui a finalidade precípua da atividade estatal, pelo que ficam vedadas quaisquer condutas que importem em sua coisificação".

Assim é que a simbiose entre a propriedade e a dignidade da pessoa humana enaltece a fulcral importância daquele direito fundamental típico de primeira geração.

Contudo, antes de prosseguir, é certo que seria grave equivoco mistificar a propriedade a ponto de considerá-la como algo sagrado ou mesmo como um direito natural inerente à essência do ser humano, como o fez, por exemplo, o art. 17 da Declaração dos Direitos do Homem e do Cidadão, de 1789, ao prever que: "Como a propriedade é um direito inviolável e sagrado, ninguém dela pode ser privado, a não ser quando a necessidade pública legalmente comprovada o exigir e sob condição de justa e prévia indenização". 
Nessa mesma linha, coloca FRIEDMAN (1985, p. 32) que:

A noção de propriedade, como foi desenvolvida ao longo dos séculos e está contida em nossos códigos legais, tornou-se de tal forma parte de nosso pensamento que já a consideramos evidente e não percebemos o quanto a propriedade em si e os direitos que a posse da propriedade confere são criações sociais complexas - e não proposições evidentes por si.

Note-se, portanto, que o art. 17 retro-transcrito, bem como o seu correspondente no Código Napoleônico de 1804, são frutos de uma concepção que dominou certo momento da história humana. Assevera RODRIGUES (1989, p. 78-79) que:

A veemência da regra do art. 544 do Código Napoleônico constitui uma vitória da Revolução de 1789 , e representa menos uma afirmativa exacerbada da vigente concepção individualista, do que uma reação contra os direitos feudais que, mesmo no século XVIII, gravavam a propriedade. A Revolução pusera termo à concepção medieval, dentro da qual o domínio se encontrava repartido entre várias pessoas, sob o nome de domínio iminente do Estado, domínio direto do senhor e domínio útil do vassalo; e havia substituído pelo conceito unitário de propriedade, peculiar ao Direito Romano, e onde o proprietário é considerado senhor único e exclusivo de sua terra.

$\mathrm{Na}$ medida em que esse direito sempre se insere dentro de um sistema sócio-econômico dinâmico, é de ser-lhe devida a reverência que cada ordenamento assim determinar, sendo naturalmente esperadas variações, muitas vezes de grande monta, segundo os elementos tempo e local.

Tanto é que o século XX marca o abandono da visão liberal-naturalista da propriedade com a entrada em cena de concepções inovadoras, como, por exemplo, a denominada função social (v.g. art. $5^{\circ}$, XXIII do Texto de 1988), questão essa que ainda é fortemente debatida na doutrina, em termos de definição, extensão, efeitos e funções.

Aliás, é de atentar-se que, bem antes do surgimento da cláusula da função social, já eram aceitas, sem grandes contestações, as inúmeras limitações impostas normativamente à propriedade, com especial destaque para: direitos de vizinhança; posturas administrativas quanto à segurança e higiene dos imóveis; direito de construir vinculado à área do terreno; impossibilidade de exercer comércio em certas regiões; poder estatal de desapropriação; perda por usucapião; obrigatoriedade de preservação dos elementos originais das edificações históricas em casos de tombamento; impossibilidade de 
desmatamento de certos tipos de vegetação; necessidade de autorização expressa para exploração do subsolo; temporariedade da proteção às marcas, patentes e aos direitos autorais. Todas elas, sem dúvida, acabam por compor de alguma forma a mencionada função social.

Com efeito, se bem notado for, percebe-se que o próprio art. 17 acima transcrito admite a privação da propriedade por motivo de necessidade pública mediante prévia indenização, restando demonstrado, assim, que, mesmo sob a mais pura inspiração individualista-liberal, o interesse coletivo tinha o condão de moldar, de certa forma, o conteúdo de um direito individual relevante para o sistema então moldado.

Porém, independentemente da evolução pela qual a propriedade tenha passado ao longo dos séculos, o sentido de apropriação sempre mostrar-se-á como um elemento comum e primordial, sob pena de não se tratar mais de propriedade.

É importante esclarecer o porquê de essa figura jurídica ser considerada pela maioria dos ordenamentos jurídicos como um direito fundamental. Definitivamente, não é porque os textos constitucionais ou legais a elegem como um direito divino ou decorrente da natureza. É exatamente nesse ponto que entra em cena, como primeira causa, a questão da dignidade da pessoa humana.

A Constituição de 1988 elenca como um dos fundamentos da República Federativa do Brasil a dignidade da pessoa humana. Segundo aponta SARLET (2006, p. 299), essa figura deve ser compreendida como:

a qualidade intrínseca e distintiva reconhecida em cada ser humano que o
faz merecedor do mesmo respeito e consideração por parte do Estado e da
comunidade, implicando, neste sentido, um complexo de direitos e
deveres fundamentais que assegurem a pessoa tanto contra todo e
qualquer ato de cunho degradante e desumano, como venham a lhe
garantir as condições existenciais mínimas para uma vida saudável, além
de propiciar e promover sua participação ativa e co-responsável nos
destinos da própria existência e da vida em comunhão com os demais
seres humanos.

Reconhece-se que esse desiderato dificilmente seria atingido sem a efetiva participação do Estado, principalmente pelo respeito e implementação dos direitos fundamentais, bem como por meio da edificação e mantença de um ambiente institucional 
que permita às pessoas atuar sob um nível mínimino de segurança e satisfação. Com efeito, aduz GOUVEIA (2008, p. 154) que:

no plano econômico, o Estado tem o dever de despender recursos para proporcionar a segurança de um meio ambiente estável o suficiente para proporcionar, por conseguinte, a efetividade da dignidade da pessoa humana. Isso para que qualquer pessoa residente no País possa ter expectativa de um futuro promissor, isto é, esperança de constituir uma vida melhor, porque conta com a garantia de poder tornar realidade seus planos e sonhos de progresso e desenvolvimento, em conformidade com os padrões condizentes com o grau de comodidade alcançado pelo desenvolvimento técnico-industrial neste início de milênio.

E, nesse ponto, nunca se pode perder de vista que é a propriedade (leia-se o patrimônio latu sensu de alguém) que, em suma, garante a dignidade material de seu titular, de maneira a não sujeitá-lo à caridade alheia ou, ainda, aos serviços e auxílios estatais, sabidamente, nem sempre prestados a tempo e hora.

De fato, ainda mais num regime capitalista, a quase totalidade da satisfação das necessidades e desejos das pessoas faz-se mediante intercâmbio de comodidades, funcionando a moeda como o principal meio de troca. Logo, não obstante sempre haver um limite instransponível para qualquer um, é comezinho perceber que há uma relação entre propriedade e bem-estar material de seu titular.

Infelizmente, e isso é uma circunstância notória, ao menos no Brasil e em muitos países cujos índices de desenvolvimento humano ainda não deslancharam, a qualidade das ações estatais, cujo objeto seja promover a dignidade da pessoa humana, principalmente o saneamento básico, a educação elementar, a saúde e o transporte público, é incipiente. Como consequência, há forte procura por tais préstimos perante a iniciativa privada, que costuma apresentar melhores resultados. Todavia, essa alternativa somente descortina-se àqueles que detenham algum nível mínimo de patrimônio e renda.

Deixa a desejar também a cobertura da assistência social. Embora o art. 203 da Constituição de 1988 garanta a quantia de um salário mínimo mensal à pessoa portadora de deficiência e ao idoso que comprovem não possuir meios de prover a própria subsistência por si ou por sua família, o $\S 3^{\circ}$ do art. 20 da Lei 8.742/93, que regulamenta o benefício, condiciona o seu recebimento ao fato da renda familiar mensal per capita ser inferior a 1/4 (um quarto) do salário mínimo. 
O problema não está na ideia em si, uma vez que se coaduna com os princípios do welfare state, mas reside na constatação de que o assistido deva estar ao desamparo pleno, quase à beira da morte, verdadeiramente desprovido de um mínimo de dignidade, situação que certamente estará configurada em núcleos cuja renda média seja tão minguada.

Ora, isso demonstra ser essencial que as pessoas, de um modo geral, procurem, ao longo da vida, amealhar algum patrimônio, com o fulcro de garantirem o atendimento de suas necessidades mais elementares e da respectiva família, pois o Poder Público, ao menos no Brasil, somente prestará socorro em último caso.

Percebe-se, outrossim, segundo expõe SEN (2008, p. 18), que: “Às vezes a ausência de liberdades substantivas relaciona-se diretamente com a pobreza econômica". Sob esse raciocínio, propriedade significa a verdadeira liberdade de escolha para a satisfação das inúmeras necessidades humanas, que variam de pessoa para pessoa, inclusive por questões emocionais e psicológicas atinentes a cada um.

A recíproca verdadeira, ou seja, quanto mais o indivíduo for destituído de patrimônio, menor será a sua liberdade de decidir os rumos da própria vida e, dependendo das privações materiais enfrentadas, terá sua dignidade humana sob séria ameaça, sujeitando-se à caridade alheia, ou, quiçá pior, submetendo-se aos nem sempre suficientes auxílios assistenciais públicos, ambas as hipóteses inegavelmente humilhantes.

Então, segundo afirma GOUVEIA (2008, p. 73): "a liberdade é um direito que deriva imediatamente do princípio da dignidade da pessoa humana”, ou, assemelhadamente, conforme é resumido por ROMITA (2005, p. 392): “A dignidade humana é indivisível: se privada das liberdades públicas, a pessoa não desfruta de direitos econômicos e sociais. Inversamente, sem o gozo dos direitos econômicos e sociais, tornase inviável o reconhecimento da liberdade e da igualdade". E, com fulcro no acima exposto, percebe-se que o gozo desses direitos requer como primeiro passo que o Estado garanta e respeite a propriedade dos individuos.

Evidentemente, a correta compreensão do significado da dignidade humana, ou seja, a composição de um mínimo de utilidades que componha essa figura, é 
de ser fincada por cada sociedade, o que pode variar também em termos de época histórica enfocada.

Nessa linha, o conjunto de condições que eventualmente satisfazia há um século, época em que sequer havia os inúmeros medicamentos que atualmente são corriqueiros (v.g. vacinas, antibióticos, hormônios), bem como quando a quantidade média de calorias diariamente ingerida pelas pessoas era bem inferior aos níveis desse início de século XXI, provavelmente está muito aquém do que possa ser acolhido hoje em dia.

Na mesma esteira, não obstante, em termos biológicos e genéticos, haver identidade entre os humanos de todos os continentes, o padrão europeu de dignidade divergirá do asiático, que, por sua vez, não será idêntico ao americano e assim por diante. Resta claro, pois, que as condições socioeconômicas e culturais de cada povo influenciam diretamente na concepção do conceito em foco, o que torna difícil estatuir um critério de aplicação universal.

Aliás, mesmo dentro de uma comunidade as variações ocorrem, pois, segundo indica PEZZI (2008, p. 41): “a dignidade já se sujeita a certa relativização, na medida em que, como os demais conceitos jurídicos, pode ser objeto de decisões divergentes quanto ao seu conteúdo por parte do juiz, do legislador, do administrador e até de um particular" e isso pode dar-se dentro de um mesmo instante histórico.

Todavia, mesmo considerando essa relativa imprecisão do significado da dignidade humana, a proteção jurídica da propriedade sob o pálio da qualidade de direito fundamental, ainda que com certas limitações justificadas pelo interesse público, é medida que inibe a submissão do indivíduo aos desígnios alheios; é garantia para a sua liberdade de escolha e consequente conquista e manutenção de sua dignidade.

Baseando-se nisso, concorda-se com VAZ (1993, p. 48) quando considera: "a propriedade privada como causa necessária ao pleno desabrochar da personalidade humana", sendo que isso decididamente contribui para explicar, justificar e fundamentar a ideia do porque de essa figura ser usualmente qualificada com o status de direito fundamental. 
Prosseguindo, a proteção jurídica à propriedade concorre para a concretização da harmonia social. Já se afirmou e aqui se repete, face à importância da ideia, que, após o século XVIII, a propriedade se tornou uma figura essencial e central do regime capitalista, uma vez que ele se baseia na produção e circulação de bens, o que não ocorreria, ao menos com a mesma intensidade, na ausência de regras jurídicas claras, minorando a eficiência do sistema, dado que a anomia quase sempre resulta num natural decréscimo das transações consensuais e, pior ainda, estimula o apossar-se sob coação ou violência.

Com efeito, quem se interessaria por produzir algo que tenha potencial para despertar o interesse de terceiros ( $v . g$. alimentos, bebidas, remédios, etc.) se pudesse simplesmente perder sua obra para outrem sem que nada pudesse fazer a respeito a não ser lamentar ou recorrer à força física? Ou, noutra seara, o que ocorreria com um pasto se qualquer um pudesse ocupá-lo com quantas rezes quisesse, sem limites?

O resultado, inclusive já bem alardeado neste trabalho, é uma notável diminuição na circulação de bens e riquezas, seja porque as pessoas não mais se interessam em contratar com outras se não possuírem segurança de que o pacto será atendido, seja porque, com a diminuição da força de trabalho decorrente da provável perda de vidas nas batalhas em torno dos bens disponíveis, a produção não mais atinge o nível anterior. Em suma, a incerteza quanto à disciplina da propriedade contribui para que os indivíduos (e em último grau a coletividade) tenham menos chances de satisfazerem as suas necessidades de forma pacífica e harmoniosa.

Trazendo novamente à baila a explicação de RODRIGUES (2007, p. 56), numa economia de mercado, em face da possibilidade de transferir-se direitos a terceiros (v.g. por compra e venda, leasing, doação, etc.), os bens tendem a acabar nas mãos de quem mais os valorize.

Assim, presume-se que, num negócio não maculado por nulidade ou anulabilidade $^{112}$, o vendedor somente realizará a avença caso o preço recebido possa superar a utilidade que o bem vendido lhe poderia oferecer. O mesmo raciocínio é

112 É indispensável, segundo expõe FRIEDMAN (1985, p. 22), que: "os indivíduos sejam, efetivamente, livres para participar ou não de trocas específicas, de modo que todas as transações possam ser realmente voluntárias". 
aplicável ao comprador, isso é, ele somente ultimará o ato se, em sua visão, lhe for mais vantajoso ter em seu domínio a coisa comprada do que o dinheiro que pagou por ela, numerário esse que inclusive poderia ser utilizado para adquirir outras comodidades.

Em verdade, segundo FRIEDMAN (1985, p. 22), seria deveras complexo discordar que: "nenhuma troca terá lugar a não ser que ambas as partes, realmente se beneficiem dela. A cooperação é, pois, obtida sem coerção".

Sob esse prisma, conclui-se que findo o negócio as partes se encontram em situação melhor (leia-se aumento de bem-estar) do que no instante anterior, sendo essa, então, uma importante característica que resulta da possibilidade de se mercadejar com a propriedade. Conforme asseverado por SZTAJN e VERÇOSA (2003, p. 08):

O resultado dessa circulação tende a deixar as duas partes em situação melhor do que estavam anteriormente. Isto porque, quando obtém o que desejam elas satisfazem suas necessidades, conseqüentemente aumentando seu bem estar. Este tipo de troca econômica será eficiente, a alocação dos bens 'Pareto superior' ou 'Pareto ótima'. Os bens circularão na economia $\mathrm{e}$, enquanto as contínuas mudanças não prejudiquem qualquer dos envolvidos, as operações serão eficientes e desejáveis.

É intuitivo perceber que as transações serão maximizadas se inseridas num ambiente institucional favorável e que tenda a minimizar as perdas. Fatores tais como segurança jurídica (quanto à imutabilidade do pacto) ${ }^{113}$, exequibilidade (execução forçada em caso de inadimplemento), ambos englobados pelo conceito de propriedade aqui tratado, e previsibilidade (elemento ligado aos riscos do negócio) devem ser considerados - e fortemente albergados - pelo sistema normativo sob pena de gerar desestímulo aos agentes econômicos pelo aumento dos custos de transação.

Ora, essas considerações mostram como, de fato e inegavelmente, o regime da propriedade termina por influir no nível de bem-estar social que uma

${ }^{113}$ Certamente por levar em conta estas evidências, é que o art. 5º XXXVI, da Constituição Federal de 1988 protege o ato jurídico perfeito, isso é, todas as modalidades de negócios jurídicos nos quais as partes manifestam livremente sua vontade. Então, o desfazimento ou modificação coercitiva de um pacto, em princípio, somente se autoriza na presença das hipóteses restritas legalmente elencadas. Trata-se dos casos de nulidade (v.g. ausência de agente capaz, objeto lícito ou desrespeito à forma legal) e dos vícios de vontade (v.g. erro, dolo, simulação, lesão, estado de perigo, fraude) tidos como hipóteses de anulabilidade. 
comunidade pode experimentar. Aliás, esse assunto muito se liga com as relações travadas entre o direito e a economia objeto de análise no item 2.6.

Assim, ante aos benefícios sociais que é capaz de promover basicamente a minoração da violência física na disputa pelos bens e o estímulo à criação e circulação de bens e riquezas, surge uma segunda causa que justifica plenamente seja a propriedade considerada como um direito fundamental (apenas para recordar, a primeira causa foi vista acima com a relação entre a propriedade e a dignidade da pessoa humana).

\subsubsection{Direito fundamental da livre iniciativa}

Outro direito fundamental de relevo é a livre iniciativa, ou seja, a liberdade para alguém exercer profissão ou empreender atividade econômica, que, no Brasil, salvo nas hipóteses previstas em lei, independe de autorização do Estado (arts. $5^{\circ}$, XIII, e 170, parágrafo único, ambos da Constituição de 1988).

Cuida-se, em verdade, de um tema que chega a extrapolar o âmbito das relações econômicas, ligando-se à proteção da liberdade considerada em toda sua amplitude, isso é, vista como uma faculdade cujo exercício se destina a proporcionar o desenvolvimento econômico, social e político não somente do indivíduo, mas da própria sociedade.

De fato, conforme expõe SILVA (2008, p. 232): “a história mostra que o conteúdo da liberdade se amplia com a evolução da humanidade. Fortalece-se, estende-se, à medida que a atividade humana se alarga. Liberdade é conquista constante”.

Trata-se, como já mencionado, de um dos valores basilares da democracia. Contudo, a noção de liberdade individual é recente em termos históricos, eis que, em eras passadas, o indivíduo e tudo o que possuía, em verdade, se amalgamavam com o grupo a que pertencia e isso era algo absolutamente normal e esperado. Nesse campo, a prevalência do coletivo sobre o individual era tamanha que sequer destoava do pensamento geral e das ações da comunidade. Assim, esclarece COULANGES (1954, v.1, p. 346) que:

Em sociedade organizada sobre tais bases, a liberdade individual não podia existir. O cidadão estava em todas as coisas, submetido, e sem 
reserva alguma, à cidade; pertencia-lhe inteiramente. A religião que criara o Estado, e o Estado que cuidava da religião, apoiavam-se mutuamente e apresentavam um só corpo [...] Nada havia no homem independente. $\mathrm{O}$ seu corpo pertencia ao Estado e estava-lhe votado na sua defesa; em Roma o serviço militar aparecia obrigatório até os quarenta-e-seis anos, e em Atenas e Esparta por toda a vida.

Liberdade não significa, evidentemente, possibilidade de levar-se a efeito todo e qualquer desejo. Alguma conformação com os interesses e os desejos de terceiros, cujas bordas usualmente são delineadas pela regra da maioria, é essencial e isso se efetiva, quando não pela cooperação de todos de forma natural, pela imposição de uma ordem dotada de coerção, seja ela escrita ou não.

O objetivo é, sem dúvida, garantir a segurança dos indivíduos que convivem em sociedade, devendo-se materializar na intensidade apenas necessária aos fins que preconiza.

Nesse sentido, pela proposta formulada por SILVA (2008, p. 232): “a autoridade é tão indispensável à ordem social - condição mesma da liberdade - como esta é necessária à expansão individual [...] O que é válido é afirmar que a liberdade consiste na ausência de toda coação anormal, ilegítima e imoral".

Segundo já pontuado anteriormente, em termos históricos, a liberdade, vista agora em sua dimensão essencialmente econômica, manifesta-se como uma conquista do século XVIII contra a ingerência desmedida do Estado nos negócios particulares, por meio da doutrina do laissez faire, laissez passer, cujo auge deu-se entre o final do século XVIII e a metade do seguinte, quando entrou em declínio, até seu abandono, na prática, ocorrido a partir das primeiras décadas do século XX com o welfare state. É desnecessário, pois, repetir esses elementos nesse aspecto já amplamente divulgados.

O que interessa, em termos de primeira acepção, é que, mesmo sob restrições legalmente estabelecidas, num regime de livre iniciativa, é a partir do exercício da atividade profissional ou da atuação econômica que os indivíduos retiram o sustento diário, adquirindo o patrimônio capaz de garantir sua dignidade. As regras de experiência demonstram que a obtenção de bens e comodidades por outras causas (v.g. doações, heranças, legados, apropriações, etc.) são efetivamente esporádicas, circunstância que serve para demonstrar a magna importância da proteção à livre iniciativa. 
Evidentemente, o regramento legal exercido dentro da razoabilidade é legítimo, pois visa à manutenção do sistema de trocas pacíficas, constituindo-se, em última instância, numa proteção aos agentes econômicos contra práticas que possam, por exemplo, prejudicar a ampla concorrência e, com isso, imporem maiores custos sociais do que o indispensável.

Os benefícios de um regime que garanta e verdadeiramente estimule a livre iniciativa não se resumem apenas à esfera individual. É que a sua dinâmica, pelas infindáveis transações e melhoria presumida de bem-estar em cada uma delas, acaba por gerar relevante riqueza social, uma vez que a livre iniciativa em ação transforma parcela da propriedade estática em propriedade dinâmica. Com efeito, esclarece VAZ (1993, p. 151) que:

Retirar o capital, os bens de produção do estado de ócio (aspecto estático), consiste, pois, em utilizá-los em qualquer empresa proveitosa a si mesma e à comunidade. É dinamizá-los para produzirem novas riquezas, gerando empregos e sustento aos cooperadores da empresa e à comunidade. É substituir o direito individual, religioso, de dar esmola pelo dever jurídico inspirado no compromisso com a comunidade, de proporcionar-lhe trabalho útil e adequadamente remunerado.

Em adição, constata-se que a liberdade econômica influi na liberdade política de um povo, sendo que FRIEDMAN (1985, p. 17) considera a primeira como instrumento indispensável para a obtenção da segunda ao deixar claro que: "não conheço nenhum exemplo de uma sociedade que apresentasse grande liberdade política ${ }^{114}$ e que também não tivesse usado algo comparável com um mercado livre para organizar a maior parte da atividade econômica".

Essa relação entre liberdade econômica e política também é percebida por SEN (2008, p.10) ao afirmar que: "há fortes indícios de que as liberdades econômicas e políticas se reforçam mutuamente, em vez de serem contrárias umas às outras (como às vezes se pensa)".

${ }^{114}$ Para o autor (idem, p. 23-24): "Liberdade política significa ausência de coerção sobre um homem por parte de seus semelhantes. A ameaça fundamental à liberdade consiste no poder de coagir, esteja nas mãos de um monarca, de um ditador, de uma oligarquia ou de uma minoria momentânea. A preservação da liberdade requer a maior eliminação possível de tal concentração de poder e dispersão e distribuição de todo o poder que não puder ser eliminado - um sistema de controle e equilíbrio". 
Uma explicação repleta de plausibilidade é fornecida por FRIEDMAN (idem, p. 24). Dessa feita, em sua compreensão, enquanto o poder econômico é passível de ser amplamente dispersado pela iteração de milhares - ou mesmo milhões - de agentes econômicos dentro do mercado, a criação de vários centros de poder político equipotentes é praticamente impossível, isso é, embora seja viável a co-existência de algumas centenas de milionários numa grande economia, em termos políticos, isso não é capaz de se repetir, uma vez que apenas poucos líderes ou partidos políticos realmente importantes, cujo carisma e aceitação social pesem de fato por ocasião dos pleitos eleitorais, é que existirão. Ao menos é isso o que tem ocorrido nas últimas décadas em muitos locais.

Portanto, se o poder econômico fundir-se com o político (v.g. por meio da contumaz estatização de empresas como tem feito Hugo Chávez na Venezuela nos últimos anos), a concentração pode tornar-se muito elevada e passar a representar um risco à manutenção da democracia.

De outro lado, se o poder econômico for mantido separado do poder político e, portanto, em outras mãos, ele poderá servir como controle e defesa contra o poder político, sendo certo que os dissidentes do regime terão como encontrar apoio notadamente financeiro - para divulgar suas ideias.

Evidentemente, esse raciocínio pressupõe que o poder econômico esteja disperso na sociedade e não concentrado em poucos grupos justamente para que exista um equilíbrio entre os interesses contrapostos dos agentes, criando, com isso, a possibilidade da plurificação de ideias e perspectivas dentro da comunidade. Vale aqui, mais uma vez, transcrever exemplos pensados por FRIEDMAN (1985, p. 25-26), cujos argumentos são, de fato, muito contundentes:

O editor competitivo, por exemplo, não se pode permitir publicar apenas obras com que concorda pessoalmente, pois a garantia de sua empresa é a de que o mercado seja bastante amplo para fornecer-lhe um retorno satisfatório sobre o investimento. Desse modo, o mercado rompe o círculo vicioso e torna finalmente possível financiar tais empreendimentos por meio de pequenas contribuições de muitas pessoas sem ter que persuadi-las primeiro. Não existe tal possibilidade na sociedade socialista: existe somente o estado todo-poderoso

[...]

Os fornecedores de papel estão dispostos a fornecer material tanto ao Daily Worker quanto ao Wall Street Journal. Numa sociedade socialista, não seria suficiente ter fundos. $\mathrm{O}$ hipotético partidário do capitalismo 
teria que persuadir uma fábrica de papel do governo a vender-lhe o material; uma editora do governo a imprimir para ele; o serviço de correios do governo a distribuir seus panfletos; uma agência do governo a lhe alugar uma sala para reuniões e conferências.

[...]

Ninguém que compra pão sabe se o trigo usado foi cultivado por um comunista ou um republicano, por um constitucionalista ou um fascista ou, ainda, por um negro ou por um branco. Tal fato ilustra como um mercado impessoal separa as atividades econômicas dos pontos de vista políticos e protege os homens da discriminação com relação a suas atividades econômicas por motivos irrelevantes para a sua produtividade - quer estes motivos estejam associados às suas opiniões ou à cor da pele.

Embora existam circunstâncias que possam influir na liberdade pessoal de transacionar (v.g. negócio concluído em estado de perigo), com risco de sua mitigação em algum nível, é um fato que a garantia e o implemento da livre iniciativa se mostra importante como um dos meios capazes de majorar o bem-estar social. Nessa esteira, na feliz exposição de SEN (2008, p. 21):

Ser genericamente contra os mercados seria quase tão estapafúrdio quanto ser genericamente contra a conversa entre as pessoas (ainda que certas conversas sejam claramente infames e causem problemas a terceiros - ou até mesmo aos próprios interlocutores). A liberdade de trocar palavras, bens ou presentes não necessita justificação defensiva com relação a seus efeitos favoráveis mais distantes; essas trocas fazem parte do modo como os seres humanos vivem e interagem na sociedade (a menos que sejam impedidos por regulamentação ou decreto). A contribuição do mecanismo de mercado para o crescimento econômico é obviamente importante, mas vem depois do reconhecimento da importância direta da liberdade de troca - de palavras, bens , presentes.

Portanto, um mercado em funcionamento é certamente um dos catalisadores que aceleram o desenvolvimento, embora não seja o único ${ }^{115}$. E isso ocorre independentemente do que o mecanismo do mercado possa fazer - ou não - para o crescimento da economia (SEN, idem, p. 21). Logo, é indispensável que qualquer regulação legal que venha disciplinar ou restringir a livre iniciativa esteja bem atenta a fatores como esse.

115 Conforme SEN (2008, p. 25), em síntese, a partir de cinco liberdades elementares é que o desenvolvimento pode ser alcançado. São elas: a) liberdades políticas; b) facilidades econômicas; c) oportunidades sociais; d) garantias de transparência; e) segurança protetora. Com efeito: "As políticas públicas visando ao aumento das capacidades humanas e das liberdades substantivas em geral podem funcionar como meio de promoção dessas liberdades distintas mas inter-relacionadas". 


\subsubsection{Proteção do indivíduo contra o exagero fiscal}

Com efeito, a tributação implica, em síntese, na transferência compulsória de uma parcela da propriedade de alguém (em sentido amplo) para o Estado, uma vez que distantes estão as épocas em que as obrigações comunitárias podiam ser satisfeitas por meio dos serviços pessoais. Segundo COSTA (2001, p. 80-81):

o direito à propriedade privada é alcançado direta e imediatamente pela tributação, porque $\mathrm{o}$ tributo consiste em prestação pecuniária compulsória, devida por força de lei, implicando a sua satisfação, necessariamente redução do patrimônio do sujeito passivo. [...] Em outras palavras, se o ordenamento constitucional ampara determinados direitos, não pode, ao mesmo tempo, compactuar com a obstância ao seu exercício, mediante uma atividade tributante desvirtuada. A atividade tributante do Estado deve conviver harmonicamente com os direitos fundamentais, não podendo conduzir, indiretamente, à indevida restrição ou inviabilização de seu exercício".

Logo, entrando em cena a ingerência coercitiva sobre direito fundamental, constitucionalmente previsto, é de todo rigor que essa operação seja levada a efeito conforme as estritas regras maiores, com destaque às limitações constitucionais ao poder de tributar, segundo a previsão do art. 150 da Constituição de 1988 (legalidade, isonomia, irretroatividade, anterioridade, vedação ao efeito de confisco, liberdade de tráfego e imunidades).

Aliás, esses preceitos devem ser considerados como cláusulas pétreas, ou seja, normas protegidas contra qualquer investida do poder constituinte derivado, nos claros moldes do art. $60, \S 4^{\circ}$ do Texto.

Esse entendimento foi adotado pelo Supremo Tribunal Federal, por exemplo, no julgamento da ADIN no 712-DF (Plenário, j. 07.10.1992, DJU 19.02.1993, p. 2032, Relator Ministro Celso de Mello), transcreve-se:

Os princípios constitucionais tributários, assim, sobre representarem importante conquista político-jurídica dos contribuintes, constituem expressão fundamental dos direitos individuais outorgados aos particulares pelo ordenamento estatal. Desde que existem para impor limitações ao poder de tributar do Estado, esses postulados tem por destinatário exclusivo o poder estatal, que se submete à imperatividade de suas restrições. 
Então, quando se fala em democracia fiscal, parte-se do pressuposto de que esses mandamentos constitucionais que limitam o poder de tributar sejam sempre atendidos por toda e qualquer regra que trate do assunto, justamente porque o seu menoscabo pode ferir o direito de propriedade e, por conseguinte, neutralizar o aspecto da liberdade. Disso se conclui, na síntese de BECHO (2009, p. 335), que: “a máxima da liberdade vai exigir que o Estado exerça sua competência tributária respeitando a liberdade de existência, livre arbítrio e de propriedade do contribuinte".

Contudo, é indispensável reconhecer que propriedade e livre iniciativa, com todos os benefícios individuais e sociais que delas emergem, dependem de uma estrutura estatal capaz de garantir ao respectivo titular a devida reparação em caso de violação ao direito.

Logo, na ausência de um Estado constituído, com instituições regulares e em funcionamento, não se concebe a propriedade, salvo aquelas poucas utilidades - alguns alimentos, cobertores, agasalhos - que eventualmente possam ser apreendidas com as mãos. O mesmo é valido para a livre iniciativa, visto que as transações em geral somente florescem sob o manto da proteção às regras contratuais.

De fato, coloca FRIEDMAN (1985, p. 23) que: "um governo é essencial para a determinação das 'regras do jogo' e um árbitro para interpretar e pôr em vigor as regras estabelecidas". Frisam MURPHY e NAGEL (2005, p. 11) que:

a economia moderna na qual ganhamos nosso salário, compramos nossa casa, temos a nossa conta bancária, economizamos para a aposentadoria e acumulamos bens pessoais, e na qual usamos nossos recursos para consumir ou investir, seria impossível sem a estrutura fornecida pelo governo, que é sustentado pelos impostos.

Mais adiante, os autores referidos (idem, p. 35) complementam o pensamento ao afirmarem que: "em se tratando de governos que não escraviza, assassinam nem perseguem partes da população, cada cidadão de uma sociedade dotada de governo está em melhor situação, depois de pagar seus impostos, do que estaria se não houvesse governo". 
E se inegavelmente o Estado faz-se essencial à manutenção da propriedade e do sistema contratual, não menos verdadeiro é a circunstância de que sem tributos que regularmente abasteçam o Tesouro Público, o Estado não opera.

Por conseguinte, até por uma questão de lógica, a tributação, embora atinja parte da propriedade individual, garante a subsistência da parcela que resta nas mãos do indivíduo. Em suma, sob tais aspectos, o tributo pode mesmo ser enfocado como o preço da liberdade. Nesse tema, NABAIS (2005b, p. 26) coloca muito claramente essa acepção, ao afirmar:

O que significa que os actuais impostos são um preço: o preço que todos, enquanto integrantes de uma dada comunidade organizada em estado (moderno), pagamos por termos a sociedade que temos. Ou seja, por dispormos de uma sociedade assente na liberdade, de um lado, e num mínimo de solidariedade, de outro.

Na mesma linha, caminha o entendimento de PEZZI (2008, p. 82-83). Em verdade, essa noção já estava presente nos teóricos do liberalismo ao final do século XVIII, conforme aponta TORRES (1991, p. 120). O que se modificou foi a ideia, amplamente aqui já proclamada, em torno das funções dos tributos, da estrita fiscalidade à convivência com a extrafiscalidade, isso é, embora permaneça o escopo de proteção à propriedade, a ampliação das funções estatais implicou em aceitar tenham os tributos funções regulatórias, de redistribuição de renda e de financiamento de políticas públicas.

Todavia, ainda que se concorde sejam os tributos um preço que o cidadão deve pagar por sua liberdade, o problema surge com a questão de identificar os aspectos que envolvem os limites desse preço.

É que, em relação aos Estados de uma maneira geral, segundo adverte FUKUYAMA (2005, p. 17): "O mesmo poder que lhes permite proteger os direitos de propriedade e prover a segurança pública também lhes permite confiscar propriedades privadas e abusar dos direitos dos seus cidadãos". Na célebre frase do juiz John Marshall, da Supreme Court dos Estados Unidos, nos idos de 1819, na ocasião do julgamento do caso McCulloch v. Maryland, citado por NABAIS (2005b, p. 25): "o poder de tributar envolve o poder de destruir". Destruir ou neutralizar o que? Principalmente a propriedade e a livre iniciativa. Entra em cena, assim, o tema da exagerada intensidade fiscal. 
A doutrina de DÓRIA (1986, p. 176 e ss.) identifica diferenças entre o tributo excessivo, o proibitivo e o confiscatório. Nesse sentido, sob o entendimento de que: “exige-se, no sistema capitalista, que a tributação poupe os valores necessários à satisfação vital do consumo, à manutenção do capital, e uma parcela destinada à formação de novos capitais" (idem, p. 176-177), o tributo será excessivo quando colocar sob entraves e amarras um desses postulados, isso é, quando incidir em demasia.

Portanto, nos termos dessa explicação, ainda que grave parcela considerável da riqueza ou do patrimônio de alguém, no tributo excessivo não chega a ocorrer impedimento ou asfixia do desenvolvimento de alguma atividade econômica, bem como é garantido ao indivíduo parcela de seu patrimônio dirigida a suportar seu consumo vital, ou seja, resta em seu poder uma parcela patrimonial mínima.

Prosseguindo, DÓRIA (idem, p. 183-184) entende que a falta de semelhança entre a exação excessiva e a proibitiva é apenas uma questão de grau, entrando em cena aqui a asfixia, a impossibilidade, a destruição da atividade tal a parcela patrimonial sacrificada. Portanto, o tributo excessivo dificulta e o proibitivo, de tão oneroso que se manifesta, destrói.

Porém, segundo o autor, o fato do tributo transmudar-se em proibitivo não é suficiente para considerá-lo ilícito, sendo de rigor que isso se dê em termos coletivos, de categoria, com o propósito de eliminá-la, uma vez que nunca pode ser descartada a incompetência do agente econômico que culpa a oneração fiscal pelo seu insucesso.

Nesse particular, discorda-se do eminente mestre, já que o afastamento de eventual incompetência do sujeito passivo pode ser objeto prova, ou seja, é viável admitir que se possa demonstrar (por perícias, laudos, estimativas, etc.) o caráter proibitivo de alguma exação independentemente de questões administrativas ou de gerenciamento, conforme será visto mais adiante com o tema da possibilidade de intervenção judicial em tais hipóteses.

Em certas ocasiões, DÓRIA (idem, p. 188) admite que o tributo proibitivo seja revestido de licitude. Trata-se da faculdade do Estado de majorar exações com base no poder de polícia de modo a restringir ou desestimular atividades que, embora 
lícitas, sejam tidas como prejudiciais ao interesse público, v.g.: produção e comércio de cigarros e bebidas alcoólicas. No mesmo diapasão, é o pensamento de CASTILHO (2002, p. 119).

Contudo, mesmo nesses casos, é discutível se o poder fiscal poderia chegar a gravar tanto alguma atividade a ponto de torná-la inoperante em face de uma elevadíssima carga fiscal. Ora, se o ordenamento jurídico não proíbe expressamente, como faz, por exemplo, em relação à produção e ao comércio de drogas, é porque a atividade é lícita, não sendo admissível, portanto, que, pela via da tributação, se atinja o mesmo efeito da proibição expressa. É provável que houvesse aí, no mínimo, um desvio de finalidade, pelo exagero que se estaria dando à função extra fiscal das exações, que, por obvio, não pode chegar a nulificar a livre iniciativa se a atividade não for legalmente vedada.

Ademais, é necessário considerar que uma oneração fiscal muito exacerbada pode estimular o contribuinte, ainda que parcialmente, a passar a exercer suas atividades de modo subterrâneo (ou informal) com o resultado imediato da interrupção do recolhimento das exações que incidiriam caso as ações operassem aos olhos da legalidade, evento que se liga ao $3^{\circ}$ fundamento da democracia fiscal visto adiante.

Por fim, na tributação confiscatória, há apropriação de parte substancial do patrimônio do indivíduo sem justa indenização (DÓRIA, idem, p. 194 - no mesmo sentido: CASTILHO; 2002, p.39; e COSTA; 2007, p. 118). Então, a tributação confiscatória suplanta as forças econômicas do contribuinte (CARRAZZA, 2004, p. 361).

Todavia, uma vez que a indenização ordinariamente cabe em face de atos delituosos diretamente contrários ao ordenamento jurídico, não sendo essa a natureza do tributo, ao menos com base na doutrina e no que dispõe o art. $3^{\circ}$ do Código Tributário Nacional, quiçá seja possível utilizar também a expressão ausência de "retorno".

Aliás, se é indiscutível que o Estado existe para proteger os indivíduos, usando seu poder de coerção para que a vida em comunidade seja harmônica e o mais próspera possível, e não o contrário, é intuitivo considerar a imperiosa necessidade de existir algum nível de "retorno" que o Estado deva conferir aos contribuintes em troca das quantias que recebeu a título de tributos. Com efeito: "Quando o Estado toma de um 
indivíduo ou de uma classe além do que lhes dá em troco, verifica-se exatamente o desvirtuamento do imposto em confisco" (DÓRIA, idem, p. 195).

Evidentemente, e isso deve ficar muito claro, essa ideia de "retorno" nada pode ter a ver com as taxas (de natureza contraprestacional) ou com a figura dos empréstimos compulsórios (restituíveis após certo período). O enfoque aqui ostenta um sentido muito mais amplo, isso é, em termos da qualidade geral das instituições legais, dos principais serviços e políticas públicas. O tema será retomado adiante.

Há entendimentos que equiparam os tributos confiscatórios aos proibitivos ou excessivos, ressaltando-se BRUYN JÚNIOR (2001, p. 72-73), quando qualifica de confiscatório o tributo capaz de inviabilizar ou dificultar sobremaneira a subsistência da pessoa ou sua capacidade de continuar criando riquezas.

Em caminho semelhante, TIPKE e YAMASHITA (2002, p. 46) consideram o confisco tributário: "quando ele consome completamente o rendimento de capital, ou quando ele torna não-rentável uma empresa, ou a leva à sua paralisia". No entendimento de BARRETO (1994, p. 100), a distinção não seria mais cabível, uma vez que a Constituição, pelo art. 150, IV, vedaria qualquer tributo que ostentasse o efeito de confisco, independentemente de poder-se qualificá-lo de excessivo ou proibitivo.

O que importa destacar nesse instante é que a presença de tributos excessivos, proibitivos ou confiscatórios, independentemente de considerarem-se essas categorias como fenômenos autônomos ou não ${ }^{116}$, poderá significar desrespeito aos direitos individuais da propriedade e da livre iniciativa, caso a intensidade da tributação neutralize de maneira desmedida um desses direitos.

Sob esse aspecto - e somente sob esse aspecto, é possível considerar que existe uma fusão entre essas categorias. Segundo HORVATH (2002, p. 49), esse raciocínio encontra guarida na Constituição de 1988. Em suas palavras:

Com efeito, ao proteger a propriedade privada, ela já está, a nosso ver, proibindo que o ônus da tributação comprometa de forma abusiva a renda

\footnotetext{
${ }^{116}$ Propõe-se, então, apenas para fins desse estudo, denominar as três ocorrências de "exagero fiscal", uma vez que o interesse da pesquisa volta-se primordialmente para os respectivos efeitos, análogos em todos os casos.
} 
e o patrimônio do cidadão (ou da pessoa jurídica), ou lhe iniba o consumo. Assim, estaria proibindo que qualquer tributo individualmente considerado, ou dentro da visão conjunta do sistema tributário - fosse excessivo ou "proibitivo".

Conforme expõe MICHELS (2005, p. 226), uma tributação exagerada traz uma série de malefícios sociais e aos cidadãos contribuintes, notadamente porque: "desvigora os laços de comprometimento desde mesmo cidadão com a sociedade de que faz parte. E segregação e degradação sociais são dois fenômenos altamente nocivos para a idéia de desenvolvimento".

A necessidade de proteger-se o sujeito passivo contra um fisco muito voraz já foi percebida há milênios. Conforme noticia FURLAN (2007, p. 66), Tibério Nero César, o segundo Imperador romano, em resposta a governadores de algumas províncias que solicitavam incrementar a arrecadação por meio de novos impostos, afirmou que o bom pastor deve tosquiar seu rebanho, mas nunca escorchá-lo. Destaque-se que nessa época não se cogitava da existência de direitos fundamentais que pudessem frear a sanha tributária imperial.

Com efeito, o Estado não pode atuar no sentido de destruir ou desconsiderar qualquer direito fundamental por meio da tributação (COSTA, 2007, p. 155). Evidentemente, em nome do interesse público, é possível restringir ou regular a ação do indivíduo, principalmente na seara econômica, mas não se pode admitir o seu menoscabo, sob pena de inversão dos papéis, ou seja, o Estado existe e se justifica na medida em que promove a proteção dos indivíduos e da comunidade, em todos os aspectos, e não o contrário $^{117}$. Por tudo isso, há quase 70 anos, BILAC PINTO (1940, p. 552) já afirmava que:

E êsse conceito atualizado de Poder Fiscal é o de que êsse Poder deve ser exercido sem perturbar a economia particular, sem suscitar embaraço ou desencorajamento da indústria, do comércio ou da lavoura, em razão de tarifas exorbitantes ou de modalidades tributárias que violem os

${ }^{117}$ Num tom absolutamente jocoso, que inclusive beira o humor negro, mas que merece ser transcrito pela crueza que encerra, segundo Jean Baptiste Colbert, tesoureiro do rei francês Luís XIV: "A arte da tributação consiste em depenar o ganso de modo a obter a maior quantidade possível de penas com o menor volume de grasnidos" (in Relatório do Banco Interamericano de Desenvolvimento: a política das políticas públicas, 2007, p. 183). Essas palavras refletem muito claramente a ideia do fisco absolutista, não indicando qualquer respeito pela figura do contribuinte, ao contrário, chega a tratá-lo como um animal irracional e "reclamão". 
postulados básicos da justiça, de igualdade, de comodidade e economia dos impostos.

Em paralelo, pondera CAMPOS (2005, p. 89) que:

Quando a imposição financeira se torna tão elevada que, embora os bens e o trabalho estejam na titularidade dos cidadãos, quem deles dispõe, quem os goza, são os governantes, seus verdadeiros proprietários; na ausência da justiça, é tão legítima a vontade dos governantes de que os cidadãos entreguem todos os seus bens como a dos cidadãos em não pagarem nada. A relação entre o nível de obrigação consentida e o grau de imposição revela um certo estado de saúde da comunidade política: saúde, se a obrigação consentida sobreleva; doença, se a imposição predomina [...] Através de uma carga fiscal demasiadamente elevada, o Estado passa a ser o real proprietário dos bens e dos rendimentos do trabalho dos cidadãos.

E, na opinião de ESCRIBANO (1987, p. 32), ao discorrer a respeito do sistema espanhol, evitar o exagero fiscal é de suma importância, não apenas porque evita a violação a direitos fundamentais, mas porque impede que o sistema tributário seja utilizado como instrumento de penalização para certas categorias, o que significaria um desvirtuamento de suas finalidades essenciais.

Embora tenha restado muito claro que o exagero fiscal ofende aos direitos fundamentais da propriedade e da livre iniciativa, os maiores problemas surgem quando se pretende identificar, com alguma acuidade, as hipóteses nas quais esse fenômeno deletério se faz sentir.

Primeiramente, é de se convir que o exagero fiscal não se manifesta necessariamente apenas pela análise do ônus financeiro gerado por um tributo determinado, mas, na maioria dos casos, decorre da somatória das imposições perpetradas sob certa pessoa, isso é, a carga tributária como um todo.

É que, em termos práticos, usualmente os tributos não possuem alíquotas sobremaneira elevadas de modo a gravar, por exemplo, mais da metade da situação econômica a que dizem respeito. A regra geral, ao menos é o que se tem observado ao 
longo dos anos, é que as alíquotas se fixem entre $1 \%$ a $10 \%$ sobre determinada base legislativamente eleita ${ }^{118}$.

Nesse tópico, segundo expõe SABBAG (2009, p. 199): “A universalidade da carga tributária, para fins de detecção do confisco tributário, é a única capaz de dimensionar se o pagador de tributos, ao se sujeitar a esta múltipla incidência, terá condições de viver e se desenvolver".

Então, sob pena de perder-se de vista uma dada realidade, que, de fato, poderia colocar em risco direitos fundamentais, é indispensável que a percepção de eventual exagero fiscal leve em conta toda parcela da propriedade de alguém que é suprimida pela tributação, o mesmo se aplicando para o nível dos entraves causados à livre iniciativa.

Certa doutrina trabalha com a presunção de restar confiscatória a carga tributária que ultrapassar $50 \%$ do PIB, encontrando-se presente também a ideia de "retorno" do tributo. Segundo indica NABAIS (1998, p. 220):

Na impossibilidade, porém, de provar a reprodutividade de cada despesa do estado [evidencia-se aqui a idéia de retorno], os autores propõem como solução a presunção da reprodutividade de todas as despesas do estado, presunção essa que, no entanto, seria arredada quando os impostos atingissem uma quota superior a 50\% do PIB. Numa tal situação inverter-se-ia o ónus da prova pelo que recairia sobre o estado o encargo de apresentar uma justificação especial para o nível de impostos atingido, nível este que há-de ter caráter manifestamente excepcional.

De acordo com CAMPOS (2005, p. 104): "Pergunto-me em que medida cargas fiscais de mais de 60\% sobre os rendimentos (impostos directos e indirectos) são compatíveis com o direito fundamental à propriedade privada, ao trabalho e ao gozo dos respectivos rendimentos”. Somente pelo tom utilizado, já é possível inferir o entendimento do autor.

118 Apenas como meros exemplos, citam-se: Imposto sobre Operações Financeiras - IOF - dificilmente ultrapassa os $3 \%$ sobre a operação; IPTU - entre $2 \%$ a $4 \%$ sobre o valor do bem, o mesmo valendo para o IPVA e para as transmissões inter vivos ou causa mortis; previdência social - até $20 \%$ sobre a remuneração; COFINS - 3\% ou 7,6\% sobre a receita; PIS - $0,65 \%$ ou $1,65 \%$ também sobre a receita. Sobre a folha de pagamentos (a cargo do empregador): salário educação - 2,5\%; SAT - 1\%, 2\% e 3\%; SESC - 1,5\%; SENAC - 1\%; SESI - 1,5\%; SENAI - 1\%; SENAR - 2,5\%, SEST - 1,5\%; SENAT - 1\%; SEBRAE - 0,3\%. O imposto de caráter pessoal mais elevado é o Imposto sobre a Renda das Pessoas Físicas - entre $0 \%$ (isenção) e $27,5 \%$ sobre o acréscimo patrimonial. 
O padrão "da metade" é ordinariamente seguido pelo Tribunal Constitucional Alemão, segundo informam TIPKE e YAMASHITA (2002, p. 47). Trata-se do princípio da repartição pela metade ou halbteilungsgryndsatz.

No Brasil, essa opinião é seguida por GOLDSCHMIDT (2004, p. 225226), que considera contra o "princípio republicano" o tributo ou a carga tributária que superam em mais da metade da renda ou do patrimônio do contribuinte, noticiando posicionamentos na mesma esteira do Tribunal Constitucional alemão, que teria firmado a jurisprudência do "princípio da repartição da metade".

Caminho análogo percorre a exposição de BARRETO (1994, p. 102). Após noticiar que na Argentina será considerado confiscatório o imposto sobre o patrimônio que onerar mais de $33 \%$ da receita ideal do imóvel, o autor frisa: "não poder o estado ficar com parcela superior àquela que restará com o produtor da renda ou titular do bem”. Assim, em suas palavras (idem, p. 103):

É sabido que os imóveis rendem de $5 \%$ a $10 \%$ ao ano de seu valor venal. Como o Estado só poderia ficar, no máximo, com a metade, as alíquotas máximas seriam de $2,5 \%$ a $5 \%$. Alíquotas superiores à metade da renda potencial (renda ótima) dos imóveis seriam confiscatórias.

Vislumbra-se, entretanto, com o devido respeito aos que pensam diversamente, que, ao estipular-se uma porcentagem do tributo ou da carga tributária como medida do exagero, corre-se o risco de deixar de considerar outras variáveis e circunstâncias muito relevantes, notadamente, a conjuntura econômica, política e social de cada país.

É notório, por exemplo, que sistemas de tributação de países como a Suécia, onde a carga tributária supera os $50 \%$ do PIB $^{119}$, em vista - e por causa - do reconhecido alto nível de benefícios e comodidades fornecidos pelo Estado aos cidadãos,

119 Estudo do Fundo Monetário Internacional aponta que a carga tributária média dos países em desenvolvimento gira em torno de $27,44 \%$ do PIB e a dos industrializados encontra-se na esfera de $38,80 \%$. Nessa linha, por exemplo, é de conferir-se a situação de alguns países: Chile $=18,72 \%$; Argentina $=25,93 \%$; África do Sul $=28,48 \%$; Rússia $=31,22 \%$; Israel $=38,97 \%$; Croácia $=41,47 \%$; Estados Unidos $=25,77 \%$; Japão $=26,28 \%$, Austrália $=30,68 \%$; Espanha $=34,23 \%$; Alemanha $=$ 39,76\%; Itália $=42,82 \%$ e Suécia $=51,35 \%$ (in O Estado de São Paulo - Caderno B, p. 03, 02.04.2006). Para o ano de 2001, PIANCASTELLI e NASCIMENTO (2005, p. 247) apontam os seguintes dados: Noruega $=45 \% ;$ Espanha $=35,2 \% ;$ Canadá $=35,2 \% ;$ Nova Zelândia $=34,8 \% ;$ Estados Unidos $=29,6 \%$; Irlanda $=29,2 \% ;$ Polônia $=34,1 \%$; Turquia $=35,8 \% ;$ Brasil $=34 \%$; Uruguai $=30,3 \% ;$ México $=18,3 \%$; Argentina $=17,4 \% ;$ Chile $=17,3 \% ;$ Venezuela $=15,9 \% ;$ Paraguai $=14,1 \%$ e Equador $=13 \%$. 
aliado ao fato de tratar-se de uma Economia sólida (diga-se: rica e estável), dificilmente poderiam ser acusados de terem cruzado a fronteira do exagero fiscal. De fato, pela proposição de VARSANO et al. (1998, 21):

O nível da carga tributária não é, contudo, absoluto: uma mesma carga tributária, medida pela relação percentual entre a arrecadação e o PIB, pode ser baixa para uma sociedade e excessiva para outra, dependendo das respectivas capacidades contributivas e provisões públicas de bens.

Noutras nações, como os Estados Unidos, em face do gigantismo da respectiva economia, basta uma carga tributária em torno de $25 \%$ do PIB para que o Estado, num sistema tradicionalmente liberal, com atenuações obviamente, consiga desvencilhar-se de suas atividades primordiais e manter o país sob um elevado índice de desenvolvimento humano ${ }^{120}$.

No Brasil, a partir da segunda metade do século XX, assistiu-se a um crescente aumento da carga tributária em relação ao PIB. Segundo aponta QUEIROZ (2003, p. 191):

a) em 1947, correspondia a $13,8 \%$ do PIB;

b) variou entre $20 \%$ e $25 \%$ entre 1970 a 1989 ;

c) elevou-se a $29,5 \%$ em 1990 ;

d) retraiu-se para $24,7 \%$ em 1993 ;

e) ascendeu para $26,97 \%$ em 1994 , e permanece aumentando;

f) em 1995 - 28,44\%; em 1996 - 28,63\%; em 1997 - 28,58\%; em 1998 -

29,33\%; em 1999 - 31,67\%; em 2000 - 34\%.

${ }^{120}$ Porém mesmo nos "mares de prosperidade e desenvolvimento" a carga tributária chega a assustar. Noticia NABAIS (2005b, p. 33) que: "ao contrário do que ocorria há alguns anos atrás, a idéia de um estado absorvente pela via fiscal esteja hoje claramente em regressão e declínio. De um lado, a excessiva carga fiscal, atingida em alguns países, levou à eleição de governos claramente apostados na diminuição do peso do estado, como ocorreu na década de oitenta do século passado nos EUA, Inglaterra e Suécia, onde foram levadas a cabo reformas fiscais que diminuíram significativamente a carga fiscal". 
Fato é que, embora a carga tributária tenha se fixado há anos num patamar entre $35 \%$ a $38 \%$ do PIB, significando que mais de um terço de todos os bens e serviços produzidos pela sociedade são absorvidos pelo Estado, persistem os bolsões de miséria, pobreza, baixa escolaridade e outras mazelas em diversas regiões. Além do mais, segundo MONTEIRO NETO (2003, p. 55), a carga tributária brasileira é: “elevadíssima para países na nossa faixa de renda per capita, sem paralelo com os nossos concorrentes diretos no mercado internacional".

Com efeito, segundo a Pesquisa Nacional por Amostra de Domicílios PNAD, lavada a efeito pelo IBGE (2008, p. 89), constatou-se que o rendimento mensal médio familiar para 2007 fixou-se em R \$ 624,00. Todavia, mais da metade das famílias vivia com renda média inferior ao salário mínimo então vigente, ou seja, com menos de $\mathrm{R} \$$ 380,00. E, para piorar, metade das famílias nordestinas vivia com até R \$214,00 ao mês.

O mesmo estudo (idem, p. 45) indica uma taxa de analfabetismo funcional de 21,7\%. Em adição, o nível de bem-estar das populações é muito diverso segundo a região enfocada. Tanto assim é que, pela informação de BARROS, MENDONÇA e DUARTE (1997, p. 30):

a renda média de cada décimo da distribuição é maior em São Paulo do que em qualquer uma das nove regiões. Conseqüentemente, o nível de bem-estar é mais elevado e o nível de pobreza mais reduzido em São Paulo do que em qualquer outra região do país, quaisquer que sejam os índices de bem-estar e pobreza e a linha de pobreza que venham a ser utilizados.

Deixando de lado as questões que se ligam à instituição de políticas públicas ineficientes, que acarretam desperdício de recursos, além de problemas com a corrupção, patrimonialismo e outras excrescências, uma circunstância capaz de explicar parcialmente essa discrepância é o tamanho da economia brasileira, possivelmente ainda insuficiente para conseguir uma relação PIB/número de habitantes que consiga gerar arrecadação num volume capaz de cobrir com maior êxito as inúmeras competências conferidas ao Estado pela Constituição de 1988.

Em verdade, se a atividade econômica é que gera a maior parte da riqueza material de uma sociedade, por meio da produção de bens sua posterior circulação, seu tamanho e estabilidade influenciarão a capacidade estatal de "retorno", dado que a 
maioria dos tributos incide sobre atos dessa natureza, destacando-se que esse tema se liga ao $3^{\circ}$ fundamento da democracia fiscal, que será discorrido mais à frente.

É claro que somente arrecadar não é suficiente para garantir um nível de bem-estar mínimo aos cidadãos, mas é, sem dúvida, o primeiro e mais importante passo para que se possa conceber um Estado funcionando e proporcionando comodidades aos indivíduos. Aliás, a questão do "retorno" não passou despercebida a ROSSEAU (1973, p. 100), que, nos idos do século XVIII, já propugnava que:

Não é pela quantidade de tributos que se deve medir o ônus, mas sim pelo caminho que têm de fazer para voltar às mãos de que saíram. Quando esta circulação é rápida e bem estabelecida, não importa que se pague muito ou pouco, pois o povo será sempre rico e as finanças andarão bem. Ao contrário, por pouco que o povo dê, quando este pouco não lhe volta, ele, dando sempre, logo se esgotará: o Estado jamais será rico e o povo sempre será miserável.

Assim, o montante da carga tributária, de maneira a identificar possível exagero, necessariamente, deve levar em conta o "retorno" oferecido pelo Estado, seja em termos de serviços gerais, nos quais não se pode identificar o beneficiário ou precificar a vantagem obtida por cada um, tais como: mantença da ordem pública interna, proteção das fronteiras, investimentos na infra-estrutura ( $v . g$ construção e manutenção de estradas, ferrovias, portos, aeroportos, usinas, redes de transmissão, tratamento de água, saneamento, etc.), preservação de interesses difusos e coletivos (v.g. cuidados com o meio ambiente, patrimônio histórico, artístico e cultural), seja em vista de comodidades mais específicas, nas quais é possível identificar o destinatário (v.g. os atendimentos de saúde e os serviços de educação pública).

Nessa esteira, caminha a lição de $\operatorname{BECHO}$ (2009, p. 470), para quem:

Nas nações em que os serviços públicos são insuficientes, onde tais serviços (como educação, saúde, segurança, seguridade social etc.) precisam ser complementados com os prestados pela iniciativa privada, a tributação tem que ser modesta, para permitir que o contribuinte tenha força econômica para recolher os tributos e pagar pelos serviços privados complementares. Naquelas nações, ao contrário, onde os serviços públicos são de qualidade e os serviços essenciais privados são desnecessários, a tributação naturalmente será mais elevada. 
No caso do Brasil, infelizmente, segundo retrata PEIXOTO (2003, p. 102): "É notório que o Estado brasileiro está longe de satisfazer às legítimas expectativas da sociedade no que diz respeito a três de suas funções clássicas: educação básica, saúde e segurança pública". Com efeito, essas deficiências devem ser consideradas na apuração de eventual exagero fiscal.

Em suma, quanto mais qualificado for esse "retorno", mais distante estará o exagero fiscal. Há aqui, destarte, uma relação diretamente proporcional e tripartite entre: 1) a carga tributária em face do PIB, 2) o "retorno estatal" e 3) o limite do exagero fiscal.

Logo, conforme será aprofundado quando da análise do $2^{\circ}$ fundamento, não se pode aceitar soluções singelas como, por exemplo, majorar ainda mais a oneração tributária dos mais ricos (pessoas físicas e jurídicas), pois é necessário antes comparar a intensidade tributária com o "retorno" que o Estado comumente apresenta.

Em que pese a relação tributária não se resumir a um contrato, em que os gravames impositivos se revelariam como um mero preço privado em estrita troca por segurança e liberdade, até porque a democracia fiscal exige mais do que isso, seria raciocínio por demais formalista deixar de considerar que algum "retorno" há de existir, ao menos para garantir um nível mínimo de dignidade dos contribuintes, até para que eles permaneçam produzindo e recolhendo suas obrigações fiscais.

Além do mais, na síntese de TIPKE e YAMASHITA (2002, p. 31): é inegável que "O Estado Tributário não pode retirar do contribuinte aquilo que, como Estado Social, tem de lhe devolver".

Então, ao invés de engessar o caráter de confisco num número previamente definido, o melhor é deixar a resposta aos princípios da razoabilidade e proporcionalidade, segundo prelecionam COELHO (2000, p. 253), COSTA, 2007, p. 118 e HORVATH (2002, p. 33), sendo que TORRES (2005, p. 40) adiciona que o sistema de tributação também deve ser permeado pela eficiência, simplificação e economicidade. 
Mas um problema adicional que daí surge é a fixação minimamente objetiva dos significados desses critérios para fins da tributação. Dificilmente, poder-se-ia conceber uma solução exata ou mesmo matemática em torno disso: o máximo que se pode pretender é alcançar certo consenso doutrinário e jurisprudencial, mas cuja perenidade não se pode garantir.

As dificuldades são de monta. De início, pela advertência de SILVA (2007, p. 27), razoabilidade e proporcionalidade não são figuras sinônimas, não obstante certa doutrina e jurisprudência assim se posicionarem, possivelmente por ostentarem objetos assemelhados, no caso, o controle das atividades legislativa e executiva. Cada uma apresenta significado e aplicação específica. A proporcionalidade é oriunda de uma construção do Tribunal Constitucional alemão e, conforme SILVA (idem, p. 30):

tem ela uma estrutura racionalmente definida, com subelementos independentes - a análise da adequação, da necessidade e da proporcionalidade em sentido estrito -, que são aplicados numa ordem pré-definida, e que conferem à regra da proporcionalidade a individualidade que a diferencia, claramente, da mera exigência de razoabilidade.

Nessa linha, o teste de proporcionalidade nem sempre implica nos três passos acima indicados, havendo casos em que a operação se encerra no primeiro, caso já se conclua pela sua ausência, motivo que aponta ser necessário seguir a ordem apresentada.

Tomando os parâmetros da explicação de SILVA (idem, p. 36 e ss.), a adequação resulta de constatar-se ser determinado meio adequado para determinada finalidade. Assim, por exemplo, para a majoração da alíquota de algum tributo, a lei é um meio adequado, aliás, salvo as hipóteses extraordinárias das medidas provisórias, que requerem ulterior apreciação legislativa, e dos tributos regulatórios (art. 153, $\S 1^{\circ}$ da Constituição), a lei é o meio mais adequado para aumentar a alíquota tributária.

A necessidade liga-se à imprescindibilidade da circunstância do objeto almejado não poder ser atingido com a mesma intensidade de outra maneira. No exemplo já lançado, se a ideia for simplesmente incrementar a arrecadação, eventualmente a lei seja dispensável, uma vez que é necessário considerar que o objetivo, dependendo do caso concreto, obviamente, também possa ser alcançado por meio da melhoria nas atividades de fiscalização e administração tributárias. 
Por fim, a proporcionalidade em sentido estrito mostra-se como um sopesamento entre as restrições causadas pela nova situação e os fins procurados por ela. No exemplo da majoração da alíquota, ter-se-ia que comparar a maior restrição à propriedade individual, com a finalidade primordial e elementar dos tributos, que, em última instância, é a garantia da própria sociedade. Contudo, cada hipótese concreta releva nuances próprias (v.g. o montante ou intensidade do aumento pretendido, a existência de majorações recentes, etc.). Em suma, aponta BRAGA (2008, p. 242) que:

Uma medida é considerada adequada quando o meio escolhido é idôneo para alcançar o fim colimado; é necessária, se não há outra menos gravosa para a persecução da finalidade estabelecida e, finalmente, proporcional em sentido estrito, se não houve restrição excessiva a um direito ou aplicação de um ônus sem o correspondente benefício.

Adentrando na razoabilidade, é certo que esta figura comporta vários sentidos, conforme aponta PEREIRA (2006, p. 208 e ss.). Assim, numa primeira acepção, ela pode indicar o contrário de arbitrariedade ao determinar que todos os atos oriundos do Poder Público devam estar revestidos de motivação a servir de causa ou fundamento. Em suma, deve existir uma congruência lógica entre a medida adotada e os critérios eleitos para sua implementação.

Numa segunda visão, a razoabilidade corresponde à equidade vista como "a justiça no caso concreto", de forma a considerar o que ordinariamente ocorre em certas situações. Nas palavras de BRAGA (2008, p. 57): “Considera-se dotado deste predicado aquilo que se encontra aceito habitualmente na sociedade, sendo o contrário, irrazoável, o que não é admitido por seus padrões".

Prosseguindo, outro sentido de enfocar a razoabilidade é a exigência de que o conteúdo das leis e das decisões judiciais sejam imbuídos de consistência e coerência lógica, de maneira a serem evitadas as contradições que poderiam impossibilitar a aplicação desses preceitos.

Por fim, a razoabilidade pode corresponder à noção de equivalência. É nesse sentido que, no campo tributário, encontra maior aplicação. Aqui, nota-se a semelhança com a última etapa do teste de proporcionalidade (aquela em sentido estrito), pois mostra-se presente uma análise ou sopesamento em relação às restrições a direitos 
fundamentais atingidos por certa medida para aferir se elas são aceitáveis frente aos objetivos buscados.

Melhor explicitando, COSTA (2007, p. 130) defende que, com fulcro no princípio da razoabilidade, existe um direito fundamental do contribuinte de submeter-se a uma tributação equilibrada, ponderada e aceitável.

Evidentemente, seria tarefa hercúlea pretender um cunho de universalidade à regra, sendo mais que esperadas variações segundo condições de tempo e local, ou seja, cada sociedade, segundo as concepções prevalentes em determinado instante histórico, é que deve decidir a respeito por meio de seus legisladores e Cortes de Justiça.

O exagero na tributação pode se materializar pela ofensa, tanto da cláusula da proporcionalidade, quanto da razoabilidade, nos casos em que a liberdade material do indivíduo restar ameaçada pelo poder de tributar exercitado pelo Estado. Em qualquer caso, não é indicado tarifar o exagero tributário contra a sanha fiscal. Aliás, na ponderação de BRAGA (2008, p. 66):

mister que permaneça um conceito fluido, suscetível de certo elastecimento, para não ser engessado impedindo-se-lhe a adaptação às mutações sociais, pois é no mesmo senso comum que encontra sua justificação, sendo num dado momento histórico que se poderá apreender se o senso comum repreenderá determinada conduta ou não.

Sem dúvida que a vagueza dificulta a sedimentação da proporcionalidade e da razoabilidade no campo da tributação, na medida em que relegar a solução a cada caso concreto pode impedir a construção de um standard elementar das figuras.

Então, merece destaque a proposta formulada por GOUVEIA (2008, p. 210 e seg) no sentido de conferir exatidão mínima ao quantum revelador do exagero fiscal. Aliás, enquanto a doutrina, de um modo geral, contenta-se em propugnar seja a ausência de proporcionalidade ou mesmo de razoabilidade tributária analisada em cada caso concreto, o autor procura conferir uma objetividade mínima de aferimento.

Segundo sua sugestão, a partir de uma categoria de pessoas, população ou classe de atividade econômica, deve ser identificado um valor médio apto a manter a dignidade das pessoas envolvidas, ou, noutras palavras, o custo de vida digno (cvd). 
Assim, a capacidade tributária (ct) particular daquela coletividade constituir-se-á no rendimento bruto mediano $(\mathrm{rm})$ subtraído do $(\mathrm{cvd})$, ou seja: $(\mathrm{ct})=(\mathrm{rm})-(\mathrm{cvd})$.

O índice da capacidade tributária (ct) deve ser comparado com o da carga fiscal (cf) e será satisfatório se a capacidade tributária for igual ou maior que a carga fiscal, isso é: (ct)/(cf) deve ser $\geq 1$ (um). Portanto, se o resultado for maior que 1 (um), significa que existe capacidade para pagar $100 \%$ da carga fiscal, mas se, por exemplo, for $0,8 \%$, há indicação de que somente é possível arcar com $80 \%$ das obrigações fiscais, sob pena de ameaça à dignidade vital.

A apuração do (cvd) deve tomar por baliza "os itens suficientes às necessidades vitais básicas e os direitos sociais que foram juridicamente referenciados pelo legislador constituinte nos arts. $6^{\circ}$ e $7^{\circ}$, IV, da Constituição Federal”.

Então, o valor necessário a garantir a dignidade humana compõe-se do seguinte: (a) custo de manutenção das necessidades vitais básicas, subtraído dos (b) benefícios públicos efetivamente recebidos direta e indiretamente do Estado, somados aos (c) custos profissionais para atualização e manutenção econômica da competitividade comercial, menos (d) a recuperação dos encargos fiscais suportados pelo grupo, repassado no preço dos salários, produtos ou serviços, mais (e) as despesas adicionais para superar fato ou calamidade que tenha provocado especial prejuízo. Então: $(\mathrm{cvd})=(\mathrm{a})-(\mathrm{b})+(\mathrm{c})-$ $(\mathrm{d})+(\mathrm{e})$.

Em esclarecimentos, o autor em foco (idem, p. 211-212) detalha a composição de cada um dos itens: (a) é composto das despesas com moradia, alimentação, educação, saúde, lazer, vestuário, higiene, transporte e segurança; (b) computam-se as subvenções diretas e indiretas recebidas do Estado para cada uma das respectivas necessidades (v.g. auxílio à educação, saúde, moradia, lazer, segurança, previdência social, assistência social); (c) os custos profissionais devem considerar as amortizações com máquinas e equipamentos necessários à atividade. Em suas palavras:

Aqui entram despesas com informática, uniformes, livros, veículos, entre outros. Estes custos tangem tanto aos profissionais autônomos (médicos, advogados, caminhoneiros, taxistas, etc) como aos empregados (enfermeiros, metalúrgicos, agentes de seguranças, funcionários públicos, 
etc), todos de alguma maneira, em maior ou menor grau, arcam com tais dispêndios que são inerentes ao desenvolvimento humano.

Embora as variáveis propostas possam dar ensejo a uma série de discussões quanto à extensão de suas aplicações em cada hipótese de fato, não se pode negar que a ideia de reduzir-se o exagero fiscal, em termos relativamente objetivos, é sedutora e merece ser aplaudida e aprimorada.

Uma última questão a ser aqui abordada é a possibilidade de intervenção judicial nos casos em que se alega o exagero fiscal, independentemente da nominação utilizada pelo contribuinte (v.g. tributação confiscatória, proibitiva, desproporcional, excessiva, etc.). Dada a cláusula da separação dos Poderes, levando em conta que a instituição e a majoração de qualquer tributo são, em essência, atos do Poder Legislativo, seria possível ao Poder Judiciário mediar a intensidade fiscal, afastando uma obrigação tributária, por considerá-la, por exemplo, excessiva ou de efeitos confiscatórios?

Pondera DÓRIA (1986, p. 179) não ser competência judicial adentrar nesse assunto pelo regime constitucional do Brasil, uma vez que, se os legisladores são eleitos pelos contribuintes, em última análise, o exagero é culpa do eleitor e não de seu representante.

Em que pese a autoridade desse posicionamento, não se pode deixar de considerar que a feitura das leis, ainda mais as ordinárias, é sempre realizada dentro de determinada conjuntura política, às vezes fruto de uma maioria-simples eventual, nem sempre atenta ao anseio do contribuinte-eleitor, relembrando-se que a tributação atua diretamente sobre direitos individuais do cidadão (propriedade e livre iniciativa).

Nessa linha, defende-se que o resultado dessa equação leve em conta outras variáveis. Assim, BILAC PINTO (1940, p. 553) há décadas já defendia a possibilidade da interferência do Poder Judiciário, pois:

Tôda vez que o exercício do Poder de Tributação perturbar o ritmo da vida econômica, aniquilar ou embaraçar as possibilidades de trabalho honesto e impedir ou desencorajar as iniciativas lícitas e proveitosas, o que ocorrerá será o desvio ou abuso dêsse Poder, o que haverá será o exercício ilegal do direito de impor tributos, ilegalidade ou abuso, que pode e deve ser obstado pelo Poder Judiciário, tôda vez que a êle se recorra. 
A posição é revestida de lucidez. Ora, se o exagero fiscal potencialmente ofende aos direitos fundamentais da propriedade e da livre iniciativa, e se o Judiciário, ao menos em nosso sistema, é o guardião da Carta Maior, não se vislumbra argumentação razoável que retire dos juízes a competência para decidir a respeito, desde que ao Estado seja garantido o constitucional direito à ampla defesa.

Nesse sentido, conforme HORVATH (2002, p. 28): “Cura-se, somente, de aplicar o Direito devidamente, dizer qual é o Direito e isso, como se sabe, cabe ao Poder Judiciário fazer". Na mesma linha é a lição de BRAGA (2008, p. 79). Em verdade, o tema do controle judicial em vista do exagero fiscal, por mais de uma vez, bateu às portas do Supremo Tribunal Federal, conforme se demonstra pelos julgamentos a seguir citados e brevemente analisados.

Inicia-se pelo RE $\mathrm{n}^{\mathrm{o}}$ 18.331, julgado em 21.07.1951, da relatoria do Ministro Orozimbo Nonato, com acórdão publicado na Revista Forense, no 595, p. $164-$ 168.

O caso teve início na Comarca de Santos-SP e cuidava de demanda com pleito de declaração de reconhecimento de inconstitucionalidade da Lei $\mathrm{n}^{\circ} 995$ daquele Município, que, em linhas gerais, aumentou o "imposto de licença" sobre cabines de banhos em 1.044\% para o exercício de 1949. Alegou-se, em síntese, excesso tributário asfixiante da atividade particular.

Em Primeira Instância, o caso foi julgado a favor do autor, tendo ocorrido reforma do decisum pelo Tribunal de Justiça de São Paulo, com a posterior ida dos autos à Corte Suprema, conforme os permissivos constitucionais então vigorantes.

Por decisão unânime, a $2^{\mathrm{a}}$ Turma do Supremo Tribunal Federal conheceu do recurso, negando-lhe provimento quanto ao mérito, segundo o voto do relator, Ministro Orozimbo Nonato, cujo seguinte trecho merece destaque: "De mim, tenho que o impôsto, ainda que imodesto, é exigível, a não ser que, como reconhece o venerando acórdão recorrido, aniquile a atividade particular. Se ocorre esse fato, nada impede a aplicação da doutrina do détournement de pouvoir". 
Verifica-se ser esse trecho o ponto central do fundamento da decisão adotada pelo Supremo, concluindo-se, destarte, que apenas os tributos proibitivos poderiam ser considerados inconstitucionais, o que não ocorreria com os excessivos, como fora considerado no caso o aumento do "imposto de licença". Fato é que, embora não tenha concedido o direito pleiteado pelo autor, a Excelsa Corte, ao conhecer da causa, entendeu válida a possibilidade do Poder Judiciário pronunciar-se a respeito da intensidade fiscal, tanto é que, no caso concreto, decidiu pelo desprovimento da demanda.

Mais recentemente, já sob a égide da Constituição de 1988, há o julgamento da ADIN-MC n 1.075-1-DF, em 17/6/1998, da relatoria do Ministro Celso de Mello, com acórdão publicado no Diário Oficial de 24.11.2006 e no Ementário nº 2.257-1.

Alegou-se, dentre outros assuntos que não interessam a esta análise, que o art. $3^{\circ}$ da Lei $8.846 / 94$, ao estatuir uma multa no importe de $300 \%$ sobre o valor o valor do bem objeto da operação ou serviço prestado ao contribuinte que não tenha emitido nota fiscal, revelar-se-ia contrário ao art. 150, IV, da Constituição, em vista de apresentar efeitos confiscatórios.

O Ministro relator reconheceu que nenhum tributo ou multa fiscal pode delinear efeitos confiscatórios, e isso traduz-se numa consequência da proteção constitucional à propriedade. Então, em seu entendimento, as obrigações tributárias não podem ser excessivas ao ponto de aniquilarem o patrimônio do sujeito passivo, devendo haver respeito ao princípio da razoabilidade. Com destaque, o seguinte trecho:

Daí a necessidade de rememorar, sempre, a função tutelar do Poder Judiciário, investido de competência institucional para neutralizar eventuais abusos das entidades governamentais, que, muitas vezes deslembradas da existência, em nosso sistema jurídico, de um "estatuto constitucional do contribuinte", consubstanciador de direitos e garantias oponíveis ao poder impositivo do Estado, culminam por asfixiar, arbitrariamente, o sujeito passivo da obrigação tributária, inviabilizandolhe, injustamente, o exercício de atividades legítimas, o que só faz conferir permanente atualidade às palavras do Justice Oliver Holmes, Jr. ("The Power to tax is not the power to destroy while this Court sits"), em "dictum" segundo o qual, em livre tradução, "o poder de tributar não significa nem envolve o poder de destruir, pelo menos enquanto existir esta Corte Suprema", proferidas, ainda como "dissenting opinion", no julgamento, em 1928, do caso "Panhandle Oil Co. v. State of Mississipi Ex Rel. Knoz (277 U.S. 218)" (grifos no original). 
Ao final, o Ministro relator concedeu a medida cautelar para suspender, com eficácia ex tunc, a norma legal impugnada até o julgamento final da causa, no que foi seguido pelos demais Ministros presentes (Carlos Velloso, Ilmar Galvão, Marco Aurélio, Moreira Alves, Nelson Jobim, Néri da Silveira, Octávio Galotti, Sydney Sanches).

Outro julgamento a ser citado é o da ADIN-MC no 2.010-DF, em 30.09.1999, também da relatoria do Ministro Celso de Mello, com acórdão publicado no Diário Oficial de 12.04.2002 e no Ementário nº 2.064-1.

Como objeto, pleiteava-se o reconhecimento do efeito confiscatório das alíquotas progressivas da contribuição social a cargo dos funcionários públicos federais. $\mathrm{O}$ art. $1^{\circ}$ da Lei $9.783 / 99$ fixou a exação em $11 \%$ sobre a remuneração, provento ou pensão. Todavia, o art. $2^{\circ}$ da referida norma determinou o seguinte:

Art. $2^{\circ}$ A contribuição de que trata o artigo anterior fica acrescida dos seguintes adicionais:

I - nove pontos percentuais incidentes sobre a parcela da remuneração, do provento ou da pensão que exceder a $\mathrm{R} \$ 1.200,00$ (um mil e duzentos reais), até o limite de $\mathrm{R} \$ 2.500,00$ (dois mil e quinhentos reais);

II - catorze pontos percentuais incidentes sobre a parcela da remuneração, do provento ou da pensão que exceder a $\mathrm{R} \$ 2.500,00$ (dois mil e quinhentos reais).

Dentre as várias ponderações realizadas pelo Ministro relator por ocasião do julgamento, merece ser destacado o seguinte:

A proibição constitucional do confisco em matéria tributária nada mais representa senão a interdição, pela Carta Política, de qualquer pretensão governamental que possa conduzir, no campo da fiscalidade - trate-se de tributos não-vinculados ou cuide-se de tributos vinculados -, à injusta apropriação estatal, no todo ou em parte, do patrimônio ou dos rendimentos dos contribuintes, comprometendo-lhes, pela insuportabilidade da carga tributária, o exercício do direito a uma existência digna, a prática de atividade profissional lícita e a regular satisfação de suas necessidades vitais (educação, saúde e habitação, por exemplo).

$[\ldots]$

Tenho para mim, portanto, assentadas essas premissas de ordem conceitual, e em face da escala de progressividade definida no art. $2^{\circ}$ da Lei 9.783/99, que a identificação do efeito confiscatório deve ser feita em função da totalidade da carga tributária, mediante verificação da capacidade que dispõe o contribuinte - considerado o montante de sua riqueza (renda e capital) - para suportar e sofrer a incidência de todos os tributos que ele deverá pagar, dentro de determinado período, à mesma 
pessoa política que os houver instituído (a União Federal, no caso), condicionando-se, ainda, a aferição do grau de suportabilidade econômico-financeira, à observância, pelo legislador, de padrões de razoabilidade destinados a neutralizar excessos de ordem fiscal eventualmente praticados pelo Poder Público (grifos no original).

Ao final, por maioria de votos, o Supremo Tribunal Federal concedeu a liminar pleiteada na ADIN-MC, com os votos favoráveis dos Ministros Carlos Velloso, Celso de Mello (relator), Ilmar Galvão, Marco Aurélio, Maurício Corrêa, Néri da Silveira, Octávio Gallotti, Sepúlveda Pertence e Sydney Sanches. Ficaram vencidos os Ministros Moreira Alves e Nelson Jobim, sendo que, na ementa do julgado, ao que aqui interessa, constou que:

\begin{abstract}
A jurisprudência do Supremo Tribunal Federal entende cabível, em sede de controle normativo abstrato, a possibilidade de a Corte examinar se determinado tributo ofende, ou não, o princípio constitucional da nãoconfiscatoriedade consagrado no art. 150, IV, da Constituição. Precedente: ADI 1.075-DF, Rel. Min. CELSO DE MELLO (o Relator ficou vencido, no precedente mencionado, por entender que o exame do efeito confiscatório do tributo depende da apreciação individual de cada caso concreto).

$[\ldots]$

Resulta configurado o caráter confiscatório de determinado tributo, sempre que o efeito cumulativo - resultante das múltiplas incidências tributárias estabelecidas pela mesma entidade estatal - afetar, substancialmente, de maneira irrazoável, o patrimônio e/ou os rendimentos do contribuinte.

O Poder Público, especialmente em sede de tributação (as contribuições de seguridade social revestem-se de caráter tributário), não pode agir imoderadamente, pois a atividade estatal acha-se essencialmente condicionada pelo princípio da razoabilidade.
\end{abstract}

Por fim, comenta-se o julgamento da ADIN-MC $n^{\circ}$ 2.551-MG, em 02.04.2003, outro feito da relatoria do Ministro Celso de Mello, com acórdão publicado no Diário Oficial de 20.04.2006 e no Ementário n² 2.229-1.

No caso, o pedido circunscreveu-se ao reconhecimento da inconstitucionalidade do art. 16 da Lei no 14.430, de 28.12.1999, do Estado Minas Gerais, que modificou o art. 15 da Lei $\mathrm{n}^{\circ}$ 12.425, de 27.12.1996, que trata da "taxa de expediente" cobrada das companhias seguradoras quando, dentre outras hipóteses, recebem dados cadastrais sobre os proprietários de veículos para fins de cobrança do Seguro Obrigatório. 
A alegação básica foi a de que a exação excederia em muito o "custo do serviço" cobrado pelo Estado, fixado em R\$ 10,00 por veículo. Nessa decisão, não obstante ter votado contra a concessão da cautelar, o Ministro Relator destacou em seu voto o seguinte:

Não se pode perder de perspectiva, neste ponto, em face do conteúdo material da norma legal ora questionada, o fato de que, especialmente quando se tratar de matéria tributária, como sucede na espécie, impõe-se, ao estado, no processo de elaboração das leis, a observância do necessário coeficiente de razoabilidade, pois, como se sabe, todas as normas emanadas do Poder Público devem ajustar-se à cláusula que consagra, em sua dimensão material, o princípio do "substantive due processo of Law" (CF, art. $5^{\circ}$, LIV), eis que, no tema em questão, o postulado da proporcionalidade qualifica-se como parâmetro de aferição da própria constitucionalidade material dos atos estatais, consoante tem proclamado a jurisprudência do Supremo Tribunal Federal (RTJ 160/140-141 - RTJ 178/22-24, v.g.) (grifos no original).

Ao final, por maioria de votos, o Supremo Tribunal Federal concedeu a liminar pleiteada na ADIN-MC, com os votos favoráveis dos Ministros Carlos Velloso, Gilmar Mendes, Ilmar Galvão, Marco Aurélio, Moreira Alves, Nelson Jobim, Sepúlveda Pertence e Sydney Sanches. Restaram vencidos os Ministros Celso de Mello (Relator) ${ }^{\mathbf{1 2 1}}$, Ellen Gracie e Maurício Correa, sendo que, na ementa do julgado, ao que aqui interessa, constou que:

O ordenamento constitucional brasileiro, ao definir o estatuto dos contribuintes, instituiu, em favor dos sujeitos passivos que sofrem a ação fiscal dos entes estatais, expressiva garantia de ordem jurídica que limita, de modo significativo, o poder de tributar de que o Estado se acha investido. Dentre as garantias constitucionais que protegem $o$ contribuinte, destaca-se, em face de seu caráter eminente, aquela que proíbe a utilização do tributo - de qualquer tributo - com efeito confiscatório (CF, art. 150, IV).

A Constituição da República, ao consagrar o postulado da nãoconfiscatoriedade, vedou qualquer medida, que, adotada pelo Estado, possa conduzir, no campo da fiscalidade, à injusta apropriação estatal do patrimônio ou dos rendimentos dos contribuintes, comprometendo-lhes, em função da insuportabilidade da carga tributária, o exercício a uma existência digna, ou a prática de atividade profissional lícita, ou, ainda, a

${ }^{121}$ Segundo manifestação do Ministro Celso de Mello no RE no 390.840-5-MG, em 18.05.2005: “[...] em diversas decisões que proferi no Supremo Tribunal Federal (RTJ 144/435-436, Rel. Min. CELSO DE MELLO - RE 428.354/RS, Rel. Min. CELSO DE MELLO, v.g.), que os desvios inconstitucionais do Estado, no exercício de seu poder de tributar, geram, na ilegitimidade desse comportamento do aparelho governamental, efeitos perversos, que, projetando-se nas relações jurídico-fiscais mantidas com os contribuintes, deformam os princípios que estruturam a ordem jurídica, subvertem as finalidades do sistema normativo e comprometem a integridade e a supremacia da própria Constituição da República, bem como o posicionamento adotado pelo Supremo Tribunal Federal” (grifos no original). 
regular satisfação de suas necessidades vitais (educação, saúde e habitação, p. ex.).

Conceito de tributação confiscatória: jurisprudência constitucional do Supremo Tribunal Federal (ADI 2.010-MC/DF, Rel. Min. CELSO DE MELLO, v.g.) e o magistério da doutrina.

Aliás, a intervenção judicial explica-se porque esses casos inegavelmente envolvem questões ligadas a princípios constitucionais, como, por exemplo, a proporcionalidade e a razoabilidade, em sua dimensão de aplicação na esfera tributária. E, segundo enfatiza LEWANDOWSKI (2005a, p. 190): “os princípios constitucionais, como se reconhece atualmente, são sempre dotados de eficácia, cuja materialização pode ser cobrada judicialmente se necessário".

Aqui, cabe ser destacada a importância da atuação do Supremo Tribunal Federal, uma vez que, como órgão máximo judicial, é o que mais eficazmente pode fixar as balizas mestras, ainda que certas vezes sem apego ao rigor técnico e científico, de figuras jurídicas cuja interpretação não agrega uniformidade, como são os princípios da proporcionalidade e da razoabilidade. Aliás, o crescente papel desempenhado pela Corte Suprema em diversos temas é notado por VIEIRA (2008, p. 57):

Embora o Supremo tenha desempenhado posição relevante nos regimes constitucionais anteriores, com momentos de enorme fertilidade jurisprudencial e proeminência política, como na Primeira República, ou ainda de grande coragem moral, como no início do período militar, não há como comparar a atual proeminência do Tribunal, com a sua atuação passada.

Nessa dimensão, entende-se que o exagero fiscal, independentemente das nominações que essa figura possa ostentar, deva ser analisado à luz de cada caso concreto, sob a inspiração dos princípios constitucionais da proporcionalidade e da razoabilidade, sendo possível ao Poder Judiciário, sobretudo por meio do Supremo Tribunal Federal em sede de controle abstrato de constitucionalidade, pronunciar-se a respeito, ainda mais porque a tributação sempre deve se harmonizar com o valor democrático da liberdade, materializado pelo respeito aos direitos fundamentais da propriedade e da livre iniciativa. 


\subsection{Conclusão do capítulo}

A democracia fiscal assenta-se em três fundamentos que atuam na forma harmônica, como um sistema de pesos e contrapesos, de modo que um influencie e seja influenciado pelos demais num desejável equilíbrio entre todos.

O primeiro fundamento é a liberdade material que se consubstancia na possibilidade do indivíduo decidir quais necessidades e desejos pretende satisfazer em determinado instante. Isso se obtém a partir da garantia, pelo Estado, dos direitos fundamentais da propriedade (em sentido amplo) e da livre iniciativa (exercício de profissão de atividade econômica), donde ordinariamente se retira os meios de sobrevivência.

Mesmo que usualmente os tributos gravem parcela dos referidos direitos individuais, aqueles devem ser considerados, do ponto de vista do contribuinte, no mínimo, como um preço a pagar pela existência de tais direitos, sendo certo que as exações são essenciais à manutenção do Estado, que, por sua vez, é o garante maior a ordem jurídica, suporte elementar para qualquer direito fundamental.

Contudo, caso a tributação atinja os direitos fundamentais da propriedade e da livre iniciativa de forma tão grave que contrarie os princípios constitucionais da proporcionalidade e da razoabilidade, encontrar-se-á em risco o valor da liberdade na democracia, pois o indivíduo terá muito reduzida a possibilidade de decidir sobre a satisfação de suas necessidades e desejos, além de restar mais próximo de depender do auxílio estatal ou da caridade alheia.

$\mathrm{O}$ aferimento de vulneração à proporcionalidade e à razoabilidade deve ocorrer em face da cada situação concreta, admitindo-se a participação do Poder Judiciário, principalmente, do Supremo Tribunal Federal, como órgão competente para declarar a respeito. 


\section{SEGUNDO FUNDAMENTO DA DEMOCRACIA FISCAL: IGUALDADE DE SACRIFÍCIOS PERANTE O FISCO}

\subsection{O tema da igualdade}

O segundo fundamento da democracia fiscal tem por objetivo imprimir um caráter isonômico à tributação com a ideia de que todos se sujeitem a um mesmo sacrifício perante o fisco, recordando-se de que a igualdade, ao lado da liberdade já enfocada acima, é um valor de alto relevo para a democracia.

Conforme define ÁVILA (2008, p. 192): "igualdade é a relação entre dois ou mais sujeitos, com base numa medida de comparação, aferida por meio de um elemento indicativo, que serve de instrumento para a realização de uma determinada finalidade”. Aduz FRAGA (2007, p. 58): “Trata-se de um princípio geral aplicável a todo o Direito, que desde Platão e Aristóteles está vinculado à idéia de justiça”.

Poder-se-ia concluir, numa primeira e matemática análise, que, se pelo exercício do voto todos influenciam juridicamente de maneira rigorosamente idêntica para eleger as pessoas que cuidarão dos rumos da nação (trata-se da máxima one man one vote), por uma questão de lógica e paridade, o ônus pela tributação deveria ser igual para todos como um simples imposto per capita, não devendo se considerar, destarte, quaisquer peculiaridades do sujeito passivo, inclusive, a ocorrência de situações econômicas diferentes.

Ainda que se considere coerente e paritário tal entendimento, numa hipótese tal estaria o princípio da igualdade atendido?

Antes da resposta, considere-se que o sacrifício requerido para votar é praticamente equivalente a todos os eleitores, além de, em regra, não implicar grande dispêndio de recursos (resume-se, de fato, às despesas de deslocamento à urna eleitoral).

Contudo, ao fixar-se um valor per capita idêntico para todos os sujeitos, a discrepância nos sacrifícios, em muitos casos, seria de fato relevante, bastando comparar 
quem recebe mensalmente o salário mínimo (que, eventualmente, nem teria como satisfazer a obrigação impositiva) e pessoas bem estabelecidas economicamente que se desincumbiriam da exação sem perda significativa de comodidade.

Chaga a ser intuitivo, pois, afirmar que, mesmo tendo cada um dos votos o mesmo peso, a divisão da carga fiscal não pode se guiar pelo mesmo paradigma, sob pena de instaurar situações concretas absolutamente desiguais entre os indivíduos.

Não é de hoje a concepção que determina seja conferido tratamento desigual a situações não equivalentes. Nesse horizonte, BARBOSA (1951, p. 31) sublinha que: "A regra da igualdade não consiste senão em quinhoar desigualmente aos desiguais, na medida em que se desigualam. [...] Tratar com desigualdade a iguais, ou a desiguais com igualdade, seria desigualdade flagrante, e não igualdade real".

E, além disso, é de atentar-se, segundo adverte ATALIBA (2007, p. 160), que: "Toda violação da isonomia é uma violação aos princípios básicos do próprio sistema, agressão a seus mais caros fundamentos e razão de nulidade das manifestações estatais. Ela é como que a pedra de toque do regime republicano".

Visto sob essa ótica, a igualdade real ou efetiva, isso é, aquela que procura coincidir o mandamento constitucional com as condições materiais fáticas, se concretiza pela discriminação justificada, ou seja, ora pela inclusão, ora pela exclusão dos sujeitos sob circunstâncias reconhecidamente diferentes, pois, na lição de BANDEIRA DE MELLO (2007, p. 12-13):

O princípio da igualdade interdita o tratamento desuniforme às pessoas. Sem embargo, consoante se observou, o próprio da lei, sua função precípua, reside exata e precisamente em dispensar tratamentos desiguais. Isto é, as normas legais nada mais fazem que discriminar situações, à moda que as pessoas compreendidas em umas ou em outras vêm a ser colhidas por regimes diferentes. Donde a algumas são deferidos determinados direitos e obrigações que não assistem a outras, por obrigadas em diversa categoria, regulada por diferente plexo de obrigações e direitos.

A igualdade também pode ser enfocada no campo tributário, comportando uma dimensão positiva e outra negativa (ROHENKOHL, 2007, p. 106). A primeira (positiva) relaciona-se com a intensidade dos sacrifícios que os contribuintes em 
geral devem levar a efeito em prol da manutenção da comunidade, enquanto a segunda (negativa) pela vedação de tratamento diverso a pessoas em situações equivalentes.

É fato que o pagamento de qualquer tributo implica numa dose de sacrifício patrimonial a alguém, ou seja, o contribuinte, ao cumprir suas obrigações fiscais, tem seu bem-estar, ainda que em potencial, diminuído, pois lhe restará em mãos menos riqueza capaz de satisfazer suas necessidades e vontades.

Como já visto, esse sacrifício, em última análise, não é um mal, mas, ao contrário, ao permitir a manutenção da propriedade (em sentido amplo), transmuda-se, antes de tudo, num benefício aos contribuintes.

Porém, entende-se ser necessário, com base no princípio maior da igualdade, que a perda de bem-estar seja, senão idêntica, ao menos equivalente entre os vários grupos de obrigados numa determinada sociedade, pois, na colocação de PAYERAS (2008, p. 22): “Admitindo que o nível de bem-estar é uma função da renda, o princípio do sacrifício eqüitativo diz que pessoas com renda igual devem contribuir com igual quantidade de tributos e pessoas com renda diferentes devem pagar quantidades diferentes de tributos".

Esse desiderato pode ser conseguido, em suma, com base em dois expedientes: a) o respeito ao princípio da capacidade contributiva; e, b) a pessoalidade das exações em geral com mínimas possibilidades de transmissão do ônus tributário a terceiros, conforme será exposto a seguir.

\subsection{O princípio da capacidade contributiva, progressividade e solidariedade}

Resta evidente que um imposto per capita, que desconsidere o nível de sacrifício daquele que o suporta fere de morte a cláusula da igualdade, posto que, segundo TIPKE e YAMASHITA (2002, p. 28): “não leva em consideração o mínimo existencial arraigado na dignidade humana".

É, portanto, indispensável que o sistema de tributação tente considerar as diferenças materiais entre os diversos contribuintes. Uma maneira eficaz de atingir esse desiderato é o respeito à capacidade contributiva, ou seja, o valor devido se eleva na 
medida em que cresce a renda e o patrimônio do obrigado, aceitando-se, inclusive, a progressividade das alíquotas ${ }^{122}$. Conforme COSTA (1996, p. 101):

O conceito de capacidade contributiva, ainda que o termo que o expressa padeça da ambigüidade e da imprecisão características da linguagem do direito positivo, pode ser singelamente definido com a aptidão, da pessoa colocada na posição de destinatário legal tributário, numa obrigação cujo objeto é o pagamento de imposto, para suportar a carga tributária, sem perecimento da riqueza lastreadora da tributação ${ }^{123}$.

A origem "científica" da capacidade contributiva na tributação é atribuída pela doutrina a Adam Smith (CONTI, 1996, p. 30; COSTA, 1996, p. 15; FRAGA, 2007, p. 61 e TORRES, 2005, p. 38), não obstante a história registrar práticas que se assemelham à ideia. Basta recordar, como mero exemplo, do tributum ex censu romano, cujo caráter era extraordinário. Sendo cobrado a cada cinco anos, seu valor restava baseado nos haveres do obrigado, conforme registrado em censos anteriores.

Mesmo a Constituição brasileira de 1824, que condicionava o direito de votar à posse de certa situação econômica, determinava que ninguém estaria isento de contribuir para as despesas do Estado segundo a proporção de seus haveres (art. 179, §15), encontrando-se aí uma referência, mesmo que não expressa, à regra da capacidade contributiva no campo tributário.

A ideia central trazida preconiza que as exações devem incidir de modo que a perda do bem-estar pela obrigação de entregar parte do patrimônio ao fisco seja

${ }^{122} \mathrm{O}$ respeito à capacidade contributiva, por exemplo, por um sistema de alíquotas progressivas não é isento de críticas, pois, à guisa de se construir a igualdade substancial, corre-se o risco de tolher sobremaneira a liberdade. Assim, conforme FRIEDMAN (1985, p. 158): "É difícil para mim, como liberal, encontrar alguma justificativa para a taxação gradual em termos de pura redistribuição de renda. Parece-me um caso claro de coerção, em que se tira de uns para dar a outros, e assim se entra em conflito frontal com a liberdade individual. Considerados todos os pontos, a estrutura de imposto de renda pessoal que me parece melhor seria um imposto uniforme sobre a renda acima do nível de isenção, com a renda definida de modo bastante amplo e as deduções permitidas apenas para despesas com a obtenção da renda, despesas essas definidas de modo bem rígido".

123 Conforme esclarece CONTI (1996, p. 33 e ss.), a doutrina distingue a capacidade contributiva da econômica e, ainda, da financeira. Nesse sentido, a capacidade contributiva deriva da relação fiscocontribuinte em que este último é obrigado a pagar certo tributo. A capacidade econômica está ligada com a possibilidade (maior ou menor) de alguém ser tributado em razão de sua riqueza e rendimentos. Assim, quem tem capacidade econômica pode ou não possuir a contributiva, $v . g$. alguém muito rico que apenas transite temporariamente pelo território nacional é titular de capacidade econômica, mas não contributiva por ausência de relação estabelecida com o fisco do país. A capacidade financeira significa a existência de numerário ou recursos líquidos para a quitação das obrigações tributárias. 
proporcionalmente equivalente ao rico e ao pobre, que pode inclusive ser dispensado de qualquer contribuição fiscal se isso lhe ameaçar o mínimo vital.

É que, na exposição feita por TIPKE e YAMASHITA (2002, p. 18): “O Direito Tributário encontra as desigualdades existentes numa economia de mercado. $\mathrm{O}$ princípio da igualdade exige que a carga tributária total seja igualmente distribuída entre os cidadãos". Portanto, é de se concordar com FRAGA (2007, p. 60) quando afirma que: "o princípio da capacidade contributiva é o critério de diferenciação em matéria tributária, de forma a ser expressão do princípio da igualdade". Na mesma linha, TIPKE e YAMASHITA (idem, p. 55).

Assim, nota-se que a relação entre a capacidade contributiva e a questão maior igualdade é muito forte. Mais uma vez, na lição de COSTA (1996, p. 38-39):

Clássica é a afirmação de que o princípio da capacidade contributiva é um desdobramento do princípio da igualdade ou de que é a manifestação ou a aplicação deste no campo tributário. [...] Cremos que a igualdade está na ausência de noção de capacidade contributiva, que não pode ser dissociada daquela. Podemos dizer que a capacidade contributiva é um subprincípio, uma derivação de um princípio mais geral que é o da igualdade, irradiador de efeitos em todos os setores do Direito.

A partir desse raciocínio, em linhas gerais, tem-se que o Estado deve buscar fazer com que o custo real, e não apenas o financeiro, seja o mais igual possível para todos. Aliás, segundo coloca MURPHY e NAGEL (2005, p. 34): “a suposição factual fundamental é a da diminuição do valor marginal do dinheiro; o princípio da igualdade de sacrifícios pode motivar um esquema tributário progressivo ou proporcional dependendo da taxa segundo a qual diminui a utilidade marginal da renda".

Com efeito, existem várias explicações que procuram justificar a necessidade de uma tributação diferenciada segundo a renda e o patrimônio do sujeito passivo, conforme demonstra CONTI (1996, p. 81-88) ao assinalar as seguintes teorias: a) sacrifício absoluto ou equivalente; b) sacrifício proporcional; c) sacrifício marginal ou mínimo; d) renda excedente; e) importância social; e, f) sócio-política.

Portanto, quem possui mais patrimônio pode gastar mais dinheiro com a tributação sem que isso signifique perda de bem-estar relevante. 
Claro que isso é verdadeiro até certo patamar, ou seja, é aceitável até que se abandone a razoabilidade na tributação e se adentre ao exagero fiscal, objeto do $1^{\circ}$ fundamento já delineado.

Não se pode negar, contudo, que, na prática, é muito difícil que a igualdade de sacrifícios perante o fisco se concretize de forma exata ou milimétrica. Em verdade, mesmo pessoas que recebam o mesmo salário podem se esforçar diversamente em termos tributários, por exemplo, se uma possuir quatro filhos e a outra apenas um. Para a primeira, a carga será certamente maior, uma vez que sua prole implica em mais necessidades pessoais a serem atendidas do que para a segunda.

No entanto, isso não invalida o princípio como um ideal a ser buscado pelo Estado, devendo o legislador utilizar mecanismos que tendam a neutralizar essas disparidades (v.g. permitindo desconto progressivo na base de cálculo do Imposto de Renda segundo o número de dependentes do contribuinte).

Aliás, nas palavras de TIPKE e YAMASHITA (2002, p. 27-28): “A justa repartição da carga tributária entre os cidadãos é imperativo ético para todo Estado de Direito". Em seguida (idem, p. 30), os autores em tela enfatizam que: “A realização do princípio da capacidade contributiva é um progresso perante uma tributação arbitrária, sem princípios, perante uma tributação segundo o oportunismo político, perante um pragmatismo ou fiscalismo ilimitado".

Independentemente das nuances teóricas que embasam a cláusula da capacidade contributiva, fato inegável é que a maioria dos países positivou o preceito em suas respectivas Constituições ou leis tributárias, tratando-se de um valor muito caro em tema de tributação.

No Brasil, sua previsão atual é expressa na primeira parte do $\S 1^{\circ}$ do art. 145 da Constituição de 1998, ou seja: "Sempre que possível, os impostos terão caráter pessoal e serão graduados segundo a capacidade econômica do contribuinte...". Assevera COELHO (2000, p. 80) que:

O mundo moderno elegeu a capacidade contributiva como um valor muito caro, em tema de tributação, certo de que alguns sistemas a 
constitucionalizaram e, outros a positivaram em texto legislativo. Quando assim não é, verifica-se que em inúmeras ocasiões a mens legislatoris orienta-se na feitura de leis pelas determinações do princípio da capacidade contributiva. No Brasil pós-88, desobredobro o princípio está expressamente consagrado no campo da Lei Maior. Assim, além de ser jurídico, o princípio é constitucional. Todo debate, portanto, que se travar academicamente em torno da efetividade do princípio será pura perda de tempo.

A afastar qualquer dúvida que possa permanecer, TIPKE e YAMASHITA (2002, p. 29) dão conta de que: “O princípio da capacidade está difundido por todo o mundo e está fundamentado numa série de Constituições".

Noutra banda, a adoção da capacidade contributiva também se fundamenta no princípio geral da solidariedade social. Nessa esteira, a contribuição impositiva deve crescer segundo a riqueza e os rendimentos do contribuinte, não apenas porque se deseja que os sacrifícios sejam proporcionalmente iguais ou equivalentes aos demais, mas também com fulcro num sentimento de pertinência a certo grupo.

Em resumo, os cidadãos que compõem o povo de certo Estado estão ligados de tal maneira que se cria a obrigação jurídica dos mais ricos de distribuírem parte de seu patrimônio aos mais pobres por intermédio da tributação diferenciada. Na lição de NABAIS (2005c, p. 112):

Do que resulta que a solidariedade pode ser entendida quer em sentido objetivo, em que se alude à relação de pertença e, por conseguinte, de partilha e de co-responsabilidade que liga cada um dos indivíduos à sorte e vicissitudes dos demais membros da comunidade, quer em sentido subjetivo e de ética social, em que a solidariedade exprime o sentimento, a consciência dessa mesma pertença à comunidade.

É que, segundo LEWANDOWSKI (2005a, p. 196):

Com efeito, se as pessoas numa república são titulares de direitos, hão também, em contrapartida, obrigações para com a comunidade, como ocorria na Roma antiga ou, mais recentemente, na Alemanha, sob a Constituição de Weimar, que enunciava um rol de direitos fundamentais.

Em linha análoga, nos dizeres de COMPARATO (2006, p. 191), é de se ter em vista que: 
a sociedade política (polis) constitui uma espécie de comunidade (koinonia), vale dizer, de agrupamento social, organizado em função de um objetivo comum a todos os seus membros, que se vêem, assim, ligados entre si por vínculos jurídicos (dikaion) e relações de solidariedade.

Com efeito, GODOI (2005, p. 152) noticia que: “a doutrina européia radica exatamente na solidariedade social o fundamento do dever constitucional de pagar impostos".

Pela solidariedade, acompanhando a lição de MOSCHETTI (1980, p. 114), alguém recebe do Estado um benefício (v.g. proteção em geral, comodidades, serviços, etc.) sem, necessariamente, ter-lhe entregue algo em troca (no caso o pagamento de tributos) e, por outro lado, outro alguém deve contribuir financeiramente sem esperar (juridicamente) o retorno na exata proporção ou equivalência.Em suas palavras: "Em certo sentido, cada um é co-responsável pelo aperfeiçoamento e desenvolvimento dos demais" ${ }^{\prime 124}$.

Nessa linha, caminha FANTOZZI (1994, p. 30) que, ao comentar o art. 53 da Constituição italiana, assevera que, com o princípio da solidariedade na tributação, se deixou para trás entendimentos que justificavam a obrigação tributária em algum tipo de benefício ou resposta positiva dada pelo Estado.

Portanto, não obstante algum "retorno" ser esperado por parte do Estado, a tributação não se resume a uma relação comutativa, na qual as prestações devam se equivaler (SACCHETTO, 2005, p. 21).

Mais uma vez, conforme NABAIS (2005c, p. 128-129): "Daí que a existência de um Estado fiscal tenha subjacente uma idéia de justiça distributiva traduzida na redistribuição dos rendimentos dos contribuintes para os que não sejam contribuintes".

Os norte americanos não costumam simpatizar com a expressão "solidariedade" por vislumbrarem nela conotações socialistas, segundo informa LIVINGSTON (2005, p. 190). De acordo com o autor, eles estão mais aptos a vê-la como uma dentre as adaptações pragmáticas entre a necessidade de se manter pelo menos um

${ }^{124} \mathrm{O}$ texto original é o seguinte: "En cierto sentido cada uno es corresponsable del perfeccionamiento y promoción de los demás". 
mínimo de justiça social e dignidade das pessoas sob a égide do Estado ao lado da proteção da liberdade concedida à iniciativa privada num balanço entre equity e efficiency.

\subsection{A cláusula da pessoalidade e a questão dos tributos "diretos" e "indiretos"}

De igual modo, para que exista uma efetiva equivalência de sacrifícios fiscais entre os contribuintes, além da edificação de um sistema que reverencie a isonomia fiscal, é muito importante observar ser necessário que as exações ostentem caráter pessoal, isso é, sejam suportadas por quem legalmente estiver obrigado ao seu pagamento.

É notório que, desde há muito, as pessoas comumente se mostram avessas às obrigações tributárias por uma série de razões, mas principalmente porque não vislumbram (e, em muitos casos, com plena razão) o recebimento de um "retorno" aceitável daquilo que entregaram ao fisco. De fato, segundo PEZZI (2008, p. 73): “As normas tributárias sempre foram alvo de grande rejeição social. Isso se explica pelo fato de que raramente na história humana a tributação se mostrou justa”.

Fato é que a rejeição fiscal já implicou no desaguar de vários movimentos violentos ao longo da história, tais como os citados por CUNHA (2002, sem paginação): Palestina em 926 a.C.; reino de Omar entre 634 e 644 d.C.; Viena em 1519 (contra o rei Carlos I da Espanha); Inglaterra dos Stuarts (1603 a 1714); Rússia em 1708 (contra Pedro "o Grande”); colônias inglesas na América do Norte em 1773. No Brasil, várias foram as insurreições contra os tributos, sendo que o movimento mais conhecido foi a Inconfidência Mineira de 1789.

No mesmo sentido, BOTELHO (2005, p. 17) aduz que várias revoltas fiscais se transformaram em formas de contestação da legitimidade do poder. Em suas palavras:

É o caso da revolta dos maillotins, sob o reinado de Charles V; dos croquants, no fim do século XV; dos va-nu-pieds, na Normandia, em 1639; dos bonnets rouges, na Bretanha, em 1675. Outras revoltas históricas são mais conhecidas, mas sua origem fiscal normalmente é esquecida: a Revolução Francesa e a Independência dos Estados Unidos. É também o caso da nossa Inconfidência Mineira. 
Em resumo, cita BALEEIRO (1998, p. 284) que: "Inúmeras convulsões políticas refletiram a controvérsia em torno do sentimento de repulsa a impostos reputados injustos por um grupo social em certo momento".

Todavia, como sem a receita dos tributos não se concebe Estado regular, e sem ele a sociedade civil corre grave risco de perecer sob o descambo da violência generalizada, na maior parte do tempo, a resistência às imposições fiscais não se mostra explícita, mas revela-se basicamente por meio de dois expedientes silenciosos: o primeiro, pela sonegação pura e simples, arcando o contribuinte com o risco da cobrança coercitiva acrescida de penalidade $^{125}$ e o segundo refere-se ao repasse, sempre que viável, do ônus financeiro das exações a terceiros, aqui sem qualquer sanção ao sujeito passivo.

Como regra, essa última atitude ocorre em vista dos tributos destinados a gravar o consumo de bens e serviços quando o comerciante ou fornecedor de bens ou serviços (o chamado contribuinte de jure) faz incluir no preço final cobrado dos consumidores (denominado de contribuinte de facto) os tributos por si devidos.

Com o intuito de minimizar esse segundo expediente, é que o $\S 1^{\circ}$ do art. 145 da Constituição de 1988 determina que, sempre que possível, os impostos devem ostentar caráter pessoal. Significa que, como regra geral, o patrimônio do sujeito passivo designado em lei é que deve arcar com a imposição justamente para que haja congruência com a capacidade contributiva do obrigado e não de um terceiro qualquer a cujo ônus financeiro da exação seja impingido.

Ainda que a transferência em foco se trate de um evento primeiramente econômico, uma vez que a responsabilidade legal de recolhimento do gravame não cabe ao consumidor, mas ao comerciante ou fornecedor, entende-se que o fenômeno não deve e não pode ser ignorado pelo Direito na medida em que sua ocorrência pode, efetivamente, tanto desqualificar a cláusula da equivalência de sacrifício tributário, quanto desmerecer o dever geral de solidariedade acima mencionado.

\footnotetext{
125 Segundo PRADO (1991, p. 80): "Na verdade, não é a contestação ao regime ou a sua derrubada o que pretendem os agentes da economia paralela mas sua sobrevivência, mantendo suas atividades, voltadas às expressões de produção, circulação e consumo de riquezas, à margem dos ônus e controles impostos pelo Estado. A economia invisível e, pois, uma resposta espontânea da sociedade que segue uma linha evolutiva de menor resistência, ditada pelo pragmatismo elementar do ser humano".
} 
Ora, se um fato econômico é capaz de contribuir de forma determinante para a materialização ou não de alguma figura jurídica, modificando e moldando o seu conteúdo na realidade fática, então é necessário que o Direito considere sob seu âmbito tal elemento.

Esse é um dos casos em que, segundo MELLO e LIPPO (2004, p. 124): "as ciências jurídica e econômica se entrelaçam indissoluvelmente". Logo, concorda-se com TIPKE e YAMASHITA (2002, p. 107) quando afirmam que:

A velha distinção entre contribuinte de jure e contribuinte de facto é enganosa, pois induz a equivocada idéia de que o chamado contribuinte de facto seria algo estranho ao Direito, quando, na verdade, como veremos adiante, ele é juridicamente um contribuinte sui generis.

A expressão "sempre que possível”, que consta do $§ 1^{\circ}$ do art. 145, já mencionado, não significa mera recomendação ao legislador. É de ser observado sempre que a índole constitucional do tributo permitir. Isso ocorre notadamente em face dos chamados “tributos diretos", isso é, aqueles em que o contribuinte é quem verdadeiramente suporta o respectivo ônus financeiro ${ }^{126}$ e assim se dá porque, na lição de CONTI (1996, p. $65)$ :

sendo a capacidade contributiva um atributo do sujeito passivo da obrigação tributária, e incidindo o imposto direto sobre a pessoa do contribuinte, nada obsta que lhe seja reconhecida sua capacidade de arcar com o ônus da imposição, observando-se o princípio.

Exemplos clássicos de tributos "diretos" são os que alcançam a renda e o patrimônio do obrigado. Então, no Brasil, merecem destaque os seguintes: Imposto de Renda - IR, Imposto sobre a Propriedade Territorial Urbana - IPTU, Imposto sobre a Propriedade Rural - ITR, Imposto sobre a Propriedade de Veículos Automotores - IPVA e os Impostos sobre Transmissões (causa mortis e inter vivos). Como não se está diante de uma cadeia produtiva, não há como o contribuinte, salvo quiçá por um ajuste contratual

126 Melhor esclarecendo, de acordo com CONTI (1996, p. 48-49): “Os impostos podem ser diretos ou indiretos, conforme atinjam um contribuinte determinado ou não. Os impostos diretos são aqueles que recaem sobre uma única pessoa, indicada na lei como contribuinte. São indiretos quando, embora formalmente recolhidos por uma pessoa - contribuinte de direito -, são efetivamente suportados por outra - contribuinte de fato". 
(evidentemente voluntário), repassar o ônus financeiro da tributação a terceiros desvinculados do fato gerador.

Ora, a quem um empregado poderia impingir o ônus do seu Imposto de Renda recolhido antecipadamente pelo empregador? Noutra banda, como um proprietário faria para empurrar a terceiro a quantia que deve recolher a título de IPTU?

De fato, nota VARSANO et al. (1998, p. 32) que: “os impostos pessoais podem ser graduados de acordo com a renda do contribuinte e a possibilidade de transferência da carga para outros contribuintes é menor do que no caso de impostos sobre produtos ou empresas".

Aliás, o Imposto de Renda é colocado por PISCITELLI (2003, p. 89) como um símbolo da justiça tributária, uma vez que promove a: "distribuição da carga segundo a capacidade contributiva de cada um, consideradas suas características pessoais e familiares" e assim ocorre porque, segundo VIANNA et al. (2000, p. 11): "a renda de um indivíduo é um indicador mais visível de sua capacidade de pagamento", no que são seguidos por VILLELA (1987, p. 27); GIAMBIAGI e ALÉM (2002, p. 45); e, PIANCASTELLI e NASCIMENTO (2005, p. 231).

Contudo, existem muitos tributos - principalmente quando incidem ao longo de uma cadeia produtiva - que não comportam a aplicação adequada do princípio da capacidade contributiva e, muito menos, da pessoalidade, por isso são usualmente denominados de "indiretos". Como exemplo tem-se: Imposto sobre Importação - II, Imposto sobre Exportação - IE, Imposto sobre Produtos Industrializados - IPI, Imposto sobre a Circulação de Mercadorias e Serviços - ICMS, Contribuição para o Financiamento da Seguridade Social - COFINS, Contribuição Social sobre o Lucro - CSSL, Contribuição ao Programa de Integração Social - PIS, Contribuição ao "salário educação", Contribuições de Intervenção no Domínio Econômico - CIDE’s, Contribuições ao "Sistema S" - SESC, SENAC, SESI, SENAI, SENAT, SENAR, SESCOOP, etc.

Mesmo que se lhes aplique o alívio da cláusula da "não cumulatividade",

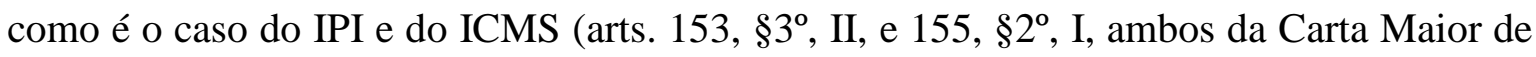
1988) e da COFINS e do PIS (esses não em todas as hipóteses), quem suporta sua carga 
econômica, seja ela qual for, em regra, é o consumidor final do produto, bem ou serviço, e não o sujeito passivo legalmente identificado, ou seja, o industrial, o comerciante, o empresário em geral, uma vez que esses, salvo em raras exceções, fazem incluir no preço cobrado o custo tributário que incide sobre a sua atividade.

Portanto, entrando em cena tributação que onere a cadeia produtiva, resta quase impossível respeitar a capacidade contributiva, na medida em que o gravame atingirá, em termos fáticos, de forma idêntica (sob os mesmos valores) uma pessoa miserável e outra economicamente forte, situação que se agrava se estiverem em jogo bens essenciais, tais como alimentos e medicamentos. Frente a tal realidade, qualquer tributo “indireto" tende a ser regressivo ${ }^{127}$. Conforme assevera SAMPAIO (2005, p. 188-189):

Críticos da tributação do consumo alegam a regressividade desse tipo de tributo já que a propensão média e marginal a consumir das pessoas de baixa renda é superior a dos indivíduos mais ricos. Portanto, o ônus fiscal é menor para os grupos mais ricos porque recai somente sobre parte da renda, já que a poupança não é afetada pela tributação do consumo.

Os próprios órgãos fiscais reconhecem esse caráter presente na tributação indireta. Conforme estudo publicado pela RECEITA FEDERAL (2002, p. 08):

Da renda total recebida, parte é consumida e parte é poupada. A propensão a poupar aumenta conforme aumenta a renda, pois as necessidades básicas são cobertas por uma fração cada vez mais baixa da renda total, podendo o agente econômico optar por investir em ativos financeiros (poupança). Conseqüientemente, tributos indiretos têm natureza regressiva em relação à renda total. Ou seja, embora as famílias com mais alta renda consumam mais e, portanto, paguem mais impostos indiretos em valores absolutos, a relação entre esse montante pago e a renda total (valores relativos) tende a ser mais alta para famílias com baixa renda.

Com efeito, os indivíduos que ostentam maiores ganhos tendem a poupar mais recursos. Segundo VIANNA et al. (2000, p. 38), considerando o caso brasileiro, de maneira geral, as famílias com ganhos de até dois salários mínimos passaram de $91 \%$ para 93\% do comprometimento de seu dispêndio com o consumo entre 1988 e 1996. Noutro

${ }^{127}$ Segundo PAYERAS (2008, p. 20): "Um imposto, ou sistema tributário, é classificado como progressivo se o aumento da contribuição for mais que proporcional ao aumento da renda. Em contraste, se a carga tributária aumenta menos que proporcionalmente com o aumento da renda o tributo é dito regressivo. Chama-se de proporcional o tributo que aumenta na mesma proporção da renda". 
giro, as famílias com recebimentos superiores a 30 salários mínimos reduziram essa mesma participação de $64 \%$ para algo em torno de $60 \%$ no mesmo período.

É de ser reconhecido, porém, que a desoneração dos produtos essenciais, notadamente por meio de isenções e "alíquotas zero", confere um respeito mínimo à capacidade contributiva ressaltando-se que, tanto o IPI, quanto o ICMS, devem ser graduados segundo a essencialidade do produto.

Na lição de COSTA (1996, p. 54-55): "Se a capacidade contributiva não puder ser levada em conta para a graduação desses tributos, ao menos prestar-se-á como indicadora da hipótese em que deverá conceder isenção total ou parcial da obrigação tributária”. Nesse mesmo sentido, tem-se CONTI (1996, p. 67).

Assim, por exemplo, pela notícia de VIANNA et al. (idem, p. 54): "Nos Estados Unidos, apenas oitos estados tributam alimentos, todos com alíquotas reduzidas, e são previstos mecanismos de reembolso dos tributos pagos para as famílias consideradas pobres".

Entretanto, mesmo nesses casos, dependendo da cadeia produtiva percorrida pelo produto, face ao intricamento de várias matérias primas e insumos que muitas vezes sofrem tributação, é muito difícil conseguir a desoneração plena. Conforme o criterioso estudo de SIQUEIRA et al. (2001, p. 542), cujo enfoque é o Brasil:

\footnotetext{
os resultados indicam que a incidência efetiva dos impostos é bem diversa daquela definida pelos formuladores de políticas econômicas ou desejada pela sociedade, revelando que o governo está, de fato, tributando pesadamente bens que intenciona isentar ou tributar apenas levemente [...] Observou-se também que as alíquotas efetivas sobre bens que representam uma grande parcela no orçamento das famílias de baixa renda, tais como alimentos e vestuário, revelaram-se ainda mais altas do que as alíquotas nominais implícitas nas receitas arrecadadas.
}

Como se isso ainda não bastasse, fato é que no Brasil a desoneração tributária sobre bens essenciais como alimentos e remédios é definitivamente incerta. Segundo informa MAGALHÃES et al. (2001a, p. 11), a incidência tributária sobre a "cesta alimentar" atinge os seguintes patamares: 14\% em Belém; 13,3\% em Belo Horizonte; 17,1\% em Brasília; 13,9\% em Curitiba; 18,2\% em Fortaleza; 14,3\% em Goiânia; 16,1\% no Rio de Janeiro; 13,8\% em Salvador, ressaltando-se que: 
Mesmo nas regiões metropolitanas de Recife, São Paulo e Porto Alegre, cujos estados já aplicam reduções nas alíquotas de ICMS para um grande número de produtos, cerca de $11 \%$ do valor total da cesta de alimentos destina-se ao pagamento de ICMS e do PIS/COFINS.

Quanto aos medicamentos, outro de grupo de bens que pode ser considerado como essencial, estudo realizado por MAGALHÃES et al. (2001b, p. 45), apurou um gravame tributário que oscila entre $26 \%$ e $30 \%$. Assim:

Os resultados mostram uma alta regressividade na carga tributária sobre medicamentos frente à renda familiar, isto é, os tributos pagos na aquisição de medicamentos recaem mais pesadamente sobre as famílias mais "pobres" do que sobre as mais "ricas". [...] O grau de regressividade é mais elevado em Curitiba e São Paulo, onde as famílias com renda até dois salários-mínimos destinam pouco mais de 3,5\% de sua renda com o pagamento de tributos incidentes sobre os medicamentos, enquanto que nas famílias do último estrato esse percentual situa-se em torno de $0,25 \%$ em ambas regiões metropolitanas.

Essas constatações apontam para a conclusão de que, em realidade, o efetivo respeito à capacidade contributiva - leia-se: equivalência de sacrifícios físcais - se consegue por meio de um sistema de tributação que efetivamente privilegie as exações que ostentem caráter nitidamente pessoal - os tributos "diretos", principalmente os que gravam o patrimônio e a renda dos contribuintes.

Contudo, mesmo sendo evidente o caráter regressivo dos tributos sobre o consumo, não se pode simplesmente aventar proposta de sua extinção plena, como, aliás, adverte MOSCHETTI (1980, p. 267), pois é preciso considerar que, além da sistemática utilizada ser eficiente em termos de arrecadação (v.g. é muito provável que no Brasil não fosse possível manter o Estado apenas com a receita das exações sobre o patrimônio e a renda), a própria Constituição, ao incluir a citada expressão "sempre que possível", admite hipóteses de tributos cuja essência se desvie do ideal de reverência à capacidade contributiva.

A realidade mostra que é indispensável conjugar o ideal da igualdade fiscal consubstanciado justamente num sistema de tributação que se vergue ao caráter pessoal do patrimônio e renda do onerado, daí originando-se a maior parte de suas receitas, com a inafastável circunstância de o Estado necessitar retirar da sociedade recursos que o 
financiem, sob pena de se colocar em risco a estabilidade e segurança da própria sociedade civil.

Nesse diapasão, a tributação do consumo - ou indireta - tende a ser altamente eficiente (em termos de custos operacionais e de resultados da arrecadação) por ordinariamente adotar mecanismos que facilitam a arrecadação e respectiva fiscalização (v.g. a figura do "fato gerador presumido", responsabilização de terceiros pelo recolhimento das exações, concentrando o número de estabelecimentos a serem fiscalizados, o controle eletrônico das notas fiscais, etc.). Conforme indica FALCÃO (2003, p. 74), há:

uma redução do universo de contribuintes, ou seja. Ao Estado caberá, apenas, controlar um determinado número de pessoas jurídicas, o que eliminará a necessidade de controle sobre todo o universo de consumidores, ao contrário do que se passa, por exemplo, na tributação sobre a renda.

Além disso, em locais onde a maioria das pessoas físicas não possui renda ou patrimônio tributável, ficando isentas, por conseguinte, dos impostos que gravam essas situações, não há outro remédio senão tributar o consumo, uma vez que, ainda que existam pessoas ricas ou bem situadas financeiramente, o tamanho da economia local não é capaz de gerar receitas fiscais mínimas, isso é, a sociedade como um todo é pobre. Não se pode esquecer que as exações, em regra, incidem sobre fatos econômicos. Logo, quanto maior a economia, mais arrecadação existirá, ao menos teoricamente.

Aqui, percebe-se que a calibração entre os tributos diretos e indiretos numa determinada sociedade depende, em grande medida, do desenvolvimento econômico e social de cada país. Segundo informa LEMGRUBER (2005, p. 214):

Interessante notar, quanto a esta questão, que países desenvolvidos dão preferência à tributação da pessoa física, enquanto países em desenvolvimento dependem mais fortemente da arrecadação da pessoa jurídica para financiar o Estado.

Como mero exemplo, segundo MANKIW (2007, p. 244), nos Estados Unidos a maior arrecadação do governo federal é proveniente do Imposto sobre a Renda pago pelas pessoas físicas, cujo patamar, para o exercício de 2001, fixou-se em $50 \%$ das receitas da União, ou seja: US\$ 994 bilhões. 
Já as pessoas jurídicas daquele país recolheram "apenas" US\$ 151 bilhões ou $8 \%$ do total. Conforme PEREIRA et al. (2006, p. 47): "observa-se correlação positiva entre o nível de renda dos países e sua estrutura tributária. Assim, países com níveis de renda mais elevados tendem a concentrar sua arrecadação tributária em impostos diretos, como o Imposto de Renda”. O mesmo estudo (idem, p. 48) apresenta o seguinte quadro:

\section{Composição da Receita Tributária por Grupo de Países - 1995/1997 em proporção do PIB - \%}

\begin{tabular}{|c|l|l|l|l|l|l|l|l|}
\hline & \multicolumn{3}{|c|}{ Imposto sobre a renda } & \multicolumn{5}{c|}{ Imposto sobre o consumo } \\
\cline { 2 - 9 } & Total & Empresas & Pessoal & Total & Geral & Excises & $\begin{array}{l}\text { Comércio } \\
\text { exterior }\end{array}$ & $\begin{array}{l}\text { Seguridade } \\
\text { social }\end{array}$ \\
\hline Países da OCDE & 14,2 & 3,1 & 10,8 & 11,4 & 6,6 & 3,6 & 0,3 & 9,5 \\
\hline América & 15,4 & 3,0 & 12,3 & 7,0 & 3,7 & 2,0 & 0,3 & 6,1 \\
\hline Pacífico & 16,3 & 4,3 & 11,4 & 8,4 & 4,3 & 2,6 & 0,6 & 3,5 \\
\hline Europa & 13,7 & 2,9 & 10,6 & 12,4 & 7,3 & 4,0 & 0,3 & 10,8 \\
\hline $\begin{array}{l}\text { Países em } \\
\text { desenvolvimento }\end{array}$ & 5,2 & 2,6 & 2,2 & 10,5 & 3,6 & 2,4 & 3,5 & 1,3 \\
\hline África & 6,9 & 2,4 & 3,9 & 11,6 & 3,8 & 2,3 & 5,1 & 0,5 \\
\hline Ásia & 6,2 & 3,0 & 3,0 & 9,7 & 3,1 & 2,2 & 2,7 & 0,3 \\
\hline Oriente Médio & 5,0 & 3,2 & 1,3 & 10,3 & 1,5 & 3,0 & 4,3 & 1,1 \\
\hline $\begin{array}{l}\text { Hemisfério } \\
\text { ocidental }\end{array}$ & 3,7 & 2,3 & 1,0 & 10,6 & 4,8 & 2,3 & 2,6 & 2,5 \\
\hline
\end{tabular}

Mas há outros fatores que afetam o resultado dessa equação, isso é, mesmo nos locais onde a economia é sólida e pujante, não se consegue edificar um sistema de tributação que abandone plenamente os gravames indiretos e isso se liga à eficiência na arrecadação desses gravames.

Com efeito, a versatilidade econômica mundial impede a fixação da tributação apenas no patrimônio e na renda, uma vez que, na clara explicação de NABAIS (2005c, p. 139):

É que, em face ao crescente número de contribuintes nômades, empresas e profissionais que facilmente deslocam a sede ou a residência para os países ou territórios com uma carga fiscal menor, escapando assim aos impostos diretos, sobretudo ao imposto sobre o rendimento pessoal, no qual, através da aplicação de taxas progressivas, era suposto pagarem mais imposto do que os contribuintes que dispõem de menor capacidade contributiva, parece não restar outra alternativa que não seja a de os 
sujeitar, ao menos, aos impostos indiretos, isto é, aos impostos sobre o consumo.

Numa constatação semelhante, LIVINGSTON (2005, p. 193) noticia que:

muitos países se convenceram de que altas alíquotas de imposto sobre a renda (isto é, progressivas) são inúteis num mundo globalizado, porque negócios e indivíduos com altos rendimentos irão simplesmente deslocar seus empreendimentos para jurisdições com menor tributação, deixando os países de alta tributação ao mesmo tempo mais pobres e não mais equânimes do que eram antes.

As dificuldades ocorridas na Itália, o que inclusive ensejou a edição de uma nova legislação mais branda quanto ao respeito à capacidade contributiva (v.g. redução do número de alíquotas), são retratadas por SACCHETTO (2005, p. 29). Em suas palavras:

Hoje, diante da dificuldade de manter tal princípio nos impostos pessoais sobre a renda - em razão das dificuldades objetivas para garantir sua efetividade -, encontram-se formas "mascaradas" para salvar o próprio princípio, mas de fato esvaziando-o, no sentido que, salvo certos níveis de alíquota e escalões de rendimentos entendidos compatíveis ou aceitáveis pela comunidade, se prevêem (para níveis particularmente elevados de rendas) ou formas de concurso sob a forma de "contribuições de solidariedade" ou outras formas de tipo subvencional. É o que se ventilou também na Itália com a reforma que deveria diminuir a pressão fiscal, com a contribuição de solidariedade ou formas análogas já experimentadas no passado em outros ordenamentos como a França com a Contribuition de solidarité de 1982 (com finalidades específicas, p.ex., fundo de sustento para o desemprego) ou o Impôt de solidarité sur la fortune (ex., imposto sobre grandes fortunas) que parece ter a natureza de um imposto patrimonial sobre os ricos.

Em verdade, na colocação de GIAMBIAGI e ALÉM (2002, p. 40): “a passagem da teoria para a prática é complexa”. Portanto, é sobretudo com base em critérios que privilegiam a eficiência econômica que FRIEDMAN (1985, p. 159) defende ser mais funcional, por exemplo, uma alíquota média de 23,5\% para o Imposto de Renda norte americano, ao invés do sistema então vigente (nos idos da década de 1980), que grava entre $20 \%$ e $91 \%$, com imputação de $50 \%$ para rendas tributáveis acima de US\$18.000,00 (e US\$ 36.000,00 para os casados com declaração em comum).

A arrecadação, na opinião do autor, tenderia a crescer por três razões: a) adoção de menos expedientes de planejamento tributário, eis que são custosos e a 
tributação mais leve poderia tornar desinteressante seu emprego; b) menor sonegação, em vista do risco de autuação fiscal para um valor não tão elevado; e, c) a menor imposição deixaria de, eventualmente, desestimular o engajamento em novos empreendimentos.

Na dura assertiva de VARSANO et al. (1998, p. 32): "dificilmente será possível criar um sistema tributário muito progressivo".

Em conclusão, ainda que os tributos "indiretos" ostentem um caráter nãodemocrático por desrespeitarem a cláusula primordial da igualdade, fato é que atualmente é muito difícil dispensar do sistema essa espécie de exação, cabendo a cada Estado, por meio dos respectivos representantes, balancear o ideal democrático com questões de eficiência econômica de modo a evitar-se um possível mal maior.

Outra questão de relevo é a tributação das empresas e pessoas jurídicas em geral (incluindo-se as firmas individuais). Nessa seara, independentemente do objeto social e área de atuação, o ônus financeiro de qualquer tributo (não apenas os "indiretos") é, em tese, possível de ser repassado ao consumidor, da mesma maneira que as demais despesas implicadas nas atividades sociais, tais como: salários dos empregados, energia elétrica, insumos e matérias primas em geral, etc. Aliás, se bem notado for, sob o ponto de vista estritamente econômico, é viável afirmar que empresas e pessoas jurídicas em geral "não pagam tributos".

Com efeito, o repasse de todo ônus fiscal geralmente recai sobre uma dessas três hipóteses ou, ainda, sobre todas simultaneamente em alguma medida: primeiramente, de modo a não diminuir os lucros, tenta-se imputar o ônus aos consumidores.

Caso isso não seja possível, por exemplo, por questões mercadológicas (v.g. concorrência acirrada que obriga à prática de preços mais baixos), o ônus é repassado aos funcionários na forma de estagnação salarial. Contudo, tal procedimento pode ser problemático, visto que os trabalhadores e os sindicatos não concordarão com essa situação indefinidamente. Logo, em último grau, o ônus tributário é aportado, ainda que parcialmente, aos sócios e acionistas com menores distribuições de lucros. 
Portanto, a aplicação do princípio da capacidade contributiva e a pessoalidade se revelam plenos em vista do patrimônio e da renda das pessoas físicas (e não jurídicas). Segundo MANKIW (2007, p. 260):

Quando o governo cobra um imposto de uma empresa, ela age mais como coletora de impostos do que como contribuinte. O ônus recai, em última instância, sobre as pessoas físicas - os proprietários, clientes ou trabalhadores da empresa [...] O imposto de renda das pessoas jurídicas é popular, em parte, porque parece ser pago por empresas ricas, mas as pessoas que realmente arcam com o ônus final do imposto - os clientes e trabalhadores das empresas - muitas vezes não são ricas.

No mesmo caminho, assevera JOST (2003, p. 25) que:

o imposto recai sobre pessoas. A empresa tributada pode repassar o imposto a seus clientes (empresas ou pessoas) ou a seus fornecedores de bens e serviços. A parte absorvida pela empresa, não repassada a fornecedores ou consumidores, recairá sobre seus acionistas e trabalhadores.

De forma a bem frisar essa ideia, ainda sobre o tema em análise,

LEMGRUBER (2007, p. 213) esclarece que:

A interpretação mais aceita é a de que, a curto prazo, o imposto é suportado pelos donos do capital, pois não há margens para ajustes. Porém, a longo prazo, é provável que os consumidores ou os trabalhadores paguem a conta de um aumento do imposto sobre a empresa. Consumidores arcarão com o custo caso seja possível repassar o imposto para os preços dos bens e serviços produzidos pela empresa; trabalhadores suportarão a incidência caso seus salários sejam diminuídos de modo a manter os custos de produção. Quem realmente será afetado, e em que nível, dependerá das elasticidades da demanda e do tipo de mercado envolvido (competitivo ou monopolístico).

Logo, o ônus da tributação das pessoas jurídicas, ainda que estejam em cena, por exemplo, impostos sob o patrimônio ou sob a renda, na prática, transmudam-se em tributação indireta (VILLELA, 1987, p. 16).

Disso conclui-se que devem ser tomadas sob ganu salis campanhas e incitações por majorações dos tributos a cargo das empresas, uma vez que o ônus fiscal acaba sendo repassado de alguma maneira aos consumidores e ou trabalhadores, o que não se sucede com relação às pessoas físicas, conforme acima aventado. 
Em conclusão, é possível afirmar que, quanto mais o Estado for sustentado por tributos "diretos" que gravem primordialmente o patrimônio e a renda das pessoas físicas, mais se estará caminhando no sentido da implantação do $2^{\circ}$ fundamento da democracia fiscal, qual seja, da igualdade ou equivalência de sacrifício tributário.

E, quanto maior for a participação dos tributos "indiretos" na composição do Tesouro, maior será a probabilidade dos pobres entregarem ao fisco, ainda que sem perceber, proporcionalmente mais do que os economicamente potentes. Com isso, poderse-ia criar uma situação paradoxal onde os menos favorecidos economicamente é que financiariam a maior parte dos gastos e, inclusive, eventuais políticas públicas de cunho social e assistencial.

Mesmo que a dinâmica da economia moderna, com as facilidades de envio de capitais para locais tributariamente mais amistosos, indiscutivelmente imponha obstáculos à instituição de um sistema tributário absolutamente igualitário totalmente inspirado pelo princípio da capacidade contributiva e pela pessoalidade, não se pode admitir que se desista simplesmente de alcançar um patamar no qual as receitas tributárias tenham origem mais relevante nos tributos "diretos", ou seja, tenham primordialmente afetado o bem-estar de quem legalmente estava designado como obrigado ao pagamento. Logo, segundo QUEIRÓZ (2005, p. 240):

Estado e cidadão devem ter por objetivo procurar estabelecer a precisa correlação entre a carga tributária e a contraprestação por meio de serviços públicos de qualidade e eficiência para que o pagamento dos tributos se dê com menor resistência e possa atingir o ponto mais próximo possível do equilíbrio entre as necessidades do Estado e a capacidade de contribuir do cidadão.

No caso específico do Brasil, segundo afirmam SIQUEIRA et al. (2001, p. 514): "os impostos indiretos respondem por mais da metade da receita tributária total". Já conforme FACCIONI (2005, p. 404), a situação seria mais crítica, isso é: "dois terços dos tributos são cobrados sobre o que as pessoas consomem e apenas um terço sobre a renda e a propriedade".

De fato, essas divergências são encontradas porque a estrutura da tributação indireta, muitas vezes com incidências que se acumulam durante a cadeia produtiva, seja em face das inúmeras matérias primas e insumos, seja em vista do produto 
terminado, gerando o que se denomina de tributação em "cascata", torna difícil a tarefa e estimar o montante arrecadado, ainda mais porque o Brasil se constitui numa Federação com três esferas políticas distintas (União, Estados e Municípios).

Mais dificultoso, ainda, é aferir o real impacto da tributação indireta na renda familiar dada a diversidade social brasileira, não obstante os tenazes esforços realizados por vários pesquisadores que se interessam pelo tema, conforme será discorrido.

Antes de prosseguir na análise numérica propriamente dita, é de se observar que essa nebulosidade que embaça os números relativos à tributação indireta, bem como obscurece a consciência do quanto ela significa em termos de ônus financeiros para cada pessoa, funciona como um dique que barra ou, ao menos amaina, a percepção daquilo que realmente cada um contribui para com o Tesouro, minimizando possíveis insatisfações quanto ao "retorno" que o Estado faz promover. Na explicação de JOST (2003, p. 10):

Por exemplo, o ICMS está formulado para que o contribuinte não tenha consciência da alíquota efetiva, sabendo apenas da existência da alíquota nominal. Na hora da compra visualiza apenas o produto e o preço final, sem conscientiza-se do valor do imposto que está pagando. Muito menos tem consciência de que a alíquota nominal de $25 \%$ corresponde a uma alíquota efetiva de $33,33 \%$. Isso porque o imposto é calculado sobre o valor total da fatura, incluindo mercadoria e o próprio imposto.

Idêntico alerta é formulado por PAES e BUGARIN (2006, p. 700) ao consignarem que: "A imposição tributária no Brasil nunca foi transparente, principalmente em relação aos tributos indiretos, já que é difícil determinar a contribuição tributária de cada cidadão no momento da aquisição de determinado produto".

Noutros países (v.g. o IVA europeu, o Sale Tax dos norte americanos), segundo informa BOTELHO (2005, p. 97): “o valor do imposto não está incluído no preço, e o comprador paga o valor da operação em duas parcelas em destaque (preço cobrado pelo comerciante, acrescido dos impostos)".

Em suma, é de se concluir que, em termos de conscientização social, como criação de um sentimento de pertinência ao grupo das pessoas que ativamente financiam o Estado e, por isso, sentem-se legitimadas a exigir o um retorno razoável em face das suas contribuições, a tributação indireta no Brasil é, em síntese, alienante. 


\subsection{A situação brasileira: maior detalhamento}

Considerando o caso brasileiro, a arrecadação tributária para o exercício de 2008, de modo sintético, foi a seguinte ${ }^{128}$ :

\begin{tabular}{|l|c|}
\hline Nome do tributo & Arrecadado em bilhões \\
\hline Imposto sobre Importação - II & 17,23 \\
\hline Imposto sobre Produtos Industrializados - IPI & 39,46 \\
\hline Imposto sobre a Renda das Pessoas Jurídicas - & 169,45 \\
IRPJ & \\
\hline Imposto sobre a Renda das Pessoas Físicas - IRPF & 107,02 \\
\hline Imposto sobre Operações Financeiras - IOF & 20,34 \\
\hline Imposto sobre a Propriedade Rural - ITR & 0,47 \\
\hline COFINS & 120,80 \\
\hline PIS & 31,59 \\
\hline CSSL Receita & 43,97 \\
\hline CIDE - combustíveis & 5,93 \\
\hline Outras receitas administradas pela & 6,75 \\
Federal & 222,22 \\
\hline ICMS & 29,96 \\
\hline Outros tributos estaduais & 41,78 \\
\hline Tributos Municipais & 856,97 \\
\hline Total &
\end{tabular}

Dos dados acima, é possível constatar o seguinte:

a) os tributos "indiretos", a cargo principalmente das pessoas jurídicas, que, por incidirem sobre a cadeia produtiva, possibilitam o repasse de seu encargo a terceiros (II, IPI, IRPJ, ICMS, COFINS, PIS, CSSL e CIDE) ${ }^{129}$ corresponderam a 650,65

128 Os dados relativos aos tributos federais foram coletados no site da Secretaria da Receita Federal (www.receita.fazenda.gov.br) e, quanto aos estaduais e municipais, junto ao site do Instituto Brasileiro de Planejamento Tributário - IBPT (www.ibpt.com.br). Foram consideradas, de maneira preponderante, as receitas que possuam "destinação geral" (no caso todos os impostos e algumas contribuições). Tributos que gerem alguma forma de contraprestação (seja direta ou indireta) ao sujeito passivo (v.g. taxas, contribuições de melhoria, contribuições previdenciárias dos funcionários públicos, contribuições previdenciárias do art. 195, incisos I, "a", e II, da Constituição e contribuição ao FGTS) não foram incluídos, na medida em que distorceriam a análise da "divisão social do ônus tributário", pois os respectivos recolhimentos, ao menos em tese, objetivam financiar atividades primordialmente em benefício daqueles contribuintes e não de terceiros. Apenas para esclarecer, contribuições tais como COFINS, PIS e CSSL, pelo art. 167, XI, da Constituição, podem ter seus recursos aplicados em atividades diversas do que o pagamento dos benefícios de previdência social, o que lhes confere caráter de "destinação geral".

${ }^{129}$ Não se computou as hipóteses em que não é dado saber qual valor foi recolhido por pessoas físicas e jurídicas (II, IOF, ITR, outras receitas administradas pela Receita Federal, outros tributos estaduais e todos os tributos municipais). Mesmo sabendo que as pessoas jurídicas pagam tais exações, a ausência de 
bilhões de reais ou 75,92\% do total. Segundo informa PEREIRA et al. (2006, p. 43): "esta proporção é de 17,6\% nos Estados Unidos, 20,1\% no Japão, 25,4\% na França, 29,9\% na Alemanha, 30,3\% na Austrália e 32,7\% no Reino Unido", ou seja, bem menor do que aqui;

b) o Imposto de Renda das Pessoas Físicas - IRPF, em tese o que mais viabiliza o respeito à capacidade contributiva e à pessoalidade, somou 107,02 bilhões de reais ou $12,48 \%$ do total.

Nesse tópico, é importante noticiar, segundo PEREIRA et al. (idem, p. 47), que: "Nos países desenvolvidos o Imposto de Renda pessoal é cerca de 3,5 a 4 vezes mais alto do que o Imposto de Renda sobre as empresas", fato esse que o coloca como o mais importante instrumento de arrecadação dos países desenvolvidos (PIANCASTELLI e NASCIMENTO, 2005, p. 231). Segundo estudo realizado pela SECRETARIA DA RECEITA FEDERAL $(2004,01)$ :

Apesar de suas qualidades, no entanto, esse imposto tem sido pouco utilizado por países em desenvolvimento, em claro contraste com sua importância nos sistemas tributários de países desenvolvidos. A explicação para tal fato está relacionada com a complexidade administrativa e de fiscalização do imposto (minimizada nos casos de retenção na fonte) e a forte concentração de renda existente em países menos desenvolvidos (que restringe a base tributável a pequena parcela da população).

Como resultado, segundo o estudo em foco (idem, p. 03), para o ano de 2001: "apenas 13\% dos brasileiros que auferem rendimentos poderiam estar sujeitos ao IRPF, o que representa cerca de 14 milhões de pessoas".

Mais adiante (idem, p. 11), é constatado que a participação do Imposto de Renda a cargo das pessoas físicas na arrecadação total brasileira é diminuta e não chega aos $10 \%$, chegando a atingir 52,7\% na Dinamarca. Em complemento, é revelado que:

mesmo os países do Leste Europeu, que têm renda per capita semelhante à do Brasil, são capazes de se financiar com maior participação do IRPF em sua arrecadação total - denotando maior progressividade em seus sistemas tributários. Por exemplo, essa relação é de 19,6\% na Hungria, 23,6\% na Polônia, 10,8\% na República Eslováquia e 12,5\% na República Tcheca.

dados precisos a respeito do quantum recolhido por elas impõe a desconsideração da variante, sob pena de distorcer as conclusões. 
Prosseguindo, a ausência de dados específicos sobre os gravames que marcam o patrimônio (IPTU, IPVA, transmissões causa mortis e inter vivos), em que também é possível (e desejável) a gradação segundo a capacidade contributiva do obrigado, além da observância à cláusula da pessoalidade, impede o seu cômputo nessa análise.

Todavia, entende-se que isso não prejudica o resultado em termos globais, pois a arrecadação dessas exações é efetivamente diminuta frente ao todo, correspondendo a aproximadamente 3\% das receitas (PISCITELLI, 2003, p. 91), o que implicaria num montante de 25,7 bilhões de reais, mas isso considerando o Brasil todo.

Aliás, esse percentual pode ser ainda mais tímido, eis que, segundo VARSANO et al. (1998, p. 06), correspondeu a meros 1,5\% do total nos anos de 1991, 1995 e 1996.

O que se constata, e não é de hoje, segundo preleciona VILLELA (1987, p. 02), é que: "Os impostos patrimoniais brasileiros deixaram de ter participação significativa no total das receitas tributárias e na composição da carga tributária nacional há décadas".

Segundo o autor, naquele instante, na Inglaterra, a tributação sobre o patrimônio chegava a atingir $4 \%$ do $\mathrm{PIB}$, enquanto que no Brasil não atingia sequer $1 \%$. Em 2002, ou seja, 15 anos depois, a situação era praticamente a mesma, sendo que os principais impostos sobre o patrimônio representaram meros 1,15\% do PIB ou 3\% da carga tributária total, conforme noticiam KHAIR e MELO (2005, p. 255), com as seguintes participações: 0,02\% - ITR; 0,52\% - IPVA; 0,04\% - ITCMD; 0,47\% - IPTU; 0,11\% - ITBI.

Em adição, o quadro elaborado por VIANNA et al. (2000, p. 16) retrata o aumento da participação dos tributos "indiretos" na carga fiscal brasileira ao longo das últimas décadas do século XX, indicando que não há perspectivas de redução do caráter regressivo do sistema, conforme segue: 


\begin{tabular}{|c|c|c|c|c|c|}
\hline & 1980-1983 & 1984-1987 & 1988-1989 & 1990-1993 & 1994-1996 \\
\hline \multicolumn{6}{|c|}{ \% da arrecadação } \\
\hline Trib. Diretos & 49,22 & 53,10 & 49,59 & 45,18 & 45,13 \\
\hline Trib. Indiretos & 50,72 & 46,89 & 50,40 & 54,81 & 54,84 \\
\hline \multicolumn{6}{|l|}{ \% sobre PIB } \\
\hline Diretos & 12,68 & 13,05 & 11,54 & 11,82 & 13,25 \\
\hline Indiretos & 13,06 & 11,52 & 11,72 & 14,34 & 16,10 \\
\hline
\end{tabular}

O texto da pesquisa não esclarece se, dentro dos tributos "diretos”, foram incluídos os impostos sobre a renda e o patrimônio das pessoas jurídicas. Caso isso tenha ocorrido, em realidade, levando em conta o fato das empresas tenderem a repassar os ônus financeiros de qualquer tributo ao consumidor final, independente de sua natureza, a participação dos tributos "indiretos" certamente seria consideravelmente maior, como, aliás, foi constatado logo acima quanto ao IRPF para o ano de 2008, que somou pouco mais de $12 \%$ do total.

Outra constatação importante do estudo em foco (idem, p. 38 e ss.) é a de que, para as famílias cuja renda mensal não ultrapassa os dois salários mínimos, os tributos "indiretos" representam aproximadamente $26 \%$ dos seus ganhos, enquanto que, para aquelas com renda superior a 30 salários mínimos, esse encargo se reduz para 7\%, notando-se alguma variação conforme a região metropolitana enfocada, segundo as tabelas a seguir:

\begin{tabular}{|l|l|l|l|l|l|}
\hline $\begin{array}{l}\text { Valor mediano em \% } \\
\text { mínimo }\end{array}$ & Média & 0 a 2 S.M. & 5 a 6 S.M. & $\begin{array}{l}\mathbf{1 0} \text { a } \\
\text { S.M. }\end{array}$ & $\begin{array}{l}\text { + de 30 } \\
\text { S.M. }\end{array}$ \\
\hline & 2,74 & 9,81 & 5,04 & 3,36 & 1,48 \\
\hline Alimentação & 0,41 & 1,09 & 0,78 & 0,51 & 0,25 \\
\hline $\begin{array}{l}\text { Despesas } \\
\text { pessoais }\end{array}$ & 0,51 & 2,17 & 0,91 & 0,64 & 0,27 \\
\hline Saúde & 0,81 & 4,18 & 1,62 & 1,02 & 0,29 \\
\hline Fumo & 0,52 & 3,14 & 1,21 & 0,53 & 0,22 \\
\hline Habitação & 0,79 & 0,95 & 0,84 & 0,92 & 0,72 \\
\hline Lazer & 1,17 & 2,43 & 1,68 & 1,48 & 0,86 \\
\hline Vestuário & 1,19 & 2,45 & 1,70 & 1,33 & 0,90 \\
\hline Transportes & 1,53 & 0,27 & 0,20 & 0,68 & 2,34 \\
\hline Veículos & 9,87 & 26,48 & 13,98 & 10,47 & 7,34 \\
\hline Total & & & & & \\
\hline
\end{tabular}


A seguir, transcrevem-se os valores médios da carga gerada pelos tributos "indiretos" sobre a renda disponível segundo algumas regiões metropolitanas, evidenciando o caráter regressivo deste modelo de tributação:

\begin{tabular}{|c|c|c|c|c|c|}
\hline \multicolumn{5}{|c|}{$\begin{array}{l}\text { Valor mediano em \% } \\
\text { mínimo }\end{array}$} & \multirow{2}{*}{$\begin{array}{l}\text { S.M. = salário } \\
\text { + de } 30 \text { S.M. }\end{array}$} \\
\hline & Média & Até 2 S.M. & 5 a 6 S.M. & 10 a 15 S.M. & \\
\hline São Paulo & 9,25 & 25,77 & 13,34 & 10,40 & 7,28 \\
\hline Curitiba & 11,00 & 30,00 & 16,23 & 12,21 & 9,07 \\
\hline Belém & 10,84 & 30,07 & 15,93 & 9,89 & 7,07 \\
\hline Fortaleza & 10,43 & 26,32 & 16,01 & 11,24 & 5,73 \\
\hline
\end{tabular}

Como se essa situação não bastasse, a estrutura dos tributos sobre a renda e o patrimônio no Brasil permite apenas que a capacidade contributiva seja respeitada num patamar mínimo. Significa dizer que, ainda que o volume principal de receitas se originasse das exações "diretas" - o que comprovadamente está longe de ocorrer, seriam necessárias mudanças de peso na sistematização desses gravames.

Com efeito, nas últimas duas décadas, assistiu-se a uma simplificação nos modos de apurar o Imposto de Renda devido pelas pessoas físicas. Segundo noticia QUEIRÓZ (2005, p. 245): “Até o ano de 1987 as alíquotas variavam de 5\% a 50\% e até o ano de 1988 eram 8 faixas de alíquotas que iam de 0\% a 45\%". Entretanto, a Lei 7.713/88, em seu art. 25, previu a existência de apenas duas alíquotas, quais sejam, $10 \%$ e $25 \%$, no que foi seguida pelas normas posteriores que trataram desse imposto, registrando-se que a alíquota maior foi majorada posteriormente para 27,5\%, conforme o art. 21 da Lei 9.532/97.

Aliás, a qualidade superior da legislação pré-1988, em termos de aptidão para tributar de forma mais isonômica as diversas classes de contribuintes, não se dava apenas em vista da presença de um número maior de alíquotas, mas também pela imposição diferenciada segundo a origem do rendimento (v.g. trabalho, aplicações financeiras, dividendos, ganhos de capital, etc.). Sobre o tema, segundo COELHO (2000, p. 457):

Antigamente a lei classificava o rendimento das pessoas físicas em cédulas que iam da letra " $\mathrm{A}$ " a " $\mathrm{H}$ ". Cada cédula ou rendimento cedular continha suas deduções próprias, que, uma vez feitas, forneciam o rendimento cedular líquido. $\mathrm{O}$ somatório dos mesmos constituía a renda 
bruta. A sua vez, a renda bruta sofria os abatimentos das quantias gastas pelos contribuintes para sobreviverem e se aprimorarem junto com seus dependentes. Este sistema foi eliminado a partir de 1989 a título de simplificar as declarações anuais das pessoas físicas. Nota Hugo de Brito Machado que, no entanto, restou modificado o caráter pessoal do imposto de renda (art. $145 \S 1^{\circ}$ da CF/88). Tem toda razão. A título de simplificar, o legislador simplificou demais, aumentando a tributação pelo cerceamento arbitrário de abatimentos e deduções, pela adoção de poucas alíquotas progressivas e pela imposição de limites genéricos divorciados da realidade, contra os princípios da pessoalidade e da capacidade contributiva, em um país de muita desigualdade de renda, por faixas de população e por estamentos etários e familiares (número de dependentes).

Ainda que a redução no número de alíquotas tenha facilitado a confecção da declaração de ajuste anual, bem como tenha dinamizado a respectiva conferência a cargo dos órgãos de fiscalização, é intuitivo perceber que se aglomerou em poucos patamares realidades financeiras e patrimoniais muito discrepantes.

Ora, isso colocou em risco o valor da igualdade na medida em que a progressividade do imposto, que poderia conferir uma maior coincidência no sacrifício fiscal dos contribuintes, restou extremamente limitada. Conforme a lição de COSTA (2009, p. 345), isso: "fere o princípio da capacidade contributiva, porquanto desatende a graduação dos impostos, que há de ser feita mediante alíquotas progressivas”.

Em adição, um efeito perverso que pode ser constatado ao longo das últimas décadas é o arrefecimento no potencial do Imposto de Renda de contribuir para a diminuição das desigualdades sociais, conforme aponta PAYERAS (2008, p. 29):

Em 1985, quando o imposto incidia sobre um número maior de faixas e tinha maior progressividade, o IR contribuía com redução de 5,20\% do índice de Gini ${ }^{130}$ quando analisada a renda familiar per capita, ao passo que em 1998 o efeito redistributivo do referido imposto foi de 4,05\%.

Um singelo avanço ocorreu apenas recentemente com a edição da Medida Provisória 451/2008 (convertida na Lei 11.945/2009), cujo art. 15 inseriu novas alíquotas na Tabela do IRPF a serem aplicadas a partir do exercício de 2009, da seguinte forma:

${ }^{130}$ Conforme SABBAG (2006, p. 102-103): "O indicador é utilizado pela ONU para avaliar as desigualdades na distribuição de renda dos países. O valor zero representa distribuição perfeita (quando a renda de todos os indivíduos tem o mesmo valor) e 1 significa desigualdade máxima”. O autor menciona os índices dos seguintes países: Namíbia $=0,707$; Lesoto $=0,632$; Botsuana $=0,630$; Serra Leoa $=0,629$; Brasil = 0,591; Colômbia $=0,576$; Chile $=0,571 ;$ Paraguai $=0,568 ;$ México $=0,546$; Rússia $=0,456$; Estados Unidos = 0,408; Japão = 0,249 e Dinamarca $=0,247$. 


\begin{tabular}{|l|l|l|}
\hline \multicolumn{3}{|c|}{ Tabela Progressiva do Imposto de Renda para 2009 } \\
\hline Base de Cálculo em Reais & Alíquota & $\begin{array}{l}\text { Parcela a deduzir em } \\
\text { Reais }\end{array}$ \\
\hline Até $1.434,59$ & Isento & Nada \\
\hline Entre $1.434,60$ a $2.150,00$ & $7,5 \%$ & 107,59 \\
\hline Entre 2.150,01 a $2.866,70$ & $15 \%$ & 268,84 \\
\hline Entre 2.866,71 a $3.582,00$ & $22,5 \%$ & 483,84 \\
\hline Acima de 3.582,00 & $27,5 \%$ & 662,94 \\
\hline
\end{tabular}

Entretanto, além do número de alíquotas ainda ser reduzido, até agora não se constata exista qualquer tendência legislativa para a reedificação de uma sistemática que diferencie a imposição com base na origem do rendimento.

Outro tema relativo ao Imposto de Renda refere-se ao afastamento parcial da cláusula da pessoalidade em face da sistemática prevista pelo art. 10 da Lei 9.249/95, cuja redação determina que:

Art. 10 - Os lucros ou dividendos calculados com base nos resultados apurados a partir do mês de janeiro de 1996, pagos ou creditados pelas pessoas jurídicas tributadas com base no lucro real, presumido ou arbitrado, não ficarão sujeitos à incidência do imposto de renda na fonte, nem integrarão a base de cálculo do imposto de renda do beneficiário, pessoa física ou jurídica, domiciliado no País ou no exterior.

E por que isso afastaria a pessoalidade do Imposto de Renda? Simplesmente porque nessas hipóteses quem suporta o ônus financeiro da exação é a pessoa jurídica que distribui lucros ou dividendos, e não o respectivo sócio, e, conforme já declinado acima, as empresas dispõem de mecanismos capazes de transferir grande parte dos custos tributários a terceiros - principalmente aos consumidores e empregados.

De fato, no alerta de GIAMBIAGI e ALÉM (2002, p. 46): “a longo prazo, a empresa pode reagir à cobrança do imposto sobre os lucros repassando-o, pelo menos em parte, para o preço final dos produtos, onerando, assim, os consumidores".

Nessa linha, em última instância, é possível concluir que o imposto que, teoricamente seria o mais apropriado para garantir o respeito à capacidade contributiva do obrigado (no caso, o sócio), tem sua pessoalidade neutralizada, o que pode representar ofensa ao $\S 1^{\circ}$ do art. 145 da Constituição de 1988 . Em vista dessas circunstâncias, segundo QUEIROZ (2005, p. 249): 
O IR previsto na legislação ordinária atual não guarda mais qualquer conexão com os princípios constitucionais e tem consagrado verdadeira injustiça fiscal, à medida que desrespeita a pessoalidade, a capacidade contributiva e a progressividade, resultando em onerar mais a classe daqueles que auferem menos rendimentos.

Avançando, o imposto que grava a propriedade territorial urbana (o IPTU), outro tributo "direto" que permite o aproveitamento da pessoalidade e o respeito à capacidade contributiva, está longe de alcançar seu máximo potencial, chegando inclusive a apresentar caráter regressivo em muitas hipóteses. Explica CARVALHO JR. (2006, p. 11) que:

O principal motivo da sua regressividade é o fato de as administrações municipais avaliarem os imóveis de maneira regressiva, isto é, os mais valorizados tendem a apresentar uma defasagem maior em relação ao seu valor de mercado que os imóveis de valores mais baixos.

O autor (idem, p. 11) apresenta um quadro que revela a participação do IPTU na renda familiar, segundo dados relativos a 2002 e 2003, nos seguintes termos:

\begin{tabular}{|c|c|c|c|c|c|c|}
\hline \multicolumn{7}{|c|}{$\begin{array}{l}\text { Valor mediano em \% } \\
\text { mínimo }\end{array}$} \\
\hline Região & $\begin{array}{l}\text { 0 a } 2 \\
\text { S.M. }\end{array}$ & $\begin{array}{l}\text { a } 5 \\
\text { S.M. }\end{array}$ & $\begin{array}{ll}5 \text { a } & 15 \\
\text { S.M. } & \end{array}$ & $\begin{array}{l}15 \text { a } 30 \\
\text { S.M. }\end{array}$ & $\begin{array}{l}\text { 30 a } 60 \\
\text { S.M. }\end{array}$ & $\begin{array}{l}+ \text { de } 60 \\
\text { S.M. }\end{array}$ \\
\hline Norte & 2,14 & 2,26 & 1,18 & 2,22 & 1,22 & 0,68 \\
\hline Nordeste & 1,42 & 0,50 & 0,72 & 0,63 & 0,45 & 0,80 \\
\hline Sudeste & 2,37 & 1,52 & 0,95 & 0,69 & 0,61 & 0,54 \\
\hline Sul & 1,55 & 1,03 & 0,75 & 0,60 & 0,50 & 0,48 \\
\hline Cent.-Oste & 1,35 & 0,92 & 0,74 & 0,62 & 0,50 & 0,47 \\
\hline Brasil & 1,60 & 1,30 & 0,88 & 0,65 & 0,60 & 0,57 \\
\hline
\end{tabular}

O autor (idem, p. 12-13) aprofunda o estudo em foco ao comparar o grau de incidência do IPTU segundo a adoção ou não de alíquotas progressivas, nos seguintes termos:

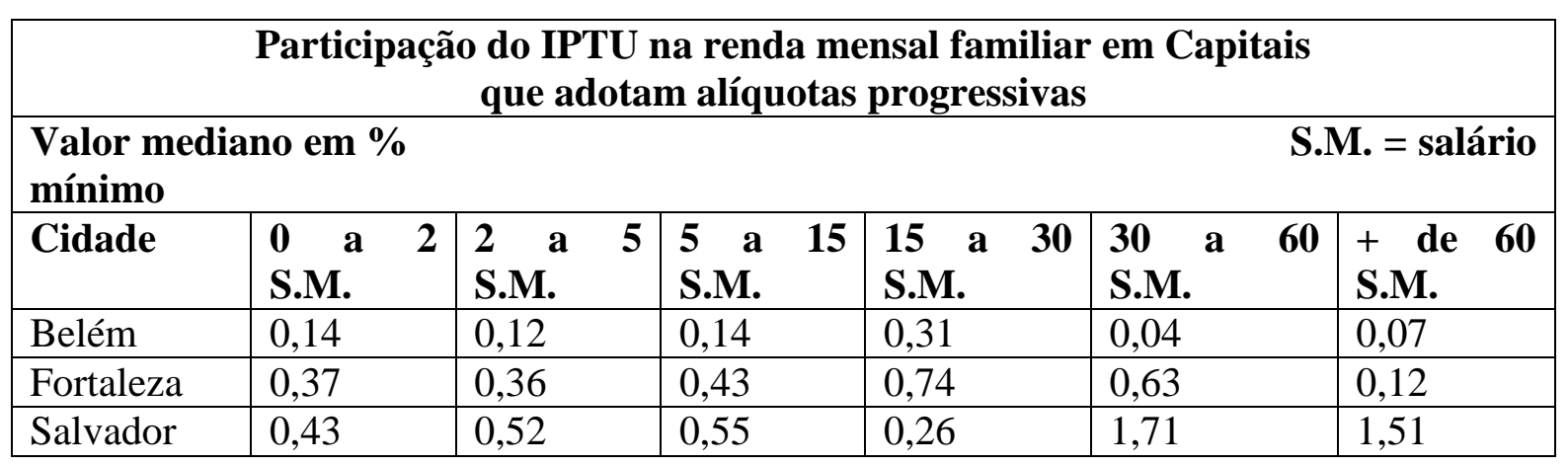




\begin{tabular}{|l|l|l|l|l|l|l|}
\hline B.Horizonte & 1,05 & 0,82 & 0,81 & 0,61 & 0,64 & 0,68 \\
\hline São Paulo & 3,18 & 1,87 & 1,08 & 0,73 & 0,56 & 0,53 \\
\hline Curitiba & 0,23 & 1,24 & 0,74 & 0,54 & 0,76 & 0,48 \\
\hline Goiânia & 1,06 & 0,65 & 0,39 & 0,68 & 1,12 & 0,88 \\
\hline
\end{tabular}

\begin{tabular}{|c|c|c|c|c|c|c|}
\hline \multicolumn{7}{|c|}{$\begin{array}{l}\text { Participação do IPTU na renda mensal familiar em Capitais } \\
\text { que NÃO adotam alíquotas progressivas }\end{array}$} \\
\hline \multicolumn{5}{|c|}{$\begin{array}{l}\text { Valor mediano em \% } \\
\text { mínimo }\end{array}$} & \multicolumn{2}{|c|}{ S.M. = salário } \\
\hline Cidade & $\begin{array}{ll}\text { 0 a } & \text { 2 } \\
\text { S.M. } & \\
\end{array}$ & $\begin{array}{l}\text { a } 5 \\
\text { S.M. }\end{array}$ & 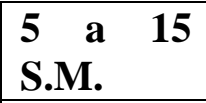 & $\begin{array}{l}\text { 15 a } 30 \\
\text { S.M. }\end{array}$ & $\begin{array}{ll}30 \text { a } & 60 \\
\text { S.M. } & \end{array}$ & $\begin{array}{l}+ \text { de } 60 \\
\text { S.M. }\end{array}$ \\
\hline $\begin{array}{l}\text { João } \\
\text { Pessoa }\end{array}$ & 1,39 & 0,86 & 0,65 & 0,40 & 0,26 & 1,86 \\
\hline Aracajú & 5,79 & 0,56 & 0,68 & 0,27 & 0,17 & 0,74 \\
\hline Vitória & 0,36 & 1,81 & 0,38 & 0,27 & 0,15 & 0,19 \\
\hline R. Janeiro & 1,60 & 1,92 & 1,28 & 3,43 & 0,66 & 0,47 \\
\hline P. Alegre & 1,47 & 1,50 & 0,92 & 0,72 & 2,43 & 0,85 \\
\hline Cuiabá & 4,60 & 3,15 & 2,27 & 1,92 & 1,88 & 0,59 \\
\hline Brasília & - & 3,86 & 0,04 & 0,92 & 0,27 & 0,47 \\
\hline
\end{tabular}

Do exame das tabelas acima, é possível verificar que, de um modo geral, nas Capitais que adotam o sistema de alíquotas progressivas, a tendência é que o IPTU represente um menor comprometimento do orçamento das famílias de mais baixa renda e, de modo inverso, observa-se que esse imposto acaba por onerar em proporção mais elevada as famílias de maior renda, com exceção da faixa que supera os 60 salários mínimos. Em complemento, CARVALHO JR. (idem, p. 26) aponta que:

\footnotetext{
Após a análise dos 223 Códigos Tributários dos municípios com população superior a 100 mil habitantes em 2000 , apenas $23,8 \%$ deles tinham progressividade ou alguma das seletividades exemplificadas acima em suas alíquotas. Desses municípios, 47,2\% tinham alíquotas progressivas, $20 \%$ seletivas por localização, $22,7 \%$ seletivas por tamanho, $11,3 \%$ seletivas por padrão de construção do imóvel e 1,9\% seletivas tanto em razão do tamanho quanto em razão do padrão de construção do imóvel.
}

Em vista do ora exposto, constata-se, por conseguinte, que o sistema de tributação brasileiro ainda não conseguiu implantar o determinado pelo $\S 1^{\circ}$ do art. 145 da Constituição de 1988, uma vez que, em seu conjunto, ostenta nítido caráter regressivo, percebendo-se que a maior parte das receitas provêm das exações "indiretas" e também das pessoas jurídicas. 
Segundo VIANNA et al. (2000, p. 07): “da forma como está atualmente estruturada, a tributação, no Brasil, representa um fator que, no mínimo, não contribui para reduzir os níveis de desigualdade social do país".

A essa constatação também chegou PAYERAS (2008, p. 109) em sua tese de doutoramento em Economia perante a Universidade de São Paulo. Em suas palavras: "A estrutura regressiva no Brasil é um forte indício de que, até a presente data, os impactos distributivos não foram devidamente considerados quando criado um imposto ou quando alterada sua alíquota”.

Por tais motivos, é possível afirmar que parcela considerável das políticas públicas que deveriam proteger justamente os economicamente menos favorecidos (v.g. educação, saúde, saneamento básico, habitação, transporte coletivo, etc.) é por eles financiada. Nesse tópico, segundo REZENDE e CUNHA (2002, p. 111): “cerca de 40\% do total das transferências monetárias e não-monetárias recebidas pelos domicílios pobres tendem a retornar ao governo na forma de tributos pagos por esses mesmos domicílios". Segundo a tabela formulada pelos autores em tela (idem, p. 11):

\begin{tabular}{|l|r|r|}
\hline \multicolumn{3}{|c|}{ Efeitos dos tributos sobre a renda dos domicílios pobres e não-pobres } \\
\hline Renda inicial & 2.329 & 14.271 \\
\hline Benefícios monetários & 944 & 3.467 \\
\hline Aposentadorias e pensões & 332 & 3.149 \\
\hline Seguro-desemprego & 109 & 129 \\
\hline Abono salarial e sal. família & 84 & 132 \\
\hline Amparo ao idoso & 63 & 40 \\
\hline Bolsas-escola, alimentação, etc. & 356 & 17 \\
\hline Renda bruta & 3.273 & 17.738 \\
\hline Tributos diretos & 38 & 1.216 \\
\hline Renda disponível & 3.235 & 16.522 \\
\hline Tributos indiretos & 815 & 1.847 \\
\hline Renda pós-tributos & 2.420 & 14.675 \\
\hline Benefícios não-monetários & 1.130 & 693 \\
\hline Renda final & 3.550 & 15.368 \\
\hline
\end{tabular}

${ }^{131}$ Os autores consideram pobre o domicílio cuja renda per capita seja inferior a meio salário mínimo. Adiante (idem, p. 113), aduzem que: "Os gastos do governo federal com saúde e ensino fundamental, por sua vez, têm beneficiado em maior proporção às camadas mais pobres da população. Todavia, assim como no caso das transferências monetárias, o efeito líquidos desses benefícios sobre o padrão de vida dos mais pobres é significativamente reduzido quando se leva em conta que grande parte de seu financiamento recai sobre os próprios beneficiários”. 
Isso claramente demonstra que a mera previsão do preceito, seja na Constituição, seja nas leis em geral, é apenas um mero e singelo primeiro passo que não garante a consecução do objetivo ali insculpido.

Indaga-se como isso poderia ser revertido. Desde logo, é evidente que o caminho não passa por aumentar sobremaneira e de inopino a tributação sobre o patrimônio e a renda dos mais ricos, pois, por primeiro, haveria alta probabilidade do Estado incorrer em exagero fiscal, pelo possível desrespeito ao direito de liberdade (leia-se propriedade e livre iniciativa), objeto do $1^{\circ}$ fundamento retro enfocado.

Por segundo, nunca se deve esquecer a possibilidade de, mediante uma tributação desmedida, o contribuinte tomar medidas no sentido de paulatinamente transferir sua riqueza para países tributariamente mais amigáveis, podendo gerar inclusive certa inibição da atividade econômica local se o fenômeno tender a se perpetuar, o que, aliás, será examinado no $3^{\circ}$ fundamento a seguir.

Logo, economicamente não é recomendável onerar tributariamente a renda ou o patrimônio a ponto de afugentar a permanência de seus titulares sob a égide do respectivo Estado. Em suma, se a sanha de repartir melhor o "bolo", exacerbar-se, corre-se o risco do volume a ser repartido simplesmente diminuir antes mesmo da divisão se ultimar, o que prejudicaria a todos, sem exceção. Aqui, conforme PEREIRA et al. (2006, p. 47):

Com mais da metade da arrecadação fiscal no Brasil sendo proveniente da tributação sobre o consumo, e apenas $16 \%$ proveniente da tributação sobre a renda, um aumento da progressividade do Imposto de Renda (por exemplo, a introdução de uma faixa de alíquota de 35) não seria instrumento muito eficaz para o aumento da progressividade da arrecadação total. Uma estratégia melhor talvez seja uma mudança gradual da estrutura tributária, na qual a arrecadação dependa cada vez menos de impostos indiretos e cada vez mais de impostos diretos.

Portanto, desde $\log o$, é certo que a solução não se encontra no curto prazo e, tão pouco, reside no campo da mera legalidade, do decreto, da Emenda forjada em gabinetes. 
$\mathrm{Na}$ verdade, o que se aventa como proposta de possível início de solução, ainda que não definitiva e sujeita à natural evolução das concepções, é justamente o conceito de democracia fiscal objeto deste trabalho.

Esse modelo seria atingido pelo balanceamento dos juízos da equidade com a eficiência econômica, em suma, pelo equilíbrio entre os três fundamentos basilares objeto deste estudo, o que, evidentemente, não pode ser alcançado em tempo reduzido.

Dessa feita, passa-se a analisar o $3^{\circ}$ e último fundamento da democracia fiscal, tão essencial quanto os anteriores, que se consubstancia na imperiosidade do sistema de tributação causar a menor inibição possível da atividade econômica legal.

\subsection{Conclusão do capítulo}

O segundo fundamento da democracia fiscal é a igualdade de sacrifício perante o fisco, que deve ser buscada por meio da aplicação das cláusulas da capacidade contributiva, progressividade, solidariedade e pessoalidade, com destaque para as exações a cargo das pessoas físicas que gravam a renda, as propriedades e as transmissões causa mortis e inter vivos, ou seja, os tributos "diretos".

Os tributos "indiretos", isso é, aqueles que incidem ao longo de uma cadeia produtiva, bem como todos a cargo das pessoas jurídicas (inclusive as imposições sobre a renda, as propriedades e as transmissões), por permitirem, em grande medida, o repasse do respectivo ônus financeiro a terceiros, principalmente ao consumidor final, impingem nítido viés regressivo ao sistema de tributação.

Em termos de eficiência de arrecadação, os tributos "indiretos" levam vantagem sobre os "diretos". Todavia, estes últimos superam aqueles em termos de equidade ou justiça fiscal, pois permitem seja respeitada, ainda que não de maneira perfeita, a igualdade de sacrifícios.

Como regra, nos países desenvolvidos em termos sociais e econômicos, a maior parcela das receitas tributárias é oriunda dos tributos "diretos", enquanto que, naqueles em desenvolvimento, predominam recursos fiscais originados nos "indiretos". 
A complexidade da dinâmica econômica atual, onde riquezas circulam globalmente sem grande dificuldade e em prazos reduzidos, impede que, mesmo nos países desenvolvidos, o sistema de tributação seja baseado quase que integralmente nos tributos "diretos", notando-se, nas últimas décadas, o aumento da participação dos "indiretos" nesses locais.

O maior desafio para os diversos sistemas de tributação possíveis é implementar um equilíbrio aceitável entre a equidade e a eficiência na tributação.

No Brasil, mais de dois terços das receitas tributárias são provenientes dos tributos "indiretos" e das pessoas jurídicas, o que impinge nítido caráter regressivo ao sistema exacional como um todo. Mesmo os impostos sobre a renda e as propriedades, teoricamente os mais aptos a proporcionarem a isonomia fiscal, são edificados segundo sistemáticas que pouco permitem o aproveitamento dessa inclinação.

Modificar esse quadro não se resume a decisões simplificadas, como, por exemplo, majorar açodadamente os tributos "diretos" a cargo dos mais favorecidos em termos econômicos, uma vez que tal medida poderia se revelar como tributação exagerada, em contrariedade, portanto, ao primeiro fundamento da democracia fiscal, bem como, em termos econômicos, poderia afugentar tais riquezas do país, fazendo minguar ainda mais a arrecadação. 


\section{TERCEIRO FUNDAMENTO DA DEMOCRACIA FISCAL: MENOR INIBIÇÃO POSSÍVEL DA ATIVIDADE ECONÔMICA LEGAL}

\subsection{Crescimento econômico e das receitas tributárias}

Se, conforme usualmente ocorre há séculos, os tributos incidem sobre situações fáticas que apresentam um componente econômico (v.g. auferir renda, ser proprietário de bem imóvel, importar ou promover a circulação de mercadorias, realizar operação financeira, prestar serviços, transferir bens por ato inter vivos ou causa mortis, etc.), por uma questão de lógica, quanto mais atos dessa natureza forem praticados numa determinada sociedade, maior será a arrecadação fiscal.

Logo, quanto maior for uma Economia, mais abastecido estará o Tesouro do Estado que, então, poderá melhor desempenhar suas competências constitucionais. Com efeito, NABAIS (1998, p. 234) enfatiza que:

[...] só o florescimento da economia, no seu todo e nas suas componentes, preenche o pressuposto para o estado de obter as receitas fiscais necessárias ao financiamento de suas tarefas. Daí que a "economização" da tributação esteja, ao fim e ao cabo, ao serviço da própria obtenção de receitas, e a função económica da tributação prima facie extrafiscal tenha assim carácter fiscal.

Nessa linha, o terceiro fundamento da democracia fiscal, na verdade, é a ferramenta que permite o alcance e o equilíbrio entre os dois fundamentos já visitados. Em verdade, se essa ferramenta não funcionar corretamente, de tão essencial que ela se manifesta, é provável que a democracia fiscal nunca chegue a ser ultimada.

Assim é que, dependendo da sistemática adotada, o conjunto das normas tributárias poderá ser um aliado ou, em sentido oposto, um inimigo do florescimento econômico. A segunda hipótese, sem dúvida, representa, no mínimo, um elevado custo social, motivo pelo qual deve ser sempre evitada.

Nesse ponto, é oportuno frisar, na indicação de SOUZA (2008, p. 13), que: "O crescimento da renda per capita é fundamental para melhorar os índices 
sociais" ${ }^{132}$, o que, se não comprova, ao menos indica ser extremamente importante o florescimento econômico em qualquer sociedade que pretenda majorar o nível de bemestar geral de seus componentes.

Em complemento, há indícios de que as economias mais abertas ao comércio internacional cresceram com maior rapidez nas últimas décadas do que aquelas que praticaram o protecionismo, o que mostra a importância da concorrência como fator de estímulo aos agentes locais. Na ênfase de SACHS, 2005, p. 402: "As economias abertas superaram decisivamente as fechadas".

Mesmo não sendo objeto deste trabalho a investigação das causas que levam ao crescimento econômico, considerando as exposições já formuladas no texto, numa acepção inicial, é possível intuir que um dos principais fatores desse fenômeno é uma ambiência institucional dotada de eficácia e previsibilidade que permita ao mercado funcionar numa espiral crescente, sendo as intervenções pontuais e com o mote de neutralizar as falhas já abordadas no texto.

E, se o crescimento econômico contribuir para criar um círculo virtuoso que permita à maioria das pessoas majorarem seu patrimônio e renda ao cabo de certo tempo e, por conseguinte, isso refletir no aumento da respectiva capacidade contributiva, além de poderem melhor satisfazer suas necessidades individuais, ficando sob menor dependência do amparo estatal, será possível, cada vez mais, edificar o sistema tributário primordialmente em face de exações que ostentem o já citado caráter pessoal e sejam graduadas conforme a capacidade contributiva do obrigado (objeto do $2^{\circ}$ fundamento retro).

Com efeito, o crescimento econômico é capaz de reduzir a pobreza ao longo de certo prazo e isso ocorre de modo relativamente apartado de políticas públicas distributivas.

Nessa esteira, segundo aponta estudo realizado por BARROS e MENDONÇA (1997, p. 06), considerando a situação brasileira de 1993, um crescimento da ordem de $3 \%$ ao ano durante uma década seria capaz de reduzir em oito pontos

${ }^{132}$ Mais adiante, o autor enfatiza que: "Maiores índices de educação e de longevidade dependem do crescimento econômico" (idem p. 18). 
percentuais a pobreza, ou seja, de $35 \%$ para $27 \%$. Um crescimento econômico mais modesto, de apenas $2 \%$ ao ano, reduziria a pobreza em cinco pontos percentuais ao final de uma década e, por fim, um crescimento contínuo de 5\% ao ano, sempre considerando o período decenal, teria o condão de minorar a pobreza em treze pontos percentuais.

Ainda que, em tese, o crescimento econômico gere proporcionalmente maior arrecadação fisscal, como há um limite na capacidade da sociedade contribuir em prol do Estado e isso se liga diretamente à sua potência para gerar riqueza com a produção de mais bens e serviços em geral, é intuitivo perceber que o aumento desmedido dos tributos gera um efeito reverso, ou seja, acaba por diminuir a arrecadação, basicamente por dois fatores:

a) primeiro, o aumento dos custos pelo pagamento das imposições sobre determinada situação tributável pode desestimular alguém a nela se inserir;

b) segundo, o exagero tributário pode implicar na ampliação da economia informal ou subterrânea, com notória perda de arrecadação pelo escape do sistema legal, o que se liga com aspectos do $1^{\circ}$ fundamento retro estudado, no que tange à liberdade e ao direito de exercício de profissão ou atividade econômica de maneira lícita e sob os olhos da lei.

Portanto, segundo aponta MONTEIRO NETO (2005, p. 56): “Estancar o crescimento contínuo da carga tributária é fundamental para a retomada de um ritmo mais forte de crescimento do produto, do emprego e da renda".

\subsection{Inibição da atividade econômica por distorção no mercado}

Mesmo que determinado país opte por uma política impositiva de baixa intensidade, a tributação sempre importará em alguma modificação no resultado das forças de oferta e demanda no mercado.

Não se pode negar que, por menor que seja uma exação, ela sempre representará um ônus financeiro a incidir sobre certa situação de fato ou de direito (v.g. um imposto que incida sobre a transferência de bens o torna mais dispendioso), o que, sob 
certos patamares, pode desestimular a prática formal de atos nos quais haveria tributação. Conforme JOST (2003, p. 45):

\begin{abstract}
A neutralidade de um imposto se dá quando ele não afeta os preços relativos e, conseqüentemente, não altera a estrutura do consumo nem dos investimentos. Nesse caso o tributo é neutro em relação a bens. Por outro lado, ele pode ser neutro em relação à renda se ele não afetar o estímulo de gerá-la. Também pode ser neutro em relação à estrutura capital/trabalho se não afetar o preço relativo dos fatores de produção. Enfim, o imposto sempre é neutro em relação a algo e dificilmente poderá ser neutro em relação a tudo.
\end{abstract}

Em suma, é muito difícil que um sistema de tributação seja absolutamente neutro em termos econômicos: sempre existirá algum nível de distorção.

Teoricamente, até poder-se-ia admitir a instituição de tributos capazes de não gerar qualquer distorção. Bastaria que sua incidência se operasse de tal modo que o contribuinte nada pudesse fazer para deixar de se enquadrar na hipótese de incidência legalmente prevista. A doutrina econômica os denomina de tributos lump sum (SIQUEIRA et al., 2005, p. 175). Um imposto per capita que desconsidera totalmente a condição econômica do obrigado para contribuir ou, ainda, uma exação que incida sobre a cor dos olhos do contribuinte seriam bons exemplos.

Entretanto, não é preciso muito pensar para concluir pela impossibilidade fática de um sistema tributário edificado em tais moldes dada a inafastável iniquidade que o marcaria. Como admitir que a cor do olho ou mesmo outra característica física (v.g. sexo, cor da pele, estatura) seja apta a orientar a oneração fiscal? Admitir tal absurdo seria neutralizar toda a tradição formada em torno da igualdade tributária, conforme estudado no capítulo anterior, ou seja, encontra-se fora de cogitação.

Portanto, concorda-se com SIQUEIRA et al. (idem, p. 175) quando afirmam que: "há um conflito básico entre equidade e eficiência na tributação, no sentido de que objetivos distributivos só podem ser alcançados a um certo custo em termos de eficiência econômica". Então, de um correto amalgamento entre a equidade e a eficiência extrai-se o "tributo ótimo". Segundo MICHELS (2005, p. 233):

tributo ótimo é aquele que permite ao governo alcançar objetivos redistributivos e arrecadar o suficiente para financiar seus gastos ao 
menor custo possível em termos de eficiência. Em outras palavras, um correto balanceamento entre equidade e eficiência deve ser a meta do legislador.

Certamente, a distorção econômica causada pelos tributos é muito variável e é fortemente influenciada pela sistemática de cada um deles. Nessa linha, um imposto causa mortis é de pouca distorção, uma vez que as partes envolvidas pouco podem fazer para modificar a incidência do gravame. Ocorrendo o evento morte, dá-se a sucessão com o recebimento das heranças e dos legados, estando o recolhimento do respectivo imposto vinculado à homologação da partilha pelo juiz (\$5 do art. 1036 do Código de Processo Civil), motivo pelo qual se pode afirmar ser o imposto dotado de neutralidade.

Efeito semelhante acompanha as exações que incidem sobre as transmissões inter vivos e aquelas que gravam a propriedade em geral, sendo certo que, pelas regras comuns de experiência, as pessoas não costumam deixar de transacionar com bens móveis ou imóveis apenas para não se sujeitarem à tributação.

É claro que, dependendo do caso concreto, isso pode se dar, mas a título de exceção. Evidentemente, essa relativa neutralidade vige apenas se os respectivos impostos forem graduados sob o parâmetro da razoabilidade, destacando-se que nesses casos as alíquotas não costumam exceder a $4 \%$ ou $5 \%$ sobre o valor da operação.

Contudo, caso as alíquotas superassem, por exemplo, $10 \%$ ou $20 \%$, é muito provável que a distorção se mostrasse com notável vigor, fazendo minguar o mercado desses bens, pois pouquíssimas pessoas estariam dispostas a arcar com o tamanho do gravame.

Não se pode esquecer que, muitas vezes, um bem imóvel representa a maior parte do patrimônio de alguém. Logo, a partir de certo patamar, o valor da tributação poderia tornar proibitivo para o sujeito passivo, tanto a transmissão, quanto a mantença da propriedade.

No mesmo diapasão, também ostenta neutralidade relativa o Imposto de Renda das pessoas físicas. Aqui, segundo explica GIAMBIAGI e ALÉM (2002, p. 40): 
a redução da renda disponível dos indivíduos diminui de forma homogênea as suas possibilidades de consumo, não causando nenhum viés em relação ao consumo - e, conseqüentemente, à produção - de nenhum bem específico. Neste caso, o imposto é até certo ponto neutro, à medida que não afeta a eficiência nas decisões de alocação de recursos para a produção e o consumo de mercadorias e serviços.

As exações com maior potencial para influírem sobre as forças da demanda e oferta são aquelas que gravam o consumo de bens ou serviços, justamente aquelas que costumam predominar nos sistemas de tributação dos países pobres ou em desenvolvimento, como, por exemplo, o Brasil. De fato, na lição de GIAMBIAGI e ALÉM (idem, p. 40): "no caso dos impostos seletivos sobre o consumo, não há neutralidade do tributo".

Assim ocorre porque nesse tipo de exação usualmente o ônus financeiro é transferido ao destinatário final com reflexo direto sobre o preço cobrado. Então, quanto mais alta for a incidência, em princípio, menor será o respectivo mercado para o bem ou serviço tributariamente onerado, uma vez que, como é sabido, salvo nas raras hipóteses dos produtos de alta elasticidade, a demanda tende a ser inversamente proporcional ao preço. Em verdade, na exposição de GOUVEIA (2008, p. 159):

A carga tributária tende a alterar o comportamento de ambos os lados: o comprador porque paga mais e por isso tenderá a consumir menos o bem ou o serviço ofertado, seja diminuindo o consumo, seja optando por algo alternativo; o fornecedor tende a receber menos, em valores líquidos, o que também o leva a buscar destinações melhores para os recursos (bens ou serviços) que são oferecidos.

O autor em foco (idem, p. 162-163) representa, por meio de três gráficos ilustrativos, a situação tratada, conforme abaixo:

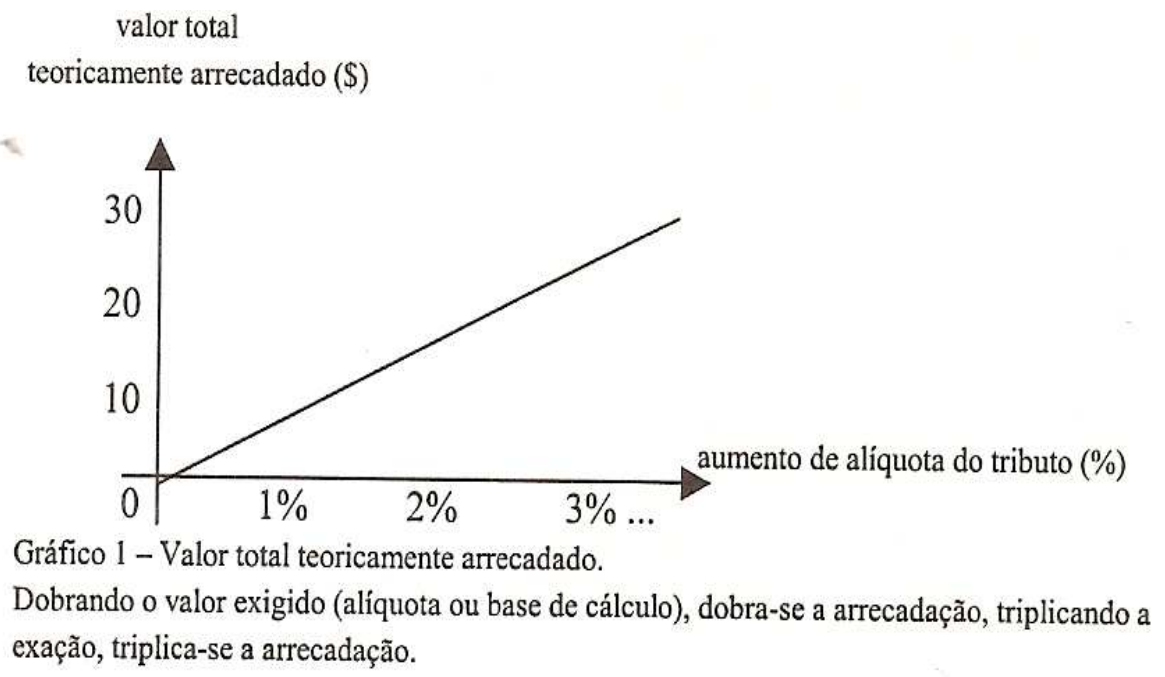


valor total

dos negócios formais não realizados (\$)

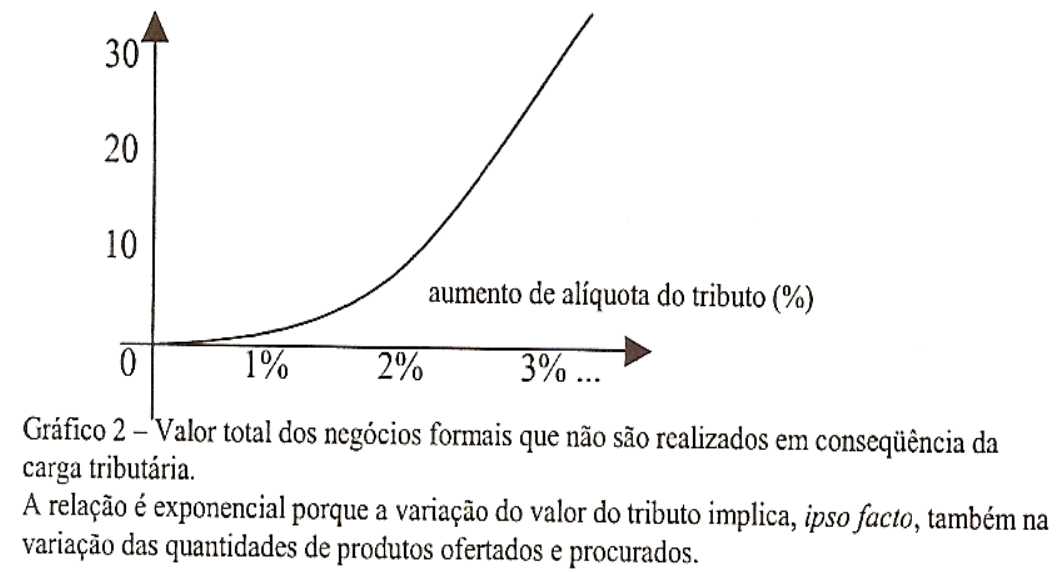

valor total

efetivamente arrecadado $(\$)$

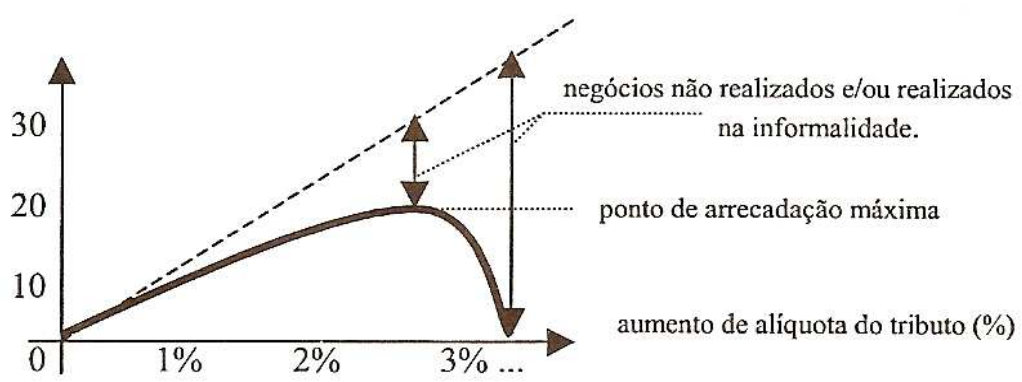

Gráfico 3 - Valor total efetivamente arrecadado.

O incremento da aliquota atinge a arrecadação máxima, depois desse ponto, a arrecadação cai drasticamente, até a situação em que a carga tributária inviabiliza completamente a atividade formal.

Essa circunstância, então, coloca-se como um motivo mais do que relevante para que o sistema de tributação se baseie primordialmente nos critérios do $2^{\circ}$ fundamento da democracia fiscal antes estudado, com destaque para as exações que permitam em sua sistemática o respeito à capacidade e, ainda, à pessoalidade.

Contudo, sabe-se que isso não se consegue por meio de um passe de mágica, mas, em verdade, depende de um longo processo de desenvolvimento, sendo condições sine qua nom o crescimento da economia, com a consequente majoração da renda per capita, e a estabilidade jurídica e institucional.

Em complemento, se os excedentes ${ }^{133}$, tanto do consumidor, quanto do produtor, forem equiparados a uma parcela de seu bem-estar, então, a incidência de

${ }^{133}$ Excedente é a diferença entre aquilo que alguém está disposto a pagar ou receber por um bem e a quantia que efetivamente entrega ou percebe por ele (JOST, 2002, p. 50). Por exemplo, um sujeito está disposto a pagar até $\mathrm{R} \$ 4,00$ por uma xícara de café expresso e acaba adquirindo essa comodidade por $\mathrm{R} \$ 2,50$, seu 
qualquer tributo num determinado mercado gerará o que os economistas denominam de "peso morto", conforme se explica a seguir com base na exposição e nos gráficos formulados por MANKIW (2007, p. 160 e ss.).

Os Efeitos de um Imposto

Um imposto sobre um bem introduz uma cunha entre o preço que os compradores pagam e 0 preço que os vendedores recebem. A quantidade vendida do bem diminui.

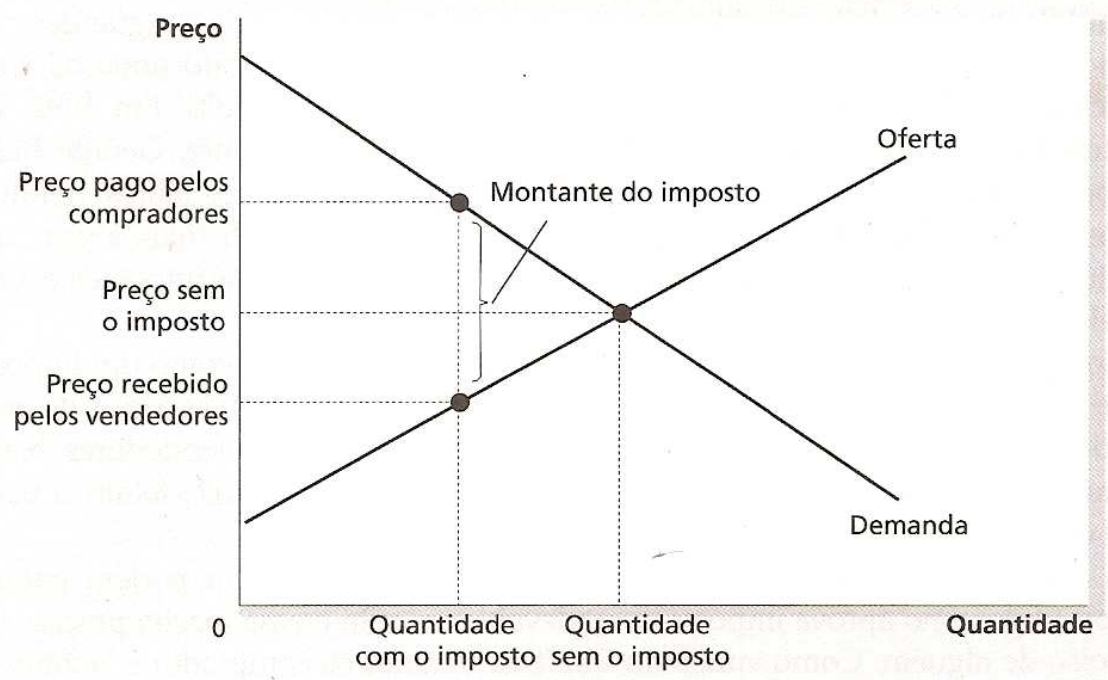

O gráfico acima representa, de maneira simplificada, o comportamento da demanda e da oferta quando um imposto é instituído sobre um bem ou serviço. Nota-se, em primeiro lugar, que a quantidade vendida cai abaixo do nível que ocorreria na ausência de tributação. Trata-se de um fenômeno normal frente ao preço majorado por causa da incidência da nova exação. De modo a não inserir elementos que trariam complexidade desnecessária, não se considera aqui questões afetas à eventual elasticidade.

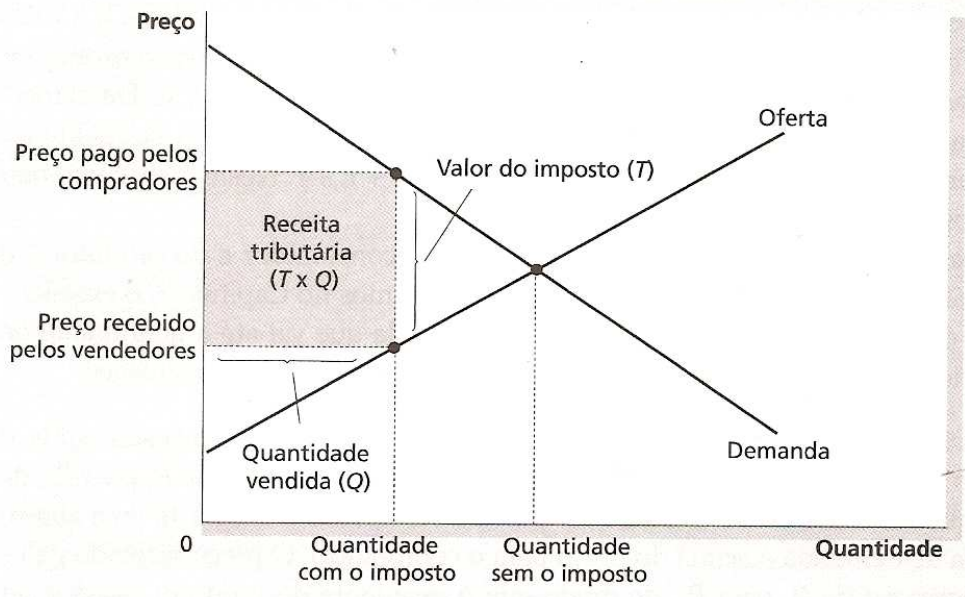

Receita Tributária

A receita tributária que o governo coleta é igual a $T \times Q$, o valor do imposto, T, multiplicado pela quantidade vendida, Q. Assim, a receita tributária é igual à área do retângulo localizado entre as curvas de oferta $e$ demanda.

excedente foi de R\$1,50. Suponha-se, nesse mesmo caso, que o comerciante não venderia o café por menos de $\mathrm{R} \$ 2,00$. Como o negócio foi fechado a $\mathrm{R} \$ 2,50$, seu excedente foi de $\mathrm{R} \$ 0,50$. Na hipótese, a soma do excedente do consumidor $(R \$ 1,50)$ e do fornecedor $(R \$ 0,50)$ corresponde a $R \$ 2,00$. 
$\mathrm{Na}$ figura acima é possível verificar a quantia arrecada, sendo que $\mathrm{T}$ (a altura do retângulo acinzentado) corresponde ao valor do imposto e Q (a largura do retângulo) à quantidade do bem ou serviço negociado. Assim, a quantia arrecadada corresponde à área $\mathrm{T} x \mathrm{Q}$.

Como um imposto Afeta o Bem-Estar

Um imposto sobre um bem reduz o excedente do consumidor (a redução é dada pelas área $B+C$ ) e o excedente do produtor (a redução é dada pelas área $D+E$ ). Como a queda dos excedentes do consumidor e do produtor excede a receita tributária (área $B+D$ ), dizemos que o imposto parece impor uma perda de peso morto (área $C+E)$.

\begin{tabular}{lccc} 
& Sem Imposto & Com Imposto & Variaçäo \\
\hline Excedente do Consumidor & $A+B+C$ & $A$ & $-(B+C)$ \\
Excedente do Produtor & $D+E+F$ & $F$ & $-(D+E)$ \\
Receita Tributária & Nenhuma & $B+D$ & $+(B+D)$ \\
Excedente Total & $A+B+C+D+E+F$ & $A+B+D+F$ & $-(C+E)$ \\
& &
\end{tabular}

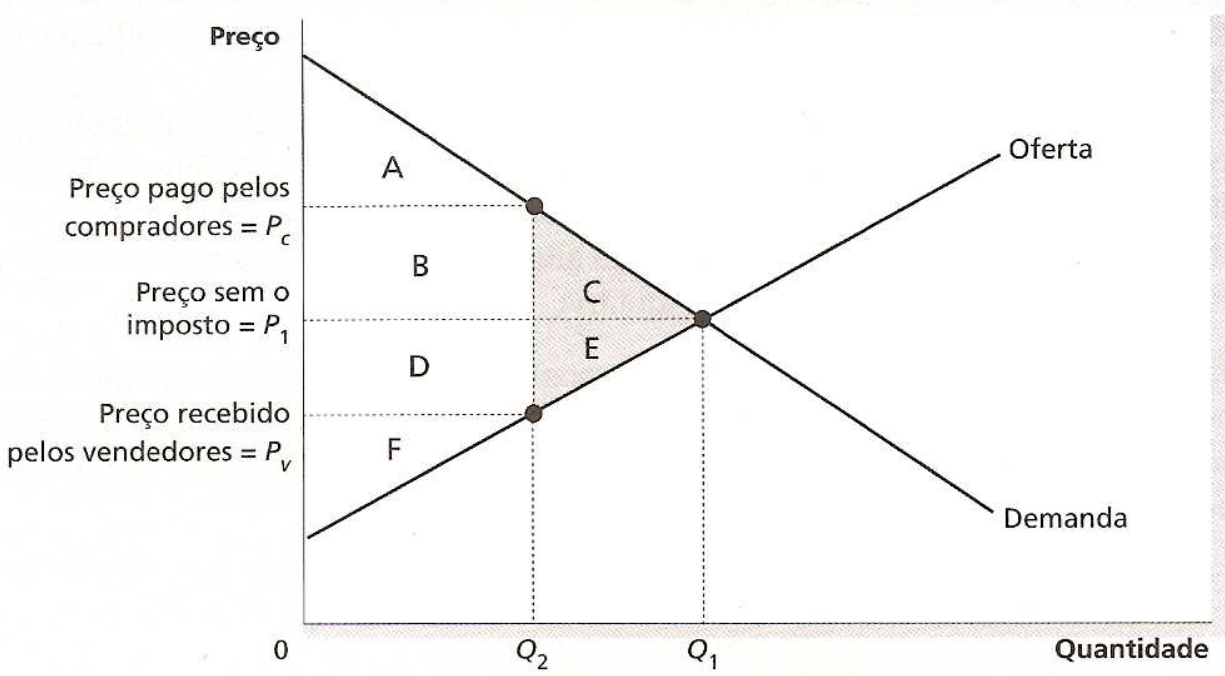

O gráfico acima representa o quanto um imposto afeta os excedentes do produtor e consumidor, diminuindo-lhes, por conseguinte, uma parcela de bem-estar. $\mathrm{Na}$ ausência de tributação, o preço e a quantidade encontram-se na intersecção das curvas de demanda e oferta.

No caso, preço é $\mathrm{P}_{1}$ e a quantidade vendida é Q1. Como a curva de demanda indica a disposição para pagar dos consumidores, o excedente do consumidor equivale à área entre a curva de demanda e o preço A + B + C. No mesmo sentido, a curva de oferta reflete os custos dos vendedores, sendo o excedente o produtor a área $\mathrm{D}+\mathrm{E}+\mathrm{F}$. 
$\mathrm{O}$ excedente total é igual à soma de todas as áreas $(\mathrm{A}+\mathrm{B}+\mathrm{C}+\mathrm{D}+\mathrm{E}+\mathrm{F})$. Como ainda não há imposto, a receita tributária é zero.

Com a instituição do imposto, o preço sobe de $\mathrm{P}_{1}$ para $\mathrm{Pc}$, de modo que o excedente do consumidor se reduz na área A (localizada abaixo da curva de demanda e acima do preço para o comprador). Deixou de compor o excedente do consumidor a área $\mathrm{B}$ + C. O preço recebido pelos vendedores cai de $\mathrm{P}_{1}$ para $\mathrm{Pv}$ e o excedente do produtor resume-se à área F (situada acima da curva de oferta e abaixo do preço para o vendedor). Deixou de integrar o excedente do produtor a área $\mathrm{D}+\mathrm{E}$. A quantidade vendida cai de $\mathrm{Q}_{1}$ para Q2 e o governo recolhe uma receita tributária equivalente à área $\mathrm{B}+\mathrm{D}$.

O excedente total, então, passa a ser a soma das áreas A (do consumidor) + $\mathrm{F}$ (do produtor) + B + D (do fisco). As áreas $\mathrm{C}+\mathrm{E}$ correspondem ao "peso morto", na medida em que não geram benefícios a qualquer das partes envolvidas. Trata-se da queda de bem-estar vivenciada pelo mercado no caso específico.

Um exemplo esclarecedor da ideia em foco é formulado por MANKIW (2007, p. 163-164). Segundo o autor:

Imagine que Joe limpe a casa de Jane a cada semana por \$100. O custo de oportunidade do tempo de Joe é $\$ 80$ e o valor de uma casa limpa para Jane é $\$ 120$. Portanto, cada um recebe um benefício de $\$ 20$ pela transação. O excedente total de $\$ 40$ mede os ganhos de comércio dessa determinada transação.

Suponhamos agora que o governo imponha um imposto de $\$ 50$ para os prestadores de serviço de limpeza. Agora, não há preço que Jane possa pagar a Joe que os deixe em melhor situação após o pagamento do imposto. O máximo que ela está disposta a pagar é $\$ 120$, mas isso deixaria Joe com apenas $\$ 70$ após pagar o imposto, menos do que os $\$$ 80 de seu custo de oportunidade. Por outro lado, para que Joe recebesse seu custo de oportunidade de $\$ 80$, Jane teria que pagar $\$ 130$, o que está acima do valor de $\$ 120$ que ela atribui a uma casa limpa. Com isso Jane e Joe cancelam seu negócio. Joe fica sem a renda e Jane tem que se acostumar a viver numa casa suja.

O imposto piorou a situação dos dois num total de $\$ 40$, uma vez que eles perderam essa quantia de excedente. Ao mesmo tempo o governo não consegue coletar nenhuma receita deles porque o negócio foi cancelado. Os \$ 40 são um peso morto: são uma perda para os compradores e vendedores em um mercado que não é compensado por um aumento da receita do governo. 
De um modo geral, o tamanho do "peso morto" acompanha a intensidade do imposto, nos moldes dos gráficos abaixo:

(a) Imposto Pequeno

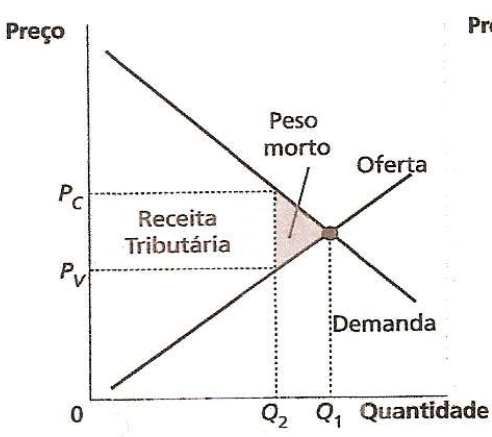

(b) Imposto Médio

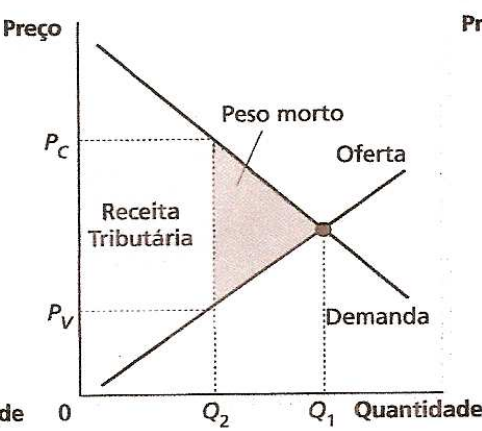

(d) Imposto Grande

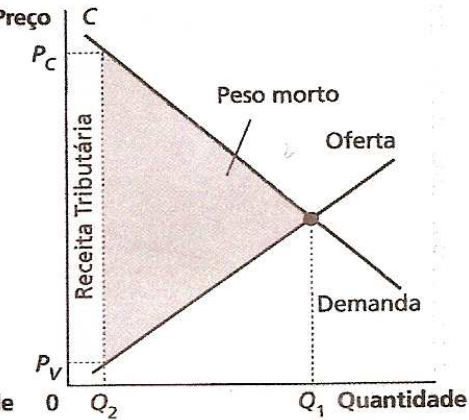

É possível verificar, segundo apontado acima, que um imposto de baixa intensidade gerará um "peso morto" pequeno e uma arrecadação diminuta. Um imposto de incidência mediana acarretará um "peso morto" maior, mas, em compensação, proporcionará uma arrecadação mais expressiva. Contudo, um imposto muito severo reduzirá em tal patamar o tamanho do mercado que a arrecadação gerada será pouco significativa.

Não se pode deixar de mencionar que o tamanho do "peso morto" está relacionado à elasticidade do bem ou serviço tributado de maneira inversamente proporcional. Logo, quanto maior for a elasticidade, menor será o "peso morto" e viceversa (MANKIW, 2007, p. 165).

Por fim, uma questão que os economistas não costumam considerar nesse tema é a circunstância do "peso morto", na realidade, não ser totalmente nocivo. Basta recordar, conforme acima já aventado, que o sistema de mercado depende de uma ordem jurídica instituída, sob pena das diversas transações terem um custo por demais elevado, sendo certo que essa ordem é garantida, em suma, pelo Estado, cujo sustento, em grande medida, depende dos tributos.

Logo, se bem pensado for, o "peso morto" resultante do sistema de tributação, se amoldado dentro de certa razoabilidade, nada mais significa do que condição ou "preço" de eficiência dos mercados. 


\subsection{Inibição da atividade econômica legal e o exagero fiscal no âmbito coletivo}

No século XX, o mundo assistiu a um brutal aumento da carga fiscal, que se deu na maioria dos países, principalmente, a partir da década de 1920 com a instituição do welfare state. Noticia FUKUYAMA (2005, p. 18) que:

Enquanto os setores estatais consumiam, no início do século, pouco mais de $10 \%$ do produto interno bruto (PIB) na maior parte dos países europeus e nos Estados Unidos, nos anos 80 eles consumiam quase 50\% (70\% no caso da Suécia social-democrata).

Não se pode esquecer que esse fenômeno ocorreu há menos de 100 anos. Questiona-se se haveria muito maior espaço para que a carga fiscal permaneça crescendo. Poder-se-ia argumentar, de modo açodado e irrefletido, que bastaria majorar as alíquotas e as bases de cálculos dos tributos em geral mediante mudanças na Constituição e leis.

Assim, como consequência, a arrecadação também aumentaria na mesma proporção, provendo com mais recursos os cofres públicos. E, com mais dinheiro em caixa, mais medidas de concretização do bem comum (segurança pública, escolas, saúde, moradia) seriam automáticas e indolores.

Com efeito, seria ótimo se o Estado pudesse aumentar os tributos de acordo com as necessidades sociais. Entretanto, a experiência de longa data confirma que a partir de determinado patamar de tributação, ou seja, acima de uma parcela tal de patrimônio individual englobado pelo Estado, a sociedade e os agentes econômicos como um todo passam a engendrar mecanismos ilícitos de evasão fiscal, diminuindo o volume de arrecadação possível.

Em verdade, o aumento pontual de um imposto pode majorar a sua arrecadação. Contudo, se o fenômeno for investigado coletivamente, considerando os diversos aumentos de outras exações ao longo de certo tempo, o que se pode constatar é uma diminuição no valor total que seria possível ao Estado perceber. Conforme NABAIS (1998, p. 198):

Pois um estado que, através de regula(menta)ção exacerbada ou de impostos exagerados, estorve, paralise ou destrua a produtividade da economia, destrói-se como estado fiscal, pois que, ao minar a sua base, 
mina, ao fim e ao cabo, automaticamente a sua própria capacidade financeira.

Em casos assim, TIPKE e YAMASHITA (2002, p. 48) constatam que: “a receita tributária cai apesar das alíquotas altas, restando menos recursos para fins sociais".

Chega a ser intuitivo, pois, que a tributação deve ser ultimada de modo a não destituir o contribuinte de sua principal fonte de renda. É também de fácil conclusão o fato de que uma carga tributária muito elevada, além do que seria razoável e suportável, certamente implicará em sérias distorções na economia, conforme acima já mencionado. Essa constatação não é recente e já fazia parte do pragmatismo dos Romanos há pelo menos dois milênios. Na simples, mas clara colocação de SIDOU (1978, p. 17):

O Estado, pela mão dos governos sábios e prudentes, não estanca nunca a fonte donde flui o tributo; estimula-a. Não porfia por descontentar, ou desencantar, o contribuinte nem provocar a antipatia popular tornando insuportável a vida; contemporiza. Na metáfora do simplório César, não mata a ovelha, tosquia-a, o que em linguagem moderna equivale a não matar a galinha dos ovos de ouro.

O fenômeno do exagero fiscal pode ser representado graficamente pela denominada "Curva de Laffer", prosaicamente desenhada em 1974 pelo economista Arthur Laffer num guardanapo durante um almoço num restaurante de Washington, segundo a forma abaixo:

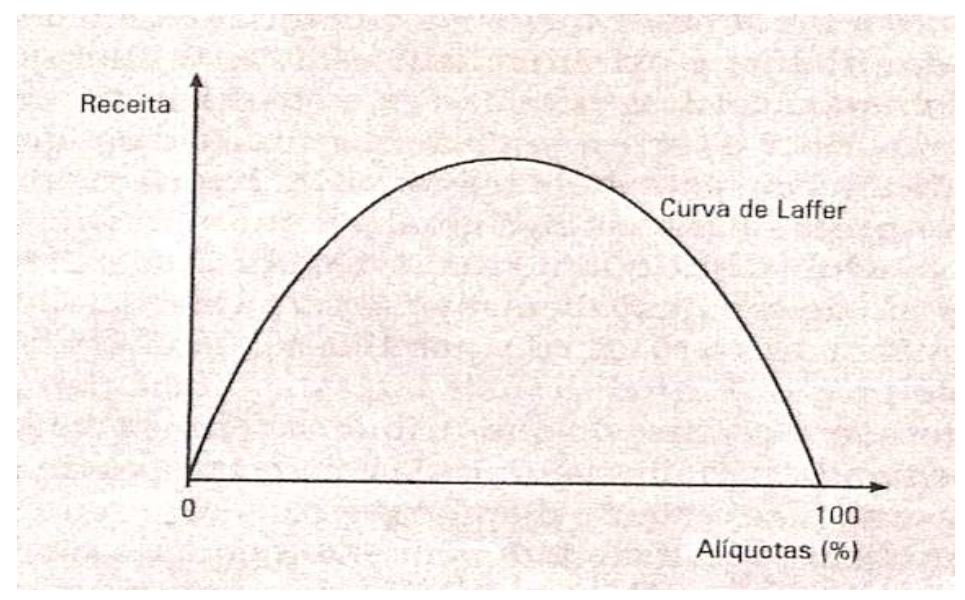

Analisando o gráfico acima, nota-se que há um ponto máximo ou ótimo de arrecadação. Logo, se a tributação for realizada de maneira abaixo do referido ponto, o resultado será uma arrecadação menor do que seria possível obter, pois, nesse caso, a 
sociedade poderia contribuir com mais recursos financeiros sem apelar, por exemplo, para os esquemas ilícitos evasivos.

Entretanto, se for ultrapassado o ponto, o resultado será o mesmo, isso é, a arrecadação possível será minorada em face do exagero da carga tributária, circunstância que, por exemplo, desestimula a continuidade dos negócios sob os olhos da lei. É possível que muitos contribuintes, então, optem pela sonegação fiscal, pois preferirão correr os riscos de uma autuação, arcando com as multas e demais penalidades daí decorrentes, do que entregar parcela relevante de seu patrimônio ao Tesouro.

Não obstante tratar-se de uma proposição de índole intuitiva, não se pode negar seja desprovida de, no mínimo, plausibilidade.

É claro que o fator sanção também deitará efeitos nesse resultado. Por exemplo, no caso de um sistema fiscal que seja desacompanhado de punição pelo descumprimento das respectivas normas, é de se esperar que, mesmo sob um ambiente tributário amigável, de baixa intensidade e com alíquotas mínimas, as pessoas tenderão a não observar suas prescrições em vista da usual aversão humana ao gravame fiscal.

A recíproca é verdadeira, isso é, mesmo que a tributação seja severa, frente a um modelo que garanta a eficácia das sanções legalmente previstas (se não em todos, ao menos na maioria dos casos), é esperado que os contribuintes, pela elevada probabilidade de serem apanhados em seus "pecadilhos", adiram e respeitem os preceitos fiscais em maior proporção.

Logo, a carga tributária deve ser razoável a ponto de evitar a extinção do contribuinte ou a tomada de medidas tendentes à evasão fiscal e, ainda, conjugada com um sistema de fiscalização minimante eficiente em termos de punição dos faltosos.

Evidentemente, o ponto ótimo de arrecadação é teórico e de muito difícil fixação, ainda mais porque, na prática, inúmeras variáveis entram em cena, dado o dinamismo econômico que a maioria das sociedades apresenta, com milhões de agentes interagindo diuturnamente. Além do mais, o citado ponto, mesmo que identificado fosse com precisão cirúrgica, não seria dotado de estabilidade, justamente porque a conjuntura 
econômica é por demais fluída, o que implicaria, por conseguinte, em infindáveis revisões periódicas.

Se, na prática, atingir o ponto ótimo de arrecadação fiscal é tarefa hercúlea, é necessário observar indícios ou pistas que possam indicar em que ponto da "Curva de Laffer" se encontra determinado sistema de tributação de modo que, havendo necessidade, se façam os correspondentes ajustes.

Assim, a seguir são propostos alguns critérios que, tomados de forma conjunta e nunca isoladamente, acredita-se sejam aptos a indicar, ainda que ausente a certeza plena, se o ponto máximo foi ultrapassado ou não. São eles: 1) relação da carga fiscal em face do PIB; 2) número de cobranças fiscais e sua tendência de aumento ou decréscimo; 3) tamanho da economia informal frente ao PIB; 4) custos de conformidade; e, 5) manifestações sociais de repulsa à tributação. É o que se passa a considerar.

1) relação da carga fiscal em face ao PIB: essa relação mostra a parcela entregue ao Estado daquilo que a sociedade produziu em certo interregno, recordando-se que o PIB é constituído por todos os bens e serviços produzidos por um sistema econômico ao longo de um dado período, normalmente um ano.

Esse número isoladamente considerado pouco significa, mas serve como um primeiro parâmetro, como que uma placa de entrada ou uma capa de um livro que, de forma ideográfica, permite uma ideia prefacial acerca de algo, mas que pode não corresponder exatamente ao que se pensou de início.

Já foi mencionado nesse texto que, em termos gerais, um vassalo laborava em torno de dois a três dias por semana nas terras do senhor (HUBERMAN, s. d., p. 04), o que, considerado o período de sete dias, chaga-se a algo entre $28,57 \%$ a $42,85 \%$ da força de trabalho disponível.

Numa acepção atual, em regra, os países desenvolvidos em termos econômicos e sociais possuem uma carga tributária superior a $30 \%$ do respectivo PIB. Assim, por exemplo, tem-se: Austrália $=30,68 \%$; Bélgica $=46,85 \%$; Espanha $=34,23 \%$; França $=45,04 \%$; Itália $=42,82 \%$; Suécia $=51,35 \%$; e, Alemanha $=39,76 \%$, ressaltando- 
se como exceções: os Estados Unidos $=25,77 \%$ e o Japão $=26,28 \%$, ambos com percentual inferior à média.

Já aqueles em situação de desenvolvimento, de um modo geral, apresentam uma relação PIB e carga tributária mais leve, como a Argentina = 25,93\%; África do Sul $=28,48 \%$; Chile $=18,72 \%$; e, Cingapura $=12,49 \%{ }^{134}$.

Considerando o ano de 2001, de modo semelhante, PIANCASTELLI e NASCIMENTO (2005, p. 247) apontam os seguintes dados: Noruega $=45 \%$; Espanha $=$ 35,2\%; Canadá $=35,2 \%$; Nova Zelândia $=34,8 \%$; Estados Unidos $=29,6 \%$; Irlanda $=$ $29,2 \% ;$ Polônia $=34,1 \%$; Turquia $=35,8 \% ;$ Brasil $=34 \% ;$ Uruguai $=30,3 \% ;$ México $=$ 18,3\%; Argentina $=17,4 \% ;$ Chile $=17,3 \% ;$ Venezuela $=15,9 \% ;$ Paraguai $=14,1 \% ;$ e, Equador $=13 \%$.

O Brasil, que sem sombra de dúvida pertence ao grupo das nações em desenvolvimento, é exceção em seu grupo, eis que há vários anos sua carga fiscal gira em torno de 35\% do PIB, com tendência de aumento (MONTEIRO NETO, 2003, p. 56-57). Todavia, não obstante chamar atenção, essa peculiaridade não indica, por si só, ser a carga fiscal brasileira exagerada.

É que, segundo já ventilado antes, na constatação do exagero fiscal, deve ser considerado o nível do retorno oferecido pelo Estado na forma de serviços, utilidades e comodidades. Como regra, quanto mais qualificados forem os préstimos estatais, seja em termos gerais (v.g. segurança pública, defesa do meio ambiente, etc.), ou específicos (v.g. serviços de educação e saúde), mais autorizada estará a intensidade tributária, até certo limite, evidentemente, sendo a recíproca verdadeira.

Contudo, salvo conjunturas bem delineadas onde se possa aferir de plano a qualidade do retorno que o Estado promove em benefício dos cidadãos, na maioria das vezes, esse juízo não é simples de precisar, ainda mais se estiverem em cena vários órgãos prestadores, recordando-se, por exemplo, que, nos Estados federativos, como é o caso do Brasil, há ações nos âmbitos federal, estadual e municipal. Além disso, há de se levar em

\footnotetext{
${ }^{134}$ Fonte: O Estado de São Paulo (Caderno B, p. 03, de 02.04.2006).
} 
conta, ainda, a atuação dos componentes da administração indireta, como as autarquias e fundações públicas.

Portanto, sendo praticamente impossível uma indicação plenamente objetiva a esse respeito, é de rigor que a conclusão acerca do exagero fiscal seja embasada e conjugada em mais critérios, conforme segue.

2) tendência ou comportamento da arrecadação: outro indicativo a ser observado para a aferição do exagero fiscal é a tendência ou o comportamento da arrecadação ao longo de certo período. Aqui, um elemento de comparação é o próprio PIB, uma vez que se ele crescer, em princípio, o mesmo deve ocorrer com as receitas tributárias, dado que as imposições fiscais gravam a maior parte dos atos que compõem o PIB, ou seja, produção e circulação de riquezas, bens e serviços. De modo análogo, se o PIB retrair, as receitas devem acompanhar a queda em proporção assemelhada.

Em realidade, muito raramente, o volume das receitas refletirá com exatidão a variação do PIB, uma vez que isso somente seria concebível na hipótese de não ocorrer mudanças na carga fiscal, seja no sentido de sua majoração, ou mesmo de arrefecimento.

Com efeito, é sabido que alterações na legislação tributária são periodicamente engendradas por razões puramente fiscais (abastecimento do Tesouro) ou, noutra banda, extrafiscais (estimulação ou inibição de comportamentos dos diversos agentes), segundo as conjunturas que a realidade vai descortinando em cada época, o que implica em oscilação da carga fiscal em face do PIB. Por esse raciocínio, partindo-se do pressuposto dos indicadores serem confiáveis, tem-se, em resumo, duas possibilidades:

a) se a arrecadação crescer proporcionalmente mais que o PIB, há indícios de que a sociedade não atingiu o limite da suportabilidade fiscal. Não se pode perder de vista, entretanto, que essa proporção tende a diminuir com o tempo, mesmo que a economia permaneça em crescimento. Isso ocorrerá na medida em que o "ponto ótimo de arrecadação" for se aproximando, em congruência com a já mencionada Curva de Laffer; 
b) se o PIB crescer mais do que a arrecadação (ou, ao contrário, se ela decrescer mais que o PIB), é muito provável que o exagero fiscal tenha sido atingido. É que, presumivelmente, em circunstâncias tais, nem todos os fatos imponíveis estarão acompanhados dos recolhimentos fiscais devidos. Caso contrário, a arrecadação deveria acompanhar a oscilação do PIB.

ser assim resumida ${ }^{135}$ :

Num quadro simplificado, a situação do Brasil nos últimos 13 anos pode

\begin{tabular}{|l|l|l|l|c|}
\hline Período & $\begin{array}{l}\text { PIB } \\
\text { em bilhões de reais }\end{array}$ & $\begin{array}{l}\text { Variação } \\
\text { em \% }\end{array}$ & $\begin{array}{l}\text { Arrecadação } \\
\text { em bilhões de reais }\end{array}$ & $\begin{array}{l}\text { Variação } \\
\text { em \% }\end{array}$ \\
\hline 1996 & 843.966 & ----- & 212.580 & ----- \\
\hline 1997 & 939.147 & $+11,27$ & 239.191 & $+12,51$ \\
\hline 1998 & 979.276 & $+4,27$ & 268.117 & $+12,09$ \\
\hline 1999 & 1.065 .000 & $+8,75$ & 304.941 & $+13,73$ \\
\hline 2000 & 1.179 .482 & $+10,47$ & 361.696 & $+18,61$ \\
\hline 2001 & 1.302 .136 & $+10,39$ & 403.745 & $+11,62$ \\
\hline 2002 & 1.477 .822 & $+13,49$ & 482.486 & $+19,50$ \\
\hline 2003 & 1.699 .948 & $+15,03$ & 553.179 & $+14,65$ \\
\hline 2004 & 1.941 .498 & $+14,20$ & 650.135 & $+17,52$ \\
\hline 2005 & 2.147 .943 & $+10,63$ & 732.864 & $+12,72$ \\
\hline 2006 & 2.332 .936 & $+8,61$ & 817.938 & $+11,60$ \\
\hline 2007 & 2.558 .821 & $+9,68$ & 923.924 & $+12,95$ \\
\hline 2008 & 2.889 .719 & $+12,93$ & 1.056 .495 & $+14,34$ \\
\hline
\end{tabular}

Nota-se que, apenas no exercício de 2003, a arrecadação cresceu proporcionalmente menos que o PIB, o que, ao menos numa acepção prefacial, permite concluir que, até o final de 2008, o Brasil se encontrava no "lado direito" da Curva de Laffer.

Contudo, essa assertiva está longe de ser peremptória, ao contrário, segundo já aventado, deve ser conjugada com os demais critérios aqui declinados, notadamente porque o "ponto ótimo de arrecadação" é um patamar ideal, não necessariamente identificável com certeza.

Essa advertência fica mais reforçada se for considerado que, no exercício de 2009, devido à crise econômica mundial que teve início em 2008, o crescimento do PIB

135 Os valores referentes ao PIB e à arrecadação foram obtidos junto ao site do Instituto Brasileiro de Planejamento Tributário. Disponível em: <http://www.ibpt.com.br/img/_publicacao/13651/176.pdf>. Acesso em 25.07.2009. 
e da arrecadação no Brasil sofreu queda em face dos períodos pretéritos, circunstância que poderá implicar em modificação na relação PIB-arrecadação.

3) quantidade de cobranças fiscais coercitivas: frente à inadimplência da obrigação tributária, a autoridade fiscal competente é obrigada a constituir o respectivo crédito por meio do lançamento (art. 142 do CTN) e, segundo os meios legais estabelecidos, elaborar a competente cobrança coercitiva perante o Poder Judiciário com objetivo de excutir bens do devedor para que a dívida seja satisfeita.

No Brasil, cuidam do assunto a Lei 6.830/80 (Lei da Execução Fiscal) e, subsidiariamente, o Código de Processo Civil.

No Direito brasileiro, conforme previsto no art. 204 do CTN: “A dívida regularmente inscrita goza da presunção de certeza e liquidez e tem o efeito de prova préconstituída”. Assim, pela lição de SOUZA (1998, p. 78):

\footnotetext{
Com efeito, sem embargo de já fixar o lançamento o an e quantum debeatur, a lei faz defluir a presunção de certeza e liquidez do ato de inscrição, por quanto pressupõe esta última, exatamente, como ato administrativo autônomo do lançamento, o controle específico e suplementar da legalidade do ato de constituição do crédito, onde é precedida a verificação da certeza e liquidez da dívida, bem como o transcurso do prazo para pagamento na esfera administrativa. Assim, a regularidade de inscrição, a qual a norma em comento atribui o efeito de gerar a presunção em foco, diz não somente com aspectos formais (requisitos extrínsecos do termo de inscrição), mas também com aspectos substanciais concernentes à própria constituição do crédito.
}

Logo, ante a uma execução fiscal aforada e instruída com a competente Certidão de Dívida Ativa, é possível presumir, com considerável certeza, a existência de uma dívida fiscal não paga voluntariamente pelo obrigado.

A quantidade de execuções fiscais ajuizadas é importante na consideração do exagero fiscal no âmbito coletivo, mesmo que esse dado isoladamente não consiga demonstrar o deletério fenômeno. Nessa linha, um número muito elevado de cobranças tributárias pode indicar, no mínimo, as seguintes circunstâncias:

a) insuportabilidade da carga fiscal pelos diversos sujeitos passivos, ou proximidade dessa situação. Caso um sistema de tributação torne-se opressivo a ponto de 
impedir ou muito dificultar que os agentes econômicos permaneçam agindo sob os olhos da lei, é bem provável que uma parcela considerável de contribuintes passe a adotar mecanismos de evasão fiscal ou, numa atitude de rebeldia ou até de desespero, simplesmente deixem de cumprir suas obrigações, preferindo arcar com os ônus de uma execução forçada.

Aqui, segundo PRADO (1991, p. 75): “Ao descumprirem as obrigações legais, os informais estão convencidos de que essa atitude lhes propicia maiores benefícios, quando comparados aos custos da informalidade";

b) ineficácia do sistema de sanção, dada a resistência usual que as pessoas apresentam às suas obrigações fiscais, é fácil perceber que, se não existir uma verdadeira ameaça de aplicação de penalidade para as hipóteses de descumprimento, será grande a probabilidade dos contribuintes deixarem de adimplir aquilo que devem na expectativa de serem beneficiados pela impunidade.

No caso, ela pode dar-se pela ausência de fiscalização que leva à decadência do direito de cobrar ou, ainda, pela lentidão dos procedimentos judiciais que permite o esvaziamento do patrimônio do devedor antes que o fisco consiga se apossar de algo de valor real;

c) noutro giro, um aumento repentino no número de cobranças fiscais pode apontar para a ocorrência de um recrudescimento das medidas de físcalização, sendo o incremento das execuções, portanto, uma consequência desse fato.

No Brasil, na última década, observou-se um crescimento expressivo no número absoluto de cobranças, conforme informações obtidas no site da Procuradoria da Fazenda Nacional (www.pgfn.fazenda.gov.br), segundo explicitado abaixo.

\begin{tabular}{|l|l|l|l|l|}
\hline Ano & $\mathbf{n}^{\mathbf{0}}$ de ajuizadas & $\begin{array}{l}\mathbf{n}^{\mathbf{0}} \mathbf{d e} \text { não } \\
\text { ajuizadas }\end{array}$ & Total & Variação \\
\hline 2000 & 1.940 .527 & 1.381 .150 & 3.321 .677 & \\
\hline 2001 & 2.026 .684 & 1.617 .540 & 3.644 .224 & $9,71 \%$ \\
\hline 2002 & 2.394 .064 & 1.975 .570 & 4.369 .634 & $19,91 \%$ \\
\hline 2003 & 2.704 .829 & 2.320 .044 & 5.024 .873 & $15,00 \%$ \\
\hline 2004 & 3.028 .472 & 2.826 .653 & 5.855 .125 & $16,52 \%$ \\
\hline 2005 & 3.550 .332 & 3.038 .676 & 6.589 .008 & $12,53 \%$ \\
\hline
\end{tabular}




\begin{tabular}{|l|l|l|l|l|}
\hline 2006 & 4.145 .165 & 3.203 .958 & 7.349 .123 & $11,54 \%$ \\
\hline 2007 & 4.345 .046 & 3.221 .480 & 7.566 .526 & $2,96 \%$ \\
\hline 2008 (novembro) & 4.466 .717 & 3.201 .127 & 7.667 .844 & $1,34 \%$ \\
\hline
\end{tabular}

Verifica-se, assim, que, em menos de 10 anos, mais que dobrou o número de execuções ajuizadas. Em complemento, segundo demonstra o quadro abaixo, o volume cobrado mais que quintuplicou no mesmo período.

\begin{tabular}{|l|l|l|l|l|}
\hline Ano & Valor ajuizado & $\begin{array}{l}\text { Valor } \\
\text { ajuizado }\end{array}$ & Total & Variação \\
\hline 2000 & $114.129 .083 .962,01$ & $11.551 .260 .390,35$ & $125.680 .344 .352,34$ & \\
\hline 2001 & $123.947 .873 .713,18$ & $26.880 .257 .517,82$ & $150.828 .131 .231,00$ & $20,01 \%$ \\
\hline 2002 & $158.460 .044 .612,83$ & $15.715 .242 .973,64$ & $174.175 .287 .586,47$ & $15,48 \%$ \\
\hline 2003 & $192.951 .792 .078,29$ & $18.407 .565 .566,67$ & $211.359 .357 .644,96$ & $21,35 \%$ \\
\hline 2004 & $237.027 .915 .611,81$ & $24.930 .437 .352,89$ & $261.958 .352 .964,70$ & $23,94 \%$ \\
\hline 2005 & $295.947 .017 .219,93$ & $38.186 .118 .370,21$ & $334.133 .135 .590,14$ & $27,55 \%$ \\
\hline 2006 & $376.447 .594 .102,14$ & $25.231 .064 .053,19$ & $401.678 .658 .155,33$ & $20,22 \%$ \\
\hline 2007 & $459.304 .684 .210,50$ & $23.049 .507 .359,42$ & $482.354 .191 .569,92$ & $20,08 \%$ \\
\hline $\begin{array}{l}2008 \\
\text { (novembro) }\end{array}$ & $520.044 .864 .384,20$ & $29.518 .053 .156,02$ & $549.562 .917 .540,22$ & $13,93 \%$ \\
\hline
\end{tabular}

Em termos de volume financeiro arrecadado pelo sistema de cobrança fiscal, tem-se o seguinte:

\begin{tabular}{|l|r|r|l|}
\hline Ano & Valor arrecadado & \multicolumn{1}{|l|}{ Variação } & Acumulado \\
\hline 2000 & $6.255 .513 .387,78$ & & \\
\hline 2001 & $5.293 .240 .330,58$ & $-15,38 \%$ & $11.548 .753 .718,36$ \\
\hline 2002 & $6.831 .794 .231,45$ & $29,07 \%$ & $18.380 .547 .949,81$ \\
\hline 2003 & $10.013 .861 .421,40$ & $46,58 \%$ & $28.394 .409 .371,21$ \\
\hline 2004 & $8.076 .828 .106,06$ & $-19,34 \%$ & $36.471 .237 .477,27$ \\
\hline 2005 & $8.810 .445 .479,44$ & $9,08 \%$ & $45.281 .632 .956,71$ \\
\hline 2006 & $9.617 .675 .553,59$ & $9,16 \%$ & $54.399 .358 .510,30$ \\
\hline 2007 & $12.892 .755 .484,84$ & $34,05 \%$ & $67.792 .113 .975,14$ \\
\hline 2008 (novembro) & $11.885 .154 .752,68$ & & $79.677 .268 .727,82$ \\
\hline
\end{tabular}

A eficácia (ou êxito) do sistema pode ser analisada comparando-se os valores devidos com o que foi arrecadado coercitivamente.

\begin{tabular}{|l|l|c|l|}
\hline Ano & Valor ajuizado & Valor arrecadado & \% de sucesso \\
\hline 2000 & $114.129 .083 .962,01$ & $6.255 .513 .387,78$ & $5,48 \%$ \\
\hline 2001 & $123.947 .873 .713,18$ & $5.293 .240 .330,58$ & $4,27 \%$ \\
\hline 2002 & $158.460 .044 .612,83$ & $6.831 .794 .231,45$ & $4,31 \%$ \\
\hline 2003 & $192.951 .792 .078,29$ & $10.013 .861 .421,40$ & $5,18 \%$ \\
\hline 2004 & $237.027 .915 .611,81$ & $8.076 .828 .106,06$ & $3,40 \%$ \\
\hline
\end{tabular}




\begin{tabular}{|l|l|r|l|}
\hline 2005 & $295.947 .017 .219,93$ & $8.810 .445 .479,44$ & $2,97 \%$ \\
\hline 2006 & $376.447 .594 .102,14$ & $9.617 .675 .553,59$ & $2,55 \%$ \\
\hline 2007 & $459.304 .684 .210,50$ & $12.892 .755 .484,84$ & $2,80 \%$ \\
\hline 2008 (novembro) & $520.044 .864 .384,20$ & $11.885 .154 .752,68$ & $2,28 \%$ \\
\hline
\end{tabular}

Do quadro acima, é possível notar que o sucesso do sistema é inegavelmente reduzido, pois, na última década, ultrapassou meros $5 \%$ do total cobrado em apenas um exercício, permanecendo em patamares inferiores aos demais.

Percebe-se, ainda, que, proporcionalmente, nos últimos anos, o volume ajuizado cresceu bem acima do que o percentual de êxito nas execuções. Isso demonstra que a respectiva estrutura institucional (normas jurídicas, órgãos administrativos e judiciais) sequer consegue atender à demanda por novas cobranças.

É possível inferir, destarte, que a baixa produtividade do sistema muito provavelmente influencia nas decisões dos contribuintes em não adimplirem suas obrigações fiscais independentemente do montante da carga tributária.

Com efeito, a conjuntura em tela autoriza a considerar a existência de sérios problemas a serem enfrentados pelo Estado e pela própria sociedade brasileira nessa seara, sob pena da ineficácia e o descrédito pleno se instalarem de vez.

4) economia informal: várias expressões podem ser empregadas para designar esse fenômeno, como, por exemplo, economia informal, subterrânea, oculta, submersa, paralela, negra, não oficial e criptoeconomia, conforme assinalado por PRADO (1991, p. 22).

Segundo expõe ROCHA (1989, p. 11), o fenômeno pode manifestar-se, em síntese, por meio de três expedientes:

a) atividades legais, mas não registradas, tais como os serviços prestados por profissionais autônomos sem a correspondente emissão de recibo ou, ainda, o denominado "Caixa 2" das empresas, oriundo de vendas e serviços prestados sem que seja emitida a nota fiscal. 
Além disso, de um modo geral, o comércio realizado por vendedores ambulantes nas ruas das cidades ocorre sem qualquer registro formal. O objetivo é, sem sombra de dúvida, afastar o máximo possível os encargos fiscais que deveriam incidir sobre estas atividades;

b) atividades legais, mas registradas indevidamente de maneira a simular situações que tenham potencial para diminuir, ainda que parcialmente, as obrigações fiscais. Cita-se, como exemplo, o pagamento de despesas particulares do sócio como se da empresa fossem de modo a diminuir os lucros ao final do exercício;

c) atividades totalmente ilegais (v.g. a exploração dos jogos de azar, da prostituição e do tráfico de entorpecentes). É evidente que aqui não se busca apenas burlar o fisco, mas, com efeito, procura-se realizar as ações bem longe dos olhos da lei para esconder a atividade em si, uma vez que a sua publicidade pode, em tese, levar à prisão as pessoas envolvidas.

Portanto, não obstante essas atividades muitas vezes se encontrarem contabilizadas em anotações particulares, obviamente não há inscrições em cadastros oficiais de contribuintes, nem a remessa das respectivas informações aos órgãos físcais.

Então, para fins deste trabalho, são consideradas informais as atividades econômicas que deveriam sofrer a incidência de algum tipo de tributação e que, por decisão dos agentes envolvidos, assim não ocorre, independentemente da causa específica (v.g. sonegação fiscal, ausência de registro ou de documentos contábeis, simulações, origem criminosa dos recursos, etc.).

A informalidade gera, em resumo, duas ordens de consequências: a) diretas; e, b) indiretas (PRADO, 1991, p. 55).

Dentre as diretas estão: desperdício e baixa produtividade, impossibilidade de desenvolverem-se economias em escala e, ainda, instabilidade social. Nas indiretas, ainda segundo o autor, tem-se: redução dos investimentos, crise no sistema tributário, estagnação tecnológica, dificuldade de formulação de políticas nacionais e de 
fomento público, desmoralização do sistema repressivo penal, descrença popular nas instituições do país e redução da liberdade política.

De fato, a economia oculta apresenta muitos custos sociais que contrariam o interesse público e isso não se resume apenas no não recolhimento dos tributos. Fatores como ausência de economia de escala (o que gera diminuição dos custos da produção) e estagnação tecnológica são presumíveis, visto que os informais, por exemplo, raramente têm acesso ao crédito para financiar o crescimento de seus empreendimentos.

Mas, o que leva alguém a escolher tal caminho? Uma das principais causas para alguém enveredar por tal caminho é o excesso fiscal. Conforme PRADO (1991, p. 44): "No momento registre-se que essa observação é tanto ou mais válida nos países subdesenvolvidos, onde a carga tributária, além de ser sentida como iníqua e sufocante, não se justifica no desempenho do Estado".

De fato, RIBEIRO (2000, p. 07-08) expõe que: "É quase unânime na literatura sobre a economia informal que a carga tributária é uma das principais causas para que os agentes possam se deslocar para a informalidade". Portanto, mesmo que uma carga fiscal elevada não possa ser considerada como causa exclusiva da economia oculta, resta fora de dúvida a existência de uma forte ligação entre ambas.

Contudo, mais complexo do que conceituar a economia informal e identificar suas causas mais prováveis é, com efeito, mensurar a extensão desse fenômeno. Justamente por se tratar de ações não registradas, é muito dificultosa a coleta de dados confiáveis.

Na seara tributária, isso é importante para investigar em que medida os contribuintes optam por evitar a legalidade econômica. É que, conforme expõe RIBEIRO (2000, p. 17): "uma aumento na economia informal leva a uma redução na receita tributária e, conseqüentemente, a uma menor quantidade de qualidade de bens e serviços públicos colocados à disposição da sociedade". 
No âmbito dos números, aponta ROCHA (1989, p. 13) que, para o ano de 1980, o IBGE estimou a economia informal no porte de 12,9\% do PIB brasileiro. Aproximadamente uma década depois, esse percentual havia saltado para algo em torno de $30 \%$ do PIB, conforme PRADO (1991, p. 37).

Mais recentemente, informa NERI (2006, p. 32) que, segundo o Banco Mundial, a informalidade no Brasil estaria em torno de 39,2\% do PIB contra apenas $12,75 \%$ estimados pelo IBGE, o que representa uma diferença considerável, ainda mais porque proveniente de instituições, ao menos em tese, idôneas.

Aliás, essa diferença entre o apurado pelo IBGE e pelas demais entidades é mencionada por RIBEIRO (idem, p. 29) e se refere ao ano de 1988. Enquanto a autarquia federal fixou o índice em 13\%, outros estudos o avaliaram em $37 \%$ do PIB.

Em evento promovido pelo Instituto Brasileiro de Ética Concorrencial, SCHNEIDER (2008, p. 19) estima que a informalidade econômica no Brasil atual corresponda a $41 \%$ do PIB e apresenta a seguinte situação em face de outros 20 países latino americanos:

\begin{tabular}{|l|l|}
\hline País & \% em relação ao PIB \\
\hline Chile & 19,4 \\
\hline Costa Rica & 26,3 \\
\hline Argentina & 27,2 \\
\hline Porto Rico & 28,2 \\
\hline México & 31,7 \\
\hline Paraguai & 33,1 \\
\hline República Dominicana & 34,8 \\
\hline Equador & 35,2 \\
\hline Venezuela & 35,4 \\
\hline Jamaica & 38,4 \\
\hline Colômbia & 42,7 \\
\hline El Salvador & 47,2 \\
\hline Nicarágua & 48,1 \\
\hline Uruguai & 49,2 \\
\hline Honduras & 49,3 \\
\hline Guatemala & 50,3 \\
\hline Peru & 58,2 \\
\hline Haiti & 59,6 \\
\hline Panamá & 62,2 \\
\hline Bolívia & 67,2 \\
\hline
\end{tabular}


Conforme apontam AMARAL et al. (2009, p. 02), a respeito do comportamento no âmbito fiscal das empresas brasileiras:

a) a sonegação fiscal vem diminuindo, mas ainda representa aproximadamente $25 \%$ do faturamento das empresas;

b) no exercício de 2000, o índice de sonegação fiscal era de $32 \%$, tendo passado para $39 \%$ em 2004;

c) os tributos sonegados pelas empresas somam $\mathrm{R} \$ 200$ bilhões por ano e o faturamento não declarado é de $\mathrm{R} \$ 1,32$ trilhão;

d) somados os tributos sonegados pelas pessoas físicas, a sonegação fiscal no Brasil se encontra na ordem de 9\% do PIB;

e) cruzamento de informações, retenção de tributos e fiscalização mais efetiva são os principais responsáveis pela queda na sonegação;

f) o tributo mais sonegado é a contribuição ao INSS, seguido pelo ICMS e Imposto de Renda;

g) indícios de sonegação estão presentes em $65 \%$ das empresas de pequeno porte, $49 \%$ mas de médio porte e $27 \%$ nas grandes empresas.

Em verdade, não há um consenso seguro acerca do tamanho da economia subterrânea brasileira, ainda mais porque não existe apenas um método de apuração. Nessa linha, por exemplo, RIBEIRO (2000, p. 20 e ss.) noticia que há métodos diretos (por meio de amostragem ou auditoria tributária) e indiretos, que utilizam indicadores macroeconômicos (discrepância entre as despesas nacionais e as estatísticas da renda, discrepância entre a taxa de participação da força de trabalho real e a sua média oficial, aproximação devido às transações, modelo de demanda por moeda, modelo pelo consumo de eletricidade, modelo das múltiplas causas e múltiplos indicadores).

O quanto a carga tributária efetivamente influencia nesse fenômeno é muito difícil saber. Contudo, não se pode negar que em algum grau isso ocorre, pelo o que 
se considera importante analisar o tamanho da informalidade num determinado sistema econômico como elemento auxiliar na determinação do exagero fiscal no âmbito coletivo.

5) custos de conformidade: o ônus fiscal não se resume ao valor dos tributos. Nesse cômputo, também deve ser incluído o quanto custa ao contribuinte cumprir os mandamentos legais. Portanto, conforme BERTOLUCCI e NASCIMENTO (2002, p. 56), eles:

correspondem ao custo dos recursos necessários ao cumprimento das determinações legais tributárias pelos contribuintes. Declarações relativas a impostos, informações ao fisco federal, estadual e municipal, inclusões e exclusões realizadas por determinações das normas tributárias, atendimento a fiscalizações, alterações da legislação, autuações e processos administrativos e judiciais.

Enquanto que, para uma pessoa física, que tenha apenas uma ou duas fontes de renda, esse cômputo poderá ser desprezível (pois, em regra, não será necessário contratar o auxílio de um profissional habilitado para tanto), isso também não se aplica às empresas, cujas atividades que geram reflexos tributários são muito mais numerosas.

Um sistema de tributação muito complexo é nocivo, pois, no mínimo, majora desnecessariamente os custos de transação. De fato, conforme MICHELS (2005, P. 231): "a tributação excessivamente complexa torna o sistema manipulável por uns poucos que detêm a possibilidade técnico-jurídica para tal, além de trazer custos complementares não raramente expressivos".

Nesse quesito, o Brasil não ostenta boas perspectivas. Na exposição de MONTEIRO NETO (2003, p. 45):

O sistema é caótico, com superposições de incidências e elevado nível de complexidade. Gera um custo fantástico de administração para contribuintes e para os diversos Erários, facilitando a sonegação dolosa e impondo, para muitos setores, a inadimplência sobrevivencial, como forma de evitar a falência.

É possível que a estrutura federativa contribua parcialmente para essa situação, uma vez que, cada esfera política, apresenta legislação específica, ainda que exista uma matriz comum indicada pela Constituição e pelo Código Tributário Nacional. 
Nesse diapasão, por exemplo, é preciso considerar que cada tributo possui regulamentação própria, além de envolver, em muitas hipóteses, diversas obrigações acessórias (v.g. retenção do Imposto de Renda e das contribuições sociais dos empregados). Assim:

a) no âmbito da União, há seis impostos instituídos, sendo que o Imposto de Renda das Pessoas Jurídicas, notadamente para os casos que utilizam o sistema do "lucro real", e o Imposto sobre Produtos Industrializado possuem estruturas altamente técnicas e complexas;

b) ainda na esfera da União, existem diversas contribuições (v.g. COFINS, PIS, CSSL, SAT, INCRA, SESI, SENAI, SESC, SENAC, SENAT, SENAR, SESCOOP, CIDE’s, "salário educação", "remunerações em geral", FGTS, etc.) com variadas alíquotas e bases de cálculo e respectivas sistemáticas;

c) quanto aos Estados-membros, entra em cena o ICMS, imposto de notória complexidade, o que implica no conhecimento das especificidades de cada uma das legislações para que uma empresa possa realizar operações interestaduais;

d) essa situação repete-se em face dos tributos municipais, recordando-se que o Brasil conta com quase 5.000 Municípios.

e) a todas essas nuances, soma-se a sistemática das taxas, cujo leque de aplicação é definitivamente vasto e podem ser instituídas por cada ente federativo.

Nessa toada, conforme MIRANDA FILHO e BORGES (2006, p. 01), ao discorrerem acerca de estudo publicado pelo Banco Mundial, em relação ao Brasil, nota-se que:

Mas é no campo tributário que aparecem as maiores divergências: o Brasil é o recordista, dentre os 155 países, no quesito "tempo gasto com o pagamento de tributos" (leia-se: burocracia). Aqui, a média é de 2,6 mil horas por ano, enquanto que na América Latina é de 529 e nos países da OCDE, 197. Logo após o Brasil, vem a Ucrânia, com 2,1 mil horas e Camarões, com 1,3 mil horas. Já na Rússia, país de dimensões continentais como o Brasil, o tempo gasto é de 256 horas. Ou seja, o Brasil é duas vezes pior que o terceiro pior colocado (Camarões) e mais do que $1000 \%$ pior que a Rússia. Além disso, o total de tributos pagos no 
Brasil equivale 147,9\% do lucro bruto, enquanto que na América Latina, a $52,8 \%$ e nos países da OCDE, a 45,4\%. Na seção do ranking denominada "ease of paying taxes", o Brasil figura no $140^{\circ}$ lugar. Nas demais seções (com exceção da seção "hiring and firing"), o Brasil está melhor colocado.

Segundo apontam AMARAL et al. (2008, p. 02), desde a promulgação da Constituição de 1988, foram editadas mais de 240 mil normas tributárias, o que atinge uma média de duas normas por hora. É evidente que muitas delas foram revogadas total ou parcialmente, mas, mesmo assim, não se pode negar que o número é de peso. Apenas no âmbito federal foram editadas:

a) 06 emendas constitucionais de revisão;

b) 56 emendas constitucionais;

c) 02 leis delegadas;

d) 4.055 leis ordinárias;

e) 1.058 medidas provisórias;

f) 5.491 reedições de medidas provisórias;

g) 9.612 decretos federais;

h) 130.075 normas complementares (portarias, instruções normativas, etc.).

Portanto, ao que tudo indica, encontrar-se dentro da lei implica num custo considerável, ao menos no sistema de tributação brasileiro, fator esse que, somado aos acima visualizados, pode contribuir para o fenômeno do exagero fiscal na órbita coletiva.

6) manifestações sociais de repulsa à tributação: outro indicador acerca do exagero fiscal, é verdade que mais fluido e quiçá menos objetivo que os demais, é a existência de movimentos sociais organizados contra o aumento da carga tributária. 
Não se cuida, com efeito, da normal e esperada animosidade dos contribuintes em vista de suas obrigações fiscais. Trata-se de uma insatisfação mais qualificada, capitaneada por entidades e associações de classe, o que coloca fora de dúvida que o limite da carga tributária está próximo ou foi ultrapassado.

Como exemplo, cita-se o caso da medida provisória 232, de 30 de dezembro de 2004, que, dentre outras disposições, majorou a alíquota da CSSL (Contribuição Social sobre o Lucro) das pessoas jurídicas que se sujeitavam à sistemática do lucro presumido de $32 \%$ para $40 \%$. A reação social não tardou e chegou a tal ponto do governo precisar desistir da majoração, conforme demonstra a transcrição da notícia jornalística abaixo ${ }^{136}$ :

Depois de adiar por duas vezes a entrada em vigor da Medida Provisória 232, o governo e a base aliada no Congresso Nacional desistiram de tentar aprovar a medida. A decisão foi anunciada nesta terça-feira (29/3). Editada em 30 de dezembro para corrigir a tabela do Imposto de Renda de Pessoa Física, a MP 232 elevou a base de cálculo da CSLL das empresas prestadoras de serviços que optam pelo lucro presumido dos atuais $32 \%$ para $40 \%$. O Imposto de Renda da Pessoa Jurídica também cresceu.

O relator da MP na Câmara, deputado Carlito Merss (PT-SC), disse que o relatório será pela rejeição integral da medida. Segundo ele a decisão foi tomada em reunião no Palácio do Planalto, na qual ficou acertado que a MP seria derrubada no Plenário.

$[\ldots]$

O aumento da carga tributária criou um movimento organizado pela rejeição da MP 232 no Congresso Nacional. O Supremo Tribunal Federal já havia recebido três ações diretas de inconstitucionalidade para derrubar a medida.

Para o presidente do Conselho Federal da Ordem dos Advogados do Brasil, Roberto Busato, "o governo está recuando diante de um grande equívoco, curiosamente cometido por ele próprio". Em nota divulgada sobre a decisão de rejeitar a MP, Busato afirmou que o governo deve tirar uma lição desse episódio: a de que ao Executivo cabe governar em obediência às leis, e ao Legislativo, legislar.

Acerca do mesmo tema ${ }^{137}$ :

A OAB de São Paulo e o Ciesp (Centro das Indústrias do Estado de São Paulo) firmaram, nesta segunda-feira (28/2), parceria para tentar reduzir a

\footnotetext{
${ }^{136}$ Disponível em:

<http://www.conjur.com.br/2005-mar-29/governo_lula_desiste_tentar_aprovar_polemica_mp_232>. Acesso em 21.07.2009.

${ }^{137}$ Disponível em:

<http://www.conjur.com.br/2005-fev-28/oab-sp_ciesp_firmam_parceria_combater_mp_232>.

Acesso em 21.07.2009.
} 
carga tributária no Brasil. O protocolo de intenções para dar continuidade à campanha "Carga tributária excessiva: chega de abuso" foi assinado pelos presidentes da OAB paulista, Luiz Flávio D’Urso, e da Ciesp, Cláudio Vaz. A informação é da OAB-SP.

Para Vaz, a edição da Medida Provisória 232, que eleva a carga tributária de empresas prestadoras de serviços, foi a gota d'água que transbordou o copo da excessiva tributação. D'Urso classificou a MP 232 como um "tsunami fiscal que o governo tenta impor à sociedade brasileira".

A parceria firmada entre as duas entidades tem o propósito de veicular campanhas publicitárias e propor uma solução prática para o problema.

Para finalizar, é de se deixar reforçado que a verificação do exagero fiscal na órbita coletiva é sempre complexa. Envolve, sem dúvida, a análise conjunta dos critérios acima de maneira aprofundada e crítica, sem prejuízo da adoção de outras observações a serem indicadas futuramente pelos mais doutos.

Contudo, se indubitavelmente for constatado a exagero da carga tributária, é muito importante verificar se o fenômeno tende a crescer, permanecer ou diminuir. Salvo na última hipótese, é vital interromper o deletério fenômeno sob pena da arrecadação em valores ótimos restar cada vez mais inatingível.

Nessa esteira, a maneira mais imediata de frear o processo é impedir a majoração de qualquer tributo até que se inverta ou se estabilize a causa inicial. Trata-se, em verdade, de uma medida drástica. Todavia, por mais malefícios que a medida possa implicar, nada pode ser tão grave quanto permitir que a carga tributária permaneça aumentando.

A manutenção do exagero fiscal pode colocar o próprio Estado e, por consequência, a sociedade civil, sob risco de instabilidades muito graves pela progressiva ineficiência estatal na manutenção da ordem e na realização de demais atividades, até que todas as condições de sustentabilidade da ordem jurídica e das instituições como um todo se esvaiam.

É o que se verifica, por exemplo, quando se instalam revoluções e guerras civis, ou, num passo mais inaugural, em certas zonas a "ordem” começa a ser controlada por grupos armados de marginais ou guerrilheiros com finalidades políticas ou meramente criminosas. 


\subsection{Conclusão do capítulo}

O terceiro fundamento da democracia fiscal constitui-se na ferramenta indispensável para que o Estado consiga atingir os demais, ao menos num regime capitalista. Trata-se da necessidade do sistema de tributação causar a menor inibição possível da atividade econômica, pois, quanto maior for a economia de um país, mais robusta será a arrecadação na medida em que as imposições ordinariamente gravam os atos de produção e circulação de bens e riquezas.

Qualquer exação causa distorções econômicas em algum nível, sendo que esse fenômeno se mostra mais intenso quando se tratar de tributo "indireto" (trata-se do denominado "peso morto"), motivo que também serve como fundamento para o sistema de tributação edificar-se primordialmente sobre as imposições "diretas", em tese, menos distorcivas.

Uma carga tributária muito intensa gera o exagero fiscal na órbita coletiva, o que, além das distorções acima indicadas, desestimula os contribuintes a permanecerem operando dentro do sistema legal, o que faz crescer a economia informal (ou oculta, subterrânea, criptoeconomia), que sabidamente não gera receita tributária.

A carga tributária deve ser fixada no denominado "ponto ótimo de arrecadação", ainda que seja muito difícil sua identificação. Se o ônus fiscal for fixado abaixo do referido ponto, o Tesouro receberá menos recursos do que a sociedade poderia contribuir, mas, se fixado para além daquele, ocorrerá o mesmo deletério fenômeno.

Não é apenas o tamanho da carga tributária que pode gerar a saída do contribuinte do sistema legal, mas também um sistema de fiscalização e punição frouxo ou pouco eficiente.

São sugeridos os seguintes critérios para aferir a ocorrência do exagero fiscal no âmbito coletivo, ficando advertido que devem ser aplicados de forma conjunta e, ainda, não haverá resposta exata e isenta da dúvida: 1) relação da carga fiscal em face do PIB; 2) tendência ou comportamento da arrecadação; 3) número de cobranças fiscais coercitivas; 4) tamanho da economia informal frente ao PIB; 5) custos de conformidade; e, 6) manifestações sociais de repulsa à tributação. 
Constatado o exagero fiscal no plano coletivo, é imprescindível interromper o fenômeno (v.g. impedindo-se a majoração de qualquer tributo) sob pena da arrecadação em valores ótimos restar cada vez mais inatingível, o que, em longo prazo, pode colocar o Estado e, por consequência, a sociedade civil sob risco de instabilidades muito graves, com potencial para o desabamento da ordem jurídica e das instituições como um todo. 


\section{CONCLUSÃO}

Qualquer sociedade humana organizada deve decidir quais patrimônios e sob qual grau serão onerados para a satisfação das despesas comuns. A resposta sofre variações segundo condições de local e período histórico.

O presente trabalho procurou construir uma teoria a respeito, com base na figura da democracia, mas sempre sob o alerta de que as conclusões científicas, ainda mais dentro das ciências sociais, como é o caso do Direito, são provisórias, ou seja, vigem até que outra proposta as falsifique ou ocorra a substituição do paradigma de amparo.

O direito é um fenômeno social milenar que surge com necessidade de disciplinar as condutas humanas numa determinada sociedade de modo que a convivência entre seus membros seja o mais pacífica possível. É fruto da criação humana e não algo que exista na natureza, motivo pelo qual são notadas enormes variações em seus fundamentos ao redor do globo, sendo muito difícil conceber alguma norma de aplicação universal.

Por sua vez, a economia também é um fenômeno social milenar e tem origem na percepção humana de que os recursos materiais são sempre escassos, o que implica na inafastável necessidade de diuturnamente escolher quais necessidades e desejos devem ser atendidos. Trata-se, em suma, de administrar constantemente as infindáveis opções ou trade offs. Numa coletividade há que se responder a três perguntas elementares: 1) O que será produzido?; 2) Como será produzido?; e, 3) Como será a divisão do resultado?

Embora se constate há muitos séculos a existência de um forte relacionamento entre os fenômenos sociais do direito e da economia na forma de estímulos e feedbacks recíprocos, não sendo possível afirmar haver uma preponderância ou hierarquia entre ambos, apenas a partir da segunda metade do século XX, nos Estados 
Unidos, principalmente, é que esse entrelaçamento passou a ser investigado cientificamente por meio do movimento da Law and Economics.

O movimento da Law and Economics é composto por uma variada epistemologia, com destaque para a Escola de Chicago (versões fundacional e pragmática), Escola de Yale ou de New Haven (versão regulatória) e Escola da Nova Economia Institucional. No Brasil, o movimento é recente, mas já despertou o interesse de parte da doutrina.

A teoria da democracia fiscal, objeto deste trabalho, se socorreu de elementos próprios das ciências do direito e da economia, segundo os postulados primordiais da Law and Economics.

Fato é que a ideia de democracia remonta à Grécia antiga, nos séculos VI e IV antes de Cristo, principalmente em Atenas, quando era exercida pela forma direta, não obstante apenas uma parcela diminuta da população ser detentora do direito de voto em assembleia. Cuidou-se de uma experiência pioneira e isolada na história da humanidade.

O tema foi retomado a partir do final do século XVIII com a vitória das "revoluções liberais", mas sob a sistemática da representação, com sufrágio altamente restrito e, ainda, considerando os valores da igualdade e da liberdade vistos sob a ótica eminentemente formal, o que implicou na manutenção das grandes desigualdades econômicas então vigentes.

Em contraposição, a democracia socialista ou marxista, cujas primeiras ideias nasceram a partir da metade do século XIX, no anseio de construir a igualdade substancial, sufocou a liberdade econômica e política, não tendo conseguido alcançar resultados significativos, vistos os exemplos históricos disponíveis.

A síntese dessas experiências, ao que tudo indica, é a social democracia, figura ainda em evolução e que, sob a égide e respeito ao sufrágio universal, tenta conjugar os valores da igualdade e da liberdade num ponto intermediário entre a visão exclusivamente formal e aquela absolutamente substancial. 
A democracia fiscal se assenta em três fundamentos que atuam de forma harmônica como um sistema de pesos e contrapesos, de modo a que um influencie e seja influenciado pelos demais num desejável equilíbrio entre todos.

O primeiro fundamento é a liberdade material que se consubstancia na possibilidade do indivíduo decidir quais necessidades e desejos pretende satisfazer em determinado instante. Isso é obtido a partir da garantia, pelo Estado, dos direitos fundamentais da propriedade (em sentido amplo) e da livre iniciativa (exercício de profissão de atividade econômica), donde ordinariamente se retira os meios de sobrevivência.

Embora usualmente os tributos gravem parcela dos referidos direitos individuais, devem ser considerados, do ponto de vista do contribuinte, no mínimo, como um preço a pagar pela existência de tais direitos, sendo certo que as exações são essenciais à manutenção do Estado, que por sua vez é o garante maior a ordem jurídica, suporte elementar para qualquer direito fundamental.

Contudo, caso a tributação atinja os direitos fundamentais da propriedade e da livre iniciativa de forma tão grave que contrarie os princípios constitucionais da proporcionalidade e da razoabilidade, encontrar-se-á em risco o valor da liberdade na democracia, pois o indivíduo terá muito reduzida a possibilidade de decidir sobre a satisfação de suas necessidades e desejos, além de restar mais próximo de depender do auxílio estatal ou da caridade alheia.

$\mathrm{O}$ aferimento de vulneração à proporcionalidade e à razoabilidade deve ocorrer ante cada situação concreta, admitindo-se a participação do Poder Judiciário, principalmente, do Supremo Tribunal Federal, como órgão competente para declarar a respeito.

O segundo fundamento da democracia fiscal é a igualdade de sacrifício perante o fisco, que deve ser buscada por meio da aplicação das cláusulas da capacidade contributiva, progressividade, solidariedade e pessoalidade, com destaque para as exações a cargo das pessoas físicas que gravam a renda, as propriedades e as transmissões causa mortis e inter vivos, ou seja, os tributos "diretos". 
Os tributos "indiretos", isso é, aqueles que incidem ao longo de uma cadeia produtiva, bem como todos a cargo das pessoas jurídicas (inclusive as imposições sobre a renda, as propriedades e as transmissões), por permitirem, em grande medida, o repasse do respectivo ônus financeiro a terceiros, principalmente ao consumidor final, impingem nítido viés regressivo ao sistema de tributação.

Em termos de eficiência da arrecadação, os tributos "indiretos" levam vantagem sobre os "diretos". Todavia, estes últimos superam aqueles em termos de equidade ou justiça fiscal, pois permitem seja respeitada, ainda que não de maneira perfeita, a igualdade de sacrifícios.

Como regra, nos países desenvolvidos, a maior parcela das receitas tributárias é oriunda dos tributos "diretos", enquanto que, naqueles em desenvolvimento, predominam recursos fiscais originados dos "indiretos".

Porém, a complexidade da dinâmica econômica atual, onde riquezas circulam globalmente sem grande dificuldade e em prazos reduzidos, impede que, mesmo nos países desenvolvidos, o sistema de tributação seja baseado quase que integralmente nos tributos "diretos", notando-se nas últimas décadas o aumento da participação dos "indiretos" nesses locais.

O maior desafio para os diversos sistemas de tributação é implementar um equilíbrio aceitável entre a equidade e a eficiência na tributação.

No Brasil, mais de dois terços das receitas tributárias são provenientes dos tributos "indiretos" e das pessoas jurídicas, o que impinge nítido caráter regressivo ao sistema exacional como um todo. Mesmo os impostos sobre a renda e as propriedades, teoricamente os mais aptos a proporcionarem a isonomia fiscal, são edificados segundo sistemáticas que pouco permitem o aproveitamento dessa inclinação.

Modificar esse quadro não se resume a decisões simplificadas, como, por exemplo, majorar inopinadamente os tributos "diretos" a cargo dos mais favorecidos economicamente, uma vez que tal medida poderia revelar-se como tributação exagerada, 
em contrariedade, portanto, ao primeiro fundamento da democracia fiscal, bem como poderia afugentar tais riquezas do país, fazendo minguar ainda mais a arrecadação.

O terceiro fundamento da democracia fiscal constitui-se na ferramenta indispensável para que o Estado consiga atingir os demais, ao menos num regime capitalista. Trata-se da necessidade do sistema de tributação de causar a menor inibição possível da atividade econômica, pois, quanto maior for a economia de um país, mais robusta será a arrecadação na medida em que as imposições ordinariamente gravam os atos de produção e circulação de bens e riquezas.

É importante considerar que qualquer exação causa distorções econômicas em algum nível, sendo que esse fenômeno se mostra mais intenso quando se tratar de tributo "indireto", motivo que também serve como fundamento para o sistema de tributação se edificar primordialmente sobre as imposições "diretas", em tese menos distorcivas.

Em adição, uma carga tributária muito intensa gera o exagero fiscal na órbita coletiva, o que, além das distorções acima indicadas, desestimula que os contribuintes permaneçam operando dentro do sistema legal, o que faz crescer a economia informal (ou oculta, subterrânea e criptoeconomia), que sabidamente não gera receita tributária.

Portanto, a carga tributária deve ser fixada no denominado "ponto ótimo de arrecadação", ainda que sua fixação seja muito complexa. Se o ônus fiscal for fixado abaixo do referido ponto, o Tesouro receberá menos recursos do que a sociedade poderia contribuir, mas, se fixado para além daquele, ocorrerá o mesmo deletério fenômeno.

De fato, não é apenas o tamanho da carga tributária que pode gerar a saída do contribuinte do sistema legal, mas também pode para isso contribuir um sistema de fiscalização e cobrança frouxo ou pouco eficiente.

São sugeridos os seguintes critérios para aferir a ocorrência do exagero fiscal no âmbito coletivo, ficando advertido que devem ser aplicados de forma conjunta: 1) relação da carga fiscal em face do PIB; 2) tendência ou comportamento da arrecadação; 3) 
número de cobranças fiscais coercitivas; 4) tamanho da economia informal frente ao PIB; 5) custos de conformidade; e, 6) manifestações sociais de repulsa à tributação.

Constatado o exagero fiscal no plano coletivo, é imprescindível interromper o fenômeno (v.g. impedindo-se a majoração de qualquer tributo), sob pena da arrecadação em valores ótimos restar cada vez mais inatingível, o que, em longo prazo, pode colocar o Estado e, por consequência, a sociedade civil sob risco de instabilidades muito graves, com potencial para o desabamento da ordem jurídica e das instituições como um todo. 


\section{REFERENCIAS}

AGUERO, Antonio Agulló. La proibición de confiscatoriedad en el sistema tributario español. Revista de Direito Tributário, n 42, p. 28-34, out/dez. de 1987.

AGUILLAR, Fernando Herren. Metodologia da ciência do direito. São Paulo: Max Limonad, 1996, 158 p.

AIETA, Vânia Siciliano. Democracia: estudos em homenagem ao prof. Siqueira Castro. Rio de Janeiro: 2006, Tomo II, 278 p.

AMARAL JR., Alberto do. Proteção do consumidor no contrato de compra e venda. São Paulo: Revista dos Tribunais, 1993, 309 p.

AMARAL, Gilberto Luiz do; OLENIKE, João Eloi; AMARAL, Letícia Mary Fernandes do; STEINBRUCH, Fernando. Estudo sobre sonegação fiscal das empresas brasileiras. Instituto Brasileiro de Planejamento Tributário. Disponível em: <http://www.ibpt.com.br/img/_publicacao/13649/175.pdf> Acesso em: 21.07.2009

AMARAL, Gustavo. Direito, escassez \& escolha. Rio de Janeiro: Renovar, 2001, 256 p.

AMARO, Luciano. Direito tributário brasileiro. 13ª ed., São Paulo: Saraiva, 2007, 512 p.

ALVAREZ, Alejandro Bugallo. Análise econômica do direito: contribuições e desmistificações. Direito, Estado e Sociedade, nº 09, p. 49-68, jul./dez. de 2006.

ALVES, Benedito Antônio; GOMES, Sebastião Edílson Rodrigues. Curso de direito financeiro. São Paulo: Juarez de Oliveira, 2001, 213 p. 
ARAÚJO, Fernando. Uma análise económica dos contratos - a abordagem económica, a responsabilidade e a tutela dos interesses contratuais. Direito \& economia (TIMM, Luciano Benetti - org.). Porto Alegre: Livraria do Advogado, 2008, p. 97-174.

ARIDA, Pérsio. A pesquisa em direito e em economia: em torno da historicidade da norma. Direito \& economia. (ZYLBERSZTAJN, Décio; SZTAJN, Raquel - orgs.). Rio de Janeiro: Elsevier, 2005, p. 60-73.

ASCARELLI, Túlio. Panorama do direito comercial. São Paulo: Saraiva, 1947, 229 p.

ATALIBA, Geraldo. República e Constituição. $2^{\mathrm{a}}$ ed. - $4^{\mathrm{a}}$ tiragem. São Paulo: Malheiros, 2007, $191 \mathrm{p}$.

Hipótese de incidência tributária. $5^{\mathrm{a}}$ ed. $-6^{\mathrm{a}}$ tiragem. São Paulo: Malheiros, 1997, 182 p.

ÁVILA, Humberto. Teoria da igualdade tributária. São Paulo: Malheiros, 2008, 208 p.

AZEVEDO, Antônio Junqueira de. O direito ontem e hoje: crítica ao neopositivismo constitucional e à insuficiência dos direitos humanos. Revista do Advogado, nº 99, p. 0714 , set. de 2008 .

BALEEIRO, Aliomar. Uma introdução à ciência das finanças. $15^{\mathrm{a}}$ ed., Rio de Janeiro: Forense, 1998, 548 p.

BANCO INTERAMERICANO DE DESENVOLVIMENTO. A política das políticas públicas: progresso econômico e social na América Latina - relatório 2006. Rio de Janeiro: Campus, 2007, 284 p.

BANDEIRA DE MELLO. Celso Antônio. Conteúdo jurídico do princípio da igualdade. $3^{\mathrm{a}}$ ed. $-15^{\mathrm{a}}$ tiragem. São Paulo: Malheiros, 2007, 48 p.

BARBOSA, Rui. Oração aos moços. Rio de Janeiro: Gráfica Olímpica Editora, 1951, 80p. 
BARRETO, Aires. Vedação ao efeito de confisco. Revista de Direito Tributário, $\mathrm{n}^{\circ}$ 64, p. 96-106, 1994.

BARRETO, Túlio Velho. Positivismo versus teoria crítica em torno do debate entre Karl Popper e Theodor Adorno acerca do método das ciências sociais. 2001. Disponível em: <http://www.fundaj.gov.br/tpd/106.html>. Acesso em: 21.05.2007.

BARROS, Ricardo Paes de; MENDONÇA, Rosane Silva Pinto de; DUARTE, Renata Pacheco Nogueira. Bem-estar, pobreza e desigualdade de renda: uma avaliação da evolução histórica e das disparidades regionais. IPEA-Instituto de Pesquisa Econômica Aplicada, texto para discussão nº 454, janeiro de 1997.

Disponível em: 〈http://www.ipea.gov.br/pub/td/1997/td_0454.pdf〉.

Acesso em: 15.05.2008.

BARROS, Ricardo Paes de; MENDONÇA, Rosane. O impacto do crescimento econômico e de reduções no grau de desigualdade sobre a pobreza. IPEA-Instituto de Pesquisa Econômica Aplicada, texto para discussão no 528, novembro de 1997.

Disponível em: 〈http://www.ipea.gov.br/pub/td/1997/td_0528.pdf〉.

Acesso em: 11.01.2009.

BARROS, Sérgio Resende de. Contribuição dialética para o constitucionalismo. Campinas: Milennium, 2007, 279 p.

BARROSO, Luís Roberto. Introdução: a reconstrução democrática do direito público no Brasil. A reconstrução democrática do direito público no Brasil (BARROSO, Luís Roberto - org.). Rio de Janeiro: Renovar, 2007, p. 01-39.

BECHO, Renato Lopes. Filosofia no direito tributário. São Paulo: Saraiva, 499 p.

BELlUZZO, Luiz Gonzaga de Mello. Planos econômicos. Revista do Direito Bancário e do Mercado de Capitais, no 43, p. 203-214, jan./mar. de 2009. 
BENTHAM, Jeremy. Uma introdução aos princípios da moral e da legislação. Os pensadores. Trad. Luiz João Baraúna. São Paulo: Abril Cultural, 1974, vol. XXXIV, p. 07-74.

BERCOVICI, Gilberto. A Constituição e o papel do Estado no domínio econômico. Revista da Academia Brasileira de Direito Constitucional, nº 02, p. 119-129, 2002.

BERTOLUCCI, Aldo V.; NASCIMENTO, Diogo Toledo do. Quanto custa pagar tributos? Revista Contabilidade \& Finanças, no 29, p. 55-67, mai./ago. de 2002.

BETTI, Emílio. Teoria geral do negócio jurídico. Trad. Fernando de Miranda. Coimbra: Coimbra Editora, 1969, Tomo I, 402 p.

BEVILAQUA, Clóvis. Código civil dos Estados Unidos do Brasil. 10a ed., Rio de Janeiro: Livraria Francisco Alves, 1955a, vol. III, 371 p.

Código civil dos Estados Unidos do Brasil. 10ª ed., Rio de Janeiro: Livraria Francisco Alves, 1955b, vol. IV, 375 p.

BITTAR, Eduardo C. B. Metodologia da pesquisa jurídica. $4^{a}$ ed., São Paulo: Saraiva, 2005, 254 p.

BOARATI, Vanessa. Economia para o direito. Barueri: Manole, 2006, 132 p.

BOBBIO, Norberto. O futuro da democracia. Trad. Marco Aurélio Nogueira. 10 ed., São Paulo: Paz e Terra, 2006, 207 p.

Teoria da norma jurídica. Trad. Fernando Pavan Baptista; Ariani Bueno Sudatti. $3^{\text {a }}$ ed., São Paulo: Edipro, 2005, 192 p.

Liberalismo e democracia. Trad. Marco Aurélio Nogueira. $6^{\mathrm{a}}$ ed. - $1^{\mathrm{a}}$ reimp., São Paulo: Brasiliense, 1995, 100 p. 
. Estado, governo e sociedade: para uma teoria geral da política. Trad. Marco Aurélio Nogueira. $2^{a}$ ed., São Paulo: Paz e Terra, 1988, 173 p.

; BOVERO, Michelangelo. Sociedade e Estado na filosofia política moderna. Trad. Carlos Nelson Coutinho. $2^{\mathrm{a}}$ ed., São Paulo: Brasiliense, 1987, 179 p.

BONAVIDES. Paulo. Curso de direito constitucional. 22a ed., São Paulo: Malheiros, 2008,827 .

Do Estado liberal ao Estado social. $8^{\text {a }}$ ed., São Paulo: Malheiros, 2007, 230p.

BORRADORI, Giovanna. A filosofia americana: conversações com Quine, Davidson, Putnam, Nozick, Danto, Rorty, Cavell, Maclntyre e Kuhn. São Paulo: Unesp, 2003.

BOWLES, Roger. Diritto e economia. Trad. Para o italiano de Guido Alpa. Bologna: Il Mulino, 1985, 300 p.

BRAGA, Valeschka e Silva. Princípios da proporcionalidade $\&$ razoabilidade. $2^{\mathrm{a}}$ ed., Curitiba: Juruá, 2008, 289 p.

BRANDÃO, Wilson de Andrade. Lesão e contrato no direito brasileiro. $3^{a}$ ed., Rio de Janeiro: Aide, 1991, 301 p.

BRUYN JÚNIOR, Herbert Cornélio Pieter de. O princípio do não confisco. São Paulo: Novas Conquistas, 2001, 97 p.

BRUTAU, José Puig. Fundamentos de derecho civil. $3^{\text {a }}$ ed., Barcelona: Bosch, 1988, tomo II, vol. 01, $513 \mathrm{p}$.

CALABRESI, Guido. Sociologia del diritto. Il futuro dell'analisi economica del diritto, $\mathrm{n}^{\circ}$ XVII-1-2, p. 47-54, 1990.

CAMARGOS, Luiz Rogério de. Estado, mercado e resultado social: reflexões sobre o 
paradigma da mão invisível. São Paulo: Annablume, 2003, 139 p.

CAMPOS, Diogo Leite. A juridicização dos impostos: garantias de terceira geração. O tributo - reflexão multidisciplinar sobre sua natureza. (MARTINS, Ives Gandra da Silva - coord.). Rio de Janeiro: Forense, 2005, p. 87-111.

CARBONNIER, Jean. Sociologia jurídica. Trad. Diogo Leite de Campos. Coimbra: Almeidina, 1979, $462 \mathrm{p}$.

CARRAZZA, Roque Antônio. Curso de direito constitucional tributário. $20^{\mathrm{a}}$ ed., São Paulo: Malheiros, 2004, 977 p.

CARVALHO, Cristiano. Teoria do sistema jurídico: direito, economia e tributação. São Paulo: Quartier Latin, 2005a, 431 p.

. Tributação e economia. Direito e economia (TIMM, Luciano Benetti - org.).

São Paulo: Thomson, 2005b, p. 97-105.

CARVALHO, Paulo de Barros. Curso de direito tributário. 16 ed., São Paulo: Saraiva, 2004, 551 p.

CARVALHO JR., Pedro Humberto Bruno de. IPTU: progressividade, arrecadação e aspectos extra-fiscais. IPEA-Instituto de Pesquisa Econômica Aplicada, texto para discussão no 1251 , dezembro de 2006.

Disponível em: <http://www.ipea.gov.br/sites/000/2/publicacoes/tds/td_1251.pdf>. Acesso em: 17.02.2008.

CASALINA, Brunella. Soberania popular, governo da lei e governo dos juízes nos Estados Unidos da América. O Estado de direito, história, teoria, crítica. (COSTA, Pietro; ZOLO, Danilo - coords.). Trad. Carlo Alberto Dastoli. São Paulo: Martins Fontes, 2006, p. 264-307.

CASTILHO, Paulo César Baria de. Confisco tributário. São Paulo: Revista dos Tribunais, 2002, 141 p. 
CASTRO, Marcus Faro de. Instituições econômicas: evolução de seus elementos constitucionais na sociedade de mercado. Revista de Direito Empresarial, no 06, p. 41 62, jul./dez. de 2006.

CASTRO JR., Osvaldo Agripino de. A importância da segurança jurídica e do direito e economia para o desenvolvimento. Direito em Revista, no 01, p. 35-52, 2001.

CHALMERS, Alan Francis. O que é ciência afinal? Trad. Raul Fiker Machado. $5^{\mathrm{a}}$ reimp., São Paulo: Brasiliense, 2006, 225 p.

CHAMON JR., Lúcio Antônio. Filosofia do direito na alta modernidade: incursões teóricas em Kelsen, Luhmann e Habermas. 2a ed., Rio de Janeiro: Lúmen Júris, 2007, $223 p$.

CHIBENI, Silvio Seno. Kuhn e a estrutura das revoluções científicas. Disponível em: <http://www.unicamp.br/ chibeni/texdid/structure-sintese.htm\#_ftnref11>. Acesso em: 21.05.2007.

COELHO, André Felipe Canuto. A necessária interação entre o direito e a economia diante da regulação do Estado na ordem econômica. Revista de Direito Administrativo \& Constitucional, n 27, p. 185-206, jan./mar. de 2007a.

COELHO, Cristiane Oliveira. A análise econômica do direito enquanto ciência. Berkeley Program in Law \& Economics, paper 050107¹0, 2007b. Disponível em:

<http://repositories.cdlib.org/cgi/viewcontent.cgi?article=1058\&context=bple>. Acesso em: 30.11.2008.

COELHO, Sacha Calmon Navarro. Curso de direito tributário brasileiro. $5^{\mathrm{a}}$ ed., Rio de Janeiro: Forense, 2000, 801 p.

Comentários à Constituição de 1988: sistema tributário. $6^{a}$ ed., Rio de Janeiro: Forense, 1996, 423 p. 
COMPARATO, Fábio Konder. Repensar a democracia. Democracia, direito e política: estudos internacionais em homenagem a Friedrich Müller. Campinas: Conceito Editorial, 2006, p. 189-224.

CONTI, José Maurício. Princípios tributários da capacidade contributiva e da progressividade. São Paulo: Dialética, 1996, 108 p.

CONSELHO NACIONAL DE JUSTIÇA. Justiça em números: indicadores estatísticos do Poder Judiciário - ano 2005. Disponível em:

<http://www.cnj.gov.br/images/stories/docs_cnj/relatorios/justica_numero_2005.pdf> Acesso em 10.12.2008.

CORDEIRO, Eros Belin de Moura. Direito natural, positivismo e pós-positivismo: compreensões a partir da história. Raízes Jurídicas, vol. 03, nº 02, p. 358-378, jul./dez. de 2007.

COSTA, Regina Helena. Curso de direito tributário. São Paulo: Saraiva, 2009, 452 p.

Praticabilidade e justiça tributária. São Paulo: Malheiros, 2007, 420 p.

Código Tributário Nacional comentado (FREITAS, Vladimir Passos de coord.). $2^{a}$ ed., São Paulo: Revista dos Tribunais, 2004, 868 p.

Princípio da capacidade contributiva. $2^{\text {a }}$ ed., São Paulo: Malheiros, 1996, $112 \mathrm{p}$.

COULANGES, Fustel de. A cidade antiga. Trad. Fernando Aguiar. $8^{\mathrm{a}}$ ed., Lisboa: Livraria Clássica Editora, vols. nº 01 e 02, 1954, 352 e 339 p., respectivamente.

COUTO E SILVA, Almiro do. Os indivíduos e o Estado na realização de tarefas públicas. Estudos em homenagem a Geraldo Ataliba: direito administrativo e constitucional. (BANDEIRA DE MELLO, Celso Antônio - org.). São Paulo: Malheiros, 1997, p. 74-110. 
CUNHA, Aécio S. Os impostos e a história. Universidade de Brasília, texto $\mathrm{n}^{\circ} 258$, novembro de 2002. Disponível em:

<http://www.unb.br/face/eco/cpe/TD/258Nov02ACunha.pdf>.

Acesso em: 17.07.2008.

DALLARI, Dalmo de Abreu. Elementos de teoria geral do Estado. 14ª ed., São Paulo: Saraiva, 1989, 259 p.

DANTAS, David Diniz. Interpretação constitucional no pós positivismo. $2^{\mathrm{a}}$ ed., São Paulo: Madras, 2005, 397 p.

DANTAS, Francisco Wildo Lacerda. Breves considerações sobre os mecanismos de participação popular no Brasil: plebiscito, referendo e participação popular. Revista da Associação dos Juízes Federais do Brasil - AJUFE, nº 89, p. 125-158, jan./jun. de 2008.

DELFIM NETO, Antonio; GIAMBIAGI, Fábio. O Brasil precisa de uma agenda de consenso. O tributo - reflexão multidisciplinar sobre sua natureza. (MARTINS, Ives Gandra da Silva - coord.). Rio de Janeiro: Forense, 2005, p. 321-330.

DE LUCCA, Newton. Reflexões sobre os 40 anos do Banco Central. Revista de Direito Bancário e Mercado de Capitais, nº 35, p. 194-206, jan./mar. de 2007.

DENARI, Zelmo. Curso de direito tributário. $6^{\text {a }}$ ed., Rio de Janeiro: Forense, 2000, $328 \mathrm{p}$.

DI PIETRO, Maria Sylvia Zanella. Direito administrativo. $14^{a}$ ed., São Paulo: Atlas, 2002, 727p.

DÓRIA, Antônio Roberto Sampaio. Direito constitucional tributário e due process of law. $2^{\mathrm{a}}$ ed., Rio de Janeiro: Forense, 1986, 215 p.

FALCÃO, Raimundo Bezerra. Tributação e mudança social. Rio de Janeiro: Forense, 1981,367 p. 
FALCÃO, Maurin Almeida. A reforma tributária brasileira: um enfoque distorcido? Reforma tributária em questão (MORHY, Lauro - org). Brasília: UNB Editora, 2003, p. $67-82$.

FANTOZZI, Augusto. Diritto tributario. 2a impressão, Torino: UTET, 1994, 804 p.

FARACO, Alexandre Ditzel; SANTOS, Fernando Muniz. Análise econômica do direito e possibilidades aplicativas no Brasil. Revista de Direito Público da Economia, no 09, p. 27-61, jan./mar. de 2005.

FARIA, José Eduardo. O direito na economia globalizada. $4^{\mathrm{a}}$ tiragem da $1^{\mathrm{a}}$ ed., São Paulo: Malheiros, 2004, 359 p.

FARINA, Elizabeth Maria Mercier Querido; AZEVEDO, Paulo Furquim de; SAES, Maria Sylvia Macchione. Competitividade: mercado, Estado e organizações. São Paulo: Singular, 1997, 286 p.

FELDENS, Luciano. Direitos fundamentais e direito penal. Porto Alegre: Livraria do Advogado, 2008, 134 p.

FERES, Marcos Vinício Chein. Do princípio da eficiência econômica. Revista do IBRAC, vol. $08, n^{\circ} 08$, p. 23-46, 2001.

FERRAZ JR., Tércio Sampaio. Direito e justiça. Estudos de filosofia do direito. $2^{\mathrm{a}}$ ed., São Paulo: Atlas, 2003, 286 p.

. Introdução ao estudo do direito. São Paulo: Atlas, 1988, 335 p.

A ciência do direito. $2^{\mathrm{a}}$ ed., São Paulo: Atlas, 1980, 111 p.

FERREIRA FILHO, Manoel Gonçalves. Estado de direito e Constituição. $4^{\mathrm{a}}$ ed., São Paulo: Saraiva, 2008, 163 p. 
FORGIONI, Paula A. Análise econômica do direito: paranóia ou mistificação? Revista do Tribunal Regional Federal da $3^{\text {a }}$ Região, no 77, p. 35-61, mai./jun. de 2006.

FRANÇA, Rubens Limongi. Instituições de direito civil. São Paulo: Saraiva, 1994, $1.051 \mathrm{p}$.

O direito a lei e a jurisprudência. São Paulo: Revista dos Tribunais, 1974,

$211 \mathrm{p}$.

FRAGA, Henrique Rocha. O imposto territorial urbano e o princípio da progressividade. São Paulo: IOB, 2007, 192 p.

FRANCISCO NETO, João. Sistema tributário nacional na atualidade e a evolução histórica dos tributos. São Paulo: Impactus, 2008, 220 p.

FRIEDE, Reis. Ciência do direito, norma, interpretação e hermenêutica jurídica. São Paulo: Forense Universitária, 1997, 170 p.

FRIEDMAN, Milton. Capitalismo e liberdade. Trad. Luciana Carli. São Paulo: Nova Cultural, 1985, 187 p.

FUKUYAMA. Francis. Construção de Estados: governo e organização no século XXI. Trad. Nivaldo Montingelli Jr. São Paulo: Rocco, 2005, 168 p.

FURLAN, Anderson. Obrigações tributárias romanas. Revista da Associação dos Juízes Federais do Brasil - AJUFE, nº 87, p. 61-80, primeiro trimestre de 2007.

GABARDO, Emerson. Eficiência e legitimidade do Estado. São Paulo: Manole, 2003, 207 p.

GALVES, Carlos. Manual de economia política. $3^{\text {a }}$ ed., Rio de Janeiro: Forense, 1967, $425 \mathrm{p}$. 
GASTALDI, J. Petrelli. Elementos de economia política. 5a ed., São Paulo: Saraiva, 1970, 419p.

GIAMBIAGI, Fábio. Cenários para a relação dívida pública/PIB: simulações e perspectivas de redução da carga tributária e da relação gasto corrente/PIB. IPEAInstituto de Pesquisa Econômica Aplicada, texto para discussão nº 1193, junho de 2006. Disponível em: <http://www.ipea.gov.br/sites/000/2/publicacoes/tds/td_1193.pdf>. Acesso em: 17.03.2008.

GIAMBIAGI, Fábio; ALÉM, Ana Cláudia. Finanças públicas: teoria e prática no Brasil. $2^{\mathrm{a}}$ ed., Rio de Janeiro: 2002, 425 p.

GODOI, Marciano Seabra de. Tributo e solidariedade social. Solidariedade social e tributação. (GRECO, Marco Aurélio; GODOI, Marciano Seabra de Godoi - orgs.). São Paulo: Dialética, 2005, p. 141-167.

GODOY, Arnaldo Moraes. Notas sobre o direito tributário na Grécia clássica. Revista de Informação Legislativa, no 142, p. 05-07, abr./jun. de 1999.

GOLDSCHMIDT, Fábio Brun. O princípio do não-confisco no direito tributário. São Paulo: Revista dos Tribunais, 2004, 304 p.

GOMES, Alexandre Travessoni. O fundamento de validade do direito em Kant e Kelsen. $2^{\text {a }}$ ed., Belo Horizonte: Mandamentos, 2004, 303 p.

GOMES, Orlando. Contratos. $15^{\text {a }}$ ed., Rio de Janeiro: Forense, 1995, 523 p.

Direitos reais. $10^{a}$ ed., Rio de Janeiro: Forense, 1993, 416 p. . Obrigações. $8^{\text {a }}$ ed., Rio de Janeiro: Forense, 1992, 431 p.

GOUVEIA, Clóvis Ernesto de. Justiça fiscal e tributação indireta. 1999. Tese (Doutorado em Direito) Faculdade de Direito da Universidade de São Paulo. São Paulo. Disponível em: <http://www.teses.usp.br>. Acesso em 25.11.2008. 
GOUVEIA, Humberto. Limites à atividade tributária e o desenvolvimento nacional: dignidade da pessoa humana e capacidade contributiva. Porto Alegre: Sérgio Antônio Fabris Editor, 2008, 263 p.

GRAU, Eros Roberto. Direito posto e pressuposto. $6^{a}$ ed., São Paulo: Malheiros, 2005, $316 \mathrm{p}$.

A ordem econômica na Constituição de 1988. $4^{\mathrm{a}}$ ed., São Paulo: Malheiros, 1998, $362 \mathrm{p}$.

HARADA, Kiyoshi. Direito financeiro e tributário. 17 ed., São Paulo: Atlas, 2008, $748 \mathrm{p}$.

HART, Herbert L. A. O conceito de direito. Trad. Armindo Ribeiro Mendes. Lisboa: Fundação Calouste Gulbenkian, 1986, 306 p.

HORVATH, Estevão. O princípio do não confisco no direito tributário. São Paulo: Dialética, 2002, 159 p.

HUBERMAN, Leo. História da riqueza do homem. Trad. Waltensir Dutra. $21^{a}$ ed., São Paulo: LTC, s. d., 286 p.

HUME, David. Ensaios morais, políticos e literários. Os pensadores. Trad. João Paulo Gomes Monteiro; Armando Mora de Oliveira. São Paulo: Abril Cultural, 1973, vol. XXIII, p. 203-325.

HUPFFER, Haide Maria. Educação jurídica e hermenêutica filosófica. 2006. Tese (Doutorado em Direito) Faculdade de Direito da Universidade do Vale do Rio dos Sinos. São Leopoldo. Disponível em:

<http://bdtd.unisinos.br/tde_busca/arquivo.php?codArquivo=81>. Acesso em 29.11.2008. 
JARDIM, Eduardo Marçal Ferreira. Manual de direito financeiro e tributário. $9^{a}$ ed., São Paulo: Saraiva, 2008, 426 p.

KELSEN, Hans. Teoria pura do direito. Trad. João Baptista Machado. $2^{\mathrm{a}}$ ed., São Paulo: Martins Fontes, 1987, 371 p.

INSTITUTO BRASILEIRO DE GEOGRAFIA E ESTATÍSTICA. Sintese de indicadores sociais: uma análise das condições de vida da população brasileira 2008. Disponível em: <http://www.ibge.gov.br/home/estatistica/populacao/condicaodevida/indicadoresminimos/ sinteseindicsociais2008/indic_sociais2008.pdf> Acesso em: 28.04.2009.

INSTITUTO BRASILEIRO DE PLANEJAMENTO TRIBUTÁRIO. Carga tributária brasileira de 2008. Disponível em:

<http://www.ibpt.com.br/img/_publicacao/13651/176.pdf>. Acesso em: 18.05.2009.

IRTI, Natalino. A ordem jurídica do mercado. Revista do Direito Bancário e do Mercado de Capitais, n 39, p. 94-100, jan./mar. de 2008.

JOST, Leodegar. Política tributária. Porto Alegre: AGE, 2003, 126 p.

KELLER, Paulo Fernandes. Competição Global \& cooperação local: uma análise das relações interfirmas no cluster têxtil de Americana - SP. ENFOQUES - Revista dos Alunos do Programa de Pós-Graduação em Sociologia e Antropologia da Universidade Federal do Rio de Janeiro, março de 2004.

Disponível em: <http://www.enfoques.ifcs.ufrj.br/marco04/pdfs/marco2004_05.pdf>. Acesso em: 26.12.2008.

KUHN, Thomas. A estrutura das revoluções científicas. Trad. Beatriz Vianna Boeira; Nelson Boeira. $8^{\text {a }}$ ed., São Paulo: Perspectiva, 2003, 260 p. 
KUNTZ, Rolf. Locke, liberdade, igualdade e propriedade. IEA-Instituto de Estudos Avançados da Universidade de São Paulo, texto de palestra proferida em 11 de abril de 1997.

Disponível em: <http://www.iea.usp.br/iea/textos/kuntzlocke.pdf> Acesso em: 26.04.2009.

LEMGRUBER, Andrea. A tributação do capital: o imposto de renda da pessoa jurídica e o imposto sobre operações financeiras. Economia do setor público no Brasil (BIDERMAN, Ciro; ARVATE, Paulo Arvate - orgs.). Rio de Janeiro: Elsevier, 2005, p. 206-230.

LÉVY-BRUHL, Henri. Sociologia do direito. Trad. Antônio de Pádua Danesi. São Paulo: Martins Fontes, 1977, 141 p.

LEWANDOWSKI, Enrique Ricardo. A proteção dos direitos humanos na ordem interna e internacional. Rio de Janeiro: Forense, 1984, 188 p.

Reflexões em torno do princípio republicano. Revista da Faculdade de Direito da USP, nº 100, p. 189-200, jan./dez. de 2005a.

Direitos fundamentais - a formação da doutrina dos direitos fundamentais.

Lições de direito constitucional em homenagem ao jurista Celso Bastos. (MARTINS, Ives Gandra; MENDES, Gilmar Ferreira; TAVARES, André Ramos - coords.). São Paulo: Saraiva, 2005b, p. 168-179.

LEWIS, Sandra Barbon. A íntima relação entre o direito e a economia. Revista de Direito Mercantil Industrial Econômico e Financeiro, nº 138, p. 231-249, abr./jun. de 2005.

LIVINGSTON, Michel A. Progressividade e solidarietà: uma perspectiva norte-americana. Solidariedade social e tributação (GRECO, Marco Aurélio; GODOI, Marciano Seabra de - coords.). São Paulo: Dialética, 2005, p. 190-197.

LOPES, José Reinaldo de Lima. Raciocínio jurídico e economia. Revista de Direito Público e Economia, no 08, p. 137-169, out./dez. de 2004. 
LUHMANN, Niklas. Sociedad y sistema: la ambición de la teoria. Trad. para o espanhol de Santiago López Petit e Pablo Martín Badosa. Barcelona: Paidós, 1990, 144 p.

Sistema juridico y dogmática jurídica. Trad. para o espanhol de Ignacio de Otto Pardo. Madrid: Centro de Estudios Constitucionales, 1983, 153 p.

MACHADO, Hugo de Brito. Curso de direito tributário. 21ª ed., São Paulo: Malheiros, 2002, 472 p.

MAfFettone, Sebastiano; VECA, Salvatore. A idéia de justiça de Platão a Rawls. Trad. Karina Jannini; Denise Agostinetti. São Paulo: Martins Fontes, 2005, 451p.

MAGALHÃES, Luis Carlos Garcia de; SILVEIRA, Fernando Geiger; TOMICH, Frederico Andrade; VIANNA, Salvador Werneck. Tributação, distribuição de renda e pobreza: uma análise dos impactos da carga tributária sobre alimentação nas grandes regiões urbanas brasileiras. IPEA-Instituto de Pesquisa Econômica Aplicada, texto para discussão $n^{\circ}$ 804, junho de 2001a.

Disponível em: 〈http://www.ipea.gov.br/pub/td/2001/td_0804.pdf〉.

Acesso em: 02.04.2008.

MAGALHÃES, Luis Carlos Garcia de; TOMICH, Frederico Andrade; SILVEIRA, Fernando Gaiger; VIANNA, Salvador Werneck; SAFATLE, Leandro; OLIVEIRA, Alexandre Batista de; DOURADO, Rodrigo. Tributação sobre gastos com saúde das famílias: avaliação da carga tributária sobre medicamentos, material médico-hospitalar e próteses/órteses. IPEA-Instituto de Pesquisa Econômica Aplicada, texto para discussão $\mathrm{n}^{\mathrm{o}} 790$, maio de 2001b.

Disponível em: <http://www.ipea.gov.br/pub/td/2001/td_0790.pdf>.

Acesso em: 02.04.2008.

MAIA, Paulo Sávio Peixoto. O direito como sistema social: a teoria do direito de Niklas Luhmann como contraponto ao positivismo jurídico. Notícia do Direito Brasileiro, $\mathrm{n}^{\circ} 13$ - nova série, p. 167-196, 2006. 
MANKIN, N. Gregory. Introdução à economia. Trad. Allan Vidigal Hastings. São Paulo: Thomson, 2007, 852 p.

MARTINS, Marcelo Guerra. Impostos e contribuições federais. Rio de Janeiro: Renovar, 2004, 639 p.

Lesão contratual no direito brasileiro. Rio de Janeiro: Renovar, 2001, $297 \mathrm{p}$.

Contribuições de intervenção no domínio econômico: uma visão genérica e preliminar. Revista do Tribunal Regional Federal da 3a Região, no 72, p. 13-35, jul./ago. de 2005 .

MARTINS, Rogério Vidal Gandra; MARONE, José Ruben. Comentários ao Código Tributário Nacional (NASCIMENTO, Carlos Valder do - coord.). Rio de Janeiro: Forense, 1997, 578 p.

MARQUES, Márcio Severo. Classificação constitucional dos tributos. São Paulo: Max Limonad, 2000, 255 p.

MEIRA. Silvio. Direito tributário romano. Revista da Academia Brasileira de Letras Jurídicas, $\mathrm{n}^{\circ}$ 08, p. 15-50, $2^{\circ}$ sem. de 1995.

MEIRELLES, Hely Lopes. Direito administrativo brasileiro. $21^{\text {a }}$ ed., São Paulo: Malheiros, 1996, 734 p.

MELlO, José Eduardo Soares de; LIPPO, Luiz Francisco. A não-cumulatividade tributária. $2^{a}$ ed., São Paulo: Dialética, 2004, 223 p.

MELLO, Olbiano de. Economia política. $2^{\mathrm{a}}$ ed., São Paulo: Revista dos Tribunais, 1968, $215 \mathrm{p}$. 
MICHELS, Gilson Wessler. Desenvolvimento e sistema tributário. Direito e desenvolvimento: análise da ordem jurídica brasileira sob a ótica do desenvolvimento (BARRAL, Welber - org.). São Paulo: Singular, 2005, p. 225-258.

MINISTÉRIO DA FAZENDA. PROCURADORIA GERAL DA FAZENDA NACIONAL. Estoque total da dívida ativa da União: quantidade das inscrições em cobrança.

Disponível em: <http://www.pgfn.gov.br/publicacoes/estatisticas-da-divida-ativa-dauniao/Estoque\%20D.A.U\%20-\%20Quant..pdf>

Acesso em: 18.07.2009.

MINISTÉRIO DA FAZENDA. PROCURADORIA GERAL DA FAZENDA NACIONAL. Estoque total da dívida ativa da União: valor das inscrições em cobrança.

Disponível em: <http://www.pgfn.gov.br/publicacoes/estatisticas-da-divida-ativa-dauniao/Estoque\%20D.A.U\%20-\%20Valor.pdf>

Acesso em 18.07.2009.

MINISTÉRIO DA FAZENDA. PROCURADORIA GERAL DA FAZENDA NACIONAL. Estoque total da dívida ativa da União: arrecadação total.

Disponível em: <http://www.pgfn.gov.br/publicacoes/estatisticas-da-divida-ativa-dauniao/Arrec.\%20Total\%20PGFN.pdf>

Acesso em 18.07.2009.

MIRAGEM, Bruno. Direito da concorrência e raciocínio econômico: intersecções entre o direito e a economia na experiência brasileira. Direito e economia (TIMM, Luciano Benetti - org.). São Paulo: Thomson, 2005, p. 141-163.

MIRANDA FILHO, Aloysio Meirelles de; BORGES, Eduardo. País do futuro: idéias para reduzir o custo Brasil, essencial ao desenvolvimento.

Disponível

em:

<http://www.conjur.com.br/2006-mai-

30/ideias_reduzir_custo_brasil_essencial_desenvolvimento>. Acesso em: 19.07.2009.

MIRANDA, Jorge. Teoria do Estado e da Constituição. Rio de Janeiro: Forense, 2003, $546 \mathrm{p}$. 
MILL, John Stuart. Sistema de lógica dedutiva e indutiva. Os pensadores. Trad. João Marcos Coelho. São Paulo: Abril Cultural, 1974, vol. XXXIV, p. 76-252.

MONCELLIN, Sandra. Economia criminale e atto economico: brevi considerazioni. Revista Trimestrale di Diritto Penale dell'Economia. Ano XI, ${ }^{\circ}$ 04, p. 1.023-1.033, oct./dez. de 1998.

MONTEIRO NETO, Armando. Reforma tributária: por um Brasil competitivo. Reforma tributária em questão (MORHY, Lauro - org.). Brasília: UNB Editora, 2003, p. 53-66.

MOSCHETTI, Francesco. El principio de capacidad contributiva. Trad. para o espanhol de Juan M. Gallego e Rafael Navas Vasques. Madrid: Instituto de Estudios Fiscales, 1980, $421 \mathrm{p}$.

NABAIS, José Casalta. Direito fiscal. $3^{\text {a }}$ ed., Coimbra: Almeidina, 2005a, 668 p.

Por um estado fiscal suportável: estudos de direito fiscal. Coimbra: Almeidina, 2005b, 638 p.

Solidariedade social, cidadania e direito fiscal. Solidariedade social e tributação. (GRECO, Marco Aurélio; GODOI, Marciano Seabra de Godoi - orgs.). São Paulo: Dialética, 2005c, p. 110-140.

O dever fundamental de pagar impostos. Coimbra: Almeidina, 1998, $746 \mathrm{p}$.

NADER, Paulo. Curso de direito civil: direito das coisas. $3^{\text {a }}$ ed., Rio de Janeiro: Forense, 2009, 486 p.

NERI, Marcelo. Informalidade.

Disponível em: <http://epge.fgv.br/portal/arquivo/2170.pdf〉. Acesso em: 04.07.2007. 
NÓBREGA, Maílson da. O futuro chegou: instituições e desenvolvimento no Brasil. São Paulo: Globo, 2005, 399 p.

NOGUEIRA, Alberto. A reconstrução dos direitos humanos da tributação. Rio de Janeiro: Renovar, 1997, 457 p.

NOGUEIRA, Ruy Barbosa. Curso de direito tributário. 11 $11^{\text {a }}$ ed., São Paulo: Saraiva, $346 \mathrm{p}$.

NORTH, Doulglass C. Institutions, transaction costs, and the rise of merchant empires. The political economy of merchant empires. Cambridge: James D. Tracy, 1991, p. 2240 .

NUSDEO, Fábio. Curso de economia: introdução ao direito econômico. $4^{\mathrm{a}}$ ed., São Paulo: Revista dos Tribunais, 2005, 393 p.

OLIVEIRA JR., José Alcebíades de. Norma fundamental kelseniana e o conceito de direito. Jurispoiesis - Revista dos Cursos de Direito da Universidade Estácio de Sá, vol. 01, no 02, p. 97-104, out./dez. de 1999.

OLIVEIRA, Regis Fernandes de. Histórico dos tributos: desenvolvimento da política financeira. Revista Tributária e de Finanças Públicas, no 63, p. 176-191, jul./ago. de 2005 .

OLIVEIRA, Regis Fernandes de; HORVATH, Estevão. Manual de direito financeiro. $2^{\mathrm{a}}$ ed., São Paulo: Revista dos Tribunais, 1997, 158 p.

PAES, Nelson Leitão; BUGARIN, Mirta Noemi Sataka. Parâmetros tributários da economia brasileira. Estudos Econômicos, vol. 36, nº 04, p. 699-720, out./dez. de 2006.

PAULSEN, Leandro. Direito tributário. Porto Alegre: Livraria do Advogado, 1998, 445p. 
PAYERAS, José Adrian Pintos. A carga tributária no Brasil e sua distribuição. 2008. Tese (Doutorado em Economia Aplicada) Escola Superior de Agronomia "Luiz de Queiroz”. Universidade de São Paulo. Piracicaba.

Disponível em: <http://www.teses.usp.br>. Acesso em 26.11.2008.

PEIXOTO, João Paulo M. Notas sobre a reforma do estado e reforma tributária. Reforma tributária em questão (Lauro Morhy - org.). Brasília: UNB, 2003, p. 83-108.

PEREIRA, Aloysio Ferraz. O direito como ciência. São Paulo: Revista dos Tribunais, 1980, 107p.

PEREIRA, Jane Reis Gonçalvez. Os imperativos de razoabilidade e de proporcionalidade. A reconstrução democrática do direito público no Brasil (BARROSO, Luís Roberto org.). Rio de Janeiro: Renovar, 2007, p. 153-215.

PEREIRA, Luiz Carlos Bresser. Economia brasileira: uma introdução crítica. $3^{\text {a }}$ ed., São Paulo: Editora 34, 1997, 222 p.

PEREIRA, Rodrigo Mendes; CÂNDIDO JR., José Oswaldo. Progressividade físcal no Brasil. Boletim de Desenvolvimento Fiscal do IPEA-Instituto de Pesquisa Econômica Aplicada, $\mathrm{n}^{\circ}$ 2, p. 43-48, setembro de 2006.

Disponível em: <http://www.ipea.gov.br/sites/000/2/publicacoes/dfb/bdf_02.pdf>. Acesso em: 12.12.2008.

PEZZI, Alexandra Cristina Giacomet. Dignidade da pessoa humana: mínimo existencial e limites à tributação no Estado Democrático de Direito. Curitiba: Juruá, 2008, 161 p.

PIANCASTELLI, Marcelo; NASCIMENTO, Edson Ronaldo. Imposto de renda da pessoa física. Economia do setor público no Brasil (BIDERMAN, Ciro; ARVATE, Paulo Arvate - orgs.). Rio de Janeiro: Elsevier, 2005, p. 231-251.

PINHEIRO, Armando Castelar. Direito e economia num mundo globalizado: cooperação ou confronto? Direito \& economia (TIMM, Luciano Benetti - org.). Porto Alegre: Livraria do Advogado, 2008, p. 19-47. 
PINTO, Olavo Bilac Pereira. Finanças e direito. Revista Forense, n 442, p. 11-26, abr. de 1940.

PISCITELLI, Roberto Bocaccio. Reforma tributária: a unanimidade de cada um. Reforma tributária em questão (MORHY, Lauro - org.). Brasília: UNB Editora, 2003, p. 83-92.

POPPER, Karl. A lógica da pesquisa científica. Trad. Leônidas Hegenberg; Octanny Silveira da Mota. São Paulo: Cultrix, 1975, 567 p.

PONTES DE MIRANDA, Francisco Cavalcanti. Tratado de direito privado. Rio de Janeiro: Editor Borsoi, 1955, tomo XI, 497 p.

POSNER, Richard A. El análisis económico del derecho. $2^{\text {a }}$ ed. Trad. para o espanhol de Eduardo L. Suárez. México: Fondo de Cultura Económica, 2007a, 1.120 p.

Problemas de filosofia do direito. Trad. Jefferson Luiz Camargo. São Paulo: Martins Fontes, 2007b, 647 p.

La decadencia del derecho como disciplina autónoma: 1962-1987. Derecho y economía: una revisión de la literatura. (ROEMER, Andrés - compil.). Trad. para o espanhol de Hector Torres. México: Fondo de Cultura Económica, 2002, p. 102-122.

PRADO, Ney. Economia informal e direito no Brasil. São Paulo: LTR, 1991, 158 p.

QUEIROZ, Cid Heráclito de. Um novo enfoque para o sistema tributário brasileiro. Reforma tributária em questão (MORHY, Lauro - org.). Brasília: UNB Editora, 2003, p. 181-195.

QUEIROZ, Mary Elbe. O imposto sobre a renda das pessoas físicas e as distorções na sua incidência - injustiça fiscal? $O$ tributo - reflexão multidisciplinar sobre sua natureza. (MARTINS, Ives Gandra da Silva - coord.). Rio de Janeiro: Forense, 2005, p. 235-249. 
RADBRUCH, Gustav. Introdução à ciência do direito. Trad. Vera Barkow. São Paulo: Martins Fontes: 1999, 232 p.

RAO, Vicente. $O$ direito e a vida dos direitos. $3^{\text {a }}$ ed., São Paulo: Saraiva, 1991, vol. $\mathrm{n}^{\circ}$ 01, 476p.

RAWLS, John. Uma teoria da justiça. Trad. Almiro Pisetta; Lenita Maria Rímoli Esteves. São Paulo: Martins Fontes, 2002, 708 p.

REALE, Miguel. Filosofia do direito. 17a ed., São Paulo: Saraiva, 1996, 749 p.

REIS, Maurício Cortez; ULYSSEA, Gabriel. Cunha fiscal, informalidade e crescimento: algumas questões e propostas de políticas. IPEA-Instituto de Pesquisa Econômica Aplicada, texto para discussão nº 1068, janeiro de 2005 .

Disponível em: <http://www.ipea.gov.br/pub/td/2005/td_1068.pdf>.

Acesso em: 13.03 .2008

REZENDE, Christiane Leles; ZYLBERSZTAJN, Décio. Pacta sunt servanda? O caso dos contratos de soja verde. Berkeley Program in Law \& Economics, paper 050207’06, 2007. Disponível em:

<http://www.pensa.org.br/anexos/biblioteca/182007111522_Alacde_ChristianeLRBrasilia 07.pdf>. Acesso em: 30.11.2008.

REZENDE, Fernando; CUNHA, Armando. Contribuintes e cidadãos: compreendendo o orçamento federal. São Paulo: FGV, 2002, 152 p.

RIBEIRO, Roberto Name. Causas, efeitos e comportamento da economia informal no Brasil. 2000. Dissertação (Mestrado em Economia) Universidade de Brasília. Brasília. Disponível em: <http://www.unb.br/face/eco/mesp/dissertacoes.html>. Acesso em 24.11.2008.

RICARDO, David. Princípios de economia política e tributação. Os pensadores. Trad. Rolf Kuntz. São Paulo: Abril Cultural, 1974, vol. XXVIII, p. 246-346. 
RISTER, Carla Abrantkoski. Direito ao desenvolvimento - antecedentes, significados e conseqüências. Rio de Janeiro: Renovar, 2006, 542 p.

ROCHA, Sônia. Economia informal: algumas considerações sobre conceituação e mensuração. IPEA-Instituto de Pesquisa Econômica Aplicada, texto $n^{\circ} 181$, dezembro de 1989.

Disponível em: <http://www.ipea.gov.br/pub/td1989/td_0181.pdf>.

Acesso em: 12.12.2007.

RODRIGUES, Silvio. Direito civil: direito das coisas. $18^{a}$ ed., São Paulo: Saraiva, 1989, $421 \mathrm{p}$.

RODRIGUES, Vasco. Análise económica do direito. Coimbra: Almeidina, 2007, 243 p.

RODRÍGUEZ, Ricardo Vélez. Keynes: doutrina e crítica. São Paulo: Massao Ohno Editor, 1999, 105 p.

ROHENKOHL, Marcelo Saldanha. O princípio da capacidade contributiva no Estado Democrático de Direito. São Paulo: Quartier Latin, 2007, 234 p.

ROMITA, Arion Sayão. Função social do tributo. O tributo - reflexão multidisciplinar sobre sua natureza. (MARTINS, Ives Gandra da Silva - coord.). Rio de Janeiro: Forense, 2005, p. 391-400.

ROSS, Alf. Direito e justiça. Trad. Edson Bini. São Paulo: Edipro, 2003, 432 p.

ROSSEAU, Jean Jacques. Do contrato social. Os pensadores. Trad. Lourdes Santos Machado. São Paulo: Abril Cultural, 1973, vol. XXIV, p. 07-151.

ROSSETTI, José Paschoal. Introdução à economia. 12a ed., São Paulo: Atlas, 1987, $766 \mathrm{p}$.

ROTH, João Luiz. Por que não crescemos como os outros países? - custo Brasil. São Paulo: Saraiva, 2006, 194 p. 
SABBAG, César de Moraes. Orçamento de desenvolvimento. Campinas: Millenium, 2006, 291p .

SABBAG, Eduardo de Moraes. Manual de direito tributário. São Paulo: Saraiva, 2009, $1.090 \mathrm{p}$.

SACCHETTO, Cláudio. O dever de solidariedade no direito tributário: o ordenamento italiano. Solidariedade social e tributação (GRECO, Marco Aurélio; GODOI, Marciano Seabra de - coords.). São Paulo: Dialética, 2005, p. 09-52.

SCHOUERI, Luís Eduardo. Normas tributárias indutoras e intervenção econômica. Rio de Janeiro: Forense, 2005, 400 p.

SALAMA, Bruno Meyerhof. O que é pesquisa em direito e economia. Cadernos Direito GV, vol. 05, março de 2008. Disponível em:

<http://www.direitogv.com.br/AppData/Publication/caderno\%20direito\%2022.pdf>. Acesso em: 20.10.2008.

SAMPAIO, Maria da Conceição. Tributação do consumo no Brasil: aspectos teóricos e aplicados. Economia do setor público no Brasil (BIDERMAN, Ciro; AVRATE, Paulo orgs.). Rio de Janeiro: Elsevier, 2005, p. 188-205.

SAN TIAGO DANTAS, Francisco Clementino de. Evolução contemporânea do direito comercial. Revista Forense, no 139, p. 05-13, jan./fev. de 1952.

SARLET, Ingo Wolfgang. A eficácia dos direitos fundamentais. $2^{\mathrm{a}}$ ed., Porto Alegre: Livraria do Advogado, 2001, 392 p.

Proibição de retrocesso, dignidade da pessoa humana e direitos sociais: manifestação de um constitucionalismo dirigente possível. Estudos em homenagem ao professor J.J. Gomes Canotilho (BONAVIDES, Paulo; LIMA, Francisco Gérson Marques de; BEDÊ, Fayaga Silveira - coords.). São Paulo, Malheiros, 2002, p. 291-335. 
A eficácia do direito fundamental á segurança jurídica: dignidade da pessoa humana, direitos fundamentais e proibição de retrocesso social no direito constitucional brasileiro. Revista Brasileira de Direito Comparado, $\mathrm{n}^{\circ} 28$, p. 89-148, $1^{\circ}$ semestre de 2005.

SASAKI, Daniel Leb. Pouso forçado: a história por trás da destruição da Panair do Brasil pelo regime militar. São Paulo: Record, 2005, 276 p.

SCHÄFER, Jairo. Classificação dos direitos fundamentais. Porto Alegre: Livraria do Advogado, 2005, 76 p.

Direitos fundamentais: proteção e restrições. Porto Alegre: Livraria do Advogado, 2001, 152 p.

SCHUMPETER, Joseph A. Capitalismo, socialismo e democracia. Trad. Ruy Jungmann. Rio de Janeiro: Fundo de Cultura, 1961, 448p.

SCHNEIDER, Friedrich. Causas e conseqüências da economia subterrânea. Instituto Brasileiro de Ética Concorrencial, nº 09, abril de 2008, p. 16-21.

SECRETARIA DA RECEITA FEDERAL. Análise da arrecadação das receitas federais - 2008. Disponível em:

<http://www.receita.fazenda.gov.br/Publico/arre/2008/Analisemensaldez08.pdf>. Acesso em: 18.05.2009.

SECRETARIA DA RECEITA FEDERAL. O imposto de renda das pessoas físicas no Brasil. Estudo Tributário nº 14, dezembro de 2004.

Disponível em:

$<$ http://www.receita.fazenda.gov.br/Publico/estudotributarios/estatisticas/31irpfnoBrasil.pd f>. Acesso em: 07.11.2008.

SECRETARIA DA RECEITA FEDERAL. A progressividade no consumo: tributação cumulativa e sobre o valor agregado. Estudo Tributário nº 04, março de 2002. Disponível em: 
<http://www.receita.fazenda.gov.br/Publico/estudotributarios/estatisticas/16\%20Progressiv idade\%20no\%20Consumo.pdf>. Acesso em: 06.11.2008.

SEN, Amartya. Desenvolvimento como liberdade. $7^{\text {a }}$ reimp. São Paulo: Cia. das Letras, 2008, 409 p.

SERRANO, Pablo Jiménez. Epistemologia do direito. Campinas: Alínea, 2007, 119 p.

SIDOU, J. M. A natureza social do tributo. $2^{\text {a }}$ ed., Rio de Janeiro: Forense, 1978, 130 p.

SILVA, José Afonso da. Curso de direito constitucional positivo. $30^{a}$ ed., São Paulo: Malheiros, 2008, 923 p.

SILVA, Luís Virgílio Afonso da. O proporcional e o razoável. Revista dos Tribunais, $\mathrm{n}^{\circ}$ 798, p. 23-50, abril de 2002.

SIQUEIRA, Rozane Bezerra de; NOGUEIRA, José Ricardo; BARBOSA, Ana Luiza Neves de Holanda. Teoria da tributação ótima. Economia do setor público no Brasil (BIDERMAN, Ciro; ARVATE, Paulo Arvate - orgs.). Rio de Janeiro: Elsevier, 2005, p. 173-187.

SIQUEIRA, Rozane Bezerra de; NOGUEIRA, José Ricardo; SOUZA, Evaldo Santana de. A incidência final dos impostos indiretos no Brasil: efeitos da tributação de insumos. Revista Brasileira de Economia, nº 04, p. 513-544, out./dez. de 2001.

SILVEIRA, Fernando Lang da. A metodologia dos programas de pesquisa: a epistemologia de Imre Lakatos.

Disponível em: <http://www.if.ufrgs.br/ lang/LAKATOS.pdf〉. Acesso em: 21.05.2007.

SMITH, Adam. Investigação sobre a natureza e as causas da riqueza das nações. Os pensadores. Trad. Conceição Jardim Maria do Carmo Cary; Eduardo Lúcio Nogueira. São Paulo: Abril Cultural, 1973, vol. XXVIII, p. 07-247. 
SIQUEIRA, Ethevaldo. Para compreender o mundo digital. São Paulo: Globo, 2008, $223 \mathrm{p}$.

SOROS, George. O novo paradigma para os mercados financeiros: a crise atual e o que ela significa. Trad. Lucia Boldrini e Paulo Migliacci. Rio de Janeiro: Agir, 2008, 207 p.

SOUZA, Maria Helena Rau. Execução fiscal - doutrina e jurisprudência. (FREITAS, Vladimir Passos de - coord.). São Paulo: Saraiva, 1998, p. 567 p.

SOUZA, Nali de Jesus de. Desenvolvimento econômico. $5^{\text {a }}$ ed., São Paulo: Atlas, 2008, $313 \mathrm{p}$.

STARR, Chester G. O nascimento da democracia ateniense: a assembléia no século V a. C. Trad. Roberto Leal Ferreira. São Paulo: Odysseus, 2005, 108 p.

SZTAJN, Raquel. Law and economics. Direito \& economia (ZYLBERSZTAJN, Décio; SZTAJN, Raquel - orgs.). Rio de Janeiro: Campus, 2005, p. 74-83.

SZTAJN, Raquel; VERÇOSA, Haroldo Malheiros Dulcrec. A incompletude do contrato de sociedade. Revista de Direito Mercantil Industrial Econômico e Financeiro, no 131, p. 07-20, jul./set. de 2003.

TELLES JR. Gofredo. Iniciação na ciência do direito. São Paulo: Saraiva, 2001, 386 p.

TIMM, Luciano Benetti. Ainda sobre a função social do direito contratual no Código Civil brasileiro: justiça distributiva versus eficiência econômica. Direito \& economia (TIMM, Luciano Benetti - org.). Porto Alegre: Livraria do Advogado, 2008, p. 63-96.

TIPKE, Klaus e YAMASHITA, Douglas. Justiça fiscal e princípio da capacidade contributiva. São Paulo: Malheiros, 2002, 127 p.

TOMAZETTE, Marlon. A viabilidade da análise econômica do direito no Brasil. Revista Tributária e de Finanças Públicas, nº 75, p. 175-198, 2007. 
TORRES, Heleno Taveira. Direito tributário internacional (TORRES, Heleno Taveira coord.). São Paulo: Quartier Latin, 2003, vol. 1, 639 p.

TORRES, Ricardo Lobo. Aspectos fundamentais e finalísticos do tributo. O tributo reflexão multidisciplinar sobre sua natureza. (MARTINS, Ives Gandra da Silva coord.). Rio de Janeiro: Forense, 2005, p. 35-54.

. Curso de direito financeiro e tributário. $8^{\mathrm{a}}$ ed., Rio de Janeiro: Renovar, 2001, 408 p.

A idéia de liberdade no Estado patrimonial e no Estado fiscal. Rio de Janeiro: Renovar, 1991, 193 p.

VARSANO, Ricardo; PESSOA, Elisa de Paula; SILVA, Napoleão Luiz Costa da; AFONSO, José Roberto Rodrigues; ARAÚJO, Érika Amorim; RAMUNDO, Júlio César Maciel. Uma análise da carga tributária do Brasil. IPEA-Instituto de Pesquisa Econômica Aplicada, texto para discussão no 583, agosto de 1998.

Disponível em: 〈http://www.ipea.gov.br/pub/td/1998/td_0583.pdf〉.

Acesso em: 02.02.2008.

VAZ, Isabel. Direito econômico das propriedades. Rio de Janeiro: Forense, 1993, 673 p.

VIANNA, Salvador Werneck; MAGALHÃES, Luis Carlos G.; SILVEIRA, Fernando Gaiger; TOMICH, Frederico Andrade. Carga tributária direta e indireta sobre as unidades familiares no Brasil: avaliação de sua incidência nas grandes regiões urbanas em 1996. IPEA-Instituto de Pesquisa Econômica Aplicada, texto para discussão n ${ }^{\circ}$ 757, setembro de 2000.

Disponível em: <http://www.ipea.gov.br/pub/td/2000/td_0757.pdf>.

Acesso em: 20.10.2008.

VICENTE, Marcelo Álvares. Kelsen e Luhmann: duas teorias sobre o direito positivo. Revista do Instituto dos Advogados de São Paulo, $\mathrm{n}^{\circ} 17$ da nova série, p. 106-124, jan./jun. de 2006. 
VIDIGAL, Geraldo de Camargo. Teoria geral do direito econômico. São Paulo: Revista dos Tribunais, 1977, $223 \mathrm{p}$.

VIEIRA, Oscar Vilhena. Supremocracia. Revista de Direito do Estado, no 12, p. 55-75, out./dez. de 2008.

VILLAS BÔAS FILHO, Orlando. O direito na teoria dos sistemas de Niklas Luhmann. São Paulo: Max Limonad, 2006, 268 p.

VILLELA, Luiz A. Tributação da renda e do patrimônio. IPEA-Instituto de Pesquisa Econômica Aplicada, texto para discussão nº 105, março de 1987.

Disponível em: <http://www.ipea.gov.br/pub/td/1987/td_0105.pdf>.

Acesso em: 15.03.2008.

WEBER, Max. História geral da economia. Trad. Klaus Von Puschen. São Paulo: Centauro, 2006, 336 p.

WILLIAMSON, Oliver. Por que direito, economia e organizações? Direito \& economia (ZYLBERSZTAJN, Décio; SZTAJN, Raquel - orgs.). Rio de Janeiro: Campus, 2005, p. 16-59.

YAZBEC, Otávio. Regulação do mercado financeiro e de capitais. Rio de Janeiro: Campus, 2007, 316 p.

ZANCHIM, Kleber Luiz. Racionalidade jurídica e racionalidade econômica: entre o monte e o rio. Revista de Direito Mercantil Industrial Econômico e Financeiro, no 142, p. 5665, abr./jun. de 2006.

ZANITELLI, Leandro Martins. A regulação dos planos de saúde no Brasil e os princípios da solidariedade e da justiça atuarial: algumas considerações em torno da assimetria informativa. Direito \& economia (TIMM, Luciano Benetti - org.). Porto Alegre: Livraria do Advogado, 2008, p. 203-223. 
ZEILINGER, Anton. A face oculta da natureza: o novo mundo da física quântica. Trad. Luiz Repa. São Paulo: Globo, 2005, 276 p.

ZOLO, Danilo. Teoria e crítica do Estado de direito. O Estado de direito, história, teoria, crítica. (COSTA, Pietro; ZOLO, Danilo coords.). Trad. Carlo Alberto Dastoli. São Paulo: Martins Fontes, 2006, p. 03-94.

ZYLBERSZTAJN, Décio; SZTAJN, Raquel. Análise econômica do direito e das organizações. Direito \& economia (ZYLBERSZTAJN, Décio; SZTAJN, Raquel - orgs.). Rio de Janeiro: Campus, 2005, p. 01-15. 